




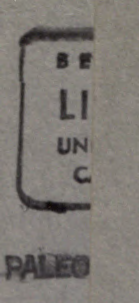



UNITED STATES NATIONAL MUSEUM

Bulletin 75

NORTH PACIFIC OPHIURANS IN THE COLLECTION OF THE UNITED STATES NATIONAL MUSEUM

BY

\section{HUBERT LYMAN CLARK}

Mrusenm of Comparative Zoölogy, Cambridge, Mass.

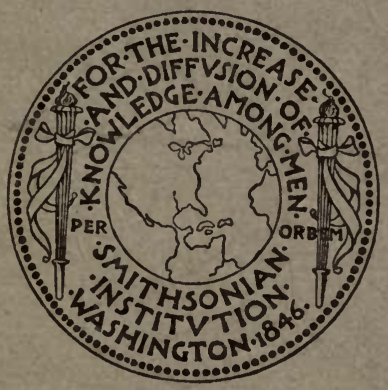

WASHINGTON

GOVERNMENT PRINTING OFFICE 

SMITHSONIAN INSTITUTION

UNITED STATES NATIONAL MUSEUM

Bulletin 75

NORTH PACIFIC OPHIURANS IN THE COLLEC- TION OF THE UNITED STATES

NATIONAL MUSEUM

BY

HUBERT LYMAN CLARK

Museum of Comparative Zoölogy, Cambridge, Mass.

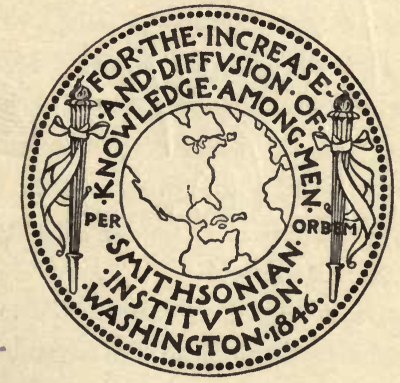

WASHINGTON

GOVERNMENT PRINTING OFFICE 
BULLETIN OF THE UNITED STATES NATIONAL MUSEUM.

Issued February 23, 1911.

Cat, as sep.

for Paleo. 


\section{ADVERTISEMENT.}

The scientific publications of the United States National Museum consist of two series, the Proceedings and the Bulletins.

The Proceedings, the first volume of which was issued in 1878, are intended primarily as a medium for the publication of original, and usually brief, papers based on the collections of the National Museum, presenting newly-acquired facts in zoology, geology, and anthropology, including descriptions of new forms of animals, and revisions of limited groups. One or two volumes are issued annually and distributed to libraries and scientific organizations. A limited number of copies of each paper, in pamphlet form, is distributed to specialists and others interested in the different subjects as soon as printed. The date of publication is printed on each paper, and these dates are also recorded in the table of contents of the volumes.

The Bulletins, the first of which was issued in 1875 , consist of a series of separate publications comprising chiefly monographs of large zoological groups and other general systematic treatises (occasionally in several volumes), faunal works, reports of expeditions, and catalogues of type-specimens, special collections, etc. The majority of the volumes are octavos, but a quarto size has been adopted in a few instances in which large plates were regarded as indispensable.

Since 1902 a series of octavo volumes containing papers relating to the botanical collections of the Museum, and known as the Contributions from the National Herbarium, has been published as bulletins.

The present work forms No. 75 of the Bulletin series.

Richard Rathbun, Assistant Secretary, Smithsonian Institution,

In charge of the United States National Museum.

Washington, D. C., January 3, 1911. 



\section{TABLE OF CONTENTS.}

List of illustrationg

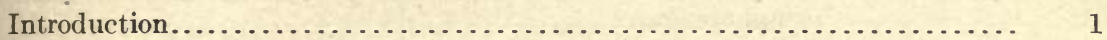

The distribution of the North Pacific Ophiuroidea................ 7

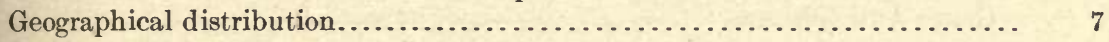

Bathymetrical and temperature distribution $\ldots \ldots \ldots \ldots \ldots \ldots \ldots \ldots \ldots \ldots . \ldots \ldots$

Associational distribution................................... 17

Conclusions as to distribution of Ophiurans in North Pacific Ocean......... 22

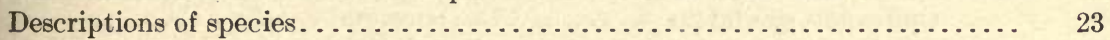

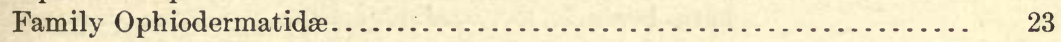

Pectinura anchista.............................. 23

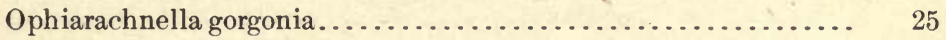

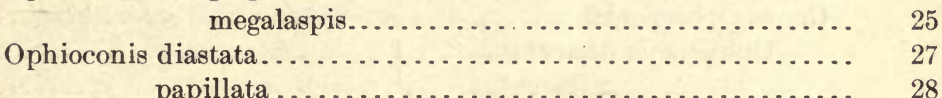

Family Ophiolepididæ................................ 30

Ophioplocus imbricatus ........................ 30

japonicus........................... 30

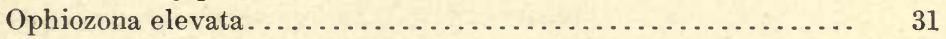

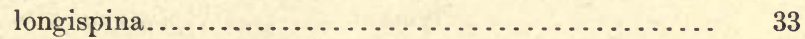

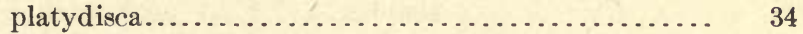

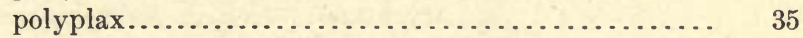

projecta................................ 36

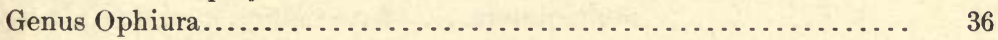

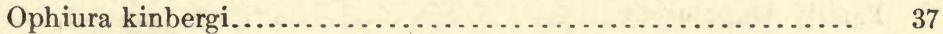

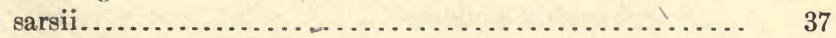

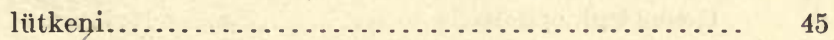

micracantha.............................. 47

maculata............................... 49

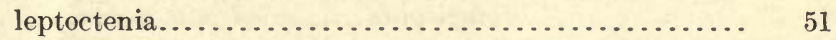

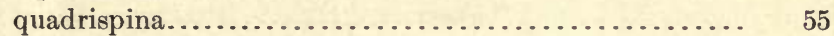

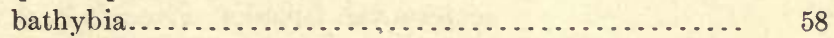

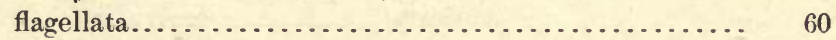

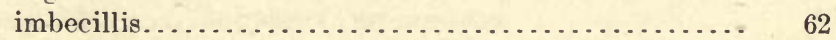

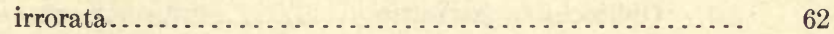

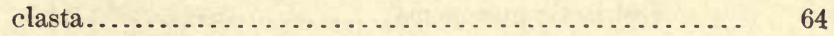

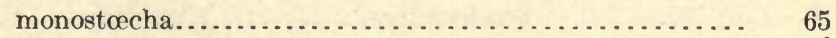

calyptolepis................................ 67

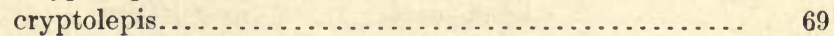

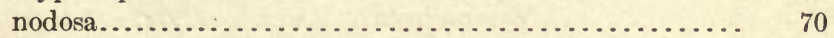

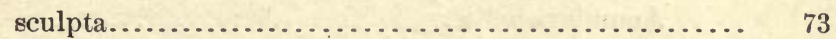

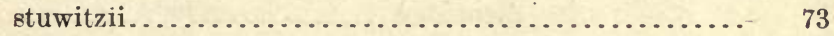

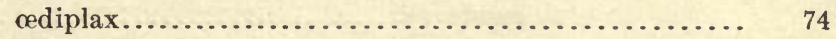


Descriptions of species-Continued.

Family Ophiolepididæ-Continued.

Genus Ophiura-Continued.

Page.

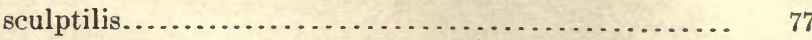

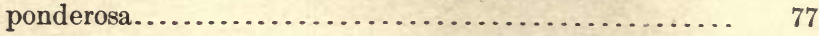

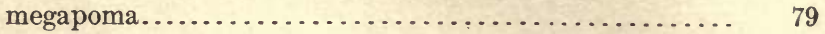

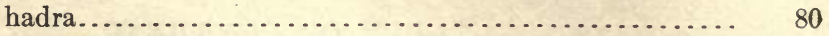

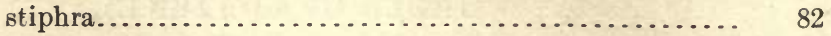

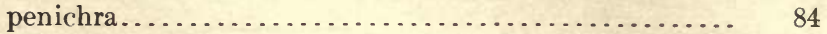

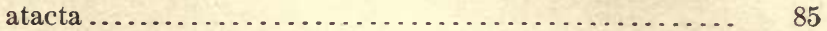

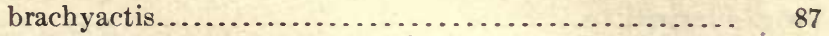

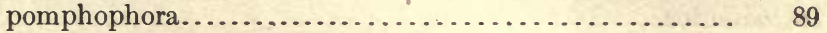

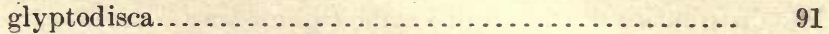

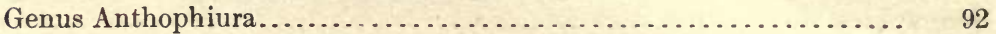

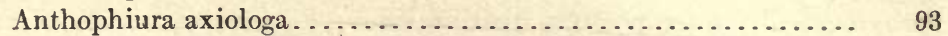

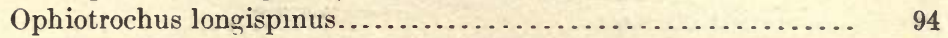

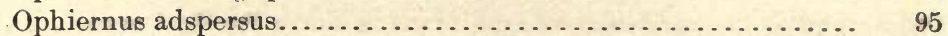

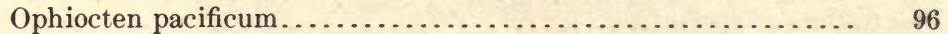

charischema............................. 97

brevispinum.......................... 98

oöplax.................................. 99

Genus Ophiopenia .................................. 102

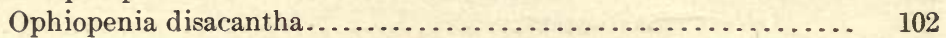

tetracantha..................................... 104

Ophiomusium cancellatum......................... 106

laqueatum............................... 106

lütkeni................................ 107

lunare............................ 107

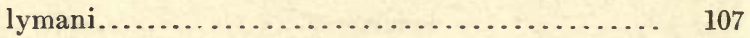

simplex............................ 109

trychnum.......................... 109

jolliensis............................... 111

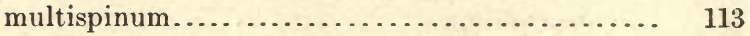

Family Amphiuridæ................................ 114

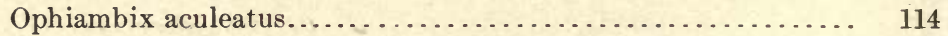

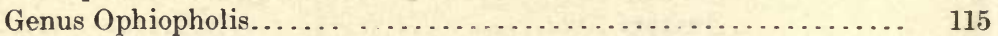

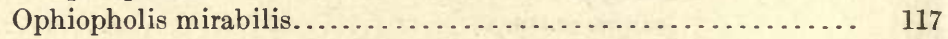

brachyactis........................... 117

longispina.......................... 119

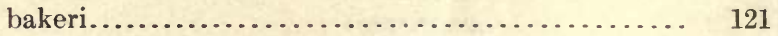

aculeata var. japonica.................... 123

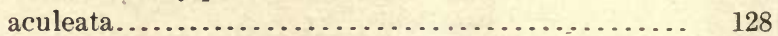

aculeata var. kennerlyi................... 132

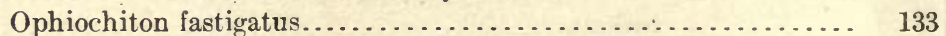

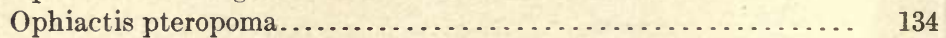

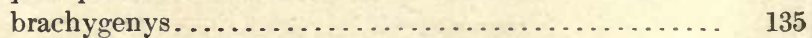

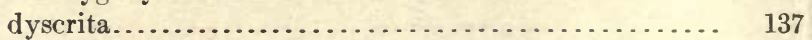

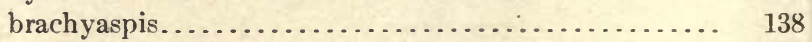

gymnochora................................ 139

Amphiura bellis................................... 140

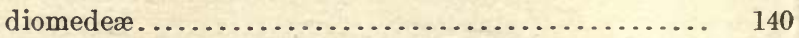

sundevalli............................... 141

carchara.................................. 142 
Descriptions of species-Continued.

Family Amphiuridæ-Continued.

Genus Amphiura-Continued. F'age.

Amphiura leptodoma............................... 143

euopla................................. 144

acrystata................................ 145

ecnomiotata................................ 148

trachydisca............................. 149

micraspis................................. 150

pycnostoma............................... 151

psilopora............................. 153

Amphiodia urtica............................... 154

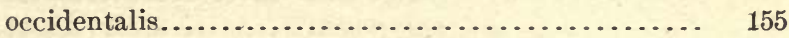

craterodmeta........................... 155

macraspis.............................. 157

euryaspis.............................. 158

periercta............................. 160

ancistrota............................... 161

digitula................................. 162

strongyloplax............................ 164

psilochora................................ 165

Amphipholis pugetana ............................. 166

Amphioplus rhadinobrachius......................... 167

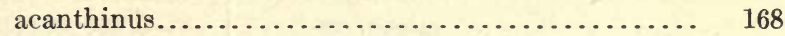

hexacanthus.......................... 170

megapomus............................... 170

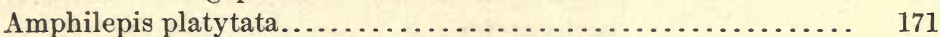

Amphilimna pentacantha.......................... 172

Ophionereis eurybrachiplax......................... 174

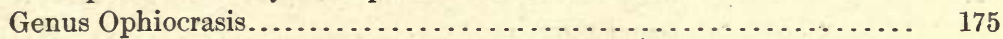

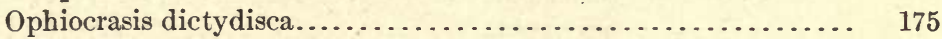

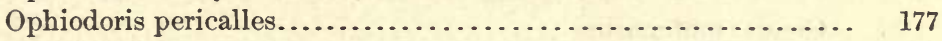

Family Ophiohelidæ.................................. 179

Ophiomitra cardiomorpha......................... 179

discycla.............................. 181

habrotata............................ 182

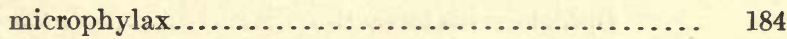

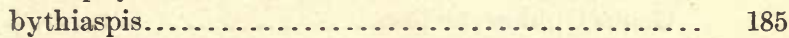

polyacantha........................... 187

codonomorpha............................ 188

acontophora............................... 190

Ophiocamax lithosora.............................. 191

polyploca.............................. 193

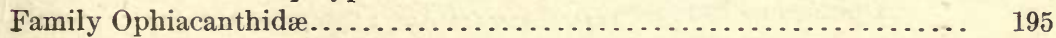

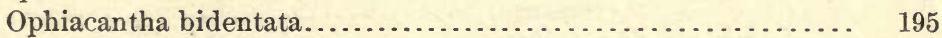

pentagona................................. 196

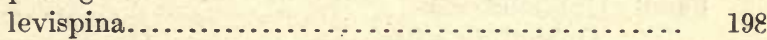

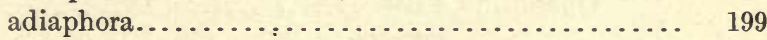

rhachophora............................. 201

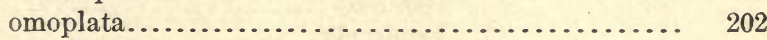

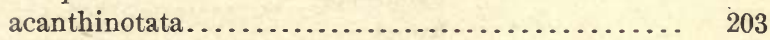

anchilabra............................... 204

trachybactra............................. 206

diploa.................................. 207 
Descriptions of species-Continued.

Family Ophiacanthidæ-Continued.

Genus Ophiacantha-Continued.

Page.

Ophiacantha inutilis.............................. 208

diplasia.................................. 209

enneactis................................ 211

prionota................................ 213

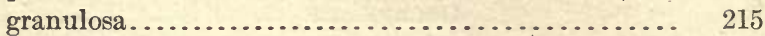

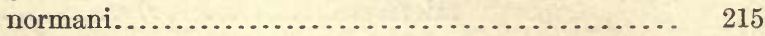

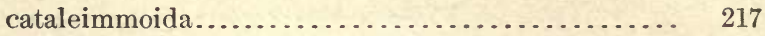

œdidisca................................. 219

leucorhabdota............................ 221

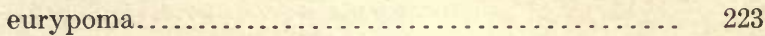

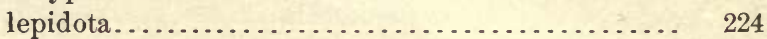

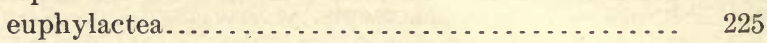

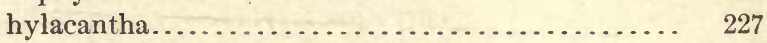

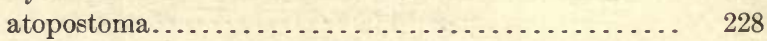

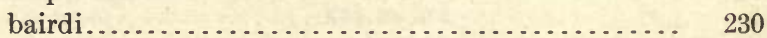

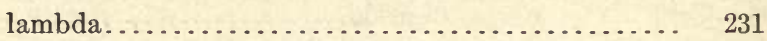

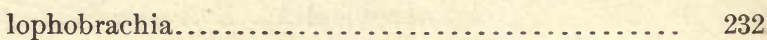

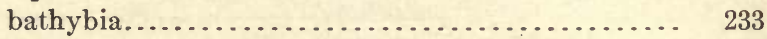

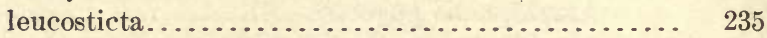

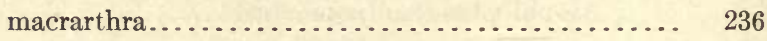

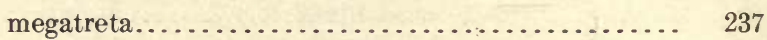

Ophiolebes asaphes................................. 239

brachygnatha............................ 240

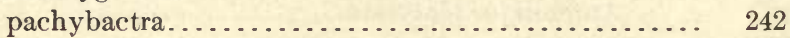

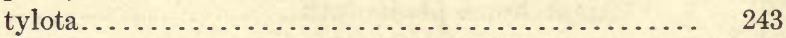

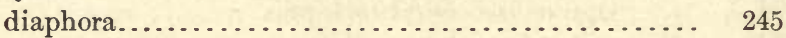

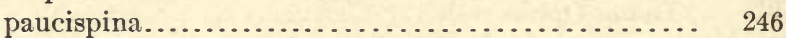

brevispina............................... 247

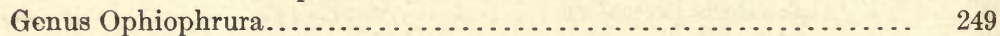

Ophiophrura liodisca................................ 249

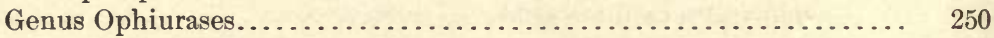

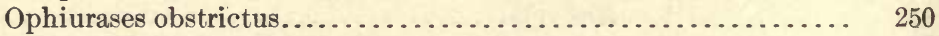

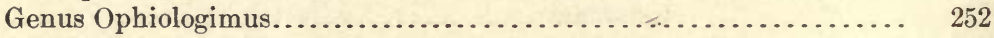

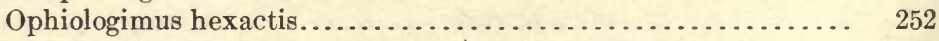

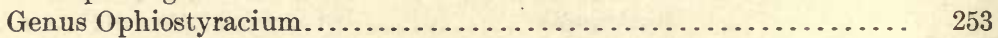

Ophiostyracium trachyacanthum........................ 253

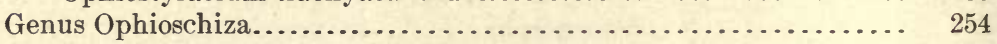

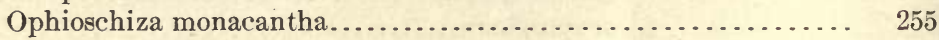

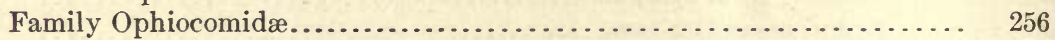

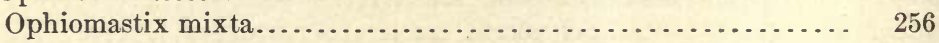

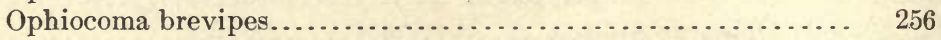

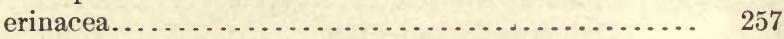

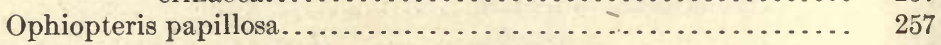

Family Ophiothricidæ.................................. 257

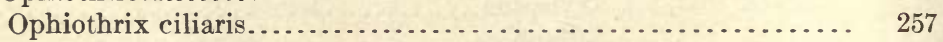

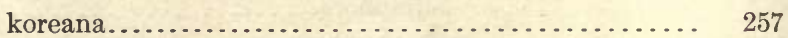

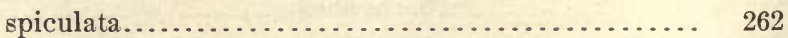

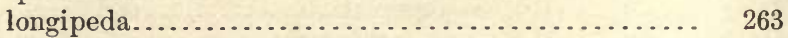

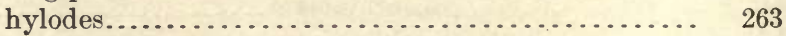

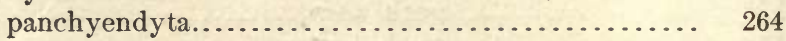

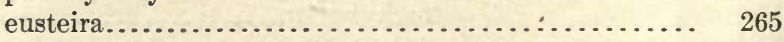

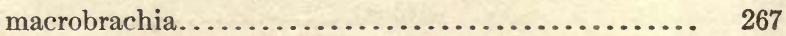


Descriptions of species-Continued.

Page.

Family Ophiomyxidæ.................................... ${ }_{269}$

Ophiobyrsa acanthinobrachia........................ 269

synaptacantha............................ 270

Ophiomyxa australis................................. 271

anisacantha.................................... 271

Genus Ophiophrixus................................. 272

Ophiophrixus acanthinus........................... 273

Genus Ophiocynodus................................ 274

Ophiocynodus corynetes........................... 274

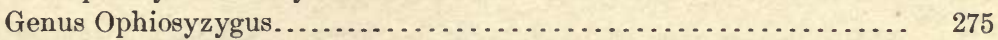

Ophiosyzygus disacanthus......................... 276

Genus Ophiohymen................................. 277

Ophiohymen gymnodiscus........................ 277

Genus Ophioleptoplax............................. 278

Ophioleptoplax megapora......................... 279

Family Astrophytidæ...................................... 280

Asteroporpa hadracantha............................ 280

Astrochele lævis................................... 281

Ophiocreas œedipus................................ 283

Astroceras pergamena............................... 284

Asteronyx loveni.................................... 285

Trichaster palmiferus................................. 287

Gorgonocephalus caryi............................... 287

sagaminus............................. 292

Astrophyton cornutum .................................. 293

pardalis.................................... 293

Euryale anopla................................... 294

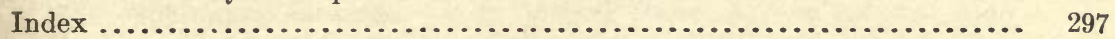





\section{LIST OF ILLUSTRATIONS.}

FIG. 1. Pectinura anchista. $\times$ 3.5. $a$, from above; $b$, from below; $c$, side view of three arm joints near disk.......................

2. Ophiarachnella megalaspsis. $\times 4$. $a$, from above; $b$, from below; $c$, side view of three arm joints near disk.................

3. Ophioconis diastata. $\times 6$. $a$, from above; $b$, from below; $c$, side view of three arm joints near disk........................

4. Ophioconis papillata. $\times 6$. $a$, from above; $b$, from below; $c$, side view of an arm joint near disk.........................

5. Ophioplocus japonicus. $\times 3$. $a$, from above; $b$, from below; $c$, side view of three arm joints near disk......................

6. Ophiozona elevata. $\times 6$. $a$, from above; $b$, from below; $c$, side view of three arm joints near disk.......................

7. Ophiozona platydisca. $\times 4$. $a$, from above; $b$, from below; $c$, side view of three arm joints near disk.......................

8. Ophiozona polyplax. $\times 3$. $a$, from above; $b$, from below; $c$, side view of two and a half arm joints near disk.................

9. Ophiura kinbergi. $\times 5$. Showing disk scaling and arm comb.....

10. Ophiura micracantha. $\times 4$. $a$, from above; $b$, from below; $c$, side view of two arm joints near disk.......................

11. Ophiura maculata; adult, $a-c \times 5$; young, $d-f \times 7$. $a$ and $d$, from above; $b$ and $e$, from below; $c$ and $f$, side views of arm joints near

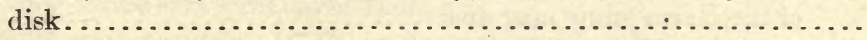

12. Ophiura leptoctenia. $\times 5$. $a$ from above; $b$, from below; $c$, side view of three arm joints near disk.......................

13. Ophiura quadrispina. $\times 5.5$. $a$, from above; $b$, from below; $c$, side view of two arm joints near disk.......................

14. Ophiura bathybia. $\times 3.3$. $a$, from above; $b$, from below; $c$, side view of three arm joints near disk.......................

15. Ophiura flagellata, young. $\times 6$. $a$, from above; $b$, from below; $c$, side view of two arm joints near disk....................

16. Ophiura clasta. $\times 3.5$. $a$, from above; $b$, from below; $c$, side view

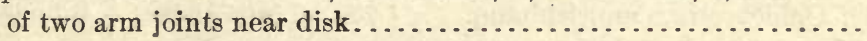

17. Ophiura monostœcha. $\times 5$. $a$, from above; $b$, from below; $c$, side view of three arm joints near disk.........................

18. Ophiura calyptolepis. $\times 4$. $a$, from above; $b$, from below; $c$, side view of two arm joints near disk.......................

19. Ophiura cryptolepis. $\times 2.5$. $a$, from above; $b$, from below; $c$, side view of two arm joints near disk........................

20. Ophiura nodosa; variety from Icy Cape, Alaska. $\times 6$. a, from above $b$, from below; $c$, side view of base of arm..................

21. Ophiura œdiplax. $\times 10 . a$, from above; $b$, from below; $c$, side view of three arm joints near disk....................... 
Fig. 22. Ophiura sterea. $\times 2.5$. $a$, from above; $b$, from below; $c$, side view

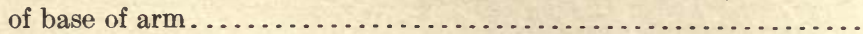

23. Ophiura megapoma. $\times 3 . a$, from above; $b$, from below; $c$, side view of three arm joints near disk.

24. Ophiura hadra. $\times 1.75$. $a$, from above; $b$, from below; $c$, side view

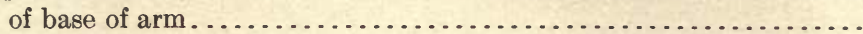

25. Ophiura stiphra. $\times 3$. $a$, from above; $b$, from below; $c$, side view of

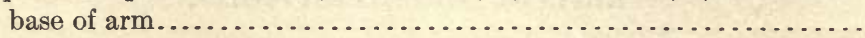

26. Ophiura penichra. $\times 2$. $a$, from above; $b$, from below; $c$, side view of three arm joints near disk.

27. Ophiura atacta. $\times 8$. $a$, from above; $b$, from below; $c$, side view of two arm joints near disk.............................

28. Ophiura brachyactis. $\times 3$. $a$, from above; $b$, from below; $c$, side

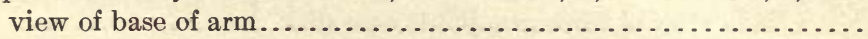

29. Ophiura pomphophora, adult. $\times 3.5 . \quad a$, from above; $b$, from below; $c$, side view of three arm joints near disk..................

30. Ophiura pomphophora, young. $\times 10 . \quad a$, from above; $b$, from below; $c$, side view of three arm joints near disk...................

31. Ophiura glyptodisca. $\times 8$. $a$, from above; $b$, from below; $c$, side view of three arm joints near disk.......................

32. Anthophiura axiologa. $\times 10$. $a$, from above; $b$, from below; $c$, side view of three arm joints near disk........................

33. Ophiotrochus longispinus. $\times 8$. $a$, from above; $b$, from below; $c$, side view of three arm joints near disk...................

34. Ophiernus adspersus. $\times 3.33 a$, from above; $b$, from below; $c$, side view of three arm joints near disk.........................

35. Ophiocten charischema. $\times 5$. $a$, from above; $b$, from below; $c$, side view of three arm joints near disk.........................

36. Ophiocten brevispinum. $\times 5.5$. $a$, from above; $b$, from below; $c$, side view of three arm joints near disk .................

37. Ophiocten oöplax. $\times 5$. $a$, from above; $b$, from below; $c$, side view

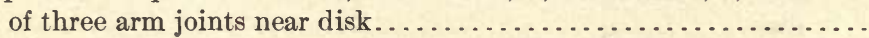

38. Ophiopenia disacantha. $a$, young, $\times 7 ; \mathrm{b}-\mathrm{d}$, adult, $\times 5$. $a$, from above; $b$, from above; $c$, from below; $d$, side view of three arm

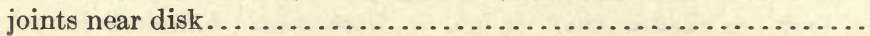

39. Ophiopenia tetracantha. $\times 8$. $a$, from above; $b$, from below; $c$, side view of three arm joints near disk.......................

40. Ophiomusium trychnum. $\times 3$. $a$, from above; $b$, from below; $c$, side view of two arm joints near disk....................

41. Ophiomusium jolliensis. $\times 2.5$. $a$, from above; $b$, from below; $c$, side view of three arm joints near disk .................

42. Ophiomusium multispinum. $\times 1.25 . \quad a$, from above; $b$, from below;

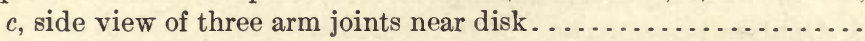

Page.

43. Ophiopholis mirabilis. $\times 3.5$. Base of one arm and adjoining portion of disk; from above..............................

44. Ophiopholis brachyactis. $\times$ 4.5. $a$, from above; $b$, from below; $c$, side view of two arm joints near disk...................

45. Ophiopholis longispina. $\times 5$. $a$, from above, $b$, from below; $c$, side

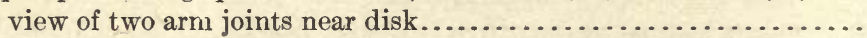

46. Ophiopholis bakeri. $\times 5$. $a$, from above; $b$, from below; $c$, side view

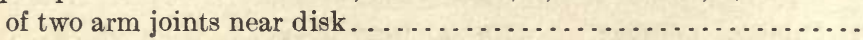


Fig. 47. Ophiopholis aculeata var japonica. $a$, extreme form with small supPage. plementary upper arm plates and numerous long disk spines, $\times 2.66$; $b$, more usual form with fewer disk spines, $\times 3.33$; $c$, unusual form with many disk scales resorbed, $\times 3.5$; $d$, typical form without disk

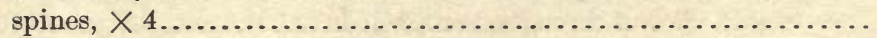

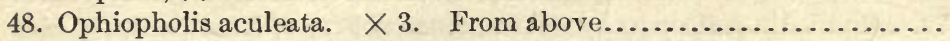

49. Ophiopholis aculeata var. kennerlyi. $\times 2.66$. From above........

50. Ophiactis pteropoma. $\times 10$. $a$, from above; $b$, from below; $c$, side

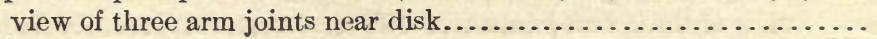

51. Ophiactis brachygenys. $\times 10 . \quad a$, from above; $b$, from below; $c$, side view of two arm joints near disk.........................

52. Ophiactis dyscrita. $\times 20$. $a$, from above; $b$, from below; $c$, side

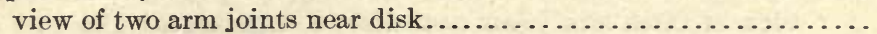

53. Ophiactis brachyaspis. $\times 16$. $a$, from above; $b$, from below; $c$, side view of three arm joints near disk.......................

54. Ophiactis gymnochora. $\times 10 . a$, from above; $b$, from below; $c$, side view of three arm joints near disk........................

55. Amphiura carchara. $\times 6$. $a$, from above; $b$, from below; $c$, side

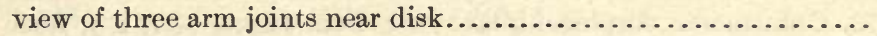

56. Amphiura leptodoma. $\times 15$. $a$, from above; $b$, from below; $c$, side

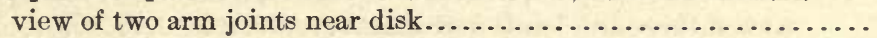

57. Amphiura euopla. $a-c, \times 5 ; d$, young, $\times 10$. $a$, from above; $b$, from below; $c$, side view of three arm joints near disk; $d$, side view of two

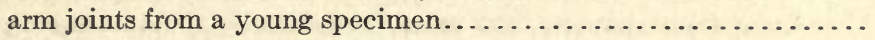

58. Amphiura acrystata. $a-f, \times 5 ; g-i, \times 4 ; a-c$, type. $a$, from above; $b$, from below; $c$, side view of two arm joints near disk; $d$, another specimen from above; $e$, from below; $f$, side view of two arm joints near disk; $g$, another specimen, from above; $h$, from below; $i$, side view of three arm joints near disk.......................

59. Amphiura ecnomiotata. $\times 8$. $a$, from above; $b$, from below; $c$, side

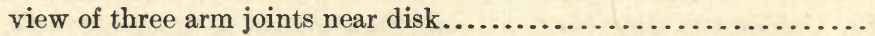

60. Amphiura trachydisca. $\times 4$. $a$, from above; $b$, from below; $c$, side view of two arm joints near disk.

61. Amphiura micraspis. $\times 12$. $a$, from above; $b$, from below; $c$, side view of three arm joints near disk; $d$, side view of an arm joint near

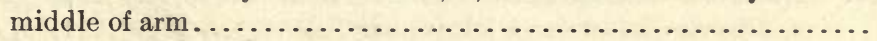

62. Amphiura pycnostoma. $\times 12$. $a$, from above; $b$, from below; $c$, side view of three arm joints near disk.........................

63. Amphiura psilopora. $\times 12$. $a$, from above; $b$, from below; $c$, side view of three arm joints near disk ..........................

64. Amphiodia urtica. $\times 6$. $a$, from above; $b$, from below; $c$, side view

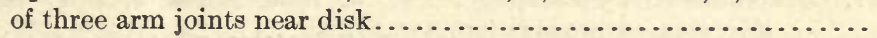

65. Amphiodia craterodmeta. $\times 6$. $a$, from above; $b$, from below; $c$, side view of three arm joints near disk.....................

66. Amphiodia macraspis. $\times 5$. $a$, from above; $b$, from below; $c$, side view of three arm joints near disk......................

67. Amphiodia euryaspis. $\times 4$. $a$, from above; $b$, from below; $c$, side

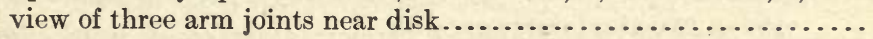

68. Amphiodia periercta. $\times 3.5$. $a$, from above; $b$, from below; $c$, side view of three arm joints near disk; $d$, a much younger specimen,

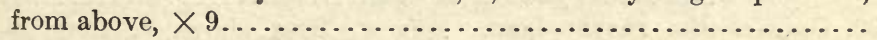

69. Amphiodia ancistrota. $\times 5$. $a$, from above; $b$, from below; $c$, side view of three arm joints near disk; $d$, next to the lowest arm spine, $\times 10$ 
Fic. 70. Amphiodia digitula. $\times 8$. $a$, from above; $b$, from below; $c$, side view of three arm joints near disk; $d$, outgrowths on upper end of

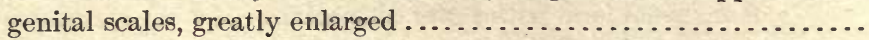

71. Amphiodia strongyloplax. $\times 9$. $a$, from above; $b$, from below; $c$, side view of three joints near disk........................

Page.

72. Amphiodia psilochora. $\times 6$. $a$, from above; $b$, from below; $c$, side view of three arm joints near disk.........................

73. Amphipholis pugetana. $\times 12$. $a$, from above; $b$, from below; $c$, side view of three arm joints near disk........................

74. Amphioplus rhadinobrachius. $\times 8$. $a$, from above; $b$, from below; $c$, side view of three arm joints near disk.....................

75. Amphioplus acanthinus. $\times 4$. $a$, from above; $b$, from below; $c$, side view of three arm joints near disk; $d$, regenerated disk and three regenerated arms....................................

76. Amphilepis platytata. $\times 6$. $a$, from above; $b$, from below; $c$, side view of three arm joints near disk.........................

77. Amphilimna pentacantha. $\times 5$. $a$, from above; $b$, from below; $c$, side view of three arm joints near disk...................

78. Ophionereis eurybrachiplax. $a-c$, from Japan, $\times 3$; $d-f$, from California, $\times 2$. $a$ and $d$, from above; $b$ and $e$, from below; $c$ and $f$, side view of three arm joints near disk.....................

79. Ophiocrasis dictydisca. $a-c, \times 7 ; d-g, \times 11$. $a$, from above; $b$, from below; $c$, side view of two arm joints near disk; $d$, a younger specimen, from above; $e$, the same, from below; $f$, side view of three arm joints near disk; $g$, another young specimen from above, showing the inequality of the two trios of arms.....................

80. Ophiodoris pericalles. $\times 4$. $a$, from above; $b$, from below; $c$, side view of three arm joints near disk........................

81. Ophiomitra cardiomorpha. $\times 4$. $a$, from above; $b$, from below; $c$, side view of two arm joints near disk....................

82. Ophiomitra discycla. $\times 9$. $a$, from above; $b$, from below; $c$, side view of two arm joints near disk........................

83. Ophiomitra habrotata. $\times 15$. $a$, from above; $b$, from below; $c$, side view of two arm joints near disk........................

84. Ophiomitra microphylax. $\times 6$. $a$, from above; $b$, from below; $c$, side view of two arm joints near disk...................

85. Ophiomitra bythiaspis. $\times 5$. $a$, from above; $b$, from below; $c$, side view of two arm joints near disk ........................

86. Ophiomitra polyacantha. $\times 8$. $a$, from above; $b$, from below; $c$, side view of two arm joints near disk.......................

87. Ophiomitra codonomorpha. $\times 4$. $a$, from above; $b$, from below; $c$, side view of two arm joints near disk....................

88. Ophiomitra acontophora. $\times 16 . a$, from above; $b$, from below; $c$, side view of three arm joints near disk..................

89. Ophiocamax lithosora. $\times 3$. $a$, from above; $b$, from below; $c$, side view of two arm joints near disk........................

90. Ophiocamax polyploca. $\times 3$. $a$, from above; $b$, fróm below; $c$, side view of two arm joints near disk.........................

91. Ophiacantha adiaphora. $\times 7$. $a$, from above; $b$, from below; $c$, side view of three arm joints near disk........................

92. Ophiacantha rhachophora. $\times 8$. $a$, from above; $b$, from below; $c$, side view of two arm joints near disk....................

93. Ophiacantha omoplata. $\times 8$. $a$, from above; $b$, from below; $c$, side view of two arm joints near disk....................... 
Fig. 94. Ophiacantha acanthinotata. $\times 6$. $a$, from above; $b$, from below; $c$, side view of two arm joints near disk...................

Page.

95. Ophiacantha anchilabra. $\times 6$. $a$, from above; $b$, from below; $c$, side view of two arm joints near disk.........................

96. Ophiacantha trachybactra. $\times 4$. $a$, from above; $b$, from below; $c$, side view of two arm joints near disk.....................

97. Ophiacantha diplasia. $\times 2.25$. $\quad \dot{a}$, from above; $b$, from below; $c$, side view of two arm joints near disk...........................

98. Ophiacantha enneactis. $\times 10$. $a$, from above, showing one arm nearly complete; $b$, from below; $c$, side view of three arm joints

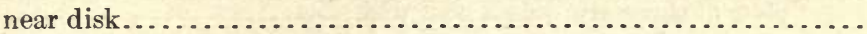

99. Ophiacantha prionota. $\times 5.5$. $a$, from above; $b$, from below; $c$, side view of two arm joints near disk ........................

100. Ophiacantha cataleimmoida. $\times 3$. $a$, from above; $b$, from below;

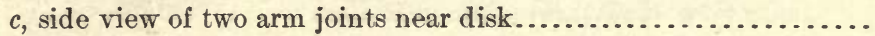

101. Ophiacantha œdidisca. $\times 5$. $a$, from above; $b$, from below; $c$, side view of three arm joints near disk.......................

102. Ophiacantha leucorhabdota. $\times 3$. $a$, from above; $b$, from below; $c$, side view of two arm joints near disk....................

103. Ophiacantha eurypoma. $\times 3.5$. $a$, from above; $b$, from below; $c$, side view of two arm joints near disk.....................

104. Ophiacantha lepidota. $\times 10$. $a$, from above; $b$, from below; $c$, side view of two arm joints near disk......................

105. Ophiacantha euphylactea. $\times 7$. $a$, from above; $b$, from below; $c$, side view of two arm joints near disk...................

106. Ophiacantha hylacantha. \4.5. $a$, from above; $b$, from below; $c$, side view of two arm joints near disk.....................

107. Ophiacantha atopostoma. $\times 5$. $a$, from above; $b$, from below; $c$, side view of two arm joints near disk....................

108. Ophiacantha lambda. $\times 5$. $a$, from above; $b$, from below; $c$, side view of two arm joints near disk........................

109. Ophiacantha lophobrachia. $\times 12$. $a$, from above; $b$, from below; $c$, side view of three arm joints near disk.....................

110. Ophiacantha bathybia. $\times 4$. $a$, from above; $b$, from below; $c$, side view of two arm joints near disk........................

111. Ophiacantha leucosticta. $\times 3$. $a$, from above; $b$, from below; $c$, three arm joints near middle of arm, seen from below; $d$, side view of two arm joints near disk ...........................

112. Ophiacantha macrarthra. $\times 25$. $a$, from above; $b$, from below; $c$, side view of two arm joints near disk.

113. Ophiacantha megatreta. $\times 2.25$. $a$, from below; $b$, side view of two arm joints near disk; $c$, upper view of three arm joints near middle

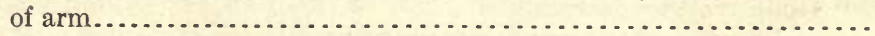

114. Ophiolebes asaphes. $\times 6$. $a$, from above; $b$, from below; $c$, side view of two arm joints near disk.........................

115. Ophiolebes brachygnatha. $\times 5$. $a$, from above; $b$, from below; $c$, side view of three arm joints near disk...................

116. Ophiolebes pachybactra. $\times 4.5$, from above; $b$, from below; $c$, side view of two arm joints near disk. ....................

117. Ophiolebes tylota. $\times 5$. $a$, from above; $b$, from below; $c$, side view of two arm joints near disk.

118. Ophiolebes diaphora. $\times 4.5$. $a$, from above; $b$, from below; $c$, side view of two arm joints near disk. 
Fı. 119. Ophiolebes paucispina. $\times 7$. $a$, from above; $b$, from below; $c$, side view of two arm joints near disk.

Page.

120. Ophiolebes brevispina. $a$, young specimen, from above, $\times 8$, $b$, adult, from above, $\times 6$. $c$, from below, $\times 6$. $d$, side view of

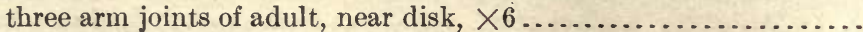

121. Ophiophrura liodisca. $\times 6$. $a$, from above; $b$, from below; $c$, side view of three arm joints near disk.......................

122. Ophiurases obstrictus. $\times 10$. $a$, from above; $b$, from below; $c$, side view of two arm joints near disk.........................

123. Ophiologimus hexactis. $\times 10$. $a$, from above; $b$, from below; $c$, side view of three arm joints near disk.......................

124. Ophiostyracium trachyacanthum. $\times 9$. $a$, from above; $b$, from below; $c$, side view of three arm joints near disk...............

125. Ophioschiza monacantha. $\times 9$. $a$, from above; $b$, from below; $c$,

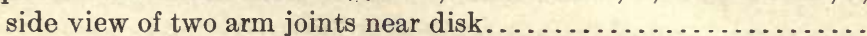

126. Ophiomastix mixta. $\times 3$. $a$, from above; $b$, from below; $c$, side view of two arm joints near disk........................

127. Ophiothrix koreana. $\times 3$. $a$, from above; $b$, from below; $c$, side view of two arm joints near disk..........................

128. Ophiothrix koreana. a, part of specimen from station 5055, from above, $\times 6 ; b$, part of specimen from station 4878 , from above, $\times 8 \ldots$

129. Ophiothrix spiculata. $\times 4.5$. $a$, from above; $b$, from below; $c$, side view of two arm joints near disk.........................

130. Ophiothrix hylodes. $\times 5$. $a$, from above; $b$, from below; $c$, side view of two arm joints near disk........................

131. Ophiothrix panchyendyta. $a$, from above, $\times 5 ; b$, from below, $\times 5$; $c$, side view of two arm joints near disk, $\times 5 ; d$, an upper arm plate, $\times 15 ; e$, an under arm plate, $\times 15 ; f$, a tentacle, $\times 15 \ldots \ldots \ldots \ldots$.

132. Ophiothrix eusteira. $\times 8$. $a$, from above; $b$, from below; $c$, side view of two arm joints near disk.......................

133. Ophiothrix macrobrachia. $\times 4.5$. $a$, from above; $b$, from below; $c$, side view of two arm joints near disk....................

134. Ophiobyrsa acanthinobrachia. $\times 2.5$. $a$, from above; $b$, from below; $c$, side view of two arm joints near disk.....................

135. Ophiobyrsa synaptacantha. $\times 4$. $a$, from above; $b$, from below; $c$, side view of three arm joints near disk....................

136. Ophiomyxa anisacantha. $\times 2.5$. $a$, from above; $b$, from below; $c$, side view of two arm joints near disk...................

137. Ophiophrixus acanthinus. $\times 4$. $a$, from above; $b$, from below; $c$, side view of two arm joints near disk...................

138. Ophiocynodus corynetes. $\times 2$. $a$, from above; $b$, from below; $c$,

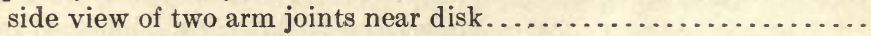

139. Ophiosyzygus disacanthus. $\times 3$. $a$, from above; $b$, from below; $c$, side view of two arm joints near disk ....................

140. Ophiohymen gymnodiscus. $\times 6$. $a$, from above; $b$, from below; $c$, side view of two arm joints near disk....................

141. Ophioleptoplax megapora. $\times 8$. $a$, from above; $b$, from below; $c$,

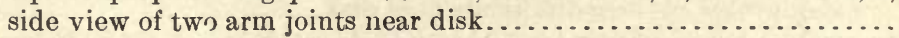

142. Asteroporpa hadracantha. $\times 7$. $a$, from above; $b$, from below; $c$, side view of three arm joints near disk.....................

143. Astrochele laevis. $\times 2.5$. $a$, from above; $b$, from below; $c$, side view of three arm joints near disk.........................

144. Euryale anopla. $\times 1.5$. $a$, from above; $b$, from below; $c$, side view

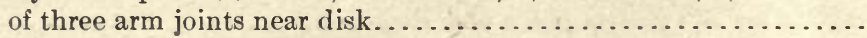




\title{
NORTH PACIFIC OPHIURANS IN THE COLLECTION OF THE UNITED STATES NATIONAL MUSEUM.
}

\author{
By Hubert Lyman Clark, \\ Of the Museum of Comparative Zoölog!, Cambridge, Mass.
}

\section{INTRODUCTION.}

The collection of Echinoderms made in Japanese waters by the U.S. Bureau of Fisheries steamer Albatross in 1900 was placed in my hands soon after its return to this country, and a preliminary examination showed that the Ophiuroidea formed the largest and perhaps the most interesting section of it. Various circumstances interfered with the completion of a report at that time, so that the collection was still in my hands when, in 1907, I was asked to undertake the study of the much more important and extensive series of ophiurans collected by the Albatross in 1906. After that work was well under way, Doctor Rathbun, of the National Museum, requested me to take over the entire series of North Pacific ophiurans in that museum and make my report inclusive of all three collections. It was agreed to make lat. $35^{\circ} \mathrm{N}$. the southern limit on the American coast, of the oceanic area to be covered by the report, and lat. $30^{\circ} \mathrm{N}$. the southern limit on the Asiatic coast. As a result of this arrangement there has been confided to my care an extraordinary amount of material, consisting of over 40,000 ophiurans, representing about 190 species. The great bulk of these were collected by the Fisheries steamer Albatross during her various voyages to and from Alaska, Bering Sea, and Japan, but there is also much material from Alaska collected by a number of different naturalists, some of it more than forty years ago. There are also some very valuable specimens collected by the United States exploring expedition in Japan half a century ago.

In view of the fact that very little work has ever been done on the ophiurans of the North Pacific, it is not strange that a very large percentage of the species in this collection proves to be undescribed. Since the publication of Lyman's monograph, based on the Challenger ophiurans, the number of known species has increased from 450 to over 1,100. Aside from a number of less important papers, Lyman's $34916^{\circ}-$ Bull. $75-11-1$ 
report on the Blake ophiurans (1883), Brock's work on East Indian species (1888), Lütken and Mortensen's report on the Albatross Panamic ophiurans (1899), and, more recently, the great works of Kohler on the ophiurans of the Travailleur and Talisman, of the Investigator and of the Siboga, have added enormously to the list of known species. Unfortunately, however, no one has attempted to coördinate this mass of material with that contained in the Challenger report, and as a result it is exceedingly difficult at the present day to determine exactly what species are really valid, or to decide whether a given specimen belongs to a known species or not. There can be little doubt that when our present knowledge is finally systematized, some, if not many, of the species here described as new will prove to belong to known forms, though an honest endeavor has been made to avoid the needless production of new names. Every one who has done any work on ophiurans knows how difficult it is to grasp a mere description without figures, even though it be very full and accurate. I am therefore very grateful that the authorities of the National Museum have approved of the extensive illustrating of this report. And I take pleasure in acknowledging, also, with sincerest gratitude, the patience and skill with which Miss Violet Dandridge has made the figures.

The classification of the Ophiuroidea as it stands to-day is little short of absurd. Not for over thirty years has any attempt been made to put it on a rational basis. Lyman never pretended to offer any classification of the group, though the material for a thoroughly scientific one was put into the generic descriptions and the plates of the Challenger report. His knowledge of ophiuran morphology was extraordinary and had not illness and death cut short his career, he might have given us a natural and satisfactory arrangement of the class. Since his day no zoölogist has devoted himself to the subject with sufficient concentration to warrant the attempt to set forth a rational classification, and consequently I find myself obliged to follow, in this report, a classification based on a compilation of the work of Lyman and some of his successors. The families which are adopted are of very unequal value and their limits are generally hazy. In fact it is difficult to discover any reason why certain genera are placed where they are rather than in another family. For example the genus Ophioconis is placed in the Ophiodermatidæ, although it is practically indistinguishable from Ophiacantha. Any limitation of the Ophiacanthidæ which excludes Ophioconis must exclude also a number of species of Ophiacantha and even of Ophiomitra. The last genus, by the way, can not be separated from Ophiacantha by any natural lines, so long as the two are used in the present broad sense, and yet in the current classification they are placed in different families. Lack of time as well as lack of knowledge compelled me to abandon any at- 
tempt in this report to present an improved classification of the Ophiuroidea, but it is at least permissible for me to make this protest against the one which I am obliged to use.

One of the principal reasons why the ophiurans are such a difficult group to classify is found in our ignorance of their growth changes. It has been recognized for some time that the number of arm spines and oral papillæ often increases with age, and Lyman called attention in the Challenger report to other changes which he had noted, particularly in Ophiactis and Ophiacantha. What is needed is a detailed study of the growth changes in some one species of each family, bringing out just what characters are evidences of immaturity. Ludwig, in his Jugendformen von Ophiuren ${ }^{a}$ has made an excellent beginning for a number of the viviparous species, but such work needs to be carried much further.

The study of this collection has satisfied me that Jackson's ${ }^{b}$ law of "localized stages" is a very real help in determining the possible relationship between small and large individuals of the same genus. For the ophiuran arm reveals at and near the tip the characters of youth and one can thus compare the base of the arm of a small specimen with the middle or tip of the arm of a large individual with most suggestive results. The extent to which the youthful characters are localized varies with different species, but as a rule they are sufficiently clear to make comparisons conclusive.

Another interesting matter is variation in the extent of calcification or of resorption of calcareous matter, which many species of ophiurans, especially in the family Amphiuridæ, reveal. As a rule, calcification progresses more or less steadily from youth on, so that old individuals are much heavier and more solid, relatively, than young ones. This is especially true in the Ophiolepididæ, where the increase may be shown not only by the heavier plates but by lumps and swellings upon the plattes, wanting or only faintly indicated in young individuals. In the Amphiuridæ and a few species of Ophiura, however, it is often true that resorption exceeds the deposit of lime, and as a result the old individuals may have most of the disk scales and even the margins of the basal arm plates extensively, if not completely, resorbed. In such species, while a small specimen will have the disk well covered with scales, both above and below, larger individuals have the interbrachial spaces below entirely bare, and old ones may have no disk scales at all except just around the radial shields. Other factors than that of age appear to enter into the matter, however, for individuals of the same size may reveal great differences in the amount of calcification. It seems quite possible that external factors, such as food, composition of the sea water, character of the bottom, etc., may be the

$b$ R. T. Jackson, Mem. Boston Soc. Nat. Hist., vol. 5, 1899, p. 4. 
essential ones in determining the relative rates of calcification and resorption.

The total number of species included in the present report is 189 , of which 129 are here described for the first time. The number of genera represented is 51 , of which 12 seem to be entirely new, and one other has been formed for a previously known species. At the same time, the large amount of material available has enabled me to satisfy myself that a number of species, hitherto accepted as valid, are really identical with others either of earlier date or from which, owing to insufficient material, they were supposed to be distinct. In this way no less than fourteen names are relegated to the ranks of synonyms. As many of the supposedly new North Pacific species are represented by only a few specimens, often by only a single one and that in poor condition, I have hesitated much over giving them names, but have concluded that as a matter of convenience to later writers it is better to designate them definitely, even though ultimately some of the names have to be abandoned.

In a few cases the question has arisen whether subspecies should be recognized or not, but it has been invariably answered in the negative, as our knowledge of ophiurans, their variation and their distribution, is as yet too imperfect to permit any wise use of subspecific names. The situation is somewhat different as regards varietal names, and I have made use of two such in connection with the widely spread Ophiopholis aculeata which appears in the northern Pacific in an extraordinary array of dissimilar forms. As no one of the forms appears to be characteristic of a particular region it would be inaccurate to regard any of them as subspecies, but as two of them are very common and easily recognized they are treated as varieties of the typical form.

A few details in regard to the collection may be of interest, even if not of great scientific importance, and I venture to add them here. Although there are altogether 189 species (and the two varieties of Ophiopholis aculeata referred to in the preceding paragraph), yet more than three-fourths of the specimens are furnished by the following five species:

\begin{tabular}{|c|c|c|}
\hline Species. & $\begin{array}{l}\text { Speci- - } \\
\text { mens. }\end{array}$ & $\begin{array}{c}\text { No. of } \\
\text { different } \\
\text { stations } \\
\text { where } \\
\text { taken. }\end{array}$ \\
\hline ophiura sarsii ......... & 20,932 & 164 \\
\hline Ophiopholis aculeata (including the two varieties & 4,192 & 166 \\
\hline 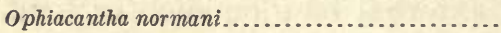 & 4,056 & 44 \\
\hline Ophiura leptoctenia $\ldots \ldots \ldots \ldots \ldots \ldots \ldots$ & 2,037 & 47 \\
\hline ophiura nodosa ...................... & 1,067 & 46 \\
\hline Total.. & 32,284 & \\
\hline
\end{tabular}


Four other very common species are represented by more than 300 specimens each:

\begin{tabular}{|c|c|c|}
\hline 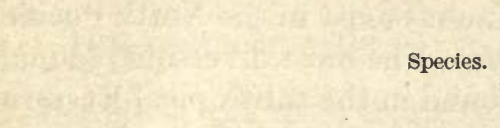 & $\begin{array}{l}\text { Speci- } \\
\text { mens. }\end{array}$ & $\begin{array}{l}\text { No. of } \\
\text { different } \\
\text { stations } \\
\text { where } \\
\text { taken. }\end{array}$ \\
\hline Ophiura lütkeni............... & 658 & 24 \\
\hline Asteronyx loveni................. & 498 & 32 \\
\hline 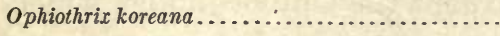 & 411 & 56 \\
\hline Gorgonocephalus caryi............... & 304 & 105 \\
\hline
\end{tabular}

There are 559 different stations represented in the collection, but at 218 of these only a single species of ophiuran was taken and at 141 other stations only two species occurred. There are 14 stations at which ten or more species were collected. The average number of species to the station is 2.6, but if there is left out of the account those at which only one or two species were taken the average number rises to 4.8. The largest number of species taken at any one station was at station 4893 , which is southwest of the Goto Islands in the Eastern Sea. Here, at a depth of about 100 fathoms, with a bottom temperature of $55.9^{\circ}$, the following seventeen species were found:

Ophiarachnella megalaspis.

Ophiozona elevata.

Ophiozona projecta.

Ophiura sculpta.

Ophiocten charischema.

Ophiomusium simplex.

Ophiodoris pericalles.

Ophiomitra habrotata.

Ophiocamax polyploca.
Ophiacantha pentagona.

Ophiacantha rhachophora.

Ophiacantha normani.

Ophiurases obstrictus.

Ophiothrix koreana.

Ophiothrix macrobrachia.

Ophiomyxa anisacantha.

Astroceras pergamena.

This is a much larger number of species than was taken at any one of the Challenger stations, but it does not equal the famous haul made by the Hassler off Barbados in 100 fathoms, when twenty species of ophiurans were taken, and it is far behind the record established by the Blake at her station 269, off St. Vincent, British West Indies, in 124 fathoms, where twenty-three species of fifteen genera, were collected. ${ }^{a}$ It is interesting to note that warm water is not essential, however, to a large and diversified ophiuran fauna, for the next largest number of species taken at one spot was at station 4781 , which is near Agattu Island, Aleutians, in 482 fathoms with a bottom temperature of $38.6^{\circ}$. Here sixteen species were taken, representing

a This record was equaled by the Siboga near the Ki Islands, at station 251, where in 114 fathoms, twenty-three species were taken, representing sixteen genera. But while the Blake took a twenty-fourth species at its next station (270), the Siboga found no other ophiurans in the immediate vicinity of its best haul. 
nine genera; none of the species is identical with any taken at station 4893 , but six of the genera are.

The collections made at the stations in a given district indicate that remarkably diversified ophiuran faunas exist in the North Pacific Ocean under widely different conditions. The most diversified fauna, as we might naturally expect, is that found in the subtropical Eastern Sea, off Kagoshima Gulf, where, on August 16, thirty species were taken at stations 4933-4939. These thirty species represented twenty-one genera and every family except the Ophiocomidæ, which, however, doubtless occurs in the region; eighteen of the species and one of the genera were previously unknown. Quite a different fauna exists about the western end of the Aleutian chain of islands, where, at stations 4781-4784, twenty-one species were found. Here, however, there are only ten genera represented and the families Ophiodermatidæ, Ophiocomidæ, Ophiothricidæ, and Ophiomyxidæ are wholly wanting. Thirteen of the species were previously unknown. Sagami Bay demonstrated anew the extraordinary richness of its marine fauna by revealing twenty-nine species of ophiurans at stations 5085-5095, while eleven other species were taken just outside at stations 5083 and 5084. But these forty species represent only sixteen genera and nineteen of the forty were previously known. The fauna of Sagami Bay is not therefore quite so diversified as that off Kagoshima Gulf.

In the descriptions of the new species I have thought it better to give an estimate as to the length of the arms, even though they may be all broken in the type-specimen, than to leave that important point in doubt. Where the measurement is given without qualification it may be understood to represent the actual measurement of an unbroken, normal arm, but when the word "about" precedes the figures given, it indicates that the measurement is based on a careful calculation from data furnished by other specimens. The addition of the word "probably" shows that satisfactory data for calculation were lacking and the measurement is therefore quite open to question. The number of arms is five in all cases, unless there is direct assertion of some other number being present.

The type-specimens of all the new species described are in the collection of the U. S. National Museum, Washington, but cotypes of more than two-thirds of them are in the Museum of Comparative Zoölogy, Cambridge.

For the pleasure and profit of studying this great collection I desire to extend my sincere thanks to the Hon. George M. Bowers and Dr. H. M. Smith of the Bureau of Fisheries, and to Dr. Richard Rathbun of the U. S. National Museum. For the collaboration of an excellent artist, Miss Violet Dandridge, and for many other 
courtesies in the preparation and publication of this report I am indebted to the National Museum, and for many helpful suggestions to Doctor Rathbun and Miss Mary J. Rathbun.

\section{THE DISTRIBUTION OF THE NORTH PACIFIC OPHIUROIDEA.}

Doubtless the most interesting result of the study of the mass of material which has just passed through my hands is found in the light which it throws on the distribution of the species of ophiurans with reference to the shore lines, to the depth and temperature of the water, and to each other.

GEOGRAPHICAL DISTRIBUTION.

The great bulk of the collection is made up of species from southern Japan, no less than 112 of the 189 species (60 per cent) being nearly or quite confined to that region, at least so far as the present collection reveals their distribution. As a good example of this group may be cited Ophiura sterea, which was taken at fourteen stations on both the eastern and western coasts of Japan as far north as $38^{\circ}$. On the eastern coast few of these 112 southern species extend beyond lat. $38^{\circ} \mathrm{N}$. and most of them seem to find their northern limit in or near Sagami Bay. On the western coast, however (i. e., in the Sea of Japan), they apparently extend somewhat farther north, as far as Tsugaru Strait (nearly $42^{\circ}$ ) and occasionally farther, even beyond the forty-third parallel. Yet nearly one-third of the 112 southern species were not taken on either coast north of the thirty-third parallel and do not appear to enter the Sea of Japan nor to extend up the east coast of Honshu Island. A large group of species which do not extend into the Sea of Japan do follow the southeastern coast of the islands as far as Suruga Gulf. On the other hand, there are very few species which occur in the Sea of Japan which do not also occur in Suruga Gulf or Sagami Bay, so that the ophiuran fauna of the Sea of Japan is apparently far less varied than that of the Pacific shores of Honshu, Shikoku, and Kiusiu islands. There can be no question that this very rich ophiuran fauna of southern Japan is closely allied to the still richer East Indian fauna, although it is far from identical with it, for scarcely a dozen of the 112 species comprising the Japanese fauna have yet been taken in the East Indian region. While there is little reason to doubt that further collecting will-show a much larger number of species common to the two regions, it seems both proper and desirable to recognize the assemblage of species around southern Japan as a distinct group, which we may conveniently call the HoNshu fauna.

Aside from this Honshu fauna; the largest assemblage of species from a given district is shown at the opposite extreme of the area 
explored, by the Albatross, namely, the vicinity of the Aleutian Islands and northward. As this group is particularly characteristic of Bering Sea, it may well be called the Bering fauna. It is made up of some twenty-four species, of which Ophiura maculata may be cited as a typical example; this species is represented in the collection from eighteen different stations, of which the farthest north is about lat. $71^{\circ} \mathrm{N}$., the farthest south at $52^{\circ}$, the farthest east is about long. $166^{\circ} \mathrm{W}$., and the farthest west near long. $159^{\circ} \mathrm{E}$. It will be noted that these limits are practically those of Bering Sea itself, except to the northward, where several of the twenty-four species extend into the Arctic Ocean. Two of the twenty-four were taken as far east as long. $136^{\circ} \mathrm{W}$., but only in water exceeding 1,500 fathoms in depth; none of the others were found east of $148^{\circ}$ and only one east of Kadiak. To the southwestward, however, we find three species extending their range along the Kurile Islands into the Okhotsk Sea.

Connecting the Honshu and Bering faunas are a group of sixteen species, which either range from Bering Sea southwestward into the sea of Japan or southeastward below lat. $52^{\circ} \mathrm{N}$., or else have been taken as yet only in the vicinity of Sakhalin or the Hokkaido. As a rule, however, it is easy to see with which fauna these species are naturally allied, and the following list is an attempt to assign each to its proper place:

Ophiura brachyactis. Bering fauna; indicated by its occurrence only in extremely cold water in the Okhotsk Sea.

Ophiura flagellata. Probably neither Bering nor Honshu, but more properly regarded as Oceanic. (See below.)

Ophiura irrorata. Like $O$. flagellata.

Ophiura penichra. Honshu fauna; indicated by relationship to sterea and the locality where taken, south of the Hokkaido.

Ophiura quadrispina. Bering fauna, but extending southwestward into the northern part of the Sea of Japan.

Ophiopenia disacantha. Bering fauna, rarely extending into the Sea of Japan.

Ophiopholis mirabilis. Honshu fauna; indicated by its temperature range.

Amphiodia craterodmeta. Bering fauna, rarely extending into the Sea of Japan.

Ophiacantha adiaphora. Bering fauna; indicated by temperature range; rarely extending southward to Sea of Japan and Sagami Bay.

Ophiacantha bathybia. Bering fauna; indicated by temperature range; extending southward to $51^{\circ}$.

Ophiacantha bidentata. Bering fauna; indicated by temperature range; extending southward into the Sea of Japan.

Ophiacantha cataleimmoida. Bering fauna, extending southward on the east coast of Japan.

Ophiacantha rhachophora. Completely connects the two faunas and can not be assigned certainly to either one.

Ophiolebes asaphes. Bering fauna; indicated by temperature range and by distribution of its related species.

Ophiolebes brachygnatha. Bering fauna.

Ophiolebes tylota. Bering fauna, rarely extending into the Sea of Japan. 
Leaving Ophiura flagellata and $O$. irrorata to be considered later, we find that with the single exception of Ophiacantha rhachophora it is possible to assign each of the above species to its proper fauna, and by so doing it appears that of the total 189 species 114 , or more than 60 per cent, belong to the Honshu fauna and 35 , or 18.5 per cent, belong to the Bering fauna. The two faunas therefore include about four-fifths of the species collected.

The next most important group of species is made up of those which occur throughout the entire North Pacific or which have been taken at such widely separated stations, it seems most probable that such is their distribution. There are fourteen species in this group, as follows:

Ophiura sarsii. From $55^{\circ} 59^{\prime}$ N. to $32^{\circ} 27^{\prime}$ N. in the Eastern Sea and to Monterey on the California coast; 5 to 695 fathoms.

Ophiura leptoctenia. From $55^{\circ} 35^{\prime} \mathrm{N}$. to $33^{\circ} 35^{\prime} 20^{\prime \prime}$ on the eastern coast of Japan and to $47^{\circ} 22^{\prime}$ on the American coast; 67 to 1,771 fathoms.

Ophiura cryptolepis. From $58^{\circ} 17^{\prime} \mathrm{N}$. to $34^{\circ} 10^{\prime} 30^{\prime \prime}$ on the Japanese coast and to $47^{\circ}$ $29^{\prime} 30^{\prime \prime}$. on the American; 230 to 636 fathoms.

Ophiura ponderosa. From $58^{\circ} 17^{\prime} \mathrm{N}$. to $48^{\circ} 43^{\prime} 30^{\prime \prime}$ on the Asiatic coast and to $36^{\circ} 49^{\prime}$ $20^{\prime \prime}$ on the American; 75 to 456 fathoms.

Ophiocien pacificum. From $51^{\circ} 23^{\prime}$ N. to $34^{\circ} 4^{\prime} 20^{\prime \prime}$ on the Japanese coast and to $45^{\circ}$ $30^{\prime}$ on the American; 501 to 876 fathoms.

Ophiomusium lymani. From $52^{\circ} 29^{\prime}$ to $30^{\circ} 59^{\prime}$ on the Japanese coast and to $47^{\circ} 22^{\prime}$ on the American; 70 to 1,588 fathoms.

Ophiomusium jolliensis. From $45^{\circ} 9^{\prime} 35^{\prime \prime}$ N. to $33^{\circ} 35^{\prime} 20^{\prime \prime}$ on the Japanese coast and to $36^{\circ} 49^{\prime} 20^{\prime \prime}$ on the American; 167 to 505 fathoms.

Ophiopholis aculeata and varieties. From $58^{\circ} \mathrm{N}$. to middle Japan and California; shore to 1,030 fathoms.

Amphiura carchara. From $56^{\circ} 55^{\prime}$ N. to $35^{\circ} 9^{\prime} 40^{\prime \prime}$ on the Japanese coast and to $47^{\circ} 25^{\prime}$ $30^{\prime \prime}$ on the American; 60 to 1,973 fathoms.

Amphiodia euryaspis. From $54^{\circ} 36^{\prime} 30^{\prime \prime}$ N. to $36^{\circ} 6^{\prime} 5^{\prime \prime}$ on the Japanese coast and to $36^{\circ} 44^{\prime} 45^{\prime \prime}$ on the American; 68 to 318 fathoms.

Ophiacantha normani. From $58^{\circ} 17^{\prime} \mathrm{N}$. to $32^{\circ} 32^{\prime}$ on the Japanese coast and to $45^{\circ} 9^{\prime}$ $35^{\prime \prime}$ on the American; 40 to 987 fathoms.

Ophicantha bairdi. From $54^{\circ} 32^{\prime}$ N. to $33^{\circ} 53^{\prime}$ N. on the Japanese coast and to $47^{\circ} 29^{\prime}$ $30^{\prime \prime}$ on the American; 344 to 943 fathoms.

Asteronyx loveni. From $57^{\circ} \mathrm{N}$. to $34^{\circ}$ on the Japanese coast and to $36^{\circ} 41^{\prime} 50^{\prime \prime}$ on the American; 83 to 918 fathoms.

Gorgonocephalus caryi. From $59^{\circ} 22^{\prime}$ N. to $30^{\circ} 57^{\prime} 20^{\prime \prime}$ on the Japanese coast and to $37^{\circ}$ $21^{\prime}$ on the American; 8 to 578 fathoms.

An examination of this list reveals some very interesting facts. Of the fourteen species nine were previously known, and six of these from outside the North Pacific region, as here restricted; five are known from the Atlantic Ocean. All of the fourteen show a considerable bathymetrical range; ten occur in less than 100 fathoms, while all are found at depths exceeding 300 fathoms; three have a bathymetrical range of over 1,500 fathoms. With only one exception these species extend farther south on the Asiatic than on the American coast. As would naturally be expected, nearly all have 
a considerable temperature range; all occur in water colder than $40^{\circ} \mathrm{F}$., and seven were found in water below $32^{\circ}$, yet six live in water warmer than $50^{\circ}$. These facts all go to show that we have here a group of hardy, adaptable species, able to live and apparently to prosper under very diverse conditions. Such a group may appropriately be spoken of as the OCEANIC fauna. To this fauna may well be assigned four other species, whose range is more discontinuous than that of the species just discussed, but which probably belong, nevertheless, to the same group. Two of the four have already been referred to in connection with the list of species joining the Honshu and Bering faunas. In placing them in the Oceanic fauna $\mathrm{I}$ am, of course, influenced by their known distribution outside of the North Pacific area.

Ophiura flagellata. From $54^{\circ} 33^{\prime} 30^{\prime \prime} \mathrm{N}$. to $9^{\circ} 3^{\prime} 24^{\prime \prime} \mathrm{N}$. on the coast of India; 53 to 876 fathoms.

Ophiura irrorata. From $55^{\circ} 23^{\prime} \mathrm{N}$. to New South Wales, 600 to 2,200 fathoms.

The other two species to be added to the Oceanic fauna are-

Ophiernus adspersus. From $33^{\circ} 25^{\prime} 20^{\prime \prime} \mathrm{N}$. to Cape Comorin, India, to $10^{\circ} 21^{\prime} \mathrm{S}$. between Sumba and Timor, and to the Galapagos Islands; 244 to 1,997 fathoms.

Amphiura diomedex. From $36^{\circ} 46^{\prime}$ N. to $9^{\circ} 3^{\prime} 24^{\prime \prime}$ S., between Sumba and Flores and to Galera Point, Ecuador; 39 to 1,573 fathoms.

To the Oceanic fauna then, eighteen species are here assigned.

There are four species (Amphiura acrystata, Amphiodia macraspis, Amphioplus hexacanthus, Ophionereis eurybrachiplax), which are reported from off the coast of California or Washington, although most of the specimens were taken in Japanese waters. In the present condition of our knowledge it is impossible to give the exact faunal position of these species, but I am inclined to consider them as members of the Honshu fauna, whose range as far as American waters is open to some doubt.

An interesting group of eight species occurs on the coasts of Washington, Oregon, and California, and has not been found north of the fifty-second parallel. One of these (Ophiopteris papillosa) is a southern species which barely enters the region included in this report. ${ }^{a}$ Of the others, four previously unknown species were taken at only a single station each and may perhaps also be southern species. They are-

Ophiomusium multispinum.

Amphilimna pentacantha.

Amphiodia strongyloplax.

Ophiocynodus corynetes.

The three remaining species, which were taken at a number of stations and seem to be characteristic of the region, are-

Ophiopholis longispina.

Ophiacantha diplasia.

Ophiopholis bakeri.

a Although Ophiothrix spiculata is recorded in this report from Alaska it, too, is unquestionably a southern species. The Alaskan record is almost certainly a mistake. 
It is probable that this trio is not an example of a special fauna, but belongs properly with the following group of species, which range from Alaska southward along the American coast and do not occur in the western Pacific:

Ophiura lütkeni.

Ophiura hadra.

Amphiodia urtica.
Amphiodia occidentalis.

Amphiodia periercta.

Amphipholis pugetana.

One variety (kennerlyi) of Ophiopholis aculeata is also restricted to this region. Since some of these species occur as far south as Southern California, the group is characteristic of the continental coast and may very appropriately be called the AMERICan fauna.

We find, then, as a result of our study of the geographical distribution of the 189 species of Ophiurans in the collection that we can recognize four quite distinct faunas in the North Pacific, as follows:

Bering fauna. Extends from the Arctic Ocean southward to Kadiak on the American coast and on the Asiatic side to Tsugaru Strait and even into the Sea of Japan: 35 species.

Honshu FAUna. Surrounds Honshu Island, Japan, but especially characterizes the southeastern and southern coasts and extends an unknown distance southward: 114 species.

American fauna. Extends from the Alaskan peninsula southward to California: 9 species.

Oceanic FAUna. Found distributed more or less regularly throughout the North Pacific: 18 species.

(Of the remaining thirteen species, a few are southern species or seem to connect two of these faunal regions, but the distribution of the majority is too imperfectly known to enable us to place them properly.)

Before leaving the matter of geographical distribution there are $a$ few points to which it may be well to call attention - the existence of a circumpolar fauna, the occurrence of West Indian species in the North Pacific, and the position of the line between the Bering and Honshu faunas.

The existence of a truly circumpolar fauna has been questioned by some zoölogists, but I see no reason to doubt that certain species of ophiurans are completely circumpolar in their distribution. At any rate they are known from north of Europe, Asia, and America, and while there are many regions, often of wide extent, where they have not been taken, such negative evidence is of little value, since such areas have, as a rule, never been zoölogically explored. Furthermore, there are, of course, many places where local conditions forbid the existence of ophiurans; their absence from such places can not therefore be rightly construed as denying their existence in the region. The following North Pacific species are also known from the North 
Atlantic and from the seas north of Europe and of western Asia and seem to me to be entitled to the name of a Circumpolar fauna:

Ophiura sarsii.

Ophiura nodosa.

Ophiura stuwitzii. ophiopholis aculeata.

Amphiura sundevalli.

Ophiacantha bidentata.

As regards the occurrence of a West Indian element in the North Pacific fauna, the following species have all been taken in the Gulf of Mexico, Caribbean Sea, or subtropical Atlantic:

Ophiura sculptilis.

Ophiernus adspersus.

Ophiacantha bairdi.

Ophiomusium lymani.

Asteronyx loveni.

But it must be noted that all of them are known from the East Indian region and perhaps represent an intertropical fauna. At any rate, with the possible exception of Ophiacantha bairdi, they can not fairly be considered as distinctively West Indian. The extent of an intertropical fauna is one of the points in the geographical distribution of marine animals upon which much light is needed. That such a fauna exists seems almost certain.

The ophiuran fauna of the Okhotsk Sea is not extensive, the Albatross collecting only thirteen species there (stations 5014-5030). Of these five are certainly representative of the Bering fauna, while the other eight belong to the widespread Oceanic group. To the north and east around the southern end of Kamchatka and off the Kurile Islands (stations 4794-4805), six additional species were taken, all belonging to the Bering fauna. Passing south and west through La Pérouse Strait into the Gulf of Tartary, and thence southward along the western coast of the Hokkaido to Tsugaru Strait (stations 4982-5013), no essential change in the fauna is found; the few ophiurans taken are all of either the Bering or the Oceanif fauna. On the other hand, passing through Yezo Strait along the eastern and southern coasts of the Hokkaido (stations 5031-5045), we meet with one species (Ophiura penichra) which, although not taken farther south, is at least suggestive of the Honshu fauna. Passing southward from Tsugaru Strait, in the Sea of Japan (stations 4807-4841) we meet at once with Ophiura stiphra, a characteristic Honshu species, while Ophiothrix koreana, an even more characteristic species, was taken in Hakodate Bay and in Tsugaru Strait. Although Ophiura odiplax was taken above Sado Island, no other representatives of the Honshu fauna were taken north of the Noto peninsula, while the Oceanic fauna is still represented by at least three species and the Bering fauna by two or three. As the vicinity of Tsuruga is reached, although Ophiura sarsii is still common, the other Oceanic and the Bering species disappear and are replaced by five Honshu species. Crossing the thirty-sixth parallel and passing into the east- 
ern channel of the Straits of Korea five other Honshu species appear, while even Ophiura sarsii is now no longer to be found. Returning to the east coast of Honshu Island, we find that the Albatross did very little collecting north of Sagami Bay, and that little was done in the vicinity of Kinkaasan Light, just above the thirtyeighth parallel. In that region the Oceanic and Bering faunas are each represented by two species and the Honshu fauna by one. In Sagami Bay, the abundant ophiuran fauna is almost exclusively Honshu. It appears, therefore, quite clear that the thirty-sixth parallel approximately indicates the line of separation between the Bering and Honshu faunas both in the Sea of Japan and on the Pacific coast. So far as the latter is concerned the reason seems obvious, for it is in this region that Honshu Island bends abruptly northward and the great, warm Kuroshiwo current from the south, on its Pacific side, meets and deflects the cold current from Bering Sea. It is less easy to see why in the Sea of Japan the two faunas should meet along the same parallel, but it is probable that the fauna of that sea has been formed by the entrance of northern species through La Pérouse Strait and of southern species through the Straits of Korea. The local conditions appear to be more favorable to the northern species in that greater part of the sea which lies above the thirty-sixth parallel.

\section{BATHYMETRICAL AND TEMPERATURE DISTRIBUTTION.}

No less interesting than the geographical distribution is the distribution with reference to depth and temperature. Seven species were taken only in water exceeding 1,000 fathoms. They are:

\begin{tabular}{|c|c|c|}
\hline Species. & Depth. & $\begin{array}{l}\text { Tempera- } \\
\text { ture. }\end{array}$ \\
\hline ophiura bathybia (taken at four stations)..... & $\begin{array}{c}\text { Fathoms. } \\
\text { 1, 569-1, } 973\end{array}$ & $\begin{array}{l}\text { Deg. F. } \\
35.1-34.9\end{array}$ \\
\hline Ophiura sculptilis (taken at one station)...... & 1,008 & 36.8 \\
\hline A nthophiura axiologa (taken at one station).. & 1,217 & 35.2 \\
\hline ophiambix aculeatus (taken at one station)... & 1,008 & 36.8 \\
\hline A mphilepis platytata (taken at two stations). & $1,569-1,973$ & $35-34.9$ \\
\hline Ophiacantha prionota (taken at one station). & 1,008 & 36.8 \\
\hline Ophiacantha eurypoma (taken at one station & 1,569 & 34.9 \\
\hline
\end{tabular}

While all are probably abyssal species, so few stations (six) are represented we have almost no light on their real bathymetrical distribution. In view of the bathymetrical range of 965 fathoms $(1,008-1,973)$, the extraordinarily limited temperature range of less than two degrees $\left(36.8^{\circ}-34.9^{\circ}\right)$ is the most interesting point about this group of species, but it would have more significance were more stations involved. 
At depths exceeding 500 fathoms, sixteen additional species were taken, which were not found at a less depth. They are:

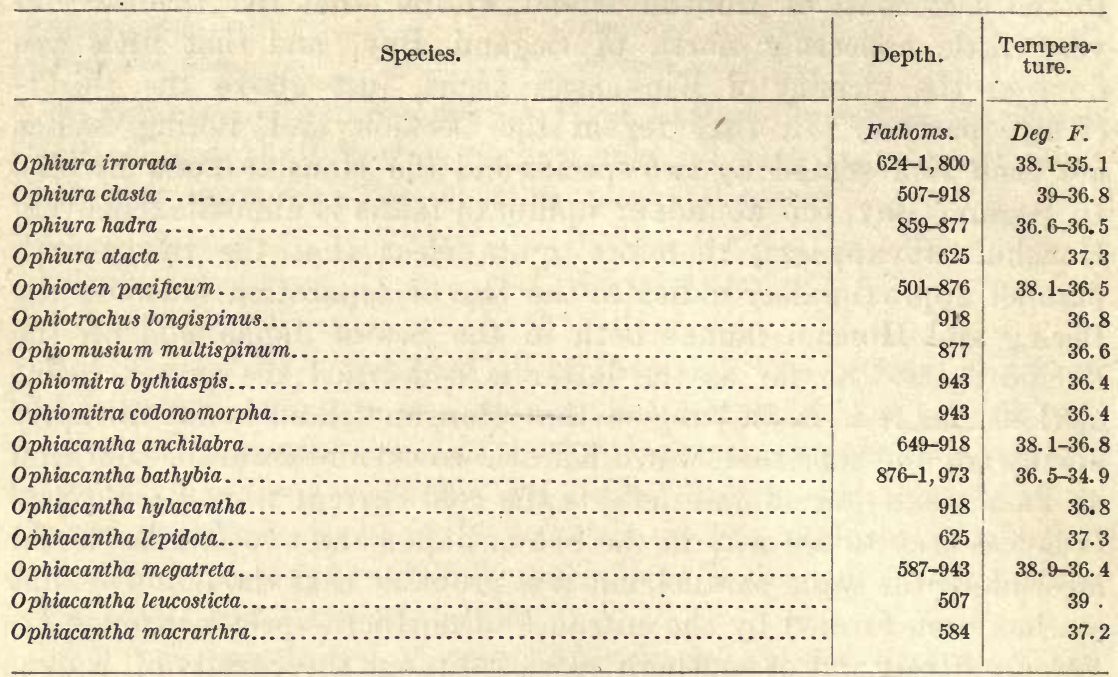

With the possible exception of Ophiotrochus, none of the genera in this list are characteristically deep-water forms; all of the others occur in less than 100 fathoms. While twelve species pass the 800 -fathom line, only two occur in water exceeding 1,000 fathoms; those two, it will be noted, have a very remarkable bathymetrical range, one of 1,097 , the other of 1,176 fathoms. In view of the considerable number of stations involved, the temperature range is very small, only $4.1^{\circ}\left(39^{\circ}-34.9^{\circ}\right)$.

Eighteen additional species occur only in water exceeding 300 fathoms in depth; eight of these extend into water exceeding 500 fathoms, but only two pass the 800 -fathom line and they do not reach 1,000 fathoms. The temperature range for these eighteen species is $7.6^{\circ}\left(42.9^{\circ}-35.3^{\circ}\right)$.

At depths from 100 to 300 fathoms, forty-one species were taken, of which sixteen were found below 300 fathoms, eleven below 500 but only two below 800 . The temperature range in this group is very great, over $30^{\circ}\left(60.6^{\circ}-30.4^{\circ}\right)$, but for any one species the extreme range is only about $12^{\circ}\left(44.1^{\circ}-31.8^{\circ}\right)$, and for about two-thirds of the species it is less than $5^{\circ}$.

There are fifty species which were taken between 50 and 100 fathoms; of these, forty-three extend their range beyond the 100fathom line, twenty-five beyond 300 fathoms, fifteen beyond 500, six beyond 800 , and four beyond 1,000. Naturally the temperature range is extensive, $45^{\circ}\left(75.4^{\circ}-30.4^{\circ}\right)$, though the extreme for any one species is $25.3^{\circ}$; one other species has a range exceeding $20^{\circ}$ and for seventeen others it exceeds $10^{\circ}$. 
There are two species the depth of whose habitat is not known, but the remainder of the collection, fifty-five species in all, were taken in water less than 50 fathoms deep, and may fairly be considered littoral forms. Of these no less than thirty-four are known to extend their range beyond 50 fathoms, twenty-eight beyond 100, twelve beyond 300 , seven beyond 500 , four beyond 800 , and two even pass the 1,000-fathom line. The temperature range can not be given because there are no temperature records for most of the shallow-water stations, but as Ophiopholis aculeata was taken at the extraordinarily low temperature of $29.8^{\circ}$, it is more than likely that the temperature range for the group exceeds $50^{\circ}$. The extreme range for any one species is $33.8^{\circ}$.

It will be noted that of the 187 species whose bathymetrical range is known, 146 , or nearly 80 per cent, are distinctly shallow-water forms, having been taken at less than 300 fathoms. Of these 146 species, 55 , or 38 per cent, extend their range beyond 300 fathoms, while 35 , or 24 per cent, are not recorded from below 100 fathoms. Of the forty-one species not taken in less than 300 fathoms, thirtyone occur below 500 fathoms. Of these really deep-water species, twelve belong to the genus Ophiacantha, six to Ophiura, and three to Ophiomitra. The remainder represent ten different genera, of which the following four may fairly be considered characteristic of the abyssal region:

Anthophiura. Ophiotrochus. Ophiambix. Amphilepis.

The following eight species have a bathymetrical range of more than 1,000 fathoms:

\begin{tabular}{|c|c|c|}
\hline Species. & Fathoms. & Range. \\
\hline Ophiura leptoctenia...... & $67-1,771$ & 1,704 \\
\hline Ophiura irrorata................ & $600-2,200$ & 1,600 \\
\hline ophiernus adspersus......... & 244-1,997 & 1,753 \\
\hline Ophiomusium lymani................. & $70-1,588$ & 1,518 \\
\hline ophiopholis aculeata (var. japonica)... & $8-1,030$ & 1,022 \\
\hline A mphiura carchara $\ldots \ldots \ldots \ldots \ldots$ & $60-1,973$ & 1,913 \\
\hline A mphiura diomedex.. & $39-1,573$ & 1,534 \\
\hline Ophiacantha bathybia.. & $876-1,973$ & 1,097 \\
\hline
\end{tabular}

With this group belong the following trio, whose range, however, is not quite so extensive:

\begin{tabular}{|c|c|c|}
\hline Species. & Fathoms. & Range. \\
\hline Ophiomusium cancellatum. & $65-1,008$ & 943 \\
\hline ophiomitra acontophora... & $229-1,217$ & 988 \\
\hline Ophiacantha normani.... & $40-987$ & 947 \\
\hline
\end{tabular}


It is worthy of note that eight of these eleven species belong to the Oceanic fauna, two to the Bering, and only one to the Honshu area, - which certainly supports the view that species with a great bathymetrical range tend to become widely distributed.

Three other species (Ophiura flagellata, Ophiacantha pentagona, Asteronyx loveni) have a bathymetrical range of over 800 fathoms. Two of these belong to the Oceanic fauna and the third is very widely distributed in the East Indian region. There are fourteen additional species which have a bathymetrical range of over 500 fathoms, and five of these belong to the Oceanic fauna. We see therefore that of the eighteen species belonging to that fauna fourteen have a bathymetrical range of over 500 fathoms, which lends support to the proposition that species occurring on both sides of the North Pacific have a great bathymetrical range.

Of the 158 species of whose temperature range we have some record, one (Ophiura brachyactis, two stations) was taken only in water colder than $32^{\circ}$ and the following seven were taken only below $36^{\circ}$ :

Ophiura odiplax, two stations.

Ophiura bathybia, four stations.

Anthophiura axiologa, one station.

Amphilepis platytata, two stations.
Ophiacantha eurypoma, one station.

Ophiacantha omoplata, one station.

Ophiolebes brachygnatha, two stations.

While there can be no doubt that all of these eight species are characteristic of very cold water, the importance of the list is vitiated by the fact that three of the species were taken at only a single station each, and only one is recorded from more than two stations.

There are forty-two other species which were not taken in water warmer than $40^{\circ}$ and twenty-three more which were not found above $45^{\circ}$. It is therefore fair to say that not less than 38 per cent of the 189 species in the collection are distinctly cold-water species, and this is rather remarkable when we consider that less than 30 per cent of the 189 belong to the Bering and Oceanic faunas combined; that only 16 per cent are really deep-water species, and that nearly 80 per cent were taken in less than 100 fathoms.

On the other hand, there are forty-one species which were not taken in water colder than $50^{\circ}$, and there is every reason to believe that at least two-thirds of those species for which no temperature is recorded (such as the two species of Ophiocoma, the two species of Ophioplocus, four species of Ophiothrix, etc.) belong in the same class. Moreover, there are nineteen additional species which were taken in water warmer than $60^{\circ}$, and two of these occurred at a temperature higher than $70^{\circ}$. It is not unreasonable, therefore, to say that the number of distinctly warm-water species nearly or quite equals that of the cold-water forms. 
The rest of the collection, about one-fourth of the species, is made up of forms with remarkable temperature ranges. The following species have ranges of $20^{\circ}$ or more:

Ophiura sarsii, from $50.1^{\circ}$ to $30.1^{\circ}$, a range of $20^{\circ}$.

Ophiomusium lymani, from $56.3^{\circ}$ to $35.3^{\circ}$, a range of $21^{\circ}$.

Ophiopholis aculeata (var. japonica), from $57.8^{\circ}$ to $30.4^{\circ}$, a range of $27.4^{\circ}$.

Amphiura diomedex, from $68.7^{\circ}$ to $34.9^{\circ}$, a range of $33.8^{\circ}$.

Amphiodia euryaspis, from $58^{\circ}$ to $32.7^{\circ}$, a range of $25.3^{\circ}$.

Ophiacantha pentagona, from $62.1^{\circ}$ to $36.4^{\circ}$, a range of $25.7^{\circ}$.

Ophiacantha normani, from $55.9^{\circ}$ to $30.9^{\circ}$, a range of $25^{\circ}$.

Ophiothrix koreana, from $68.7^{\circ}$ to $42.5^{\circ}$, a range of $26.2^{\circ}$.

Gorgonocephalus caryi, from $60.6^{\circ}$ to $30.7^{\circ}$, a range of $29.9^{\circ}$.

It is interesting to note that seven of these nine species belong to the Oceanic fauna, as might have been expected, while the other two are typical examples of the Honshu fauna. Of the remaining eleven species of the Oceanic fauna, six have a temperature range of more than $10^{\circ}$, while in four it is $3^{\circ}$ or less; in Amphiura carchara, which has the enormous bathymetrical range of over 1,900 fathoms, the temperature range is only $7.8^{\circ}$, from $42.8^{\circ}$ to $35^{\circ}$. Probably in this species the bathymetrical range is determined by the temperature rather than by any other factor.

It is clear that the Oceanic fauna contains two quite distinct elements: One, which we may call group A, and which is much the larger (thirteen species), is made up of forms to which temperature is a secondary factor, and a second, which we will call B, whose wide distribution seems to be due to the uniformly low temperature of deep water. We have already seen (p. 14) that all the strictly deep-water species (i. e., those not occurring in less than 300 fathoms) have a very restricted temperature range, and of course the more abyssal the habitat the more restricted is the temperature range. Although in the present state of our knowledge, group B is only a small part (fiveeighteenths) of the Oceanic fauna, it is very probable that all the strictly deep-water species really belong to that fauna, and should not, simply because of their geographical habitat, be placed in the Honshe: or Bering or American faunas. If such a redistribution of the species were made, group A would certainly prove to be the less important half of the Oceanic fauna.

\section{ASSOCIATIONAL DISTRIBUTION.}

One of the most interesting phases of the study of a large collection of any group of animals from a limited region is the determination of what species occur together at any given station or in any restricted area. Particularly interesting is it to note whether closely related species occur together or in adjoining areas or are widely separated from each other. We may approach the matter in two ways; first, $34916^{\circ}-$ Bull. $75-11-2$ 
by an examination of localities, and, second, by a study of the commoner species.

On Bowers Bank, Bering Sea, stations 4767-4775, at a depth of 237-771 fathoms, with a bottom temperature. of $38.5^{\circ}-36.5^{\circ}$, the Albatross collected fourteen species, of which five are Ophiuras and six are Ophiacanthas. Ophiopholis, Ophiolebes, and Astrochele are each represented by a single species. The Ophiuras (sarsii, leptoctenia, quadrispina, maculata, flagellata) all belong to the typical section of the genus and are very nearly related to each other; leptoctenia and quadrispina are nearer to each other than to any other species, and both are very close to sarsii. The Ophiacanthas (rhachophora, adiaphora, atopostoma, normani, bairdi, macrarthra) are less nearly related to each other, but rhachophora and adiaphora are very closely allied.

On August 9, southwest of the Goto Islands, Eastern Sea, stations $4893-4895$, in 95 to 106 fathoms of water, with a bottom temperature of $55.9^{\circ}$, a remarkable assemblage of ophiurans was found, twenty-two species in all, representing sixteen genera. Of Ophiozona, two species were taken, but they are not particularly nearly allied, and the same is true of the two species of Ophiothrix. Ophiomyxa, however, is represented by two very closely related but quite distinct species (anisacantha and australis). Ophiacantha furnishes four species, of which rhachophora and pentagona are very closely related indeed.

A week later, at the entrance of Kagoshima Gulf, stations 49334937 , in 58 to 152 fathoms, with a bottom temperature of $64.8^{\circ}-56^{\circ}$, a larger number of ophiurans were found than that at any other place, no less than twenty-nine species being taken there. The list is sufficiently interesting to warrant giving it here:

Ophiura micracantha.

Ophiura stiphra.

Ophiocten charischema.

Ophiomusium laqueatum.

Ophiomusium lütkeni.

Ophiomusium lunare.

Ophiomusium lymani.

Ophiomusium simplex.

Ophiopholis brachyactis.

Ophiactis dyscrita.

Amphiura diomeder.

Ophiodoris pericalles.

Ophiomitra polyacantha.

Ophiomitra microphylax.

Ophiocamax polyploca.
Ophiacantha granulosa.

Ophiacantha lophobrachia.

Ophiacantha leucorhabdota.

Ophiurases obstrictus.

Ophiothrix koreana.

Ophiothrix macrobrachia.

Ophiomyxa australis.

Ophiobyrsa synaptacantha.

Ophiosyzygus disacanthus.

Asteroporpa hadracantha.

Astroceras pergamena.

Astrophyton pardalis.

Gorgonocephalus caryi.

Euryale anopla.

The most remarkable points about this assemblage are the absence of Ophiodermatidx and Ophiocomidæ, the very small number of Amphiuridæ, and the presence of five species of Ophiomusium, all rather nearly related to each other. The two species of Ophiura are 
very different from each other, and the same is true of the two species of Ophiomitra, the two of Ophiothrix, and the three of Ophiacantha.

Sagami Bay has long been known as a rich collecting ground, and the Albatross found numerous ophiurans there. At the entrance to the Gulf of Tokio stations 5091-5095, in water 58 to 302 fathoms deep, with a bottom temperature of $57.8^{\circ}-43.9^{\circ}$, twenty-four species were collected, of which three are species of Ophiacantha, three belong to Ophiophotis, four to Ophiomusium, and six to Ophiura. The most notable cases of closely allied species in this group are those of $O$ phiura micracantha, sarsii, and flagellata, and of Ophiopholis mirabilis and aculeata.

But the best way in which to decide whether closely allied species occur together is to take certain well-defined species whose nearest allies are also North Pacific forms and see whether the two species often or ever occur at the same place. It is not always possible to say what other species is the nearest ally of any given species; such a point is necessarily largely a matter of personal opinion. But for any fair discussion of associational distribution it is sufficient if the two species are closely enough allied so that one might naturally have arisen from the other.

The species of the genus Ophiura form a large proportion of the ophiuran fauna of the North Pacific, and of these species sarsii is by far the commonest and most widely distributed. A very closely related species, lütkeni, is also common in the eastern Pacific and there is little doubt that sarsii is the nearest relative of lütkeni. There is no possible question, however, of their specific distinctness, for the difference between them is obvious and remarkably constant. Yet these two species were taken at the same station seven times (stations 2858, 2862, 2882, 3047, 3053, 3059, and Sitka) and twice they were taken at adjoining stations where conditions were essentially identical (stations 2867 and 2868, and 2883 and 2884). It is clear, therefore, that they are not geographically or bathymetrically isolated from each other.

Another equally interesting illustration of the same facts in the same genus is shown by the species leptoctenia and quadrispina; the latter certainly seems to find in the former its nearest ally, yet the difference between the two is sharp enough to prevent any difficulty of identification. The two species were taken together at stations 3331, 3332, $3337,4770,4781,4791$, and 5026. Another species (micracantha) is also very closely allied to sarsii and leptoctenia; it was taken at station 5091, while sarsii occurred close by under identical conditions at station 5092, and leptoctenia not very far away at station 5083.

The two species of the new genus Ophiopenia were taken twice at the same station (at Captains Harbor, Unalaska, and at station 2854), and there can be no possible doubt that they are much more nearly allied to each other than to any other known ophiurans. 
The genus Ophiomusium throws considerable light on the subject. The species cancellatum and jolliensis are very closely allied, and there is little doubt that the latter is more nearly related to the former than to any other species. Yet they were taken together at stations 3738, 4965, 5079, and 5091. At station 4933, O. lütkeni was taken, while at the neighboring station, 4934, under the same conditions, 0. Iunare, a very closely related species, was taken. The three species, lymani, simplex, and trychnum, are very nearly allied and the two latter probably find their nearest relative in the former. At station 4933, simplex and lymani were taken together, while trychnum and lymani were found at stations 3704 and 5092. Furthermore, lymani was found at station 4956 and at station 4959, only 5 miles away, under nearly identical conditions, trychnum occurred.

In the genus Amphiura the species bellis and diomeder are very nearly related; they were taken together at. station 3697 , and while diomedex occurred at station 5082, bellis was found under identical conditions close by at station 5083. Two species of Amphiodia (macraspis and euryaspis) were taken together at stations 4862 and 4997 , but the value of this occurrence is vitiated by the fact that these two so-called species may be identical. At station 3713 Amphiodia ancistrota and $A$. digitula were found together.

In the genus Ophiacantha many of the species are none too well defined, and this is particularly true of the pentagona group, including among others rhachophora and levispina. Nevertheless it is of some interest to record that pentagona and levispina occurred together at station 4916, while rhachophora and pentagona were found associated at stations $3698,3713,4893,4902,4903,4965$, and 4967. Although Ophiacantha cataleimmoida may be most nearly allied to 0 . relicta, it is very near normani, and its occurrence with the latter at stations 2853 , $3332,3338,3340$, and 4980 is worthy of note.

Of the genus Ophiolebes, four species (tylota, paucispina, diaphora, and brevispina) are so nearly allied that it is hard to determine just what their interrelationships are. At station 3480, brevispina and paucispina were found together; at station 3599, tylota and diaphora occurred; at station 4781, tylota, paucispina, and diaphora were all three taken; and at station 4784 tylota and diaphora were again found.

The two species of Ophiomyxa, australis, and anisacantha are so closely allied there is no doubt that the former is the nearest relative of the latter; australis was found at stations 4894 and 4895, while anisacantha was taken at stations 4892 and 4893 ; yet external conditions at the four stations were not essentially different.

The Japanese basket-fish, Gorgonocephalus sagaminus, certainly finds its nearest ally in $G$. caryi, yet the two are perfectly distinct. They were taken together, however, at three stations (3707, 4986, 
4987) and caryi was taken at station 4892 while sagaminus was found close by at station 4894 .

It seems clear from this unusual array of facts regarding their distribution that ophiurans do not as a group well illustrate "Jordan's Law," which has been stated as follows:

Given any species (or kind) in any region, the nearest related species (or kind) is not to be found in the same region nor in a remote region, but in a neighboring district separated from the first by a barrier of some sort or at least by a belt of country, the breadth of which gives the effect of a barrier. $a$

Jordan adds (pp. 73, 74):

This law holds good as a general rule among animals. The only exceptions yet indicated are found among plants ***, among Protozoa $* * *$ and in a few cases which seem to be explainable on the ground of reinvasion.

So far as we have any evidence there is neither "barrier" nor "belt of country" separating the ophiurans mentioned above from their nearest allies. Further evidence in support of this conclusion may be gleaned from Lyman's reports on the ophiurans collected by the Challenger and the Blake. ${ }^{b}$ One illustration from each will suffice. The genus Ophioplinthus contains only two known species (grisea and medusa); they were taken by the Challenger at the same station (156), in very deep water (1,975 fathoms) in the Antarctic Ocean and have never been taken elsewhere. The Blake collected near Martinique (station 203) in 96 fathoms of water, and near Santa Cruz (station 132) in 115 fathoms, a remarkably well characterized species (tuberculosa) of Hemieuryale, a genus which was previously monotypic. The known species (pustulata) was, however, common at both the stations where tuberculosa occurred. It may be worth mentioning that Sigsbeia murrhina, whose nearest ally is probably Hemieuryale, was also common at both stations. These cases from the Challenger and Blake collections agree in that the two species concerned in each instance are not merely congeneric and the only known species of the genus, but they are very closely allied, although differing by very definite characters. ${ }^{c}$

One other illustration may be given in this matter, not simply to add weight to the preceding evidence, but because it affords an expla-

$a$ D. S. Jordan, Isolation as a Factor in Organic Evolution: in Fifty Years of Darwinism, 1909, p. 73.

$b$ Kœhler's great work on the Siboga ophiurans furnishes numerous similar cases, but it is not necessary to detail them here. Suffice it to say that at Banda, the Siboga collected eleven species of $O$ phiothrix, at its station 50, ten species and at station 99 , nine species. It also took six species of Ophiacantha (in a restricted sense) and five of Ophiura at station 45, and six species of Ophiacantha were also taken at station 85.

$c$ Verrill (1899, Oph. Bahama Exp., in Bull. Lab. Nat. Hist. Univ. Iowa, vol. 5, p. 70) makes Hemieuryale tuberculosa the type of a new genus, but whether such a genus is accepted or not the fact remains that the nearest ally of tuberculosa is undoubtedly H. pustulata. 
nation why geographical isolation is not necessarily an important factor among marine animals. Throughout the West Indian region one of the commonest genera of brittle-stars is Ophiocoma, of which three well-marked species are found there. Two of these echinata and riisei, are very nearly related and there can be no doubt that the latter finds in the former its nearest ally. The differences between the two species, while neither conspicuous nor of morphological importance, are very constant and perfectly obvious. Yet the two species occur not only on the same reefs and shores, but under the same stones, where they mingle with each other, often in considerable numbers. So far as the records, supplemented by the examination of large series of specimens, living and preserved, show, hybridization between the two species is unknown, yet both are wholly oviparous with external fertilization. The explanation of this curious situation was discovered by Grave in $1897,{ }^{a}$ when he found that echinata breeds in late July and in August while riisei probably breeds in April and May, as it had entirely finished its breeding season before the end of June. We have here then a most striking case of "physiological isolation," and geographical isolation is no longer a factor with the two species concerned.

To sum up the evidence here presented, it seems fair to say that, in view of the large number of cases cited above where Jordan's law does not seem to apply to ophiurans, geographical isolation has been a less important factor in the specific differentiation of brittle-stars than some form of physiological isolation.

CONCLUSIONS AS TO DISTRIBUTION OF OPHIURANS IN NORTH PACIFIC OCEAN.

1. Four distinct faunas combine to make up the North Pacific group of species and these are designated as the Honshu, Bering, Oceanic, and American. Of these the Honshu is the largest and most diversified, while the Oceanic is the most widely distributed.

2. Six species, well known from the North Atlantic and the seas north of Europe, confirm the belief in a circumpolar fauna.

3. The line of division, on the Asiatic coast, between the Bering and Honshu faunas, is not at either La Pérouse or Tsugaru Strait, but much farther south, at about the thirty-sixth parallel of latitude. On the Pacific coast of Japan the line is apparently determined by the meeting of the warm Kuroshino current with the cold current from Bering Sea. The Sea of Japan appears to have been colonized by the gradual influx of Bering species through the northern straits and of Honshu species through the straits of Korea, the two groups meeting in the southern half of the sea.

4. About four-fifths of the species are shallow-water forms, only forty-one being confined to water exceeding 300 fathoms in depth. 
There are only four genera represented which can be considered as characteristic of deep water.

5. The distribution of the deep-water species confirms the view that species with a great bathymetrical range tend to become widely distributed.

6. The bathymetrical range of the species in the Oceanic fauna confirms the view that species occurring on both sides of the North Pacific have a great bathymetrical range.

7. Although only one-sixth of the species are deep-water forms and less than one-third belong to the Bering and Oceanic faunas combined, nearly two-fifths of the species are distinctly cold-water forms, occurring only in water under $45^{\circ} \mathrm{F}$.

8. Two groups of species combine to form the Oceanic fauna:

A, composed of hardy species, with great temperature ranges, to whom the temperature of the water seems to be relatively unimportant, and

$\mathrm{B}$, composed of species to whom a uniformly low temperature appears to be essential.

9. There seems to be abundant évidence that very closely related species of Ophiurans, often the most closely related, inhabit the same area and that "Jordan's law" does not apply to this class of Echinoderms.

10. There is evidence that "physiological isolation" in some form has been a more important factor than geographical or bathymetrical isolation in the specific differentiation of Ophiurans.

\section{DESCRIPTIONS OF SPECIES.}

\section{Family OPHIODERMATIDE.}

\section{PECTINURA $a$ ANCHISTA, new species. $b$}

Disk $14 \mathrm{~mm}$. in diameter; arms $70 \mathrm{~mm}$. long. Disk rather pentagonal, closely and completely covered by a fine granulation (about 80 grains to a square millimeter), which even conceals the radial shields. Upper arm plates tetragonal and broadly in contact on basal half of arm, but on terminal half becoming triangular and finally well separated from each other; at first they are much wider than long, even twice as wide, but they ultimately are longer than wide; lateral margins, at first nearly parallel, gradually diverge distally, proximal margin becoming shorter and shorter, until at last it is obliterated. Interbrachial spaces below covered, like disk, by a fine granulation. Genital slits moderate, about as long as three arm joints. Oral

$a$ For a revision of Pectinura and allied genera see Clark, Bull. Mus. Comp. Zoöl., vol. 52, 1909, pp. 111-132.

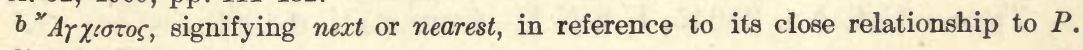
cylindrica (Hutton). 
shields about as long as wide, or sometimes longer, rather triangular, with convex sides. No supplementary oral shields. Adoral plates rather small, mostly free from granulation. Oral plates completely concealed by a coarse granulation. Oral papillæ seven or eight on a side, outer ones truncate, inner pointed, penultimate decidedly largest. No pores between basal under arm plates. First under arm plate large, somewhat pentagonal, much wider than long; succeeding plates rather hexagonal, with distal margin convex, at first wider than long, but soon becoming longer than wide and near tip of arm more than twice as long as wide; distinctly in contact until near tip of arm. Side arm plates moderate, not meeting either above or below, until

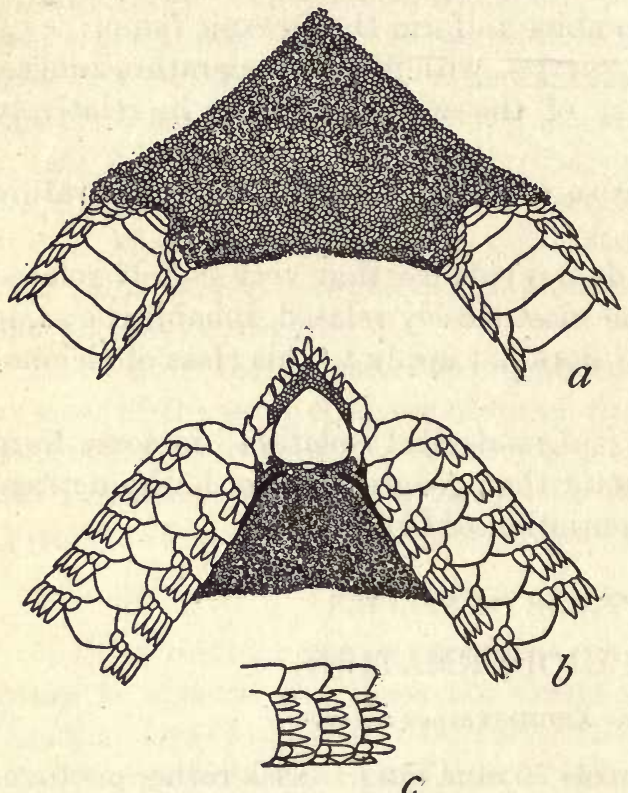

Fig. 1.-Pectinura ANCHISta. $\times 3.5$. $a$, FROM ABOVE; $b$, FROM BELOW; $c$, SIDE VIEW OF THREE ARM JOINTS NEAR DISK. near tip of arm; each plate carries five to seven flat, pointed spines, of which lowest is longest, but does not quite equal joint. Tentacle-scales two, inner, larger, outer overlapping base of lowest arm spine. Color (dried from alcohol), very variable; the type is uniformly whitish; another is variegated with dusky whitish and dull pink or reddish, the arms being distinctly banded; a third has arms distinctly banded and lighter parts spotted with purplish-red, but disk is uniformly whitish. Small specimens are very light, but banding of arms is usually distinct.

Localities.-Albatross station 3746, off Suno Saki, Japan, 49 fathoms, gray sand, pebbles, 2 specimens; station 4894, Eastern Sea, lat. $32^{\circ} 33^{\prime} \mathrm{N}$.; long. $128^{\circ} 32^{\prime} 10^{\prime \prime}$ E., 95 fathoms, green sand, broken shells, pebbles, 2 specimens; station 4895 , Eastern Sea, lat. $32^{\circ} 33^{\prime}$ $10^{\prime \prime}$ N.; long. $128^{\circ} 32^{\prime} 10^{\prime \prime}$ E., 95 fathoms, green sand, broken shells, pebbles, 1 specimen; station 4900 , Eastern Sea, lat. $32^{\circ} 28^{\prime} 50^{\prime \prime}$ N.; long. $128^{\circ} 34^{\prime} 40^{\prime \prime}$ E., 139 fathoms, gray sand, broken shells; bottom temperature $52.9^{\circ}, 1$ specimen; station 4939 , Kagoshima Gulf, lat. $31^{\circ} 18^{\prime} 30^{\prime \prime} \mathrm{N}$.; long. $130^{\circ} 42^{\prime}$ E., 85 fathoms, 1 specimen. Bathymetrical range, 49 to 139 fathoms. Seven specimens.

Type.-Cat. No. 25645, U.S.N.M., from station 4900. 
This species is so near P. cylindrica (Hutton) that it is not without much hesitation I have kept them separate. On comparing specimens of the two species with each other there are, however, certain differences which seem to be constant and which give the two species quite unlike facies. The color of cylindrica, although variable, is chiefly shades of gray and brown, with no tendency to pink or purplishred, the dominant shades in anchista. The arm spines of cylindrica are also less flattened and are truncate, particularly the lowest, rather than pointed. The arms themselves, moreover, are as a rule more flattened in cylindrica than in anchista and more arm spines are visible when looking down on the animal from above. Finally, cylindrica is a smaller species, 7 to $9 \mathrm{~mm}$. across the disk, with shorter arms, only three or four times diameter of disk. Since cylindrica has not yet been taken outside of the New Zealand region, it seems best to me to regard these trivial differences as specific, at least for the present.

\section{OPHIARACHNELLA GORGONIA.}

Ophiarachna gorgonia Müller and Troschel, Sys. Ast., 1842, p. 105.

Ophiarachnella gorgonia ClaRK, Bull. Mus. Comp. Zoöl., vol. 52, 1909, p. 123.

\section{Locality.-Japan, onę specimen.}

As I have elsewhere ${ }^{a}$ discussed in some detail the relationships of this genus and the synonymy of this species, I do not need to go over the ground here. Suffice it to say that this specimen from Japan is a fine example of Pectinura stearnsii Ives, agreeing in all particulars with the figures and description of that species, which was based on a single large specimen from Japan. Ives' type was $30 \mathrm{~mm}$. across the disk, while the one before me is even larger, measuring a full $33 \mathrm{~mm}$. The examination of this specimen has confirmed my opinion that stearnsii can not be distinguished from marmorata Lyman, of which it is doubtless the fully grown adult. Nor can I find, from the material I have examined, or from the descriptions and figures which have been published, any satisfactory characters by which marmorata is to be distinguished from gorgonia.

\section{OPHIARACHNELLA MEGALASPIS, new species. $b$}

Disk $12 \mathrm{~mm}$. in diameter; arms 50 to $55 \mathrm{~mm}$. long. Disk pentagonal, covered with a close, fine granulation (100 to 175 granules to the square millimeter); radial shields and one or more (usually three) small rounded plates distal to them, just at the base of the arm, bare. Radial shields very large (about $2.5 \mathrm{~mm}$. long by $1.5 \mathrm{~mm}$. wide), smooth and bare; distance between the two shields of a pair is less than the width of a shield and much less than the interradial dis-

$a$ Bull. Mus. Comp. Zoöl., vol. 52, 1909, pp. 121-123.

$b$ M r $_{\text {as }}(\mu \varepsilon \gamma a \lambda-)$, signifying $b i g$, and $a \sigma \pi \xi$, signifying shield, in reference to the large radial shields. 
tance between two pairs. Arms rather stout, somewhat flattened. Upper arm plates at first rounded hexagonal and somewhat wider than long, but soon becoming tetragonal with distal side longer than lateral and much longer than proximal, and finally triangular; in contact with each other except at tip of arm. Interbrachial areas covered with a fine granulation like that of disk. Oral shields longer than broad, somewhat rounded pentagonal. Supplementary oral shields often present, roundish; they may be partly or wholly concealed by the granulation and they are often wanting in two or more of the interradii; one specimen has none; the type has three large ones (see fig. 2b), one small one, and one minute one. Adoral plates small,
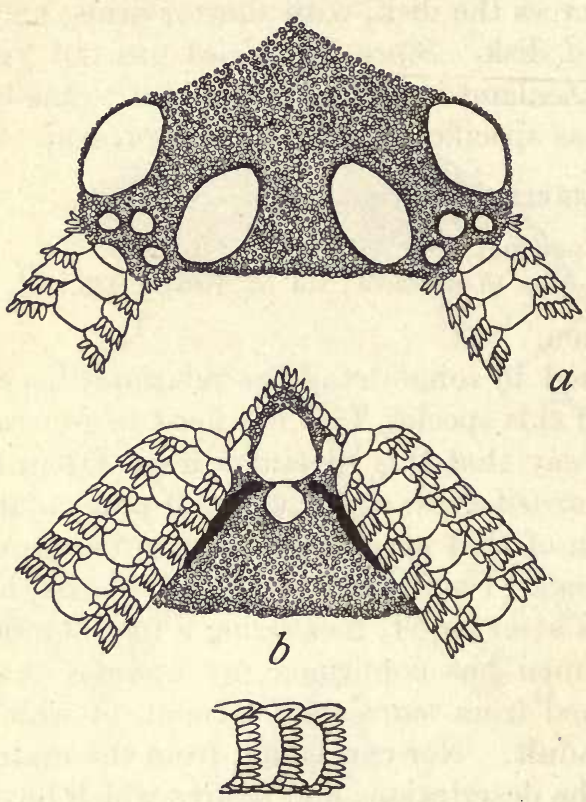

c

Fig. 2.-Ophiarachnella MEgalaspis. $\times 4$. $a$, From ABOVE; $b$, FROM BELOW; $c$, SIDE VIEW OF THREE ARM JOINTS NEAR DISK. at sides of oral shield, mostly free from granulation. Oral plates completely covered by a somewhat coarser granulation than that of disk. Oral papillæ numerous, eight to ten on a side; distal ones truncate, inner ones pointed, penultimate distinctly largest. Genital slits rather large, as long as three arm joints. No pores between basal under arm plates. First under arm plate rather large, diamondshaped or somewhat pentagonal, much wider than long; succeeding plates pentagonal, hexagonal, or heptagonal, with more or less rounded corners, at first wider than long and broadly in contact with each other, but soon becoming longer than wide, and

ultimately very long, narrow, and distinctly separated. Side arm plates rather large, but not meeting either below or above, except at very tip of arm; each one carries nine or ten short, little flattened, bluntly-pointed arm spines, of which the lowest is a little the longest, though it does not equal joint. Tentacle scales two, inner larger, outer overlapping base of lowest arm spine. Color (dried from alcohol), light brown or gray, variegated with lighter and darker shades and with arms more or less distinctly banded with darker; oral surface, whitish.

Localities.-Albatross station 3764, off Suno Saki, Honshu Island, Japan, 44 to 50 fathoms, fine gravel, broken shells, 2 specimens; station 4893 , Eastern Sea, lat. $32^{\circ} 33^{\prime}$ N.; long. $128^{\circ} 32^{\prime} 50^{\prime \prime}$ E., 95 to 106 fathoms, gray sand, broken shells, pebbles, bottom temperature 
$55.9^{\circ}, 2$ specimens; station 4894 , Eastern Sea, lat. $32^{\circ} 33^{\prime}$ N.; long. $128^{\circ} 32^{\prime} 10^{\prime \prime}$ E., 95 fathoms, gray sand, broken shells, pebbles, 1 specimen; station 4895 , Eastern Sea, lat. $32^{\circ} 33^{\prime} 10^{\prime \prime} \mathrm{N}$.; long. $128^{\circ}$ $32^{\prime} 10^{\prime \prime}$ E., 95 fathoms, gray sand, broken shells, pebbles, 2 specimens. Bathymetrical range, 44 to 106 fathoms. Seven specimens.

Type.-Cat. No. 25600, U.S.N.M., from station 3764.

Although this species is obviously related to $O$. infernalis, it differs so markedly in two important particulars that I have no doubt it is entirely distinct, and there is no other species with which it can be confused. In the first place, the granulation of the disk is nearly twice as fine in infernalis as in megalaspis, there being 400 to 500 granules to the square millimeter in the former. This difference in the size and number of the granules results in a noticeable difference in the apparent smoothness of the disk in dry specimens. The second, and much more noticeable, character in which the two species differ is found in the radial shields; in infernalis they are small, often no larger than one of the other bare disk plates, and never larger than an upper arm plate, while the distance between the two of a pair greatly exceeds the width of the plate. The contrast between these proportions and those shown by megalaspis is thus very striking.

OPHIOCONIS DIASTATA, new species. $a$

Disk $9 \mathrm{~mm}$. in diameter; arms about $45 \mathrm{~mm}$. long. Disk covered with a close fine coat of granules, about 130 to the square millimeter at center of disk. Radial shields entirely covered. Upper arm plates triangular, much wider than long, even the basal ones scarcely in contact. Interbrachial spaces below finely granulated like the disk above. Oral shields wider than long, with rounded sides and a blunt proximal angle. Adoral plates rather small, narrowest proximally, with outer end more or less concealed by an extension of granulation of interbrachial space, and with tip of inner end often concealed by a coarser granulation which completely conceals the oral plates. Oral papillæ four or five on each side, the outermost much the widest; an infradental papilla sometimes present but often wanting; teeth, three or four, moderately wide, rather blunt. First under arm plate, not half as large as second, narrower distally; succeeding plates much wider than long, more or less pentagonal, with a wide proximal angle. Side arm plates large, meeting above and still more broadly below; each carries four or five flat, smooth, hollow, not very acute arm spines; next to uppermost longest, somewhat exceeding joint. Tentacle scale single, large, longer than wide, rounded or sometimes bluntly pointed. Color (dried from alcohol), nearly white.

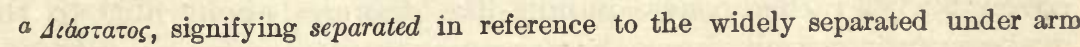
plates. 
Localities.-Albatross station 4967, off Shio Misaki Light, Japan, lat. $33^{\circ} 25^{\prime} 10^{\prime \prime} \mathrm{N}$.; long. $135^{\circ} 37^{\prime} 20^{\prime \prime}$ E., 244 to 253 fathoms, brown mud, sand, foraminifera, bottom temperature $45.9^{\circ}, 1$ specimen; station 4968, off Shio Misaki Light, Japan, lat. $33^{\circ} 24^{\prime} 50^{\prime \prime}$ N.; long. $135^{\circ}$ $38^{\prime} 40^{\prime \prime}$ E., 253 fathoms, dark gray sand, brown mud, broken shells, bottom temperature $45.7^{\circ}, 2$ specimens. Bathymetrical range, 244 to 253 fathoms. Temperature range, $45.9^{\circ}$ to $45.7^{\circ}$. Three specimens.

Type.-Cat. No. 25531, U.S.N.M., from station 4967.

Although there is no doubt that this species is a true Ophioconis, as comparison with both miliaria Lyman and antarctica Lyman has satisfied me, it has raised serious doubt in my mind as to the relation-

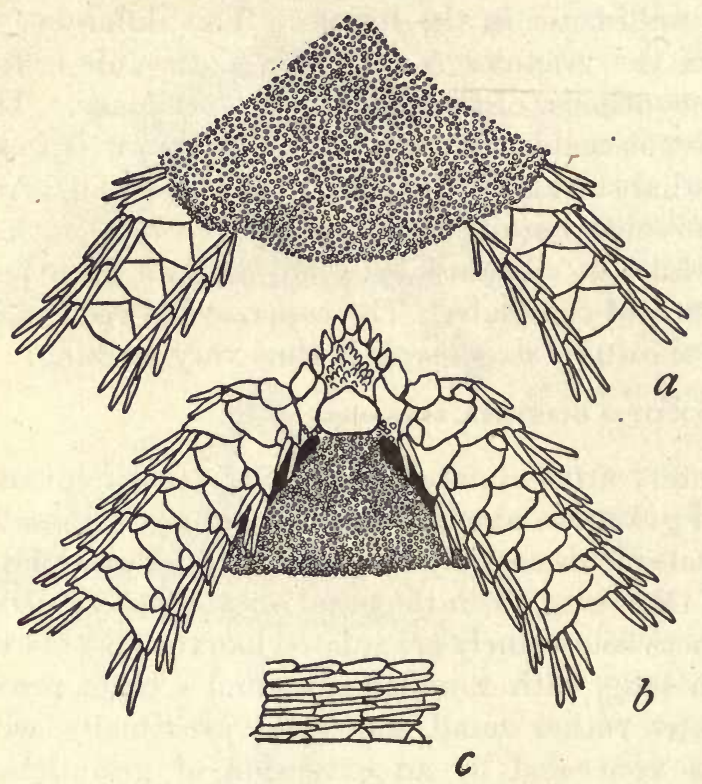

Fig. 3.-OPHIOconis DIASTAtA. $\times 6$. $a$, FROM ABOVE; $b$, FROM BELOW; $c$, SIDE VIEW OF THREE ARM JOINTS NEAR DISK. ships of the genus. Both Lütken and Lyman regarded Ophioconis as allied to $\mathrm{Pec}$ tinura and the other Ophiodermatidæ, but I am unable to find even one constant character to distinguish the genus from Ophiacantha in the old, broad sense. Unfortunately neither of the Mediterranean species of Ophioconis is at all common, and I have never seen specimens of either, so that I am unable to reach any definite conclusions, but I shall not be surprised if some of the species now placed in Ophioconis, really belong in the Ophiacanthidæ, while others are perhaps properly placed in the Ophiodermatidæ. The present species, like miliaria and antarctica, has hollow arm spines, certainly a very remarkable character for one of the Ophiodermatidæ. From all other species of Ophioconis, diastata is distinguished by its few arm spines, widely separated under arm plates, single tentacle scale, and very fine disk granulation, a combination of characters shown by none of the others.

\section{OPHIOCONIS PAPILLATA, new species. $a$}

Disk $8 \mathrm{~mm}$. in diameter; arms about $43 \mathrm{~mm}$. long. Disk closely covered with rather coarse papilla-like granules about fifty to the

a Papillatus, signifying shaped like a bud, in reference to the papilla-like granules on the disk. 
square millimeter; those at center of disk are longer and more like spinelets than those near margin. Radial shields entirely concealed. Upper arm plates triangular with proximal angle more or less truncated, according to amount of contact between them. Interbrachial spaces below covered with papilla-like granules, which become spinelets near and around oral shields and on oral plates; these spinelets are very little larger than those at center of disk above. Oral shields ellipsoidal, wider than long. Adoral plates rather small, much longer than wide, widest distally, their outlines more or less obscured byspinelets. Oral papillæ four or five on each side with often an infradental one in addition; outermost very much the widest. Teeth four or five, not peculiar. First under arm plate much smaller than second, distinctly wider than long; second and succeeding plates more or less pentagonal with a wide proximal angle; seventh and succeeding plates usually wider than long and widely separated from each other; those preceding the seventh are often longer than wide and only slightly or scarcely separated from each other. Side arm plates rather large, meeting slightly above and more or less broadly below;

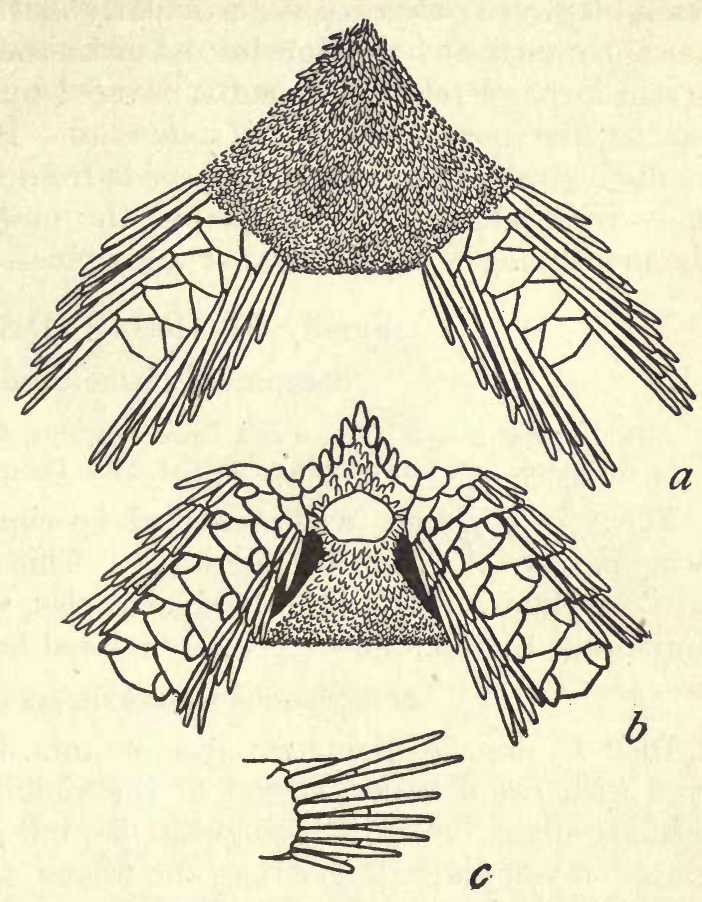

Fig. 4.-OPHIOCONIS PAPILlata. $\times 6$. $a$, FROM ABOVE; $b$, FROM BELOW; $c$, SIDE VIEW OF AN ARM JOINT NEAR DISK.

each plate carries six or seven long smooth, rather blunt, hollow spines, the uppermost or next to it, the longest, and, at base of arm, equalling or exceeding two joints. Tentacle scale single, very large, about as wide as long. Color (dried from alcohol), very pale fawn or yellowish-brown; beneath and arm spines, nearly white.

Localities.-Albatross station 2842, off Aleutian Islands, lat. $54^{\circ}$ $15^{\prime} \mathrm{N}$.; long. $166^{\circ} 3^{\prime} \mathrm{W}$., 72 fathoms, pebbles, bottom temperature $41^{\circ}$, ten specimens; station 3315, Bering Sea, lat. $54^{\circ} 2^{\prime} 40^{\prime \prime} \mathrm{N}$.; long. $166^{\circ} 42^{\prime}$ W., 277 fathoms, green mud, sand, bottom temperature $38.5^{\circ}, 1$ specimen; station 3331 , Bering Sea, lat. $54^{\circ} 1^{\prime} 40^{\prime \prime}$ N.; long. 
$166^{\circ} 48^{\prime} 50^{\prime \prime}$ W., 350 fathoms, mud, 11 specimens; station 3480 , Bering Sea, lat. $52^{\circ} 6^{\prime} \mathrm{N}$.; long. $171^{\circ} 45^{\prime}$ W., 283 fathoms, black sand, coral, rocky, 1 specimen; station (?), 1 specimen. Bathymetrical range, 72 to 350 fathoms. Temperature range, $41^{\circ}$ to $38.5^{\circ}$. Twentyfour specimens.

Type.-Cat. No. 25643, U.S.N.M., from station 2842.

This species is even more Ophiacantha-like than the preceding and I believe its natural relationships are with that genus. But it is so obviously congeneric with Ophioconis miliaria and antarctica that I am obliged to place it in Ophioconis, at least for the present. The resemblance to antarctica is particularly marked in a specimen which has apparently at some time lost its disk; the regenerated disk, which is still incompletely developed is covered by coarse granules, almost exactly like those of the disk of antarctica. But papillata may always be distinguished from antarctica, aside from the disk covering, by its more triangular upper arm plates, the more spiniform granules of the mouth angles, and the fewer arm spines.

\section{Family OPHIOLEPIDIDÆ.}

OPHIOPLOCUS IMBRICATUS.

Ophiolepis imbricata Müller and Troschel, Sys. Ast., 1842, p. 93.

Ophioplocus imbricatus Lyman, Ill. Cat. Mus. Comp. Zoöl., 1865, p. 69.

There is a single, well-preserved specimen from Okinawa, the principal one of the Riu Kiu Islands. This appears to be about the northern limit of this Indo-Pacific species, which is replaced to the northward by the following closely related but quite distinct form.

\section{OPHIOPLOCUS JAPONICUS, new species. $a$}

Disk $18 \mathrm{~mm}$. in diameter; arms $66 \mathrm{~mm}$. long. Disk closely covered with small scales, largest in the vicinity of the radial shields; primary plates scarcely distinguishable, but on each interradial margin are seven plates larger than the others, the middle one being the largest of the seven. Radial shields bare, but very small and widely separated. Upper arm plates broken up into a considerable number of plates, of which one at each side and five along the proximal border of each arm joint are the largest. Interbrachial spaces below covered with a close scaling, which is finest along the genital slits and close to the oral shield. Genital slits long, extending from the oral shield more than halfway to disk margin. Oral shields more or less pentagonal, about as long as wide, with all angles, except most proximal, rounded. Adoral plates, meeting within, somewhat wider at outer than at inner end; oral plates well marked, but smaller than adoral. Oral papillæ about five on each side, the penultimate much the widest;

a Japonicus signifying belonging to Japan, in reference to the apparently limited geographical distribution. 
an infradental papilla commonly present. Teeth about five, very broad, flat, and rounded. First under arm plate more or less triangular, much smaller than second; second and succeeding plates quadrilateral, wider than long, broadly in contact. Side arm plates small, low, each with three short, thick, blunt arm spines, of which the middle one about equals the arm joint; the uppermost is decidedly shorter, the lowest decidedly longer. Tentacle scales, two on proximal side of pore, and two, or often only one, smaller, on distal side. Color (dried from alcohol), deep olive-gray; arms irregularly banded with light and dark olive-gray.

Localities.-Japan, five specimens; Misaki, Japan, nine specimens; Enoshima, Japan, one specimen; Ayukawa, Japan, six specimens.

Type.-Cat. No. 25621, U.S.N.M., from Misaki, Japan.

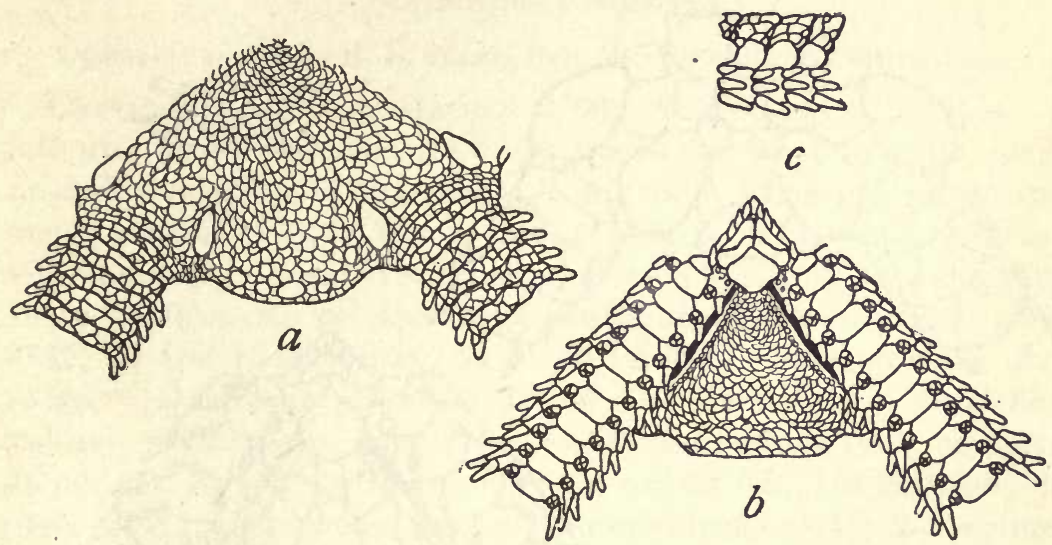

FIG. 5.-OPHIOPLOCUS JAPONICUS. $\times 3$. $a$, FROM ABOVE; $b$, FROM BELOW; $c$, SIDE VIEW OF THREE ARM JOINTS NEAR DISK.

Although this species is superficially much like imbricatus, it can be at once distinguished from that species by the genital slits which in imbricatus are very short, and never start at the oral shield. In this particular japonicus resembles the species from Southern California (esmarki), but it is at once distinguished from that species by the arm spines, which in esmarki are short and nearly equal. Lyman long ago ${ }^{a}$ pointed out the peculiar genital slits of Japanese specimens of Ophioplocus.

\section{OPHIOZONA ELEVATA, new species. $b$}

Disk $9 \mathrm{~mm}$. in diameter; arms about $27 \mathrm{~mm}$. long. Disk elevated, $2 \mathrm{~mm}$. thick, covered with about 100 to 150 flat plates or scales, among which the most conspicuous are the centrodorsal, two radial in each radius, one of which lies between the ends of a pair of large

b Elevatus, signifying raised $u p$, in reference to the elevated disk. 
radial shields, and three or four interradial in each interradius, one of which is a very large marginal plate. Radial shields widely separated, oval, slightly wider at outer end. First two or three upper arm plates quadrilateral, much wider than long; succeeding plates in contact with each other, but with proximal side becoming shorter and shorter until each plate is triangular and separated from its fellows. Interbrachial spaces below covered with about fifteen plates, of which a marginal one is decidedly the largest. Oral shields with a proximal angle, but rounded distally, about as long as wide. Adoral plates wider at outer end, meeting within; oral plates small and indefinite. Oral papillæ, four or five on each side, the penultimate

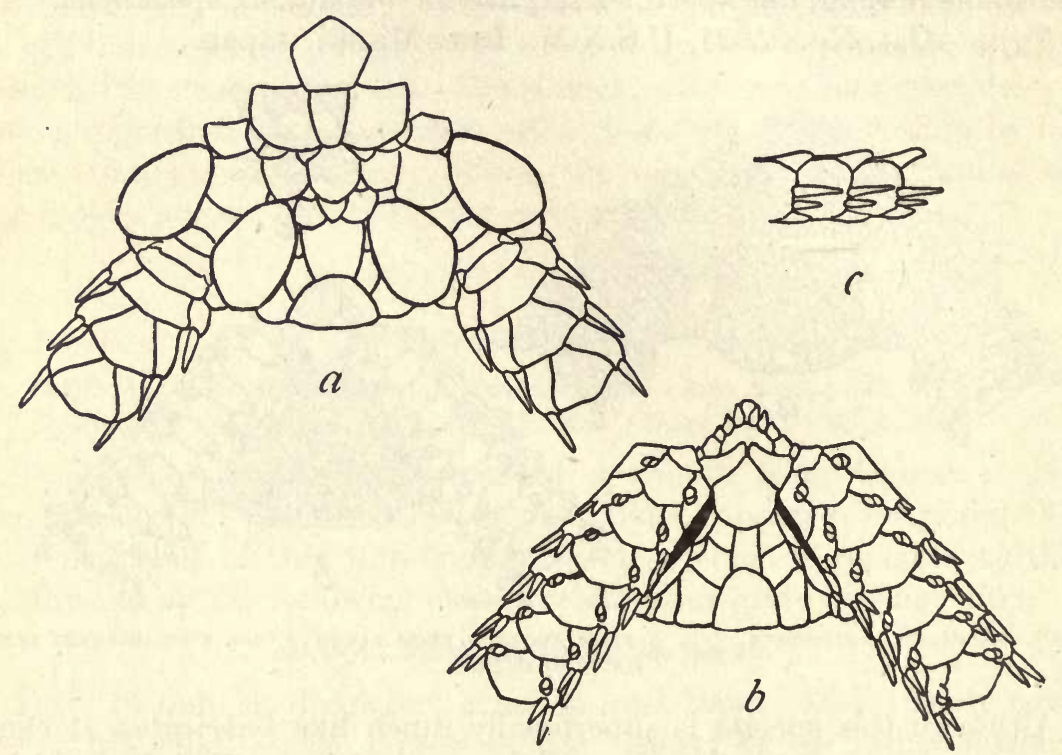

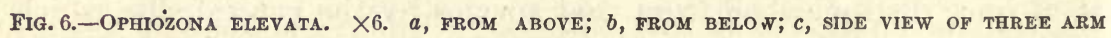
JOINTS NEAR DISK.

much the largest. Teeth about five; lowest much the smallest. First under arm plate very much wider than long, about one-fourth as large as second, which is somewhat pentagonal, with a rounded distal angle, about as long as wide or longer; third to eighth plates about as wide as long or wider, imperfectly pentagonal, gradually becoming triangular, more or less in contact with each other; succeeding plates triangular, rather longer than wide, separated from each other. Side arm plates large, slightly swollen, meeting above and below beyond eighth to tenth joints; each plate carries two arm spines, the upper decidedly the longer and nearly as long as a joint. Tentacle scales, two, or occasionally three, quite small. Color (dried from alcohol), dull purplish-brown, irregularly and indistinctly marked with darker 
and lighter; arms with three or four narrow, irregular, cream-colored cross-bands; lower surface of disk and arms, yellowish-white.

Locálity.-Albatross station 4893, off Goto Islands, Japan, lat. $32^{\circ} 32^{\prime} \mathrm{N}$.; long. $128^{\circ} 32^{\prime} 50^{\prime \prime}$ E., 95 to 106 fathoms, gray sand, broken shells, pebbles, bottom temperature $55.9^{\circ}, 3$ specimens.

Type.-Cat. No. 25532, U.S.N.M., from station 4893.

Although this species is very near bispinosa Kœhler, it appears to be well distinguished from that species by the shape of the upperarm plates and the much shorter arm spines. Kohler's figure also indicates that the disk plates of bispinosa are more or less convex or swollen, while in elevata they are perfectly flat, although the disk itself is decidedly elevated, sloping from the central area to the interradial margins.

\section{OPHIOZONA LONGISPINA.}

Ophiozona longispina H. L. Clark, Bull. Mus. Comp. Zoöl., vol. 51, 1908, p. 290.

Localities.-Albatross station 3706, off Port Heda, Japan, 337 fathoms, green volcanic mud, 50 specimens; station 3707 , off Ose Zaki, Japan, 63 to 75 fathoms, volcanic sand, ashes, gravel, 10 specimens; station 3708, off Ose Zaki, Japan, 60 to 70 fathoms, green mud, volcanic sand, ashes, 191 specimens; station 3713, off Ose Zaki, Japan, 45 to 48 fathoms, volcanic sand, shells, rocks, 4 specimens; station 3739, off Ose Zaki, Japan, 55 to 65 fathoms, volcanic sand, shells, rocks, 6 specimens; station 3740, off Ose Zaki, Japan, 65 fathoms, volcanic sand, shells, pebbles, 5 specimens; station 4965 , off eastern Japan, lat. $33^{\circ} 35^{\prime} 20^{\prime \prime} \mathrm{N}$.; long. $135^{\circ} 10^{\prime} 50^{\prime \prime}$ E., 191 fathoms, dark green-gray sand, shells, bottom temperature, $49.4^{\circ}, 2$ specimens; station 5055, in Suruga Gulf, Japan, lat. $34^{\circ} 53^{\prime}$ N.; long. $138^{\circ} 44^{\prime} 15^{\prime \prime}$ E., 124 fathoms, green mud, gray sand, broken shells, pebbles, bottom temperature $56.6^{\circ}, 1$ specimen; station 5095, in Uraga Strait, lat. $35^{\circ} 5^{\prime} 34^{\prime \prime} \mathrm{W}$.; long. $139^{\circ} 38^{\prime} 36^{\prime \prime}$ E., 58 fathoms, fine black sand, broken shells, bottom temperature $57.8^{\circ}, 3$ specimens. Bathymetrical range, 45 to 337 fathoms. Temperature range, $57.8^{\circ}$ to $49.4^{\circ}$. Two hundred and seventy-two specimens.

The largest of these specimens has the disk $14 \mathrm{~mm}$. in diameter and the arms over $40 \mathrm{~mm}$. long. The disk is covered by about three hundred plates, but two-thirds of these are mere scales intercalated between the regular plates. The first fifteen upper arm plates are in contact and several of the basal ones are pentagonal or tetragonal, and wider than long. Interbrachial spaces below are covered by forty to fifty plates. Under arm plates in contact out to about the fifteenth joint. Oral papillæ, oral shields, arm spines, tentacle scales and color as in the original specimens. The specimen from station 5055 is peculiar in having much narrower arms than specimens of its own size from station 3708 .

$34916^{\circ}-$ Bull. $75-11-3$ 
OPHIOZONA PLATYDISCA, new species. $a$

Disk $12 \mathrm{~mm}$. in diameter; arms about $40 \mathrm{~mm}$. long. Disk very flat and thin, covered by about two hundred scales among which the centro-dorsal, the five primary radial, and the radial shields are conspicuous, while other large plates occur between the proximal ends of the radial shields and in the interradii; but there is no conspicuous marginal plate in each interradius. The upper arm plates, the covering of the jaws, the oral shields, the oral papillæ, the under arm plates, the side arm plates and arm spines, and the tentacle scales are like those of elevata. Interbrachial spaces below covered with about thirty plates, no one of which is conspicuously larger than the others. Color (dried from alcohol), dull, light purple, variegated

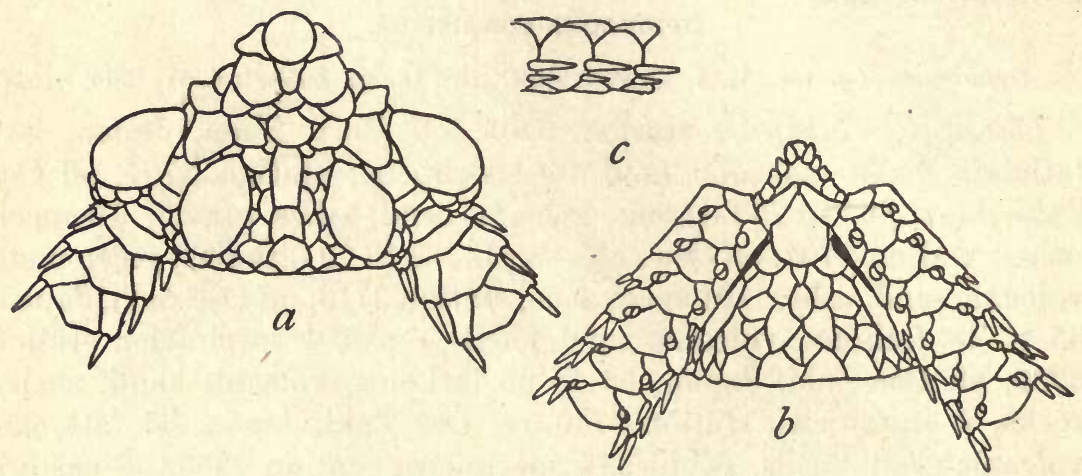

Fig. 7.-Ophiozona Platydisca. \4. $a$, FROM ABOve; $b$, FROM BELOW; $c$, SIDE VIEW OF THREE ARM JOINTS NEAR DISK.

with whitish; arms with four narrow, irregular, whitish cross-bands; lower surface of disk and arms, whitish.

Locality.-Albatross station 4965, off Hiro Misaki Light, Japan, lat. $33^{\circ} 35^{\prime} 20^{\prime \prime} \mathrm{N}$.; long. $135^{\circ} 10^{\prime} 50^{\prime \prime} \mathrm{E}$., 191 fathoms, dark greengray sand, shells, bottom temperature $49.4^{\circ}, 3$ specimens.

Type.-Cat. No. 25717, U.S.N.M., from station 4965.

It seems quite possible that this is the adult form of elevata, but the differences in the form and scaling of the disk have induced me to keep them separate for the present. The absence of a large marginal plate in each interradius, above and below, distinguishes platydisca, but this may be the result of its considerably larger size. From bispinosa this species is at once distinguished by its upper arm plates and shorter arm spines.

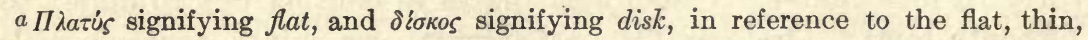
disk. 
OPHIOZONA POLYPLAX, new species.a

Disk, $17 \mathrm{~mm}$. in diameter; arms $53 \mathrm{~mm}$. long. Disk flattened, covered with a close coat of three hundied (or more) scales, among which the centro-dorsal and five radial can be easily distinguished, though they are not conspicuous. Radial shields rather large and widely separated. Upper arm plates more or less triangular, those at base of arm becoming tetragonal by truncation of proximal angle; first two or three much wider than long; only the basal four or five in contact. Interbrachial spaces below covered with about thirty plates. Oral shields pentagonal with sharp proximal angle and rounded distal angles. Adoral plates large, wider without than within, where they meet; oral plates small. Oral papillæ about five on each side, the penultimate largest. First under arm plate very small, triangular or diamond shaped, much wider than long; second,

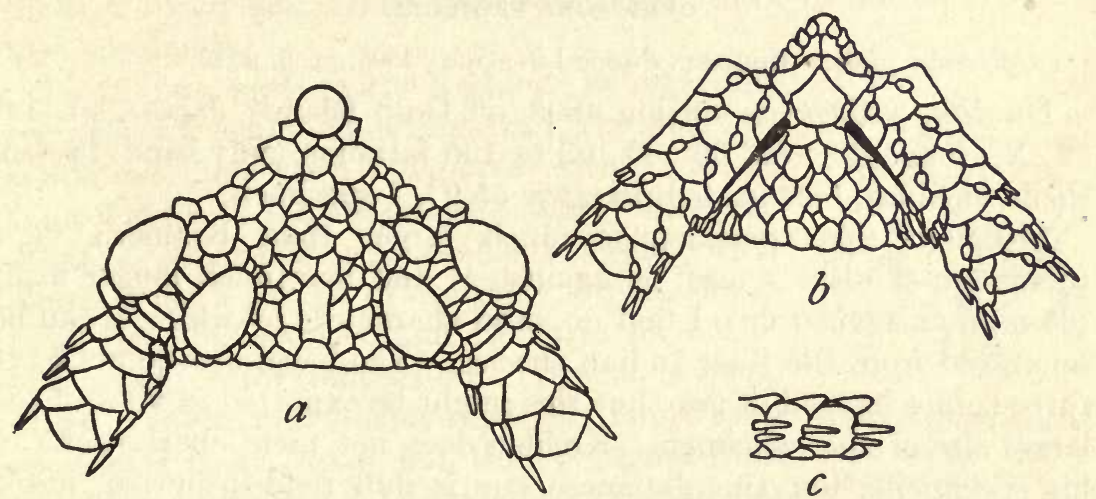

Fig. 8.-OPHIOzONA POLYPLAX. $\times$ 3. $a$, FROM ABOVE; $b$, FROM BELOW; $c$, SWE VIEW OF TWO AND A HALF ARM JOINTS NEAR DISK.

third, and fourth plates tetragonal, becoming hexagonal, longer than wide; succeeding plates hexagonal with rounded distal angles, becoming pentagonal, wider than long, until outer part of arm is reached where they are widely separated and are longer than wide. Side arm plates large but little swollen, meeting above beyond the third or fourth joint and below beyond the seventh or eighth; each plate carries two thick, blunt spines of which the upper is the longer, but is distinctly shorter than a joint. Tentacle scale single, moderately large. Color (dried from alcohol), nearly uniformly white, the disk strongly tinged with gray above.

Localities.-Albatross station 4957, off southeastern Japan, 437 fathoms, green-brown mud, fine gray sand, foraminifera, bottom temperature $39.8^{\circ}$, 1 specimen; station 4969 , off Shio Misaki Light, Japan, lat. $33^{\circ} 23^{\prime} 40^{\prime \prime} \mathrm{N}$.; long. $135^{\circ} 33^{\prime}$ E., 587 fathoms, brown mud,

a Moגús signifying many and $\pi \lambda \dot{a} \xi$ signifying anything flat and broad, a plate, in reference to the numerous disk plates. 
sand, stones; bottom temperature $38.9^{\circ}, 1$ specimen; station 4972 , off Shio Misaki Light, Japan, lat. $33^{\circ} 25^{\prime} 45^{\prime \prime}$ N.; long. $135^{\circ} 33^{\prime}$ E., 440 fathoms, brown-green mud, foraminifera, bottom temperature $38.1^{\circ}, 24$ specimens. Bathymetrical range, 437 to 587 fathoms. Temperature range, $39.8^{\circ}$ to $38.1^{\circ}$. Twenty-six specimens.

Type.-Cat. No. 25624, U.S.N.M., from station 4969.

This species is obviously near both alba Lütken and Mortensen and longispina H. L. Clark. It is easily distinguished from alba by the scaling of the disk and the much larger (relatively) radial shields; there are also slight differences in the side arm plates, the oral shields, and the arm spines, so that the two species look unlike. From longispina, the upper arm plates, side arm plates, and arm spines are quite sufficient to distinguish it, the general facies of the two species being quite different.

\section{OPHIOZONA PROJECTA.}

Ophiozona projecta KøHLer, Siboga Litt. Oph., 1905, pt. 2, p. 19.

Locality.-Albatross station 4893, off Goto Islands, Japan, lat. $32^{\circ}$ $32^{\prime}$ N.; long. $128^{\circ} 32^{\prime} 50^{\prime \prime}$ E., 95 to 106 fathoms, gray sand, broken shells, pebbles, bottom temperature $55.9^{\circ}, 1$ specimen.

Although this specimen is much larger than Kœhler's type (diameter of disk, $7 \mathrm{~mm}$. as against 4) and has much longer arms (35 mm. as against 20 ), I find no valid characters by which it can be separated from the East Indian species. The basal arm-joints have three spines instead of two, but this might be expected in view of the larger size of the specimen. Kohler does not mention the color of his specimens, but this Japanese one is dull reddish-purple, indistinctly variegated above with darker and lighter, and uniformly lighter below.

\section{Genus OPHIURA.}

While it is to be regretted that a name which has been so widely used as Ophioglypha must be abandoned, there seems to be no escape from Bell's ${ }^{a}$ reasoning, which shows clearly that $O$ phioglypha Lyman is a pure synonym of Ophiura as limited by Agassiz and then by Forbes. Consequently the name Ophiura is used in this report for the group of ophiurans widely known as Ophioglypha. With the possible exception of Ophiothrix, no genus in the whole class is so greatly in need of revision as is this one. Indeed Ophiothrix is a far more homogeneous group than Ophiura, for there are several very different generic types now included in this genus, of which over one hundred species are known. I regret to be obliged to add so considerably to this already unwieldy number, but I hope that the figures and descriptions here given will make the ultimate revision 
of the genus less, rather than more, difficult. In the arrangement. of the species I have followed the "Key" in Lyman's Challenger report, interpolating the new species, so far as possible, among their natural allies.

\section{OPHIURA KINBERGI.}

Ophioglypha kinbergi LuUngman, Öfv. Köng. Akad., 1866, p. 166.

Ophioglypha sinensis Lyman, Ill. Cat. Mus. Comp. Zoöl., vol. 6, 1871, p. 12.

Ophiura kinbergi Meissner, Bronn's Thierreichs, vol. 2, pt. 3, 1901, p. 925.

Localities.-Albatross station 3725, off Noma Saki, Japan, 13 fathoms, sand, shells, gravel, 3 specimens; station 3726, off Japan, 26 fathoms, gray volcanic sand, 6 specimens; station 4815, sea of Japan, lat. $38^{\circ} 16^{\prime}$ N.; long. $138^{\circ} 52^{\prime}$ E., 70 fathoms, dark green sand, bottom temperature $51^{\circ}, 2$ specimens; station 4885 , Eastern Sea, lat. $32^{\circ} 31^{\prime}$ $30^{\prime \prime}$ N.; long. $129^{\circ} 30^{\prime} 15^{\prime \prime}$ E., 53 fathoms, dark gray sand, broken shells, 2 specimens. Bathymetrical range, 13 to 70 fathoms. Thirteen specimens.

I can but agree with $\mathrm{K} œ h l e r{ }^{a}$ in regarding sinensis as a synonym of kinbergi. The Albatross specimens have been compared with Lyman's type of sinensis and are unquestionably identical; other specimens from Australia (including what seems to be a cotype of kinbergi), Japan, Hongkong, the Philippines, and Calcutta have also been available for comparison. Australian specimens have the oral shields relatively larger than specimens from Japan, but the specimens from the Philippines are intermediate and I do not

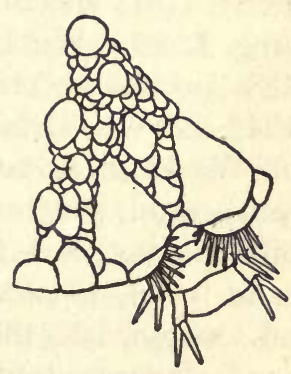

FIG. 9.-OPHIURA KINBERGI. $\times 5$. SHOWING DISK SCALING AND ARM COMB. think the character warrants keeping sinensis and kinbergi separate.

As the arm comb of this species has never been figured, it has seemed desirable to figure it herewith (fig. 9), as it is this character which specially distinguishes kinbergi from the two following species.

\section{OPHIURA SARSII.}

Ophiura sarsii LüTKEN, Vid. Medd. for 1854, 1855, p. 101.

Localities.-Albatross station 2841, off Alaska, lat. $54^{\circ} 18^{\prime} \mathrm{N}$.; long. $165^{\circ} 55^{\prime}$ W., 56 fathoms, pebbles, bottom temperature $41^{\circ}$, 192 specimens; station 2842 , off Alaska, lat. $54^{\circ} 15^{\prime} \mathrm{N}$.; long. $166^{\circ} 3^{\prime}$ W., 72 fathoms, pebbles, bottom temperature $41^{\circ}, 37$ specimens; station 2843 , off Alaska, lat. $53^{\circ} 56^{\prime}$ N.; long. $165^{\circ} 56^{\prime}$ W., 45 fathoms, broken shells, pebbles, bottom temperature $43.5^{\circ}, 3$ specimens; station 2844, off Alaska, lat. $53^{\circ} 56^{\prime} \mathrm{N}$.; long. $165^{\circ} 40^{\prime} \mathrm{W}$., 54 fathoms, gray sand, bottom temperature $42^{\circ}, 63$ specimens; station 2845 , off Alaska, lat. $54^{\circ} 5^{\prime}$ N.; long. $164^{\circ} 9^{\prime}$ W., 42 
fathoms, coarse black sand, bottom temperature $42^{\circ}, 22$ specimens; station 2847, off Alaska, lat. $55^{\circ} 1^{\prime} \mathrm{N}$.; long. $160^{\circ} 12^{\prime} \mathrm{W}$, 48 fathoms, fine gray sand, bottom temperature $42^{\circ}, 3$ specimens; station 2848 , off Alaska, lat. $55^{\circ} 10^{\prime} \mathrm{N}$.; long. $160^{\circ} 18^{\prime}$ W., 110 fathoms, green mud, bottom temperature $41^{\circ}, 7$ specimens; station 2851 , off Alaska, lat. $54^{\circ} 55^{\prime} \mathrm{N}$.; long. $159^{\circ} 52^{\prime} \mathrm{W}$., 35 fathoms, gray sand, broken shells, bottom temperature $44.8^{\circ}, 167$ specimens; station 2856, off Alaska, lat. $58^{\circ} 7^{\prime}$ N.; long. $151^{\circ} 36^{\prime}$ W., 68 fathoms, gray sand with black specks, bottom temperature $44^{\circ}, 25$ specimens; station 2858 , off Alaska, lat. $58^{\circ} 17^{\prime} \mathrm{N}$.; long. $148^{\circ} 36^{\prime}$ W., 230 fathoms, blue mud, gravel, bottom temperature $39.8^{\circ}$, 104 specimens; station 2862, off British Columbia, lat. $50^{\circ} 49^{\prime} \mathrm{N}$.; long. $127^{\circ} 36^{\prime} 30^{\prime \prime}$ W., 238 fathoms, gray sand, pebbles, bottom temperature $44.7^{\circ}$, 40 specimens; station 2863 , off Washington, lat. $48^{\circ} 58^{\prime} \mathrm{N}$.; long. $123^{\circ} 10^{\prime} \mathrm{W}$., 67 fathoms, fine sand, broken shells, bottom temperature $48.5^{\circ}, 1,765$ specimens; station 2866 , off Washington, lat. $48^{\circ} 9^{\prime} \mathrm{N}$.; long. $125^{\circ} 3^{\prime} \mathrm{W}$., 171 fathoms, gray sand, bottom temperature $43.2^{\circ}$, 488 specimens; station 2867 , off Washington, lat. $48^{\circ} 7^{\prime} \mathrm{N}$.; long. $124^{\circ} 55^{\prime}$ W., 37 fathoms, fine gray sand, 6 specimens; station 2876 , off Washington, lat. $48^{\circ} 33^{\prime} \mathrm{N}$.; long. $124^{\circ} 53^{\prime} \mathrm{W}$., 59 fathoms, black sand, mud, bottom temperature $45.5^{\circ}, 33$ specimens; station 2877 , off Washington, lat. $48^{\circ} 33^{\prime} \mathrm{N}$.; long. $124^{\circ} 53^{\prime}$ W., 59 fathoms, black sand, mud, bottom temperature $45.5^{\circ}, 18$ specimens; station $28 \dot{8} 2$, off Oregon, lat. $46^{\circ} 9^{\prime} \mathrm{N}$.; long. $124^{\circ} 22^{\prime} 30^{\prime \prime}$ W., 68 fathoms, gray sand, bottom temperature $45.8^{\circ}, 71$ specimens; station 2883 , off Oregon, lat. $45^{\circ} 56^{\prime}$ N.; long. $124^{\circ} 1^{\prime} 30^{\prime \prime}$ W., 29 fathoms, fine gray sand, bottom temperature $50.1^{\circ}, 3$ specimens; station 2890 , off Oregon, lat. $43^{\circ} 46^{\prime} \mathrm{N}$.; long. $124^{\circ} 57^{\prime}$ W., 277 fathoms, gray sand, bottom temperature $42.2^{\circ}, 209$ specimens; station 3047 , off Oregon, lat. $46^{\circ} 47^{\prime} \mathrm{N}$.; long. $124^{\circ} 30^{\prime} 15^{\prime \prime} \mathrm{W}$., 50 fathoms, fine gray sand, bottom temperature $45.9^{\circ}$, 3 specimens; station 3053 , off Oregon, lat. $44^{\circ} 4^{\prime} 30^{\prime \prime} \mathrm{N}$.; long. $124^{\circ} 50^{\prime}$ W., 64 fathoms, coral, broken shells, rocky, bottom temperature $47.3^{\circ}, 4$ specimens; station 3059 , off Oregon, lat. $44^{\circ} 56^{\prime} \mathrm{N}$.; long. $124^{\circ} 12^{\prime} 30^{\prime \prime}$ W., 77 fathoms, mud, bottom temperature $45.1^{\circ}, 5$ specimens; station 3077 , off Alaska, lat. $55^{\circ} 46^{\prime} \mathrm{N}$.; long. $132^{\circ} 24^{\prime}$ W., 322 fathoms, green mud, gravel, bottom temperature $42.4^{\circ}, 29$ specimens; station 3112 , off California, lat. $37^{\circ} 8^{\prime} \mathrm{N}$.; long. $122^{\circ} 47^{\prime}$ W., 296 fathoms, fine gray sand, bottom temperature $41.8^{\circ}, 1$ specimen; station 3218 , off Alaska, lat. $54^{\circ}$ $15^{\prime} 40^{\prime \prime}$ N.; long. $164^{\circ} 21^{\prime}$ W., 41 fathoms, black sand, bottom temperature $37.7^{\circ}, 35$ specimens; station 3219 , off Alaska, lat. $54^{\circ} 14^{\prime} \mathrm{N}$.; long. $164^{\circ} 35^{\prime} \mathrm{W}$., 59 fathoms, black sand, gravel, bottom temperature $38^{\circ}$, 8 specimens; station 3222 , Bering Sea, lat. $54^{\circ} 20^{\prime} \mathrm{N}$.; long. $165^{\circ} 30^{\prime}$ W., 50 fathoms, black sand, pebbles, shells, bottom temperature $39.7^{\circ}, 104$ specimens; station 3223 , Bering Sea, lat. $54^{\circ}$ 
$26^{\prime} 15^{\prime \prime} \mathrm{N}$.; long. $165^{\circ} 32^{\prime} \mathrm{W}$., 56 fathoms, black pebbles, bottom temperature $39^{\circ}, 50$ specimens; station 3224 , Bering Sea, lat. $54^{\circ}$ $42^{\prime} 50^{\prime \prime} \mathrm{N}$.; long. $165^{\circ} 37^{\prime}$ W., 121 fathoms, black sand, gravel, bottom temperature $38.7^{\circ}$, 50 specimens; station 3252 , Bering Sea, lat. $57^{\circ} 22^{\prime} 20^{\prime \prime} \mathrm{N}$.; long. $164^{\circ} 24^{\prime} 40^{\prime \prime}$ W., $29 \frac{1}{2}$ fathoms, black mud, bottom temperature $44.8^{\circ}, 165$ specimens; station 3253 , Bering Sea, lat. $57^{\circ} 5^{\prime} 50^{\prime \prime} \mathrm{N}$.; long. $164^{\circ} 27^{\prime} 15^{\prime \prime}$ W., 36 fathoms, mud, sand, bottom temperature $35^{\circ}, 122$ specimens; station 3254 , Bering Sea, lat. $56^{\circ} 50^{\prime} \mathrm{N}$.; long. $164^{\circ} 27^{\prime} 50^{\prime \prime} \mathrm{W}$., 46 fathoms, green mud, sand, bottom temperature $36.2^{\circ}$, 445 specimens; station 3255 , Bering Sea, lat. $56^{\circ} 33^{\prime} 30^{\prime \prime} \mathrm{N}$.; long. $164^{\circ} 31^{\prime} 40^{\prime \prime}$ W., 43 fathoms, green mud, sand, bottom temperature $37^{\circ}, 5,743$ specimens; station 3256 , Bering Sea, lat. $56^{\circ} 18^{\prime} \mathrm{N}$.; long. $164^{\circ} 34^{\prime} 10^{\prime \prime}$ W., 49 fathoms, green mud, black specks, bottom temperature $35^{\circ}, 253$ specimens; station 3257 , Bering Sea, lat. $54^{\circ} 49^{\prime} \mathrm{N}$.; long. $165^{\circ} 32^{\prime}$ W., 81 fathoms, gray sand, gravel, bottom temperature $39^{\circ}, 79$ specimens; station 3258 , Bering Sea, lat. $54^{\circ} 48^{\prime} \mathrm{N}$.; long. $165^{\circ} 13^{\prime} 30^{\prime \prime}$ W., 70 fathoms, black sand, gravel, bottom temperature $39^{\circ}$, 56 specimens; station 3260 , Bering Sea, lat. $54^{\circ} 36^{\prime} 15^{\prime \prime} \mathrm{N}$.; long. $164^{\circ} 52^{\prime}$ W., 13 fathoms, fine black sand, bottom temperature $42^{\circ}, 8$ specimens; station 3279 , Bering Sea, lat. $56^{\circ} 25^{\prime} 40^{\prime \prime} \mathrm{N}$.; long. $162^{\circ} 39^{\prime} 15^{\prime \prime} \mathrm{W}$., 41 fathoms, fine gray sand, bottom temperature $37^{\circ}, 177$ specimens; station 3280 , Bering Sea, lat. $56^{\circ} 27^{\prime}$ N.; long. $162^{\circ} 8^{\prime}$ W., 36 fathoms, fine gray sand, bottom temperature $41^{\circ}, 96$ specimens; station 3309, Bering Sea, lat. $56^{\circ} 56^{\prime} \mathrm{N}$.; long. $172^{\circ} 55^{\prime} \mathrm{W}$., 71 fathoms, green mud, bottom temperature $37.9^{\circ}, 750$ specimens; station 3311 , Bering Sea, lat. $53^{\circ} 59^{\prime} 36^{\prime \prime}$ N.; long. $166^{\circ} 29^{\prime} 43^{\prime \prime}$ W., 85 fathoms, green mud, bottom temperature $41^{\circ}, 7$ specimens; station 3312 , Bering Sea, lat. $53^{\circ} 59^{\prime} 11^{\prime \prime} \mathrm{N}$.; long. $166^{\circ} 25^{\prime} 9^{\prime \prime}$ W., 45 fathoms, fine sand, mud, bottom temperature $43^{\circ}$, 1 specimen; station 3313 , Bering Sea, lat. $54^{\circ} 1^{\prime} 51^{\prime \prime}$ N.; long. $166^{\circ}$ $27^{\prime} 38^{\prime \prime}$ W., 68 fathoms, fine black sand, bottom temperature $42.7^{\circ}$, 52 specimens; station 3314 , Bering Sea, lat. $54^{\circ} 2^{\prime} 24^{\prime \prime}$ N.; long. $166^{\circ}$ $32^{\prime} 47^{\prime \prime}$ W., 74 fathoms, black sand, bottom temperature $42.5^{\circ}, 16$ specimens; station 3315 , Bering Sea, lat. $54^{\circ} 2^{\prime} 40^{\prime \prime}$ N.; long. $166^{\circ}$ $42^{\prime}$ W., 277 fathoms, green mud, sand, bottom temperature $38.5^{\circ}$, 1 specimen; station .3318 , Bering Sea, lat. $53^{\circ} 47^{\prime} 40^{\prime \prime} \mathrm{N}$.; long $.167^{\circ}$ $14^{\prime}$ W., 61 fathoms, black sand, gravel, shells, bottom temperature $42^{\circ}, 21$ specimens; station 3322 , Bering Sea, lat. $53^{\circ} 28^{\prime} 45^{\prime \prime} \mathrm{N}$.; long. $167^{\circ} 23^{\prime} 50^{\prime \prime}$ W., 35 fathoms, black sand, bottom temperature $42.4^{\circ}, 4$ specimens; station 3339 , off Alaska, lat. $54^{\circ} 46^{\prime} \mathrm{N}$.; long. $157^{\circ} 43^{\prime} 30^{\prime \prime}$ W., 138 fathoms, mud, gravel, bottom temperature $37.4^{\circ}, 3$ specimens; station 3340 , off Alaska, lat. $55^{\circ} 26^{\prime}$ N.; long. $155^{\circ}$ $26^{\prime}$ W., 695 fathoms, mud, bottom temperature $36.8^{\circ}, 3$ specimens; station 3439 , Bering Sea, lat. $57^{\circ} 6^{\prime}$ N.; long. $170^{\circ} 35^{\prime}$ W., 41 fathoms, fine black sand, bottom temperature $44^{\circ}, 418$ specimens; station 
3440 , Bering Sea, lat. $57^{\circ} 5^{\prime}$ N.; long. $170^{\circ} 41^{\prime}$ W., 48 fathoms, black mud, shells, bottom temperature ?, 901 specimens; station 3441, Bering Sea, lat. $57^{\circ} 4^{\prime} 20^{\prime \prime} \mathrm{N}$.; long. $170^{\circ} 52^{\prime} 30^{\prime \prime}$ W., 51 fathoms, black mud, shells, bottom temperature $39^{\circ}, 319$ specimens; station 3442 , Bering Sea, lat. $57^{\circ} 10^{\prime} \mathrm{N}$.; long. $170^{\circ} 47^{\prime} 15^{\prime \prime} \mathrm{W}$., 47 fathoms, blue mud, shells, bottom temperature $40^{\circ}, 59$ specimens; station 3443 , off Washington, lat. $48^{\circ} 13^{\prime} 30^{\prime \prime} \mathrm{N}$.; long. $123^{\circ} 11^{\prime} 20^{\prime \prime}$ W., 97 fathoms, green mud, pebbles, bottom temperature $46^{\circ}, 1$ specimen; station 3449 , off Washington, lat. $48^{\circ} 29^{\prime} 40^{\prime \prime} \mathrm{N}$.; long. $124^{\circ} 40^{\prime}$ $10^{\prime \prime} \mathrm{W} ., 135$ fathoms, gray sand, gravel, 121 specimens; station 3450 , off Washington, lat. $48^{\circ} 26^{\prime} 50^{\prime \prime}$ N.; long. $124^{\circ} 39^{\prime} 35^{\prime \prime}$ W., 151 fathoms, gravel, bottom temperature $44^{\circ}, 21$ specimens; station 3452 , off Washington, lat. $48^{\circ} 24^{\prime} 40^{\prime \prime} \mathrm{N}$.; long. $124^{\circ} 29^{\prime} 10^{\prime \prime} \mathrm{W} ., 125$ fathoms, rocky, black gravel, bottom temperature $44.5^{\circ}, 7$ specimens; station 3453 , off Washington, lat. $48^{\circ} 20^{\prime} \mathrm{N}$.; long. $124^{\circ} 13^{\prime} 40^{\prime \prime} \mathrm{W}$., 120 fathoms, gray sand, black specks, bottom temperature $44.4^{\circ}, 102$ specimens; station 3454 , off Washington, lat. $48^{\circ} 27^{\prime} 50^{\prime \prime} \mathrm{N}$.; long. $124^{\circ} 42^{\prime} 40^{\prime \prime} \mathrm{W}$., 152 fathoms, gray sand, rocky, bottom temperature $44.2^{\circ}, 3$ specimens; station 3456 , off Washington, lat. $48^{\circ} 31^{\prime} 15^{\prime \prime} \mathrm{N}$.; long. $124^{\circ} 43^{\prime} 15^{\prime \prime} \mathrm{W}$., 136 fathoms, gray sand, bottom temperature $44.2^{\circ}, 21$ specimens; station 3457 , off Washington, lat. $48^{\circ} 28^{\prime} 20^{\prime \prime} \mathrm{N}$.; long. $124^{\circ} 52^{\prime} 5^{\prime \prime} \mathrm{W}$., 142 fathoms, gray sand, bottom temperature $44.2^{\circ}$, 90 specimens; station 3459 , off Washington, lat. $48^{\circ} 24^{\prime} 20^{\prime \prime} \mathrm{N}$.; long. $124^{\circ} 24^{\prime} 40^{\prime \prime}$ W., 123 fathoms, gray sand, pebbles, bottom temperature $44.5^{\circ}, 21$ specimens; station 3482 , Bering Sea, lat. $57^{\circ} 18^{\prime} \mathrm{N}$.; long. $170^{\circ} 42^{\prime} \mathrm{W}$., 42 fathoms, green mud, fine sand, bottom temperature $38.9^{\circ}, 491$ specimens; station 3483 , Bering Sea, lat. $57^{\circ} 18^{\prime}$ $\mathrm{N}$; ; long. $171^{\circ} 18^{\prime} \mathrm{W}$., 56 fathoms, green mud, bottom temperature $36.8^{\circ}$, 5 specimens; station 3485 , Bering Sea, lat. $57^{\circ} 18^{\prime} \mathrm{N}$.; long. $172^{\circ} 34^{\prime}$ W., 62 fathoms, green mud, bottom temperature $37.1^{\circ}, 18$ specimens; station 3486 , Bering Sea, lat. $57^{\circ} 19^{\prime}$ N.; long. $173^{\circ} 53^{\prime}$ W., 150 fathoms, green mud, fine sand, bottom temperature $38^{\circ}, 6$ specimens; station 3487 , Bering Sea, lat. $57^{\circ} 10^{\prime} \mathrm{N}$.; long. $173^{\circ} 45^{\prime}$ W., 81 fathoms, green mud, fine sand, bottom temperature $37.6^{\circ}$, 30 specimens; station 3490 , Bering Sea, lat. $56^{\circ} 47^{\prime}$ N.; long. $173^{\circ}$ $14^{\prime} \mathrm{W}$., 78 fathoms, green mud, fine sand, bottom temperature $38^{\circ}$, 8 specimens; station 3491 , Bering Sea, lat. $56^{\circ} 32^{\prime}$ N.; long. $172^{\circ} 28^{\prime}$ W., 103 fathoms, green mud, fine gray sand, bottom temperature?, 14 specimens; station 3492 , Bering Sea, lat. $56^{\circ} 32^{\prime}$ N.; long. $171^{\circ}$ $50^{\prime} \mathrm{W}$., 70 fathoms, green mud, fine sand, bottom temperature $37.8^{\circ}$, 5 specimens; station 3495 , Bering Sea, lat. $56^{\circ} 37^{\prime} \mathrm{N}$.; long. $170^{\circ} 1^{\prime}$ W., .56 fathoms, green mud, fine sand, bottom temperature $38.5^{\circ}$, 5 specimens; station 3504 , Bering Sea, lat. $56^{\circ} 57^{\prime}$ N.; long. $169^{\circ} 27^{\prime}$ W., 34 fathoms, fine gray sand, black specks, bottom temperature $37.8^{\circ}, 95$ specimens; station 3505 , Bering Sea, lat. $57^{\circ} 9^{\prime} \mathrm{N}$.; long. 
$168^{\circ} 17^{\prime}$ W., 44 fathoms, fine gray sand, bottom temperature $38.1^{\circ}$, 234 specimens; station 3511 , Bering Sea, lat. $57^{\circ} 32^{\prime}$ N.; long. $169^{\circ}$ $38^{\prime} \mathrm{W}$., 39 fathoms, fine sand, dark mud, bottom temperature $37.2^{\circ}, 2$ specimens; station 3513 , Bering Sea, lat. $58^{\circ} 27^{\prime}$ N.; long. $169^{\circ} 1^{\prime}$ W., 35 fathoms, fine sand, green mud, bottom temperature ?, 32 specimens; station 3520 , Bering Sea, lat. $59^{\circ} 28^{\prime}$ N.; long. $170^{\circ} 57^{\prime}$ W., 38 fathoms, green mud, fine sand, bottom temperature $32.2^{\circ}$, 1 specimen; station 3521 , Bering Sea, lat. $59^{\circ} 9^{\prime} \mathrm{N}$.; long. $170^{\circ} 48^{\prime}$ W., 40 fathoms, green mud, fine sand, bottom temperature $31.9^{\circ}, 310$ specimens; station 3522, Bering Sea, lat. $57^{\circ} 58^{\prime}$ N.; long. $170^{\circ} 9^{\prime}$ W., 41 fathoms, coarse gray sand, gravel, bottom temperature $35.7^{\circ}, 21$ specimens; station 3523 , Bering Sea, lat. $57^{\circ} 39^{\prime}$ N.; long. $170^{\circ} 2^{\prime}$ W., 39 fathoms, green mud, fine sand, bottom temperature $38^{\circ}, 30$ specimens; station 3527 , Bering Sea, lat. $57^{\circ} 48^{\prime}$ N.; long. $171^{\circ} 21^{\prime}$ W., 52 fathoms, green mud, bottom temperature $38^{\circ}$, 18 specimens; station 3528 , Bering Sea, lat. $58^{\circ} 19^{\prime} 30^{\prime \prime}$ N.; long. $172^{\circ} 2^{\prime}$ W., 55 fathoms, dark green mud, fine sand, bottom temperature $35.9^{\circ}$, 90 specimens; station 3529 , Bering Sea, lat. $58^{\circ} 36^{\prime}$ N.; long. $172^{\circ} 24^{\prime}$ W., 56 fathoms, green mud, bottom temperature $36.1^{\circ}, 237$ specimens; station 3530 , Bering Sea, lat. $59^{\circ} 39^{\prime} \mathrm{N}$.; long. $173^{\circ} 53^{\prime}$ W., 59 fathoms, dark green mud, fine sand, bottom temperature $34.9^{\circ}, 127$ specimens; station 3531 , Bering Sea, lat. $59^{\circ} 55^{\prime} \mathrm{N}$.; long. $174^{\circ} 17^{\prime} \mathrm{W}$., 59 fathoms, green mud, bottom temperature $35.1^{\circ}, 70$ specimens; station 3535, Bering Sea, lat. $57^{\circ} 2^{\prime} \mathrm{N}$.; long. $170^{\circ} 46^{\prime}$ W., 52 fathoms, green mud, fine sand, bottom temperature $39^{\circ}, 6$ specimens; station 3536 , Bering Sea, lat. $57^{\circ} 5^{\prime} \mathrm{N}$.; long. $170^{\circ} 35^{\prime} \mathrm{W}$., 40 fathoms, green mud, fine sand, bottom temperature $42.4^{\circ}, 110$ specimens; station 3540 , Bering Sea, lat. $56^{\circ}$ $27^{\prime}$ N.; long. $166^{\circ} 8^{\prime}$ W., 51 fathoms, green mud, fine sand, bottom temperature $36^{\circ}, 46$ specimens; station 3541 , Bering Sea, lat. $56^{\circ} 14^{\prime}$ N.; long. $164^{\circ} 8^{\prime}$ W., 49 fathoms, black mud, fine sand, bottom temperature $36.1^{\circ}, 55^{\circ}$ specimens; station 3542 , Bering Sea, lat. $56^{\circ} 10^{\prime}$ N.; long. $163^{\circ} 26^{\prime}$ W., 49 fathoms, dark mud, fine sand, bottom temperature $39.2^{\circ}, 50$ specimens; station 3543 , Bering. Sea, lat. $54^{\circ}$ $41^{\prime}$ N.; long. $169^{\circ} 39^{\prime}$ W., 43 fathoms, black sand, shells, bottom temperature $42.7^{\circ}, 3$ specimens; station 3546 , Bering Sea, lat. $54^{\circ} 12^{\prime}$ N.; long. $165^{\circ} 42^{\prime}$ W., 36 fathoms, gravel, black sand, bottom temperature $45.6^{\circ}, 78$ specimens;' station 3547 , Bering Sea, lat. $54^{\circ} 16^{\prime}$ N.; long. $165^{\circ} 45^{\prime}$ W., 51 fathoms, fine black sand, bottom temperature $45^{\circ}, 29$ specimens; station 3553 , Bering Sea, lat. $56^{\circ} 28^{\prime} \mathrm{N}$.; long. $169^{\circ} 46^{\prime}$ W., 51 fathoms, fine gray sand, mud, bottom temperature $39.5^{\circ}, 25$ specimens; station 3554 , Bering Sea, lat. $56^{\circ} 34^{\prime}$ N.; long. $170^{\circ} 19^{\prime}$ W., 62 fathoms, green mud, bottom temperature $39.5^{\circ}, 12$ specimens; station 3556 , Bering Sea, lat. $56^{\circ} 57^{\prime} 30^{\prime \prime}$ N.; long. $170^{\circ}$ $33^{\prime}$ W., 49 fathoms, green mud, fine sand, bottom temperature $41^{\circ}$, 5 specimens; station 3560 , Bering Sea, lat. $56^{\circ} 40^{\prime}$ N.; long. $169^{\circ} 20^{\prime}$ 
W., 43 fathoms, fine gray sand, black specks, bottom temperature $40.7^{\circ}, 36$ specimens; station 3561 , Bering Sea, lat. $56^{\circ} 31^{\prime}$ N.; long. $169^{\circ} 17^{\prime}$ W., 48 fathoms, gray sand, black specks, bottom temperature $40.7^{\circ}, 28$ specimens; station 3594 , off Washington, lat. $48^{\circ} 12^{\prime} \mathrm{N}$.; long. $122^{\circ} 50^{\prime}$ W., 36 fathoms, sand, pebbles, bottom temperature $46^{\circ}, 7$ specimens; station 3602 , Bering Sea, lat. $56^{\circ} 32^{\prime}$ N.; long. $172^{\circ}$ $40^{\prime}$ W., 81 fathoms, green mud, sand, bottom temperature $37.1^{\circ}, 50$ specimens; station 3609, Bering Sea, lat. $55^{\circ} 35^{\prime}$ N.; long. $168^{\circ} 20^{\prime}$ W., 74 fathoms, green mud, sand, bottom temperature $37.9^{\circ}, 165$ specimens; station 3610 , Bering Sea, lat. $55^{\circ} 58^{\prime}$ N.; long. $167^{\circ} 16^{\prime}$ W., 75 fathoms, green mud, bottom temperature $36.8^{\circ}, 381$ specimens; station 3611 , Bering Sea, lat. $56^{\circ} 45^{\prime} \mathrm{N}$.; long. $167^{\circ} 25^{\prime} \mathrm{W}$., 50 fathoms, green mud, sand, bottom temperature $34.6^{\circ}, 408$ specimens; station 3658, Hakodate Bay, Japan, 22 fathoms, fine gray sand, 3 specimens; station 3659, Hakodate Bay, Japan, 15.5 fathoms, fine gray sand, 1 specimen; station 3673 , off Washington, lat. $48^{\circ}$ $21^{\prime} 45^{\prime \prime} \mathrm{N}$.; long. $124^{\circ} 50^{\prime} 30^{\prime \prime}$ W., 77 fathoms, green mud, sand, 10 specimens; station 3675, locality unknown (the station is missing from the record), 10 specimens; station 3769 , off Nagane Saki, Japan, 40-42 fathoms, green mud, sand, 12 specimens; station 3775 , off Kinkwasan Light, Honshu Island, Japan, 57 fathoms, green mud, sand, 1 specimen; station 3789 , off Washington, lat. $48^{\circ} 21^{\prime} 45^{\prime \prime} \mathrm{N}$.; long. $124^{\circ} 52^{\prime} 30^{\prime \prime}$ W., 115 fathoms, coarse gray sand, gravel, 123 specimens; station 4770 , Bering Sea, lat. $54^{\circ} 31^{\prime} \mathrm{N}$.; long. $179^{\circ} 15^{\prime}$ E., 247 fathoms, 14 specimens; station 4784, off Aleutian Islands, lat. $52^{\circ} 55^{\prime} 40^{\prime \prime} \mathrm{N}$.; long. $173^{\circ} 26^{\prime}$ E., 135 fathoms, coarse pebbles, 1 specimen; station 4786, off Aleutian Islands, lat. $54^{\circ} 51^{\prime} 30^{\prime \prime} \mathrm{N}$.; long. $167^{\circ} 14^{\prime}$ E., 54 fathoms, green sand, 7 specimens; station 4788 , near Copper Island, lat. $54^{\circ} 50^{\prime} 24^{\prime \prime}$ N.; long. $167^{\circ} 13^{\prime}$ E., $56-57$ fathoms, green sand, 13 specimens; station 4789 , near Copper Island, lat. $54^{\circ} 49^{\prime} 45^{\prime \prime} \mathrm{N}$.; long. $167^{\circ} 12^{\prime} 30^{\prime \prime} \mathrm{E}$., 56 fathoms, green sand, 44 specimens; station 4790 , off Bering Island, lat. $54^{\circ} 38^{\prime} 45^{\prime \prime} \mathrm{N}$.; long. $167^{\circ} 11^{\prime} 45^{\prime \prime}$ E., 64 fathoms, pebbles, 4 specimens; station 4791, off Bering Island, lat. $54^{\circ} 36^{\prime} 15^{\prime \prime} \mathrm{N}$.; long. $166^{\circ} 58^{\prime} 15^{\prime \prime} \mathrm{E}$, $72-76$ fathoms, rocky, 30 specimens; station 4792, off Bering Island, lat. $54^{\circ} 36^{\prime} 15^{\prime \prime}$ N.; long. $166^{\circ} 57^{\prime} 15^{\prime \prime}$ E., 72 fathoms, pebbles, 147 specimens; station 4807, off Cape Tsiuka, Japan, lat. $41^{\circ} 36^{\prime} 12^{\prime \prime}$ N.; long. $140^{\circ} 36^{\prime}$ E., 44-47 fathoms, shells, coarse gravel, 5 specimens; station 4822 , off No Saki. Japan, lat. $37^{\circ} 8^{\prime} 10^{\prime \prime}$ N.; long. $137^{\circ}$ $8^{\prime}$ E., 130 fathoms, green mud, bottom temperature $39.4^{\circ}, 4$ specimens; station 4826 , off Sudzu, Misaki Light, Japan, lat. $37^{\circ} 25^{\prime} \mathrm{N}$.; long. $137^{\circ} 32^{\prime}$ E., 114 fathoms, fine gray sand, black specks, bottom temperature, $42.5^{\circ}, 10$ specimens; station 4828 , off Hondo, Japan, lat. $37^{\circ} 23^{\prime} \mathrm{N}$.; long. $137^{\circ} 36^{\prime}$ E., 163 fathoms, green mud, bottom temperature $34.9^{\circ}$, 1 specimen; station 4832 , off Ando Zaki, Japan, lat. 
$36^{\circ} 14^{\prime} 30^{\prime \prime} \mathrm{N}$.; long. $135^{\circ} 56^{\prime} 30^{\prime \prime}$ E., 76-79 fathoms, dark gray sand, bottom temperature $53.2^{\circ}, 5$ specimens; station 4833 , off Ando Zaki, Japan, lat. $36^{\circ} 13^{\prime} 40^{\prime \prime} \mathrm{N}$.; long. $135^{\circ} 56^{\prime} 30^{\prime \prime}$ E., 79 fathoms, dark gray sand, rocks, 1 specimen; station 4835 , off O Shima, Japan, lat. $36^{\circ} 3^{\prime}$ $30^{\prime \prime} \mathrm{N}$.; long. $135^{\circ} 52^{\prime} 30^{\prime \prime} \mathrm{E}$., 134 fathoms, green mud, bottom temperature $34.9^{\circ}, 27$ specimens; station 4840 , Sea of Japan, lat. $36^{\circ} 2^{\prime}$ N.; long. $135^{\circ} 30^{\prime}$ E., 154 fathoms, green mud, bottom temperature $33.9^{\circ}, 6$ specimens; station 4842 , off Dogo Island, lat. $36^{\circ} 13^{\prime} \mathrm{N}$.; long. $133^{\circ} 27^{\prime}$ E., 82 fathoms, fine gray sand, shells, bottom temperature $54.6^{\circ}, 13$ specimens; station 4854 , off Korea, lat. $35^{\circ} 54^{\prime} \mathrm{N}$.; long. $129^{\circ} 46^{\prime}$ E., 335 fathoms, green mud, bottom temperature $32.4^{\circ}, 22$ specimens; station 4861 , off Korea, lat. $36^{\circ} 19^{\prime}$ N.; long. $129^{\circ}$ $47^{\prime}$ E., 163 fathoms, green mud, bottom temperature $33.4^{\circ}, 15$ specimens; station 4862 , off Korea, lat. $36^{\circ} 20^{\prime}$ N.; long. $129^{\circ} 50^{\prime}$ E., 184 fathoms, green mud, bottom temperature $32.9^{\circ}, 1$ specimen; station 4891 , Eastern Sea, lat. $32^{\circ} 27^{\prime}$ N.; long. $128^{\circ} 34^{\prime}$ E. 181 fathoms gray sand, broken shells, rocks, bottom temperature $50.2^{\circ}, 5$ specimens; station 4981, off Benkei Misaki Light, Japan, lat. $42^{\circ} 58^{\prime} 15^{\prime \prime}$ N.; long. $140^{\circ} 9^{\prime} 10^{\prime \prime}$ E., 390-406 fathoms; green mud, bottom temperature $32.7^{\circ}, 11$ specimens; station 4982 , Sea of Japan, lat. $43^{\circ}$ N.; long. $140^{\circ} 10^{\prime} 30^{\prime \prime}$ E., 390-428 fathoms, green mud, bottom temperature $37.7^{\circ}, 1$ specimen; station 4986 , Sea of Japan, lat. $43^{\circ} 1^{\prime} 40^{\prime \prime}$ N. ; long. $140^{\circ} 22^{\prime} 40^{\prime \prime}$ E., 172 fathoms, fine black sand, black mud, bottom temperature $33.9^{\circ}, 4$ specimens; station 4987 , Sea of Japan, lat. $43^{\circ} 19^{\prime} 20^{\prime \prime} \mathrm{N}$.; long. $140^{\circ} 17^{\prime}$ E., 59 fathoms, rocky, bottom temperature $44.8^{\circ}, 2$ specimens; station 4988 , Sea of Japan, lat. $43^{\circ}$ $23^{\prime} 10^{\prime \prime} \mathrm{N}$.; long. $140^{\circ} 21^{\prime} 10^{\prime \prime}$ E., 68 fathoms, sand, bottom temperature $45^{\circ}, 17$ specimens; station 4989 , Sea of Japan, lat. $43^{\circ} 23^{\prime} 10^{\prime \prime}$ N.; long. $140^{\circ} 37^{\prime}$ E., 92 fathoms, sand, bottom temperature $39.7^{\circ}$, 14 specimens; station 4991, Sea of Japan, lat. $45^{\circ} 23^{\prime} 20^{\prime \prime} \mathrm{N}$.; long. $140^{\circ} 48^{\prime}$ E., 325 fathoms, green mud, bottom temperature $33^{\circ}, 1$ specimen; station 4994 , Sea of Japan, lat. $45^{\circ} 27^{\prime} 50^{\prime \prime} \mathrm{N}$.; long. $140^{\circ} 54^{\prime}$ E., 190 fathoms, brown mud, fine black sand, bottom temperature $34^{\circ}$, 9 specimens; station 4997 , Gulf of Tartary, lat. $47^{\circ} 38^{\prime} 40^{\prime \prime} \mathrm{N}$.; long. $141^{\circ} 24^{\prime} 30^{\prime \prime}$ E., 318 fathoms, green mud, bottom temperature $32.8^{\circ}$, 15 specimens; station 5022 , Okhotsk Sea, lat. $48^{\circ} 35^{\prime} 30^{\prime \prime} \mathrm{N}$.; long. $145^{\circ} 20^{\prime}$ E., 109 fathoms, green mud, coarse black sand, bottom temperature $30.1^{\circ}, 1$ specimen; station 5023, Okhotsk Sea, lat. $48^{\circ} 43^{\prime}$ $30^{\prime \prime} \mathrm{N}$.; long. $145^{\circ} 3^{\prime} \mathrm{E}$., 75 fathoms, sand, pebbles, bottom temperature $30.9^{\circ}, 2$ specimens; station 5037, off Urakawa Light, Japan, lat. $42^{\circ} 2^{\prime} 40^{\prime \prime} \mathrm{N}$.; long. $142^{\circ} 33^{\prime} 20^{\prime \prime} \mathrm{E}$., 175-349 fathoms, bottom temperature $37.9^{\circ}, 1$ specimen; station 5038, off Urakawa Light, Japan, lat. $42^{\circ} 2^{\prime} 40^{\prime \prime} \mathrm{N}$.; long. $142^{\circ} 36^{\prime}$ E., 175 fathoms, bottom temperature $37.1^{\circ}, 3$ specimens; station 5092, in Uraga Strait, lat. $35^{\circ} 4^{\prime} 20^{\prime \prime}$ $\mathrm{N}$. ; long. $139^{\circ} 38^{\prime} 18^{\prime \prime}$ E., 70 fathoms, coarse black sand, bottom tem- 
perature $56.3^{\circ}, 3$ specimens; Coal Station, Unga, 1 specimen; Arctic Cruise of the Corwin, 183 specimens; Arctic Ocean, 1,139 specimens; St. Pauls Island, 1 specimen; Bering Straits, 12 fathoms, gravel, 34 specimens; Bering Straits, 1 specimen; 10 miles west of Point Franklin, Alaska, $13 \frac{1}{2}$ fathoms, sand, 41 specimens; Popoff Strait, 6 fathoms, 6 specimens; Alaska, 143 specimens; Cape Sabine, Alaska, 13 fathoms, 4 specimens; 15 miles west of Cape Krusenstern, 5 fathoms, mud, 5 specimens; $66^{\circ} 45^{\prime} \mathrm{N}$. by $166^{\circ} 35^{\prime}$ W., 13 specimens; Iliuliuk, 78 specimens; Nazan Bay, Atka, 21 specimens; Captains Harbor, Unalaska, 21 specimens; Port Levasheff, Unalaska,' 3 specimens; Kadiak, 23 specimens; Sitka, Alaska, 15 fathoms, 9 specimens; Monterey, California, 1 specimen; unknown stations, 1,812 specimens. Bathymetrical range, 5 to 695 fathoms. Temperature range, $56.3^{\circ}$ to $30.1^{\circ}$. Twenty thousand nine hundred and thirty-two specimens.

This extraordinary array of specimens exhibits considerable diversity in several details. The smallest specimens have the disk about $3 \mathrm{~mm}$. in diameter, while in the largest specimens it exceeds 32 . Most of the specimens are uniformly gray in color, but there is great variety of shade, some being very dark, others very light, others decidedly yellowish, and others more or less brown. Some specimens, generally young ones, have the arms banded with yellowish or whitish, and in a few cases there are whitish spots or markings on the disk. Several specimens are distinctly spotted with black. There is equal diversity in the length of the arm spines; in some specimens even the uppermost spine is scarcely as long as a joint, while at the other extreme we find specimens in which it equals twojoints. The scales of the disk exhibit more or less diversity, for they are commonly perfectly flat, but they may be more or less swollen, so that the disk is sometimes very rough. The arm comb, too, displays considerable variety, for while the papillæ are never as broad, truncate, and crowded as in lütkeni nor as slender and delicate as in kinbergi, yet they range from those which are wider than long and bluntly rounded to those which are several times as long as they are thick and are nearly cylindrical in form. In any case they are almost always well spaced. In large specimens they are sometimes greatly reduced. The chief interest in this huge collection of sarsii is the light which it throws on the distribution of the species in the North Pacific Ocean. Previously known from the North Atlantic and Arctic oceans and from Bering Sea down to depths of about 1,700 fathoms, this collection shows it to be by far the most abundant ophiuran in the North Pacific, occurring at least as far south on both coasts as lat. $38^{\circ} \mathrm{N}$., and down to depths of about 700 fathoms. It is interesting to note that some of the diversities of form and color referred to above are associated with certain geographical areas. Thus the black-spotted 
specimens are all from the coasts of Japan, and the same is true of the specimens which have long comb papillæ. Moreover, many of the Japanese specimens are brown rather than gray. It is remarkable that in these particulars these Japanese specimens of sarsii are almost exactly like many specimens from off the New England coast. The large series of specimens in the Museum of Comparative Zoölogy collection from Europe, Greenland, and the eastern coast of North America, when compared with this huge series from the North Pacific, seems to indicate that the northern specimens are as a rule larger, duller, and with shorter comb papillæ than those from near the southern limit of distribution. The latter tend to have elongated slender comb papillæ and a brown or variegated coloration. There is no hard and fast rule, however, for typical sarsii are often taken at the extreme southern part of the range and occasionally at the same station with the more divergent form. The specimens from stations $3658,3659,3775,48074833,4987$, and 4988 , and one specimen from 4826 and one from 4989, have elongated comb papillæ. In this respect they approach kinbergi, but the papillæ are not as slender as in that species, and in several other characters the specimens are different.

\section{OPHIURA LÜTKENI.}

Ophioglypha lütkeni Lyman, Proc. Bos. Soc. Nat. Hist., vol. 7, 1860, p. 197.

Ophiura lïtkeni Meissner, Bronn's Thierreichs, vol. 2, pt. 3, 1901, p. 925.

Localities.-Albatross station 2858, off Alaska, lat. $58^{\circ} 17^{\prime} \mathrm{N}$.; long. $148^{\circ} 36^{\prime}$ W., 230 fathoms, blue mud, gravel, bottom temperature $39.8^{\circ}, 1$ specimen; station 2862, off British Columbia, lat. $50^{\circ} 49^{\prime} \mathrm{N}$.; long. $127^{\circ} 36^{\prime} 30^{\prime \prime}$ W., 238 fathoms, gray sand and pebbles, bottom temperature $44.7^{\circ}, 112$ specimens; station 2868, off Washington, lat. $47^{\circ} 52^{\prime} \mathrm{N}$.; long. $124^{\circ} 44^{\prime} \mathrm{W}$., 31 fathoms, gray sand, bottom temperature $46.9^{\circ}, 7$ specimens; station 2869 , off Washington, lat. $47^{\circ}$ $38^{\prime}$ N.; long. $124^{\circ} 39^{\prime}$ W., 32 fathoms, black sand, bottom temperature, $48.4^{\circ}, 8$ specimens; station 2870 , off Washington, lat. $46^{\circ} 44^{\prime}$ N.; long. $124^{\circ} 32^{\prime}$ W., 58 fathoms, rocky, bottom temperature $46.5^{\circ}$, 11 specimens; station 2872 , off Washington, lat. $48^{\circ} 17^{\prime} \mathrm{N}$.; long. $124^{\circ} 52^{\prime}$ W., 38 fathoms, gray sand, bottom temperature $45.5^{\circ}, 3$ specimens; station 2882 , off Oregon, lat. $46^{\circ} 9^{\prime} \mathrm{N}$.; long. $124^{\circ} 22^{\prime} 30^{\prime \prime}$ W., 68 fathoms, gray sand, bottom temperature $45.8^{\circ}, 15$ specimens; station 2884 , off Oregon, lat. $45^{\circ} 55^{\prime} \mathrm{N}$.; long. $124^{\circ} 2^{\prime}$ W., 29 fathoms, fine gray sand, bottom temperature $50.2^{\circ}, 2$ specimens; station 3046 , off Washington, lat. $46^{\circ} 48^{\prime} 30^{\prime \prime} \mathrm{N}$.; long. $124^{\circ} 28^{\prime}$ W., 48 fathoms, fine gray sand, bottom temperature $46.1^{\circ}, 18$ specimens; station 3047 , off Washington, lat. $46^{\circ} 47^{\prime} \mathrm{N}$.; long. $124^{\circ} 30^{\prime} 15^{\prime \prime} \mathrm{W}$., 50 fathoms, fine gray sand, bottom temperature $45.9^{\circ}, 9$ specimens; station 3049 , off Washington, lat. $46^{\circ} 31^{\prime}$ N. ; long. $124^{\circ} 22^{\prime}$ W., 43 fathoms, fine black sand, bottom temperature $46.7^{\circ}, 12$ specimens; station 
3053 , off Oregon, lat. $44^{\circ} 4^{\prime} 30^{\prime \prime} \mathrm{N}$.; long. $124^{\circ} 50^{\prime} \mathrm{W}, 64$ fathoms coral, broken shells, rocky, bottom temperature $47.3^{\circ}, 3$ specimens; station 3059 , off Oregon, lat. $44^{\circ} 56^{\prime}$ N.; long. $124^{\circ} 12^{\prime} 30^{\prime \prime} \mathrm{W} ., 77$ fathoms, mud, bottom temperature $45.1^{\circ}, 9$ specimens; station 3064, off Oregon, lat. $46^{\circ} 3^{\prime} 15^{\prime \prime} \mathrm{N}$.; long. $124^{\circ} 9^{\prime} \mathrm{W}$., 46 fathoms, fine gray sand, gravel, bottom temperature $45.6^{\circ}, 9$ specimens; station 3078 , off Oregon, lat. $43^{\circ} 59^{\prime} 15^{\prime \prime} \mathrm{N}$.; long. $124^{\circ} 46^{\prime} \mathrm{W} ., 68$ fathoms, gray mud, bottom temperature $45.7^{\circ}, 1$ specimen; station 3114 , off California, lat. $37^{\circ} 6^{\prime} \mathrm{N}$.; long. $122^{\circ} 32^{\prime}$ W., 62 fathoms, mud, bottom temperature ?, 185 specimens; station 3147 , off California, lat. $37^{\circ} \mathrm{N}$.; long. $122^{\circ} 20^{\prime} \mathrm{W}$., 56 fathoms, brown mud, bottom temperature $49.2^{\circ}$, 45 specimens; station 3148 , off California, lat. $37^{\circ} 8^{\prime} \mathrm{N}$.; long. $122^{\circ}$ $28^{\prime} 10^{\prime \prime}$ W., 47 fathoms, brown mud, bottom temperature $51.3^{\circ}, 56$ specimens; station 3173 , off California, lat. $38^{\circ} 19^{\prime} 25^{\prime \prime}$ N.; long. $123^{\circ}$ $14^{\prime} 30^{\prime \prime}$ W., 62 fathoms, mud, bottom temperature $48.2^{\circ}, 12$ specimens; station 3350 , off California, lat. $38^{\circ} 58^{\prime} 10^{\prime \prime} \mathrm{N}$.; long. $123^{\circ} 57^{\prime}$ $5^{\prime \prime}$ W., 75 fathoms, fine sand, mud, bottom temperature $48.4^{\circ}, 34$ specimens; station 3671 , off California, lat. $37^{\circ} \mathrm{N}$.; long. $122^{\circ} 20^{\prime} \mathrm{W}$., 56 fathoms, green mud, sand, 20 specimens; Sitka, 15 fathoms, 10 specimens; Bellkoffsky Bay, 15 to 25 fathoms, shells, 4 specimens; un. known stations, 72 specimens. Bathymetrical range, 15 to 238 fathoms. Temperature range, $51.3^{\circ}$ to $39.8^{\circ}$. Six hundred and fiftyeight specimens.

Among these 658 specimens, the diameter of the disk ranges from 7 to $27 \mathrm{~mm}$., and there is some diversity of color, but the appearance of the arm comb and the length of the arm spines show surprisingly little variety. One of the specimens from station 2858 is perfectly tetramerous. The characteristic color of this species is bright gray, with whitish and blackish markings on the disk and particularly on the distal half of the oral interbrachial spaces. These light and dark spots are occasionally present also on the arms. The lower surface of the entire animal is nearly white. In many specimens the light spots of the disk are very conspicuous, but it is quite as common to find specimens on which there are no markings of any kind. The general structure of lütkeni, is, as a rule, lighter and handsomer than that of sarsii, and the disk is commonly distinctly pentangular rather than circular. Some specimens, however, at first sight, are hard to distinguish from sarsii, but in every such case the arm comb offers an unmistakable character, the wide, truncate, closely-crowded papillæ of lütkeni being entirely unlike those of any specimen of sarsii which I have ever seen. There can be no doubt that lïtkeni on the western American coast and kinbergi on the eastern Asiatic coast are southern forms of sarsii, for which species the center of abundance in the eastern hemisphere is undoubtedly in the vicinity of the Aleutian Islands and in Bering Sea. 
1 The range of kinbergi extends from the Gulf of Tokyo to the Red Sea and New South Wales, while lïtkeni ranges from Alaska to San Diego, California. The two are thus very evidently warm-water species, found only in comparatively shallow water. They are therefore widely separated from each other, but the range of sarsii broadly overlaps that of each of them, so that sarsii and kinbergi may both be found on the coast of Honshu Island, Japan, while sarsii and lütkeni are both common off the coast of Oregon and Washington. The three species are easily distinguished as follows:

KEY TO SPECIES.

Arm comb made up of short, broad, truncate papillæ, which are closely crowded side by side, so that there is no resemblance to a comb.................. lütkeni. Arm comb made up of well-spaced, blunt or pointed papillæ, so that there is more or less resemblance to a comb.

Disk scales variable; more or less irregular, and angular, often somewhat swollen; primary plates rarely noticeable; comb-papillæ short and bead-like or more or less elongated, the length not often exceeding three times the greatest thickness; middle arm spine becoming the longest at tip of arm. sarsii.

Disk scales flat, the primary plates conspicuous and usually surrounded by belts of smaller ones much as in Ophiolepis; comb-papillæ very slender, their length at least five times their thickness; middle arm spine becoming the shortest at

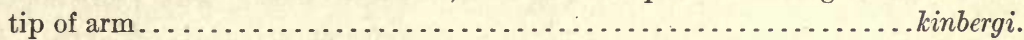

\section{OPHIURA MICRACANTHA, new species. $a$}

Disk $12 \mathrm{~mm}$. in diameter; arms about $50 \mathrm{~mm}$. long. Disk covered by several hundred overlapping scales, of varying size, among which the centro-dorsal and several radial and interradial plates can be distinguished by their larger size. Radial shields about as wide as long, separated, or barely in contact at middle, outer ends rounded, inner somewhat pointed. Basal upper arm plates much wider than long, tetragonal, distal side longest and distinctly convex; gradually the plates become longer and narrower, until at middle of arm they are longer than wide and are very narrow proximally; they remain in contact nearly to tip of arm; in small specimens (disk diameter about $8 \mathrm{~mm}$.) only first two or three plates are wider than long. Interbrachial spaces below covered by numerous scales, of which those nearest margin are largest. Oral shields pentagonal, wider than long, with a slight notch in lateral margins at end of genital slits. Adoral plates long and slender, three or four times as long as wide; oral plates shorter and stouter. Oral papillæ three on each side, wide, two outer ones with a thin sharp edge which is often distinctly notched. Teeth about four, lowermost smallest. Genital slits long but not conspicuous. Genital scales hidden by scaling of interbrachial spaces, but

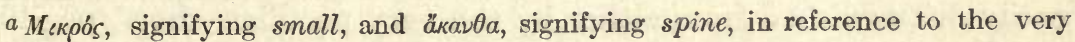
small, middle arm spine. 
wide and conspicuous at their upper, outer ends; marginal row of papillæ well developed; seen from above, arm comb consists of six to eight slender well-spaced papillæ, succeeded by much broader ones in contact with each other. First under arm plate wider than long, somewhat pointed distally; second plate much larger, nearly as long as wide, somewhat hexagonal; succeeding plates much wider than long, somewhat triangular, rapidly becoming very small; only first two or three in contact. Side arm plates large, meeting below but not above; each plate carries three arm spines, of which lowest is longest and stoutest and exceeds one-half joint; middle arm spine very short and peg-like, not half as long as lowest. Oral tentacle pores

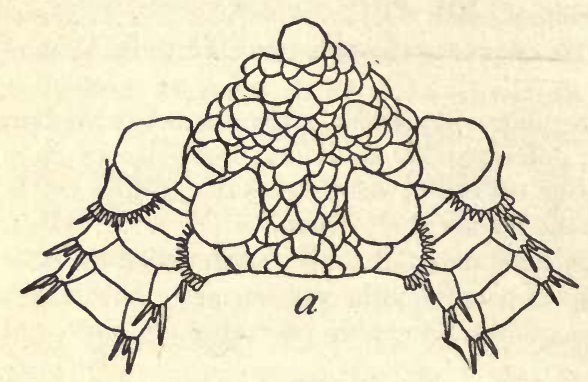
not opening clearly into mouth slit, with about four scales on each side. First two or three pairs of pores of arm rather large, with two to five (usually three or four) scales on each side; succeeding pores small or wanting, with only a single tentacle scale, but that seems to persist to end of arm. Color (dried from alcohol), dull purplish-gray above, creamywhitish below; in some specimens the arms show indications of being banded with darker.

Localities.-Albatross station 4900, off Goto Islands, Japan, lat. $32^{\circ} 28^{\prime} 50^{\prime \prime} \mathrm{N}$.; long. $128^{\circ}$ $34^{\prime} 40^{\prime \prime}$ E., 139 fathoms, gray sand, broken shells, bottom temperature $52.9^{\circ}, 2$ specimens;

Fig.10.-OPHIURA MICRACANTHA. X4. $a$, FROM ABOVE; $b$, FROM BELOW; $c$, SIDE VIEW OF TWO ARM JOINTS NEAR DISK.

station 4933, off Kagoshima Gulf, Japan, lat. $30^{\circ} 59^{\prime} \mathrm{N}$.; long. $130^{\circ} 29^{\prime} 50^{\prime \prime}$ E., 152 fathoms, rocky, bottom temperature $56^{\circ}$, 1 specimen; station 5091, in Uraga Gulf, Japan, lat. $35^{\circ} 4^{\prime} 10^{\prime \prime} \mathrm{N}$.; long. $139^{\circ} 38^{\prime} 12^{\prime \prime}$ E., 197 fathoms, green mud, coarse black sand, pebbles, bottom temperature $47.6^{\circ}, 2$ specimens. Bathymetrical range, 139 to 197 fathoms. Temperature range, $56^{\circ}-47.6^{\circ}$. Five specimens.

Type.-Cat. No. 25535, U.S.N.M., from station 5091.

Although this species is nearly related to sarsii and kinbergi, it is easily distinguished from either by the very peculiar, short, peg-like middle arm spine. The size and proportions of the arm spines show some diversity in the different specimens, but in every case the middle 
spine is disproportionately small. In one specimen the lowest spine is as long as the joint, at the base of the arm, and is conspicuously bigger than the uppermost. There are neither pits nor depressions between the basal under arm plates, but the surface of those plates is usually rough, as though wrinkled.

\section{OPHIURA MACULATA.}

Ophioglypha maculata Ludwig, Zool. Jahrb. Syst., vol. 1, 1886, p. 283.

Localities.-Albatross station 2842, off Aleutian Islands, lat. $54^{\circ}$ $15^{\prime} \mathrm{N}$.; long. $166^{\circ} 3^{\prime} \mathrm{W}$., 72 fathoms, pebbles, bottom temperature $41^{\circ}, 9$ specimens; station 4769 , Bering Sea, lat. $54^{\circ} 30^{\prime} 40^{\prime \prime} \mathrm{N}$.; long. $179^{\circ} 14^{\prime}$ E., 237 to 244 fathoms, gray sand, green mud, bottom temperature $38.5^{\circ}, 1$ specimen; station 4778 , Bering Sea, lat. $52^{\circ}$ $12^{\prime} \mathrm{N}$.; long. $179^{\circ} 52^{\prime} \mathrm{E}$., 33 to 43 fathoms, fine black gravel, 2 specimens; station 4779 , on Petrel Bank, lat. $52^{\circ} 11^{\prime \prime} \mathrm{N}$.; long. $179^{\circ} 57^{\prime}$ W., 54 to 56 fathoms, broken shells, pebbles, sand, 1 specimen; station 4782 , off Aleutian Islands, lat. $52^{\circ} 55^{\prime} \mathrm{N}$.; long. $173^{\circ} 27^{\prime}$ E., 57 to 59 fathoms, rocks and gravel, 2 specimens; station 4784 , off Aleutian Islands, lat. $52^{\circ} 55^{\prime} 40^{\prime \prime} \mathrm{N}$.; long. $173^{\circ} 26^{\prime}$ E., 135 fathoms, coarse pebbles, 9 specimens. Plover Bay, Siberia, 10 to 25 fathoms, hard, 2 specimens; 10 miles west of Point Franklin, Alaska, $13 \frac{1}{2}$ fathoms, sand, 154 specimens; Awatska Bay (Kamtchatka), 1 specimen; Constantine Harbor, 6 to 10 fathoms, 8 specimens; Bering Straits, 1 specimen; Indian Point, Bering Straits, 17 fathoms, 15 specimens; Kyska Harbor, Aleutian Islands, 16 specimens; Bay of Islands, Aleutian Islands, 10 specimens; Nazan Bay, Atka, Aleutian Islands, 1 specimen; Port Levasheff, Unalaska, Aleutian Islands, 1 specimen; Alaska, 8 specimens. Bathymetrical range, 6 to 244 fathoms. Two hundred and forty specimens.

The specimens from Plover Bay answer so well to Ludwig's description of his specimens from the same place that there can be no question as to their identity, but the other specimens show such a wide range of diversity that there are several which, taken by themselves, would never be regarded as maculata. What Ludwig considered a distinguishing character of the species, the absence of an arm comb, proves to be a very inconstant feature, for while some specimens appear to have none, it is usually more or less evident and is often well developed. The color of those specimens which are not bleached by alcohol is rather variable, the shade of olive-green showing great diversity, as does the amount of cream color, with which the disk and arms are marked. Some specimens have a large blotch of cream color at the center of the disk, but usually there is only a small spot and often there are no markings at all. One feature of the coloration is quite constant, and that is the $34916^{\circ}-$ Bull. $75-11-4$ 
division of each radial shield into a light outer and a dark inner half. This seems to be a helpful diagnostic mark for the species. One of the most constant specific characters is the number (four) and relative size of the arm spines, and the absence of tentacle pores and

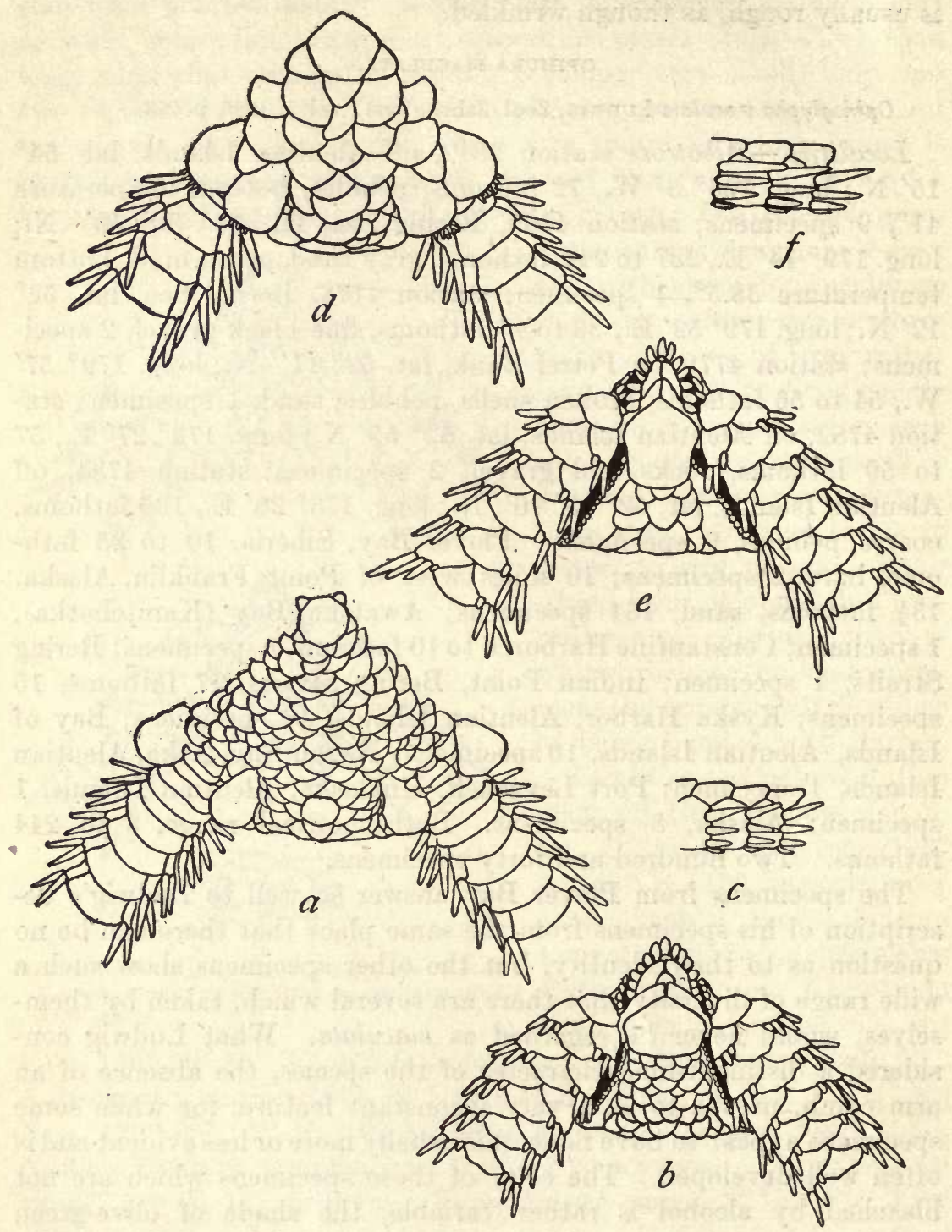

Fig. 11.-OPHIURA MACULATA; ADULT, $a-c, \times 5$; YOUNG, $d-f, \times 7$. $a$ AND $d$, FROM ABOVE; $b$ AND $e$, FROM BELOW; $c$ AND $f$, SIDE VIEWS OF ARM JOINTS NEAR DISK.

tentacle scales on the arms. The number of disk scales and the form of the oral shields are unusually variable, while the radial shields which are in contact in young specimens and in some adults are often very widely separated from each other. The figures given 
herewith reveal some of these notable variations; figs. $11 d-f$ are from a specimen having the disk $7 \mathrm{~mm}$. in diameter, while figs. $11 a-c$ are from a much larger specimen, with a disk $11 \mathrm{~mm}$. across. A number of the specimens are labeled "Ophioglypha robusta (Ayres)," but this is clearly an error. I have not yet seen a specimen of robusta from Bering Sea or the North Pacific. It is rather remarkable that neither Grieg ${ }^{a}$ nor Meissner ${ }^{b}$ mention this species, although both writers in their bibliographies refer to Ludwig's paper.

OPHIURA LEPTOCTENIA, new species.c

Disk $11 \mathrm{~mm}$. in diameter; arms about $30 \mathrm{~mm}$. long. Disk flat and more or less circular, covered by a close coat of two or three hundred scales, among which the centrodorsal is easily distinguishable, though it is seldom so large as in fig. $12 a$; one radial plate just proximal to or between radial shields is commonly larger than the other disk scales. Radial shields large, longer than wide, sometimes wholly separated, but usually in contact distally, inner sides nearly or quite straight, but more or less strongly diverging. Basal upper arm plates tetragonal, with edges more or less curved, much wider than long; near middle of arm they are about as long as wide, and at tip they are

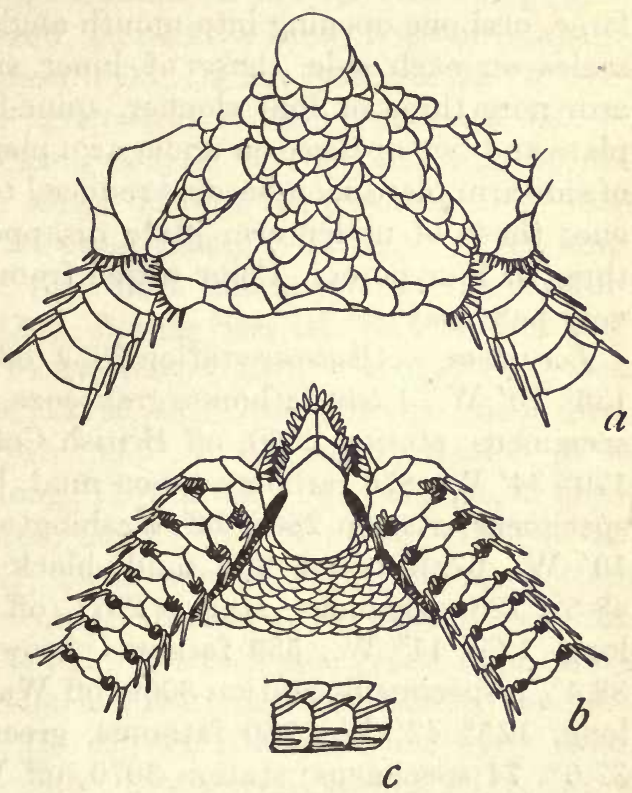

FIG.12.-OPHIURA LEPTOCTENIA. $\times 5$. $a$,FROM ABOVE; $b$, FROM BELOW; $c$, SIDE VIEW OF THREE ARM JOINTS NEAR DISK.

very much longer than wide and are nearly triangular; in contact with each other whole length of arm. Interbrachial spaces below closely covered with numerous small scales. Oral shields much longer than wide, with a broad proximal angle and a curved distal margin. Adoral plates and oral plates well marked and about of a size. Oral papillæ numerous, six or more on a side, narrow and sharp. Teeth narrow and pointed. Genital slits conspicuous, reaching from oral shield to margin of disk. Genital scales large,

a Fauna Arctica, vol. 1, pt. 2, 1900, pp. 259-286.

$b$ Bronn's Thierreichs, vol. 2, pt. 3, 1901, p. 925.

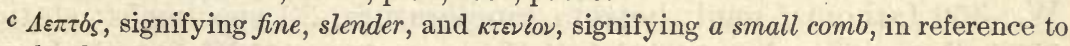
the slender comb papillæ. 
with broad upper ends; each scale carries, orally, a crowded series of minute papillæ, which elongate as we pass upward and form a conspicuous arm comb; as seen from above this comb consists of ten or a dozen long, very slender spinelets, middle ones longest. More or less of a secondary comb is often developed on arm plates beneath true comb. First under arm plate about three times as wide as long; succeeding plates wider than long, more or less triangular, diamond shaped or elliptical; all widely separated from each other. Side arm plates large but low, meeting broadly on under side of arm, but widely separated above except at tip of arm, where they nearly meet; each plate carries three slender, sharp arm spines, uppermost distinctly longest and equaling or exceeding joint. Tentacle pores large, oral one opening into mouth angle and protected by five or six scales on each side, those of inner side somewhat larger; at first arm pore three or four slender, spine-like scales stand on side arm plate and two or three on under arm plate; on succeeding pores, scales of side arm plate soon become reduced to two and at middle of arm to one; those of under arm plate disappear altogether after the first three or four pores. Color (dried from alcohol), white, yellowish, or very pale gray.

Localities.-Albatross station 2859 , off Alaska, lat. $55^{\circ} 20^{\prime} \mathrm{N}$.; long. $136^{\circ} 20^{\prime}$ W.', 1,569 fathoms, gray ooze, bottom temperature $34.9^{\circ}, 3$ specimens; station 2860 , off British Columbia, lat. $51^{\circ} 23^{\prime} \mathrm{N}$.; long. $130^{\circ} 34^{\prime}$ W., 876 fathoms, green mud, bottom temperature $36.5^{\circ}, 57$ specimens; station 2863 , off Washington, lat. $48^{\circ} 58^{\prime} \mathrm{N}$.; long. $123^{\circ}$ $10^{\prime}$ W., 67 fathoms, fine sand, black specks, bottom temperature $48.5^{\circ}, 123$ specimens; station 2871 , off Washington, lat. $46^{\circ} 55^{\prime} \mathrm{N}$.; long. $125^{\circ} 11^{\prime}$ W., 559 fathoms, brown ooze, bottom temperature $38.4^{\circ}, 9$ specimens; station 3069 , off Washington, lat. $47^{\circ} 25^{\prime} 30^{\prime \prime} \mathrm{N}$.; long. $125^{\circ} 42^{\prime}$ W., 760 fathoms, green mud, bottom temperature $37.6^{\circ}, 74$ specimens; station 3070 , off Washington, lat. $47^{\circ} 29^{\prime} 30^{\prime \prime}$ $\mathrm{N}$.; long. $125^{\circ} 43^{\prime} \mathrm{W}$., 636 fathoms, green mud, bottom temperature $37.6^{\circ}, 14$ specimens; station 3071 , off Washington, lat. $47^{\circ} 29^{\prime} \mathrm{N}$.; long. $125^{\circ} 33^{\prime} 30^{\prime \prime} \mathrm{W}$., 685 fathoms, green mud, bottom temperature $38^{\circ}, 11$ specimens; station 3075 , off Washington, lat. $47^{\circ} 22^{\prime} \mathrm{N}$.; long. $125^{\circ} 41^{\prime}$ W., 859 fathoms, green mud, bottom temperature $36.6^{\circ}, 19$ specimens; station 3227 , Bering Sea, lat. $54^{\circ} 36^{\prime} 30^{\prime \prime}$ N.; long. $166^{\circ}$ $54^{\prime}$ W., 225 fathoms, green mud, bottom temperature $38.6^{\circ}, 155$ specimens, station 3324 , Bering Sea, lat. $53^{\circ} 33^{\prime} 50^{\prime \prime}$ N.; long. $167^{\circ}$ $46^{\prime} 50^{\prime \prime}$ W., 109 fathoms, coarse black sand, gravel, rocks, 1 specimen; station 3329 , Bering Sea, lat. $53^{\circ} 56^{\prime} 50^{\prime \prime}$ N.; long. $167^{\circ} 8^{\prime} 15^{\prime \prime}$ W., 399 fathoms, fine black sand, bottom temperature $37.7^{\circ}, 35$ specimens; station 3331 , Bering Sea, lat. $54^{\circ} 1^{\prime} 40^{\prime \prime}$ N.; long. $166^{\circ} 48^{\prime} 50^{\prime \prime}$ W., 350 fathoms, mud, bottom temperature; 22 specimens; station 3332 , Bering Sea, lat. $54^{\circ} 2^{\prime} 50^{\prime \prime}$ N.; long. $166^{\circ} 45^{\prime}$ W., 406 fathoms, 
rocky, sand, 1 specimen; station 3337, off Aleutian Islands, lat. $53^{\circ}$ $55^{\prime} 30^{\prime \prime} \mathrm{N}$.; long. $163^{\circ} 26^{\prime}$ W., 280 fathoms, green mud, bottom temperature $39.3^{\circ}, 2$ specimens; station 3340 , off Aleutian Islands, lat. $55^{\circ} 26^{\prime} \mathrm{N}$.; long. $155^{\circ} 26^{\prime}$ W., 695 fathoms, mud, bottom temperature $36.8^{\circ}, 14$ specimens; station 3343 , off Washington, lat. $47^{\circ} 40^{\prime}$ $40^{\prime \prime} \mathrm{N}$.; long. $125^{\circ} 20^{\prime} \mathrm{W}$., 516 fathoms, green mud, bottom temperature $38.2^{\circ}, 6$ specimens; station 3344 , off Washington, lat. $47^{\circ} 20^{\prime}$ N.; long. $125^{\circ} 7^{\prime} 30^{\prime \prime}$ W., 831 fathoms, green mud, bottom temperature $36.8^{\circ}, 39$ specimens; station 3346 , off Oregon, lat. $45^{\circ} 30^{\prime} \mathrm{N}$.; long. $124^{\circ} 52^{\prime}$ W., 786 fathoms, green mud, bottom temperature $37.3^{\circ}, 21$ specimens; station 3603 , Bering Sea, lat. $55^{\circ} 23^{\prime} \mathrm{N}$.; long. $170^{\circ} 31^{\prime}$ W., 1,771 fathoms, blue ooze, bottom temperature $35.1^{\circ}, 1$ specimen; station 3607, Bering Sea, lat. $54^{\circ} 11^{\prime} 30^{\prime \prime} \mathrm{N}$.; long. $167^{\circ}$ $25^{\prime}$ W., 987 fathoms, green mud, black lava sand, bottom temperature $35.9^{\circ}, 4$ specimens; station 3608 , Bering Sea, lat. $55^{\circ} 19^{\prime} \mathrm{N}$.; long. $168^{\circ} 11^{\prime}$ W., 276 fathoms, gray sand, bottom temperature $37.8^{\circ}$, 209 specimens; station 3609 , Bering Sea, lat. $55^{\circ} 35^{\prime}$ N.; long. $168^{\circ} 20^{\prime}$ W., 74 fathoms, green mud, sand, bottom temperature $37.9^{\circ}, 423$ specimens; station 4765, off Aleutian Islands, lat. $53^{\circ} 12^{\prime} \mathrm{N}$.; long. $171^{\circ} 37^{\prime}$ W., 1,217 fathoms, fine black sand, bottom temperature $35.2^{\circ}$, 6 specimens; station 4766 , Bering Sea, lat. $52^{\circ} 38^{\prime} \mathrm{N}$.; long. $174^{\circ} 49^{\prime}$ W., 1,766 fathoms, 14 specimens; station 4769, Bering Sea, lat. $54^{\circ} 30^{\prime} 40^{\prime \prime} \mathrm{N}$.; long. $179^{\circ} 14^{\prime} \mathrm{E} ., 237-244$ fathoms, green mud, gray sand, bottom temperature $38.9^{\circ}, 2$ specimens; station 4770 , Bering Sea, làt. $54^{\circ} 31^{\prime}$ N.; long. $179^{\circ} 15^{\prime}$ E., 247 fathoms, 1 specimen; station 4774, Bering Sea, lat. $54^{\circ} 33^{\prime} \mathrm{N}$.; long. $178^{\circ} 45^{\prime} \mathrm{E}$., 557-584 fathoms, green mud, black specks, foraminifera, bottom temperature $37.2^{\circ}, 311$ specimens; station 4775, Bering Sea, lat. $54^{\circ} 33^{\prime} 30^{\prime \prime} \mathrm{N}$.; long. $178^{\circ} 44^{\prime}$ E., 584 fathoms, green mud, black specks, foráminifera, 94 specimens; station 4781, Bering Sea, lat. $52^{\circ} 14^{\prime} 30^{\prime \prime} \mathrm{N}$; ; long. $174^{\circ} 13^{\prime} \mathrm{E} ., 482$ fathoms, fine gray sand, pebbles, bottom temperature $38.6^{\circ}, 1$ specimen; station 4814 , Sea of Japan, lat. $38^{\circ} 32^{\prime}$ N.; long. $138^{\circ} 43^{\prime}$ E., 429 fathoms, brown mud, bottom temperature $32.9^{\circ}, 2$ specimens; station 4818 , Sea of Japan, lat. $38^{\circ} 8^{\prime} 55^{\prime \prime} \mathrm{N}$.; long. $138^{\circ} 31^{\prime} 30^{\prime \prime}$ E., $225-245$ fathoms, fine brown mud, bottom temperature $33.7^{\circ}, 2$ specimens; station 4819 , Sea of Japan, lat. $38^{\circ} 9^{\prime}$ N.; long. $138^{\circ} 32^{\prime} 12^{\prime \prime}$ E., 245 fathoms, fine brown mud, bottom temperature $33.1^{\circ}$, 5 specimens; station 4854 , off coast of Korea, lat. $35^{\circ} 54^{\prime} \mathrm{N}$.; long. $129^{\circ} 46^{\prime}$ E., 335 fathoms, green mud, bottom temperature $32.4^{\circ}$, 121 specimens; station 4863 , Sea of Japan, lat. $36^{\circ} 21^{\prime}$ N.; long. $129^{\circ} 53^{\prime}$ E., 250 fathoms, green mud, bottom temperature $32.7^{\circ}, 1$ specimen; station 4965 , off eastern Japan, lat. $33^{\circ} 35^{\prime} 20^{\prime \prime} \mathrm{N}$.; long. $135^{\circ} 10^{\prime} 50^{\prime \prime} \mathrm{E} ., 191$ fathoms, green-gray sand, shells, bottom temperature $49.4^{\circ}, 3$ specimens; station 4980 , off eastern Japan, lat. $34^{\circ} 9^{\prime} \mathrm{N}$.; long. $137^{\circ} 55^{\prime} \mathrm{E}$., 
507 fathoms, brown mud, fine sand, foraminifera, bottom temperature $39^{\circ}, 4$ specimens; station 4981 , Sea of Japan, lat. $42^{\circ} 58^{\prime} 15^{\prime \prime}$ N.; long. $140^{\circ} 9^{\prime} 10^{\prime \prime}$ E., 390-406 fathoms, green mud, bottom temperature $32.7^{\circ}, 49$ specimens; station 4986 , Sea of Japan, lat. $43^{\circ} 1^{\prime}$ $40^{\prime \prime} \mathrm{N}$.; long. $140^{\circ} 22^{\prime} 40^{\prime \prime}$ E., 172 fathoms, fine black sand, black mud, bottom temperature $33.9^{\circ}, 1$ specimen; station 4989 , Sea of Japan, lat. $43^{\circ} 23^{\prime} 10^{\prime \prime} \mathrm{N}$; l long. $140^{\circ} 37^{\prime}$ E., 92 fathoms, sand, bottom temperature $39.7^{\circ}, 1$ specimen; station 4991, Sea of Japan, lat. $45^{\circ} 23^{\prime} 20^{\prime \prime} \mathrm{N}$.; long. $140^{\circ} 48^{\prime}$ E., 325 fathoms, green mud, bottom temperature $33^{\circ}, 1$ specimen; station 4997, Gulf of Tartary, lat. $47^{\circ} 38^{\prime} 40^{\prime \prime} \mathrm{N}$.; long. $141^{\circ} 24^{\prime} 30^{\prime \prime}$ E., 318 fathoms, green mud, bottom temperature $32.8^{\circ}, 4$ specimens; station 5020, Okhotsk Sea, lat. $48^{\circ} 32^{\prime} 45^{\prime \prime} \mathrm{N}$.; long. $145^{\circ} 7^{\prime} 30^{\prime \prime} \mathrm{E}$., 73 fathoms, green mud, sand, pebbles, bottom temperature $30.9^{\circ}, 4$ specimens; station 5021 , Okhotsk Sea, lat. $48^{\circ} 32^{\prime} 30^{\prime \prime}$ N.; long. $145^{\circ} 8^{\prime} 45^{\prime \prime}$ E., 73 fathoms, green mud, sand, pebbles, bottom temperature $30.9^{\circ}, 3$ specimens; station 5026, Okhotsk Sea, lat. $48^{\circ} 36^{\prime} 10^{\prime \prime}$ N.; long. $145^{\circ} 17^{\prime} 30^{\prime \prime}$ E., 119 fathoms, green mud, black sand, gravel, bottom temperature $30.4^{\circ}, 1$ specimen; station 5037, off the Hokkaido, Japan, lat. $42^{\circ} 2^{\prime}$ $40^{\prime \prime} \mathrm{N}$.; long. $142^{\circ} 33^{\prime} 20^{\prime \prime}$ E., 175-349 fathoms, bottom temperature, $37.9^{\circ}, 2$ specimens; station 5082, off Omai Saki, Japan, lat. $34^{\circ} 5^{\prime} \mathrm{N}$.; long. $137^{\circ} 59^{\prime \prime}$ E., 662 fathoms, green mud, fine sand, globigerina, bottom temperature $37.7^{\circ}, 18$ specimens; station 5083 , off Omai Saki, Japan, lat. $34^{\circ} 4^{\prime} 20^{\prime \prime}$ N.; long. $137^{\circ} 57^{\prime} 30^{\prime \prime}$ E., 624 fathoms, green mud, fine sand, globigerina, bottom temperature $38.1^{\circ}$, 85 specimens; Bering Sea, 60 specimens. Bathymetrical range, $67-$ 1,771 fathoms. Temperature range, $49.4^{\circ}$ to $30.9^{\circ}$. Two thousand and thirty-seven specimens.

Type.-Cat. No. 25732, U.S.N.M., from station 3069.

Although these two thousand specimens come from such widely separated localities and such greatly different depths, they exhibit surprisingly little diversity. There are slight differences in the number of disk scales and particularly in the conspicuousness of the centrodorsal and other primary plates, in the form of the oral shields, and in the length and thickness of the arm spines; but these peculiarities are very insignificant and do not seem to be associated at all with either locality or depth. In a few individuals from considerable depths there are widely scattered, minute spines on the disk scales, but other individuals from the same stations have none and the peculiarity appears to be of no systematic importance. The geographical range of this species is extended but peculiar; on the American coast it ranges from northern Oregon (lat. $45^{\circ} 30^{\prime} \mathrm{N}$.; long. $124^{\circ} 52^{\prime}$ W.) to the western end of the Aleutian Islands (long. $174^{\circ}$ $13^{\prime}$ E.) and northward into Bering Sea (lat. $55^{\circ} 35^{\prime}$ N.); on the Asiatic coast it was taken off eastern Japan, as far south as $33^{\circ} 35^{\prime} 20^{\prime \prime}$, 
and at various stations in the Sea of Japan, from lat. $35^{\circ} 54^{\prime} \mathrm{N}$.; and long. $129^{\circ} 46^{\prime}$ E., northward to Saghalin Island (lat. $48^{\circ} 32^{\prime}$ $45^{\prime \prime}$ N.; long. $145^{\circ} 7^{\prime} 30^{\prime \prime}$ E.). Between Saghalin and the western end of the Aleutians no specimens of this ophiuran were taken, though it is hard to explain their absence in that region; perhaps we may assume that depth, temperature, and bottom were not suitably combined at any of the thirty-two stations of the Albatross. Off the American coast the bathymetrical range of this species is extraordinary, extending, as stated above, from 67 fathoms to 1,771, while the bottom temperature varied from $48.5^{\circ}$ down to $34.9^{\circ}$. In the Sea of Japan, however, the bathymetrical range is only from 172 to 429 fathoms, with a very low bottom temperature, $33.9^{\circ}-32.4^{\circ}$; off the east coast of Saghalin specimens were taken in only 73 fathoms, but the bottom temperature was extraordinarily low, $30.9^{\circ}$, while off eastern Japan they were taken in water as warm as $49.4^{\circ}$ and again in water as deep as 507 fathoms.

It is remarkable that, among previously known species, one of the nearest allies of leptoctenia appears to be a species taken by the Challenger off the coast of Brazil and called by Lyman Ophioglypha ljungmani. Judging only by the figures of the upper side, it is almost impossible to distinguish the two species; orally, however, there are some obvious and important differences in the shape of the oral shields and the first under arm plate, as well as in the oral papillæ and tentacle scales. When the specimens themselves are compared, the much longer arms and thicker disk of ljungmani distinguish the two species at a glance. It is interesting to note (what Lyman does not mention) that in some specimens of ljungmani the disk scales carry scattered minute spinelets exactly like those which occur in leptoctenia. From kinbergi, which it resembles somewhat in its slender comb papillæ, leptoctenia is distinguished by the difference in the disk scaling, the absence of pits between the basal under arm plates, and the absence of a rounded tentacle scale on the arm pores. From young individuals of sarsii or lütkeni, with which it is most likely to be confused, the sharp, slender comb papillæ will invariably distinguish it.

\section{OPHIURA QUADRISPINA, new species.a}

Disk $9 \mathrm{~mm}$. in diameter; arms about $30 \mathrm{~mm}$. long. Disk rather flat, nearly circular, covered by two or three hundred scales, among which the six primary plates are more or less distinguishable though they, are very rarely conspicuous. Radial shields of moderate size, rather longer than broad, separated or touching distally. Upper arm plates more or less tetragonal, at first wider than long and

a Quattuor (quadri-), signifying four, and spinus, signifying spine, in reference to the four arm spines. 
broadly in contact, but soon becoming longer than wide; outer margin decidedly convex; at tip of arm the plates are triangular and separated from each other. Interbrachial space below closely scaled. Oral shield somewhat pentagonal, with a wide proximal angle, much longer than wide. Adoral and oral plates moderate and subequal. Oral papillæ five or six on a side subequal. Teeth long, narrow, and pointed. Genital slits conspicuous, but genital scales very narrow and almost completely hidden. Each scale carries a marginal series of minute, sharp papillæ, which become larger as they approach the upper side of the arm, to form the arm comb; as seen from above this comb is continuous across the base of the arm, and some of the papillæ may be borne by either the

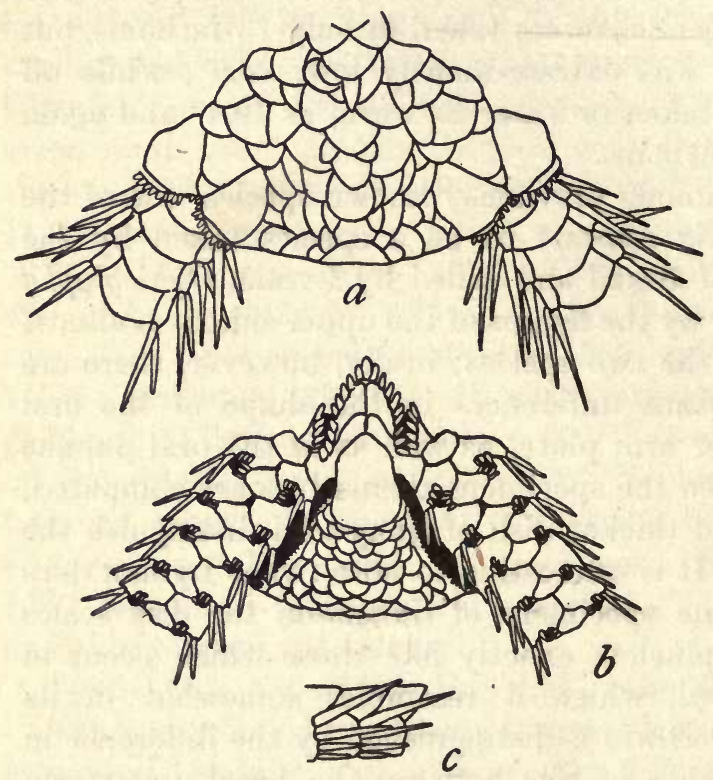

FIG. 13.-OPHIURA QUADRISPINA. $\times 5.5$. $a$, FROM ABOVE; $b$, FROM BELOW; $c$, SIDE VIEW OF TWO ARM JOINTS NEAR DISK. radial shields or the marginal disk scale between them; the papillæ are always short, but may be either sharp or blunt. A slight secondary comb may be developed on the basal upper arm plates but it is almost wholly hidden by the true comb. First under arm plate wider than long, nearly quadrangular; succeeding plates small, wider than long, at first pentagonal, but soon becoming triangular and then half-moon shaped, with the proximal side straight and the distal strongly convex; all the plates are widely separated from each other, except second and third, which are sometimes in contact. Side arm plates rather large and low, meeting beneath even within disk but not above until near tip of arm; each one carries four long, slender, acute spines, of which uppermost is decidedly longest, equaling one-and-a-half to two joints. Tentacle pores large; oral pair opening into mouth slit and guarded by four to six long, flat, conspicuous scales on each side; these scales are noticeable for their length, which is much greater than that of the oral papillæ. Basal arm pores guarded by several long, sharp scales, of which there are three or four on each side; farther out there are three, two, and finally only one, borne on proximal side; they are all slender and 
acute. Color (dried from alcohol), very light gray, yellowish, or white.

Localities.-Albatross station 2842, off Alaskan peninsula, lat. $54^{\circ}$ $15^{\prime} \mathrm{N}$; ; long. $166^{\circ} 3^{\prime} \mathrm{W}$., 72 fathoms, pebbles, bottom temperature $41^{\circ}, 1$ specimen; station 2853 , off Alaskan peninsula, lat. $56^{\circ} \mathrm{N}$.; long. $154^{\circ} 20^{\prime}$ W., 159 fathoms, gray sand, bottom temperature $41^{\circ}, 44$ specimens; station 2854 , off Alaskan peninsula, lat. $56^{\circ}$ $55^{\prime} \mathrm{N}$.; long. $153^{\circ} 4^{\prime}$ W., 60 fathoms, black sand, bottom temperature $42.8^{\circ}, 4$ specimens; station 2858 , off Alaskan peninsula, lat. $58^{\circ}$ $17^{\prime} \mathrm{N}$.; long. $148^{\circ} 36^{\prime}$ W., 230 fathoms, blue mud, gravel, bottom temperature $39.8^{\circ}, 6$ specimens; station 3331 , Bering Sea, lat. $54^{\circ}$ $1^{\prime} 40^{\prime \prime}$ N.; long. $168^{\circ} 48^{\prime} 50^{\prime \prime}$ W., 350 fathoms, mud, 6 specimens; station 3332 , Bering Sea, lat. $54^{\circ} 2^{\prime} 50^{\prime \prime}$ N.; long. $166^{\circ} 45^{\prime}$ W., 406 fathoms, rocky sand, 1 specimen; station 3337 , Bering Sea, lat. $53^{\circ}$ $55^{\prime} 30^{\prime \prime}$ N.; long. $163^{\circ} 26^{\prime} \mathrm{W}$., 280 fathoms, green mud, rocks, bottom temperature $39.3^{\circ}, 2$ specimens; station 3338 , Bering Sea, lat. $54^{\circ}$ $19^{\prime} \mathrm{N}$; ; long. $159^{\circ} 40^{\prime} \mathrm{W}$., 625 fathoms, green mud, sand, bottom temperature $37.3^{\circ}, 1$ specimen; station 3785,150 miles north of Aleutian Islands, 270 fathoms, gray sand, broken shells, 1 specimen; station 4770 , Bering Sea, lat. $54^{\circ} 31^{\prime}$ N.; long. $179^{\circ} 15^{\prime}$ W., 247 fathoms, 2 specimens; station 4781 , Bering Sea, lat. $52^{\circ} 14^{\prime} 30^{\prime \prime}$ N.; long. $174^{\circ} 13^{\prime}$ E., 482 fathoms, fine gray sand, pebbles, bottom temperature $38.6^{\circ}, 17$ specimens; station 4784, Bering Sea, lat. $52^{\circ} 55^{\prime} 40^{\prime \prime} \mathrm{N}$.; long. $173^{\circ} 26^{\prime}$ E., 135 fathoms, coarse pebbles, 1 specimen; station 4788, near Copper Island, Bering Sea, lat. $54^{\circ} 50^{\prime} 24^{\prime \prime}$ N., long. $167^{\circ} 13^{\prime}$ E., 56 to 57 fathoms, green sand, 1 specimen; station 4789, near Copper Island, Bering Sea, lat. $54^{\circ} 49^{\prime} 45^{\prime \prime} \mathrm{N}$; long. $167^{\circ} 12^{\prime} 30^{\prime \prime}$ E., 56 fathoms, green sand, 4 specimens; station 4790 , near Bering Island, Bering Sea, lat. $54^{\circ} 48^{\prime} 35^{\prime \prime}$ N.; long. $167^{\circ}$ $11^{\prime} 45^{\prime \prime}$ E., 64 fathoms, pebbles, 1 specimen; station 4791 , near Bering Island, Bering Sea, lat. $54^{\circ} 36^{\prime} 15^{\prime \prime}$ N.; long. $166^{\circ} 58^{\prime} 15^{\prime \prime}$ E., 72 to 76 fathoms, rocky, 1 specimen; station 4792, near Bering Island, Bering Sea, lat. $54^{\circ} 36^{\prime} 15^{\prime \prime} \mathrm{N}$.; long. $166^{\circ} 57^{\prime} 15^{\prime \prime}$ E., 72 fathoms, pebbles, 3 specimens; station 4982 , Sea of Japan, lat. $43^{\circ} \mathrm{N}$.; long. $140^{\circ} 10^{\prime} 30^{\prime \prime}$ E., 390 to 428 fathoms, green mud, bottom temperature $37.7^{\circ}, 1$ specimen; station 4991 , Sea of Japan, lat. $45^{\circ} 23^{\prime} 20^{\prime \prime}$ N.; long. $140^{\circ}$ $48^{\prime}$ E., 325 fathoms, green mud, bottom temperature $33^{\circ}, 2$ specimens; station 5022, Okhotsk Sea, lat. $48^{\circ} 35^{\prime} 30^{\prime \prime}$ N.; long. $145^{\circ} 20^{\prime}$ E., 109 fathoms, green mud, coarse black sand, bottom temperature $30.1^{\circ}, 5$ specimens; station 5026, Okhotsk Sea, lat. $48^{\circ} 36^{\prime} 10^{\prime \prime} \mathrm{N}$.; long. $145^{\circ}$ $17^{\prime} 30^{\prime \prime} \mathrm{E}$., 119 fathoms, green mud, black sand, gravel, bottom temperature $30.4^{\circ}, 1$ specimen; station 5027, Okhotsk Sea, lat. $48^{\circ} 27^{\prime}$ $30^{\prime \prime} \mathrm{N}$.; long. $145^{\circ} 23^{\prime} 30^{\prime \prime} \mathrm{E}$., 188 fathoms, fine gray sand, pebbles (?), bottom temperature $32^{\circ}, 1$ specimen; station 5033, Yezo Strait, lat. $44^{\circ} 4^{\prime} 20^{\prime \prime} \mathrm{N}$.; long. $145^{\circ} 28^{\prime}$ E., 533 fathoms, green mud, fine black 
sand, bottom temperature $35.9^{\circ}$, 1 specimen. Bathymetrical range, 56 to 625 fathoms. Temperature range, $42.8^{\circ}$ to $30.1^{\circ}$. One hundred and seven specimens.

Type.-Cat. No. 25629, U.S.N.M., from station 3331.

Although this species is superficially so near leptoctenia that it might easily be mistaken for that species, the four arm spines and the peculiar arm comb easily distinguish quadrispina from that, and from every other near ally. The 107 specimens show very little diversity of structure, though a few have minute disk spines as in leptoctenia. It is a more northern form than that species, as it has not been collected south of $53^{\circ} 55^{\prime} 30^{\prime \prime} \mathrm{N}$. on the American coast nor south of $43^{\circ}$ on the Asiatic. Its bathymetrical range is also less, 56 to 625 fathoms.

\section{OPHIURA BATHYBIA, new species. $a$}

Disk $15 \mathrm{~mm}$. in diameter; arms about $65 \mathrm{~mm}$. long. Disk covered with a close coat of numerous small, overlapping scales, many of
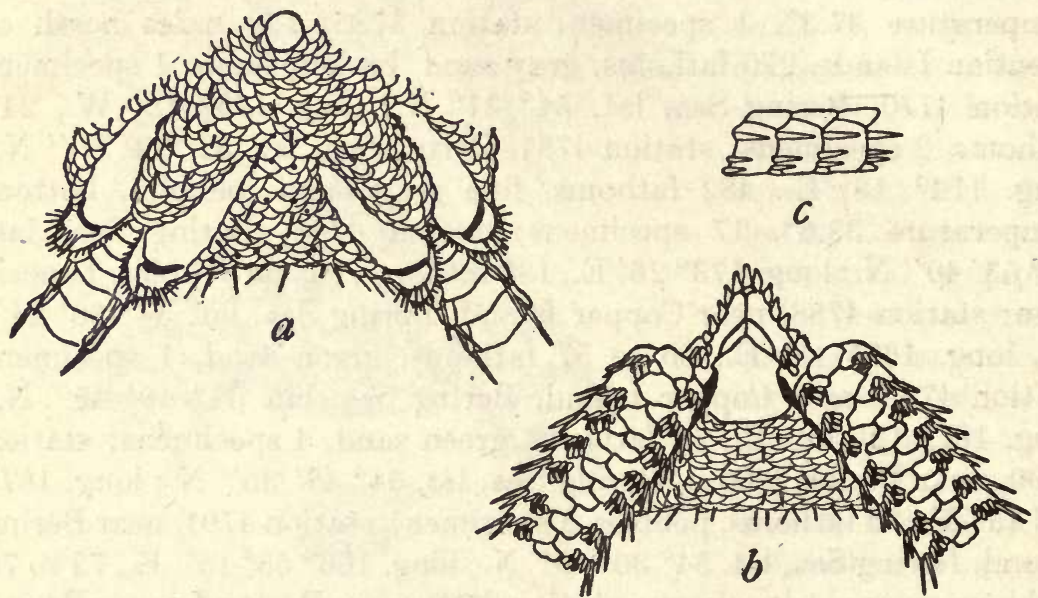

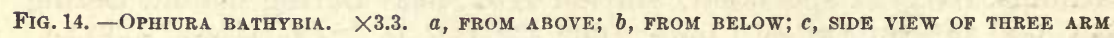
JOINTS NEAR DISK.

which carry very slender spinelets nearly a millimeter long; these spinelets are easily rubbed off, but the places of attachment remain more or less clearly indicated as minute pits. Radial shields somewhat crescentic, about three times as long as wide, widest at outer end, where they are most nearly in contact, though even there distinctly separate. Upper arm plates tetragonal, at first wider than long, but soon becoming longer than wide, with distal margin more or less convex; in contact the whole length of arm. Interbrachial spaces below closely covered with scales, upon which minute spines are

a Batús, signifying deep, and $\beta$ kos, signifying life, in reference to the unusual depth at which it lives. 
even more numerous than on disk. Oral shield large, about as wide as long, somewhat pentagonal, with a broad, proximal angle and a straight distal margin. Adoral plates variable, sometimes apparently confined to inner end of oral shield, but usually reaching the first side arm plates; oral plates large, usually much larger than adoral. Oral papillæ five on each side, well spaced, outermost widest and truncate, inner ones narrow and sharp; an infradental papilla is often present. Teeth about six, moderately wide, pointed. Genital slits long, proximal end nearer center of mouth than is distal end of a mouth slit. Genital scales large, upper, outer end very broad; each scale has a marginal fringe of very minute papillæ which become rapidly elongated distally into very slender spines, forming a well-marked arm comb, when viewed from above. Beneath this comb on the basal arm plates is a smaller secondary comb, which extends inward between ends of radial shields and is often very conspicuous. Under arm plates much wider than long; first two decidedly largest and more or less clearly in contact; succeeding plates widely separated, becoming rapidly smaller, oblong-hexagonal, pentagonal, or tetragonal. Side arm plates rather large, but low and meeting only on lower side of arm; each plate carries three arm spines, of which uppermost is longest, but does not equal joint; other two much smaller, close together near lower edge of plate. Tentacle pores at base of arm large but quickly becoming much smaller; oral and basal arm pores guarded by about three scales on each side; further out on arm there are three and then two scales on proximal side of pore, and finally only a single scale is present. , On oral pores, tentacle scales long and flat, but on basal arm pores they are spine-like and out on arm they are very slender spinelets. Color (dried from alcohol), yellow, yellowish, or white.

Localities.-Albatross station 2859, off Alaska, lat. $55^{\circ} 20^{\prime} \mathrm{N}$.; long. $136^{\circ} 20^{\prime}$ W., 1,569 fathoms, gray ooze, bottom temperature $34.9^{\circ}$, 1 specimen; station 3603 , Bering Sea, lat. $55^{\circ} 23^{\prime}$ N.; long. $170^{\circ} 31^{\prime}$ W., 1,771 fathoms, blue ooze, bottom temperature $35.1^{\circ}, 22$ specimens; station 4761, off Alaska, lat. $53^{\circ} 57^{\prime} 30^{\prime \prime} \mathrm{N}$.; long. $159^{\circ} 31^{\prime} \mathrm{W}$., 1,973 fathoms, blue clay, bottom temperature $35^{\circ}, 258$ specimens; station 4766 , Bering Sea, lat. $52^{\circ} 38^{\prime}$ N.; long. $174^{\circ} 49^{\prime}$ W., 1,766 fathoms, bottom ?, bottom temperature ?, 18 specimens. Bathymetrical range, 1,569 to 1,973 fathoms. Temperature range, $35.1^{\circ}$ to $34.9^{\circ}$. Two hundred and ninety-nine specimens.

Type.-Cat. No. 25611, U.S.N.M., from station 4766.

This seems to be a remarkably well-characterized species, confined to very deep water in the vicinity of the Alaskan peninsula and islands. Its nearest relative is probably leptoctenia, but the form of the radial shields, the much smaller and more numerous disk scales, the numerous disk spinelets and the larger and better spaced oral papillæ serve 
to distinguish bathybia easily. The numerous disk spinelets and pits (where spines have been rubbed off) are very remarkable, but similar spinelets sometimes occur, as has already been pointed out, in leptoctenia, ljungmani, and quadrispina.

\section{OPHIURA FLAGELLATA.}

Ophioglypha flagellata Lyman, Bull. Mus. Comp. Zoöl., vol. 5, 1878, p. 69.

Ophiura flagellata Merssner, Bronn's Thierreichs, vol. 2, pt. 3, 1901, p. 925.

Localities.-Albatross station 2860, off southern Alaska, lat. $51^{\circ}$ $23^{\prime} \mathrm{N}$.; long. $130^{\circ} 34^{\prime}$ W., 876 fathoms, green mud, bottom temperature $36.5^{\circ}, 1$ specimen; station 3338 , Aleutian Islands, lat. $54^{\circ} 19^{\prime}$ N.; long. $159^{\circ} 40^{\prime}$ W., 625 fathoms, green mud, sand, bottom temperature $37.3^{\circ}, 1$ specimen; station 3704 , off Honshu Island, Japan, 94 to 150 fathoms, fine volcanic sand, 5 specimens; station 3784 , off Aleutian Islands, lat. $54^{\circ} 32^{\prime} \mathrm{N}$.; long. $178^{\circ} 31^{\prime}$ E., 85 fathoms, green mud, fine gray sand, 11 specimens; station 4767 , Bering Sea, lat. $54^{\circ} 12^{\prime} \mathrm{N}$.; long. $179^{\circ} 7^{\prime} 30^{\prime \prime}$ E., 771 fathoms, green mud, bottom temperature $36.5^{\circ}, 2$ specimens; station 4768 , Bering Sea, lat. $54^{\circ} 20^{\prime} 30^{\prime \prime}$ N.; long. $179^{\circ} 9^{\prime} 30^{\prime \prime}$ E., 764 fathoms, green-brown mud, fine black sand, bottom temperature $37^{\circ}, 78$ specimens; station 4774 , Bering Sea, lat. $54^{\circ} 33^{\prime}$ N.: long. $178^{\circ} 45^{\prime}$ E., 557 to 584 fathoms, green mud, black specks foraminifera, 48 specimens; station 4775 , Bering Sea, lat. $54^{\circ} 33^{\prime} 30^{\prime \prime} \mathrm{N}$.; long. $178^{\circ} 44^{\prime}$ E., 584 fathoms, green mud, black specks, foraminifera, bottom temperature $37.2^{\circ}, 1$ specimen; station 4916, Eastern Sea, lat. $30^{\circ} 25^{\prime}$ N.; long. $129^{\circ} 6^{\prime}$ $40^{\prime \prime}$ E., 361 fathoms, gray sand, globigerina broken shells, bottom temperature $42.7^{\circ}, 3$ specimens; station 5049, off eastern Japan, lat. $38^{\circ} 12^{\prime} \mathrm{N}$., long. $142^{\circ} 2^{\prime}$ E., 182 fathoms, dark gray sand, broken shells, foraminifera, bottom temperature $37.8^{\circ}, 4$ specimens; station 5079, off Omai Saki, Japan, lat. $34^{\circ} 15^{\prime}$ N.; long. $138^{\circ}$ E., 475 to 505 fathoms, pebbles; bottom temperature $39.1^{\circ}, 1$ specimen; station 5086, Sagami Bay, lat. $35^{\circ} 8^{\prime} 15^{\prime \prime}$ N.; long. $139^{\circ} 20^{\prime}$ E., 292 fathoms, green mud, coarse black sand, bottom temperature $43.7^{\circ}$, 3 specimens; station 5088, Sagami Bay, lat. $35^{\circ} 11^{\prime} 25^{\prime \prime} \mathrm{N}$.; long. $139^{\circ} 28^{\prime} 20^{\prime \prime}$ E., 369 to 405 fathoms, green mud, bottom temperature $41.8^{\circ}, 1$ specimen; station 5091, Uraga Strait, lat. $35^{\circ} 4^{\prime} 10^{\prime \prime}$ $\mathrm{N}$.; long. $139^{\circ} 38^{\prime} 12^{\prime \prime}$ E., 197 fathoms, green mud, coarse black sand, pebbles, bottom temperature $47.6^{\circ}, 2$ specimens; station 5092 , Uraga Strait, lat. $35^{\circ} 4^{\prime} 50^{\prime \prime}$ N.; long. $139^{\circ} 38^{\prime} 18^{\prime \prime}$ E., 70 fathoms, coarse black sand, bottom temperature $56.3^{\circ}, 2$ specimens; station 5093, Uraga Strait, lat. $35^{\circ} 3^{\prime} 15^{\prime \prime}$ N. ; long. $139^{\circ} 37^{\prime} 42^{\prime \prime}$ E., 302 fathoms, coarse black sand, bottom temperature $43.9^{\circ}, 2$ specimens; station 5094, Uraga Strait, lat. $35^{\circ} 4^{\prime} 42^{\prime \prime}$ N.; long. $139^{\circ} 38^{\prime} 20^{\prime \prime}$ E., 88 fathoms, black sand, broken shells, bottom temperature $54.8^{\circ}$, 
11 specimens. Bathymetrical range, 70 to 876 fathoms. Temperature range, $56.3^{\circ}$ to $36.5^{\circ}$. One hundred and seventy-six specimens.

These specimens show a most remarkable difference in the calcification of the disk, for while several of them have the disk covering thick, with the scales hardly distinguishable, as in Lyman's type, others have it much thinner with the scales evident, while still others have a greater or less part of the disk covered by a naked skin, the calcification being confined to the vicinity of the radial shields and to the interradial margins. The gradation between the two extremes is so complete that there can be no doubt, that the amount of calcification is an individual and not a specific or even a local matter. Thus the specimen from station 5094 has the disk fully calcified, while of two specimens from station 5093 , one has the center of the disk bare with ten bare lines running out into the radii and interradii, and the other has the disk completely lacking calcification save about the margin and the radial shields. That it is not a matter of age would seem to be indicated by the fact that the largest (disk diameter, $26 \mathrm{~mm}$.) and one of the smallest (disk diameter, $9 \mathrm{~mm}$.) specimens have less calcification than any others. Considerable diversity is shown also in the length of the arm spines,

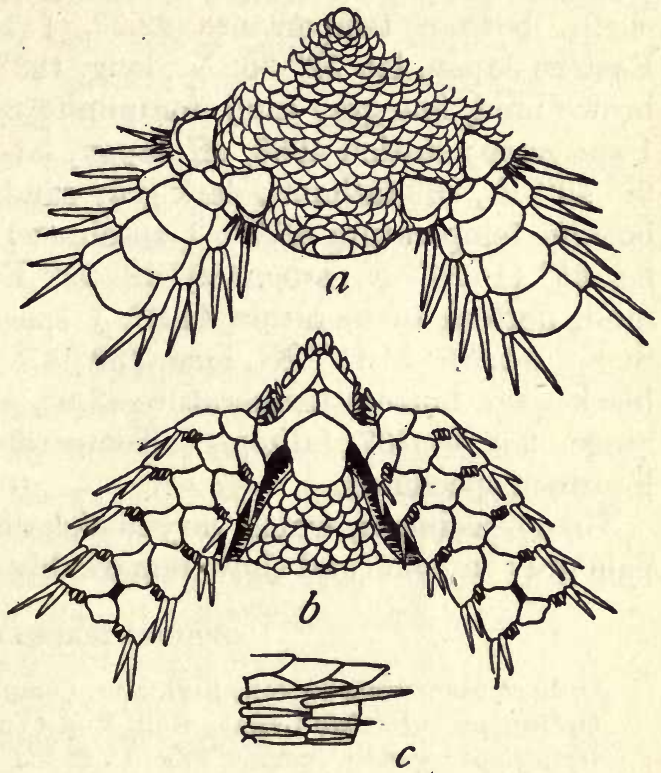

FIG. 15.-OPHIURA FLAGELLATA, YOUNG. $\times 6$. $a$, FROM ABOVE $b$, FROM BELOW; $c$, SIDE VIEW OF TWO ARM JOINTS NEAR DISK.

in the form of the radial shields and in the number of tentacle scales, but these differences do not seem to be correlated in any definite way with the amount of calcification. The form of the radial shields, arm plates, and arm spines, the number of the latter (three) and the arm comb appear to be very constant features in mature specimens. In young individuals (see fig. 15) both the upper and under arm plates are much longer and narrower than in adults, and sometimes the side arm plates do not quite meet below, though the under arm plates are widely separated nevertheless. The comb papillæ are much longer and more slender than Lyman's figure ${ }^{a}$ indicates. 
The range of this species is remarkable, extending as it does geographically from lat. $9^{\circ} 3^{\prime} 24^{\prime \prime} \mathrm{N}$. and from long. $79^{\circ} 37^{\prime} \mathrm{E}$. (according to Kohler) to lat. $54^{\circ} 33^{\prime} 30^{\prime \prime} \mathrm{N}$. and to long. $130^{\circ} 34^{\prime} \mathrm{W}$., and bathymetrically from 53 fathoms to 876 . But Kohler ${ }^{a}$ has made a serious blunder in saying that the species was taken by the Challenger "entre les îles Philippines et les îles Carolines," for the only recorded Challenger station is 232, not far from Yokohama, Japan.

\section{OPHIURA IMBECILLIS.}

Ophioglypha imbecillis Lyman, Bull. Mus. Comp. Zoöl., vol. 5, 1878, p. 73.

Ophiura imbecillis Meissner, Bronn's Thierreichs, vol. 2, pt. 3, 1901, p. 925.

Localities.-Albatross station 4918, Eastern Sea, lat. $30^{\circ} 22^{\prime} \mathrm{N}$.; long. $129^{\circ} 8^{\prime} 30^{\prime \prime}$ E., 361 fathoms, gray sand, globigerina; broken shells, bottom temperature $42.7^{\circ}, 1$ specimen; station 4957, off Eastern Japan, lat. $32^{\circ} 36^{\prime}$ N.; long. $132^{\circ} 23^{\prime}$ E., 437 fathoms, greenbrown mud, fine gray sand, foraminifera, bottom temperature $39.8^{\circ}$, 1 specimen; station 4968 , off Japan, lat. $33^{\circ} 24^{\prime} 50^{\prime \prime}$ N.; long. $135^{\circ}$ $38^{\prime} 40^{\prime \prime}$ E., 253 fathoms, dark gray sand, brown mud, broken shells, bottom temperature $45.7^{\circ}, 1$ specimen; station 5088, Sagami Bay, lat. $35^{\circ} 11^{\prime} 25^{\prime \prime} \mathrm{N}$.; long. $139^{\circ} 28^{\prime} 20^{\prime \prime}$ E., 369 to 405 fathoms, green mud, bottom temperature $41.8^{\circ}, 7$ specimens; station 5093, Uraga Strait, lat. $35^{\circ} 3^{\prime} 15^{\prime \prime} \mathrm{N}$. ; long. $139^{\circ} 37^{\prime} 42^{\prime \prime} \mathrm{E}$., 302 fathoms, coarse black sand, bottom temperature $43.9^{\circ}, 4$ specimens. Bathymetrical range, 253 to 437 fathoms. Temperature range, $45.7^{\circ}$ to $39.8^{\circ}$. Fourteen specimens.

These specimens, which vary in disk diameter from $3 \frac{1}{2}$ to $7 \mathrm{~mm}$., are pale gray in color and show remarkably little diversity of structure.

\section{OPHIURA IRRORATA.}

Ophioglypha irrorata Lyman, Bull. Mus. Comp. Zoöl., vol. 5, 1878, p. 73.

Ophioglypha orbiculata Lyman, Bull. Mus. Comp. Zoöl., vol. 5, 1878, p. 74.

Ophioglypha grandis Verrill, Proc. U. S. Nat. Mus., vol. 17, 1894, p. 293.

Ophioglypha tumulosa Lütrken and Mortensen, Mem. Mus. Comp. Zoöl., vol.23, 1897, p. 120.

Ophioglypha involuta Kanler, Ann. Sci. Nat. Zool. (8), vol. 4, 1897, p. 295.

Ophiura irrorata MeIssner, Bronn's Thierreichs, vol. 2, pt. 3, 1901, p. 925.

Localities.-Albatross station 3603, Bering Sea, lat. $55^{\circ} 23^{\prime} \mathrm{N}$.; long. $170^{\circ} 31^{\prime} \mathrm{W}$., 1,771 fathoms, brown ooze, bottom temperature $35.1^{\circ}, 2$ specimens; station 3783,40 miles off Copper Island, 1,567 fathoms, gray volcanic sand, green mud, 1 specimen; station 4956, Inland Sea, Japan, lat. $32^{\circ} 32^{\prime}$ N.; long. $132^{\circ} 25^{\prime}$ E., 720 fathoms, green-brown mud, fine gray sand, foraminifera, bottom temperature $37.5^{\circ}, 1$ specimen; station 4971 , off eastern Japan, lat. $33^{\circ} 23^{\prime} 30^{\prime \prime} \mathrm{N}$.; long. $135^{\circ} 34^{\prime}$ E., 649 fathoms, brown-green mud, foraminifera, bottom temperature $38.1^{\circ}, 2$ specimens; station 4979, off Japan, 
lat. $33^{\circ} 53^{\prime}$ N.; long. $137^{\circ} 42^{\prime}$ E., 943 fathoms, brown mud, fine sand, foraminifera, bottom temperature $36.4^{\circ}, 4$ specimens; station 5030 , Okhotsk Sea, lat. $46^{\circ} 29^{\prime} 30^{\prime \prime}$ N.; long. $145^{\circ} 46^{\prime}$ E., 1,800 fathoms, brown mud, bottom temperature?, 2 specimens; station 5083, off Omai Saki light, lat. $34^{\circ} 4^{\prime} 20^{\prime \prime}$ N.; long. $137^{\circ} 57^{\prime} 30^{\prime \prime}$ E., 624 fathoms, fine gray sand, globigerina, bottom temperature $38.1^{\circ}, 2$ specimens; station 5084, off Omai Saki light, lat. $34^{\circ}$ N.; long. $137^{\circ} 49^{\prime} 40^{\prime \prime}$ E., 918 fathoms, green mud, fine sand, globigerina, bottom temperature $36.8^{\circ}, 2$ specimens. Bathymetrical range, 624 to 1,800 fathoms. Temperature range, $38.1^{\circ}$ to $35.1^{\circ}$. Sixteen specimens.

This excellent series of specimens, ranging in size from a disk diameter of $7 \mathrm{~mm}$. to one of $33 \mathrm{~mm}$., has been carefully compared with the Blake specimens of irrorata from the Caribbean Sea and the Challenger specimens of irrorata from off the coast of Australia and the coast of Portugal, with a cotype of orbiculata from Japan, with a cotype of grandis from Albatross station 2573, and with specimens of tumulosa from the Albatross collection in the Panamic deep-water region, and I am fully satisfied that these four nominal species are in reality one and the same. Moreover, I see no character by which involuta can be distinguished, and I have accordingly included that name as a synonym. It seems, therefore, that in irrorata we have a cosmopolitan deep-water species, like Ophiomusium lymani, and it is of some interest to note here the various stations at which it has been taken: Off New England, off Portugal, in the West Indies, southeast of the Cape of Good Hope, in the Bay of Bengal, off New South Wales, off Japan, in Bering Sea, in the Gulf of California, in the Gulf of Panama, and among the Galapagos Islands. Except the very young specimens taken by the Challenger off New South Wales, and regarding the identification of which some doubt might reasonably be raised, specimens have not been taken in less than 600 fathoms, and the species ranges from that depth to over 2,200 fathoms. In spite of its extensive geographical and bathymetrical range, the species is not remarkably variable, the differences with which the various names have been associated being mainly due to size or age. In the young, the arm spines even at the base of the arm are about equally spaced, but in larger specimens the upper one becomes widely separated from the other two. If, however, we follow the arm of an adult from base to tip, we find the spines gradually approaching each other, so that at the tip of the arm in a big specimen the arm spines correspond to those at the base of the arm in a young specimen, an interesting illustration of a "localized stage." In all adult specimens, however, the middle arm spine at the tip of the arm terminates, as Lyman pointed out, in a hook. The size of the arm spines differs greatly in different individuals, but these differences do not seem to be correlated with size, or locality, or depth. The shape of the oral shields and of the 
basal under arm plates is very variable, within certain limits; the oral shield is usually more or less pentagonal and longer than wide, but it may be rounded triangular or even oval, and it is often wider than long; the second under arm plate is usually squarish but it may be much longer than wide or often wider than long; the number of basal under arm plates which are in contact with each other varies greatly with age. The arm comb, the upper arm plates, and the radial shields do not show very much diversity, but the disk scales are variable and the distinctness of the primary plates differs greatly in different individuals.

\section{OPHIURA CLASTA, new species. $a$}

Disk $15 \mathrm{~mm}$. in diameter; arms about $40 \mathrm{~mm}$. long. Disk covered with a thick skin, in or upon which are numerous more or less

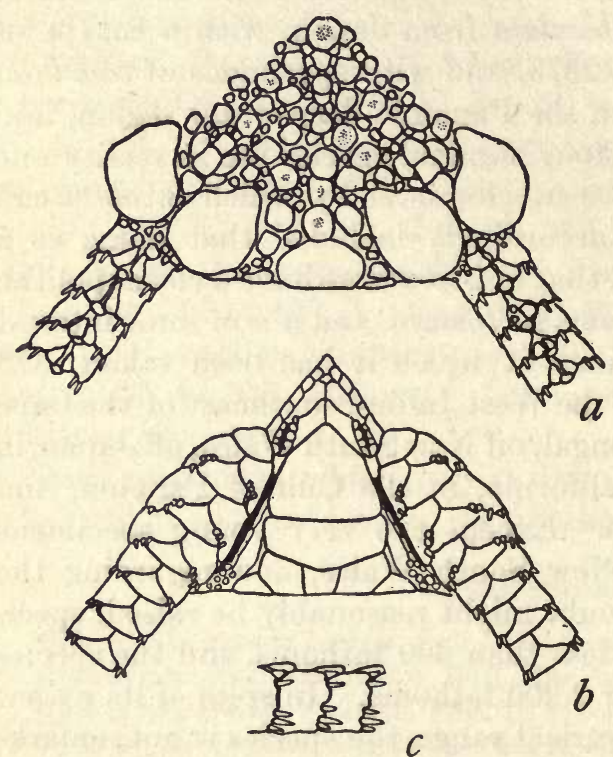

Fig. 16.-OPHURA Clasta. $\times 3.5$. $a$, FroM ABOVE; $b$, FROM BELOW; $c$, SIDE VIEW OF TWO ARM JOINTS NEAR DISK. circular plates of variablesize; these plates do not overlap, and in most cases are scarcely in contact with each other; one at the margin of each interradius is very much larger than the rest and nearly or quite fills the space between two adjoining pairs of radial shields. Latter, rounded, about as wide as long, more or less lightly in contact, at least distally. First, and sometimes second, upper arm plate more or less tetragonal; remainder small, triangular, and widely separated from each other; all are more or less completely broken up into irregular fragments, so that in many cases the original form of the plate can scarcely be distinguished. Interbrachial spaces below covered by the huge oral shield, an accessory shield, the two genital plates, and about five marginal plates. Oral shields rounded triangular or pentagonal, about as wide as long. Adoral plates variable in shape according to the position of the oral tentacle pore; when this is far back the adoral plate appears to be short and wide (as in the figure), but when the pore is a little nearer the mouth the adoral plate is long and narrow; oral plates well developed and quite distinct. Oral papillæ squarish, crowded, five or six on each side,

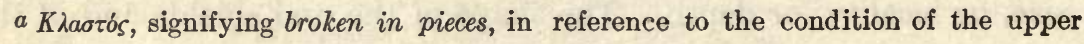
arm plates. 
outermost widest; an unpaired infradental papilla is often present. Genital slits rather short. Genital scales large, broad distally, but completely overshadowed by radial shields, so that they are not visible from above; each scale carries a few irregular marginal papillæ but these are so imperfectly developed that there is no arm comb in any of the specimens; some small, irregular scales just distal to the radial shields give the superficial appearance of a comb in some cases, but these have no connection with the genital scales. First under arm plate rounded triangular; succeeding plates pentagonal, soon becoming triangular; all are much wider than long, and are distinctly separated from each other. Side arm plates large, meeting broadly both above and below; each plate carries four minute arm spines, one of which is high up on the plate, well separated from the other three, which are very low down and close together; the middle one of these three is usually the longest spine but scarcely equals half the joint; the lowest one might easily be mistaken for a tentacle scale. Tentacle pores on arm minute and confined to the three or four basal joints; each one is protected by several minute scales. Oral pore not opening into mouth slit, protected by three or four rounded scales on each side. Color (dried from alcohol); scales and plates above clay color or brown, the skin between them decidedly darker; beneath, uniform dirty whitish, or brown.

Localities.-Albatross station 4980 , off eastern Japan, lat. $34^{\circ} 9^{\prime} \mathrm{N}$.; long. $137^{\circ} 55^{\prime}$ E., 507 fathoms, brown mud, fine sand, foraminifera, bottom temperature $39^{\circ}, 4$ specimens; station 5083, off Omai Saki light, lat. $34^{\circ} 4^{\prime} 20^{\prime \prime} \mathrm{N}$.; long. $137^{\circ} 57^{\prime} 30^{\prime \prime}$ E., 624 fathoms, fine gray sand, globigerina, bottom temperature $38.1^{\circ}, 16$ specimens; station 5084, off Omai Saki light, lat. $34^{\circ}$ N.; long. $137^{\circ} 49^{\prime} 40^{\prime \prime}$ E., 918 fathoms, green mud, fine sand, globigerina, bottom temperature $36.8^{\circ}, 2$ specimens. Bathymetrical range, 507 to 918 fathoms. Temperature range, $39^{\circ}$ to $36^{\circ} 8^{\prime}$. Twenty-two specimens.

Type.-Cat. No. 25547, U.S.N.M., from station 5084.

Although this species bears some resemblance dorsally to Ophioglypha divisa Lütken and Mortensen, the oral side is so different there can be no confusion between the two. I do not think there is any other species more nearly related to this Japanese novelty, unless it be $O$. confragosa Lyman, from off La Plata, but the upper arm plates of the latter are alone sufficient to distinguish the two.

OPHIURA MONOSTECHA, new species. $a$

Disk $10 \mathrm{~mm}$. in diameter; arms about $35 \mathrm{~mm}$. long. Disk covered with a smooth coat of scales, among which the six primary plates, another plate in each radius, and two in each interradius, one of

a Mbvos, signifying one, single, and $\sigma \tau o$ ¿os, signifying a row, line, in reference to the peculiar arm comb.

$34916^{\circ}-$ Bull. $75-11-5$ 
which is marginal, can be distinguished with more or less ease. Radial shields about as wide as long, more or less united distally; in the type-specimen, several rounded knobs or papillæ are borne on the inner distal corners of the plates (some times also on the distal margin) and in fig. $17 a$ these appear like three small plates separating the radial shields distally. Basal upper arm plates tetragonal, but rapidly becoming triangular as they pass outward; in the type, the first seven to nine are in contact but in others (smaller specimens) only the first two or three. Interbrachial spaces below covered by twelve to twenty plates of which the marginal are largest. Oral shields pentagonal. with rounded corners, about as wide as long.

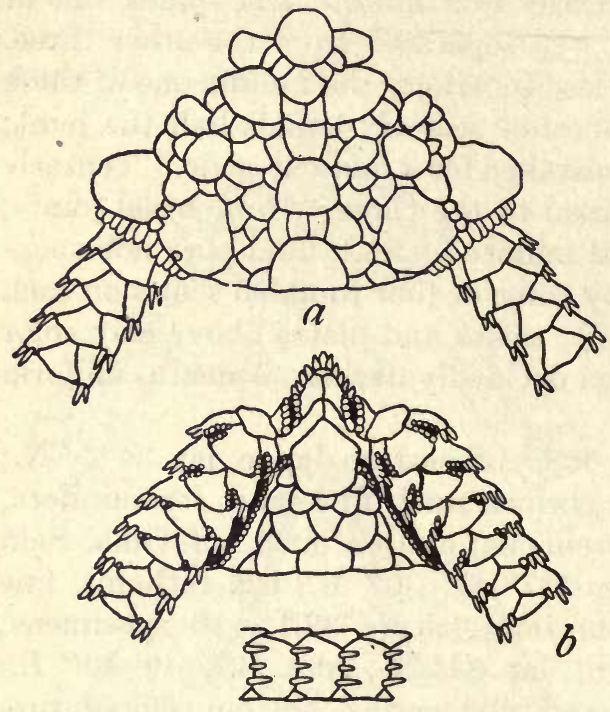

c

Frg. 17.-OPHIURA MONOSTCECHA. $\times 5$. $a$, FROM ABOVE; 3 , FROM BELOW; $c$, SIDE VIEW OF THREE ARM JOINTS NEAR DISK.
Adoral plates long and narrow; oral plates considerably broader than adoral but not so long. 'Oral papillæ about five or six on a side; those at apex of jaw are pointed, but outer ones are truncate and may be wide and squarish. Genital slits long and genital scales wide; each scale has a marginal series of small, close-set, truncate papillæ, which are more elongated on upper side of arm, where the two series (of opposite sides of arm) meet and form a single unbroken series across base of arm. First under arm plate rounded diamond shaped; second plate squarish; succeeding plates

pentagonal, becoming triangular; all these plates are wider than long, and except first two are nearly or quite separate from each other. Side arm plates large, meeting above and below, except at base of arm; each plate carries three subequal, well-spaced, peg-like arm spines, less than half as long as joint. Oral tentacle pores may or may not open into mouth slit; in the type they do; they are protected by five or six scales on each side. There seem to be no tentacle pores on arm distal to first three or four joints, and these are guarded by three and two scales or by two and one; but throughout whole length of arm, the lowest arm spine is accompanied by a minute peg-like tentacle scale crowded close against it. Color (dried from alcohol), pale gray or whitish. 
Localities.-Albatross station 3698, off Honshu Island, Jápan, 153 fathoms, green mud, volcanic ashes, sand, 2 specimens; station 4957 , Inland Sea, lat. $32^{\circ} 36^{\prime} \mathrm{N}$, ; long. $132^{\circ} 23^{\prime}$ E., 437 fathoms, greenbrown mud, fine gray sand, foraminifera, bottom temperature $39.8^{\circ}$, 4 specimens; station 4959 , Inland Sea, lat. $32^{\circ} 36^{\prime} 30^{\prime \prime} \mathrm{N}$.; long, $132^{\circ} 23^{\prime} 20^{\prime \prime}$ E., 405 to 578 fathoms, green-brown mud, fine gray sand, foraminifera, 1 specimen; station 5057, Suruga Gulf, lat. $34^{\circ}$ $58^{\prime} 40^{\prime \prime}$ N.; long. $138^{\circ} 34^{\prime}$ E., 270 fathoms, gray mud, bottom temperature $44.8^{\circ}, 1$ specimen. Bathymetrical range, 153 to 578 fathoms. Temperature range, $44.8^{\circ}$ to $39.8^{\circ}$. Eight specimens.

Type.-Cat. No. 25545, U.S.N.M., from station 3698.

This species is easily distinguished by its unique arm comb. While Ophioglypha clemens Kœhler and $O$. jejuna Lyman also have a continuous arm comb, the disk covering of the former species and the arm joints, arm spines, and upper arm plates of the latter are so different from what is found in monostocha that the three species can not possibly be confused. In the type and the specimen from station 5057 the side arm plates are minutely tuberculated, while in the other specimens they are perfectly smooth; it is these latter specimens also which have the oral tentacle pores separated from the mouth slits, and the oral papillæ very short, wide, and truncate. These differences can hardly be magnified, however, into distinctions of any systematic importance.

\section{OPHIURA CALYPTOLEPIS, new species. $a$}

Disk $13 \mathrm{~mm}$. in diameter; arms about 35 to $40 \mathrm{~mm}$. long. Disk covered by rather coarse thick scales, which are more or less concealed by a delicate, very finely granular skin; a large interradial marginal scale is prominent, and in the youngest specimen the primary plates can easily be made out. Radial shields somewhat swollen, a little longer than wide, distinctly separated from each other. Basal upper arm plates oblong, much wider than long, followed by pentagonal or tetragonal plates, which rapidly become triangular with a sharp, proximal angle; the first five to nine in contact with each other. Interbrachial spaces below covered by partly concealed plates, like those of the disk. Oral shields wider than long or longer than wide, somewhat pentangular, the lateral margins more or less concave. Adoral plates long and narrow; oral plates shorter and wider. Oral papillæ, five or six on each side, wide and truncate distally, but becoming longer and pointed at apex of jaw. Genital slits not conspicuous. Genital scales, hidden by scaling of interbrachial areas, their marginal papillæ few and small, so that no arm comb or at most only a small and inconspicuous one is visible from above.

$a K a \lambda u \pi \tau \delta s$, signifying covered, and $\lambda \varepsilon \pi i s$, signifying scale, in reference to the more or less concealed scaling of the disk. 
First under arm plate hexagonal, large, much wider than long; next two about as long as wide, somewhat pentagonal; succeeding ones rounded pentagonal or oblong, very much wider than long; all but first three or four well separated from each other. Side arm plates somewhat swollen, nearly or quite in contact both above and below from base to tip of arm; each plate carries six, or often seven, short, peg-like arm spines, middle ones usually longest, though not noticeably longer than lowest; none is half as long as a joint. Oral tentacle pores rather large, opening into mouth slit, with four or five scales on each side. Tentacle pores of arm confined to first four or five joints, but a single, minute tentacle scale extends far out on arm, lying close against lowest arm spine. There are several tentacle scales on each of the basal pores, but they can be distinguished only with difficulty from the little arm spines. Color (dried from alcohol), nearly white, though with more or less of a yellow tinge.

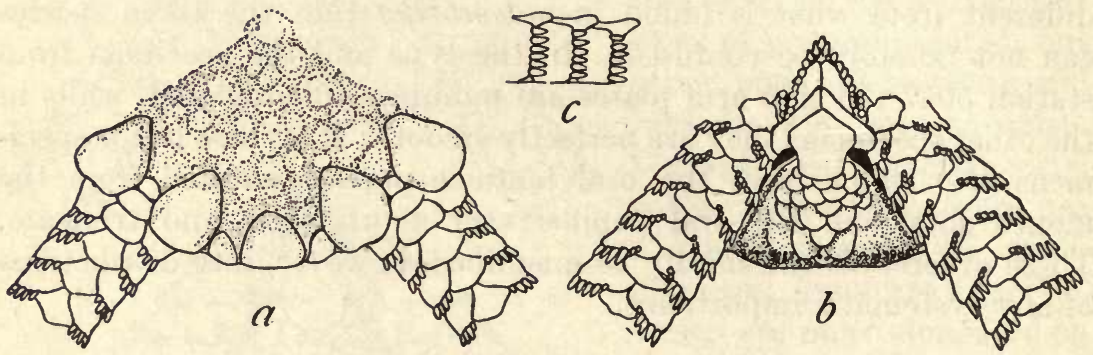

Fig. 18.-OPHIURA CALYPTOLEPIS. $\times$ 4. $a$, FROM ABOVE; $b$, FROM BELOW; $c$, SIDE VIEW of TWO ARM JOINTS NEAR DISK.

Localities.-Albatross station 3698, off Manazuru Zaki, Honshu, Japan, 153 fathoms, green mud, volcanic ashes, sand, 2 specimens; station 5088, Sagami Bay, lat. $35^{\circ} 11^{\prime} 25^{\prime \prime}$ N.; long. $139^{\circ} 28^{\prime} 20^{\prime \prime}$ E., 369 to 405 fathoms, green mud, bottom temperature $41.8^{\circ}, 1$ specimen; station 5091, Uraga Strait, lat. $35^{\circ} 4^{\prime} 10^{\prime \prime} \mathrm{N}$.; long. $139^{\circ} 38^{\prime}$ $12^{\prime \prime}$ E., 197 fathoms, green mud, coarse black sand, pebbles, bottom temperature, $47.8^{\circ}, 21$ specimens; station 5092, Uraga Strait, lat. $35^{\circ} 4^{\prime} 50^{\prime \prime} \mathrm{N}$.; long. $139^{\circ} 38^{\prime} 18^{\prime \prime}$ E., 70 fathoms, coarse black sand, bottom temperature $56.3^{\circ}, 1$ specimen. Bathymetrical range, 70 to 405 fathoms. Temperature range, $56.3^{\circ}$ to $41.8^{\circ}$. Twenty-five specimens.

Type.-Cat. No. 25635, U.S.N.M., from station 3698.

There can be no doubt that this species is closely allied to O. albata Lyman, which was collected by the Challenger near Japan. I have not seen that species, but the description and figures of the upper arm plates are entirely different from what calyptolepis shows, and moreover no reference is made to any concealment of the disk scales by a granular skin in albata. It has therefore seemed best to me to keep the two species separate, at least for the present. 
Disk $20 \mathrm{~mm}$. in diameter; arms about $55 \mathrm{~mm}$. long. Disk completely covered by a thick granular skin, through which, in adults, not even radial shields can be seen; in many smaller specimens outlines of radial shields and even of disk scales can be more or less easily distinguished. Upper arm plates small, tetragonal, all but first one or two much longer than wide, with a narrow, proximal, and a strongly convex, distal margin; on basal third or half of arm they are in contact with each other, but distally they become triangular and separate. Interbrachial spaces below like disk above. Oral shields and all mouth parts, under arm plates, tentacle pores, and tentacle scales, essentially as in calyptolepis, the differences being trivial and of no systematic importance; tentacle pores extend out six joints on arm, and first under arm plate is relatively smaller. Arm comb well developed, forming a conspicuous marginal fringe just distal to radial

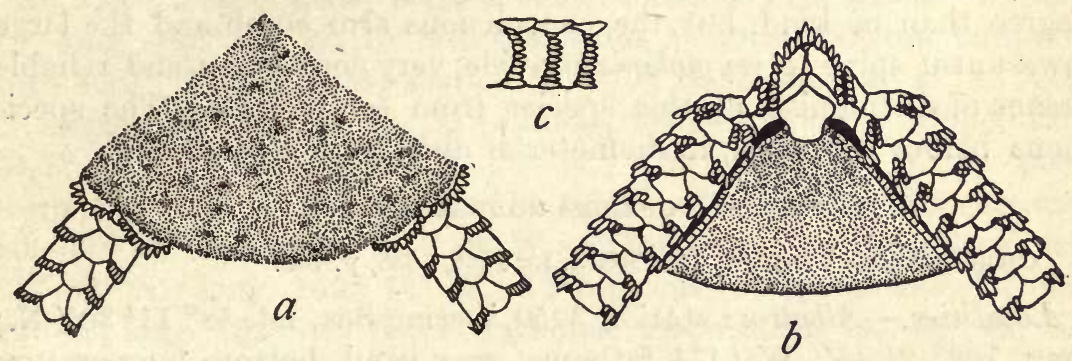

FIG. 19.-OPHIURA CRTPTOLEPIS. $\times 2.5$. $a$, FROM ABOVE; $b$, FROM BELOW; $c$, SIDE VIEW OF TWO ARM JOINTS NEAR DISK.

shields; the two parts do not unite into a single comb. Side arm plates large, meeting below but not above at base of arm; each plate carries seven to nine arm spines, lowest very distinctly largest and may equal or exceed half a joint; in some cases, especially small specimens, it appears to be next to lowest spine, which is longest, but in fact, what looks like lowest spine is tentacle scale. Color (dried from alcohol), yellow, yellowish, cream color or nearly white; some of the young specimens are dull purplish gray.

Localities.-Albatross station 2858, off Alaska, lat. $58^{\circ} 17^{\prime} \mathrm{N}$.; long. $148^{\circ} 36^{\prime}$ W., 230 fathoms, blue mud, gravel, bottom temperature $39.8^{\circ}, 1$ specimen; station 3070 , off Washington, lat. $47^{\circ} 29^{\prime} 30^{\prime \prime}$ $\mathrm{N}$; l long. $125^{\circ} 43^{\prime}$ W., 636 fathoms, green mud, bottom temperature $37.9^{\circ}, 2$ specimens; station 3332 , Bering Sea, lat. $54^{\circ} 2^{\prime} 50^{\prime \prime}$ N.; long. $166^{\circ} 45^{\prime}$ W., 406 fathoms, rocky, sand, bottom temperature $37.8^{\circ}$ ?, 1 specimen; station 3337 , off Alaskan peninsula, lat. $53^{\circ} 55^{\prime} 30^{\prime \prime} \mathrm{N}$.; long. $163^{\circ} 26^{\prime}$ W., 280 fathoms, green mud, bottom temperature

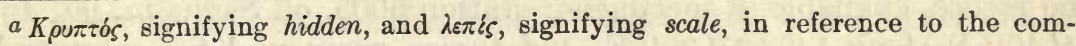
pletely concealed disk scales. 
$39.3^{\circ}, 11$ specimens; station 3338 , off Alaskan peninsula, lat. $54^{\circ} 19^{\prime}$ N.; long. $159^{\circ} 40^{\prime}$ W., 625 fathoms, green mud, sand, bottom temperature $37.3^{\circ}, 4$ specimens; station 3343 , off Washington, lat. $47^{\circ}$ $40^{\prime} 40^{\prime \prime} \mathrm{N}$.; long. $125^{\circ} 20^{\prime}$ W., 516 fathoms, green mud, bottom temperature $38.2^{\circ}, 3$ specimens; station 4781 , Bering Sea, lat. $52^{\circ} 14^{\prime} 30^{\prime \prime}$ N.; long. $174^{\circ} 13^{\prime}$ E., 482 fathoms, fine gray sand, pebbles, bottom temperature $38.6^{\circ}, 3$ specimens; station 5079, off Omai Saki Light, Japan, lat. $34^{\circ} 15^{\prime}$ N.; long. $138^{\circ}$ E., 475 to 505 fathoms, pebbles, bottom temperature $39.1^{\circ}, 3$ specimens; station 5080, off Omai Saki Light, Japan, lat. $34^{\circ} 10^{\prime} 30^{\prime \prime}$ N.; long. $138^{\circ} 40^{\prime}$ E., 505 fathoms, fine gray sand, globigerina, bottom temperature, $38.7^{\circ}, 1$ specimen. Bathymetrical range, 230 to 636 fathoms. Temperature range, $39.8^{\circ}$ to $37.3^{\circ}$. Twenty-nine specimens.

Type.-Cat. No. 25710, U.S.N.M., from station 3337.

This species is very near the preceding but seems to be constantly distinct. The concealment of the disk scales is more a difference of degree than of kind, but the conspicuous arm comb and the large lowest arm spine in cryptolepis provide very convenient and reliable means of distinguishing this species from calyptolepis. The specimens before me range, in diameter of disk, from 4 to $20 \mathrm{~mm}$.

\section{OPHIURA NODOSA.}

Ophiura nodosa LưTken, Vid. Medd. for 1854, 1855, p. 100.

Localities.-Albatross station 3250 , Bering Sea, lat. $58^{\circ} 11^{\prime} 30^{\prime \prime} \mathrm{N}$.; long. $163^{\circ} 2^{\prime} 45^{\prime \prime}$ W., $17 \frac{1}{2}$ fathoms, gray sand, bottom temperature $46.2^{\circ}, 3$ specimens; station 3251 , Bering Sea, lat. $57^{\circ} 35^{\prime} 50^{\prime \prime} \mathrm{N}$.; long. $164^{\circ} 5^{\prime}$ W., $25 \frac{1}{2}$ fathoms, fine gray sand, bottom temperature $37.5^{\circ}$, 12 specimens; station 3252 , Bering Sea, lat. $57^{\circ} 22^{\prime} 20^{\prime \prime} \mathrm{N}$.; long. $164^{\circ} 24^{\prime} 40^{\prime \prime}$ W., $29 \frac{1}{2}$ fathoms, black mud, bottom temperature $44.8^{\circ}$, 1 specimen; station 3269 , Bering Sea, lat. $55^{\circ} 19^{\prime} \mathrm{N}$.; long. $163^{\circ} 4^{\prime} 30^{\prime \prime}$ W., 16 fathoms, fine gray sand, black specks, bottom temperature $42.3^{\circ}, 1$ specimen; station 3297 , Bering Sea, lat. $57^{\circ} 38^{\prime} \mathrm{N}$.; long. $159^{\circ} 7^{\prime} 30^{\prime \prime}$ W., 26 fathoms, gray sand, bottom temperature $41.5^{\circ}, 1$ specimen; station 3298 , Bering Sea, lat. $57^{\circ} 38^{\prime} 30^{\prime \prime} \mathrm{N}$.; long. $158^{\circ}$ $22^{\prime} 30^{\prime \prime}$ W., 20 fathoms, fine gray sand, bottom temperature $43.8^{\circ}$, 18 specimens; station 3304 , Bering Sea, lat. $58^{\circ} 2^{\prime} 30^{\prime \prime} \mathrm{N}$.; long. $161^{\circ}$ $13^{\prime} 45^{\prime \prime}$ W., 28 fathoms, fine gray sand, 1 specimen; station 3305 , Bering Sea, lat. $57^{\circ} 51^{\prime} 30^{\prime \prime}$ N.; long. $161^{\circ} 40^{\prime}$ W., 23 fathoms, fine gray sand, bottom temperature $41.8^{\circ}, 23$ specimens; station 3504, Bering Sea, lat. $56^{\circ} 57^{\prime}$ N.; long. $169^{\circ} 27^{\prime}$ W., 34 fathoms, fine gray sand, black specks, bottom temperature $37.8^{\circ}, 1$ specimen; station 3507 , Bering Sea, lat. $57^{\circ} 43^{\prime}$ N.; long. $164^{\circ} 42^{\prime}$ W., 31 fathoms, fine gray sand, bottom temperature $37.5^{\circ}, 35$ specimens; station 3675 , loc. ?, no record available, 6 specimens; station 5005 , off Saghalin, lat. $46^{\circ}$ $4^{\prime} 40^{\prime \prime} \mathrm{N}$. ; long. $142^{\circ} 27^{\prime} 30^{\prime \prime}$ E., 42 fathoms, green mud, fine gray sand, 
bottom temperature $30.7^{\circ}$ ?, 78 specimens; station 5006, off Saghalin, lat. $46^{\circ} 4^{\prime} \mathrm{N}$.; long. $142^{\circ} 29^{\prime}$ E., 42 to 43 fathoms, green mud, fine gray sand, bottom temperature $36.1^{\circ}, 7$ specimens; station 5007 , off Saghalin, lat. $46^{\circ} 3^{\prime}$ N. ; long. $142^{\circ} 31^{\prime}$ E., 42 fathoms, green mud, fine gray sand, bottom temperature $34.8^{\circ}, 9$ specimens; station 5008 , off Saghalin, lat. $46^{\circ} 7^{\prime} 50^{\prime \prime}$ N.; long. $142^{\circ} 37^{\prime} 20^{\prime \prime}$ E., 40 fathoms, green mud, fine gray sand, bottom temperature 33.9 , 9 specimens; station 5011 , off Saghalin, lat. $46^{\circ} 18^{\prime} 30^{\prime \prime}$ N.; long. $143^{\circ} 5^{\prime} 40^{\prime \prime}$ E., 42 fathoms, green mud, bottom temperature $33.9^{\circ}, 1$ specimen; station 5020 , off Saghalin, lat. $48^{\circ} 32^{\prime} 45^{\prime \prime} \mathrm{N}$.; long. $145^{\circ} 7^{\prime} 30^{\prime \prime}$ E., 73 fathoms, green mud, sand, pebbles, bottom temperature $30.9^{\circ}, 4$ specimens; station 5021, Okhotsk Sea, lat. $48^{\circ} 32^{\prime} 30^{\prime \prime}$ N.; long. $145^{\circ} 8^{\prime} 45^{\prime \prime}$ E., 73 fathoms, green mud, sand, pebbles, bottom temperature $30.9^{\circ}, 1$ specimen; station 5022 , Okhotsk Sea, lat. $48^{\circ} 35^{\prime} 30^{\prime \prime} \mathrm{N}$.; long. $145^{\circ}$ $20^{\prime}$ E., 109 fathoms, green mud, coarse black sand, bottom temperature $30.1^{\circ}, 2$ specimens; station 5023 , Okhotsk Sea, lat. $48^{\circ} 43^{\prime} 30^{\prime \prime}$ N.; long. $145^{\circ} 03^{\prime}$ E., 75 fathoms, sand, pebbles, bottom temperature $30.9^{\circ}, 3$ specimens; station 5024, off Saghalin, lat. $48^{\circ} 43^{\prime} 30^{\prime \prime}$ N.; long. $144^{\circ} 56^{\prime} 45^{\prime \prime}$ E., 52 fathoms, pebbles, bottom temperature $31.7^{\circ}, 2$ specimens; lat. $60^{\circ} 22^{\prime} \mathrm{N}$.; long. $168^{\circ} 45^{\prime} \mathrm{W} .9$ specimens; lat. $62^{\circ} 15^{\prime} \mathrm{N}$.; long. $167^{\circ} 40^{\prime}$ W., 20 fathoms, 2 specimens; lat. $62^{\circ} 54^{\prime} \mathrm{N}$; ; long. $166^{\circ} 38^{\prime}$ W., 22 fathoms, 105 specimens; lat. $63^{\circ} 37^{\prime} \mathrm{N}$.; long. $165^{\circ} 19^{\prime} \mathrm{W}$., 12 fathoms, 69 specimens; lat. $64^{\circ}$ $12^{\prime} \mathrm{N}$.; long. $162^{\circ} 52^{\prime} \mathrm{W} ., 17$ fathoms, 1 specimen; lat. $66^{\circ} 45^{\prime} \mathrm{N}$.; long. $166^{\circ} 35^{\prime} \mathrm{W} ., 10$ specimens; Arctic cruise of the Corwin, 35 specimens; Dall's Alaska collection, 26 specimens; Arctic Ocean, 210 specimens; off Cape Sabine, Alaska, 62 specimens; off Icy Cape, Alaska, 36 specimens; near coal station, Unga, Aleutians, 45 specimens; off Point Barrow, Alaska, 15 fathoms, mud, 1 specimen; 10 miles west of Point Franklin, Alaska, $13 \frac{1}{2}$ fathoms, 29 specimens; Sitka Harbor, Alaska, 10 to 25 fathoms, 2 very small specimens; Point Belcher, Alaska, 9 fathoms, sand, 74 specimens; mouth of Yukon River, Alaska, 9 specimens; Port Clarence, Alaska, 4 specimens; Point Hope, Alaska, 25 fathoms, 4 specimens; 12 miles east of King's Island, Bering Strait, 9 specimens; Plover Bay, Siberia, 8 to 20 fathoms, mud, 90 specimens; Indian Point, Bering Strait, 17 fathoms, 5 specimens; East Cape, Siberia, 3 specimens; Cape Etolin, Nuniak Island, Alaska, 2 specimens; Port Levasheff, Alaska, 6 specimens; locality ?, 1 specimen. Bathymetrical range, 8 to 109 fathoms.' Temperature range $46.2^{\circ}$ to $30.1^{\circ}$. One thousand and sixty-seven specimens.

This large series of specimens is of interest not merely because it extends the bathymetric range of the species to over 100 fathoms and the geographic range on the Asiatic coast south to the lower end of Saghalin, but because it shows the growth changes and the great 
range of variability of the species. The smallest specimen has the diameter of the disk rather less than $2 \mathrm{~mm}$. with the primary plates covering nearly all of the upper side; the radial shields and the large interradial marginal plates are very small in comparison. The upper arm plates are nearly circular and much swollen, and the under arm plates are longer than wide, but little swollen. The side arm plates are decidedly swollen, and carry two short, sharp, well-spaced arm spines. The oral shields occupy most of the interbrachial spaces below and the tentacle pores have only one or two tentacle scales each. The largest specimen has the disk $17 \mathrm{~mm}$. in diameter and covered by about 150 scales among which the primary plates are not conspicu-
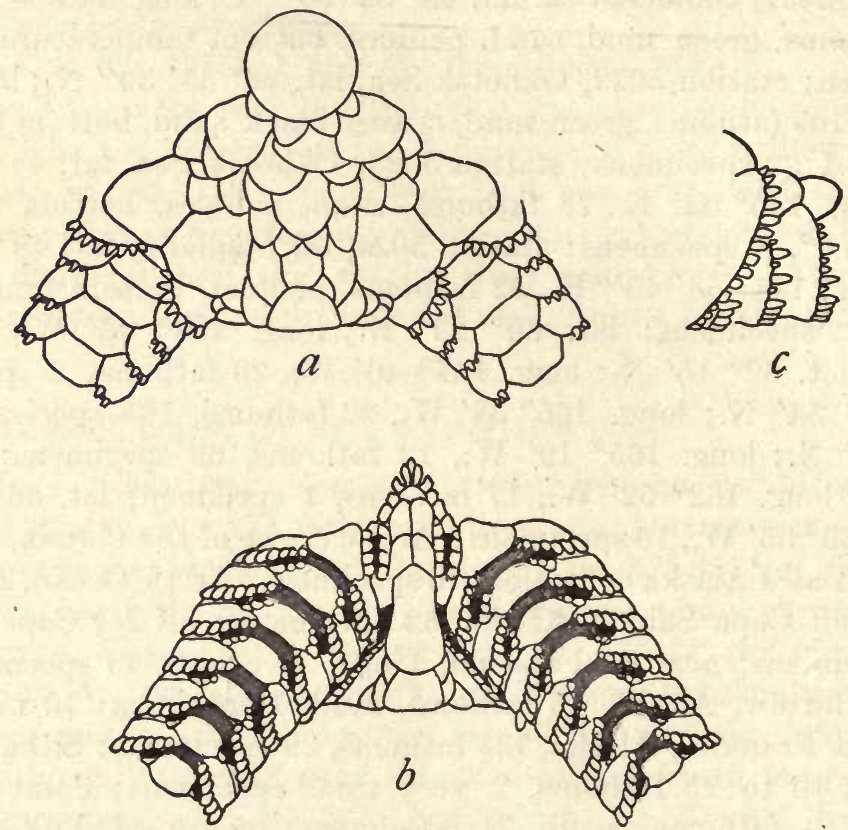

Fig. 20.-OPHURA NODOSA; VARIETY FROM ICY CAPE, ALASKA. $\times 6$. $a$, FROM ABOVE; $b$, FROM BELOW; $c$, SIDE VIEW OF BASE OF ARM.

ous. The upper arm plates are less swollen, hexagonal or pentagonal, the basal ones much wider than long; the basal under arm plates are also wider than long, the first one nearly triangular. The side arm plates are very high and little swollen; they carry from three to six arm spines, of which two are usually larger than the others and of somewhat different shape. The tentacle scales have become very numerous and there may be as many as eleven (seven proximal and four distal) on a pore. Even far out on the arm there are three or four scales borne on each side arm plate, at the proximal edge of the pore. The chief variations shown by the different specimens are found in the number and arrangement of the disk scales, the amount of swelling 
of the arm plates, the shape of the oral shields, and particularly the number and arrangement of the arm spines. Usually two arm spines, larger than the others and of somewhat different shape, can be quite easily distinguished, one next to the tentacle scales, the other high up on the arm, but either one or both of these may be wanting or at best no larger than the adjoining spinelets. In some specimens the contrast between these two spines and those which accompany them, is very marked, the latter being flat, thin and scale-like, while in other specimens all the arm spines are reduced to minute, rounded papillæ. It is very often difficult to distinguish sharply between the tentacle scales and the lowest arm spines. The most extreme variation is shown by some of the specimens from Icy Cape (see fig. 20) in which the oral shields are extraordinarily elongated and there are deep transverse grooves between the basal under arm plates. The arms are also high and strongly compressed, so that they are virtually keeled near the base. I at first considered this form a distinct species, but the connecting series is too complete to warrant its recognition.

OPHIURA SCULPTA.

Ophioglypha sculpta Duncan, Journ. Linn. Soc. London, vol. 14, 1879, p. 455.

Ophiura sculpta Merssner, Bronn's Thierreichs, vol. 2, ser. 3, 1901, p. 925.

Localities.-Albatross station 3702, off Honshu Island, Japan, 31 to 41 fathoms, volcanic mud, sand, rocks, 2 specimens; station 4893, Eastern Sea, lat. $32^{\circ} 32^{\prime}$ N.; long, $128^{\circ} 32^{\prime} 50^{\prime \prime}$ E., 95 to 106 fathoms, gray sand, broken shells, pebbles, bottom temperature $55.9^{\circ}$, 5 specimens; station 4894 , Eastern Sea, lat. $32^{\circ} 33^{\prime}$ N.; long. $128^{\circ}$ $32^{\prime} 10^{\prime \prime} \mathrm{E}, 95$ fathoms, green sand, broken shells, pebbles, 2 specimens; station 4895 , Eastern Sea, lat. $32^{\circ} 33^{\prime} 10^{\prime \prime} \mathrm{N}$.; long. $128^{\circ} 32^{\prime} 10^{\prime \prime}$ E., 95 fathoms, green sand, broken shells, pebbles, 5 specimens; station 4900 , Eastern Sea, lat. $32^{\circ} 28^{\prime} 50^{\prime \prime}$ N. ; long. $128^{\circ} 34^{\prime} 40^{\prime \prime}$ E., 139 fathoms, gray sand, broken shells, bottom temperature $52.9^{\circ}, 1$ specimen; station 4903 , Eastern Sea, lat. $32^{\circ} 31^{\prime} 10^{\prime \prime}$ N.; long. $128^{\circ} 33^{\prime} 20^{\prime \prime}$ E., 107 to 139 fathoms, gray sand, broken shells, 1 specimen. Bathymetrical range, 31 to 139 fathoms. Temperature range, $55.9^{\circ}$ to $52.9^{\circ}$. Sixteen specimens.

These specimens answer very well to Duncan's description and figures, and show very little diversity of structure among themselves. The largest one is only a trifle larger than Duncan's type, having the disk a little more than $8 \mathrm{~mm}$. in diameter and the arms nearly $13 \mathrm{~mm}$. long.

\section{OPHIURA STUWITZII.}

Ophiura stuwitzii LüTkeN, Vid. Medd. for 1857, 1857, p. 51.

Localities.-Albatross station 2845, off Alaska, lat. $54^{\circ} 5^{\prime} \mathrm{N}$.; long. $164^{\circ} 9^{\prime}$ W., 42 fathoms, coarse black sand, bottom temperature $42^{\circ}$, 1 specimen; Alaska, 23 specimens; Alaska, Dall's collection, 1 specimen; Kyska Harbor, Alaska, 9 to 14 fathoms, 1 specimen. 
These specimens vary in disk diameter from 3 to $8 \mathrm{~mm}$. They show considerable diversity in height and form of disk, and in the shape and length of the arm-comb papillæ, but even the smallest specimens are at once distinguishable from young nodosa by the arm spines.

\section{OPHIURA CEDIPLAX, new species. $a$}

Disk $5 \mathrm{~mm}$. in diameter; arms about $12 \mathrm{~mm}$. long. Disk covered by twenty-one plates, a centro-dorsal, five radial, five interradial, and five pairs of radial shields; all disk scales more or less tumid though the radial shields are least so. Radial shields squarish, joined for most of their length. Upper arm plates thick and swollen,

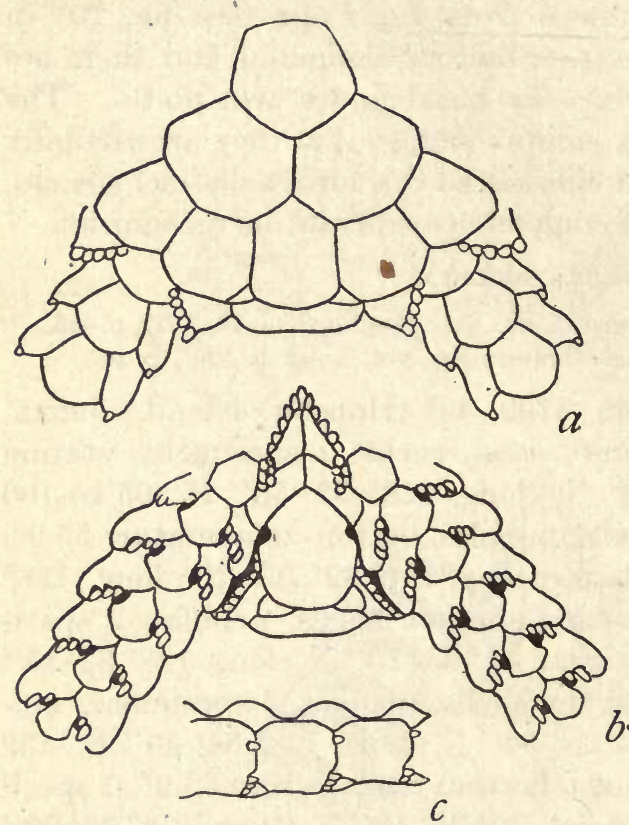

FIG.21.-OPHIURA EDIPLAX. $\times 10$. $a$, FROM ABOVE; $b$, FROM BELOW; $c$, SIDE VIEW OF THREE ARM JOINTS NEAR DISK. somewhat pentagonal (becoming tetragonal and finally trigonal), but with more or less rounded angles; all but basal ones longer than wide, first three, four, or five $\mathrm{n}$ contact. Interbrachial spaces below covered almost wholly by the oral shields, distal to which a large marginal plate and the two genital scales may be seen; a couple of small angular plates often lie bètween oral shields and marginal plate. Oral shields longer than wide, rounded without, pointed within. Adoral plates very large, twice as long as wide; oral plates somewhat smaller but quite indistinct. Oral papillæ minute, about five on a side. Genital scales very stout, with a marginal series of about a dozen short, blunt papillæ, which form the inconspicuous arm comb when seen from above. Basal under arm plates somewhat hexagonal or pentagonal, and though the plates rapidly diminish in size, they undergo little change of form, except that they become wider than long distally, while at first they are decidedly longer than wide. Side arm plates somewhat swollen, at first higher than long, but rapidly becoming longer than high, in contact except at base of arm; each plate carries one small arm spine, high up on the distal

a $0{ }^{\prime} \delta \xi \omega$, signifying to swell, and $\pi \lambda \dot{a} \xi$, signifying a plate, in reference to the swollen disk and upper arm plates. 
margin. Oral tentacle pores do not open distinctly into mouth slit; they are protected by two or three scales on each side. Tentacle pores of arm with three or two scales, and at last only a single scale, on proximal margin. Color (dried from alcohol), nearly white.

Localities.-Albatross station 4812 , Sea of Japan, lat. $38^{\circ} 33^{\prime} \mathrm{N}$.; long. $138^{\circ} 40^{\prime}$ E., 176 to 200 fathoms, fine brown mud (?), bottom temperature $34.9^{\circ}, 6$ specimens; station 4819 , Sea of Japan, lat. $38^{\circ} 9^{\prime}$ N.; long. $138^{\circ} 32^{\prime} 12^{\prime \prime}$ E., 245 fathoms, fine brown mud, bottom temperature $33.1^{\circ}, 4$ specimens. Bathymetrical range, 176 to 245 fathoms. Temperature range, $34.9^{\circ}$ to $33.1^{\circ}$. Ten specimens.

Type.-Cat. No. 25618, U.S.N.M., from station 4812.

Although this interesting little brittle-star is nearly related to both Ophiura bullata and $O$. convexa, it is easily distinguished from either (even young specimens) by the single short, blunt arm spine, the wide oral shields, and the large tentacle scales. It is quite possible that cediplax is the young of a larger species, but I know of none to which it can be assigned, and it seems to me therefore desirable to both name and figure it.

\section{OPHIURA STEREA.}

Ophioglypha sterea H. L. Clark, Bull. Mus. Comp. Zoöl., vol. 51, 1908, p. 293.

Localities.-Albatross station 3771, off Honshu Island, Japan, 61 fathoms, green mud, sand, 40 specimens; station 3774, off Honshu Island, Japan, 81 fathoms, gray sand, 2 specimens; station 3775 , off Honshu Island, Japan, 57 fathoms, green mud, sand, 2 specimens; station 4815, Sea of Japan, lat. $38^{\circ} 16^{\prime} \mathrm{N}$.; long. $138^{\circ} 52^{\prime}$ W., 70 fathoms, dark green sand, bottom temperature $51^{\circ}, 1$ specimen; station 4826, off Honshu Island, Japan, lat. $37^{\circ} 25^{\prime} \mathrm{N}$.; long. $137^{\circ} 32^{\prime}$ E., 114 fathoms, fine gray sand, black specks, bottom temperature $42.5^{\circ}, 2$ specimens; station 4832 , off Honshu Island, Japan, lat. $36^{\circ}$ $14^{\prime} 30^{\prime \prime} \mathrm{N}$.; long. $135^{\circ} 56^{\prime} 30^{\prime \prime}$ E., 76 to 79 fathoms, dark gray sand, bottom temperature $53.2^{\circ}, 14$ specimens; station 4833, off Honshu Island, Japan, lat. $36^{\circ} 13^{\prime} 40^{\prime \prime} \mathrm{N}$.; long. $135^{\circ} 56^{\prime} 30^{\prime \prime}$ E., 79 fathoms, dark gray sand, rocks, bottom temperature $53.2^{\circ}, 6$ specimens; station 4842 , off Korea, lat. $36^{\circ} 13^{\prime} \mathrm{N}$.; long. $133^{\circ} 27^{\prime}$ E., 82 fathoms, fine green sand, shells, bottom temperature $54.6^{\circ}, 1$ specimen; station 4965 , off Japan, lat. ' $33^{\circ} 35^{\prime} 20^{\prime \prime} \mathrm{N}$.; long. $135^{\circ} 10^{\prime} 50^{\prime \prime}$ E., 191 fathoms, dark green-gray sand, shells, bottom temperature $49.4^{\circ}$, 1 specimen; station 5046, off Honshu Island, Japan, lat. $38^{\circ} 15^{\prime} 7^{\prime \prime}$ N.; long. $141^{\circ} 44^{\prime} 20^{\prime \prime}$ E., 82 fathoms, dark gray sand, pebbles, bottom temperature $50.8^{\circ}, 20$ specimens; station 5055, in Suruga Gulf, Japan, lat. $34^{\circ} 53^{\prime}$ N.; long. $138^{\circ} 44^{\prime} 15^{\prime \prime}, 124$ fathoms, green mud, gray sand, broken shells, pebbles, bottom temperature $56.6^{\circ}, 6$ specimens; station 5092, Uraga Strait, Japan, lat. $35^{\circ} 4^{\prime} 50^{\prime \prime}$ N.; long. $139^{\circ} 38^{\prime} 13^{\prime \prime}$ E., 70 fathoms, coarse black sand, bottom temperature 
$56.3^{\circ}, 3$ specimens; station 5094, Uraga Strait, Japan, lat. $35^{\circ} 4^{\prime} 42^{\prime \prime} \mathrm{N}$.; long. $139^{\circ} 38^{\prime} 20^{\prime \prime}$ E., 88 fathoms, black sand, broken shells, bottom temperature $54.8^{\circ}, 5$ specimens; locality (?), 2 specimens. Bathymetrical range, 57 to 191 fathoms. Temperature range, $56.6^{\circ}$ to $42.5^{\circ}$. One hundred and five specimens.

This fine series of specimens, the disk diameters of which range from 6 to $20 \mathrm{~mm}$., shows conclusively that the original specimens, on which the species was based, were immature. It has therefore seemed advisable to give figures of the adult. The only important changes which take place as the individuals increase from a disk diameter of $7 \mathrm{~mm}$. to one of 20 are found in the arm comb and the arm spines. The change in the arm comb is an increase in the
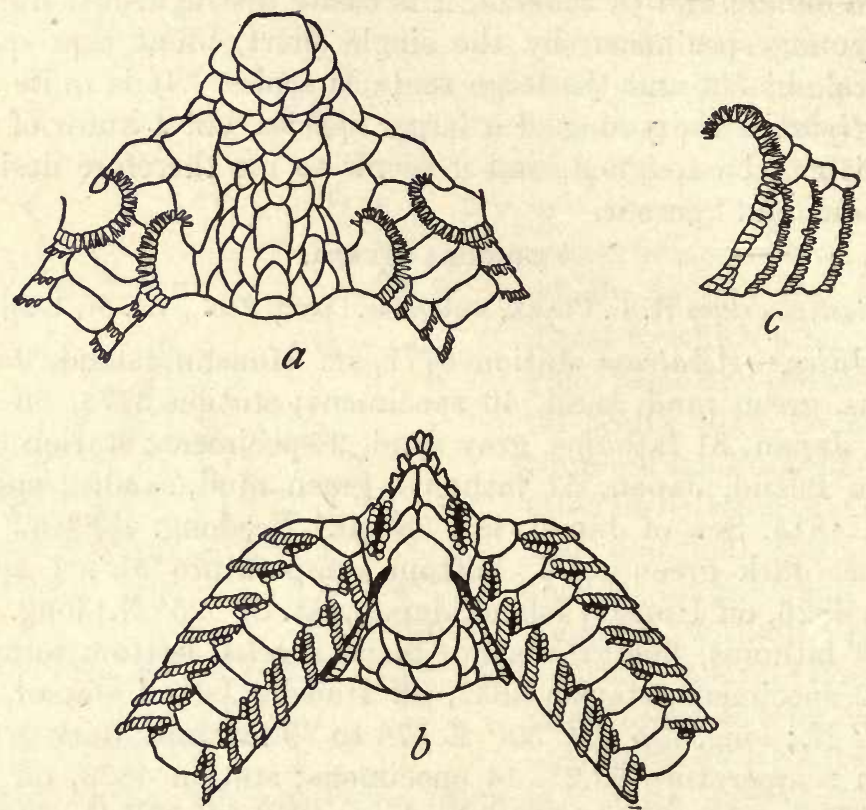

Fig. 22.-OpHIURA STEREA. $\times 2.5$. $a$, FROM ABOVE; $b$, FROM BELOW; $c$, SIDE VIEW OF BASE OF ARM.

number of papillæ, of which there may be as many as twenty-five. The change in the arm spines is far more important; the number of what we may call true arm spines changes little, for there are usually four or five; and only rarely six, but there develops on the distal margin of the side arm plates a secondary series of spines, which may be quite conspicuous, and consist of as many as fifteen spinelets. These spinelets are usually flatter, thinner, and more truncate than the true spines, but while the differences may be marked, it is often difficult to distinguish between the true and the secondary spines. This is particularly so at the base of the arm, as may be seen in fig. 22c. On the whole, sterea seems to be very well characterized and quite distinct from any of its nearest relatives. 


\section{OPHIURA SCULPTILIS.}

Ophioglypha sculptilis Lyman, Bull. Mus. Comp. Zoöl., vol. 5, 1878, p. 84. Ophioglypha variabilis Lyman, Bull. Mus. Comp. Zoöl., vol. 5, 1878, p. 85.

Ophiura sculptilis MeIssner, Bronn's Thierreichs, vol. 2, pt. 3, 1901, p. 925.

Locality.-Albatross station 4928, southeast of Yakushima Island, Japan, lat. $29^{\circ} 51^{\prime}$ N.; long. $131^{\circ} 2^{\prime} 30^{\prime \prime}$ E., 1,008 fathoms, gray sand, globigerina ooze, bottom temperature $36.8^{\circ}, 3$ specimens.

I have compared these specimens, which have the disk about 9 $\mathrm{mm}$. in diameter, with a cotype of variabilis (Challenger station 195, off Amboina), and with numerous specimens from the West Indies, and I have no doubt of the correctness of the identification. I have also examined, in connection with these specimens, a cotype of O. sculptilis Lyman (Challenger station 237, off Japan), which is of almost exactly the same size and proportions as the cotype of variabilis, and I am forced to the conclusion that the two are conspecific. Koehler ${ }^{a}$ has expressed the view that while sculptilis and variabilis are very closely allied they seem to be constantly different in the oral papillæ and the arrangement of scales just proximal to the radial shields. I do not find that these trivial differences hold in the series before me, and it seems to me necessary to unite the two nominal forms under the name sculptilis, which has the priority of one page over the very appropriate name variabilis. The number of arm spines is given by Lyman as "six" in sculptilis and "four or five" in variabilis; at the base of the arm, however, there are commonly six or seven and not rarely eight. The Challenger specimen of variabilis has six or seven, the Albatross specimen has seven, and on one joint eight, and several of the Blake specimens have eight on one or more of the arm joints. After the first half dozen joints the number is commonly four or five.

\section{OPHIURA PONDEROSA.}

Ophioglypha ponderosa Lyman, Bull. Mus. Comp. Zoöl., vol. 5, 1878, p. 93.

Ophiura ponderosa MeIssner, Bronn's Thierreichs, vol. 2, pt. 3, 1901, p. 925.

Localities.-Albatross station 2853, off Alaska, lat. $56^{\circ} \mathrm{N}$.; long. $154^{\circ} 20^{\prime}$ W., 159 fathoms, gray sand, bottom temperature $41^{\circ}, 3$ specimens; station 2858 , of Alaska, lat. $58^{\circ} 17^{\prime} \mathrm{N}$. ; long. $148^{\circ} 36^{\prime} \mathrm{W}$., 230 fathoms, blue mud, gravel, bottom temperature $39.8^{\circ}, 2$ specimens; station 2861, off Alaska, lat. $51^{\circ} 14^{\prime} \mathrm{N}$.; long. $129^{\circ} 50^{\prime} \mathrm{W} ., 204$ fathoms, bottom?, bottom temperature $42.6^{\circ}, 1$ specimen; station 3126 , off California, lat. $36^{\circ} 49^{\prime} 20^{\prime \prime} \mathrm{N}$.; long. $122^{\circ} 12^{\prime} 30^{\prime \prime} \mathrm{W} ., 456$ fathoms, green mud, bottom temperature?, 4 specimens; station 3337 , off Alaska, lat. $53^{\circ} 55^{\prime} 30^{\prime \prime}$ N.; long. $163^{\circ} 26^{\prime}$ W., 280 fathoms, green mud, bottom temperature $39.3^{\circ}, 43$ specimens; station 3339 ,

a Investigator Deep Sea Oph., 1899, p. 20.

$b$ The published temperature for this station is obvfously erroneous, as shown by the context, 
off Alaska, lat. $54^{\circ} 46^{\prime} \mathrm{N}$.; long. $157^{\circ} 43^{\prime} 30^{\prime \prime}$ W., 138 fathoms, mud, gravel, bottom temperature $37.4^{\circ}, 1$ specimen; station 5023 , Okhotsk Sea, lat. $48^{\circ} 43^{\prime} 30^{\prime \prime}$ N.; long. $145^{\circ} 3^{\prime}$ E., 75 fathoms, sand, pebbles, bottom temperature $30.9^{\circ}, 7$ specimens; station 5029 , Okhotsk Sea, lat. $48^{\circ} 22^{\prime} 30^{\prime \prime} \mathrm{N}$.; long. $145^{\circ} 43^{\prime} 30^{\prime \prime}$ E., 440 fathoms, black sand, gravel, bottom temperature $35.3^{\circ}, 4$ specimens; station 5079 , off Omai Saki, Japan, lat. $34^{\circ} 15^{\prime}$ N.; long. $138^{\circ}$ E., 475 to 505 fathoms, pebbles, bottom temperature $39.1^{\circ}, 8$ specimens. Bathymetrical range, 75 to 505 fathoms. Temperature range, $42.6^{\circ}$ to $30.9^{\circ}$. Seventy-three specimens.

This splendid series of specimens is of great interest in showing the growth changes of one of the largest, and probably the heaviest, of the simple-armed ophiurans. The smallest specimen has the disk $6 \mathrm{~mm}$. in diameter and nearly $3 \mathrm{~mm}$. thick. It is covered by about sixty plates, of which the primary plates and five additional plates (one proximal to each pair of radial shields) are more or less swollen and correspondingly conspicuous. In the largest specimen the disk is $47 \mathrm{~mm}$. in diameter and is $14 \mathrm{~mm}$. thick just proximal to the radial shields; it is covered by about one hundred and fifty plates. While the diameter has increased about eight times, the thickness has only increased five times and the number of plates on the disk only two and a half times. In another specimen, in which the disk diameter is about $42 \mathrm{~mm}$. there are only about seventyfive disk plates. In all specimens regardless of size, the radial plate just proximal to the radial shields, is the most swollen and usually the most conspicuous. In the largest specimen the arm is extraordinarily triangular (in cross section) at base; each of the three sides is $10 \mathrm{~mm}$. across. In small specimens the arm is not so sharply keeled, but it is distinctly trigonal. The arm spines show considerable diversity in different individuals, quite apart from size. There was only a single specimen in the Challenger collection and it is probable Lyman did not dry that one completely, so that he was misled in regard to the number and arrangement of the arm spines. In reality we can distinguish here, as in sterea, between true and secondary spines. The true spines are usually two in number, short, thick, and peg-like; often there are three, frequently only one, and sometimes they appear to be wholly wanting. The secondary spines are very flat, thin, and blunt, and first appear on the angle of the arm between the lowest true spine and the tentacle scales. They may be wholly wanting, especially in young specimens. In adults, they may be numerous (as many as twelve) and reach clear to the top of the side arm plate. Usually they are distinctly more marginal than the true spines, but sometimes all are in the same plane, and then the true spines can only be distinguished, if at all, by their larger size and different shape. In the Challenger specimen, the true spines 
were either wanting or were indistinguishable. The color of most of the individuals before me is some shade of brownish-yellow, but those from station 3126 are nearly pure white. In these specimens also, the oral shields are much narrower and more constricted than in any of the others, but the differences are not sufficiently marked to raise any question as to the specific identity of the form.

OPHIURA MEGAPOMA, new species. $a$

Disk $17 \mathrm{~mm}$. in diameter; arms about $50 \mathrm{~mm}$. long. Disk rather high but flat, covered by about 100 to 150 stout, coarse plates, among which the primary plates are not conspicuous. Radial shields of moderate size, rather longer than broad, well separated both without and within, but usually more or less in contact at the middle. Arms rather high, more or less compressed near base. Upper arm plates hexagonal and wider than long at base of arm, but more or less rapidly

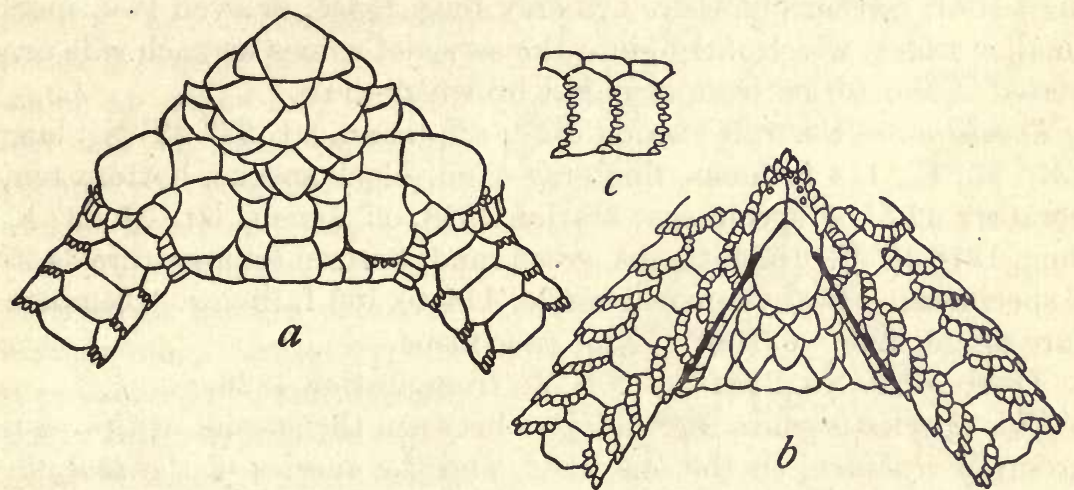

FIG. 23.-OPHIURA MEgAPOMA. $\ 3$. $a$, FROM ABOVE; $b$, FROM BELOW; $c$, SIDE VIEW OF THREE ARM JOINTS NEAR DISK.

becoming longer than wide, and pentagonal or even tetragonal near tip ; in contact except at extremity of arm. Interbrachial areas below covered by about twenty rather coarse plates. Oral shields longer than wide, rounded distally but pointed at inner end. Adoral plates large, about twice as long as wide; oral plates smaller, much wider proximally than distally; in the type-specimen there are a number of rounded granules on the inner ends of these plates, but these are wanting in the other specimens. Oral papillæ only three on each side, . rather small and somewhat pointed; they are directly continuous with the tentacle scales on the outer side of the oral tentacle pore. Genital slits long and moderately conspicuous. Genital scales short and wide distally, rather conspicuous from above; each scale carries about eight wide, truncate, crowded papillæ, which, with two additional ones on the outer end of each radial shield, make up the conspicuous arm

a Ḿr ras, signifying $b i g$, and $\pi \tilde{\omega} \mu a$, signifying lid, in reference to the large lid-like tentacle scales. 
comb. First under arm plate much longer than wide, with a median keel-like swelling; second plate similar, but wider, and with the keel flat and broad; succeeding plates more or less elongated hexagonal, ultimately becoming tetragonal and then triangular, in contact on basal two-thirds of arm. Side arm plates moderate, somewhat swollen, separated both above and beneath, until near tip of arm; each plate bears four or five minute papilla-like arm spines, which grade so closely into the tentacle scales it is difficult to draw a line between them. Oral tentacle pores opening into mouth slit, but guarded on outer side by four very large scales, of which the most distal is nearly or quite as large as the other three together; these scales are so-appressed in all the specimens, that the pore is completely concealed, and one can not even see whether there are any scales on the inner margin of the pore or not; the first four or five tentacle pores of the arm are protected in the same way by from four to seven big scales; farther out there are only four, three, or even two, much smaller scales, which merge into the series of spines on each side arm plate. Color (dried from alcohol), brownish-drab.

Localities.-Albatross station 4826, off Japan, lat. $37^{\circ} 25^{\prime} \mathrm{N}$.; long. $137^{\circ} 32^{\prime}$ E., 114 fathoms, fine gray sand, black specks, bottom temperature $42.5^{\circ}, 5$ specimens; station 4828 , off Japan, lat. $3723^{\prime}$ N.; long. $137^{\circ} 36^{\prime}$ E., 163 fathoms, green mud, bottom temperature $34.9^{\circ}$, 4 specimens. Bathymetrical range, 114 to 163 fathoms. Temperature range, $42.5^{\circ}$ to $34.9^{\circ}$. Nine specimens.

Type.-Cat. No. 25546, U.S.N.M., from station 4826.

This species is quite intermediate between the species of the sarsii group of Ophiura, on the one hand, and the species of the sculptilis group on the other, though it appears to be more nearly related to the latter. It is easily distinguished from previously known species by the coarse disk scales and wide, appressed comb papillæ in combination with the minute, blunt arm spines, and the big, flat tentacle scales. The smallest of the specimens before me has the disk $9 \mathrm{~mm}$. in diameter; it has, for the most part three well-spaced arm spines, and only two tentacle scales, often only one, beyond the three or four basal pores.

\section{OPHIURA HADRA, new species. $a$}

Disk $32 \mathrm{~mm}$. in diameter; arms probably about $100 \mathrm{~mm}$. long. Disk stout, flat or slightly arched, nearly $10 \mathrm{~mm}$. thick, covered by about seventy-five plates, among which only the radial shields are conspicuously large; the plate just proximal to each pair of radial shields is more or less swollen, much as in ponderosa. Radial shields longer than wide, in contact except at inner end, where they diverge. Arms stout, rounded and little compressed, about $7 \mathrm{~mm}$. wide and 5

$a^{*} A \delta \rho o s$, signifying stout, thick, in reference to its very heavy, solid appearance. 
$\mathrm{mm}$. high at base. Upper arm plates tetragonal with convex distal margin and slightly flaring sides, becoming pentagonal near middle of arm, broadly in contact throughout; basal plates much wider than long, but the length rapidly increases until the plates are much longer than wide. Interbrachial spaces below covered by oral shield and nine or ten marginal and submarginal plates. Oral shields more or less triangular, outer angles slightly rounded, lateral margins more or less strongly notched at head of genital slits. Adoral plates narrow, diverging; oral plates nearly as large, approximately parallel. Oral papillæ stout, more or less pointed, five or six on a side. Genital slits short and inconspicuous. Genital scales short and only little visible from below, but exceptionally wide and conspicuous from above. Each scale carries a marginal series of fifteen to twenty flat, truncate, appressed papillæ (see fig. 24), which at upper end of scale are less crowded, and are pointed or rounded at tip, and at lower end pass gradually into a series of small papillæ on margin of an inconspicuous, accessory, or supplementary genital scale. Basal under arm plate somewhat hexagonal, much wider than long,distal margin longer than proximal; five or six succeeding plates tetragonal, wider than long; remaining plates somewhat hexagonal, with narrow proximal end,

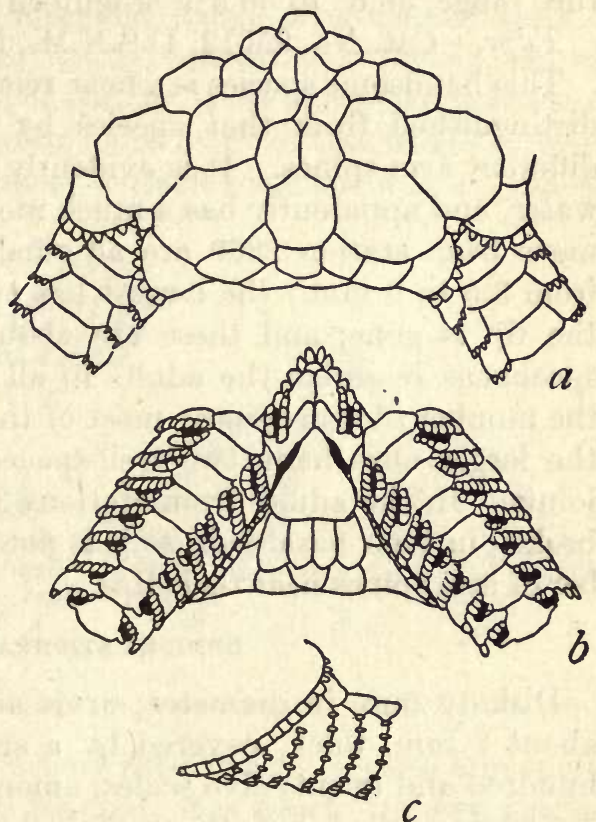

FIG. 24.-OPHIURA HADRA. X1.75. $a$, FROM ABOVE; $b$, FROM BELOW; $c$, SIDE VIEW OF BASE OF ARM.

longer than wide, gradually becoming tetragonal, or sometimes diamond shaped, and wider than long; all under arm plates in contact with each other until about eighteenth joint, after which they rapidly become widely separated. Side arm plates high but narrow, not meeting above or below on basal half of arm; each plate carries five very small, thick, blunt, well-spaced arm spines; there is no development of a secondary series as in ponderosa. Oral tentacle pores large, nearly but not quite opening into mouth slit, protected by three to six scales on the outer side and two to four on inner; outermost scale in each series very broad; tentacle pores of arm very large, the basal ones protected by eight to five scales on proximal side and five to two $34916^{\circ}-$ Bull. $75-11-6$ 
on distal; after about the seventh pore, there are no scales on distal side, though there may still be six on the proximal; on terminal part of arm there are three or two scales on the proximal side only. Color (dried from alcohol), dirty-whitish or ivory white.

Localities.-Albatross, station 2860 , off Washington, lat. $51^{\circ} 23^{\prime} \mathrm{N}$.; long. $130^{\circ} 34^{\prime} \mathrm{W}$., 876 fathoms, green mud, bottom temperature $36.5^{\circ}$, 11 specimens; station 3074 , off Washington, lat. $47^{\circ} 22^{\prime} \mathrm{N}$.; long. $125^{\circ} 48^{\prime} 30^{\prime \prime}$ W., 877 fathoms, green mud, bottom temperature $36.6^{\circ}$, 1 specimen; station 3075 , off Washington, lat. $47^{\circ} 22^{\prime} \mathrm{N}$.; long. $125^{\circ} 41^{\prime}$ W., 859 fathoms, green mud, bottom temperature $36.6^{\circ}$, 6 specimens. Bathymetrical range, 859 to 877 fathoms. Temperature range, $36.6^{\circ}$ to $36.5^{\circ}$. Eighteen specimens.

Type.-Cat. No. 25612, U.S.N.M., from station 3075 .

This handsome species is a near relative of ponderosa but is at once distinguished from that species by the rounded arms, with very different arm spines. It is evidently an inhabitant of deeper, colder water, and apparently has a much more restricted range. The specimens from station 2860 are all small, with disk diameters ranging from 3.5 to $9 \mathrm{~mm}$; t the largest has two arms nearly unbroken, only the tip is gone, and these are about $30 \mathrm{~mm}$. long. These young specimens resemble the adults in all essential particulars, except in the number of arm spines; most of them have only a single spine, but the larger ones have two well-spaced spines on most of the basal joints. In the adults from stations 3074 and 3075 , the arms are all broken in their basal half, so it is not possible to determine the number of arm spines near their tips.

\section{OPHIURA STIPHRA, new species. $a$}

Disk $16 \mathrm{~mm}$. in diameter; arms about $42 \mathrm{~mm}$. long. Disk high, about $7 \mathrm{~mm}$. thick, covered by a smooth, firm coat, of about one hundred and twenty-five scales, among which the primary plates can be distinguished but the radial shields are the most prominent. Radial shields about as wide as long, in contact near middle but separated within and widely so distally, by a single large scale. Arms high at base, distinctly compressed. Upper arm plates rather variable in shape, but tending to be more or less distinctly hexagonal, though basal ones have decidedly convex distal margins; basal ones also much wider than long but beyond middle of arm, length generally exceeds width. Interbrachial spaces below, each nearly one-half covered by oral shield, distal to which is a series of about four long plates, which occupy most of remaining space. Oral shield oval, narrower proximally. Adoral plates nearly triangular, pointed distally, but with very indistinct outlines; oral plates narrow but conspicuously swollen at proximal end, so that there is a marked eleva-

$a \sum \tau \iota \phi \rho \delta s$, signifying compact, solid, in reference to the hard, compact structure. 
tion on face of each jaw. Oral papillæ about five on a side, those at tip of jaw rather large and pointed. Genital slits inconspicuous but genital scales large and very conspicuous from above; each scale carries a closely crowded series of about thirty marginal papillæ which are flat and truncate orally but become very slender and somewhat pointed at upper end of scale. Basal under arm plates wider than long and wider without than within, each with a conspicuous swelling or keel occupying median part of plate; succeeding plates squarish or hexagonal without a keel, gradually becoming longer than wide. Side arm plates high but narrow, and not meeting above or below until far out on terminal part of arm; each plate carries two or three true arm spines and a marginal fringe of secondary spines; secondary fringe resembles arm comb, consisting at lower end of flat, truncate papillæ and above of slender, more spine-like processes; altogether there may be a dozen or more teeth in this fringe; lowest true arm spine just above outermost tentacle scale, for which it might

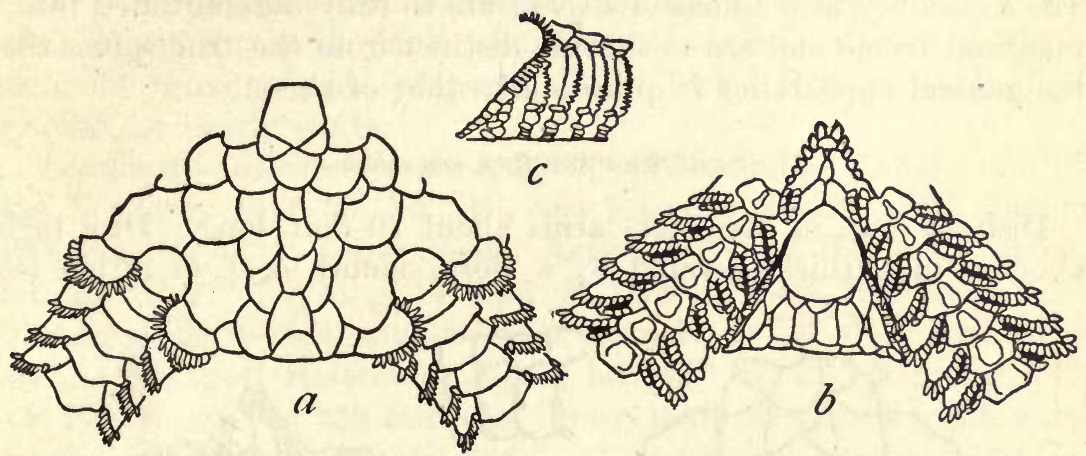

FIG. 25.-OPHIURA STIPHRA. $\times 3$. $a$, FROM ABOVE; $b$, FROM BE̊LOW; $c$, SIDE VIEW OF BASE OF ARM.

easily be mistaken as it exceeds it very little in size; second arm spine a little longer and usually quite pointed; it is nearly its own length above lowest; third spine, when present, is at extreme upper corner of side arm plate and is smallest of three. Oral tentacle pores large, not opening into mouth slit, protected by about five large flatscales on each side; basal tentacle pores of arm similar but with as many as eight scales on proximal side and only three or four on distal; beyond about eighth or ninth pore there are no scales on distal margin of pore but there are three or four on the proximal side far out on arm; outermost tentacle scale quite similar in form to lowest true arm spine. Color (dried from alcohol), fawn color, pale buff, pale gray, or whitish.

Localities.-Albatross station 3700, off Honshu Island, Japan, 63 fathoms, volcanic mud, sand, 1 specimen; station 3708, off Honshu Island, Japan, 60 to 70 fathoms, green mud, volcanic sand, ashes, 3 specimens; station 3713, off Honshu Island, Japan, 45 to 48 
fathoms, volcanic sand, shells, rocks, 6 specimens; station 3716 , off Ose Zaki, Japan, 65 to 125 fathoms, volcanic sand, shells, rocks, 5 specimens; station 4807 , Sea of Japan, lat. $41^{\circ} 36^{\prime} 12^{\prime \prime} \mathrm{N}$.; long. $140^{\circ} 36^{\prime}$ W., 44 to 47 fathoms, shells, coarse gravel, 1 specimen; station 4874 , Korea Strait, lat. $34^{\circ} 38^{\prime}$ N.; long. $130^{\circ} 3^{\prime}$ E., 66 fathoms, green sand, broken shells, 1 specimen; station 4933, off Kagoshima Gulf, lat. $30^{\circ} 59^{\prime} \mathrm{N}$.; long. $130^{\circ} 29^{\prime} 50^{\prime \prime}$ E., 152 fathoms, rocky, bottom temperature $56^{\circ}, 1$ specimen; station 4934, off Kagoshima Gulf, lat. $30^{\circ} 58^{\prime} 30^{\prime \prime}$ N.; long. $130^{\circ} 32^{\prime}$ E., 103 to 152 fathoms, rocky, bottom temperature $56^{\circ}, 4$ specimens. Bathymetrical range, 44 to 152 fathoms. Twenty-two specimens.

Type.-Cat. No. 25728, U.S.N.M., from station 4807.

This species resembles sterea so closely that viewed simply from above it can not be distinguished with certainty, although the upper arm plates are somewhat different. But a glance at the arm spines is sufficient to enable one to separate the two species without fail. The secondary arm spines of stiphra are so fully differentiated into a marginal fringe and are so sharply distinct from the true spines that the general appearance is quite unlike that of sterea.

\section{OPHIURA PENICHRA, new species.a}

Disk $24 \mathrm{~mm}$. in diameter; arms about $70 \mathrm{~mm}$. long. Disk high, about $7 \mathrm{~mm}$. thick, covered by a close, smooth coat, of rather less

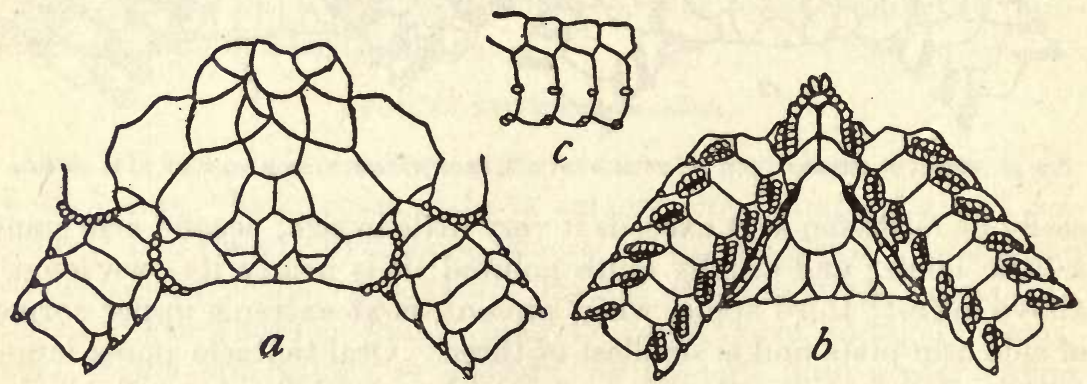

Fig. 26.-OPHIURA PENICHRA. $\times 2$. $a$, FROM ABOVE; $b$, FROM BELOW; $c$, SIDE VIEW OF THREE ARM JOINTS NEAR DISK.

than one hundred scales, among which the primary plates are not always distinguishable, but the radial shields are conspicuous. Radial shields rather longer than wide, united for about two-thirds of their length, inner ends diverging. Arms high, compressed, and faintly keeled at base. Upper arm plates tetragonal, much wider than long, gradually becoming hexagonal and ultimately, longer than wide, in contact nearly to tip of arm. Interbrachial spaces below mostly covered by oral shield and three elongated plates distal to it.

$a \prod_{\varepsilon \nu є} \chi \delta_{\varsigma}$, signifying poor, needy, in reference to the depauperate arm spines. 
Oral shields moderately large, much longer than wide. Adoral plates large, well defined, twice as long as wide; oral plates smaller, more or less parallel, with a conspicuous unpaired plate at their proximal ends. Oral papillæ few and stout, about four on a side. Genital slits small but genital scales large and conspicuous, especially when seen from above; each scale carries a marginal series of about eighteen short, thick, blunt papillæ which change little in form as they pass from lower to upper end of scale. Basal under arm plates squarish, wider than long, becoming octagonal, heptagonal, hexagonal, pentagonal, and at last rhombic; they are broadly in contact on basal half of arm but become widely separated distally. Side arm plates not very large, well separated from each other below and above, except near tip of arm; each plate carries near its middle, on distal margin, a single minute, papilla-like arm spine; there is no trace of secondary arm spines. Oral tentacle pore opens into mouth slit; it is protected by four or five flat, stout, scales on each side; basal pores on arms similar, but with no scales on distal side of pore after about the sixth joint; two tentacle scales continue to tip of arm, on proximal side of pore. Color (dried from alcohol), buff, grayish, or nearly white.

Localities.-Albatross station 5036, off Hokkaido, Japan, lat. $41^{\circ}$ $58^{\prime} \mathrm{N}$.; long. $142^{\circ} 30^{\prime} 30^{\prime \prime}$ E., 464 fathoms, brown mud, bottom temperature $37.9^{\circ}, 5$ specimens; station 5038, off Hokkaido, Japan, lat. $42^{\circ} 2^{\prime} 40^{\prime \prime} \mathrm{N}$.; long. $142^{\circ} 36^{\prime}$ E., 175 fathoms, fine black sand, broken shells, brown mud, bottom temperature $37.1^{\circ}, 5$ specimens; station 5043, off Hokkaido, Japan, lat. $42^{\circ} 10^{\prime} 20^{\prime \prime}$ N.; long. $142^{\circ}$ $15^{\prime} 20^{\prime \prime}$ E., 309 to 330 fathoms, brown mud, fine black sand, coral, sand, bottom temperature $37.9^{\circ}, 11$ specimens; station 5044 , off Hokkaido, Japan, lat. $42^{\circ} 10^{\prime} 40^{\prime \prime} \mathrm{N}$.; long. $142^{\circ} 14^{\prime}$ E., 309 to 359 fathoms, gray sand, coral, sand, bottom temperature $32.1^{\circ}, 6$ specimens. Bathymetrical range, 175 to 464 fathoms. Temperature range, $37.9^{\circ}$ to $32.1^{\circ}$. Twenty-seven specimens.

Type.-Cat. No. 25528, U.S.N.M., from station 5038.

This is another species, very similar to sterea at first sight, but easily distinguished by a glance at the arm spines. The arm comb is also very different from those of sterea and stiphra. The conspicuous unpaired plate at apex of the jaw is not characteristic as a similar plate can usually be seen in sterea, ponderosa, and the other related forms.

\section{OPHIURA ATACTA, new species.a}

Disk $6 \mathrm{~mm}$. in diameter; arms about $15 \mathrm{~mm}$. long, probably. Disk somewhat arched, covered with 150 to 175 scales, which are of very diverse sizes and show no definite arrangement. Radial shields

a $A^{\prime \prime}$ тактоs, signifying out of order, in reference to the disordered appearance of the disk scales. 
large, somewhat triangular, nearly twice as long as wide, well separated within but touching distally. Upper arm plates tetragonal (becoming triangular on distal half of arm), with distal margin convex and much longer than proximal; lateral margins somewhat concave, and distinctly longer than distal; only first six or eight, in contact. Interbrachial spaces below covered by fifteen to twenty irregular plates. Genital slits long and conspicuous, bounded by very large genital scales; each scale carries near its distal end a few blunt papillæ, which are flat, squarish, and closely in contact with each other, when seen, as an arm comb, from above. Oral shields large, about as long as broad, or longer, somewhat pentagonal. Adoral plates long and narrow, meeting within; oral plates rather large, three times as long as wide. Oral papillæ about five on a side, subequal, squarish but pointed, crowded. First under arm plate large, hexagonal, much wider than long; succeeding plates triangular

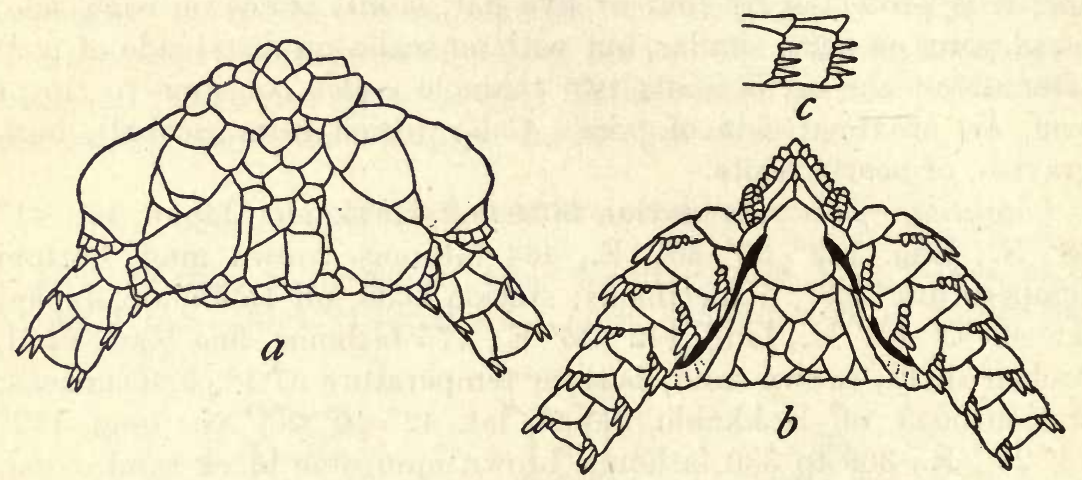

FIG. 27. -OPHIURA ATACTA. $\times 8$. $a$, FROM ABOVE; $b$, FROM BELOW; $c$, SIDE VIEW OF TWO ARM JOINTS NEAR DISK.

or pentagonal, wider than long, only first two, or none, in contact. Side arm plates large, broadly in contact below and above, except at very base of arm; each plate carries three short, subequal, bluntly pointed arm spines, about half as long as joint. Oral tentacle pores open into mouth slit; each pore with five or six scales on either side; next two or three pores with three or two scales on side arm plate, proximally; remaining pores with a single small scale. Color (dried from alcohol), nearly white.

Locality.-Albatross station 3338, off Aleutian Islands, lat. $54^{\circ}$ $19^{\prime} \mathrm{N}$, long.; $159^{\circ} 40^{\prime} \mathrm{W}$., 625 fathoms, green mud, sand, bottom temperature $37.3^{\circ}, 1$ specimen.

Type.-Cat. No. 25533, U.S.N.M., from station 3338.

In several particulars this specimen resembles monostœcha, but it can not be referred to that species, the radial shields and upper arm plates are so different, aside from other minor points. The peculiarly 
irregular arrangement of the disk scales may not be a species character, for such a condition is occasionally found as an individual variation in species which normally have the disk scales very regularly disposed.

\section{OPHIURA BRACHYACTIS, new species. $a$}

Disk $17 \mathrm{~mm}$. in diameter; arms about $35 \mathrm{~mm}$. long. Disk high, $6 \mathrm{~mm}$. thick, covered by a smooth, firm coat of some seventy-five scales; central primary plate very small (peculiarly elongated in the type, but pentagonal in the other specimen), surrounded by the five very large radials, which look as though they overlapped each other clockwise (probably they do not really overlap at all). Radial shields
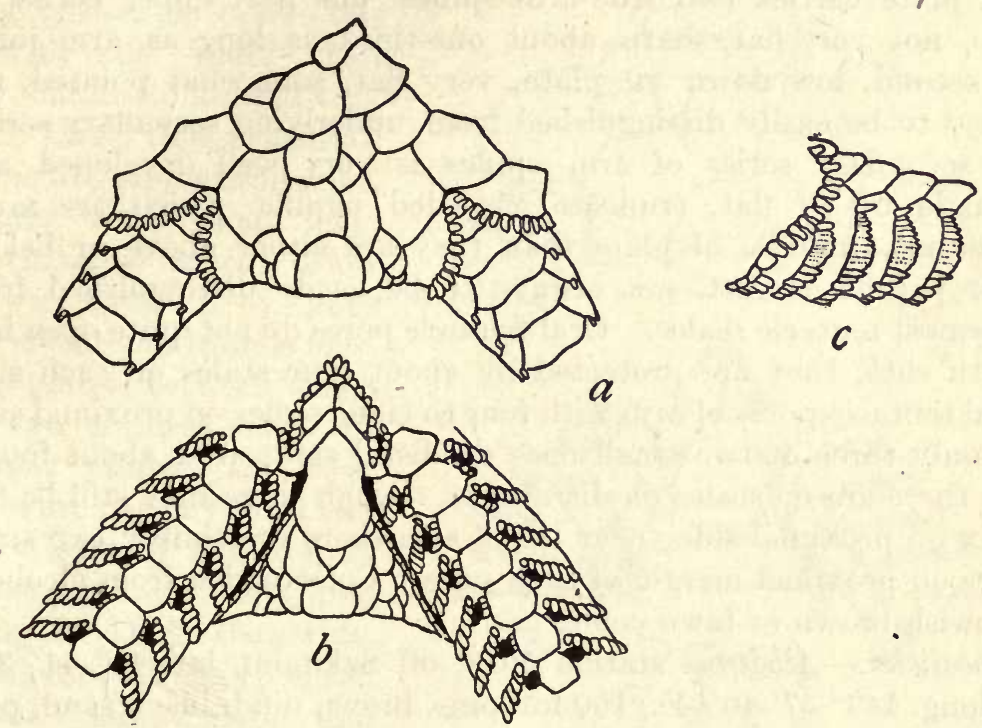

FIG. 28.-OPHIURA BRACHYACTIS. $\times$ 3. $a$, FROM ABOVE; $b$, FROM BELOW; $c$, SIDE VIEW OF BASE OF ARM

very large, closely joined, a trifle longer than wide; outer ends slightly diverging and inner ends more or less separated by a single scale. Arms high and compressed at base, but not really keeled. Upper arm plates more or less hexagonal, becoming tetragonal; basal ones much wider than long, distal ones somewhat longer than wide, in contact throughout. Interbrachial spaces below covered by oral shields and about a dozen scales. Oral shields very much longer than wide, rounded distally, pointed at inner end. Adoral plates small and narrow, about three times as long as wide; oral plates wider but not so long; an unpaired plate at tip of jaw. Oral papillæ small, four or five on a side, besides a terminal infradental papilla.

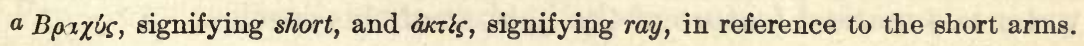


Genital slits long, but not conspicuous; genital scales short, but very wide distally with a well-marked supplementary scale at proximal end; each genital scale (with its supplementary scale) carries a marginal series of about twenty-two papillæ, which are flat, truncate, and crowded below, but become longer, more spine-like, and better spaced above. First under arm plate somewhat triangular or tetragonal, with distal margin much longer than proximal; succeeding four or five plates squarish, wider than long; remaining plates tetragonal, longer than wide, becoming ultimately very minute and triangular; all under arm plates are in contact until near tip of arm. Side arm plates not very large, well separated both above and below; each plate carries two true arm spines; one near upper corner of plate, not very flat, sharp, about one-third as long as arm joint; the second, low down on plate, very flat, somewhat pointed, not always to be easily distinguished from underlying secondary series; this secondary series of arm spines is very well developed and is made up of flat, truncate, crowded papillæ which are much longer near middle of plate than they are either above or below; lower papillæ largest, not always to be easily distinguished from outermost tentacle scales. Oral tentacle pores do not quite open into mouth slits; they are protected by about four scales on each side. Basal tentacle pores of arm with four to eight scales on proximal side, but only three or two small ones on distal side; after about fourth pore there are no scales on distal side, though there may still be five or six on proximal side; near tip of arm there are simply two small scales on proximal margin of each pore. Color.(dried from alcohol), yellowish-brown or fawn color.

Localities.-Albatross station 5018, off Sakhalin, lat. $46^{\circ} 41^{\prime} 30^{\prime \prime}$ $\mathrm{N}$.; long. $143^{\circ} 57^{\prime} 40^{\prime \prime} \mathrm{E}$., 100 fathoms, brown mud, black sand, pebbles, bottom temperature $30.4^{\circ}, 1$ specimen; station 5023, off Saghalin, lat. $48^{\circ} 43^{\prime} 30^{\prime \prime} \mathrm{N}$.; long. $145^{\circ} 3^{\prime}$ E., 75 fathoms, sand, pebbles, bottom temperature $30.9^{\circ}, 1$ specimen. Bathymetrical range, 75 to 100 fathoms. Temperature range, $30.9^{\circ}$ to $30.4^{\circ}$.

Type.-Cat. No. 25548, U.S.N.M., from station 5023.

This is still another species of the sterea group, easily distinguished by the secondary arm spines. It is somewhat doubtful whether the peculiar arrangement of the disk scales shown by these two specimens will really prove sufficiently constant to afford a specific character; if it should prove constant, it would be very useful as an easy means of recognition, even apart from the secondary arm spines, for I know of no other species in which the centrodorsal is so small in proportion to the radial plates. The extremely low temperature of the water is a marked feature of the habitat of this species. 
Disk $15 \mathrm{~mm}$. in diameter; arms about $45 \mathrm{~mm}$. long. Disk convex, but only moderately high at margin, covered by about forty plates, each of which is more or less convex, the six primary plates most so. Radial shields longer than wide, joined for about half their length, but well separated proximally by a large diamond-shaped plate. Arms rather wide at base, somewhat depressed, very flat orally, and becoming flat dorsally near tip. Upper arm plates convex or somewhat swollen, only first six or seven in contact; first two plates rounded tetragonal, very much wider than long; next three or four plates also tetragonal, and wider than long, but distal margin very much longer than proximal; succeeding plates triangular, slightly wider than long. Interbrachial spaces below narrow, covered by huge oral shields, and single marginal plates, between which are two or three small triangular plates; all these plates are notably thick and heavy, even if not exactly convex. Oral shields long triangular, longer than wide, rounded distally and pointed within. Adoral plates and oral plates distinct, moderate, slightly convex. Oral papillæ three or four on a

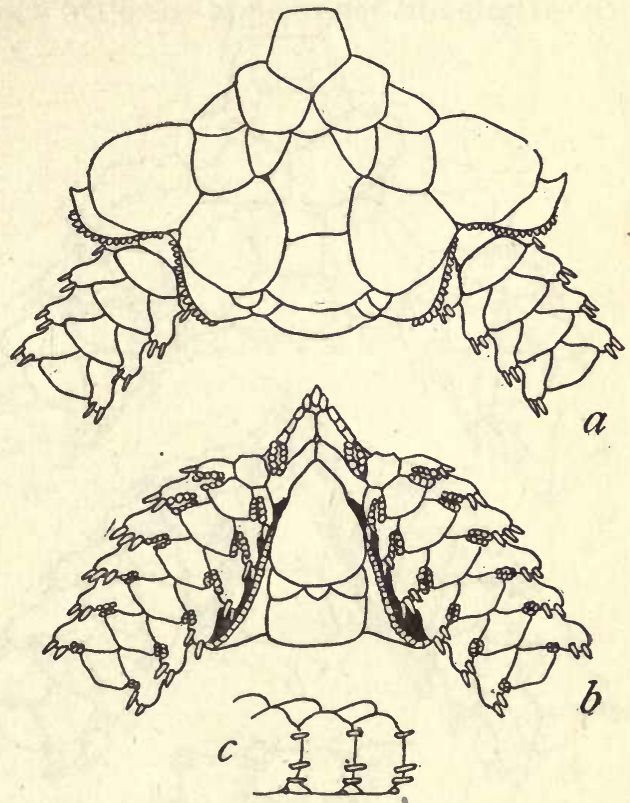

FIG. 29.-OPHIURA POMPHOPHORA, ADULT. $\times 3.5 \quad a$, FROM ABOVE; $b$, FROM BELOW; $c$, SIDE VIEW OF THREE ARM JOINTS NEAR DISK.

side, outer ones very wide and truncate; an infradental papilla present at apex of jaw. Genital slits long and conspicuous; each genital scale with about twenty-five marginal papillæ, which are truncate and crowded orally, but become rounded at tip or bluntly pointed at upper end of genital scales; arm comb thus formed, directly continued by a series of four or five small papillæ on outer end of radial shields; the two series on opposite sides do not quite meet, however, across base of arm. First under arm plate octagonal, about as long as wide; second, larger, more tetragonal

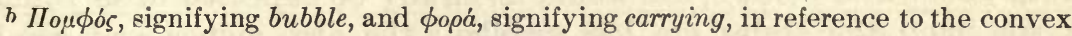
disk plates. 
with outer margin convex; third, still larger, oblong, wider than long: succeeding plates heptagonal, but quickly becoming pentagonal, in contact up to eighth or ninth joint, after which they become small and widely separated. Side arm plates large and somewhat swollen, but not in contact either below or above on basal part of arm; each plate carries three cylindrical spines, about one-third as long as plate (or nearly one-half), and situated well back from margin; two lower spines near together, while uppermost is near upper margin of plate. Oral tentacle pores scarcely opening into mouth slit, protected by five scales on each side; tentacle pores of arm protected by scales as

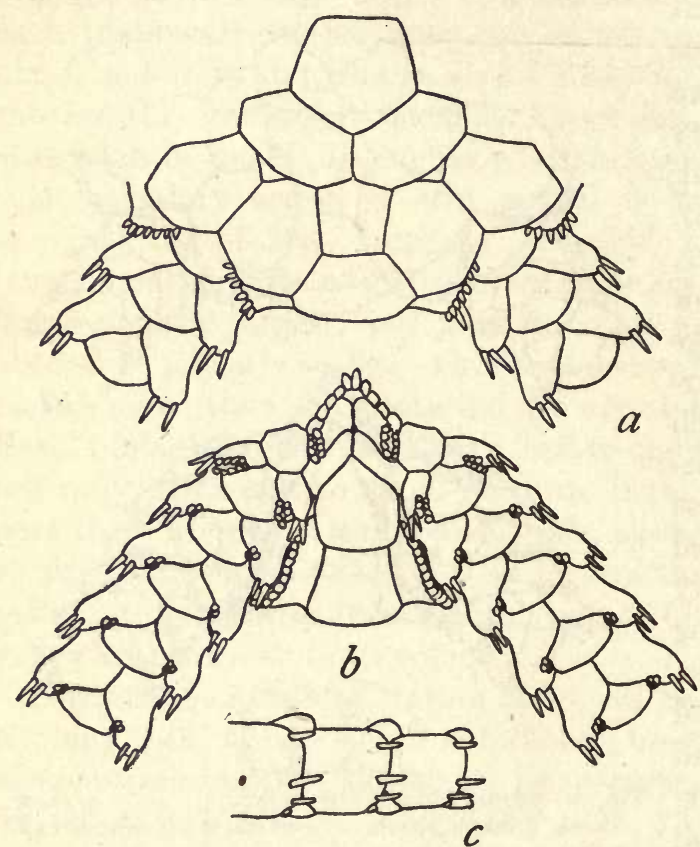

FIG. 30.-OPHIURA POMPHOPHORA, YOUNG. $\times 10$. $a$, FROM ABOVE; $b$, FROM BELOW; $c$, SIDE VIEW OF THREE $\triangle$ RM JOINTS NEAR DISK.

bottom temperature $50.2^{\circ}, 1$ young specimen.

follows, the number on proximal side of pore being given first: $4-5$, $4-4,4-3,4-2,3-2$, and $2-1$; of course the number on any particular pore varies somewhat on different arms, but at least one distal scale seems to continue even to very tip of arm. Color (dried from alcohol), ivory-white.

Localities.-Albatross station 3749 , off Suno Saki, Japan, 83 to 158 fathoms, black sand, shells, 1 specimen; station 4892, Eastern Sea, lat. $32^{\circ} 27^{\prime} 30^{\prime \prime} \mathrm{N}$.; long. $128^{\circ} 33^{\prime}$ E., 181 fathoms, gray sand, broken shells, rocks,

Bathymetrical range, 83 to 181 fathoms.

Type.-Cat. No. 25604, U.S.N.M., from station 3749.

The specimen from station 4892 is only $4 \mathrm{~mm}$. across the disk, and both disk and arms are very flat. I at first supposed it to represent a different species, but I am at last convinced it is simply the young of pomphophora. The figures given herewith (figs. 29 and 30) bring out better than words can the differences in the scaling of disk and arms, both above and below. As would naturally be expected in so young a specimen, the scales are less swollen; the arm spines and comb papillæ are more pointed and the tentacle scales are much less numerous. The species appears to be very well characterized, for while it 
resembles 0 . undata Lyman in some particulars, a single glance at the interbrachial areas and oral shields is sufficient to distinguish the two species. From $O$. solida Lyman, the arm plates alone are enough to separate pomphophora.

\section{OPHIURA GLYPTODISCA, new species.a}

Disk nearly $6 \mathrm{~mm}$. in diameter; arms $21 \mathrm{~mm}$. long. Disk thick, flat, covered by six primary plates, radial shields and two plates in each interradius, but each of these plates is surrounded by smaller ones, and the small plates seem to be raised above the large ones, so that the surface of the disk has a little the appearance of being sculptured. Radial shields large, longer than wide, closely joined. Arms nearly cylindrical near base and tapering to a very slender tip. Upper arm plates swollen, only first two in contact; they are more or less triangular with outer corners rounded, diminish rapidly in size, and are entirely wanting after about the twelfth joint. Interbrachial spaces below covered by huge oral shields and single marginal plates; at outer corners of oral shields, there may be one or two small plates. Fig. 31.-OPHIURA GLYPTODISCA. $\times 8$. $a$, FROM ABOVE; $b$, FROM Oral shields rounded

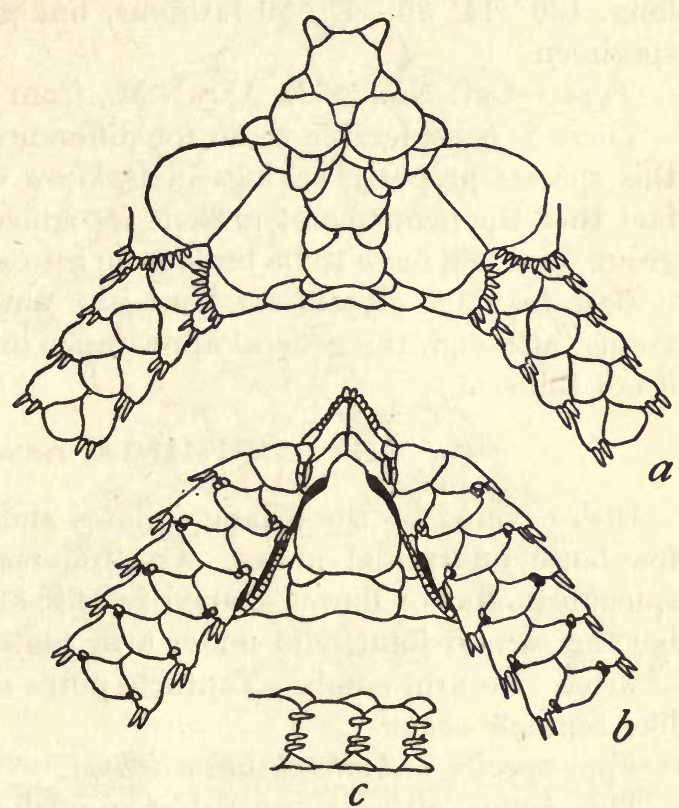
BELOW; $c$, SIDE VIEW OF THREE ARM JOINTS NEAR DISK. without, abruptly narrowed within, about as wide as long. Adoral and oral plates well defined, the latter decidedly the larger. Oral papillæ seven or eight on a side, closely soldered, outermost much the widest. Genital slits long; genital scales large, each one with a marginal series of minute papillæ which become sufficiently elongated dorsally to make a conspicuous arm comb of stout, pointed teeth. First under arm plate triangular, with rounded corners about as long as wide; succeeding plates well separated from each other, pentagonal quickly becoming tetragonal, with more or less

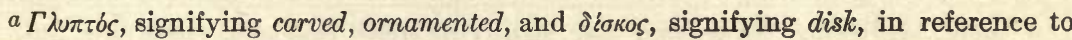
the prettily ornamented appearance of the disk. 
rounded angles, much wider than long. Side arm plates very large, somewhat swollen, meeting above and below; each plate carries three arm spines, not half as long as joint, the uppermost of which is farther from the other two than they are from each other. Oral tentacle pores small, opening at some distance distal to the mouth slit, and guarded by one to three scales on each side; usually there are two scales on one side and one on the other; first two tentacle pores of arm with two minute scales, but succeeding pores have only a single scale; there are neither scales nor pores at tip of arm. Color (dried from alcohol), pale gray; arms nearly white.

Locality.-Albatross station 4878 , Korea Strait, lat. $34^{\circ} 18^{\prime} 30^{\prime \prime}$ N.; long. $130^{\circ} 14^{\prime} 30^{\prime \prime}$ E., 59 fathoms, fine gray sand, broken shells, 1 specimen.

Type.-Cat. No. 25539, U.S.N.M., from station 4878.

There is considerable room for difference of opinion as to whether this species properly belongs in Ophiura or not, but in view of the fact that the genus as at present recognized is a very heterogeneous group, and will have to be broken up into a number of genera, I think it best to place glyptodisca here just now. The specimen may be young, although the general appearance indicates full maturity, even if not full size.

\section{ANTHOPHIURA, new genus. $a$}

Disk corered by the primary plates and radial shields with a very few large interradial plates. Centrodorsal plate elevated and conspicuously star or flower shaped (see fig. 32a). No upper arm plates beyond second joint, and under arm plates confined to basal joints of arm. No arm comb. Tentacle pores of arm with a single spinelike tentacle scale.

Type-species.-Anthophiura axiologa.

This genus, although probably an offshoot from Ophiura, does not seem to be very nearly related to any other genus. While it resembles Ophiopyrgus in some particulars, it differs in the absence of an arm comb and in the shape of the centrodorsal plate, and moreover the differences in tentacle scales, as well as in the form of the disk and of the arms, are so great, the two can not be confused. There is also a certain suggestion of Ophiomastus in this new genus, but Ophiomastus has upper and under arm plates on the terminal part of the arms and the tentacle scales are utterly different, to say nothing of the centrodorsal plate. From Ophiomusium, Anthophiura is readily distinguished by the large tentacle pores and peculiar tentacle scales.

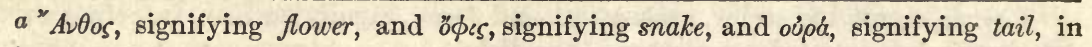
reference to the flower-like appearance of the centrodorsal plate, and in keeping with the name of the largest genus (and the class) of brittle-stars. 
ANTHOPHIURA AXIOLOGA, new species.a

Disk $5 \mathrm{~mm}$. in diameter; arms $12 \mathrm{~mm}$. long. Disk rather high, its vertical diameter at center being nearly $2 \mathrm{~mm}$.; it is covered by twenty-six plates, of which six are primary plates, ten are radial shields, and ten are interradial plates, arranged in pairs, one plate in each pair being marginal and one lying against two radial plates; centrodorsal plate very high and very distinctly star-shaped. Radial shields, longer than wide, closely joined, somewhat depressed below the other disk plates. Arms cylindrical and slender, gradually tapering to tip. First upper arm plate rather large, swollen, just beneath outer ends of radial shields; second plate much smaller or wanting; no upper arm plates beyond second joint. Interbrachial spaces below covered by oral shield, a supplementary plate, the marginal plate so conspicuous from above, and very wide genital plates. The last carry no marginal papillæ and hence there is no trace of an arm comb. Oral shields somewhat triangular, with outer corners rounded, nearly as wide as long. Adoral and oral plates moderately large, about of a size. Oral

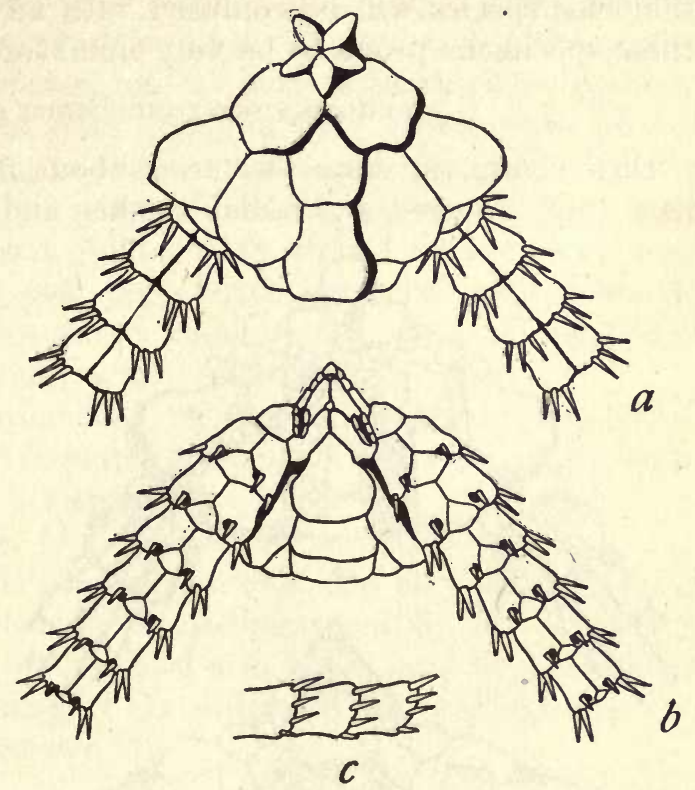

Fig. 32.-ANthophiura axiologa. $\times 10$. $a$, From Above; $b$, FROM BELOW; $c$, SIDE VIEW OF THREE ARM JOINTS NEAR DISK. papillæ small, close-set, about three on a side, of which outermost is as wide as other two together. Basal under arm plates moderately large, more or less pentagonal; first longer than wide, but others wider than long; beyond the disk the plates are much smaller and triangular, and after about the sixth joint are entirely wanting. Side arm plates very large, meeting broadly above and below; beyond the sixth joint they cover the entire surface of the arm; each plate carries three sharp, rather thick arm spines, of which the uppermost is longest and approximately equals half an arm joint. Oral tentacle pore with two or three scales on each side much as in Ophiura; it does not open into the mouth slit. Tentacle 
pores of arm large, round, with a single, big, spinelike tentacle scale on proximal side. Color (dried from alcohol), pale gray.

Locality.-Albatross station 4765 , Aleutian Islands, lat. $53^{\circ} 12^{\prime} \mathrm{N}$.; long. $171^{\circ} 37^{\prime} \mathrm{W}$., 1,217 fathoms, fine black sand, bottom temperature $35.2^{\circ}, 8$ specimens.

Type-Cat. No. 25534, U.S.N.M., from station 4765.

The smallest specimen has the disk only about $3 \mathrm{~mm}$. in diameter but in practically all of its characters it agrees with the others, except that there seems to be a well-developed second upper arm plate, which is not present in the type specimen. There is no danger that this species will be confused with any other ophiuran, even if these specimens prove to be very immature.

OPHIOTROCHUS LONGISPINUS, new species. $a$

Disk $6 \mathrm{~mm}$. in diameter; arms about $30 \mathrm{~mm}$. long. Disk very flat, thin, covered by radial shields and about twenty-six large

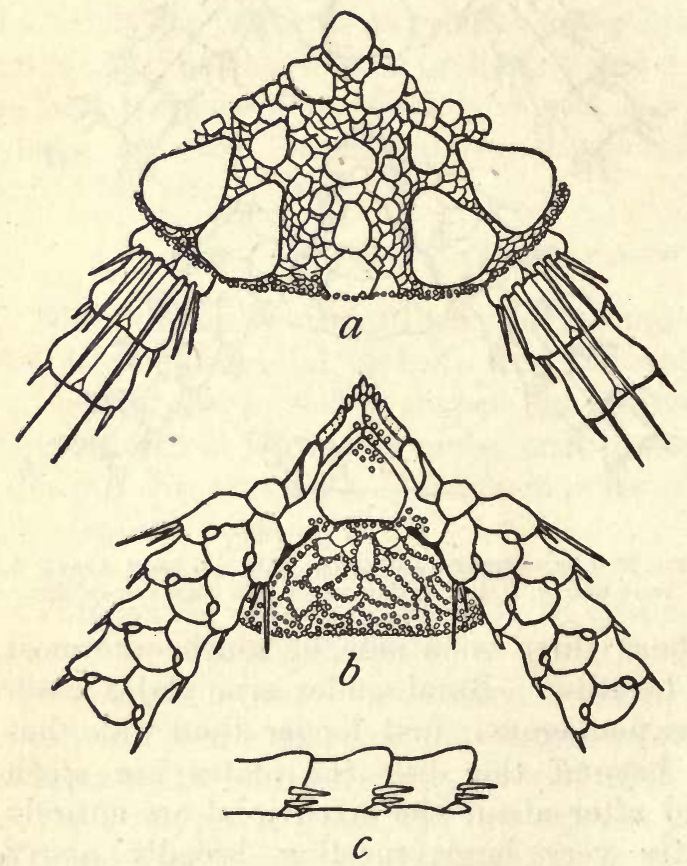

Fig. 33.-OphiotrochUS loNgispinUS. $\times 8$. $a$, FROM ABOVE; $b$, FROM BELOW; $c$, SIDE VIEW OF THREE ARM JOINTS NEAR DISK: plates (six primaries, five other radials, and three plates in each interradius) regularly arranged and surrounded by numerous much smaller scales; along margin of disk are numerous small granules. Radialshields longer than broad, rounded at both ends, separated by a narrow line of scales or barely in contact. Upper arm plates triangular, or tetragonal with outer end rounded, very minute but apparently present to very tip of arm. Interbrachial spaces below covered with scales, which are more or less concealed, especially near margin, by coarse granules. Oral shields not very large, triangular, with outer corners more or less rounded. Adoral plates very long,

a Longus, signifying long, and spinus, signifying spine, in reference to the very long arm spines of the first joint. 
narrow within but much expanded distally; oral plates long and narrow. Oral papillæ small, those along side of jaw more or less completely fused into a low but very wide plate; at apex of jaw are four or five longer and more pointed papillæ. On adoral plates and tip of oral shield are a number of granules like those on interbrachial spaces. Genital slits short and genital scales inconspicuous, with no trace of an arm comb. First under arm plate pentagonal, as long as wide; second plate pentagonal, longer than wide; third plate similar but much wider distally than it is long, and with convex distal margin; succeeding plates similar but continually becoming smaller and yet relatively wider. Side arm plates very large, meeting broadly above and below, much swollen distally; each plate carries two short, pointed arm spines, half as long as joint, close together, low down on arm; second joint (the first one visible from above) bears in addition two much longer spines on upper part of plate; uppermost spine, which lies near midline of upper surface of arm, is nearly equal to three arm joints, while second little exceeds one. Oral tentacle pore with one very large, long oral scale; tentacle pores of arm, each with a single small round scale. Color (dried from alcohol), disk, grayish; arms, yellowish.

Locality.-Albatross station 5084, off Sagami Bay, Japan, lat. $34^{\circ} \mathrm{N}$.; long. $137^{\circ} 49^{\prime} 40^{\prime \prime}$ W., 918 fathoms, green mud, fine sand, globigerina, bottom temperature $36.8^{\circ}, 1$ specimen.

Type.-Cat. No. 25538, U.S.N.M., from station 5084.

Although this species is near panniculus, the only species of the genus hitherto known, it may be distinguished by the very long spines on the upper side of the basal arm joints, and by the coarser and more ornamental scaling of the disk; the radial shields are also very much longer and narrower.

\section{OPHIERNUS ADSPERSUS.}

Ophiernus adspersus Lyman, Bull. Mus. Comp. Zoöl., vol. 10, 1883, p. 236.

Ophiernus annectens Lütren and Mortensen, Mem. Mus. Comp. Zoöl., vol. 23, 1899, p. 107.

Localities.-Albatross station 4919, Fastern Sea, lat. $30^{\circ} 34^{\prime} \mathrm{N}$.; long. $129^{\circ} 19^{\prime} 30^{\prime \prime}$ E., 440 fathoms, globigerina ooze, bottom temperature $31.8^{\circ}, 1$ specimen; station 4928 , Colnett Strait, lat. $29^{\circ} 51^{\prime} \mathrm{N}$.; long. $131^{\circ} 2^{\prime} 30^{\prime \prime}$ E., 1,008 fathoms, gray sand, globigerina, bottom temperature $36.8^{\circ}, 1$ specimen; station 4960 , off southern Japan, lat. $32^{\circ} 34^{\prime} \mathrm{N}$.; long. $132^{\circ} 21^{\prime} 45^{\prime \prime} \mathrm{E}$., 578 fathoms, green-brown mud, fine gray sand, foraminifera, bottom temperature $38.7^{\circ}, 2$ specimens; station 4966 , off Japan, lat. $33^{\circ} 25^{\prime} 20^{\prime \prime}$ N.; long. $135^{\circ} 36^{\prime} 20^{\prime \prime}$ E., 244 to 290 fathoms, brown mud, sand, foraminifera, bottom tempera- 
ture $44.1^{\circ}, 2$ specimens. Bathymetrical range, 244 to 1,008 fathoms. Temperature range, $44.1^{\circ}$ to $31.8^{\circ}$. Six specimens.

The most careful comparison of these specimens with a large series from the West Indies, among which is the type of adspersus, has failed to bring to light any character by which they can be distinguished. I have also examined carefully three cotypes of annectens and I do not find that the characters, by which the distinguished Danish zoologists suggested that that species might be recognized, are in any degree reliable. I have therefore placed the name as a synonym of adspersus, a conclusion which Lütken and Mortensen themselves predicted might prove to be correct. We have in adspersus then, an intertropical, if not a cosmopolitan species, for it has been taken in the West Indian region by the Blake, in the eastern Atlantic by the

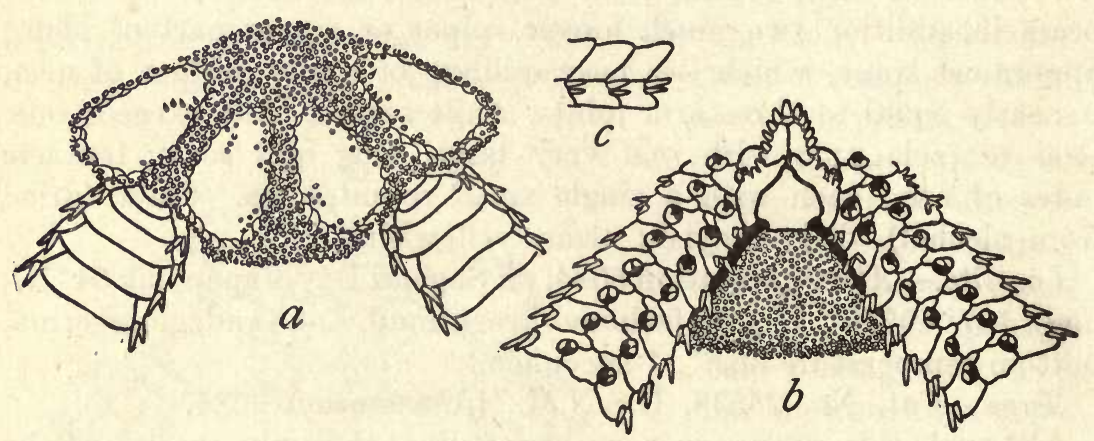

FiG. 34.-OPHIERNUS ADSPERSUS. $\times$ 3.33. $a$, FROM ABOVE; $b$, FROM BELOW; $c$, SIDE VIEW OF THREE ARM JOINTS NEAR DISK.

Talisman, in the Indian Ocean by the Investigator, in the East Indian region by the Siboga, in the Galapagian region by the Fisheries steamer Albatross, and finally off southern Japan by the Albatross.

\section{OPHOCTEN PACIFICUM.}

Ophiocten pacificum Lütken and Mortensen, Mem. Mus. Comp. Zoöl., vol. 23, 1899 , p. 131.

Localities.-Albatross station 2860 , off Washington, lat. $51^{\circ} 23^{\prime} \mathrm{N}$.; long. $130^{\circ} 34^{\prime} \mathrm{W}$., 876 fathoms, green mud, bottom temperature $36.5^{\circ}$, 1 specimen; station 3075 , off Washington, lat. $47^{\circ} 22^{\prime} \mathrm{N}$.; long. $125^{\circ} 41^{\prime}$ W., 859 fathoms, green mud, bottom temperature $36.6^{\circ}, 2$ specimens; station 3346 , off Washington, lat. $45^{\circ} 30^{\prime} \mathrm{N}$. ; long. $124^{\circ} 52^{\prime}$ W., 786 fathoms, green mud, bottom temperature $37.3^{\circ}, 1$ specimen; station 3696, off Honshu Island, Japan, 501 to 749 fathoms, green mud, volcanic ashes, sand, 52 specimens; station 5082, off Suruga Gulf, Japan, lat. $34^{\circ} 5^{\prime}$ N.; long. $137^{\circ} 59^{\prime}$ E., 662 fathoms, green mud, fine sand, globigerina, bottom temperature $37.7^{\circ}, 3$ specimens; station 5083, off Suruga Gulf, Japan, lat. $34^{\circ} 4^{\prime} 20^{\prime \prime}$ N.; long. $137^{\circ} 57^{\prime} 30^{\prime \prime}$ E., 624 fathoms, fine gray sand, globigerina, bottom temperature $38.1^{\circ}$, 
1 specimen; station 5085, Sagami Bay, Japan, lat. $35^{\circ} 6^{\prime} 45^{\prime \prime} \mathrm{N}$.; long. $139^{\circ} 19^{\prime} 45^{\prime \prime}$ E., 622 fathoms, green mud, fine black sand, bottom temperature $37.8^{\circ}, 3$ specimens. Bathymetrical range, 501 to 876 fathoms. Temperature range, $38.1^{\circ}$ to $36.5^{\circ}$. Sixty-three specimens.

These specimens have been compared with specimens from the Panamic region identified by Lütken and Mortensen, and there seems to be no reason to doubt their identity. The largest specimen is 14 $\mathrm{mm}$. across the disk, the smallest only $6 \mathrm{~mm}$.

\section{OPHIOCTEN CHARISCHEMA, new species.a}

Disk $11 \mathrm{~mm}$. in diameter; arms about $70 \mathrm{~mm}$. long. Disk very flat, thin, deeply notched at the base of the arms (radius, $5 \mathrm{~mm}$. long, interradius $6 \mathrm{~mm}$.), covered with a coat of fine, unequal scales which are normally completely concealed by a very dense covering of minute

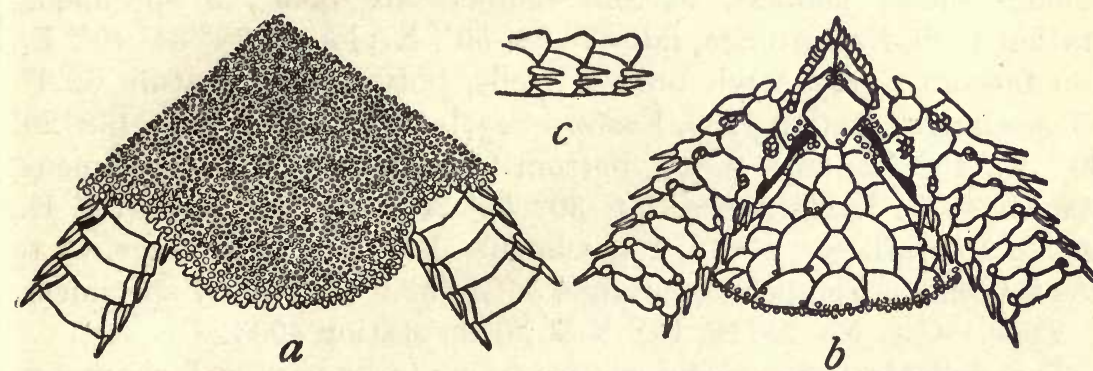

FIG. 35.-OPHIOCTEN CHARISCHEMA. $\times 5$. $a$, FROM ABOVE; $b$, FROM BELOW; $c$, SIDE VIEW OF THREE ARM JOINTS NEAR DISSK.

granules, several hundred to a square millimeter. Radial shields also completely hidden. Upper arm plates tetragonal, distal margin convex, lateral margins divergent; basal plates much wider than long but becoming longer than wide on terminal half of arm; all are broadly in contact. There is no trace of an arm comb. Interbrachial spaces below covered by a coat of about thirty scales, among which a few minute granules are scattered. Oral shields quite variable in shape, but commonly longer than wide; usually they are pentagonal, with somewhat rounded angles, and the sides nearly equal, but sometimes (as in fig. 35b) the distal side is very short. Adoral and oral plates not peculiar, save for bearing a few scattered granules. Oral papillæ numerous, about seven on a side. Genital slits and scales short, without marginal papillæ. First under arm plate somewhat octagonal, about as long as wide; second plate more hexagonal, distal margin longer than proximal; third and fourth plates more tetragonal, but

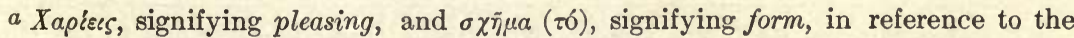
very graceful appearance.

$34916^{\circ}-$ Bull. $75-11 \longrightarrow 7$ 
with a short proximal margin; succeeding plates very much wider than long and well separated from each other. Side arm plates rather small, widely separated above, but more or less broadly in contact below, outside of disk; each plate carries two short, sharp, subequal spines, a little longer than half a joint, placed close together, well up on plate, but low down on arm. Oral tentacle pore opening into mouth slit, protected by a very large scale on inner side, and one or two smaller ones on outer side; latter directly continuous with oral papillæ; first pore of arm with two or three scales on each side; second with about two scales; succeeding pores each with a single, small, round scale. Color (dried from alcohol), dull yellowish, pale gray, or nearly white.

Localities.-Albatross station 3720, off Honshu Island, Japan, 63 fathoms, volcanic sand, shells, 1 specimen; station 4893, Eastern Sea, lat. $32^{\circ} 32^{\prime} \mathrm{N}$.; long. $128^{\circ} 32^{\prime} 50^{\prime \prime}$ E., 95 to 106 fathoms, gray sand, broken shells, pebbles, bottom temperature $55.9^{\circ}, 3$ specimens; station 4900 , Eastern Sea, lat. $32^{\circ} 28^{\prime} 50^{\prime \prime}$ N.; long. $128^{\circ} 34^{\prime} 40^{\prime \prime}$ E., 139 fathoms, gray sand, broken shells, bottom temperature $52.9^{\circ}$, 10 specimens; station 4933 , Eastern Sea, lat. $30^{\circ} 59^{\prime}$ N.; long. $130^{\circ} 29^{\prime}$ $50^{\prime \prime}$ E., 152 fathoms, rocky, bottom temperature $56^{\circ}, 5$ specimens; station 4934, Eastern Sea, lat. $30^{\circ} 58^{\prime} 30^{\prime \prime}$ N.; long. $130^{\circ} 32^{\prime}$ E., 103 to 152 fathoms, rocky, 1 specimen. Bathymetrical range, 63 to 152 fathoms. Temperature range, $56^{\circ}$ to $52.9^{\circ}$. Twenty specimens.

Type.-Cat. No. 25718, U.S.N.M., from station 4933.

This delicate and graceful species seems to be very well characterized, for while it resembles $O$. depressum in many particulars, the oral surface is different, the under arm plates alone being quite sufficient to distinguish the two forms.

\section{OPHIOCTEN BREVISPINUM, new species. $a$}

Disk $9 \mathrm{~mm}$. in diameter; arms about $70 \mathrm{~mm}$. long. Disk very thin and flat, notched at base of each arm, interradii being distinctly longer than radii; it is covered by a coat of scales among which primary plates, some large interradial scales and radial shields are prominent; larger scales and many smaller ones surrounded by belts of minute granules, giving disk a highly ornamental appearance. Radial shields somewhat triangular with rounded corners, longer than wide, nearly in contact distally. Upper arm plates tetragonal, lateral margins somewhat divergent, wider than long at base of arm, but soon becoming longer than wide, broadly in contact, remarkably elevated or swollen at middle of distal margin, more so than in any other species of Ophiocten yet known. Interbrachial spaces below covered

a Brevis, signifying short, and spinus, signifying a spine, in reference to the short arm spines. 
by about twenty-two large scales, with numerous granules along margin and near genital slits. Oral shields small, pentagonal, usually wider than long. Adoral and oral plates rather large, each with a few granules. Oral papillæ about five on a side, outer ones truncate, inner ones pointed. Genital slits short; genital scales rather large, but without marginal papillæ; no trace of an arm comb. First two under arm plates longer than wide; next three about as long as wide; succeeding plates wider than long; plates not in contact beyond disk; first plate hexagonal, succeeding plates tetragonal, becoming triangular, with outer corners rounded. Side arm plates rather small, not meeting above, but meeting below beyond disk; each plate carries two short, thick, pointed spines less than half as long as joint, placed close together, high up on plate but low down on arm. Oral tentacle pore concealed by a huge lid-like scale on its outer side; first arm pore with one low, wide scale or two smaller scales on each side; second

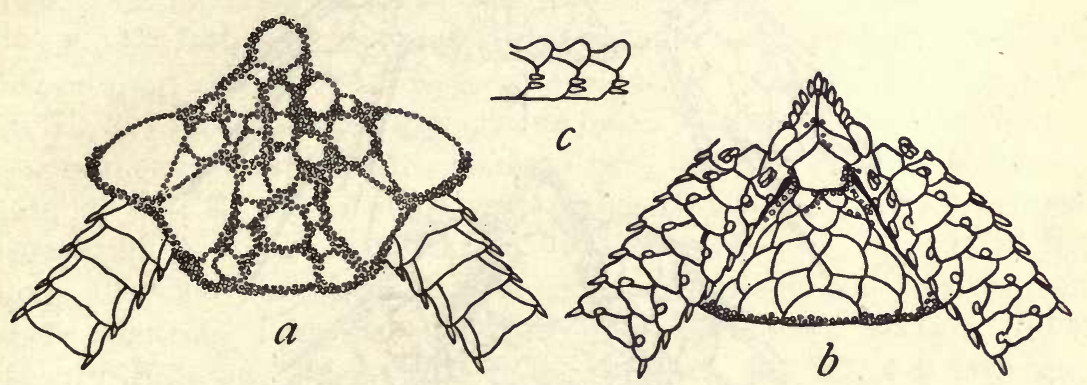

Fig. 36.-OPHOCTEN BREVISPINUM. $\times 5.5$. $a$, FROM ABOVE; $b$, FROM BELOW; $c$, SIDE VIEW OF THREE ARM JOINTS NEAR DISK.

pore with two small scales; succeeding pores with only a single small, round scale. Color (dried from alcohol), pale gray.

Localities.-Albatross station 4917, Eastern Sea, lat. $30^{\circ} 24^{\prime} \mathrm{N}$.; long. $129^{\circ} 6^{\prime}$ E., 361 fathoms, gray sand, globigerina, broken shells, 2 specimens.

Type.-Cat. No. 25617, U.S.N.M., from station 4917.

Although the general appearance of this species is similar to that of charischema, the granulation of the disk is entirely different in the two species, and the huge oral tentacle scales, the short arm spines, and the decidedly "humped" upper arm plates make brevispinum very easy to recognize.

\section{OPHIOCTEN OÖPLAX, new species. $a$}

Disk $10 \mathrm{~mm}$. in diameter; arms about $65 \mathrm{~mm}$. long. Disk flat, nearly circular, covered by several hundred overlapping scales, smallest near center of disk, largest between radial shields. Radial shields

$a^{\prime} \varrho o^{\prime} \nu$ signifying $e g g$, and $\pi \lambda \alpha^{\xi} \xi$, signifying plate, in reference to the oval upper arm plates. 
curved, triangular, twice as long as wide, with distal end rounded, separated proximally by a large group of scales and distally by basal upper arm plates. First three upper arm plates very short, much wider than long, crowded between distal ends of radial shields; fourth plate longer and narrower, with a very convex distal margin; succeeding plates narrow, oval, very much longer than wide, only basal ones or none in contact. Interbrachial spaces below, covered by oral shields and numerous, small, imbricating scales. Oral shields large, broad, pentagonal, about as wide as long, with lateral margins more or less concave. Adoral plates long and narrow, wider within than

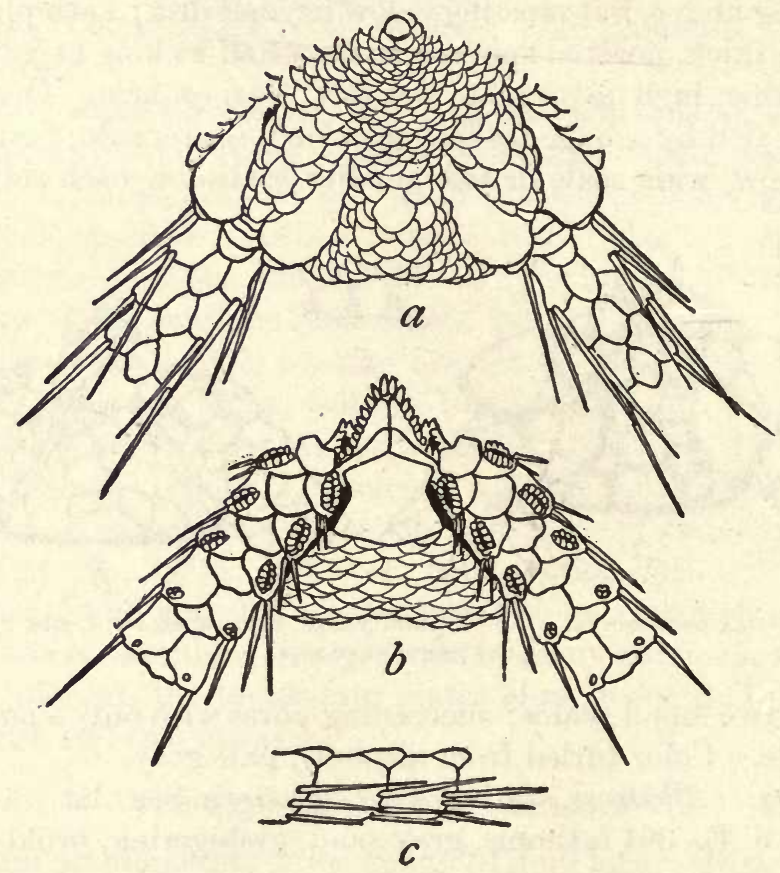

FIG. 37.-OPHIOCTEN OÖPLAX. $\times 5$. $a$, FROM ABOVE; $b$, FROM BELOW; $c$, SIDE VIEW OF THREE ARM JOINTS NEAR DISK.

without; oral plates large, nearly triangular, markedly swollen at tip. Oral papillæ three or four on each side, narrow and pointed. Genital slits long and conspicuous; genital scales narrow; in young specimens each scale carries a marginal series of very minute papillæ, which become long enough on upper end of scale, visible from above, to form a more or less distinct arm comb; in adults this comb is either insignificent or entirely wanting, and the genital scales are scarcely visible from above. First under arm plate more or less hexagonal, wider than long; second plate more pentagonal, with a sharp proximal angle and outer corners rounded; succeeding plates more tetragonal or triangular, very much wider than long; only first two or three plates in contact. Side arm plates large, meeting above and below, 
except at base of arm; each plate carries three long, very slender, acicular spines, of which uppermost is longest, equaling one and a half joints, or at base of arm, exceeding two joints. Oral tentacle pore large, opening into mouth slit, protected by six to eight scales on each side; first three basal pores of arm, similar, though there may not be quite so many tentacle scales; fourth pore with only three or four scales; succeeding pores with a single small scale, though there may be two on fifth and sixth pores. Color (dried from alcohol), grayish, yellowish, or nearly white.

Localities.-Albatross station 3704, off Honshu Island, Japan, 94 to 150 fathoms, fine volcanic sand, 3 specimens; station 4906, Eastern Sea, lat. $31^{\circ} 39^{\prime}$ N.; long. $129^{\circ} 20^{\prime} 30^{\prime \prime}$ E., 369 to 406 fathoms, gray globigerina ooze, bottom temperature $43.4^{\circ}, 3$ specimens; station 4907 , Eastern Sea, lat. $31^{\circ} 39^{\prime} 30^{\prime \prime}$ N.; long. $129^{\circ} 24^{\prime}$ E., 406 fathoms, gray globigerina ooze, bottom temperature $42.6^{\circ}, 5$ specimens; station 4909 , Eastern Sea, lat. $31^{\circ} 38^{\prime} 30^{\prime \prime}$ N.; long. $129^{\circ} 27^{\prime}$ $30^{\prime \prime}$ E., 434 fathoms, gray globigerina ooze, bottom temperature $42.9^{\circ}$, 1 specimen; station 4912 , Eastern Sea, lat. $31^{\circ} 39^{\prime} 40^{\prime \prime}$ N.; long. $129^{\circ}$ $20^{\prime}$ E., 391 fathoms, gray globigerina ooze, bottom temperature $41.9^{\circ}$, 5 specimens; station 4913 , Eastern Sea, lat. $31^{\circ} 39^{\prime} 10^{\prime \prime} \mathrm{N}$.; long. $129^{\circ} 22^{\prime} 30^{\prime \prime}$ E., 391 fathoms, gray globigerina ooze, bottom temperature $41.9^{\circ}, 5$ specimens; station 4915 , Eastern Sea, lat. $31^{\circ} 3^{\prime} \mathrm{N}$.; long. $129^{\circ} 25^{\prime} 30^{\prime \prime}$ E., 427 fathoms, gray globigerina ooze, broken shells, bottom temperature $41.9^{\circ}, 39$ specimens; station 4919 , Eastern Sea, lat. $30^{\circ} 34^{\prime}$ N.; long. $129^{\circ} 19^{\prime} 30^{\prime \prime}$ E., 440 fathoms, globigerina ooze, bottom temperature $41.8^{\circ}, 1$ specimen; station 4965, off Eastern Japan, lat. $33^{\circ} 35^{\prime} 20^{\prime \prime}$ N.; long. $135^{\circ} 10^{\prime} 50^{\prime \prime}$ E., 191 fathoms, dark green-gray sand, shells, bottom temperature $49.4^{\circ}$, 28 specimens; station 4972 , off Eastern Japan, lat. $33^{\circ} 25^{\prime} 45^{\prime \prime}$ N.; long. $135^{\circ} 33^{\prime} \mathrm{E}$., 440 fathoms, brown-green mud, foraminifera, bottom temperature $39.8^{\circ}, 3$ specimens; station 4980 , off Eastern Japan, lat. $34^{\circ} 9^{\prime}$ N.; long. $137^{\circ} 55^{\prime}$ E., 507 fathoms, brown mud, fine sand, foraminifera, bottom temperature $39^{\circ}, 1$ specimen; station 5086, Sagami Bay, lat. $35^{\circ} 8^{\prime} 15^{\prime \prime} \mathrm{N}$.; long. $139^{\circ} 20^{\prime}$ E., 292 fathoms, green mud, coarse, black sand, bottom temperature $43.7^{\circ}, 37$ specimens; station 5087, Sagami Bay, lat. $35^{\circ} 9^{\prime} 40^{\prime \prime}$ N. ; long. $139^{\circ}$ $19^{\prime} 5^{\prime \prime}$ E., 614 fathoms, green mud, bottom temperature $37.5^{\circ}, 1$ specimen. Bathymetrical range, 94 to 614 fathoms. Temperature range, $49.4^{\circ}$ to $37.5^{\circ}$. One hundred and thirty-two specimens.

Type.-Cat. No. 25719, U.S.N.M., from station 4972.

This species is so easily recognized by the peculiar upper arm plates, that it is not likely to be confused with any other. The smallest specimens have the disk only $5 \mathrm{~mm}$. across, but they show very little difference from the adults save in the greater prominence of their arm combs, a peculiarity referred to above. 
OPHIOPENIA, nevv genus. ${ }^{a}$

Disk covered with scales, many of which may be small and swollen so as to look like coarse grains; arms short, less than twice diameter of disk. Upper arm plates more or less widely separated from each other. Basal under arm plates not in contact. Oral papillæ few, large, and ill-defined. Tentacle scales none (except on oral pore) though lowest arm spine may function as one. Arm spines few and short. Genital slits very minute, close beside first side arm plates.

Type species.-Ophiopenia disacantha.

This is a very curious and interesting genus, the relationship of which is quite obscure. I am inclined to the opinion that it is perhaps as near Ophiozona as it is to any genus now known, but the relationship even with that genus is certainly not close. The distribution of the genus appears to be very restricted, as it has been taken only once outside Bering Sea and the vicinity of the Aleutian Islands. Most of the specimens were taken in quite shallow water, but a few were collected at depths of 100 to 225 fathoms. Cold water seems to be an essential feature of the habitat, as the temperature range is only from $43^{\circ}$ down:

\section{OPHIOPENIA DISACANTHA, new species. $b$}

Disk $10 \mathrm{~mm}$. in diameter; arms about $15 \mathrm{~mm}$. long. Disk pentagonal, flat, covered with hundreds of small angular scales, among which the centrodorsal and a marginal plate in each interradius are quite distinct (in younger individuals, fig. 38a, larger radial plates are easily distinguished and the radial shields may be very conspicuous). Radial shields entirely concealed beneath the coat of small scales, or if visible, widely separated and much longer than wide. Upper arm plates transversely oval, much wider than long, those on basal half of arm separated from each other and completely surrounded by numerous minute scales like those of disk; these scales extend far down on each side between side arm plates. Interbrachial spaces below densely covered by minute angular plates, which may even extend a little ways onto under surface of arm. Genital slits very minute, crescent-shaped, lying, one on each side, against inner corner of first side arm plate; genital scales completely hidden. Oral shields small, transversely oval. Adoral plates very large, oblong but nearly as wide as long. Oral plates ill-defined swollen into a sort of knob at proximal end, which looks like an oral papilla. Oral papillæ ill-defined, apparently two on a side, outer flatter, inner more round and swollen; at apex of jaw there are from one to several indistinct

$a^{\prime \prime} 0 \phi \iota s$, signifying snake, and $\pi \varepsilon v i a$, signifying poverty, in reference to the lack of tentacle scales and the small number of oral papillæ, and in keeping with the customary formation of ophiuroid genera.

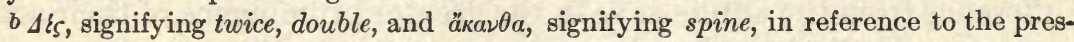
ence of only two arm spines. 
swellings, which might perhaps be considered tooth papillæ, but their real nature is very doubtful. First under arm plate very small, pentagonal, wider than long; succeeding plates pentagonal or squarish, soon becoming roundish and more or less swollen, in contact with each other outside disk. Side arm plates moderate, but concealed above and, in part, on sides of arm, on basal half, by granules; each plate carries two short, stout spines, low down, near under side of arm; upper spine very short and thick, nearly spherical, about one-third as long as joint; lower spine a trifle longer, not quite so stout, and placed just proximal to tentacle, where it apparently functions as a tentacle scale. Oral tentacle pore concealed by a single large scale of very variable shape, sometimes nearly circular, more often truncate and wide, like an outer oral papilla; between the two pores, in the
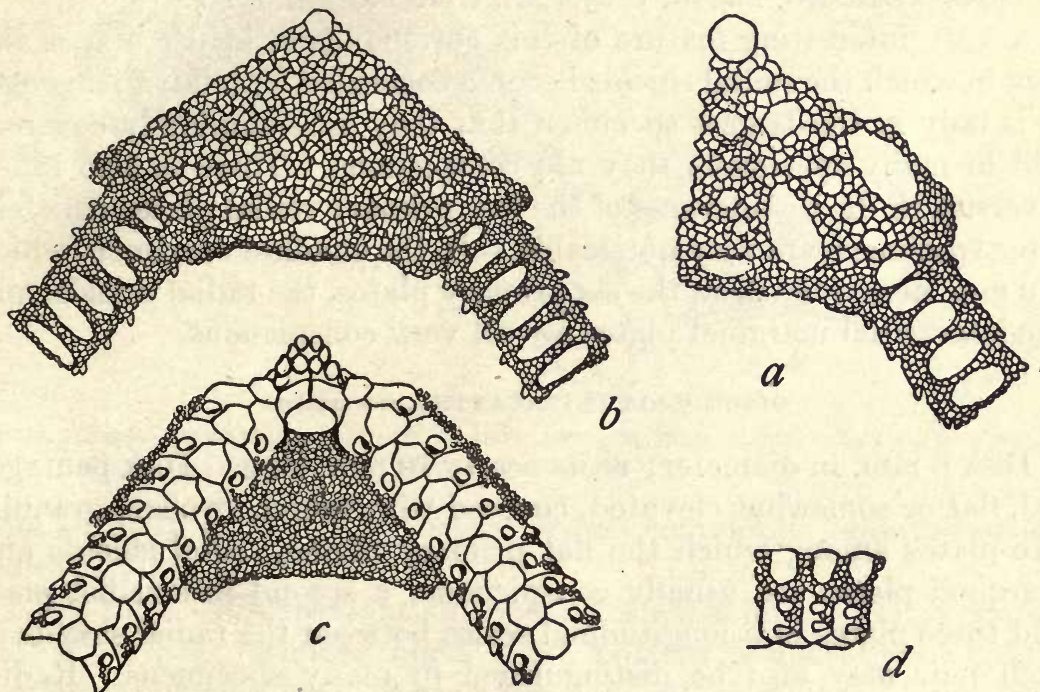

FIG. 38.-OPHIOPENA DISACANTHA. $a$, YOUNG, $\times 7 ; b-d$, $\triangle D U L T, \times 5$. $a$, TROM ABOVE; $b$, FROM $\triangle$ BOVE; $c$, FROM BELOW; $d$, SIDE VIEW OF THREE ARM JOINTS NEAR DISK.

midline of the arm, there projects a thick, plate-like outgrowth, which is sometimes double and apparently acts as an inner scale for both pores. Tentacle pores of arm without tentacle scales but protected by lower arm spine. Color (dried from alcohol), yellowish or very light grayish.

Localities.-Albatross station 2849, off Alaska, lat. $55^{\circ} 16^{\prime} \mathrm{N}$.; long. $160^{\circ} 28^{\prime}$ W., 69 fathoms, green mud, bottom temperature $43^{\circ}, 1$ specimen; station 2852 , off Alaska, lat. $55^{\circ} 15^{\prime}$ N.; long. $159^{\circ} 37^{\prime}$ W., 58 fathoms, black sand, bottom temperature $41.8^{\circ}, 1$ specimen; station 2854 , off Alaska, lat. $56^{\circ} 55^{\prime} \mathrm{N}$.; long. $153^{\circ} 4^{\prime}$ W., 60 fathoms, black sand, bottom temperature $42.8^{\circ}, 1$ specimen; station 3227 , Bering Sea, lat. $54^{\circ} 36^{\prime} 30^{\prime \prime} \mathrm{N}$.; long. $166^{\circ} 54^{\prime}$ W., 225 fathoms, green mud, bottom temperature, $38.6^{\circ}$, 1 specimen; station 3312 , Bering Sea, lat. 
$53^{\circ} 59^{\prime} 11^{\prime \prime}$ N.; long. $166^{\circ} 25^{\prime} 9^{\prime \prime}$ W., 45 fathoms, fine sand, mud, bottom temperature $43^{\circ}, 2$ specimens; station 3313 , Bering Sea, lat. $54^{\circ}$ $1^{\prime} 51^{\prime \prime}$ N.; long. $166^{\circ} 27^{\prime} 38^{\prime \prime}$ W., 68 fathoms, fine black sand, bottom temperature $42.7^{\circ}, 1$ specimen; station 3483 , Bering Sea, lat. $57^{\circ} 18^{\prime}$ $\mathrm{N}$.; long. $171^{\circ} 18^{\prime} \mathrm{W}$., 56 fathoms, green mud, bottom temperature $36.8^{\circ}, 1$ specimen; station 3609 , Bering Sea, lat. $55^{\circ} 35^{\prime}$ N.; long. $168^{\circ}$ $20^{\prime}$ W., 74 fathoms, green mud, sand, bottom temperature $37.9^{\circ}, 3$ specimens; station 4812 , Sea of Japan, lat. $38^{\circ} 31^{\prime} \mathrm{N}$.; long. $138^{\circ} 40^{\prime}$ E., 176 to 200 fathoms, fine brown mud, bottom temperature $34.9^{\circ}, 2$ specimens; Captains Harbor, Unalaska, 9 to 14 fathoms, 4 specimens; Port Etches, Alaska, 12 to 18 fathoms, 3 specimens; between Icy Cape and Cape Lisburne, 1 specimen. Bathymetrical range, 9 to 225 fathoms. Temperature range, $43^{\circ}$ to $34.9^{\circ}$. Twenty-one specimens.

Type.-Cat. No. 25540, U.S.N.M., from station 3312.

A very interesting feature of this curious little, brittle star is the way in which the radial shields become concealed with advancing age. It is only in the largest specimen that they are completely covered, and in many specimens they are conspicuous. There is also much diversity in the distinctness of the five primary radial plates which in some specimens are very noticeable. In the smallest specimen, which is $6 \mathrm{~mm}$. across the disk, the six primary plates, the radial shields, and the interradial marginal plates are all very conspicuous.

\section{OPHIOPENIA TETRACANTHA, new species. $a$}

Disk $6 \mathrm{~mm}$. in diameter; arms nearly $10 \mathrm{~mm}$. long. Disk pentagonal, flat or somewhat elevated, covered with round, swollen, granulelike plates among which the flat primary plates, radial shields and marginal plates are usually conspicuous; a second interradial plate and three plates in a longitudinal series between the radial shields of each pair may also be distinguished in many specimens. Radial shields very narrow and often more or less concealed. Upper arm plates somewhat swollen, transversely oval, well separated; granular scales of disk do not extend out around the arm plates; toward tip of arm, plates become triangular. Interbrachial spaces below covered by a scaling similar to that of disk. Genital slits very minute, crescentic, at each inner corner of first side arm plates; genital scales concealed. Oral shields transversely oval, small. Adoral plates squarish, each one nearly as large as oral shield. Oral plates ill defined but with a knob-like swelling on proximal end. Oral papillæ small, ill defined and of variable shape, probably two on each side and perhaps an unpaired one at apex of jaw. First under arm plate somewhat pentagonal, about as wide as long; succeeding plates

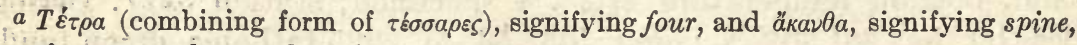
in reference to the number of arm spines. 
larger, swollen, wider than long, oblong with rounded corners, becoming triangular, all well separated from each other. Side-arm plates swollen, not meeting above or below, at least on basal half of arm; each plate carries four well developed, thick, blunt arm spines; uppermost, longest, rather more than half as long as joint; lowest, close to tentacle pore and apparently functioning as a tentacle scale. Oral tentacle pores provided with a very long, stout and conspicuous tentacle scale on outer side; inner side protected by a conspicuous median projection between the two pores. Tentacle pores of arm round and conspicuous, but with no tentacle scales. Color (dried

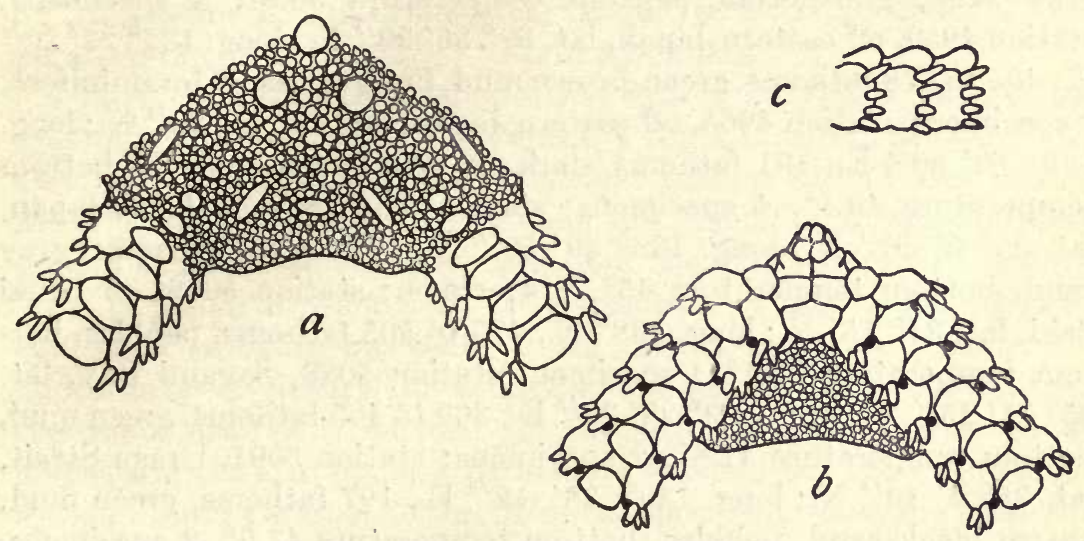

Fig. 39.-Ophiopenia tetracantha. $\times 8$. $a$, From ABOVE; $b$, FRom Below; $c$, SIDE VIeW of three ARM JOINTS NEAR DISK.

from alcohol), dull purplish brown or less commonly light yellowishbrown.

Localities.-Albatross station 2854 , off Alaska, lat. $56^{\circ} 55^{\prime}$ N.; long. $153^{\circ} 4^{\prime}$ W., 60 fathoms, black sand, bottom temperature $42.8^{\circ}, 2$ specimens; station 3279 , Bering Sea, lat. $56^{\circ} 25^{\prime} 40^{\prime \prime}$ N.; long. $162^{\circ}$ $39^{\prime} 15^{\prime \prime}$ W., 41 fathoms, fine gray sand, bottom temperature $37^{\circ}, 1$ specimen. Captains Harbor, Unalaska, 9 to 14 fathoms, 5 specimens; same harbor, 60 to 80 fathoms, 2 specimens; Port Levasheff, 3 specimens; W. of Amaknak Island, 60 fathoms, 7 specimens; Chagafka cove, Kadiak, 12 to 20 fathoms, 330 specimens; Nazan Bay, Atka, 38 specimens; between Icy Cape and Cape Krusenstern, 1 specimen. Bathymetrical range, 12 to 80 fathoms. Temperature range $42.8^{\circ}$ to $37^{\circ}$. Three hundred and eighty-nine specimens.

Type.-Cat. No. 25597, U.S.N.M., from station 3279.

Although this species occurs in the same locality, and sometimes even at the same station, as the preceding, it can not be confused with it, for the two may be distinguished at once by the difference in the arm spines. Even the smallest specimen of tetracantha, with a disk diameter of only $3 \mathrm{~mm}$., has four spines on one joint, three on the 
others. The difference between the two species in the nature of the disk scales is also very constant. It is interesting to find two such closely allied, yet very distinct species, occupying the same area.

\section{OPHIOMUSIUM CANCELLATUM.}

Ophiomusium cancellatum Lyman, Bull. Mus. Comp. Zoöl., vol. 5, 1878, p. 111.

Localities.-Albatross station 3718, off Ose Zaki, Japan, 65 fathoms, volcanic sand, shells, rocks, 1 specimen; station 3738, off Port Heda, Japan, 168 fathoms, stiff blue mud, 1 specimen; station 4928, in Colnett Strait, lat. $29^{\circ} 51^{\prime}$ N.; long. $131^{\circ} 2^{\prime} 30^{\prime \prime}$. E., 1,008 fathoms, gray sand, globigerina, bottom temperature $36.8^{\circ}, 3$ specimens; station 4959 , off eastern Japan, lat. $32^{\circ} 36^{\prime} 30^{\prime \prime} \mathrm{N}$.; long. $132^{\circ} 23^{\prime} 20^{\prime \prime}$ E., 405 to 578 fathoms, green-brown mud, fine gray sand,foraminifera, 1 specimen; station 4965 , off eastern Japan, lat. $33^{\circ} 35^{\prime} 20^{\prime \prime} \mathrm{N}$.; long. $135^{\circ} 10^{\prime} 50^{\prime \prime}$ E., 191 fathoms, dark green-gray sand, shells, bottom temperature $49.4^{\circ}$, 4 specimens; station 5059, Suruga Gulf, Japan, lat. $35^{\circ} 5^{\prime} 30^{\prime \prime} \mathrm{N}$.; long. $138^{\circ} 39^{\prime} 50^{\prime \prime}$ E., 197 to 297 fathoms, gray sand, bottom temperature $45^{\circ}, 1$ specimen; station 5079, off Omai Saki, lat. $34^{\circ} 15^{\prime}$ N.; long. $138^{\circ}$ E., 475 to 505 fathoms, pebbles, bottom temperature $39.1^{\circ}, 1$ specimen; station 5088, Sagami Bay, lat. $35^{\circ} 11^{\prime} 25^{\prime \prime} \mathrm{N}$.; long. $139^{\circ} 28^{\prime} 20^{\prime \prime}$ E., 369 to 405 fathoms, green mud, bottom temperature $41.8^{\circ}, 2$ specimens; station 5091, Uraga Strait, lat. $35^{\circ} 4^{\prime} 10^{\prime \prime} \mathrm{N}$.; long. $139^{\circ} 38^{\prime} 12^{\prime \prime}$ E., 197 fathoms, green mud, coarse black sand, pebbles, bottom temperature $47.6^{\circ}, 2$ specimens. Bathymetrical range, 65 to 1,008 fathoms. Temperature range, $49.4^{\circ}$ to $36.8^{\circ}$. Sixteen specimens.

These specimens range in diameter of disk from 5 to $16 \mathrm{~mm}$., and are therefore both larger and smaller than Lyman's type. They show considerable diversity in the form of the oral shields, the length of the arm spines and in other details, but on the whole, they agree so well with Lyman's description and figures, I feel no doubt of their identity. The number of arm spines in young specimens is often only three or two, even at the base of the arm. Although apparently not a very common, or widely distributed form, this species has a notable bathymetrical range.

\section{OPHIOMUSIUM LAQUEATUM.}

Ophiomusium laqueatum LyMaN, Bull. Mus. Comp. Zoöl., vol. 5, 1878, p. 113.

Localities.-Albatross station 4934, Eastern Sea, lat. $30^{\circ} 58^{\prime} 30^{\prime \prime} \mathrm{N}$.; long. $130^{\circ} 32^{\prime}$ E., 103 to 152 fathoms, rocky, bottom temperature $56^{\circ}$ to $60.6^{\circ}, 1$ specimen; station 4936 , Eastern Sea, lat. $30^{\circ} 54^{\prime} 40^{\prime \prime} \mathrm{N}$.; long. $130^{\circ} 37^{\prime} 30^{\prime \prime}$ E., 103 fathoms, stones, bottom temperature $60.6^{\circ}$, 1 specimen. Bathymetrical range, 103 to 152 fathoms. Temperature range, $60.6^{\circ}$ to $56^{\circ}$. Two specimens.

These specimens agree well with Lyman's description and figures. One is $13 \mathrm{~mm}$., the other $18 \mathrm{~mm}$., across the disk. In both, the arms 
are badly broken and the uppermost arm spine is missing from most of the remaining joints. Perhaps this is due to the character of the bottom from which they were dredged.

\section{OPHIOMUSIUM LÜTKENI.}

Ophiomusium lütkeni Lyman, Bull. Mus. Comp. Zoöl., vol. 5, 1878, p. 114.

Localities.-Albatross station 4900 , Eastern Sea, lat. $32^{\circ} 28^{\prime} 50^{\prime \prime} \mathrm{N}$.; long. $128^{\circ} 34^{\prime} 40^{\prime \prime}$ E., 139 fathoms, gray sand, broken shells, bottom temperature $52.9^{\circ}, 5$ specimens; station 4933 , Eastern Sea, lat. $30^{\circ}$ $59^{\prime} \mathrm{N}$.; long. $130^{\circ} 29^{\prime} 50^{\prime \prime}$ E., 152 fathoms, rocky, bottom temperature $56^{\circ}, 3$ specimens. Bathymetrical range, 139 to 152 fathoms. Temperature range, $56^{\circ}$ to $52.9^{\circ}$. Eight specimens.

I have compared these specimens with a cotype of lütkeni and although there-are slight differences, I think it safe to call them that species. In the lütkeni from Challenger station 192 (off Kei Islands, Arafura Sea), many grains of sand and shells of foraminifera still remain attached to the specimens, and the whole surface of disk and arms is pitted as though by the pressure of similar bodies when the epidermal covering was soft. I am unable to decide whether this appearance is natural or artificial, but at any rate the Japanese specimens are not so pitted. In the latter, too, the arm spines are longer and the arm plates a little more swollen, but these differences are slight and variable. The Albatross specimens have the disk 10 to $13 \mathrm{~mm}$. in diameter and are light brown in color.

\section{OPHIOMUSIUM LUNARE.}

Ophiomusium lunare Lyman, Bull. Mus. Comp. Zoöl., vol. 5, 1878, p. 116.

Locality.-Albatross station 4934, Eastern Sea, lat. $30^{\circ} 58^{\prime} 30^{\prime \prime} \mathrm{N}$.; long. $130^{\circ} 32^{\prime}$ E., 103 to 152 fathoms, rocky, bottom temperature, $60.6^{\circ}$ to $56^{\circ}, 7$ specimens.

The disk diameter of these specimens ranges from 6 to $13 \mathrm{~mm}$; they are thus larger than the Challenger specimen, but none of them is so large as the largest taken by the Siboga. The species is remarkably well characterized and correspondingly easy to recognize. There is very little difference in appearance between the smallest and largest specimens, even in the number and arrangement of the disk scales; only in the larger specimens, the basal side arm plates carry some minute scattered spinelets above the regulation pair.

\section{OPHIOMUSIUM LYMANI.}

Ophiomusium lymani Wrville Thomson, The Depths of the Sea, 1873, p. 172.

Localities.-Albatross station 3074 , off Washington, lat. $47^{\circ} 22^{\prime} \mathrm{N}$.; long. $125^{\circ} 48^{\prime} 30^{\prime \prime}$ W., 877 fathoms, green mud, bottom temperature $36.6^{\circ}, 29$ specimens; station 3075 , off Washington, lat. $47^{\circ} 22^{\prime} \mathrm{N}$.; $125^{\circ} 41^{\prime}$ W., 859 fathoms, green mud, bottom temperature $36.6^{\circ}$, 
6 specimens; station 3342 , off British Columbia, lat. $52^{\circ} 29^{\prime} 30^{\prime \prime} \mathrm{N}$.; long. $132^{\circ} 38^{\prime} \mathrm{W} ., 1,588$ fathoms, gray ooze, coarse sand, bottom temperature $35.3^{\circ}, 24$ specimens; station 3704 , off Honshu Island, Japan, 94 to 150 fathoms, fine volcanic sand, 5 specimens; station 4933 , Eastern Sea, lat. $30^{\circ} 59^{\prime}$ N.; long. $138^{\circ} 29^{\prime} 50^{\prime \prime}$ E., 152 fathoms, rocky, bottom temperature $56^{\circ}, 38$ specimens; station 4956 , off eastern Japan, lat. $32^{\circ} 32^{\prime} \mathrm{N}$.; long. $132^{\circ} 25^{\prime} \mathrm{E}$., 720 fathoms, green-brown mud, fine gray sand, foraminifera, bottom temperature $37.5^{\circ}, 10$ specimens; station 4969 , off eastern Japan, lat. $33^{\circ} 23^{\prime} 40^{\prime \prime}$ N.; long. $135^{\circ} 38^{\prime}$ E., 587 fathoms, brown mud, sand, stones, bottom temperature $38.9^{\circ}$, 6 specimens; station 4971 , off eastern Japan, lat. $33^{\circ} 23^{\prime} 30^{\prime \prime} \mathrm{N}$.; long. $135^{\circ} 34^{\prime}$ E., 649 fathoms, brown-green mud, foraminifera, bottom temperature $38.1^{\circ}, 7$ specimens; station 4976 , off eastern Japan, lat. $33^{\circ} 22^{\prime} 50^{\prime \prime} \mathrm{N}$.; long. $135^{\circ} 38^{\prime} 30^{\prime \prime}$ E., 544 to 545 fathoms, brown mud, small stones, bottom temperature $38.7^{\circ}, 3$ specimens; station 4977 , off eastern Japan, lat. $33^{\circ} 23^{\prime}$ N.; long. $135^{\circ} 37^{\prime} 40^{\prime \prime}$ E., 544 fathoms, brown mud, fine sand, bottom temperature $38.9^{\circ}, 1$ specimen; station 4980 , off eastern Japan, lat. $34^{\circ} 9^{\prime} \mathrm{N}$.; long. $137^{\circ}$ $55^{\prime}$ E., 507 fathoms, brown mud, fine sand, foraminifera, bottom temperature $39^{\circ}, 6$ specimens; station 5082, off Omai Saki, Japan, lat. $34^{\circ} 5^{\prime} \mathrm{N}$.; long. $137^{\circ} 59^{\prime}$ E., 662 fathoms, green mud, fine sand, globigerina, bottom temperature $37.7^{\circ}, 14$ specimens; station 5083 , off Omai Saki, Japan, lat. $34^{\circ} 4^{\prime} 20^{\prime \prime}$ N.; long. $137^{\circ} 57^{\prime} 30^{\prime \prime}$ E., 624 fathoms, fine gray sand, globigerina, bottom temperature $38.1^{\circ}, 20$ specimens; station 5084, off Omai Saki,Japan, lat. $34^{\circ} \mathrm{N}$.; long. $137^{\circ} 49^{\prime}$ $40^{\prime \prime}$ E., 918 fathoms, green mud, fine sand, globigerina, bottom temperature $36.8^{\circ}, 6$ specimens; station 5092 , Uraga Strait, lat. $35^{\circ} 4^{\prime}$ $50^{\prime \prime} \mathrm{N}$.; long. $139^{\circ} 38^{\prime} 18^{\prime \prime}$ E., 70 fathoms, coarse black sand, bottom temperature $56.3^{\circ}, 7$ specimens. Bathymetrical range, 70 to 1,588 fathoms. Temperature range, $56.3^{\circ}$ to $35.3^{\circ}$. One hundred and eighty-two specimens.

This is a fine series of this cosmopolitan species, already known from many of the deeper parts of the sea, but not previously recorded from the North Pacific. The specimens range in disk diameter from 6.5 to $35 \mathrm{~mm}$., and show considerable diversity of form and structure. The largest specimen is circular and very flat, the vertical diameter of the disk being only $7.5 \mathrm{~mm}$., or 21 per cent of the horizontal, while another specimen, $30 \mathrm{~mm}$. in diameter, is pentagonal and $10 \mathrm{~mm}$. thick, the vertical diameter therefore being 33 per cent of the horizontal. The various differences noted are not very important nor are they sufficiently constant to be of systematic use. But this species would certainly prove an excellent subject for careful comparative study of variation in widely separated geographical areas. The bathymetrical range is no less remarkable than the geographical. 


\section{OPHIOMUSIUM SIMPLEX.}

Ophiomusium simplex Lyman, Bull. Mus. Comp. Zoöl., vol. 5, 1878, p. 115. Ophiomusium sanctum Käler, Siboga Oph. Mer Prof., 1904, p. 59.

Localities.-Albatross station 4888, Eastern Sea, lat. $32^{\circ} 26^{\prime} \mathrm{N}$.; long. $129^{\circ} 27^{\prime} 30^{\prime \prime}$ E., 71 fathoms, dark gray sand, broken shells, bottom temperature $59.7^{\circ}, 1$ specimen; station 4893 , Eastern Sea, lat. $32^{\circ} 32^{\prime} \mathrm{N}$.; long. $128^{\circ} 32^{\prime} 50^{\prime \prime} \mathrm{E}$., 95 to 106 fathoms, gray sand, broken shells, pebbles, bottom temperature $55.9^{\circ}, 2$ specimens; station 4894 , Eastern Sea, lat. $32^{\circ} 33^{\prime}$ N.; long. $128^{\circ} 32^{\prime} 10^{\prime \prime}$ E., 95 fathoms, green sand, broken shells, pebbles, 2 specimens; station 4895 , Eastern Sea, lat. $32^{\circ} 33^{\prime} 10^{\prime \prime}$ N.; long. $128^{\circ} 32^{\prime} \cdot 10^{\prime \prime}$ E., 95 fathoms, green sand, broken shells, pebbles, 1 specimen; station 4903 , Eastern Sea, lat. $32^{\circ} 31^{\prime} 10^{\prime \prime}$ N.; long. $128^{\circ} 33^{\prime} 20^{\prime \prime}$ E., 107 to 139 fathoms, gray sand, broken shells, 7 specimens; station 4936, Eastern Sea, lat. $30^{\circ} 54^{\prime} 40^{\prime \prime}$ N.; long. $130^{\circ} 37^{\prime} 30^{\prime \prime}$ E., 103 fathoms, stones, bottom temperature $60.6^{\circ}, 3$ specimens. Bathymetrical range, 71 to 139 fathoms. Temperature range, $60.6^{\circ}$ to $55.9^{\circ}$. Sixteen specimens.

As these specimens range in size from 4 to $14 \mathrm{~mm}$. across the disk, they serve to connect Lyman's single specimen of simplex (disk diameter, $6 \mathrm{~mm}$.) with Kœhler's specimens of sanctum (disk diameter, 10 to $19 \mathrm{~mm}$.). The specimen $4 \mathrm{~mm}$. across is almost exactly like Lyman's description and figures, while the largest specimen answers too well to Kœhler's to permit any doubt as to its identity. It is clear, therefore, that in this species the growth changes involve an increasing swelling of the disk plates, especially the marginal ones, a wide separation of the radial shields, a greater or less separation of the five primary radial plates, an increase in the number of disk scales, the addition of two plates in the interbrachial space below, and often, but not always, the addition of a third arm spine. On the other hand, there is absolutely no change in the under arm plates and tentacle pores, and practically none in the upper arm plates, oral shields, and mouth parts. These facts are of importance in determining the validity of species within the genus, and their relationship with each other.

\section{OPHIOMUSIUM TRYCHNUM, new species. $a$}

Disk $18 \mathrm{~mm}$. in diameter; arms about $70 \mathrm{~mm}$. long. Disk somewhat elevated, $6 \mathrm{~mm}$. thick, covered with about one hundred and fifty scales, of which the six primary plates, three large plates in each interradius and three smaller ones in each radius, are most conspicuous. Each of these is swollen into a large central tubercle, or flattened, elevated area. Radial shields large, much longer than

a $T \rho \dot{y} \chi \nu 0 s$, signifying rough, rugged, in reference to the lumpy disk scales. 
wide, with central area thick and elevated; surface more or less tuberculous or rough. Interradial marginal plates of disk with conspicuous tubercles; three or four similar plates distal to radial shields at base of arm. First upper arm plate oblong, wider than long; second and third triangular and somewhat swollen; succeeding plates to tip of arm, minute, triangular. Interbrachial spaces below covered by oral shield, genital scales and six or seven plates (in each space), of which the marginal are greatly swollen; exact arrangement of these plates variable; much smaller plates usually scattered among them. Oral shields somewhat triangular, longer than wide, very flat. Adoral plates large, wider without than

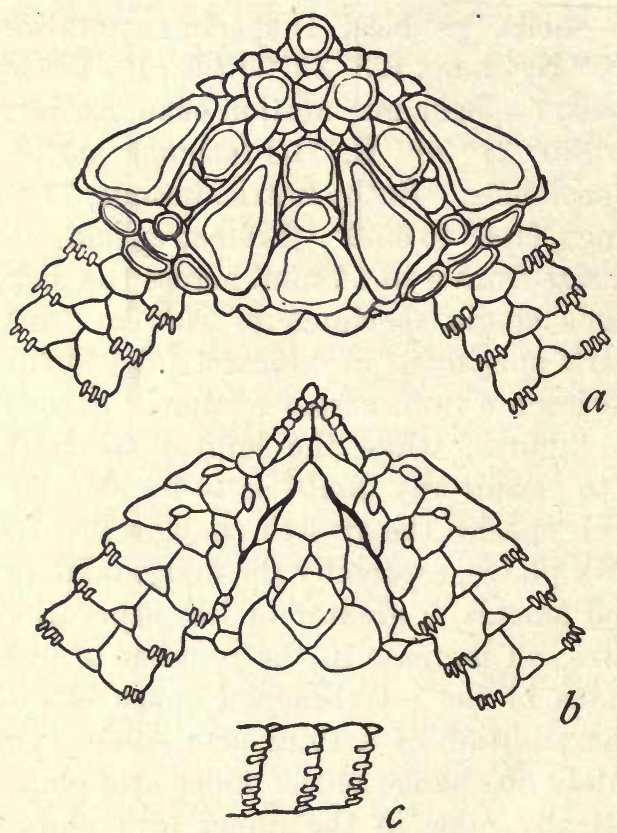

Fig. 40.-OPHOMUSIUM TR YChNUM. $\ 3$. $a$, FROM ABOVE; $b$, FROM BELOW; $c$, SIDE VIEW OF TWO ARM JOINTS NEAR DISK. within; oral plates small. Oral papillæ about five on a side, outermost much the largest; a pointed one at apex of jaw. Genital slits short, but genital scales long and broad. First under arm plate small, somewhat hexagonal; second and third more octagonal or even enneagonal, second longer than wide, third about as wide as long; first and second and second and third plates in contact; succeeding plates small and triangular, but persistent to end of . arm. Side arm plates very large, somewhat swollen, broadly in contact above and below; each plate carries five or six short, blunt, irregularly spaced arm spines, scarcely one-third as long as joint. Tentacle pores small, covered by a single scale, and confined to first and second joints of arm. Color (dried from alcohol), yellow-brown, dull brownish, or nearly white.

Localities.-Albatross station 3661, off Uki Shima, Gulf of Tokyo, Japan, 169 fathoms, mud, pebbles, 2 specimens; station 3704 , off Seno Umi, Japan, 94 to 150 fathoms, fine volcanic sand, 1 specimen; station 4959 , off eastern Japan, lat. $32^{\circ} 36^{\prime} 30^{\prime \prime} \mathrm{N}$.; long. $132^{\circ} 23^{\prime}$ $20^{\prime \prime}$ E., 405 to 578 fathoms, green-brown mud, fine gray sand, foraminifera, 1 specimen; station 4965 , off eastern Japan, lat. $33^{\circ} 35^{\prime}$ $20^{\prime \prime} \mathrm{N}$.; long. $135^{\circ} 10^{\prime} 50^{\prime \prime}$ E., 191 fathoms, dark green-gray sand, 
shells, bottom temperature $49.4^{\circ}, 4$ specimens; station 5069, Suruga Gulf, lat. $35^{\circ} 3^{\prime} 10^{\prime \prime}$ N.; long. $138^{\circ} 47^{\prime}$ E., 108 to 131 fathoms, mud, sand, broken shells, bottom temperature $55.8^{\circ}, 2$ specimens; station 5091, Uraga Strait, lat. $35^{\circ} 4^{\prime} 10^{\prime \prime}$ N.; long. $139^{\circ} 38^{\prime} 12^{\prime \prime}$ E., 197 fathoms, green mud, coarse black sand, pebbles, bottom temperature $47.6^{\circ}, 7$ specimens; station 5092, Uraga Strait, lat. $35^{\circ} 4^{\prime} 50^{\prime \prime}$ N.; long. $139^{\circ} 38^{\prime} 18^{\prime \prime}$ E., 70 fathoms, coarse black sand, bottom temperature $56.3^{\circ}, 2$ specimens; station 5093, Uraga Strait, lat. $35^{\circ} 3^{\prime} 15^{\prime \prime} \mathrm{N}$.; long. $139^{\circ} 37^{\prime} 42^{\prime \prime}$ E., 302 fathoms, coarse black sand, bottom temperature $43.9^{\circ}, 1$ specimen; station 5094, Uraga Strait, lat. $35^{\circ} 4^{\prime} 42^{\prime \prime}$ N.; long. $139^{\circ} 38^{\prime} 20^{\prime \prime}$ E., 88 fathoms, black sand, broken shells, bottom temperature $54.8^{\circ}, 16$ specimens. Bathymetrical range, 70 to 578 fathoms. Temperature range, $56.3^{\circ}$ to $43.9^{\circ}$. Thirty-six specimens.

Type.-Cat. No. 25646, U.S.N.M., from station 5069.

The smallest specimen has the disk $7 \mathrm{~mm}$. in diameter. It differs from the large ones in having fewer, less swollen, but more tuberculous disk scales, radial shields in contact near middle, only one or three scales in interbrachial space distal to oral shield, and only three or four arm spines. The growth changes, therefore, are the same in this species as in simplex, which is apparently the nearest ally of trychnum, but from which it is easily distinguished by the persistence of the under arm plates, the much rougher disk and the number of arm spines. I know of no other species with which trychnum is likely to be confused.

OPHIOMUSIUM JOLLIENSIS.

Ophiomusium jolliensis McClendon, Univ. of California Publ., Zoöl., vol. 6, 1909, no. 3, p. 36 .

Disk $21 \mathrm{~mm}$. in diameter; arms 50 to $55 \mathrm{~mm}$. long. Disk relatively thin and flat, covered with numerous scales, among which only a big marginal plate in each interradius and the radial shields are prominent. Radial shields much longer than wide, well separated. Distal to each radial shield, on side of base of arm, are numerous coarse, granule-like scales. First two or three upper arm plates decidedly wider than long, but succeeding plates are longer than wide; at first rounded pentagonal, but soon becoming diamondshape. Near tip of arm the plates are very minute, nearly triangular, and about as wide as long; only first three to six in contact. Interbrachial spaces below covered by numerous scales, of which a median series and those near margin are somewhat larger than others. Oral shields small, much longer than wide, narrower distally than proximally. Adoral plates short and wide, lying beside, instead of proximal to, oral shield; oral plates small. Oral papillæ small, six to seven on a side, outermost largest; an odd one at 
apex of jaw. Genital slits remarkably long and conspicuous, reaching from middle of oral shield to fourth joint of arm. First under arm plate very small, hexagonal, about as long as wide; next two or three plates somewhat pentagonal, wider than long; succeeding plates small, pentagonal or triangular, becoming minute, diamond-shaped. Side arm plates moderate, little swollen, meeting broadly below, and above except at base of arm. Each plate carries three small, blunt spines, close together, low down on the plate, but on the basal joints there may be only two, one, or none. Tentacle pores on second, third, and fourth joints of arm small, protected usually by one, rarely by two, scales. Color (dried from alcohol), pale yellowish, or light brown.

Localities.-Albatross station 3104 , off California, lat. $37^{\circ} 23^{\prime} \mathrm{N}$.; long. $123^{\circ} 8^{\prime}$ W., 391 fathoms, clay, bottom temperature $40.8^{\circ}, 1$

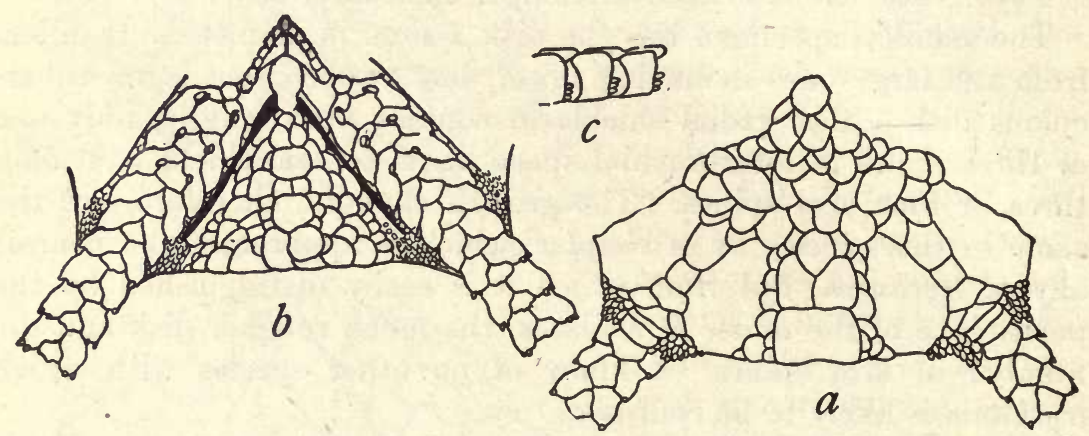

FIG. 41.-OPHIOMUSIUM JOLLIENSIS. $\times 2.5$. $a$, FROM ABOVE; $b$, FROM BELOW; $c$, SIDE VIEW OF THREE ARM JOINTS NEAR DISK.

specimen; station 3126 , off California, lat. $36^{\circ} 49^{\prime} 20^{\prime \prime} \mathrm{N}$.; long. $122^{\circ} 12^{\prime} 30^{\prime \prime} \mathrm{W} ., 456$ fathoms, green mud, bottom temperature? (42.8), 145 specimens; station 3347 , off Washington, lat. $45^{\circ} 9^{\prime} 35^{\prime \prime}$ N.; long. $124^{\circ} 45^{\prime}$ W., 345 fathoms, mud, bottom temperature $40.9^{\circ}$, 21 specimens; station 3738, off Port Heda, Japan, 167 fathoms, stiff blue mud, 3 specimens; station 4965, off eastern Japan, lat. $33^{\circ} 35^{\prime} 20^{\prime \prime} \mathrm{N}$.; long. $135^{\circ} 10^{\prime} 50^{\prime \prime}$ E., 191 fathoms, dark greengray sand, shells, bottom temperature $49.4^{\circ}, 11$ specimens; station 5079, off eastern Japan, lat. $34^{\circ} 15^{\prime}$ N.; long. $138^{\circ}$ E., 475 to 505 fathoms, pebbles, bottom temperature $39.1^{\circ}, 1$ specimen; station 5091, Uraga Strait, Japan, lat. $35^{\circ} 4^{\prime} 10^{\prime \prime}$ N.; long. $139^{\circ} 38^{\prime} 12^{\prime \prime}$ E., 197 fathoms, green mud, coarse black sand, pebbles, bottom temperature $47.6^{\circ}, 11$ specimens. Locality?, 1 specimen. Bathymetrical range, 167 to 505 fathoms. Temperature range, $49.4^{\circ}$ to $39.1^{\circ}$. One hundred and ninety-four specimens.

Although this species is closely allied to cancellatum, armigerum, and eburneum, it may be at once distinguished from any of these species by the combination of long genital slits with the very 
peculiar oral shields and the three pairs of tentacle pores. The smallest specimen $(10 \mathrm{~mm}$. across the disk) differs from the large only in having the primary plates of the disk distinguishable and in there being only two arm spines on many of the joints. As my description and figures of this species were prepared before the publication of McClendon's paper, and as they are taken from much larger specimens, it has seemed best to let them stand.

\section{OPHIOMUSIUM MULTISPINUM, new species. $a$}

Disk $40 \mathrm{~mm}$. in diameter; arms about $240 \mathrm{~mm}$. long. Disk flat, thin, pentagonal or rather decagonal, owing to great size of radial shields, covered with numerous, irregular, rounded, small plates more or less embedded in the skin, and five pairs of huge radial shields; the latter are about $14 \mathrm{~mm}$. long by $6 \mathrm{~mm}$. wide, but their inner ends are more or less buried in the scale-bearing skin; they are widely separated throughout their length. Upper arm plates persistent to tip of arm; basal ones somewhat pentagonal, wider than long, but from
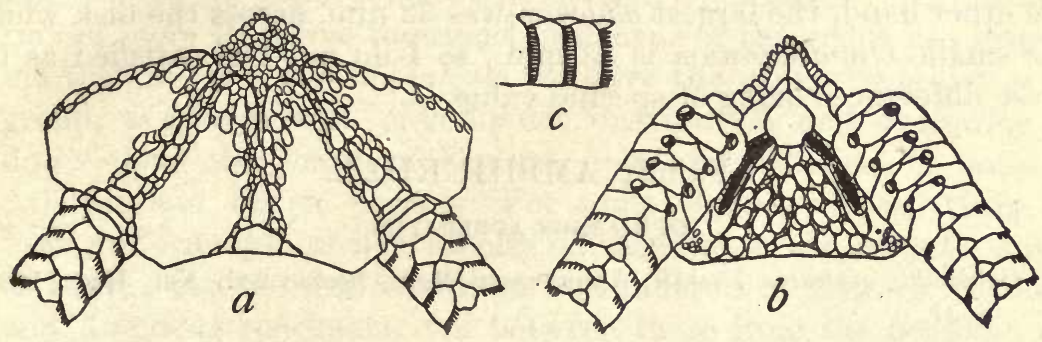

Fig. 42.-OPHOMUSIUM MULTISPINUM. $\times 1.25$. $a$, FROM ABOVE; $b$, FROM BELOW; $c$, SIDE VIEW OF THREE ARM JOINTS NEAR DISK.

about fourth on they become diamond-shaped and as a rule are longer than wide; they are in contact, or nearly so, to about the eleventh plate. Interbrachial spaces below covered by numerous rounded scales like those of disk. Oral shields arrowhead-shaped, nearly as wide as long. Adoral plates long, wider without than within; oral plates large, somewhat swollen proximally. Oral papillæ numerous, nine or ten on a side, outermost much the biggest. Genital slits moderate, about equal to three joints; genital scales long and rather conspicuous. First under arm plate pentagonal, twice as wide as long; next three similar, but longer; succeeding plates small, triangular, persistent to end of arm. Side arm plates moderate, little swollen, meeting broadly above and below except at extreme base of arm; each plate carries twelve to sixteen very slender, closely crowded, pointed spines, hardly one-fourth as long as side arm plate; lowest spine (or two) often much stouter and more conspicu-

a Multus, signifying many, and spinus, signifying spine, in reference to the numerous arm spines. 
ous than others. Tentacle pores on four basal joints of arm, rather large, protected by one, two, or three scales. Color (dried from alcohol), light cream-color or vêry light yellowish-brown, with center of disk sometimes very much darker.

Locality.-Albatross station 3074 , off Washington, lat. $47^{\circ} 22^{\prime} \mathrm{N}$.; long. $125^{\circ} 48^{\prime} 30^{\prime \prime}$ W., 877 fathoms, green mud, bottom temperature $36.6^{\circ}, 3$ specimens.

Type.-Cat. No. 25606, U.S.N.M., from station 3074.

I am not at all sure that this species will not prove to be identical with glabrum Lütken and Mortensen. I have compared it with some of their specimens and find it easy to distinguish the two species by the differences in the arm spines and in the upper and under arm plates. Thus glabrum has seven to eleven arm spines, small triangular upper arm plates and more or less pentagonal under arm plates, while multispinum has twelve to sixteen arm spines, larger, more elongated, diamond-shaped upper arm plates and (except the basal ones, which are much broader than'long) the under arm plates are triangular. On the other hand, the largest glabrum was $32 \mathrm{~mm}$. across the disk while the smallest multispinum is $33 \mathrm{~mm}$., so I do not feel satisfied as to these differences being of specific value.

\section{Family AMPHIURID正.}

\section{OPHIAMBIX ACULEATUS.}

Ophiambix aculeatus Lyman, Anniversary Mem. Boston Soc. Nat. Hist., 1880, p. 11.

Locality.-Albatross station 4928 , in Colnett Strait, lat. $29^{\circ} 51^{\prime} \mathrm{N}$.; long. $131^{\circ} 2^{\prime} 30^{\prime \prime}$ E., 1,008 fathoms, gray sand, globigerina, bottom temperature $36.8^{\circ}, 1$ specimen.

It is a matter for great regret that a single specimen, $5 \mathrm{~mm}$. across the disk, is all the material which the collection affords of this interesting and important genus. I know of no ophiuran which gives as much promise of throwing light on the relation of brittle-stars to starfishes as does Ophiambix. Seen from above the resemblance to a starfish is most striking, while the huge tentacles and tentacle pores and the simple mouth parts give to the oral surface a very suggestive appearance. It is rather curious that Lyman makes no reference to the asteroid resemblances of this genus. To judge from the position assigned it in the Challenger report, he seems to have considered it allied to Ophioscolex. Meissner ${ }^{a}$ considers it nearer Ophiopholis. $\mathrm{My}$ own opinion is that its real position is very doubtful, and that we shall not understand its relationships until more abundant material shall make possible a complete study of its structure. For the present it may as well stand at the beginning of the family Amphiuridæ as anywhere else. 


\section{Genus OPHIOPHOLIS.}

The vast amount of material of this genus which has accumulated in the National Museum from the North Pacific makes it possible to offer here a revision of the species. The task has been a very difficult one on account of the extraordinary diversity which individuals show in all those features upon which specific distinctions must be based. Few animals show as great individual diversity in color as do the brittle-stars of this genus; it is scarcely an exaggeration to say that in all the thousands of specimens I have examined I have never seen two that were exactly alike, and there are few shades of color which can not be matched in a living group of the best-known species. The same diversity is seen in the covering of the disk and the separation of species solely by the number and arrangement of the bare plates is perfectly futile. In the length of the arm spines, the development of disk spines and the shape of the arm plates, and particularly in the number, form, and arrangement of the supplementary upper arm plates, the same remarkable diversity is found. The examination of more than five thousand specimens of the genus has satisfied me that in Ophiopholis aculeata we have the primary species of the group, a species with circumpolar distribution and extending far down along the coasts of Europe, Asia, and America, in both the Atlantic and Pacific oceans. For some obscure reason, there has been no formation of new species or varieties in the Atlantic areaat least, I can not find any important differences between European and American specimens, nor between those from the northern and southern parts of the American range. In Bering Sea and the northern Pacific, however, Ophiopholis seems to have met with very favorable conditions and has become diversified to such a degree that we can properly recognize at least two very distinct species (mirabilis and brachyactis), two others (longispina and bakeri) which are fairly well differentiated, and two well-marked varieties which, however, grade into the parent form completely-in Bering Sea. These two varieties have already received names from Lyman, who, in the absence of extensive material, regarded them as valid species, distinguished by the number and arrangement of the disk scales. One of them (kennerlyi, including also caryi Lyman) is the characteristic form of the Pacific coast of the United States, while the other (japonica) is apparently the most common form on the coast of Japan. My first inclination was to consider these two forms as subspecies of aculeata, each characteristic of a geographical area, but I soon found that this is not the case, for some of the finest examples of japonica are from Alaska, typical aculeata occurs on the coast of Japan, and some of the best specimens of kennerlyi are from the Aleutian Islands. The typical form was taken by the Fisheries steamer Albatross at 
twenty-nine stations, where japonica also occurred, and at five of these stations kennerlyi was also taken; at four other stations the typical form and kennerlyi occurred together. In view of these facts, I retain the names therefore simply to designate certain well-marked forms, which it is convenient to distinguish on account of their striking difference in appearance. In order to make as clear as possible the conclusions to which I have been led regarding the members of this genus, I give herewith an artificial key to the species and varieties of Ophiopholis.

\section{KEY TO-SPECIES AND VARIETIES OF OPHIOPHOLIS.}

$A^{1}$. In addition to the usual small supplementary plates, adjacent to the upper arm plates, there is a large, distinct plate on each side of each upper arm plate.

mirabilis.

$\mathrm{A}^{2}$. No one of the supplementary upper arm plates differentiated as an accessory to the upper arm plate.

$B^{1}$. Supplementary upper arm plates confined to a transverse series, distal to each arm plate, and not present at their sides; under arm plates short, very much wider than long; arms short, only about 3-5 times disk diameter.

brachyactis.

$B^{2}$. Supplementary upper arm plates present, and often particularly abundant at sides of upper arm plates; under arm plates usually almost or quite as long as wide; arms usually more than five times disk diameter.

$\mathrm{C}^{1}$. Supplementary plates very small, often mere pointed granules, commonly not in contact with each other along distal margin of upper arm plates; latter more or less nearly circular, or longer than wide (sometimes wider than long), usually more or less swollen distally; disk spines very slender and acicular, or minutely thorny and with several points; general appearance remarkably $O$ phiothrix-like.

Radial shields large and bare; disk spines few and long; arm spines very long..........................................

Radial shields and disk, more or less completely covered by very slender, more or less thorny spines; arm spines moderately long.. bakeri.

$\mathrm{C}^{2}$. Supplementary plates very variable, often large and angular, often small but angular, sometimes rounded and granule-like but usually in more or less close contact distal to upper arm plates; latter more or less transverse oval, sometimes circular, but usually much wider than long, little or not at all swollen distally; disk spines coarse or wanting........ aculeata.

Supplementary plates small, numerous, often rounded particularly at sides of upper arm plates; arm spines long and pointed $=1 \frac{1}{2}-2$ arm joints; radial shields usually bare and conspicuous, longer than wide; disk with or without spines ..................aculeata var. japonica.

Supplementary plates more or less numerous (ten to twenty-four to each upper arm plate), angular or rounded; arm spines $=\frac{3}{4}-1 \frac{1}{2}$ arm joints, blunt; radial shields covered, or if bare, nearly circular; disk with or (more commonly in Atlantic specimens) without spines.

aculeata var. typica.

Supplementary plates few (six to ten to each upper arm plate), large, angular and crowded; arm spines short, rarely equal to a joint; disk without spines......................... aculeata var. kennerlyi. 


\section{OPHIOPHOLIS MIRABILIS.}

Ophiolepis mirabilis Duncan, Jour. Linn. Soc. London, Zool., vol. 14, 1879, p. 460. Ophiopholis mirabilis Lyman, Bull. Mus. Comp. Zoöl., vol. 6, 1879, p. 43.

Localities.-Albatross station 3656, Hakodate Bay, 11.5 fathoms, green mud, sand, 7 specimens; station 3657, Hakodate Bay, 13.5 fathoms, fine gray sand, 12 specimens; station 3658, Hakodate Bay, 22 fathoms, fine gray sand, 4 specimens; station 3659, Hakodate Bay, 15.5 fathoms, fine gray sand, 14 specimens; station 3771 , off Doumiki Saki, Japan, 61 fathoms, green mud, sand, 3 specimens; station 3773, off Kinkwasan Light, Japan, 78 fathoms, black sand, 4 specimens; station 4832 , off Ando Zaki, Japan, lat. $36^{\circ} 14^{\prime} 30^{\prime \prime} \mathrm{N}$.; long. $135^{\circ} 56^{\prime} 30^{\prime \prime}$ E., 76 to 79 fathoms, dark gray sand, bottom tem- perature $53.2^{\circ}, 1$ specimen; station 5095, Uraga Strait, Japan, lat. $35^{\circ} 5^{\prime} 34^{\prime \prime} \mathrm{N}$.; long. $139^{\circ} 38^{\prime} 36^{\prime \prime}$ E., 58 fathoms, fine black sand, broken shells, bottom temperature $57.8^{\circ}, 2$ specimens. Bathymetrical range, 11.5 to 79 fathoms. Temperature range, down to $53.2^{\circ}$. Fortyseven specimens.

These specimens range in disk diameter from 4 to $16 \mathrm{~mm}$. and make up an excellent series of this interesting species, the most easily recognized of any in the genus. Duncan's types were only 7 or $8 \mathrm{~mm}$. across the disk (Lyman's estimate of $4 \mathrm{~mm}$. seems to me too low), but specimens of that size show the generic and specific characters clearly and it is quite incomprehensible to me why Duncan should have considered

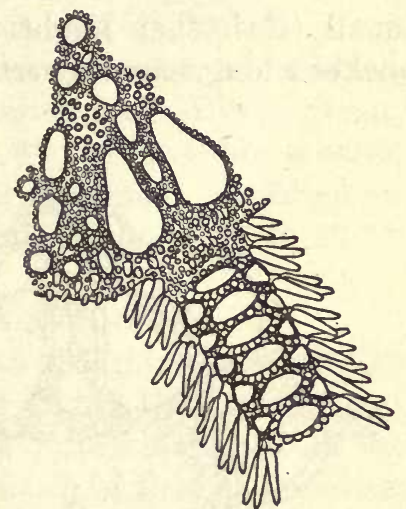

FIG. 43.-OPHIOPHOLIS MIRABILIS. $\times$ 3.5. BASE OF ONE ARM AND ADJOINING PORTION OF DISK; FROM ABOVE.

his specimens as Ophiolepis or in any way connecting links with that genus. Apparently mirabilis is confined to rather warm, shallow water on the northern coasts of Japan and does not extend south of Sagami Bay or north of the Hokkaido.

\section{OPHIOPHOLIS BRACHYACTIS, new species. $a$}

Disk $11 \mathrm{~mm}$. in diameter; arms about $55 \mathrm{~mm}$. long. Disk covered by large radial shields and small circular or oval plates, surrounding which are more or less numerous rounded or angular granules; these granules are largest at the interradial margins and in some specimens become there thick, tubercle-like spines with rough tips. Radial shields always conspicuous, much longer than broad. Arms rather broad and stout at base, with very attenuate tips; they measure three to five times the diameter of the disk, but as the attenuate tip is

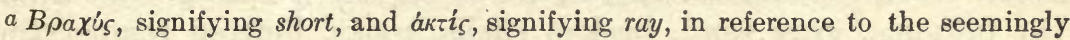
short, stout arms. 
easily broken, most of the specimens have the appearance of being unusually short-armed; this appearance is added to by the habit the animal has of coiling the arms vertically; a process by which the attenuate tips are protected but also concealed. Upper arm plates narrowly transverse elliptical in outline, nearly three times as wide as long at base of arm but becoming relatively narrower and longer; distal to each plate is a series of six to eight large squarish granules, placed together and not extending proximally along the sides of the upper arm plates. Interbrachial areas below covered by numerous short thorny stumps. Oral shields commonly wider than long, rounded laterally but with a distal angle. Adoral plates oblong, short, and wide. Oral papillæ spine-like but rather stout, in a cluster of four to six, just proximal to adoral plates. Teeth numerous, in . about a dozen horizontal series, the lowest of which contain several small teeth that might be called tooth papilla; the whole group makes a long, narrow, vertical or oblique oval, widest near the bottom.

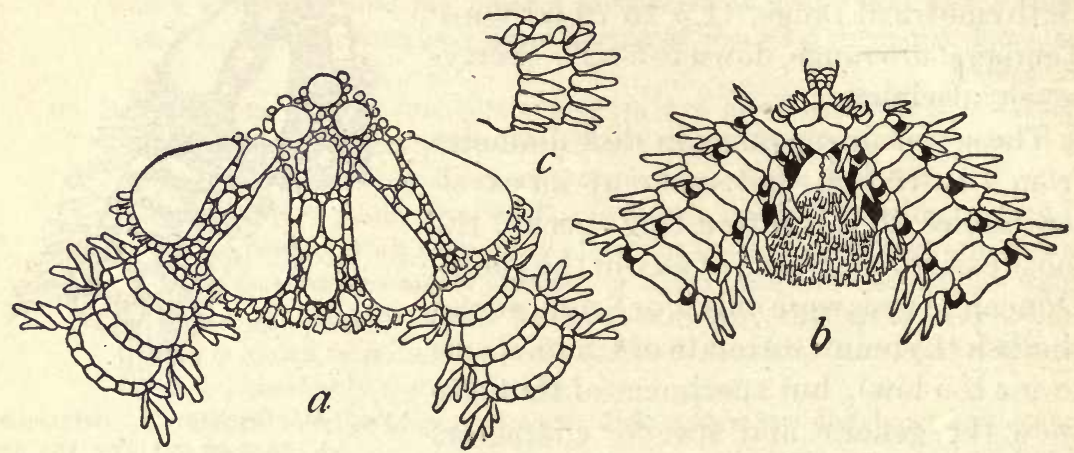

FIG. 44.-OPHIOPHOLIS BRACHYACTIS. $\times$ 4.5. $a$, FROM ABOVE; $b$, FROM BELOW; $c$, SIDE VIEW OF TWO ARM JOINTS NEAR DISK.

Genital slits and scales large. First under arm plate very small and indistinct; succeeding plates oblong, nearly twice as wide as long, separated from each other by spaces nearly as wide as themselves. Side arm plates moderate, not nearly meeting either below or above, the distal margin elevated into a conspicuous spine-bearing ridge; each plate carries seven short, thick, pointed spines, the middle ones longest (about equal to joint), the uppermost shortest. Tentacle pores large with a single tentacle scale. Color (dried from alcohol), yellow, cream color, or dirty white.

Localities.-Albatross station 3698, off Manazuru Zaki, Japan, 153 fathoms, green mud, volcanic ashes, sand, 7 specimens; station 4833 , off Ando Zaki, Japan, lat. $36^{\circ} 13^{\prime} 40^{\prime \prime}$ N.; long. $135^{\circ} 56^{\prime} 30^{\prime \prime}$ E., 79 fathoms, dark-gray sand, rocks, bottom temperature $53.2^{\circ}, 2$ specimens; station 4892 , Eastern Sea, lat. $32^{\circ} 27^{\prime} 30^{\prime \prime}$ N. ; long. $128^{\circ} 33^{\prime}$ E., 181 fathoms, gray sand, broken shells, rocks, bottom temperature $50.2^{\circ}, 7$ specimens; station 4900 , Eastern Sea, lat. $32^{\circ} 28^{\prime} 50^{\prime \prime}$ N.; 
long. $128^{\circ} 34^{\prime} 40^{\prime \prime}$ E., 139 fathoms, gray sand, broken shells, bottom temperature $52.9^{\circ}, 10$ specimens; station 4916 , Eastern Sea, lat. $30^{\circ}$ $25^{\prime} \mathrm{N}$.; long. $129^{\circ} 6^{\prime} 40^{\prime \prime} \mathrm{E} ., 361$ fathoms, gray sand, globigerina, broken shells, bottom temperature $42.7^{\circ}, 1$ specimen; station 4918 Eastern Sea, lat. $30^{\circ} 22^{\prime}$ N. ; long. $129^{\circ} 8^{\prime} 30^{\prime \prime}$ E., 361 fathons, gray sand, globigerina, broken shells, bottom temperature $42.7^{\circ}, 1$ specimen; station 4933 , Eastern Sea, lat. $30^{\circ} 59^{\prime}$ N. ; long. $130^{\circ} 29^{\prime} 50^{\prime \prime}$ E., 152 fathoms, rocky, bottom temperature $56^{\circ}, 8$ specimens; station 4934 , Eastern Sea, lat. $30^{\circ} 58^{\prime} 30^{\prime \prime}$ N.; long. $130^{\circ} 32^{\prime}$ E., 103 to 152 fathoms, rocky, bottom temperature $60.6^{\circ}$ to $56^{\circ}, 9$ specimens; station 4965 , off eastern Japan, lat. $33^{\circ} 35^{\prime} 20^{\prime \prime}$ N. ; long. $135^{\circ} 10^{\prime} 50^{\prime \prime}$ E., 191 fathoms, dark green-gray sand, shells, bottom temperature $49.4^{\circ}, 2$ specimens; station 5069, Suruga Gulf, lat. $35^{\circ} 3^{\prime} 10^{\prime \prime}$ N.; long. $138^{\circ} 47^{\prime}$ E., 108 to 131 fathoms, mud, sand, broken shells, bottom temperature $55.8^{\circ}$, 6 specimens; station 5091, Uraga Strait, lat. $35^{\circ} 4^{\prime} 10^{\prime \prime} \mathrm{N}$.; long. $139^{\circ} 38^{\prime} 12^{\prime \prime}$ E., 197 fathoms, green mud, coarse black sand, pebbles, bottom temperature $47.6^{\circ}, 2$ specimens; station 5094, Uraga Strait, lat. $35^{\circ} 4^{\prime} 42^{\prime \prime} \mathrm{N}$.; long. $139^{\circ} 38^{\prime} 20^{\prime \prime}$ E., 88 fathoms, black sand, broken shells, bottom temperature $54.8^{\circ}, 2$ specimens. Bathymetrical range, 79 to 361 fathoms. Temperature range $60.6^{\circ}$ to $42.7^{\circ}$. Fifty-seven specimens.

\section{Type.-Cat. No. 25642, U.S.N.M., from station 4833.}

Like mirabilis, this species is very easy to recognize, for it shows little tendency to variation, and in its color and in the arrangement of its supplementary upper arm plates, it is quite different from the other members of the genus. Its range is south of that of the other species, and it may be regarded as one of the characteristic ophiurans of southern Japan.

\section{OPHIOPHOLIS LONGISPINA, new species. $a$}

Disk $10 \mathrm{~mm}$. in diameter; arms about $80 \mathrm{~mm}$. long. Disk covered in large part by radial shields; between these and on center of disk are a number of more or less circular or elliptical plates; on many of these there is a single long slender spine; these spines may be acicular as in fig. $45 a$, or they may be rough with minute thorns and end in several teeth. Radial shields very large, much longer than wide, separated from each other or just touching at distal end. Upper arm plates circular or longer than wide, much swollen distally, more or less surrounded by rounded granules, which are not in close contact except at sides of plates, where several may touch each other; basal upper arm plates smaller than those farther out. Interbrachial areas below covered by spine-bearing plates. Oral shield very short and wide, with adoral plates nearly as large. Oral papillæ long, flat, and blunt, three or four in a cluster just proximal to adoral plate. Teeth

a Longus, signifying long, and spinus, signifying spine, in reference to the long arm spines. 
in a very narrow, oblique, oval area. Genital slits large, but genital scales rather slender and inconspicuous. First under arm plate very small, but succeeding plates large and somewhat hexagonal, scarcely in contact, about as long as wide. Side arm plates rather large, each one carrying a vertical spine-ridge upon which are borne six to eight rather slender, bluntly pointed arm spines; uppermost spine longest, about equal to three arm joints, lower ones successively shorter. Tentacle pores moderately large, each with a single blunt tentacle

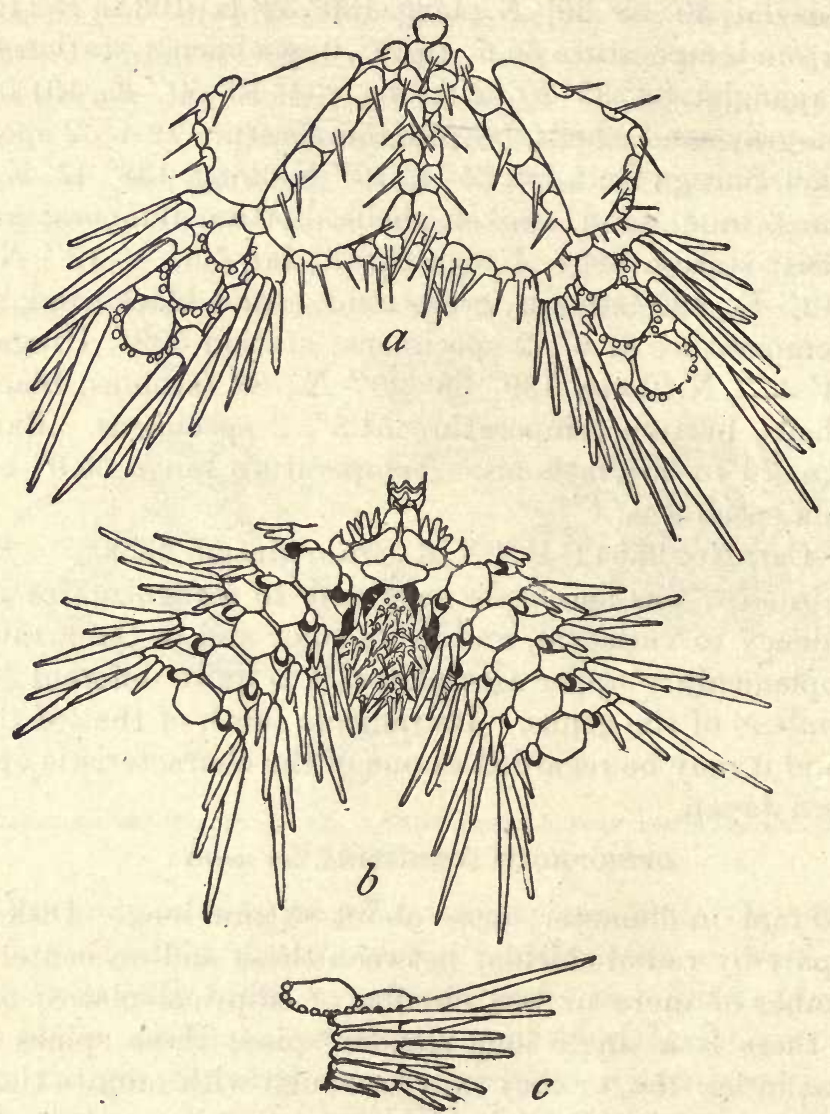

Fig. 45.-OPHIOPHOLIS LONGISPINA. $\times 5$. $a$, FROM ABOVE; $b$, FROM BELOW; $c$, SIDE VIEW OF TWO ARM JOINTS NEAR DISK.

scale. Color (dried from alcohol), deep pink, marked with lighter; pale pink becoming almost white; or light yellowish brown.

Localities.-Albatross station 2890 , off Oregon, lat. $43^{\circ} 46^{\prime} \mathrm{N}$.; long. $124^{\circ} 57^{\prime} \mathrm{W}$., 277 fathoms, gray sand, bottom temperature $42.2^{\circ}$, 3 specimens; station 3070 , off Washington, lat. $47^{\circ} 29^{\prime} 30^{\prime \prime} \mathrm{N}$.; long. $125^{\circ} 43^{\prime}$ W., 636 fathoms, green mud, bottom temperature $37.9^{\circ}$, 43 specimens; station 3071 , off Washington, lat. $47^{\circ} 29^{\prime} \mathrm{N}$.; long. $125^{\circ} 33^{\prime} 30^{\prime \prime}$ W., 685 fathoms, green mud, bottom temperature $38^{\circ}$, 3 specimens; station 3104 , off California, lat. $37^{\circ} 23^{\prime}$ N.; long. $123^{\circ} 8^{\prime}$ 
W., 391 fathoms, clay, bottom temperature $40.8^{\circ}, 3$ specimens. Bathymetrical range, 277 to 685 fathoms. Temperature range, $42.2^{\circ}$ to $37.9^{\circ}$. Fifty-two specimens.

Type.-Cat. No. 25653, U.S.N.M., from station 3071.

This species is undoubtedly very near the japonica forin of aculeata but the character of the disk spines is quite distinctive and the huge radial shields, long arm spines, and peculiar upper arm plates combine to give longispina an easily recognizable appearance. Some specimens, however, have the upper arm plates very clearly wider than long and scarcely at all swollen, while the supplementary granules are angular and near together. Such specimens resemble japonica very much, but the character of the disk distinguishes them. The general appearance of this species is remarkably Ophiothrix-like, the long arm spines, and finely spiny disk combining with the long, slender arms to make one think of that genus. The geographical, bathymetrical, and temperature ranges of longispina are all remarkably limited.

\section{OPHIOPHOLIS BAKERI.}

Ophiopholis bakeri McClendon, Univ. of California Publ., Zool., vol. 6, 1909, no. 3, p. 41.

Disk $10 \mathrm{~mm}$. in diameter; arms about $65 \mathrm{~mm}$. long. Disk plates completely concealed under a dense coat of delicate spines; these spines show great diversity in length, being longest near center of disk and in the interradial areas and shortest on the radial shields; they are more or less thorny and generally end in several teeth. Radial shields entirely concealed, though their outline can often be distinguished, emphasized by the shortness of the spines which cover them. Upper arm plates roundish, sometimes wider than long, often swollen distally; supplementary plates fairly numerous, especially at sides of upper arm plates, but not closely in contact. Interbrachial spaces below covered by a close coat of spines. Oral shields very small, somewhat hexagonal, much wider than long, with long, narrow adoral plates proximal to them. Oral papillæ flat and blunt, about three in a group proximal to each adoral plate. Teeth not peculiar. Under arm plates, side arm plates, tentacle pores, and tentacle scales essentially the same as in longispina. Arm spines five to seven; uppermost longest but hardly equal to two joints. Color (dried from alcohol), some shade of pink, ranging from very pale to quite deep, more or less marked and variegated with white.

Localities.-Albatross station 2861, off British Columbia, lat. $51^{\circ} 14^{\prime} \mathrm{N}$.; long. $129^{\circ} 50^{\prime}$ W., 204 fathoms, bottom temperature $42.6^{\circ}, 1$ specimen; station 2866 , off Washington, lat. $48^{\circ} 9^{\prime} \mathrm{N}$.; long. $125^{\circ} 3^{\prime}$ W., 171 fathoms, gray sand, bottom temperature $43.2^{\circ}$, 2 specimens; station 2877, off Washington, lat. $48^{\circ} 33^{\prime} \mathrm{N}$.; long. $124^{\circ} 53^{\prime} \mathrm{W}$., 59 fathoms, black sand, mud, bottom temperature $45.5^{\circ}$, 3 specimens; station 2886 , off Oregon, lat $43^{\circ} 59^{\prime}$ N.; long. $124^{\circ} 56^{\prime}$ 
$30^{\prime \prime}$ W., 50 fathoms, rocky, bottom temperature $48.1^{\circ}, 237$ specimens; station 2887 , off Oregon, lat. $43^{\circ} 58^{\prime} \mathrm{N}$.; long. $124^{\circ} 57^{\prime} \mathrm{W}$., 42 fathoms, clay, pebbles, bottom temperature $47.1^{\circ}, 49$ specimens; station 2888, off Oregon, lat. $43^{\circ} 58^{\prime} \mathrm{N}$.; long. $124^{\circ} 57^{\prime} 30^{\prime \prime} \mathrm{W}$., 41 fathoms, clay, pebbles, bottom temperature $47.6^{\circ}, 22$ specimens; station 2889 , off Oregon, lat. $43^{\circ} 59^{\prime}$ N.; long. $124^{\circ} 56^{\prime}$ W., 46 fathoms, clay, shells, bottom temperature $47.7^{\circ}, 4$ specimens; station 3050 , off Oregon, lat. $44^{\circ} 1^{\prime} 15^{\prime \prime} \mathrm{N}$.; long. $124^{\circ} 57^{\prime} \mathrm{W} ., 46$ fathoms, coral, broken shells, bottom temperature $46.1^{\circ}, 2$ specimens; station 3051 , off Oregon, lat. $43^{\circ} 59^{\prime} 15^{\prime \prime} \mathrm{N}$.; long. $124^{\circ} 58^{\prime} 30^{\prime \prime}$ W., 59 fathoms, coral, broken shells, rocky, 16 specimens; station 3052 , off

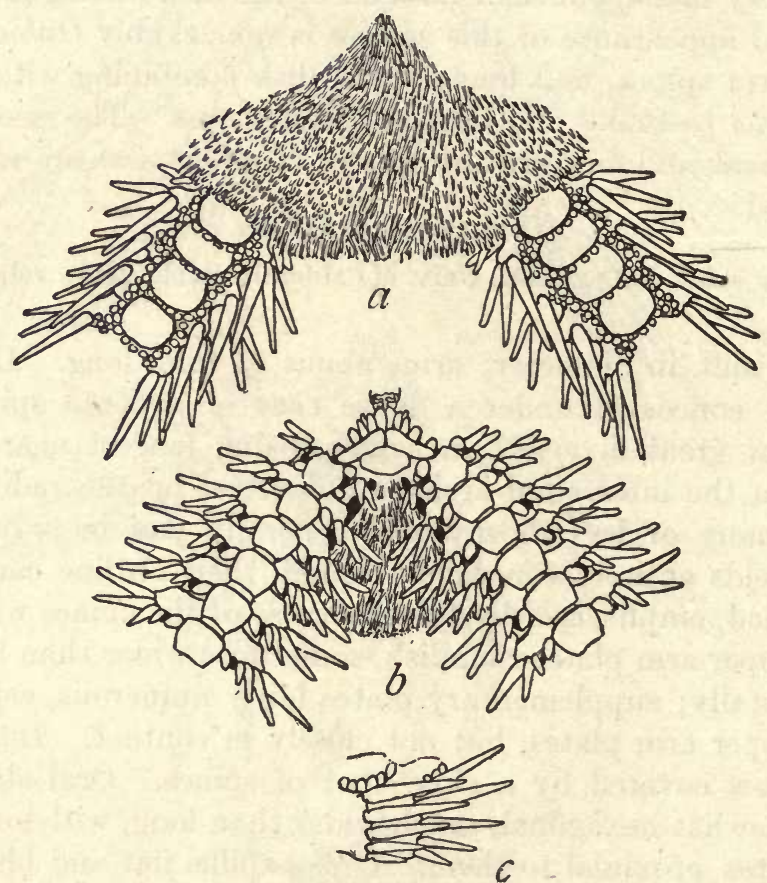

Fig. 46.-OPHIOPHOLIS BAKERI. $\times 5$. $a$, FROM ABOVE; $b$, FROM BELOW, $c$, SIDE VIEW OF TWO ARM JOINTS NEAR DISK.

Oregon, lat. $44^{\circ} \mathrm{N}$.; long. $124^{\circ} 57^{\prime}$ W., 48 fathoms, coral, broken shells, rocky, bottom temperature $49^{\circ}, 2$ specimens; station 3053 , off Oregon, lat. $44^{\circ} 4^{\prime} 30^{\prime \prime} \mathrm{N}$.; long. $124^{\circ} 50^{\prime}$ W., 64 fathoms, coral, broken shells, rocky, bottom temperature $47.3^{\circ}, 22$ specimens; station 3054 , off Oregon, lat. $44^{\circ} 13^{\prime} \mathrm{N}$.; long. $124^{\circ} 44^{\prime} 30^{\prime \prime}$ W., 53 fathoms, rocks, bottom temperature $48^{\circ}, 5$ specimens; station 3079 , off Oregon, lat. $43^{\circ} 59^{\prime} 15^{\prime \prime} \mathrm{N}$.; long. $124^{\circ} 44^{\prime} 40^{\prime \prime}$ W., 55 fathoms, rocky, bottom temperature $46.7^{\circ}, 2$ specimens; station 3160 , off California, lat. $37^{\circ} 48^{\prime} 35^{\prime \prime} \mathrm{N}$.; long. $123^{\circ} 12^{\prime} 40^{\prime \prime} \mathrm{W}$., 39 fathoms, rocky, bottom temperature $51.8^{\circ}, 2$ specimens; station 3184 , off California, lat. $36^{\circ} 26^{\prime} 40^{\prime \prime} \mathrm{N}$.; long. $122^{\circ} 00^{\prime} 5^{\prime \prime} \mathrm{W}$., 77 fathoms, sand, gravel, bottom 
temperature $46.4^{\circ}, 8$ specimens; station 3672 , off California, lat. $37^{\circ} 30^{\prime}$ N.; long. $123^{\circ} 2^{\prime}$ W., 68 fathoms, sand, coral, rocks, bottom temperature $49^{\circ}, 6$ specimens. Bathymetrical range, 39 to 204 fathoms. Temperature range, $51.8^{\circ}$ to $42.6^{\circ}$. Two hundred and eightythree specimens.

After this report had been completed, McClendon's paper on the ophiurans of the San Diego Region appeared, and it became evident that this Ophiopholis, which I had described and figured as new, was identical with the species to which he had given the name bakeri. But I determined to let my description and figures stand for comparison with those of longispina to which bakeri is very nearly allied. Typical specimens of the two forms are so different that anyone would regard them as perfectly distinct species, but some specimens of longispina have numerous disk spines which crowd around the radial shields, though not actually encroaching on them, while in some specimens of bakeri the spines on the radial shields are much smaller and farther apart than elsewhere. I have not seen a specimen which could not be placed in one species or the other with little hesitation, and for that reason it seems best to use two names, but it must be admitted that the line of separation between the two forms is very narrow. It is interesting to note that although bakeri ranges much farther south, the geographical areas of the two overlap, while the bathymetrical and temperature ranges are quite distinct.

\section{OPHIOPHOLIS ACULEATA var. JAPONICA.}

Ophiopholis japonica Lyman, Bull. Mus. Comp. Zoöl., vol. 6, 1879, p. 42.

Localities.-Albatross station 2842 , off.Alaska, lat. $54^{\circ} 15^{\prime} \mathrm{N}$.; long. $166^{\circ} 3^{\prime} \mathrm{W}$., 72 fathoms, pebbles, bottom temperature $41^{\circ}, 18$ specimens; station 2843 , off Alaska, lat. $53^{\circ} 56^{\prime}$ N.; long. $165^{\circ} 56^{\prime}$ W., 45 fathoms, broken shells, pebbles, bottom temperature $43.5^{\circ}, 2$ specimens; station 2846, off Alaska, lat. $54^{\circ} 8^{\prime}$ N.; long. $162^{\circ} 44^{\prime}$ W., 44 fathoms, gravel, bottom temperature $42^{\circ}, 115$ specimens; station 2847 , off Alaska, lat. $55^{\circ} 1^{\prime} \mathrm{N}$. ; long. $160^{\circ} 12^{\prime}$ W., 48 fathoms, fine gray sand, bottom temperature $42^{\circ}, 1$ specimen; station 2849, off Alaska, lat. $55^{\circ} 16^{\prime} \mathrm{N}$.; long. $160^{\circ} 28^{\prime} \mathrm{W}$., 69 fathoms, green mud, bottom temperature $43^{\circ}, 24$ specimens; station 2853 , off Alaska, lat. $56^{\circ} \mathrm{N}$.; long. $154^{\circ}$ $20^{\prime}$ W., 159 fathoms, gray sand, bottom temperature $41^{\circ}, 11$ specimens; station 2854 , off Alaska, lat. $56^{\circ} 55^{\prime}$ N.; long. $153^{\circ} 4^{\prime}$ W., 60 fathoms, black sand, bottom temperature $42.8^{\circ}, 2$ specimens; station 2856, off Alaska, lat. $58^{\circ} 7^{\prime} \mathrm{N}$.; long. $151^{\circ} 36^{\prime}$ W., 68 fathoms, gray sand, black specks, bottom temperature $44^{\circ}, 20$ specimens; station 2857, off Alaska, lat. $58^{\circ} 5^{\prime} \mathrm{N}$.; long. $150^{\circ} 46^{\prime} \mathrm{W}$., 51 fathoms, broken shells, gray sand, bottom temperature $44.6^{\circ}, 10$ specimens; station 2858 , off Alaska, lat. $58^{\circ} 17^{\prime} \mathrm{N}$.; long. $148^{\circ} 36^{\prime} \mathrm{W}$., 230 fathoms, blue mud, gravel, bottom temperature $39.8^{\circ}, 67$ specimens; station 3212 . 
off Alaska, lat. $54^{\circ} 5^{\prime} 30^{\prime \prime} \mathrm{N}$.; long. $162^{\circ} 54^{\prime}$ W., 49 fathoms, gray sand, black specks, bottom temperature $38^{\circ}, 219$ specimens; station 3213 , off Alaska, lat. $54^{\circ} 10^{\prime}$ N.; long. $162^{\circ} 57^{\prime} 30^{\prime \prime}$ W., 41 fathoms, black sand, 44 specimens; station 3214 , off Alaska, lat. $54^{\circ} \cdot 13^{\prime} \mathrm{N}$.; long. $163^{\circ} 6^{\prime}$ W., 38 fathoms, gray sand, gravel, 136 specimens; station 3215 , off Alaska, lat. $54^{\circ} 14^{\prime} 40^{\prime \prime} \mathrm{N}$.; long. $163^{\circ} 24^{\prime}$ W., 43 fathoms, gravel, bottom temperature $38.5^{\circ}, 50$ specimens; station 3226 , Bering Sea, lat. $55^{\circ} 1^{\prime}$ N.; long. $167^{\circ} 25^{\prime}$.W., 128 fathoms, mud, sand, shells, bottom temperature $38.5^{\circ}, 19$ specimens; station 3228 , Bering Sea, lat. $58^{\circ} 39^{\prime} 20^{\prime \prime} \mathrm{N}$.; long. $157^{\circ} 17^{\prime} 30^{\prime \prime}$ W., 8 fathoms, gray sand, pebbles, 1 specimen; station 3285 , Bering Sea, lat. $56^{\circ} 45^{\prime} 45^{\prime \prime} \mathrm{N}$.; long. $160^{\circ} 42^{\prime} 45^{\prime \prime}$ W., 35 fathoms, gray sand, black specks, bottom temperature $41^{\circ}, 3$ specimens; station 3311 , Bering Sea, lat. $53^{\circ} 39^{\prime}$ $36^{\prime \prime} \mathrm{N}$. ; long. $166^{\circ} 29^{\prime} 43^{\prime \prime} \mathrm{W}$., 85 fathoms, green mud, bottom temperature $41^{\circ}, 108$ specimens; station 3312 , Bering Sea, lat. $53^{\circ} 59^{\prime} 11^{\prime \prime} \mathrm{N}$.; long. $166^{\circ} 25^{\prime} 9^{\prime \prime} \mathrm{W}$., 45 fathoms, fine sand, mud, bottom temperature $43^{\circ}, 7$ specimens; station 3315 , Bering Sea, lat. $54^{\circ} 2^{\prime} 40^{\prime \prime}$ N.; long. $166^{\circ} 42^{\prime}$ W., 277 fathoms, green mud, sand, bottom temperature $38.5^{\circ}, 10$ specimens; station 3316 , Bering Sea, lat. $54^{\circ} 1^{\prime}$ N.; long. $166^{\circ} 48^{\prime} 45^{\prime \prime}$ W., 309 fathoms, black sand, gravel, bottom temperature $38.2^{\circ}, 9$ specimens; station 3317 , Bering Sea, lat. $53^{\circ} 57^{\prime} 40^{\prime \prime} \mathrm{N}$.; long. $166^{\circ} 59^{\prime} \mathrm{W}$., 165 fathoms, coarse sand, gravel, rocks, bottom temperature $39.5^{\circ}, 10$ specimens; station 3321 , Bering Sea, lat. $53^{\circ}$ $33^{\prime} 30^{\prime \prime} \mathrm{N}$.; long. $167^{\circ} 15^{\prime} 40^{\prime \prime}$ W., 54 fathoms, dark mud, bottom temperature $41.5^{\circ}, 13$ specimens; station 3322 , Bering Sea, lat. $53^{\circ}$ $28^{\prime} 45^{\prime \prime} \mathrm{N}$.; long. $167^{\circ} 23^{\prime} 50^{\prime \prime}$ W., 35 fathoms, black sand, bottom temperature $42.4^{\circ}, 5$ specimens; station 3331 , Bering Sea, lat. $54^{\circ} 1^{\prime}$ $40^{\prime \prime} \mathrm{N}$.; long. $166^{\circ} 48^{\prime} 50^{\prime \prime}$ W., 350 fathoms, mud, 2 specimens; station 3332 , Bering Sea, lat. $54^{\circ} 2^{\prime} 50^{\prime \prime}$ N.; long. $166^{\circ} 45^{\prime}$ W., 406 fathoms, rocky, sand, 13 specimens; station 3337, Bering Sea, lat. $53^{\circ} 55^{\prime} 30^{\prime \prime} \mathrm{N}$.; long. $163^{\circ} 26^{\prime} \mathrm{W}^{\circ}, 280$ fathoms, green mud, bottom temperature $39.3^{\circ}, 39$ specimens; station 3480 , Bering Sea, lat. $52^{\circ} 6^{\prime}$ $\mathrm{N}$.; long. $171^{\circ} 45^{\prime} \mathrm{W}$., 283 fathoms, black sand, coral, rocky, 6 specimens; station 3486, Bering Sea, lat. $57^{\circ} 19^{\prime}$ N.; long. $173^{\circ} 58^{\prime} \mathrm{W}$., 150 fathoms, green mud, fine sand, bottom temperature $38^{\circ}, 13$ specimens; station 3487 , Bering Sea, lat $57^{\circ} 10^{\prime} \mathrm{N}$.; long. $173^{\circ} 45^{\prime} \mathrm{W}$., 81 fathoms, green mud, fine sand, bottom temperature $37.6^{\circ}, 4$ specimens; station 3495 , Bering Sea, lat. $56^{\circ} 37^{\prime}$ N. ; long. $170^{\circ} 1^{\prime}$ W., 56 fathoms, green mud, fine sand, bottom temperature $38.5^{\circ}$, 3 specimens; station 3500 , Bering Sea, lat. $56^{\circ} 2^{\prime}$ N.; long. $169^{\circ} 30^{\prime}$ W., 121 fathoms, fine gray sand, gravel, bottom temperature $38.6^{\circ}, 3$ specimens; station 3545 , Bering Sea, lat. $56^{\circ} 15^{\prime}$ N.; long. $171^{\circ} 33^{\prime}$ W., 1,030 fathoms, green mud, fine sand, clay, bottom temperature $36^{\circ}$, 1 specimen; station 3602 , Bering Sea, lat. $56^{\circ} 32^{\prime} \mathrm{N}$. ; long. $172^{\circ} 40^{\prime} \mathrm{W}$., 81 fathoms, green mud, sand, bottom temperature $37.1^{\circ}, 45$ speci- 
mens; station 3661, Gulf of Tokyo, 169 fathoms, mud, pebbles, bottom temperature $48^{\circ}, 3$ specimens; station 3699, off Port Arari, Japan, 400 to 7.26 fathoms, gray mud, volcanic particles, 1 specimen; station 3785 , Bering Sea, North of Aleutian Islands, 270 fathoms, gray sand, broken shells, 21 specimens; station 4769 , Bering Sea, lat. $54^{\circ} 40^{\prime} 30^{\prime \prime}$ $\mathrm{N}$.; long. $179^{\circ} 14^{\prime}$ E., 237 to 244 fathoms, gray sand, green mud, bottom temperature $38.5^{\circ}, 2$ specimens; station 4770 , Bering Sea, lat. $54^{\circ} 31^{\prime} \mathrm{N}$.; long. $179^{\circ} 15^{\prime}$ E., 247 fathoms, 43 specimens; station 4771 , Bering Sea, lat. $54^{\circ} 30^{\prime}$ N.; long. $179^{\circ} 17^{\prime}$ E., 426 fathoms, broken shells, 183 specimens; station 4772 , Bering Sea, lat. $54^{\circ} 30^{\prime} 30^{\prime \prime}$ N.; long. $179^{\circ} 14^{\prime}$ E., 344 to 372 fathoms, green-brown sand, bottom temperature $38.1^{\circ}, 173$ specimens; station 4777 , Bering Sea, lat. $52^{\circ}$ $11^{\prime} \mathrm{N}$.; long. $179^{\circ} 49^{\prime}$ E., 43 to 52 fathoms, fine gravel, 2 specimens; station 4779 , Bering Sea, lat. $52^{\circ} 11^{\prime} \mathrm{N}$.; long. $179^{\circ} 57^{\prime}$ W., 54 to 56 fathoms, broken shells, pebbles, sand, 1 specimen; station 4781, off Aleutian Islands, lat. $52^{\circ} 14^{\prime} 30^{\prime \prime} \mathrm{N}$.; long. $174^{\circ} 13^{\prime}$ E., 482 fathoms, fine gray sand, pebbles, bottom temperature $38.6^{\circ}, 165$ specimens; station 4782 , off Aleutian Islands, lat. $52^{\circ} 55^{\prime} \mathrm{N}$.; long. $173^{\circ} 27^{\prime} \mathrm{E}$., 57 to 59 fathoms, rocks, gravel, 7 specimens; station 4784 , off Attu Island, lat. $52^{\circ} 55^{\prime} 40^{\prime \prime} \mathrm{N}$.; long. $173^{\circ} 26^{\prime}$ E., 135 fathoms, coarse pebbles, 145 specimens; station 4788 , off Copper Island, lat. $54^{\circ} 50^{\prime}$ $24^{\prime \prime}$ N.; long. $167^{\circ} 13^{\prime}$ E., 56 to 57 fathoms, green sand, 4 specimens; station 4789, off Copper Island, lat. $54^{\circ} 49^{\prime} 45^{\prime \prime} \mathrm{N}$.; long. $167^{\circ} 12^{\prime} 30^{\prime \prime}$ E., 56 fathoms, green sand, 1 specimen; station 4790 , off Bering Island, lat. $54^{\circ} 38^{\prime} 45^{\prime \prime} \mathrm{N}$.; long. $167^{\circ} 11^{\prime} 45^{\prime \prime}$ E., 64 fathoms, pebbles, 10 specimens; station 4791, off Bering Island, lat. $54^{\circ} 36^{\prime} 15^{\prime \prime} \mathrm{N}$.; long. $166^{\circ} 58^{\prime} 15^{\prime \prime}$ E., 72 to 76 fathoms, rocky, 10 specimens; station 4792 , off Bering Island, lat. $54^{\circ} 36^{\prime} 15^{\prime \prime} \mathrm{N}$.; long. $166^{\circ} 57^{\prime} 15^{\prime \prime}$ E., 72 fathoms, pebbled, 24 specimens; station 4797 , off Kamchatka, lat. $52^{\circ} 37^{\prime} 30^{\prime \prime}$ N.; long. $158^{\circ} 50^{\prime}$ E., 682 fathoms, green mud, coarse black sand, broken shells, bottom temperature $36.6^{\circ}, 2$ specimens; station 4803 , off Simushir Island, lat. $46^{\circ} 42^{\prime}$ N.; long. $151^{\circ} 45^{\prime}$ E., 229 fathoms, coarse pebbles, black sand, bottom temperature $35.9^{\circ}, 44$ specimens; station 4804 , off Simushir Island, lat. $46^{\circ} 42^{\prime}$ N.; long. $151^{\circ} 47^{\prime}$ E., 229 fathoms, coarse pebbles, black sand, bottom temperature $35.9^{\circ}$, 74 specimens; station 4809 , sea of Japan, lat. $41^{\circ} 18^{\prime} \mathrm{N}$.; long. $140^{\circ}$ $8^{\prime} 40^{\prime \prime}$ E., 90 to 207 fathoms, gray sand, pebbles, broken shells, bottom temperature $48.8^{\circ}, 61$ specimens; station 4810, Sea of Japan, lat. $41^{\circ} 17^{\prime} 20^{\prime \prime} \mathrm{N}$.; long. $140^{\circ} 7^{\prime}$ E., 195 fathoms, fine gray sand, bottom temperature $44.7^{\circ}, 18$ specimens; station 4812 , Sea of Japan, lat. $38^{\circ} 33^{\prime} \mathrm{N}$.; long. $138^{\circ} 40^{\prime}$ E., 176 to 200 fathoms, fine brown mud (?), bottom temperature $34.9^{\circ}, 6$ specimens; station 4822 , Sea of Japan, lat. $37^{\circ} 8^{\prime} 10^{\prime \prime} \mathrm{N}$.; long. $137^{\circ} 8^{\prime} \mathrm{E}$., 130 fathoms, green mud, bottom temperature $39.4^{\circ}, 40$ specimens; station 4826 , Sea of Japan, lat. $37^{\circ} 25^{\prime} \mathrm{N}$.; long. $137^{\circ} 32^{\prime}$ E., 114 fathoms, fine gray sand, 
black specks, bottom temperature $42.5^{\circ}, 6$ specimens; station 4861 , off Korea, lat. $36^{\circ} 19^{\prime} \mathrm{N}$.; long. $129^{\circ} 47^{\prime}$ E., 163 fathoms, green mud, bottom temperature $33.4^{\circ}, 1$ specimen; station 4967 , off eastern Japan, lat. $33^{\circ} 25^{\prime} 10^{\prime \prime} \mathrm{N}$.; long. $135^{\circ} 37^{\prime} 20^{\prime \prime}$ E., 244 to 253 fathoms, brown mud, sand, foraminifera, bottom temperature $45.9^{\circ}, 1$ specimen; station 4971, off eastern Japan, lat. $33^{\circ} 23^{\prime} 30^{\prime \prime}$ N.; long. $135^{\circ} 34^{\prime}$ E., 649 fathoms, brown-green mud, foraminifera, bottom temperature $38.1^{\circ}, 1$ specimen; station 4972 , off eastern Japan, lat. $33^{\circ} 25^{\prime} 45^{\prime \prime} \mathrm{N}$.; long. $135^{\circ} 33^{\prime}$ E., 440 fathoms, brown-green mud, foraminifera, bottom temperature $39.8^{\circ}, 1$ specimen; station 4980 , off eastern Japan, lat. $34^{\circ} 9^{\prime} \mathrm{N}$.; long. $137^{\circ} 55^{\prime}$ E., 507 fathoms, brown mud, fine sand, foraminifera, bottom temperature $39^{\circ}, 2$ specimens; station 4982 , Sea of Japan, lat. $43^{\circ}$ N.; long. $140^{\circ} 10^{\prime} 30^{\prime \prime}$ E., 390 to 428 fathoms, green mud, bottom temperature $32.7^{\circ}, 6$ specimens; station 4985 , Sea of Japan, lat. $43^{\circ} 5^{\prime} 20^{\prime \prime} \mathrm{N}$.; long. $140^{\circ} 15^{\prime} 15^{\prime \prime}$ E., 224 fathoms, green mud (?), bottom temperature $33.1^{\circ}, 1$ specimen; station 4987 , Sea of Japan, lat. $43^{\circ} 19^{\prime} 20^{\prime \prime}$ N. ; long. $140^{\circ} 17^{\prime}$ E., 59 fathoms, rocky, bottom temperature $44.8^{\circ}, 51$ specimens; station 4991, Sea of Japan, lat. $45^{\circ} 23^{\prime} 20^{\prime \prime}$ N.; long. $140^{\circ} 48^{\prime}$ E., 325 fathoms, green mud, bottom temperature $33^{\circ}, 2$ specimens; station 4995 , Sea of Japan, lat. $45^{\circ} 33^{\prime}$ $40^{\prime \prime}$ N.; long. $140^{\circ} 54^{\prime}$ E., 86 fathoms, black sand, pebbles, bottom temperature $43.4^{\circ}, 62$ specimens; station 4996 , Sea of Japan, lat. $45^{\circ}$ $35^{\prime} \mathrm{N}$.; long. $140^{\circ} 55^{\prime} \mathrm{E}$., 86 fathoms, black sand, pebbles, bottom temperature $43.4^{\circ}, 13$ specimens; station 4997, Gulf of Tartary, lat. $47^{\circ} 38^{\prime} 40^{\prime \prime} \mathrm{N}$.; long. $141^{\circ} 24^{\prime} 30^{\prime \prime}$ E., 318 fathoms, green mud, bottom temperature $32.8^{\circ}, 2$ specimens; station 5010, off Saghalin, lat. $46^{\circ} 30^{\prime} 30^{\prime \prime} \mathrm{N}$.; long. $142^{\circ} 43^{\prime} 30^{\prime \prime} \mathrm{E}$., 21 to 32 fathoms, green mud, sand, bottom temperature ?, 11 specimens; station 5017, Okhotsk Sea, lat. $46^{\circ} 43^{\prime} 30^{\prime \prime} \mathrm{N}$.; long. $143^{\circ} 45^{\prime}$ E., 64 fathoms, brown mud, fine black sand, rocks, coral, bottom temperature ?, 7 specimens; station 5018, Okhotsk Sea, lat. $46^{\circ} 41^{\prime} 30^{\prime \prime} \mathrm{N}$.; long. $143^{\circ} 57^{\prime}$ $40^{\prime \prime}$ E., 100 fathoms, brown mud, black sand, pebbles, bottom temperature $30.4^{\circ}, 2$ specimens; station 5031, Yezo Strait, lat. $44^{\circ} 4^{\prime} \mathrm{N}$.; long. $145^{\circ} 32^{\prime}$ E., 86 fathoms, dark sand, gravel, bottom temperature $43.7^{\circ}, 5$ specimens; station 5037 , off southern Hokkaido, lat. $42^{\circ} 2^{\prime} 40^{\prime \prime}$ N.; long. $142^{\circ} 33^{\prime} 20^{\prime \prime}$ E., 175 to 349 fathoms, bottom temperature $37.9^{\circ}, 4$ specimens; station 5038, off southern Hokkaido, lat. $42^{\circ} 2^{\prime} 40^{\prime \prime}$ N.; long. $142^{\circ} 36^{\prime}$ E., 175 fathoms, fine black sand, brown mud, broken shells, bottom temperature $37.1^{\circ}, 1$ specimen; station 5049, off Kinkwasan, Japan, lat. $38^{\circ} 12^{\prime}$ N.; long. $142^{\circ} 2^{\prime}$ E., 82 fathoms, dark gray sand, broken shells, foraminifera, bottom temperature $37.8^{\circ}, 2$ specimens; station 5079 , off Omai Saki, Japan, lat. $34^{\circ} 15^{\prime} \mathrm{N}$.; long. $138^{\circ}$ E., 475 to 505 fathoms, pebbles, bottom temperature $39.1^{\circ}$, 7 specimens; station 5080, off Omai Saki, Japan, lat. $34^{\circ} 10^{\prime} 30^{\prime \prime} \mathrm{N}$.; long. $138^{\circ} 40^{\prime}$ E., 505 fathoms, fine gray sand, globigerina, bottom 
temperature $38.7^{\circ}, 8$ specimens, station 5088, Sagami Bay, lat. $35^{\circ}$ $11^{\prime} 25^{\prime \prime}$ N.; long. $139^{\circ} 28^{\prime} 20^{\prime \prime}$ E., 369 to 405 fathoms, green mud, bottom temperature $41.8^{\circ}, 1$ specimen; station 5093, Uraga Strait, lat. $35^{\circ} 3^{\prime} 15^{\prime \prime} \mathrm{N}$.; long. $139^{\circ} 37^{\prime} 42^{\prime \prime}$ E., 302 fathoms, coarse black sand, bottom temperature $43.9^{\circ}, 1$ specimen; station 5095, Uraga Strait, lat. $35^{\circ} 5^{\prime} 34^{\prime \prime}$ N.; long. $139^{\circ} 38^{\prime} 36^{\prime \prime}$ E., 58 fathoms, fine black sand, broken shells, bottom temperature $57.8^{\circ}, 4$ specimens; Kadiak, 1 specimen; Prince of Wales Island, 1 specimen; Dolgoi Sound, 1
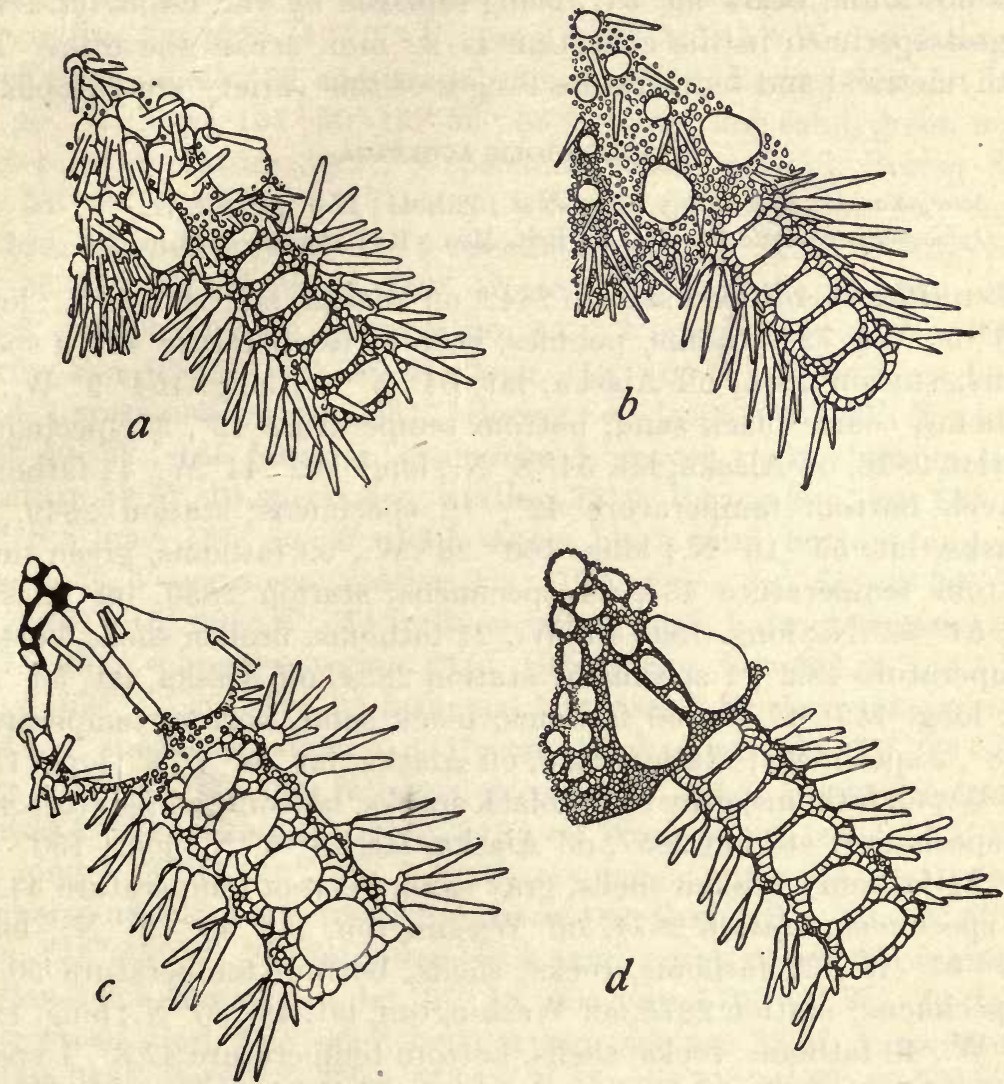

Fig. 47.-OPHiopholis ACULEATA VAR. JAPONICA. $a$, E TREME FORM WITH SMALL SUPPLEMENTARY UPPER ARM PLATES AND NUMEROUS LONG DISK SPINES, $\times 2.66 ; b$, MORE USUAL FORM WITH FEWER DISK BPINES, $\times 3.33 ; c$, UNUSUAL FORM WITH MANY DISK SCALES RESORBED, $\times 3.5 ; d$, TYPICAL FORM WITHOUT DISK SPINES, $\times 4$.

specimen; locality ?, 4 specimens. Bathymetrical range, 8 to 1,030 fathoms. Temperature range, 57.8 to $30.4^{\circ}$. Two thousand two hundred and eighty-two specimens.

A number of these specimens agree so well with Lyman's figures and description of japonica that I felt no doubt as to their identification, even before comparison with a cotype of that species. But I soon found that these specimens intergrade so completely with 
typical aculeata that it is impossible for me to separate them satisfactorily. The four figures $(47 a-d)$ will give a little idea of the diversity which this species shows in the disk covering and in the plates of the upper side of the arm. While typical japonica approaches kennerlyi, we find specimens at the other extreme which approach very near to longispina and bakeri. Although japonica is very common in Bering Sea and near the Aleutian Islands, it extends down on the Japanese coast nearly to lat. $33^{\circ}$, while on the American coast it is not found below lat. $54^{\circ}$, being replaced by var. kennerlyi. The largest specimen in the collection is $22 \mathrm{~mm}$. across the disk. The bathymetrical and temperature ranges of this variety are notable.

\section{OPHIOPHOLIS ACULEATA.}

Asterias aculeata Linnseus, Syst. Nat., 12th ed., 1767, p. 1101.

Ophiopholis aculeata GraY, List Brit. Mus., Rad. Anim., 1848, p. 25.

Localities.-Albatross station 2842, off Alaska, lat. $54^{\circ} 15^{\prime} \mathrm{N}$.; long. $166^{\circ} 3^{\prime}$ W., 72 fathoms, pebbles, bottom temperature $41^{\circ}, 9$ specimens; station 2845, off Alaska, lat. $54^{\circ} 5^{\prime} \mathrm{N}$.; long. $164^{\circ} 9^{\prime} \mathrm{W} ., 42$ fathoms, coarse black sand, bottom temperature $42^{\circ}, 37$ specimens; station 2846, off Alaska, lat. $54^{\circ} 8^{\prime} \mathrm{N}$.; long. $162^{\circ} 44^{\prime} \mathrm{W}$., 44 fathoms, gravel, bottom temperature $42^{\circ}, 12$ specimens; station 2849 , off Alaska, lat. $55^{\circ} 16^{\prime} \mathrm{N}$.; long. $160^{\circ} 28^{\prime} \mathrm{W}$., 69 fathoms, green mud, bottom temperature $43^{\circ}, 24$ specimens; station 2850, off Alaska, lat. $54^{\circ} 52^{\prime} \mathrm{N}$.; long. $159^{\circ} 46^{\prime} \mathrm{W}$., 21 fathoms, broken shells, bottom temperature $48.2^{\circ}, 1$ specimen; station 2854 , off Alaska, lat. $56^{\circ} 55^{\prime}$ N.; long. $153^{\circ} 4^{\prime}$ W., 60 fathoms, black sand, bottom temperature $42.8^{\circ}, 2$ specimens; station 2856 , off Alaska, lat. $58^{\circ} 7^{\prime} \mathrm{N}$.; long. $151^{\circ}$ $36^{\prime}$ W., 68 fathoms, gray sand, black specks, bottom temperature $44^{\circ}$, 15 specimens; station 2857 , off Alaska, lat. $58^{\circ} 5^{\prime} \mathrm{N}$.; long. $150^{\circ} 46^{\prime}$ W., 51 fathoms, broken shells, gray sand, bottom temperature $44.6^{\circ}$, 10 specimens; station 2874 , off Washington, lat. $48^{\circ} 30^{\prime} \mathrm{N}$.; long. $124^{\circ} 57^{\prime}$ W., 27 fathoms, rocks, shells, bottom temperature $50.3^{\circ}$, 4 specimens; station 2875 , off Washington, lat. $48^{\circ} 30^{\prime} \mathrm{N}$.; long. $124^{\circ}$ $57^{\prime}$ W., 40 fathoms, rocks, shells, bottom temperature $47.8^{\circ}, 1$ specimen; station 2887 , off Oregon, lat. $43^{\circ} 58^{\prime} \mathrm{N}$.; long. $124^{\circ} 57^{\prime}$ W., 42 fathoms, clay, pebbles, bottom temperature $47.1^{\circ}, 1$ specimen; station 3095 , off Oregon, lat. $42^{\circ} 44^{\prime} 45^{\prime \prime}$ N.; long. $124^{\circ} 38^{\prime} 10^{\prime \prime}$ W., 42 fathoms, rocks, stones, broken shells, bottom temperature $47^{\circ}, 3$ specimens; station 3158 , off California, lat. $37^{\circ} 47^{\prime} 30^{\prime \prime} \mathrm{N}$.; long. $123^{\circ}$ $10^{\prime} 40^{\prime \prime}$ W., 29 fathoms, rocky, bottom temperature $51.4^{\circ}, 1$ specimen; station 3159 , off California, lat. $37^{\circ} 47^{\prime} 20^{\prime \prime} \mathrm{N}$.; long. $123^{\circ} 10^{\prime}$ W., 27 fathoms, rocky, 1 specimen; station 3168 , off California, lat. $38^{\circ} 1^{\prime} 25^{\prime \prime} \mathrm{N}$.; long. $123^{\circ} 26^{\prime} 55^{\prime \prime} \mathrm{W}$., 34 fathoms, rocky, coral, 1 specimen; station 3212 , off Alaska, lat. $54^{\circ} 5^{\prime} 30^{\prime \prime} \mathrm{N}$.; long. $162^{\circ} 54^{\prime} \mathrm{W}$., 49 fathoms, gray sand, black specks, bottom temperature $38^{\circ}, 99$ 
specimens; station 3213 , off Alaska, lat. $54^{\circ} 10^{\prime} \mathrm{N}$.; long. $162^{\circ} 57^{\prime} 30^{\prime \prime}$ W., 41 fathoms, black sand, 43 specimens; station 3214, off Alaska, lat. $54^{\circ} 13^{\prime} \mathrm{N}$.; long. $163^{\circ} 6^{\prime} \mathrm{W}$., 38 fathoms, gray sand, gravel, 14 specimens; station 3215 , off Alaska, lat. $54^{\circ} 14^{\prime} 40^{\prime \prime} \mathrm{N}$.; long. $163^{\circ}$ $24^{\prime}$ W., 43 fathoms, gravel, bottom temperature $38.5^{\circ}, 7$ specimens; station 3262 , Bering Sea, lat. $54^{\circ} 49^{\prime} 30^{\prime \prime} \mathrm{N}$.; long. $165^{\circ} 2^{\prime} \mathrm{W}$., 43 fathoms, black sand, rocks, bottom temperature $43^{\circ}, 4$ specimens; station 3263 , Bering Sea, lat. $55^{\circ} 4^{\prime}$ N.; long. $165^{\circ} 4^{\prime}$ W., 61 fathoms, black mud, bottom temperature $39.5^{\circ}, 1$ specimen; station 3274 , Bering Sea, lat. $55^{\circ} 34^{\prime} 30^{\prime \prime}$ N.; long. $162^{\circ} 31^{\prime} 45^{\prime \prime}$ W., 19 fathoms, black sand, shells, 36 specimens; station 3282 , Bering Sea, lat. $56^{\circ}$ $30^{\prime} 45^{\prime \prime} \mathrm{N}$.; long. $161^{\circ} 50^{\prime} 15^{\prime \prime} \mathrm{W}$., 53 fathoms, fine sand, green mud, bottom temperature $38.2^{\circ}, 8$ specimens; station 3283 , Bering Sea, lat. $56^{\circ} 28^{\prime} \mathrm{N}$.; long. $161^{\circ} 16^{\prime} 30^{\prime \prime} \mathrm{W}$., 39 fathoms, fine gray sand, bottom temperature $40.3^{\circ}, 1$ specimen; station 3285, Bering Sea, lat. $56^{\circ} 45^{\prime} 45^{\prime \prime} \mathrm{N}$.; long. $160^{\circ} 42^{\prime} 45^{\prime \prime}$ W., 35 fathoms, gray sand, black specks, bottom temperature $41^{\circ}, 3$ specimens; station 3289 , Bering Sea, lat. $56^{\circ} 44^{\prime} 30^{\prime \prime} \mathrm{N}$.; long. $159^{\circ} 16^{\prime} \mathrm{W}$., 16 fathoms, black sand, 1 specimen; station 3317 , Bering Sea, lat. $53^{\circ} 57^{\prime} 40^{\prime \prime}$ N.; long. $166^{\circ} 59^{\prime} \mathrm{W}$., 165 fathoms, coarse sand, gravel, rocks, bottom temperature $39.5^{\circ}$, 10 specimens; station 3319 , Bering Sea, lat. $53^{\circ} 40^{\prime}$ $30^{\prime \prime} \mathrm{N}$.; long. $167^{\circ} 30^{\prime} \mathrm{W}$., 59 fathoms, black sand, bottom temperature $40.8^{\circ}, 3$ specimens; station 3321 , Bering Sea, lat. $53^{\circ} 33^{\prime} 30^{\prime \prime} \mathrm{N}$.; long. $167^{\circ} 15^{\prime} 40^{\prime \prime} \mathrm{W}$., 54 fathoms, dark mud, bottom temperature $41.5^{\circ}, 20$ specimens; station 3322 , Bering Sea, lat. $53^{\circ} 28^{\prime} 45^{\prime \prime} \mathrm{N}$.; long. $167^{\circ} 23^{\prime} 50^{\prime \prime}$ W., 35 fathoms, black sand, bottom temperature $42.4^{\circ}, 1$ specimen; station 3337 , off Alaska, lat. $53^{\circ} 55^{\prime} 30^{\prime \prime} \mathrm{N}$.; long. $163^{\circ} 26^{\prime}$ W., 280 fathoms, green mud, sand, bottom temperature $39.3^{\circ}, 6$ specimens; station 3443 , off Washington, lat. $48^{\circ} 13^{\prime} 30^{\prime \prime}$ N.; long. $123^{\circ} 11^{\prime} 20^{\prime \prime}$ W., 97 fathoms, green mud, pebbles, bottom temperature $46^{\circ}, 2$ specimens; station 3480 , Bering Sea, lat. $52^{\circ} 6^{\prime} \mathrm{N}$.; long. $171^{\circ} 45^{\prime} \mathrm{W}$.; 283 fathoms, black sand, coral, rocky, 6 specimens; station 3482 , Bering Sea, lat. $57^{\circ} 18^{\prime}$ N.; long. $170^{\circ} 42^{\prime}$ W., 42 fathoms, green mud, fine sand, bottom temperature $38.9^{\circ}, 1$ specimen; station 3485 , Bering Sea, lat. $57^{\circ} 18^{\prime}$ N. ; long. $172^{\circ} 34^{\prime}$ W., 62 fathoms, green mud, bottom temperature $37.1^{\circ}, 1$ specimen; station 3487 , Bering Sea, lat. $57^{\circ} 10^{\prime}$ N. ; long. $173^{\circ} 45^{\prime}$ W., 81 fathoms, green mud, fine sand, bottom temperature $37.6^{\circ}, 4$ specimens; station 3496 , Bering Sea, lat. $56^{\circ} 32^{\prime}$ N.; long. $169^{\circ} 45^{\prime}$ W., 41 fathoms, gray sand, stones, green mud, bottom temperature $39.9^{\circ}, 13$ specimens; station 3497 , Bering Sea, lat. $56^{\circ} 18^{\prime} \mathrm{N}$.; long. $169^{\circ} 38^{\prime}$ W., 86 fathoms, gray sand, black specks, bottom temperature $38.7^{\circ}, 1$ specimen; station 3498 , Bering Sea, lat. $56^{\circ} 13^{\prime}$ N.; long. $169^{\circ} 36^{\prime}$ W., 142 fathoms, fine gray sand, gravel, bottom temperature $38.6^{\circ}, 3$ specimens; $34916^{\circ}-$ Bull. $75-11-9$ 
station 3500 , Bering Sea, lat. $52^{\circ} 2^{\prime}$ N. ; long. $169^{\circ} 30^{\prime}$ W., 121 fathoms, fine gray sand, gravel, bottom temperature $38.6^{\circ}, 11$ specimens; station 3546 , Bering Sea, lat. $54^{\circ} 12^{\prime}$ N. ; long. $165^{\circ} 42^{\prime}$ W., 36 fathoms, gravel, black sand, bottom temperature $45.6^{\circ}, 4$ specimens; station 3552 , Bering Sea, lat. $56^{\circ} 28^{\prime}$ N.; long. $169^{\circ} 28^{\prime}$ W., 54 fathoms, black sand, rocky, bottom temperature $39.8^{\circ}, 19$ specimens; station 3558 , Bering Sea, lat. $56^{\circ} 58^{\prime}$ N.; long. $170^{\circ} 9^{\prime}$ W., 25 fathoms, sand, dark specks, rocky, bottom temperature $42.5^{\circ}, 33$ specimens; station 3560 , Bering Sea, lat. $56^{\circ} 40^{\prime}$ N.; long. $169^{\circ} 20^{\prime}$ W., 43 fathoms, fine gray sand, black specks, bottom temperature $40.7^{\circ}, 3$ specimens; station 3599 , Bering Sea, lat. $52^{\circ} 5^{\prime}$ N.; long. $177^{\circ} 40^{\prime}$ W., 55 fathoms, rocky, fine sand, shells, 60 specimens; station 3609 , Bering Sea, lat. $55^{\circ} 35^{\prime}$ N.; long. $168^{\circ} 20^{\prime}$ W., 74 fathoms, green mud, sand, bottom temperature $37.9^{\circ}, 1$ specimen; station 4772 , Bering Sea, lat. $54^{\circ} 30^{\prime} 30^{\prime \prime} \mathrm{N}$.; long. $179^{\circ} 14^{\prime}$ E., 344 to 372 fathoms, green-brown sand, bottom temperature $38.1^{\circ}, 5$ specimens; station 4777 , Bering Sea, lat. $52^{\circ} 11^{\prime} \mathrm{N}$.; long. $179^{\circ} 49^{\prime}$ E., 43 to 52 fathoms, fine gravel, 240 specimens; station 4778 , Bering Sea, lat. $52^{\circ} 12^{\prime}$ N.; long. $179^{\circ} 52^{\prime}$ E., 33 to 43 fathoms, fine black gravel, pebbles, broken shells, 85 specimens; station 4779 , Bering Sea, lat. $52^{\circ} 11^{\prime}$ N.; long. $179^{\circ} 57^{\prime}$ W., 54 to 56 fathoms, broken shells, pebbles, sand, 102 specimens; station 4782, off Aleutians, lat. $52^{\circ} 55^{\prime} \mathrm{N}$.; long. $173^{\circ} 27^{\prime}$ E., 57 to 59 fathoms, rocks, gravel, 156 specimens; station 4788 , off Copper Island, lat. $54^{\circ} 50^{\prime} 24^{\prime \prime}$ N.; long. $167^{\circ} 13^{\prime}$ E., 56 to 57 fathoms, green sand, 1 specimen; station 4792 , off Bering Island, lat. $54^{\circ} 36^{\prime} 15^{\prime \prime} \mathrm{N}$.; long. $166^{\circ} 57^{\prime} 15^{\prime \prime}$ E., 72 fathoms, pebbles, 3 specimens; station 4860 , Sea of Japan, lat. $36^{\circ} 18^{\prime} \mathrm{N}$.; long. $129^{\circ} 44^{\prime}$ E., 122 fathoms, green mud, bottom temperature $34.1^{\circ}, 1$ specimen; station 4987 , Sea of Japan, lat. $43^{\circ} 19^{\prime}$ $20^{\prime \prime} \mathrm{N}$. ; long. $140^{\circ} 17^{\prime} \mathrm{E}$., 59 fathoms, rocky, bottom temperature $44.8^{\circ}, 4$ specimens; station 4994 , Sea of Japan, lat. $45^{\circ} 27^{\prime} 50^{\prime \prime} \mathrm{N}$.; long. $140^{\circ} 54^{\prime}$ E., 190 fathoms, brown mud, fine black sand, bottom temperature $34^{\circ}, 24$ specimens; station 4996 , Sea of Japan, lat. $45^{\circ}$ $35^{\prime} \mathrm{N}$.; long $140^{\circ} 55^{\prime}$ E., 86 fathoms, black sand, pebbles, bottom temperature $43.4^{\circ}, 4$ specimens; station 4997 , Gulf of Tartary, lat. $47^{\circ}$ $38^{\prime} 40^{\prime \prime} \mathrm{N}$.; long. $141^{\circ} 24^{\prime} 30^{\prime \prime}$ E., 318 fathoms, green mud, bottom temperature $32.8^{\circ}, 1$ specimen; station 5016 , Okhotsk Sea, lat. $46^{\circ}$ $44^{\prime} 30^{\prime \prime} \mathrm{N}$.; long. $143^{\circ} 45^{\prime}$ E., 64 fathoms, brown mud, fine black sand, rocks, coral, bottom temperature $29.8^{\circ}, 1$ specimen; station 5017 , Okhotsk Sea, lat. $46^{\circ} 43^{\prime} 30^{\prime \prime}$ N.; long. $143^{\circ} 45^{\prime}$ E., 64 fathoms, brown mud, fine black sand, rocks, coral, bottom temperature $29.8^{\circ}$, 2 specimens; station 5020, Okhotsk Sea, lat. $48^{\circ} 32^{\prime} 45^{\prime \prime}$ N.; long. $145^{\circ} 7^{\prime} 30^{\prime \prime}$ E., 73 fathoms, green mud, sand, pebbles, bottom temperature $30.9^{\circ}, 3$ specimens; station 5021 , Okhotsk Sea, lat. $48^{\circ} 32^{\prime}$ $30^{\prime \prime} \mathrm{N}$.; long. $145^{\circ} 8^{\prime} 45^{\prime \prime} \mathrm{E}$., 73 fathoms, green mud, sand, pebbles, bottom temperature $30.9^{\circ}, 3$ specimens; Captains Harbor, Unalaska, 
40 specimens; Unalaska, 4 specimens; Kyska, 9 to 12 fathoms, 62 specimens; Port Levasheff, Unalaska, 20 to 30 fathoms, 1 specimen; Port Etches, Alaska, 5 specimens; Constantine Harbor, 15 specimens; Unga, 3 specimens; Agattu, 46 specimens; Iliuliuk, 64 specimens; Port Althorp, Alaska, 1 specimen; Chineak Bay, Kadiak, 1 specimen; Medui Island, 2 specimens; Aleutian Islands, 2 specimens; Bering Island, 19 specimens; Shumagin Islands, 1 specimen; Dolgoi Sound, 30 fathoms, 1 specimen; Bay of Islands, 8 specimens; Avatscha Bay, Kamtchatka, 1 specimen; 10 miles west of Point Franklin, Alaska, $13 \frac{1}{2}$ fathoms, sand, 21 specimens; between Icy Cape and Cape Lisburne, Alaska, 7 specimens; lat. $53^{\circ} 11^{\prime} \mathrm{N}$.; long. $166^{\circ} 51^{\prime} \mathrm{W}$. 84 fathoms, black sand, pebbles, bottom temperature $40.6^{\circ}, 8$ specimens; Bering Straits, 2 specimens; Sitka, 1 specimen; Alaska, 134 specimens; Arctic Ocean, 1 specimen; Albatross Hydrographic station 1141, off Alaska, 84 fathoms, 8 specimens. Bathymetric range, 9 to 372 fathoms. Temperature range, $51.4^{\circ}$ to $29.8^{\circ}$. One thousand six hundred and forty-three specimens.

These specimens vary greatly in the disk covering, ranging all the way from those with numerous disk plates separated by lines and bands of nearly spherical granules to those in which the disk is largely covered by coarse spines, and only one or two plates can be distinguished. Many of the specimens so grade into japonica that separation from that variety is difficult and arbitrary. As a rule, the supplementary upper arm plates are much

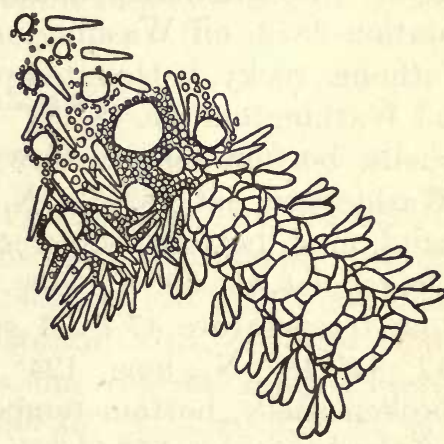

Fig. 48.-Ophiopholis aculeata. $\times 3$. FROM ABOVE. coarser and more angular than in japonica (compare fig. 48 with fig. $47 b)$, and this peculiarity is very noticeable when these Alaskan specimens are compared with some from the coast of Maine. The majority of the Alaskan specimens have relatively few large supplementary plates, as in fig. 48, while the Maine specimens have numerous small ones; in the Alaskan specimens, too, the disk is commonly more or less spiny, while I have never seen spiny specimens from the Atlantic. The Albatross collections leave no doubt that in Ophiopholis aculeata, as in Ophiura sarsii and $O$. nodosa, we have a species of circumpolar distribution extending far to the south in both the Atlantic and Pacific oceans. The specimens here recorded from off Washington, Oregon, and California are all small and obviously young. They would probably be more properly regarded as var. kennerlyi, but as they are too young to show definite characters, it has seemed best to record them simply as aculeata One of the specimens from Captains Harbor is remark- 
able in that it has only four rays. The largest specimen is $18 \mathrm{~mm}$. across the disk, a smaller maximum than that of either of the two varieties.

\section{OPHIOPHOLIS ACULEATA var. KENNERLYI.}

Ophiopholis kennerlyi Lyman, Proc. Boston Soc. Nat. Hist., vol. 7, 1860, p. 200.

Ophiopholis caryi Lyman, Proc. Boston Soc. Nat. Hist., vol. 7, 1860, p. 261.

Localities.-Albatross station 2849 , off Alaska, lat. $55^{\circ} 16^{\prime} \mathrm{N}$.; long. $160^{\circ} 28^{\prime}$ W., 69 fathoms, green mud, bottom temperature $43^{\circ}$, 1 specimen; station 2850 , off Alaska, lat. $54^{\circ} 52^{\prime} \mathrm{N}$.; long. $159^{\circ} 46^{\prime} \mathrm{W}$., 21 fathoms, broken shells, bottom temperature $48.2^{\circ}, 62$ specimens; station 2856, off Alaska, lat. $58^{\circ} 7^{\prime}$ N.; long. $151^{\circ} 36^{\prime} \mathrm{W}$., 68 fathoms, gray sand, black specks, bottom temperature, $44^{\circ}, 5$ specimens; station 2862 , off Washington, lat. $50^{\circ} 49^{\prime} \mathrm{N}$.; long. $127^{\circ} 36^{\prime} 30^{\prime \prime} \mathrm{W}$., 238 fathoms, gray sand and pebbles, bottom temperature $44.7^{\circ}, 7$ specimens; station 2865 , off Washington, lat. $48^{\circ} 12^{\prime} \mathrm{N}$.; long. $122^{\circ}$ $49^{\prime} \mathrm{W}$., 40 fathoms, pebbles, bottom temperature $51.7^{\circ}, 6$ specimens; station 2873 , off Washington, lat. $48^{\circ} 30^{\prime} \mathrm{N}$.; long. $124^{\circ} 57^{\prime} \mathrm{W}$, 40 fathoms, rocky, bottom temperature $47.8^{\circ}, 3$ specimens; station 2875 , off Washington, lat. $48^{\circ} 30^{\prime} \mathrm{N}$.; long. $124^{\circ} 57^{\prime} \mathrm{W}$., 40 fathoms, rocks, shells, bottom temperature $47.8^{\circ}, 12$ specimens; station 2877 , off Washington, lat $48^{\circ} 33^{\prime} \mathrm{N}$.; long. $124^{\circ} 53^{\prime}$ W., 59 fathoms, black sand, mud, bottom temperature $45.5^{\circ}, 3$ specimens; station 2889 , off Oregon, lat. $43^{\circ} 59^{\prime} \mathrm{N}$.; long. $124^{\circ} 56^{\prime}$ W., 46 fathoms, clay, shells, bottom temperature $47.7^{\circ}, 1$ specimen; station 3095 , off Oregon, lat. $42^{\circ} 44^{\prime} 45^{\prime \prime} \mathrm{N}$.; long. $124^{\circ} 38^{\prime} 10^{\prime \prime} \mathrm{W}$., 42 fathoms, rocks, stones, broken shells, bottom temperature $47^{\circ}, 3$ specimens; station 3116 , off California, lat. $37^{\circ} 5^{\prime} 30^{\prime \prime} \mathrm{N}$.; long. $122^{\circ} 19^{\prime} \mathrm{W}$., 16 fathoms, rocky, 6 specimens; station 3159 , off California, lat. $37^{\circ} 47^{\prime} 20^{\prime \prime} \mathrm{N}$.; long. $123^{\circ} 10^{\prime} \mathrm{W}$., 27 fathoms, rocky, 4 specimens; station 3214 , off Alaska, lat. $54^{\circ} 13^{\prime} \mathrm{N}$.; long. $163^{\circ} 6^{\prime}$ W., 38 fathoms, gray sand, gravel, 2 specimens; station 3220 , Bering Sea, lat. $54^{\circ} 15^{\prime} \mathrm{N}$.; long. $165^{\circ} 6^{\prime} \mathrm{W}$., 34 fathoms, gravel, broken shells, 2 specimens; station 3262 , Bering Sea, lat. $54^{\circ} 49^{\prime} 30^{\prime \prime}$ N.; long. $165^{\circ} 2^{\prime}$ W., 43 fathoms, broken shells, rocks, bottom temperature $40.7^{\circ}, 16$ specimens; station 3322 , Bering Sea, lat. $53^{\circ} 28^{\prime} 45^{\prime \prime} \mathrm{N}$.; long. $167^{\circ} 23^{\prime} 50^{\prime \prime}$ W., 35 fathoms, black sand, bottom temperature $42.4^{\circ}, 2$ specimens; station 3593 , off Washington, lat. $48^{\circ} 11^{\prime} 30^{\prime \prime} \mathrm{N}$.; long. $122^{\circ} 48^{\prime} \mathrm{W}$., 37 fathoms, rocky, bottom temperature $46^{\circ}, 3$ specimens; station 4193 , off Bowen Island, Gulf of Georgia, 18 to 23 fathoms, green mud, fine sand, bottom temperature $50.3^{\circ}, 1$ specimen; Humboldt Bay, Alaska, 41 specimens; Kadiak, 16 specimens; Portage Bay, Alaska, 7 specimens; Bellkofski, 1 specimen; Unalaska, 6 specimens; Semidi Island, 8 fathoms, 5 specimens; Donnelly Point, Loring, Alaska, 16 specimens; Killisnoo, Alaska, 15 specimens; Mary Island, Alaska, 
1 specimen; Round Island, Unga, 2 specimens; Sitka, 1 specimen; Alaska, 9 specimens; Straits of Fuca, 2 specimens; Puget Sound, 1 specimen; Monterey, California, 4 specimens; west coast of America, 1 specimen. Bathymetrical range, 8 to 238 fathoms. Temperature range, $51.7^{\circ}$ to $40.7^{\circ}$. Two hundred and sixty-seven specimens.

The Albatross collections leave no room for doubt that the intergradation between caryi, kennerlyi, and aculeata is complete, but it is convenient to retain the name kennerlyi for the ordinary American Pacific coast form which has only radial plates visible, or none at all, and no spines on the disk. The largest specimen in the collec-

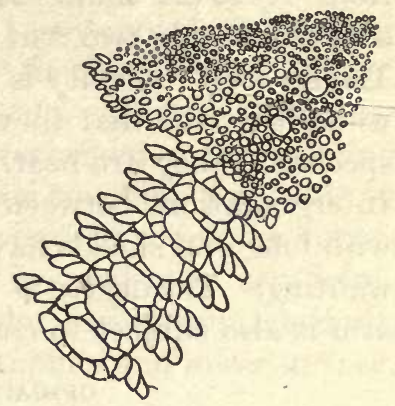

Fig. 49.-OPHIOPHOLIS ACULEATA VAR. KENNERLYI. $\times 2.66 . \quad$ FROM ABOVE. tion is from Kadiak and measures $22 \mathrm{~mm}$. across the disk on which only three of the radii have bare plates.

\section{OPHIOCHITON FASTIGATUS.}

Ophiochiton fastigatus Lyman, Bull. Mus. Comp. Zoöl., vol. 5, 1878, p. 132.

Localities.-Albatross station 3695, off Tsuragi Saki, Honshu Island, Japan, 110 to 259 fathoms, green mud, fine sand, 8 specimens; station 3697, off Manazuru Zaki, Honshu Island, Japan, 120 to 265 fathoms, gray mud, volcanic sand, 2 specimens; station 3704, off Seno Umi, Honshu Island, Japan, 94 to 150 fathoms, fine volcanic sand, 4 specimens; station 4907 , Eastern Sea, lat. $31^{\circ} 39^{\prime} 30^{\prime \prime}$ N.; long. $129^{\circ} 24^{\prime}$ E., 406 fathoms, gray globigerina ooze, bottom temperature $42.6^{\circ}, 1$ specimen; station 5056 Suruga Gulf, Japan, lat. $34^{\circ} 57^{\prime} 35^{\prime \prime}$ N.; long. $138^{\circ} 43^{\prime} 35^{\prime \prime}$ E., 258 fathoms, green mud, broken shells, foraminifera, bottom temperature $46^{\circ}, 1$ specimen; station 5057, Suruga Gulf, Japan, lat. $34^{\circ} 58^{\prime} 40^{\prime \prime}$ N.; long. $138^{\circ} 34^{\prime}$ E., 270 fathoms, gray mud, bottom temperature $44.8^{\circ}, 1$ specimen; station 5073, Suruga Gulf, Japan, lat. $34^{\circ} 46^{\prime} \mathrm{N}$.; long. $138^{\circ} 21^{\prime} 50^{\prime \prime}$ E., 148 fathoms, gray mud, bottom temperature $54.6^{\circ}, 3$ specimens; station 5088, Sagami Bay, lat. $35^{\circ} 11^{\prime} 25^{\prime \prime} \mathrm{N}$.; long. $139^{\circ} 28^{\prime} 20^{\prime \prime}$ E., 369 to 405 fathoms, green mud, bottom temperature $41.8^{\circ}, 2$ specimens; station 5091, Uraga Strait, lat. $35^{\circ} 4^{\prime} 10^{\prime \prime} \mathrm{N}$.; long. $139^{\circ} 38^{\prime} 12^{\prime \prime}$ E., 197 fathoms, green mud, coarse black sand, pebbles, bottom temperature $47.6^{\circ}, 1$ specimen; station 5092, Uraga Strait, lat. $35^{\circ} 4^{\prime} 50^{\prime \prime} \mathrm{N}$.; long. $139^{\circ} 38^{\prime} 18^{\prime \prime}$ E., 70 fathoms, coarse black sand, bottom temperature $56.3^{\circ}, 3$ specimens; station 5094, Uraga Strait, lat. $35^{\circ} 4^{\prime} 42^{\prime \prime}$ N.; long. $139^{\circ} 38^{\prime} 20^{\prime \prime}$ E., 88 fathoms, black sand, broken shells, bottom temperature 54.8, 4 specimens. Bathymetrical range, 70 to 406 fathoms. Temperature range, $56.3^{\circ}$ to $41.8^{\circ}$. Thirty specimens. 
These specimens have been compared with a cotype of Lyman's and there is no doubt of their identity. The disk diameter ronges from 11 to $22 \mathrm{~mm}$. There are usually three arm spines present, sometimes only two, but in the larger specimens there are often four. The greatest diversity is shown in the shape of the mouth shields, for while it is true that they are usually much wider than long, in some specimens they are nearly oval in outline and quite as long as broad. Intergradations between the two extremes are common. Specimens with long oral shields have the adoral plates very indistinct or almost wanting. The degree of carination on the under side of the base of the arm is also subject to considerable variation.

OPHIACTIS PTEROPOMA, new species. $a$

Disk $5 \mathrm{~mm}$. in diameter; arms about 20 to $25 \mathrm{~mm}$. long. Disk covered by rather coarse scales, 150 to 200 altogether, without any disk

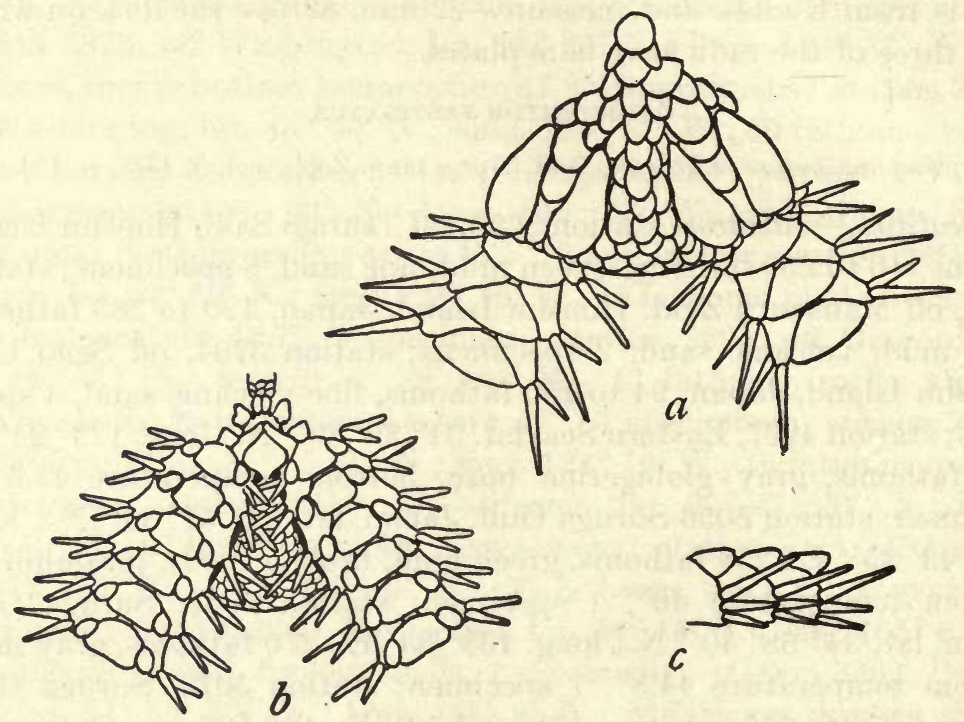

Fig. 50.-OPHIACTIS PTERopoma. $\times 10$. $a$, From ABOVE; $b$, FROM BELOW; $c$, SIDE VIEW OF THREE ARM JOINTS NEAR DISK.

spines. Radial shields long and narrow, separated by a linear series of three scales, or in contact at outer end. Arms six, broad at base, but becoming attenuate at tip. Upper arm plates broadly triangular, with rounded angles, much wider than long, not actually in contact even at base of arm, though side arm plates do not meet between them there. Interbrachial spaces below closely covered with scales. Oral shields variable, broad, triangular, or top-shaped, with lateral angles rounded. Adoral plates long and narrow, wider without than

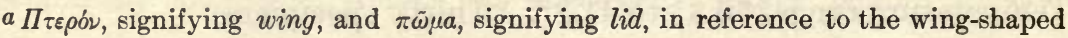
oral papillæ. 
within. Oral papillæ single, at outer corner of mouth angle, very large, flat, and wing-shaped. Teeth minutely notched. Genital slits narrow. First under arm plate very small, tetragonal, about as wide as long; second, much larger, somewhat pentagonal; succeeding plates tetragonal, becoming wider than long; first and second in contact, but succeeding plates hardly touch each other, though they separate the side arm plates widely. Latter rather large, not meeting either above or below at base of arm, but soon touching and meeting broadly at tip; each plate carries three arm spines, of which the uppermost is about twice as long as lowest, which is equal to an arm joint. Tentacle scales single, very large, oval. Color (dried from alcohol), disk, pale gray; upper side of arms, pink; arm spines and lower surface, whitish.

Localities.-Albatross station 4810, Sea of Japan, lat. $41^{\circ} 17^{\prime} 20^{\prime \prime}$ N.; long. $140^{\circ} 7^{\prime}$ E., 195 fathoms, fine gray sand, bottom temperature $44.7^{\circ}, 1$ specimen; station 4965 , off eastern Japan, lat. $33^{\circ} 35^{\prime} 20^{\prime \prime} \mathrm{N}$.; long. $135^{\circ} 10^{\prime} 50^{\prime \prime}$ E., 191 fathoms, dark green-gray sand, shells, bottom temperature $49.4^{\circ}, 6$ specimens; station 4967 , off eastern Japan, lat. $33^{\circ} 25^{\prime} 10^{\prime \prime}$ N.; long. $135^{\circ} 37^{\prime} 20^{\prime \prime}$ E., 244 to 253 fathoms, brown mud, sand, foraminifera, bottom temperature $45.9^{\circ}, 1$ specimen. Bathymetrical range, 191 to 253 fathoms. Temperature range $49.4^{\circ}$ to $44.7^{\circ}$. Eight specimens.

Type-Cat. No. 25640, U.S.N.M., from station 4965.

Although there are several indications besides the size and the presence of six arms that the specimens from station 4965 are young, the individual from 4967 measures $6 \mathrm{~mm}$. across the disk, and is quite probably mature, yet it does not differ in any important particular from the others, except that the upper arm spine is not equal to two joints and the color is uniformly whitish. In any case, the very large oral papillæ, the six arms, the long arm spines and the peculiar upper arm plates combine to give a very characteristic appearance, and I know of no species to which the specimens could be referred. The one from station 4810 is, however, so small (disk diameter less than 3 $\mathrm{mm}$.) that its identity is bound to be somewhat uncertain.

OPHIACTIS BRACHYGENYS, new species. $a$.

Disk $5 \mathrm{~mm}$. in diameter; arms about $25 \mathrm{~mm}$. long. Disk covered with about two hundred scales of diverse sizes and indefinite arrangement. Radial shields long and narrow, separated except at their distal ends. Arms five, broad at base, but slender at tip. Upper arm plates transverse, elliptical, or low triangular, with rounded angles, scarcely in contact even at base of arm. Interbrachial spaces below completely covered with fine scales. Oral shields low, trian-

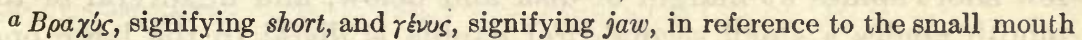
angles. 
gular, with rounded angles, wider than long, somewhat variable. Side mouth shields large, nearly horizontal, much wider without than within. Oral papillæ single in outer corner of mouth angle, large, flat, and wing-shaped. Teeth notched so that some of the lower ones seem to have three points. Genital slits broad and conspicuous. First under arm plate small, triangular, with a distal angle or tetragonal with distal margin narrow; succeeding plates more or less hexagonal (or tetragonal) with rounded angles, wider than long, scarcely or not at all in contact, though the side arm plates do not meet between them at base of arm. Side arm plates large, meeting below and above on distal part of arm; each plate carries three mod-
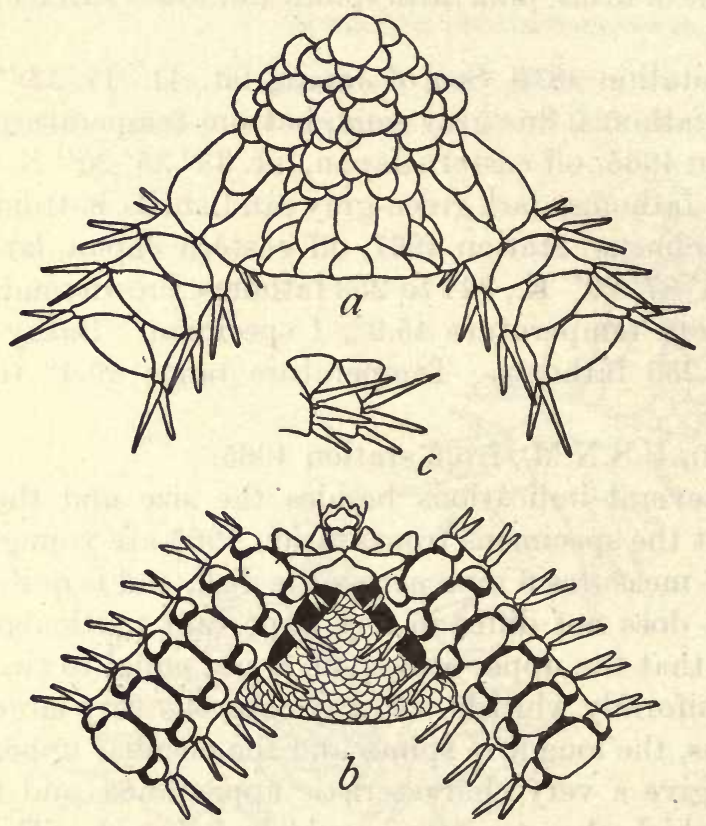

Fia. 51.-OPHACTIS BRACHYGENYS. $\times 10$. $a$, FROM $A$ BOVE; $b$, FROM BELOW; $c$, SIDE VIEW OF TWO ARM JOINTS NEAR DISK. erately stout spines, uppermost longest and longer than an arm joint. Tentacle scales single, large, oval. Color (dried from alcohol), very light yellowish, grayish, or nearly white.

Localities.-Albatross station 3697, off Manazuru Zaki, Honshu Island, Japan, 120 to 265 fathoms, gray mud, volcanic sand, 1 specimen; station 4956, southeastern Japan, lat. $32^{\circ} 32^{\prime} \mathrm{N}$.; long. $132^{\circ} 25^{\prime} \mathrm{E}, 720$ fathoms green-brown mud, fine gray sand, foraminifera, bottom temperature $37.5^{\circ}, 1$ specimen; station 4957, southeastern Japan, lat. $32^{\circ} 36^{\prime}$ N.; long. $132^{\circ} 23^{\prime}$ E., 437 fathoms, green-brown mud, fine gray sand, foraminifera, bottom temperature $39.8^{\circ}, 2$ specimens. Bathymetrical range 120 to 720 fathoms. Temperature range $39.8^{\circ}$ to $37.5^{\circ}$. Four specimens.

Type.-Cat. No. 25602, U.S.N.M., from station 4957.

The specimen from station 3697 measures $9 \mathrm{~mm}$. across the disk. It differs from the type in having the radial shields separated even at the tip, the upper arm plates are lower and wider, and both the upper and under arm plates seem to be nearer together. There are a very few short spines at margin of disk and below, and in several of the mouth angles a small second oral papilla is distal to the large one. 
The adoral plates are broadly in contact both radially and interradially and so make a continuous circumoral ring, as in Hemipholis. The principal difference between this species and the preceding is in the number of arms, but this striking difference is associated with several minor ones, such as the form of the oral shields and adoral plates, the length of the arm spines, and the color.

OPHIACTIS DYSCRITA, new species. $a$

Disk $2.5 \mathrm{~mm}$. in diameter; arms about $10 \mathrm{~mm}$. long. Disk covered with about one hundred and fifty coarse scales. Radial shields long and narrow, separated, except at distal ends, by a single wedgeshaped scale. Arms six, not very attenuate. Upper arm plates somewhat pentagonal (or hexagonal) much wider than long, with lateral angles rounded, more or less in contact with each other, on

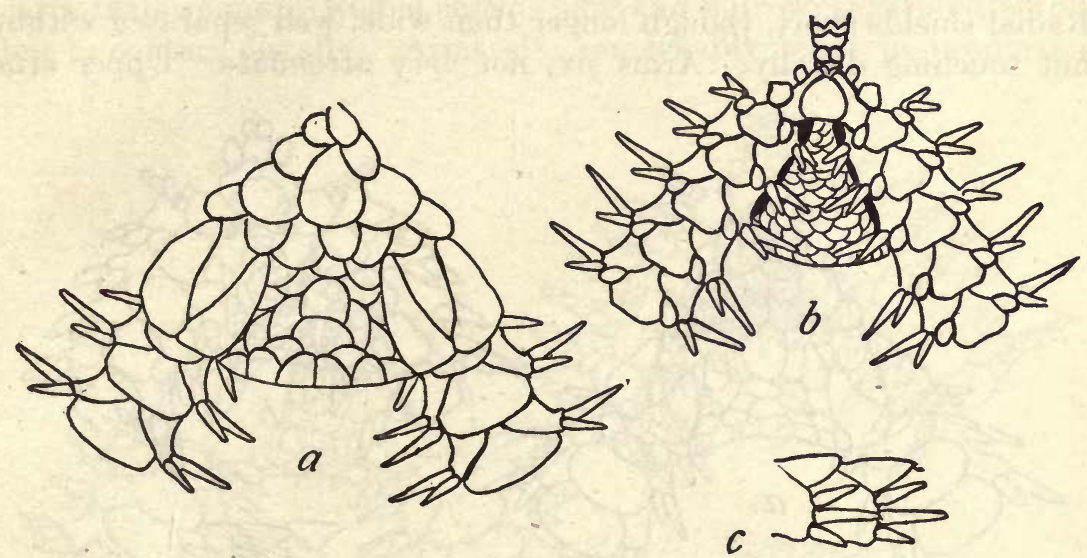

FIG. 52.-OPHIACTIS DYSCRITA. $\times 20$. $a$, FROM ABOVE; $b$, FROM BELOW; $c$, SIDE VIEW OF TWO ARM JOINTS NEAR DISK.

basal half of arm. Interbrachial spaces below closely scaled. Genital slits rather conspicuous. Oral shields oval or ovoidal, about as long as wide or a little shorter. Adoral plates large, not meeting within, enlarged at outer ends. Oral papillæ, single, on each side of mouth angle, small and flat. First under arm plate small, longer than wide, narrowed distally; succeeding plates more or less pentagonal, about as wide as long, more or less in contact on basal part of arm. Side arm plates moderate, meeting above and below on distal half of arm; each plate carries three spines, of which the middle one is longest or at least as long as the uppermost, and equals the joint. Tentacle scales single, moderately large, oval. Color (dried from alcohol), gray.

a disкрьтоs, signifying hard to determine, in reference to the doubtful value of the specific characters. 
Locality.-Albatross station 4937, Kagoshima Gulf, lat. $31^{\circ} 13^{\prime} \mathrm{N}$.; long. $130^{\circ} 43^{\prime} 10^{\prime \prime}$ E., 58 fathoms, mud, lava, pebbles, bottom temperature $64.8,1$ specimen.

Type.-Cat. No. 25610, U.S.N.M., from station 4937.

This specimen is so small and so obviously young, it is a great pity to have to give it a name, but it clearly does not belong with any of the other species of Ophiactis in the collection, for the oral shields, adoral plates, oral papillæ, arm plates and spines are all more or less distinctive. I can not find any previously known species to which I can refer it and I have therefore decided to call it dyscrita.

OPHIACTIS BRACHYASPIS, new species. $a$

Disk $3 \mathrm{~mm}$. in diameter; arms about $15 \mathrm{~mm}$. long. Disk covered by about one hundred and seventy-five irregular scales, without spinelets. Radial shields short, though longer than wide, well separated within but touching distally. Arms six, not very attenuate. Upper arm

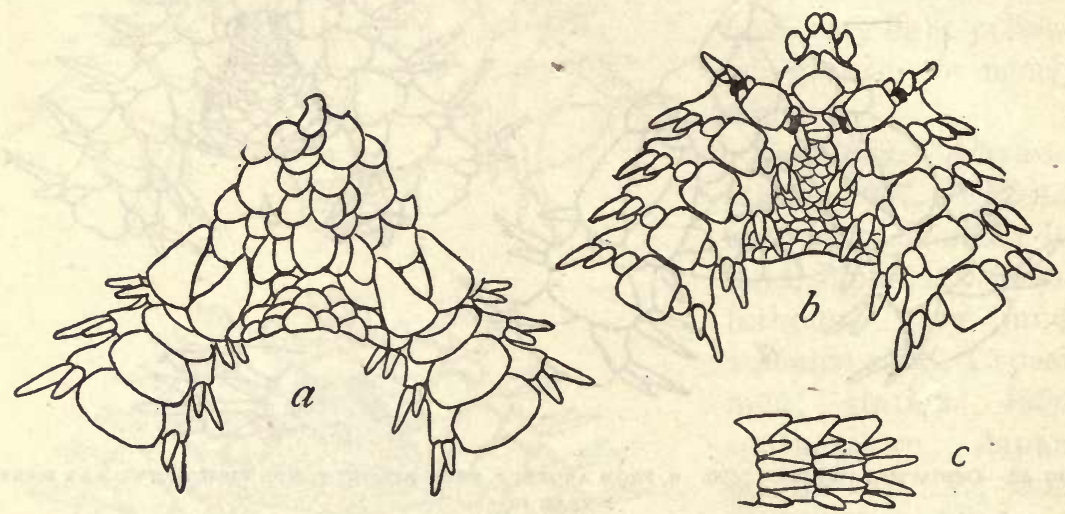

FIG. 53.-OPHIACTIS BRACHYASPIS. $\times 16$. $a$, FROM ABOVE; $b$, FROM BELOW; $c$, SIDE VIEW OF THREE ARM JOINTS NEAR DISK.

plates elliptical, much wider than long, broadly in contact far out on arm. Interbrachial spaces below covered with scales. Genital slits very inconspicuous. Oral shields rounded pentagonal, much wider than long. Adoral plates short and broad but meeting in midradial line. Oral papillæ single, one on each jaw margin, flat and wide. First under arm plate, apparently concealed by meeting of adoral plates; second plate (seemingly first) large, squarish or broadly hexagonal; succeeding plates somewhat longer than wide, almost if not quite, broadly in contact. Side arm plates moderate, not meeting above or below on basal half of arm, each with four short, thick arm spines, of which the middle pair are longest and about equal the

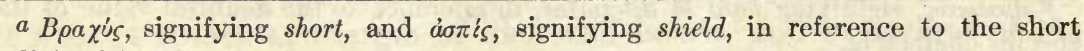
radial shields. 
joint. Tentacle pores on first arm joint very large, protected by two scales; succeeding pores less conspicuous, protected by a single large, oval scale. Color (dried from alcohol), light brown.

Locality.-Albatross station? "No label in jar, Nov. 1892."

Type.-Cat. No. 25638, U.S.N.M.

This little specimen is doubtless still young, but the unusual combination of six arms, short radial shields, elliptical upper arm plates, long tetragonal under arm plates and four short arm spines distinguish it from any other known Ophiactis. It is a great pity that there is no clue to the locality of this interesting species.

OPHIACTIS GYMNOCHORA, new species. $a$

Disk $5 \mathrm{~mm}$. in diameter; arms about $30 \mathrm{~mm}$. long. Disk covered by about two hundred small scales, which, along the margin, carry little spines. Radial shields long and narrow, separated within but in contact distally. Arms six, remarkably stout in proportion

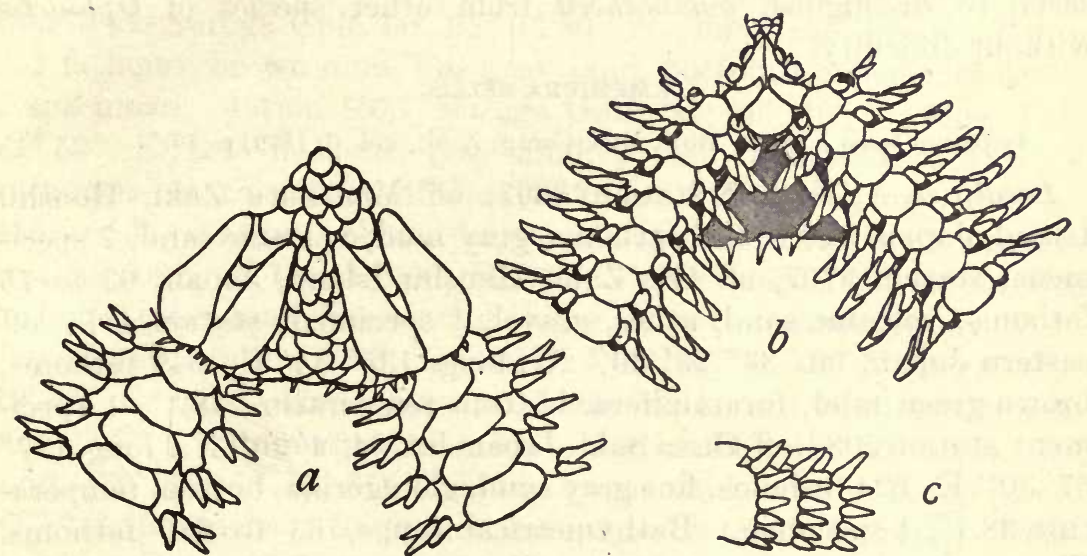

Fig. 54.-OPHIACTIS GYMNOCHORA. $\times 10$. $a$, FROM ABOVE; $b$, FROM BELOW; $c$, SIDE VIEW OF THREE ARM JOINTS NEAR DISK.

to the size of disk. Upper arm plates broadly hexagonal or heptagonal, much wider than long, in contact throughout; many are broken into two or more pieces. Interbrachial spaces below quite bare, save for scales alongside the genital slits, which are rather large. Oral shields rounded without and pointed within, about as wide as long. Adoral shields narrow within and much broader at outer end, not meeting either radially or interradially. Oral papillæ two or three on a side, large, flat, rounded at tip. First under arm plate small, triangular; succeeding plates much larger, more or less octagonal, nearly or quite as long as wide, broadly in contact throughout. Side arm plates rather small, not meeting either above or below;

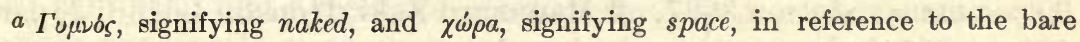
interbrachial spaces. 
each one carries five or six short, thick arm spines, of which the uppermost is longest and equals the joint. First tentacle pore with two scales; succeeding pores with single, large, oval scales. Color (dried from alcohol), brown, the terminal portions of the arms faintly banded or variegated with a lighter shade.

Locality.-Tanegasima, Japan (North Pacific Exploring Expedition), three specimens.

\section{Type.-Cat. No. 3324, U.S.N.M.}

The smallest specimen has the disk less than $3 \mathrm{~mm}$. across. It has only four arm spines, a single oral papilla on each side, and short radial shields, so that it resembles the type of brachyaspis quite strongly, but the shape of the arm plates and particularly the form and arrangement of the oral shields and adoral plates make it impossible for me to regard the two as identical. The six stout arms, small disk, naked interbrachial spaces, characteristic arm plates and oral shields, two or three oral papillæ, and six arm spines will serve to distinguish gymnochora from other species of Ophiactis without difficulty.

\section{AMPHIURA BELLIS.}

Amphiura bellis Lyman, Bull. Mus. Comp. Zoöl., vol. 6, 1879, p. 19.

Localities.-Albatross station 3697, off Manazuru Zaki, Honshu Island, Japan, 120 to 265 fathoms, gray mud, volcanic sand, 2 specimens; station 3707, off Ose Zaki, Honshu Island, Japan, 63 to 75 fathoms, volcanic sand, ashes, gravel, 1 specimen; station 4971, off eastern Japan, lat. $33^{\circ} 23^{\prime} 30^{\prime \prime}$ N.; long. $135^{\circ} 34^{\prime}$ E., 649 fathoms, brown-green mud, foraminifera, bottom temperature $38.1^{\circ}, 1$ specimen; station 5083, off Omai Saki, Japan, lat. $34^{\circ} 4^{\prime} 20^{\prime \prime}$ N.; long. $137^{\circ}$ $57^{\prime} 30^{\prime \prime}$ E., 624 fathoms, fine gray sand, globigerina, bottom temperature $38.1^{\circ}, 1$ specimen. Bathymetrical range, 63 to 649 fathoms. Five specimens.

These specimens agree admirably in all particulars with Lyman's description and figures. The largest specimen is $11 \mathrm{~mm}$. across the disk, but one of the others, which now has a pentagonal disk, with deeply concave sides, $7 \mathrm{~mm}$. across, was formerly nearly $13 \mathrm{~mm}$. across the disk, as shown by the condition of the base of the arms. It is an unusually interesting example of disk-shedding followed by regeneration.

\section{AMPHIURA DIOMEDEA.}

Amphiura diomedeæ Lütken and Mortensen, Mem. Mus. Comp. Zoöl., vol. 23, 1899, p. 151.

Localities.-Albatross station 3696, off Manazuru Zaki, Honshu Island, Japan, 501 to 749 fathoms, green mud, volcanic ashes, sand, 9 specimens; station 3697, off Manazuru Zaki, Honshu Island, Japan, 120 to 265 fathoms, gray mud, volcanic sand, 1 specimen; station 
3699, off Port Arari, Honshu Island, Japan, 400 to 726 fathoms, gray mud, volcanic particles, 24 specimens; station 4833, Sea of Japan, lat. $36^{\circ} 13^{\prime} 40^{\prime \prime} \mathrm{N}$.; long. $135^{\circ} 56^{\prime} 30^{\prime \prime}$ E., 79 fathoms, dark gray sand, rocks, bottom temperature $53.2^{\circ}, 1$ specimen; station 4937 , Kagoshima Gulf, lat. $31^{\circ} 13^{\prime} \mathrm{N}$.; long. $130^{\circ} 43^{\prime} 10^{\prime \prime}$ E., 58 fathoms, mud, lava, pebbles, bottom temperature $64.8^{\circ}, 1$ specimen; station 4946 , off eastern Japan, lat. $31^{\circ} 29^{\prime} 10^{\prime \prime} \mathrm{N}$.; long. $130^{\circ} 34^{\prime} 30^{\prime \prime}$ E., 39 fathoms, brown sand, broken shells, pebbles, bottom temperature $68.7^{\circ}, 1$ specimen; station 5053, Suruga Gulf, lat. $34^{\circ} 49^{\prime} 20^{\prime \prime} \mathrm{N}$.; long. $138^{\circ} 40^{\prime} 15^{\prime \prime}$ E., 503 fathoms, green mud, bottom temperature $34.9^{\circ}, 34$ specimens; station 5054, Suruga Gulf, lat. $34^{\circ} 52^{\prime} 45^{\prime \prime} \mathrm{N}$.; long. $138^{\circ} 42^{\prime} 20^{\prime \prime}$ E., 282 fathoms, green mud, broken shells, foraminifera, bottom temperature $45.3^{\circ}, 2$ specimens; station 5056, Suruga Gulf, lat. $34^{\circ} 57^{\prime} 35^{\prime \prime}$ N.; long. $138^{\circ} 43^{\prime} 35^{\prime \prime}$ E., 258 fathoms, green mud, broken shells, foraminifera, bottom temperature $46^{\circ}, 1$ specimen; station 5057, Suruga Gulf, lat. $34^{\circ} 58^{\prime} 40^{\prime \prime} \mathrm{N}$.; long. $138^{\circ} 34^{\prime} \mathrm{E}$., 270 fathoms, gray mud, bottom temperature $44.8^{\circ}, 5$ specimens; station 5061, Suruga Gulf, lat. $35^{\circ} 4^{\prime} 50^{\prime \prime}$ N.; long. $138^{\circ} 38^{\prime}$ E., 250 to 332 fathoms, brown mud, fine gray sand, bottom temperature $43.7^{\circ}$, 2 specimens; station 5073, Suruga Gulf, lat. $36^{\circ} 46^{\prime}$ N.; long. $138^{\circ}$ $21^{\prime} 50^{\prime \prime}$ E., 148 fathoms, gray mud, bottom temperature $54.6^{\circ}, 4$ specimens; station 5079 , off Omai Saki, lat. $34^{\circ} 15^{\prime} \mathrm{N}$.; long. $138^{\circ} \mathrm{E}$., 475 to 505 fathoms, pebbles, bottom temperature $39.1^{\circ}, 1$ specimen; station 5082, off Omai Saki, lat. $34^{\circ} 5^{\prime} \mathrm{N}$.; long. $137^{\circ} 59^{\prime}$ E., 662 fathoms, green mud, fine sand, globigerina, bottom temperature $37.7^{\circ}$, 1 specimen; station 5085, Sagami Bay, lat. $35^{\circ} 6^{\prime} 45^{\prime \prime} \mathrm{N}$.; long. $139^{\circ}$ $19^{\prime} 45^{\prime \prime}$ E., 622 fathoms, green mud, fine black sand, bottom temperature $37.8^{\circ}, 1$ specimen; station 5087, Sagami Bay, lat. $35^{\circ} 9^{\prime} 40^{\prime \prime} \mathrm{N}$.; long. $139^{\circ} 19^{\prime} 5^{\prime \prime}$ E., 614 fathoms, green mud, bottom temperature $37.5^{\circ}, 3$ specimens. Bathymetrical range, 39 to 749 fathoms. Temperature range, $68.7^{\circ}$ to $34.9^{\circ}$. Ninety-one specimens.

These specimens range in size from those $3 \mathrm{~mm}$. across the disk to those $11 \mathrm{~mm}$. They agree well with the descriptions and figures of Lütken and Mortensen, and comparison with some of their Panamic specimens confirms the identification. It is noteworthy indeed to find this species on the Japanese coast.

\section{AMPHIURA SUNDEVALLI.}

Ophiolepis sundevalli Müller and Troschel, Sys. Ast., 1842, p. 93.

Amphiura sundevalli LuUngman, Oph. Viv., 1866, p. 320.

Localities.-Alaska, Corwin coll., 1 specimen; Bering Strait, 12 fathoms, gravel, 2 specimens.

The specimens measure about $10 \mathrm{~mm}$. across the disk and are well preserved. There seems to be no room for doubt as to their identity with European and Greenland specimens, so that we have here still another apparently circumpolar species of ophiuran. 
AMPHIURA CARCHARA, new species. $a$

Disk $8 \mathrm{~mm}$. in diameter; arms about $35 \mathrm{~mm}$. long. Disk covered by numerous (250 to 300 ) scales. Radial shields long and narrow, separated throughout or in contact distally. Upper arm plates more or less pentagonal or hexagonal, decidedly rounded distally, in contact at least to some extent on basal half of arm. Interbrachial spaces below naked, save near margin, where the scaling ends abruptly. Oral shields, rounded pentagonal, rather wider than long. Adoral plates narrow within but broader at outer end, not in contact with each other at either end. Oral papillæ two on a side, one rounded knob-like, at apex of jaw, and one, which is long and spiniform, in outer corner of mouth angle. Genital slits large. First under arm plate very small, pentagonal; succeeding plates squarish or pentagonal, slightly in contact with each other basally. Side arm plates large, meeting

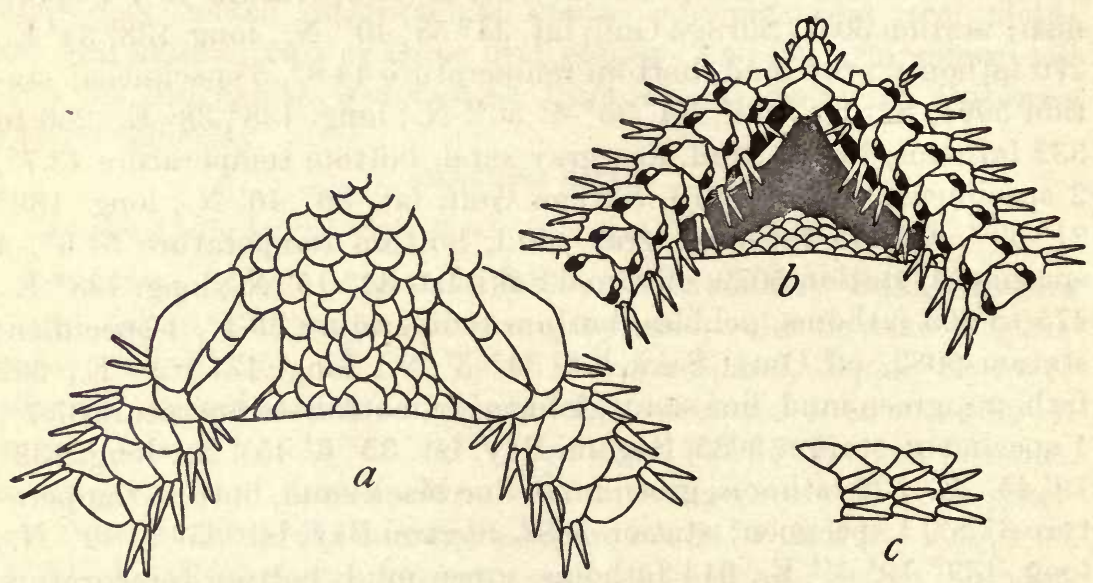

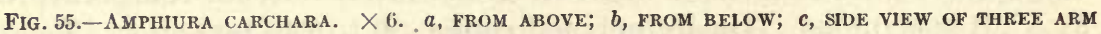
JOINTS NEAR DISK.

above and below except on basal part of arm, where they are slightly separated; each plate carries three subequal arm spines about equal to a joint. Tentacle scale single and small. Color (dried from alcohol), pale gray or nearly white, except interbrachial spaces below which are brownish-yellow.

Localities.-Albatross station 2854 , off Alaska, lat. $56^{\circ} 55^{\prime} \mathrm{N}$.; long. $153^{\circ} 4^{\prime}$ W., 60 fathoms, black sand, bottom temperature $42.8^{\circ}, 4$ specimens; station 3069 , off Washington, lat. $47^{\circ} 25^{\prime} 30^{\prime \prime} \mathrm{N}$.; long. $125^{\circ} 42^{\prime}$ W., 760 fathoms, green mud, bottom temperature $37.6^{\circ}, 1$ specimen; station 3338 , of Alaska, lat. $54^{\circ} 19^{\prime} \mathrm{N}$.; long. $159^{\circ} 40^{\prime} \mathrm{W}$., 625 fathoms, green mud, sand, bottom temperature $37.3^{\circ}, 6$ specimens; station 3340 , off Alaska, lat. $55^{\circ} 26^{\prime}$ N.; long. $155^{\circ} 26^{\prime}$ W., 695

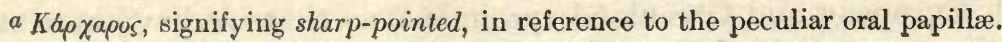


fathoms, mud, bottom temperature $36.8^{\circ}, 113$ specimens; station 4761 , off Alaska, lat. $53^{\circ} 57^{\prime} 30^{\prime \prime} \mathrm{N}$.; long. $159^{\circ} 31^{\prime} \mathrm{W}$., 1,973 fathoms, blue clay, bottom temperature $35^{\circ}, 3$ specimens; station 4766 , Bering Sea, lat. $52^{\circ} 38^{\prime}$ N.; long. $174^{\circ} 49^{\prime}$ W., 1,766 fathoms, bottom temperature ? (about $35^{\circ}$ ), 13 specimens; station 5087, Sagami Bay, lat. $35^{\circ} 9^{\prime} 40^{\prime \prime} \mathrm{N}$.; long. $139^{\circ} 19^{\prime} 5^{\prime \prime}$ E., 614 fathoms, green mud, bottom temperature $37.5^{\circ}, 1$ specimen; locality ?, 21 specimens. Bathymetrical range, 60 to 1,973 fathoms. Temperature range, $42.8^{\circ}$ to $35^{\circ}$. One hundred and sixty-two specimens.

Type.-Cat. No. 25594, U.S.N.M., from station 2859.

This species will be easily recognized by the combination of naked interbrachial spaces, long radial shields, one tentacle scale, three arm

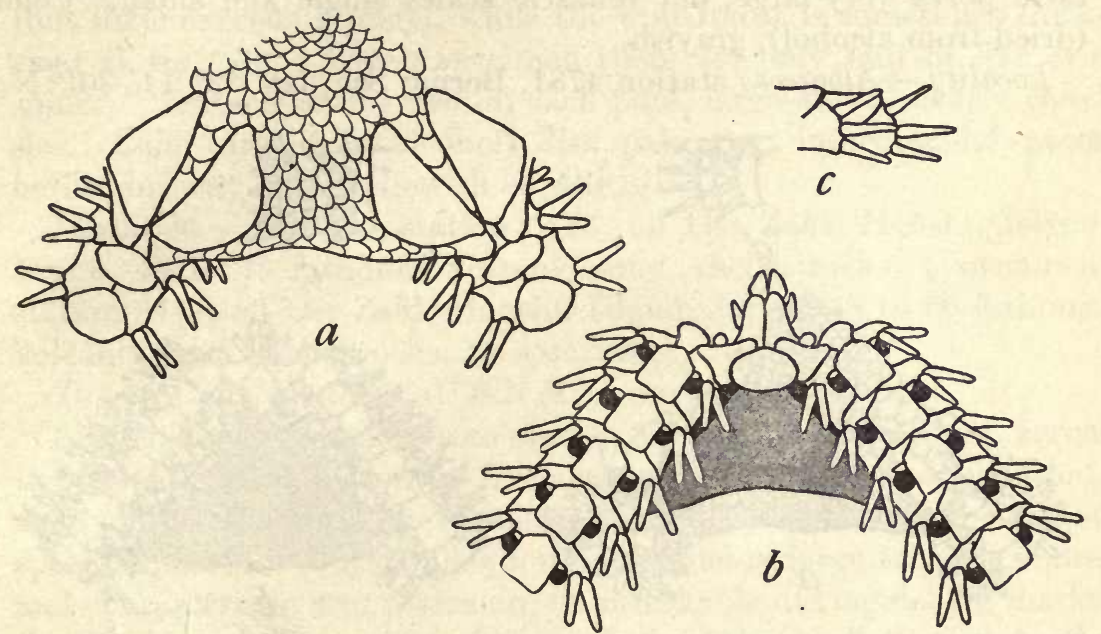

Fig. 56.-Amphiura leptodoma. $\times$ 15. $a$, From ABOVE; $b$, From Below; $c$, Side VieW of tWo arm JOINTS NEAR DISK.

spines, and spine-like outer, oral papillæ. The specimens range in size from less than $3 \mathrm{~mm}$. disk diameter to a full $8 \mathrm{~mm}$. No differences were detected between the specimens from 60 fathoms and those from 1,973. It is interesting to note that in spite of this great bathymetrical range, the temperature range is less than $8^{\circ}$ and the bottom at all the stations was soft, without rocks or shells.

\section{AMPHIURA LEPTODOMA, new species. $a$}

Disk a little more than $3 \mathrm{~mm}$. in diameter; arms about $25 \mathrm{~mm}$. long. Disk covered by numerous (300 to 400) small scales. Radial shields large, about twice as long as wide, separated, except at distal ends. First upper arm plate twice as wide as long, elliptical; succeeding plates broadly oval, wider than long, scarcely in contact. 
Interbrachial spaces below naked. Genital slits rather large. Oral shields nearly elliptical, much wider than long. Adoral plates roughly triangular, with the side next the oral shield deeply concave, not meeting either radially or interradially. Oral papillæ two on a side, one large and conspicuous at apex of jaw, one minute and scalelike at outer corner of mouth angle; first oral tentacle scale conspicuous and giving the impression of being a third oral papilla. First under arm plate small, tetragonal or pentagonal; succeeding plates much larger, somewhat pentagonal, with a proximal angle, rather longer than wide, scarcely in contact. Side arm plates rather small, barely meeting, above and below, on basal part of arm; each plate carries three subequal spines, about as long as the arm joint. Tentacle pores very large, but tentacle scales single and small. Color (dried from alcohol), grayish.

Locality.-Albatross station 4781 , Bering Sea, lat. $52^{\circ} 14^{\prime} 30^{\prime \prime}$ N.;
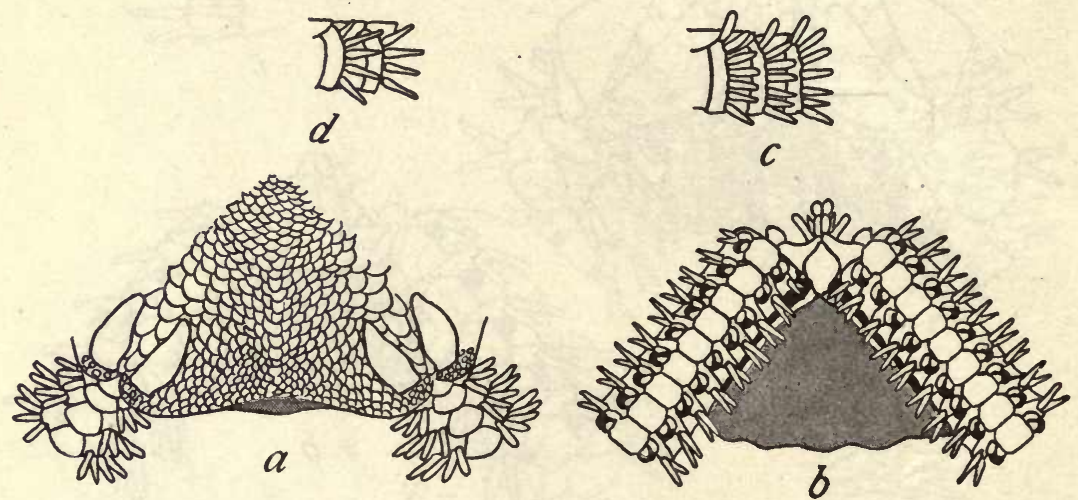

Fig. 57.-AMPHIURA EUOPLA. $a-c, \times 5 ; d$, YOUNG, $\times 10$. $a$, FROM ABOVE; $b$, FROM BELOW; $c$, SIDE VIEW OF THREE ARM JOINTS NEAR DISK; $d$, SIDE VIEW OF TWO ARM JOINTS FROM A YOUNG SPECIMEN.

long. $174^{\circ} 13^{\prime}$ E., 482 fathoms, fine gray sand, pebbles, bottom temperature $38.6^{\circ}, 1$ specimen.

Type.-Cat. No. 25627, U.S.N.M., from station 4781.

This specimen does not seem to be referable to any known amphiuroid and I have accordingly thought best to give it a name. The naked interbrachial spaces, the three arm spines, the peculiar oral papillæ, and the single tentacle scale combine with the characteristic oral shields, adoral plates, and upper arm plates to give the species a unique appearance.

\section{AMPHIURA EUOPLA, new species.a}

Disk $10 \mathrm{~mm}$. in diameter; arms about $80 \mathrm{~mm}$. long. Disk covered by numerous (500 to 600) small scales, the largest of which are around the radial shields. Radial shields about twice as long as broad, more

a Ë̌orilos, signifying well-armed, in reference to the numerous, rather crowded arm spines. 
or less separated at least proximally. Upper arm plates tetragonal or somewhat pentagonal, wider than long, becoming transversely elliptical, more or less broadly in contact throughout. Interbrachial spaces below naked. Oral shields longer than wide, somewhat rounded diamond-shaped. Adoral plates large, roughly triangular in outline. Oral papillæ two on a side, one thick, rounded at apex of jaw, and one long, thick and spine-like at outer corner of mouth angle. Genital slits large.' First under arm plate small, tetragonal, narrowest distally; succeeding plates squarish with rounded corners, about as wide as long, more or less completely in contact. Side arm plates high but short, not meeting below or above, each with six or seven flattened, blunt arm spines, of which the lowest is the longest (but little exceeds a joint), while the uppermost is sometimes thickened at tip. In a young specimen there are only four or five arm spines. Tentacle scales two on each pore, large and of nearly equal size. Color (dried from alcohol), disk, pale gray; interbrachial spaces below, brown; arms yellowish or whitish.

Localities.-Albatross station 3713, off Ose Zaki, Honshu Island, Japan, 45 to 48 fathoms, volcanic sand, shells, rocks, 1 specimen; station 3714, off Ose Zaki, Honshu Island, Japan, 48 to 60 fathoms, volcanic sand, shells, rocks, 11 specimens.

Type.-Cat. No. 25651, U.S.N.M., from station 3714.

Although the specimen from station 3713 is less than $4 \mathrm{~mm}$. across the disk and has only four or five arm spines, there is no doubt whatever of its identity with the large ones. The naked interbrachial spaces, spine-like oral papillæ, long oral shields, large tentacle scales, and characteristic arm plates are unmistakable distinguishing marks. Combined with the numerous arm spines of the adult they make the species an easily recognized one.

AMPHIURA ACRYSTATA, new species. $a$

Disk $10 \mathrm{~mm}$. in diameter; arms about 130 to $150 \mathrm{~mm}$. Disk usually more or less naked at center and in the interradii, but around the radial shields there is a variable amount of close, fine scaling; in some specimens (fig. $58 \mathrm{~g}$ ) the entire disk is covered by minute scales. Radial shields long and narrow, in contact distally. Basal upper arm plates rather small, somewhat pentagonal, with a short proximal side; succeeding plates more transverse, elliptical (though sometimes angular), very much wider than long, in contact throughout. Interbrachial spaces below naked, or more or less covered with minute scales. Oral shields nearly oval, almost as wide as long. Adoral plates large, narrow and meeting within (or nearly so), very broad at

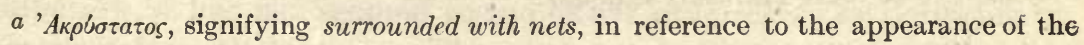
radial shields.

$34916^{\circ}-$ Bull. $75-11-10$ 
outer end. Oral papillæ two on a side, one thick and knob-like at apex of jaw, the other long, thick, and spine-like at outer corner of . mouth angle; tentacle scale of first oral tentacle pore, long and
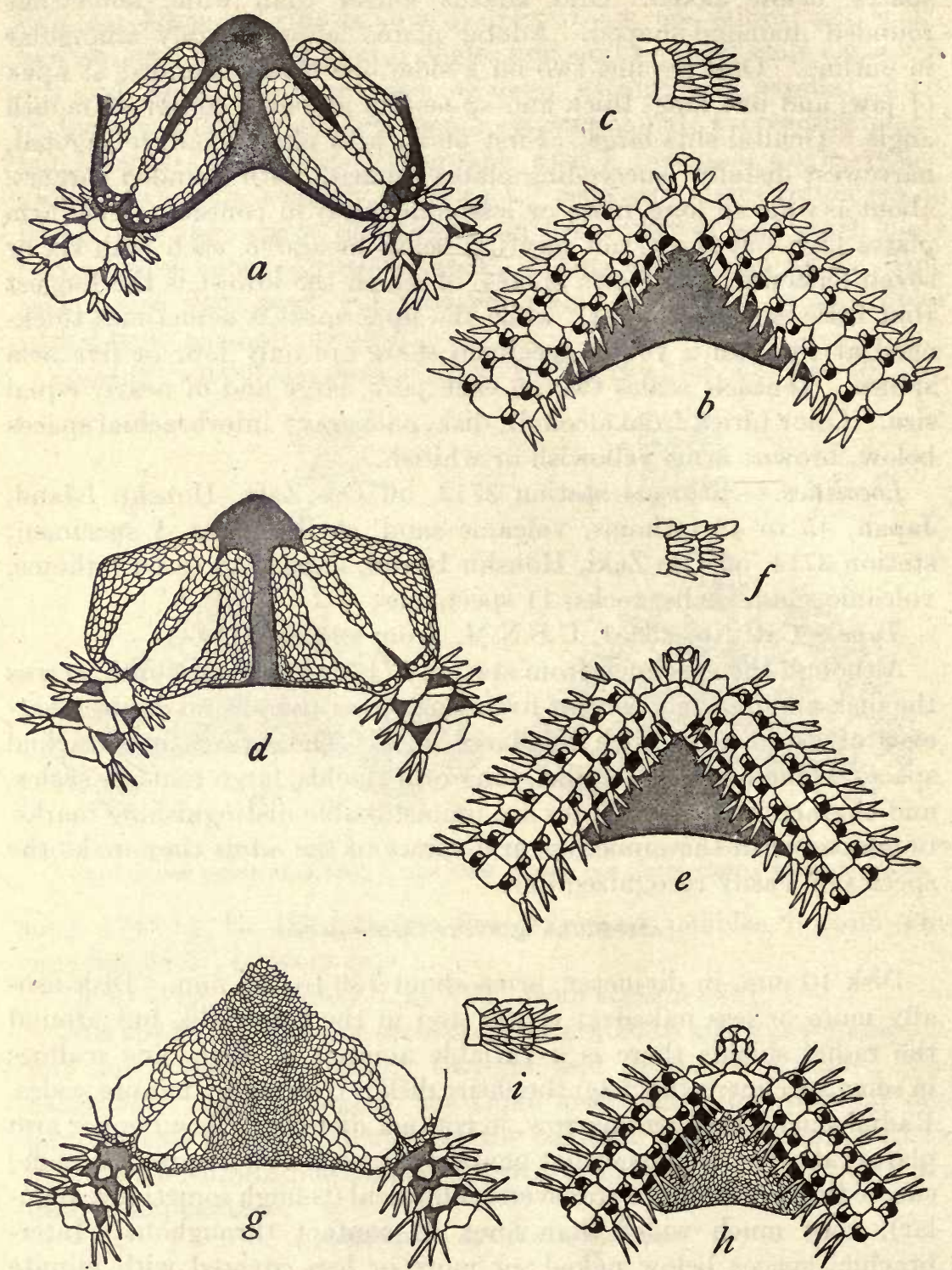

Fig. 58.-A MPHIURA ACRYSTATA. $a-f, \times 5: g-i, \times$ 4. $a-c$, TYPE. $a$, FROM ABOVE; $b$, FROM BELOW; $c$, SIDE VIEW OF TWO ARM JOINTS NEAR DISK; $d$, ANOTHER SPECIMEN, FROM ABOVE; $e$, FROM BELOW; $f$, SIDE VIEW OF TWO ARM JOINTS NEAR DISK; $g$, ANOTHER SPECIMEN, FROM ABOVE; $h$, FROM BELOW; $i$, SIDE VIEW OF THREE ARM JOINTS NEAR DISK.

spine-like, easily mistaken for an oral papilla. First under arm plate much wider within than distally; second plate pentagonal; succeeding 
plates more tetragonal, rather wider than long in the type, but in some specimens (fig. 58e) longer than wide, in contact throughout. Side arm plates high, but narrow, particularly near base of arm, where they are well separated by patches of naked skin; each plate carries six or seven (rarely only five) slender, more or less flattened, sharp spines, of which the lowest is the longest, a little exceeding the joint. Tentacle pores large, each with two rather small tentacle scales. Color (dried from alcohol), bare skin, deep brown; scales, grayish; arms, yellowish.

Localities.-Albatross station 3132 , off California, lat. $36^{\circ} 44^{\prime} \mathrm{N}$.; long. $121^{\circ} 51^{\prime} \mathrm{W}$., 33 fathoms, brown mud, bottom temperature $52.1^{\circ}$, 26. specimens; station 3695, off Tsuragi Saki, Honshu Island, Japan, 110 to 259 fathoms, green mud, fine sand, 4 specimens; station 4965 , off eastern Japan, lat. $33^{\circ} 35^{\prime} 20^{\prime \prime}$ N.; long. $135^{\circ} 10^{\prime} 50^{\prime \prime}$ E., 191 fathoms, dark green-gray sand, shells, bottom temperature $49.4^{\circ}, 2$ specimens; station 4987, Sea of Japan, lat. $43^{\circ} 19^{\prime} 20^{\prime \prime} \mathrm{N}$.; long. $140^{\circ} 17^{\prime}$ E., 59 fathoms, rocky, bottom temperature $44.8^{\circ}, 2$ specimens; station 5036, south of the Hokkaido, lat. $41^{\circ} 58^{\prime}$ N.; long. $142^{\circ}$ $30^{\prime} 30^{\prime \prime}$ E., 464 fathoms, brown mud, bottom temperature $37.9^{\circ}$, 2 specimens; station 5039 , south of the Hokkaido, lat. $42^{\circ} 11^{\prime} \mathrm{N}$.; long. $141^{\circ} 57^{\prime}$ E., 269 to 326 fathoms, green mud, bottom temperature $37.9^{\circ}, 8$ specimens; station 5043 , south of the Hokkaido, lat. $42^{\circ} 10^{\prime} 20^{\prime \prime} \mathrm{N}$.; long. $142^{\circ} 15^{\prime} 20^{\prime \prime} \mathrm{E}$., 309 to 330 fathoms, brown mud, fine black sand, coral, sand, bottom temperature $37.9^{\circ}, 9$ specimens; Monterey Harbor, Cal., 8 to 12 fathoms, 1 specimen. Bathymetrical range, 33 to 464 fathoms. Temperature range, $52.1^{\circ}$ to $37.9^{\circ}$. Fiftyfour specimens.

Type.-Cat. No. 25623, U.S.N.M., from station 3132.

These specimens vary in disk diameter from 5 to $16 \mathrm{~mm}$. In the smallest, the disk is covered with minute scales except close to the interradial margins, while in the largest there is no. scaling on the disk except very close to the radial shields. In specimens of all sizes (except one large one), there are six or seven arm spines. The diversity in the amount of scaling on the disk and interbrachial spaces below is most remarkable, affording an unusually interesting case of resorption of calcareous matter. Scales seem to be present in young specimens and in regenerating disks, but their presence is not wholly a matter of youthfulness, for there is some individual variation in the matter. The condition of the disk in the type-specimen reminds one strongly of Ophionephthys, but the oral papillæ are. quite different from those of that genus. In all particulars, except the naked disk of many large specimens, acrystata is so evidently an Amphiura, it has not seemed to me either practicable or desirable to remove it from that genus. There seem to be no characters by which the specimens from station 3132 can be distinguished from the 
others; one can hardly avoid the suspicion that " 3132 " should read " 3732 ," which is a station in Japanese waters. The specimen from Monterey Harbor is very possibly not this species, but it seems to belong here rather than with any known Californian species.

AMPHIURA ECNOMIOTATA, new species. $a$

Disk $6 \mathrm{~mm}$. in diameter; arms probably about $85 \mathrm{~mm}$. long. Disk naked, except close to radial shields, which are unusually long and narrow, and, though very close together, are in contact only near outer ends. Upper arm plates extraordinarily narrow, somewhat elongated oval, nearly concealed by the apparent meeting of the rows of arm spines on upper side of arm; upper arm plates in contact with each other, at least at base of arm. Interbrachial spaces below, naked. Oral shields, long pentagonal, rounded and narrow distally, longer than wide. Adoral plates nearly horizontal, wider without than within. Oral papillæ two on a side, one at apex of jaw, short and thick, one near tip of adoral plate, long and spine-like; tentacle

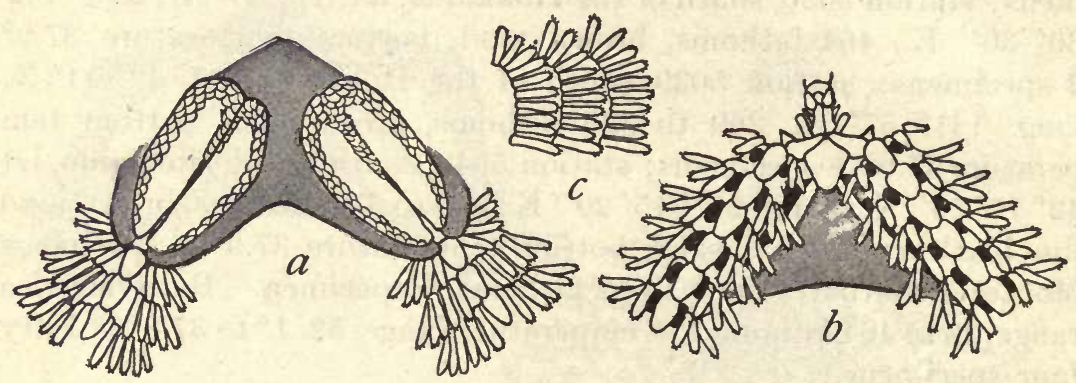

FIG. 59.-AMPHIURA ECNOMIOTATA. $\times$ 8. $a$, FROM ABOVE; $b$, FROM BELOW; $c$, SIDE VIEW OF THREE ARM JOINTS NEAR DISK.

scale of first oral pore, sharp and spine-like, easily mistakable for an oral papilla. Genital slits, short but wide. First under arm plate very small, nearly triangular, with the base proximal; succeeding plates at first oval and much longer than wide, but gradually becoming squarish, about as wide as long, with rounded angles, and a notch in the distal margin; more or less in contact with each other throughout. Side arm plates very large, though apparently not in contact with each other either above or below, at least on basal part of arm; each plate carries ten delicate though rather thick arm spines, the lowest the longest, a little exceeding a joint; at the tip these spines are very rough with minute hooklets and spinelets; the arm spines are so numerous, crowded, long, and rough that the arm fairly bristles with then. Tentacle pores large, but tentacle scales none. Color (dried from alcohol), dull yellowish-white.

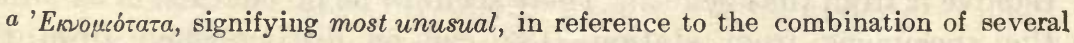
unusual characters. 
Locality.-Albatross station 3702, off Seno Umi, Honshu Island, Japan, 31 to 41 fathoms, volcanic mud, sand, rocks, 1 specimen.

Type.-Cat. No. 25628, U.S.N.M., from station 3702.

It is to be regretted that only a single, badly broken specimen represents this remarkable species in the collection. It combines such an unusually large number of arm spines with such peculiar upper arm plates and unusually naked disk that it is really quite unique.

AMPHIURA TRACHYDISCA, new species. $a$

Disk $13 \mathrm{~mm}$. in diameter; arms probably from 125 to $150 \mathrm{~mm}$. in length. Disk covered with very numerous scales, the larger of which bear hemispherical or more elevated swellings, which on the interradial margins become somewhat cylindrical, and may be nearly half a millimeter long. Radial shields about twice as long as wide, separated or just in contact distally. Upper arm plates about twice as

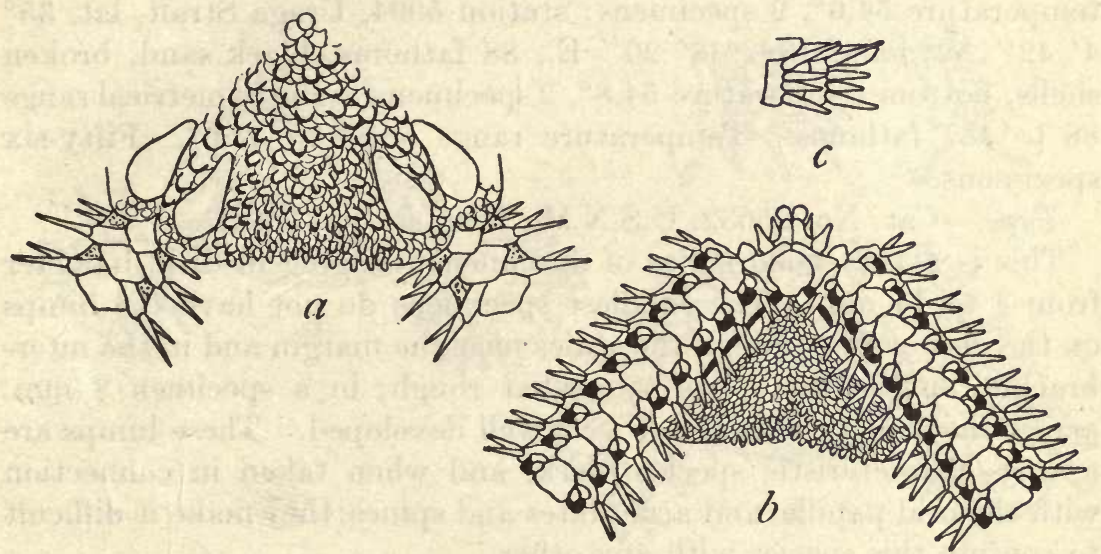

FIG. 60.-AMPHIURA TRACHYDISCA. $\times$ 4. $a$, FROM ABOVE; $b$, FROM BELOW; $c$, SIDE VIEW OF TWO ARM JOINTS NEAR DISK.

wide as long, rather broadly in contact; the shape may be considered either a more or less angular transverse oval, or a very wide, short hexagon with rounded angles; the first two or three are smaller than those which follow. Interbrachial spaces below covered by a very close coat of small and minute scales, only the larger, marginal ones bearing the characteristic swellings. Oral shields broadly oval, about as wide as long, somewhat abruptly narrowed distally. Adoral plates roughly triangular, with the longest side adjoining the oral shield and deeply concave. Oral papillæ, two on a side, one round and thick at apex of jaw, and one stout, acute and spine-like at outer corner of mouth angle; tentacle scale of first oral pore also large and spine-like. Genital slits short and inconspicuous. First under arm

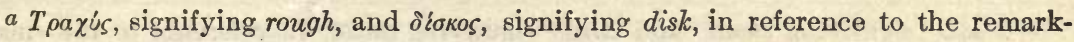
ably rough disk. 
plate tetragonal, wider within than distally; succeeding plates more or less hexagonal, pentagonal, or tetragonal, with rounded corners, more or less broadly in contact throughout. Side arm plates rather small, those at base of arm separated from each other by areas of naked skin; each plate carries four arm spines, of which the highest and lowest are somewhat the longest and rather exceed the joint. Tentacle pores large, protected by two rather large scales. Color (dried from alcohol), pale gray, pale yellow, or nearly white.

Localities. - Albatross station 3737, off Port Heda, Honshu Island, Japan, 161 to 167 fathoms, green mud, volcanic sand, 18 specimens; station 3738, off Port Heda, Honshu Island, Japan, 167 fathoms, stiff blue mud, 24 specimens ; station 5069, Suruga Gulf, lat. $35^{\circ} 3^{\prime} 10^{\prime \prime}$ N.; long. $138^{\circ} 47^{\prime}$ E., 108 to 131 fathoms, mud, sand, broken shells; bottom temperature $55.8^{\circ}$, 3 specimens; station 5073, Suruga Gulf, lat. $34^{\circ} 46^{\prime} \mathrm{N}$.; long. $138^{\circ} 21^{\prime} 50^{\prime \prime}$ E., 148 fathoms, gray mud, bottom temperature $54.6^{\circ}, 9$ specimens; station 5094, Uraga Strait, lat. $35^{\circ}$ $4^{\prime} 42^{\prime \prime}$ N.; long. $139^{\circ} 38^{\prime} 20^{\prime \prime}$ E., 88 fathoms, black sand, broken shells, bottom temperature $54.8^{\circ}, 2$ specimens. Bathymetrical range 88 to 167 fathoms. Temperature range $55.8^{\circ}$ to $54.6^{\circ}$. Fifty-six specimens.

Type.-Cat. No. 25632, U.S.N.M., from station 5094.

This is a very good series of specimens, ranging in disk diameter from 4 to $14 \mathrm{~mm}$. The smallest specimens do not have the lumps on the disk scales, though the scales near the margin and in the interbrachial spaces below are somewhat rough; in a specimen $8 \mathrm{~mm}$. across the disk, the lumps are very well developed. These lumps are a very characteristic species mark, and when taken in connection with the oral papillæ and arm plates and spines, they make it difficult to confuse this species with any other.

\section{AMPHIURA MICRASPIS, new species. $a$}

Disk $4 \mathrm{~mm}$. in diameter; arms about $20 \mathrm{~mm}$. long probably. Disk covered by numerous small scales, of which the largest are near center. Radial shields very small, well separated, two or three times as long as broad. Upper arm plates somewhat hexagonal or fan-shaped, about as wide as long, narrow proximally, in contact with each other, at least on base of arm. Interbrachial spaces below covered by a close coat of fine scales. Oral shields large, broadly oval, about as wide as long. Adoral plates triangular, lying at sides of oral shields. Oral papillæ, two on a side, one thick and rounded at apex of jaw, and one broad, flat, and fan-shaped, on adoral plate. Genital slits short and wide. First under arm plate broadly tetragonal, but very small; succeeding plates tetragonal, with

a Mıкрós, signifying small, and dorís, signifying shield, in reference to the small radial shields. 
rounded corners, longer than wide, broadly in contact. Side arm plates moderate, not meeting above or below, at least on base of arm; each plate carries six or seven cylindrical, blunt arm spines, of which all but the lowest are subequal and about as long as the joint; the lowest is decidedly longer than the rest, and near the middle of the arm is fully twice as long as the others. Tentacle scale, single, elongated oval. Color (dried from alcohol), very light gray.

Locality.-Albatross station 3735, off Omai Zaki, Honshu Island, Japan, 36 fathoms, coarse gray volcanic sand, broken shells, 1 specimen.

Type.-Accidentally destroyed immediately after the illustrations given herewith had been completed.

It is, of course, a matter of great regret that the unique specimen here described should have met with such an untimely fate, but

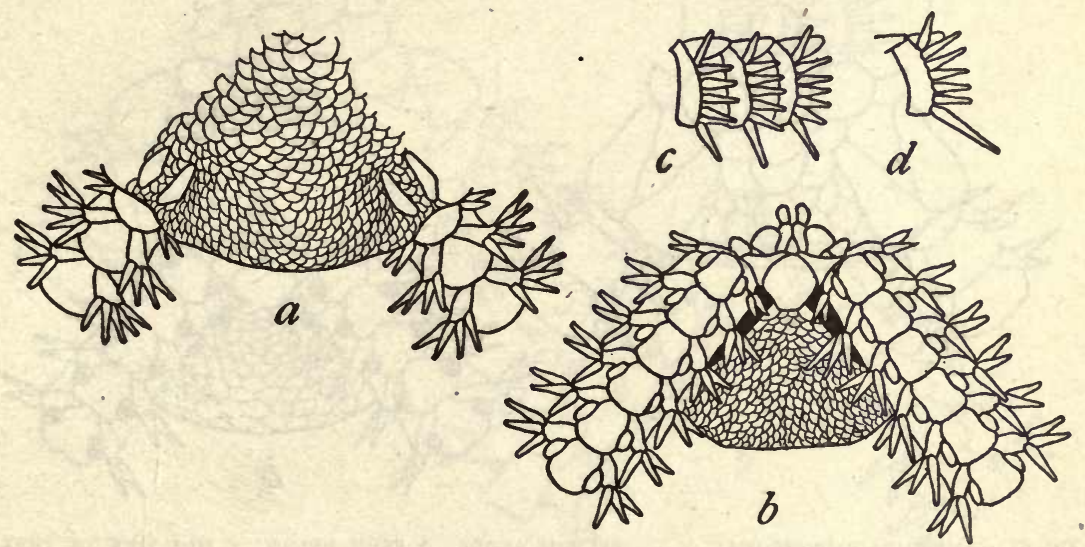

FTG. 61.-AMPHIURA MICRASPIS. $\times 12$. $a$, FROM ABOVE; $b$ FROM BELOW; $c$, SIDE VIEW OF THREE ARM JOINTS NEAR DISK; $d$, SIDE VIEW OF AN ARM JOINT NEAR MIDDLE OF ARM.

nevertheless it seems best to publish the description and figures since the small radial shields, peculiar oral papillæ, and the conspicuous lowest arm spine combine to make the species one which will be very easily recognized.

\section{AMPHIURA PYCNOSTOMA, new species.a}

Disk $4 \mathrm{~mm}$. in diameter; arms $22 \mathrm{~mm}$. long. Disk covered by about two hundred coarse scales, among which the six primary plates are rather prominent. Radial shields twice as long as wide, in contact distally, but well separated at inner ends. Upper arm plates somewhat hexagonal, with outer corners much rounded, decidedly wider than long, broadly in contact. Interbrachial spaces below, well

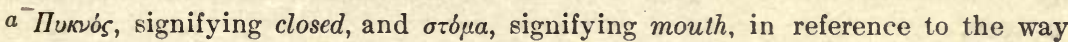
in which the peculiar scales of the first pair of oral tentacle pores close the mouth. 
covered with scales. Genital slits short. Oral shields very broadly oval, much wider than long. Adoral plates unusually large and conspicuous, meeting broadly within, about twice as long as wide; oral plates, correspondingly large. Oral papillæ, two on a side, one small, thick, rounded, at apex of jaw, the other small, flat, somewhat triangular, on adoŕal plate; scales of first oral tentacle pores very wide and flat, but low and truncate, meeting each other across the mouth slits so as to tightly close the mouth. First under arm plate elongated (so that mouth slits are short), much longer than wide, narrow at inner end, but rather abruptly widened near middle, and gradually narrowed a little at distal end; succeeding plates somewhat hexagonal or heptagonal, with rounded corners, and lateral sides concave, about as wide as long, rather broadly in contact. Side arm plates low and long, not meeting either below or above; each one carries three stout spines, thick at base but taper-

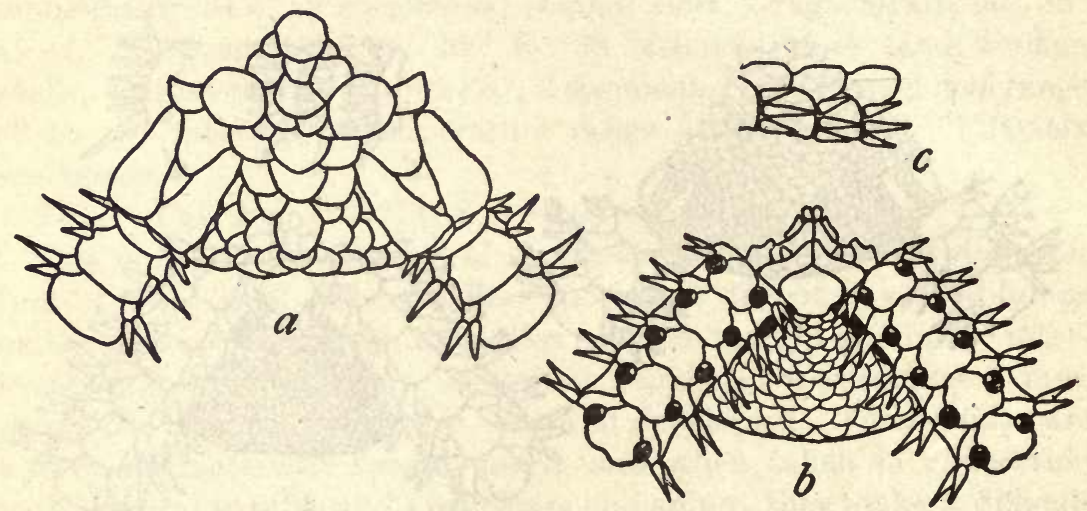

Fig. 62.-AMPHIURA PYCNOSTOMA. $\times 12$. $a$, FROM ABOVE; $b$, FROM BELOW; $c$, SIDE VIEW OF THREE ARM JOINTS NEAR DISK.

ing rapidly to a sharp point; middle one longest and about as long as joint. Tentacle pores large, but the single tentacle scale is very small. Color (dried from alcohol), disk, very pale gray, arms whitish.

Locality.-Albatross station 4972 , off eastern Japan, lat. $33^{\circ} 25^{\prime} 45^{\prime \prime}$ $\mathrm{N}$.; long. $135^{\circ} 33^{\prime}$ E., 440 fathoms, brown-green mud, foraminifera, bottom temperature $39.8^{\circ}, 1$ specimen.

Type.-Cat. No. 25641, U.S.N.M., from station 4972.

Although this specimen is probably young and is unique in the collection, it seems best to make it the type of a new species on account of the remarkable mouth parts, which are unlike those of any Amphiura I have ever seen. The peculiarly stout arm spines and large tentacle pores, each with a very small scale, are additional diagnostic characters. 


\section{AMPHIURA PSILOPORA, new species. $a$}

Disk $4 \mathrm{~mm}$. in diameter; arms about $20 \mathrm{~mm}$. long. Disk covered by comparatively few (180 to 200) large scales. Radial shields short, rounded triangular, not twice as long as wide, widely separated proximally but touching distally. Upper arm plates broadly triangular, wider than long, scarcely in contact; distal margin very convex. Interbrachial spaces below covered by about fifteen to twenty coarse scales. Oral shields rounded distally and with a rounded point proximally, somewhat longer than wide. Adorak plates very large, triangular with a truncate angle where they touch the second under arm plate, and a blunt angle where they touch each other, proximal to the oral shield; oral plates also very large. Oral papillæ, two on a side, one very large, thick, and rounded at apex of jaw, the other

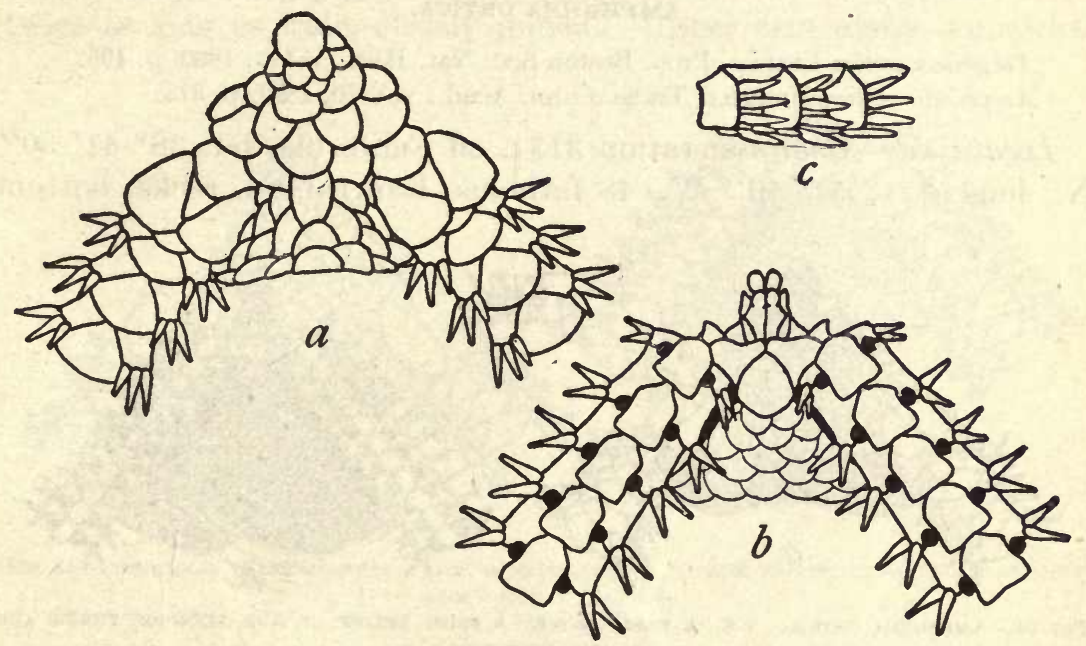

Fig. 63. - AMPHIURA PSILOPORA. $\times 12$. $a$, FROM ABOVE; $b$, FROM BELOW; $c$, SIDE VIEW OF THRFE ARM JOINTS NEAR DISK.

long, stout and spine-like at inner end of adoral plate; scale of first oral tentacle pore conspicuous, broad, and truncate. Genital slits small. First under arm plate tetragonal, wider within than distally; succeeding plates somewhat hexagonal, longer than wide, more or less broadly in contact. Side arm plates moderately large, not meeting either above or below, at least near base of arm; each plate carries four (or three on most joints) rather stout, terete spines, of which the lowest is scarcely longer than the others and about equals the joint. Tentacle pores large and wholly naked. Color (dried from alcohol), yellowish-white.

a Tilós, signifying naked, and rópos, signifying a way through, a pore, in reference to the absence of tentacle scales. 
Locality.-Plover Bay, East Siberia, 15 to 20 fathoms (William H. Dall).

Type.-Cat. No. 16586, U.S.N.M.

It is most unsatisfactory to establish new species upon single, young specimens, but it seems to me much better to name, figure, and describe them than to ignore them or to refer them to species to which they almost certainly do not belong. This unique specimen, which I have called psilopora, is like A. gymnopora Lütken and Mortensen in the absence of tentacle scales and the presence of three arm spines; but as there are four spines on some of the basal joints, and as the disk scales, radial shields, outer oral papillæ, and upper and under arm plates are so different from the Panamic form, I am sure it does not belong to that species.

\section{AMPHIODIA URTICA.}

Amphiura urtica Lymai, Proc. Boston Soc. Nat. Hist., vol. 7, 1860, p. 195.

Amphiodia urtica Verrill, Trans. Conn. Acad., vol. 10, 1899, p. 313.

Localities.-Albatross station 3131 , off California, lat. $36^{\circ} 41^{\prime} 30^{\prime \prime}$ N.; long. $121^{\circ} 54^{\prime} 10^{\prime \prime}$ W., 48 fathoms, brown mud, rocks, bottom

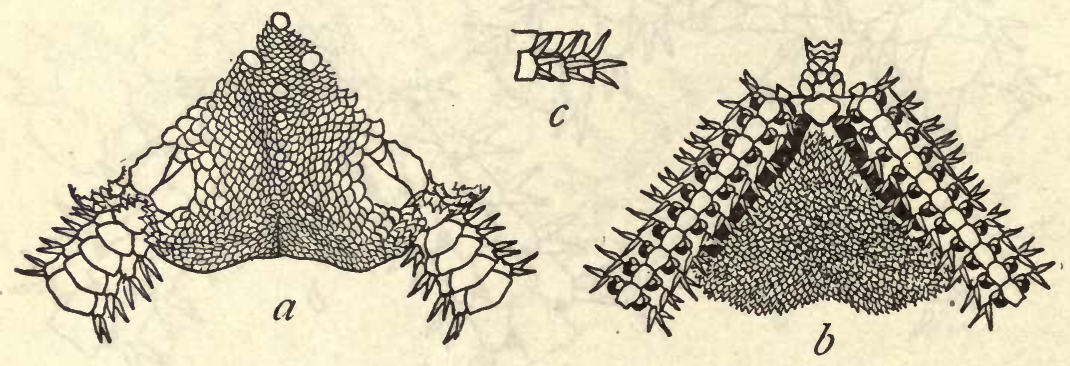

FIG. 64.-AMPHIODIA URTICA. $\times 6$. $a$, FROM ABOVE; $b$, FROM BELOW; $c$, SIDE VIEW OF THREE ARM JOINTS NEAR DISK.

temperature $50.8^{\circ}, 91$ specimens; station 3148 , off California, lat. $37^{\circ} 8^{\prime} \mathrm{N}$.; long. $122^{\circ} 28^{\prime} 10^{\prime \prime} \mathrm{W}$., 47 fathoms, brown mud, bottom temperature $51.3^{\circ}, 1$ specimen; station 3165 , off California, lat. $37^{\circ} 59^{\prime} 45^{\prime \prime} \mathrm{N}$.; long. $123^{\circ} 8^{\prime} 35^{\prime \prime} \mathrm{W}$., 50 fathoms, green mud, bottom temperature $49^{\circ}, 29$ specimens; Sanborn Harbor, Alaska, 50 specimens; Sitka, 15 fathoms, mud, 3 specimens; Puget Sound, 3 specimens (Lyman's originals); Loc. ?, 1 specimen. Bathymetrical range, 15 to 50 fathoms. Temperature range $51.3^{\circ}$ to $49^{\circ}$. One hundred and seventy-eight specimens.

As this very interesting species has never been figured, it seems to be worth while to give some illustrations showing the essential char. acters. The specimens before me range in disk diameter from 2 to 9 $\mathrm{mm}$., so that it is evident the species is of small size, though the arms are exceedingly long. and slender. 


\section{AMPHIODIA OCCIDENTALIS.}

Amphiura occidentalis Lyman, Proc. Boston Soc. Nat. Hist., vol. 7, 1860, p. 194.

Amphiodia occidentalis VerriLl, Trans. Conn. Acad., vol. 10, 1899, p. 313.

Localities.-Monterey, California, 1 specimen (Lyman's type); Puget Sound, 1 specimen; Kadiak, Alaska, 1 specimen.

This species has been sufficiently figured by Lyman, so that no iltustrations need be given here. The arm spines are the most characteristic specific character. The range northward is greatly extended by the discovery of occidentalis at Kadiak.

\section{AMPHIODIA CRATERODMETA, new species. $a$}

Disk $8 \mathrm{~mm}$. in diameter; arms about $32 \mathrm{~mm}$. long. Disk rather thick and stout, covered by numerous, coarse, distinct scales, among which the primary plates are not conspicuous. Radial shields about twice as long as wide, closely joined. Upper arm plates somewhat

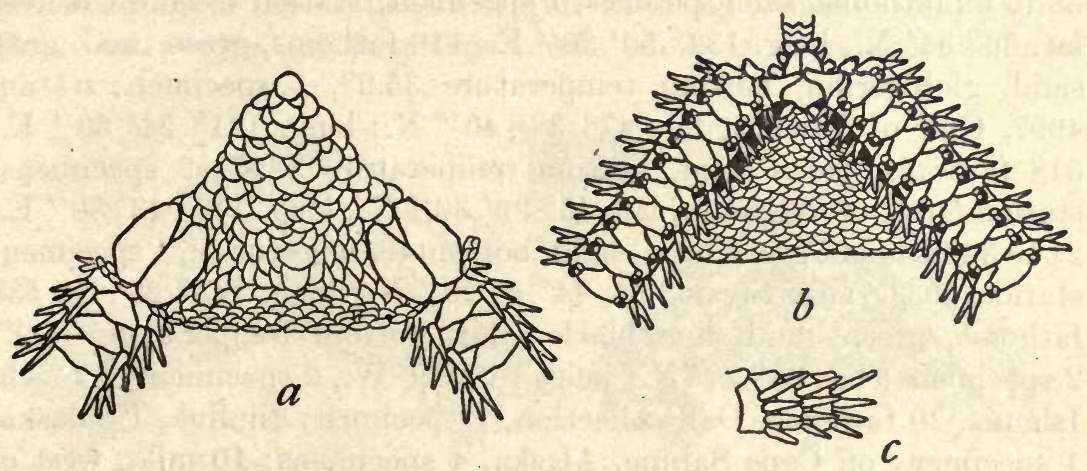

FIG. 65.- M PHIODIA CRATERODMETA. $\times 6$. $a$, FROM ABOVE; $b$, FROM BELOW; $c$, SIDE VIEW OF THREE ARM JOINTS NEAR DISK.

variable, broadly triangular, or diamond-shaped, with lateral angles truncate, 'or somewhat hexagonal, much wider than long, only narrowly in contact. Interbrachial spaces below well covered with numerous, distinct scales. Oral shields small, rather variable, but usually wider than long and pointed proximally. Adoral plates very large, variable in shape, somewhat triangular in the type, with inner sides concave, but usually they are tetragonal and meet broadly at their inner ends, which are nearly as wide as outer. Oral papillæ three on a side, subequal, thick and rounded, or the two inner ones may be somewhat pointed. Genital slits rather large. First under arm plate small, wider than long; succeeding plates variable, but generally more or less in contact, somewhat pentagonal and about as long as wide; in the type they are much wider than long. Side

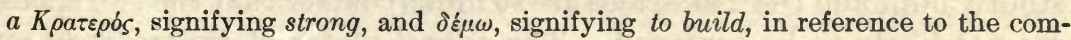
paratively stout structure. 
arm plates moderate, hardly meeting above or below, at least at base of arm; each plate carries three, and at base of arm, four sharp, rather slender spines, of which the uppermost may be a little the longest and somewhat exceed the joint. Tentacle scales, two, small. Color (dried from alcohol), gray-brown, brownish-yellow, pale gray or nearly white.

Localities.-Albatross station 2848, off Alaska, lat. $55^{\circ} 10^{\prime} \mathrm{N}$.; long. $160^{\circ} 18^{\prime} \mathrm{W}$., 110 fathoms, green mud, bottom temperature $41^{\circ}$, 5 specimens; station 3255 , Bering Sea, lat. $56^{\circ} 33^{\prime} 30^{\prime \prime}$ N.; long. $164^{\circ}$ $31^{\prime} 40^{\prime \prime}$ W., 43 fathoms, green mud, sand, bottom temperature $37^{\circ}$, 5 specimens; station 3529 , Bering Sea, lat. $58^{\circ} 36^{\prime}$ N.; long. $172^{\circ} 24^{\prime}$ W., 56 fathoms, green mud, bottom temperature $36.1^{\circ}, 1$ specimen; station 3540 , Bering Sea, lat. $56^{\circ} 27^{\prime}$ N.; long. $166^{\circ} 8^{\prime}$ W., 51 fathoms, green mud, fine sand, bottom temperature $36^{\circ}, 2$ specimens; station 4794, Sea of Okhotsk, lat. $52^{\circ} 47^{\prime} 20^{\prime \prime}$ N.; long. $158^{\circ} 44^{\prime} 30^{\prime \prime}$ E., 58 to 69 fathoms, sand, pebbles, 1 specimen; station 4844 , off Korea, lat. $36^{\circ} 34^{\prime} \mathrm{N}$.; long. $132^{\circ} 50^{\prime} 20^{\prime \prime}$ E., 116 fathoms, green mud, gray sand, globigerina, bottom temperature $35.9^{\circ}, 1$ specimen; station 4997, Gulf of Tartary, lat. $47^{\circ} 38^{\prime} 40^{\prime \prime}$ N.; long. $141^{\circ} 24^{\prime} 30^{\prime \prime}$ E., 318 fathoms, green mud, bottom temperature $32.8^{\circ}, 2$ specimens; station 5010, off Saghalin, lat. $46^{\circ} 30^{\prime} 30^{\prime \prime}$ N.; long. $142^{\circ} 43^{\prime} 30^{\prime \prime}$ E., 21 to 32 fathoms, green mud, sand, bottom temperature ?, 1 specimen; station 5033, Yezo Strait, lat. $44^{\circ} 4^{\prime} 20^{\prime \prime}$ N.; long. $145^{\circ} 28^{\prime}$ E., 533 fathoms, green mud, fine black sand, bottom temperature $35.9^{\circ}$, 2 specimens; lat. $63^{\circ} 37^{\prime} \mathrm{N}$.; long. $165^{\circ} 19^{\prime} \mathrm{W}$., 2 specimens; Chiachi Islands, 20 fathoms, Dall collection, 1 specimen; Iliuliuk, Unalaska, 1 specimen; off Cape Sabine, Alaska, 4 specimens; 10 miles west of Point Franklin, Alaska, $13 \frac{1}{2}$ fathoms, sand, 1 specimen; Bay of Islands, Adak, Dall collection, 1 specimen; Port Levashef, Alaska, 2 specimens; off Point Hope, Alaska, 25 fathoms, 1 specimen; Coal Harbor, Unga, 3 specimens; Captains Harbor, Alaska, 15 specimens; Arctic Ocean, 3 specimens; Alaska, 10 specimens; Alaska, Dall collection, 11 specimens; Port Clarence, Alaska, 12 fathoms, 5 specimens; Loc. ?, 4 specimens. Bathymetrical range, 12 to 533 fathoms. Temperature range, $41^{\circ}$ to $32.8^{\circ}$. Eighty-four specimens.

Type.-Cat. No. 25613, U.S.N.M., from station 4997.

These specimens range in disk diameter from 3 to $9 \mathrm{~mm}$. Several, in which the disk is being regenerated, are remarkable for the small size and irregular form of the radial shields. Such specimens, if dark colored, have a striking superficial resemblance, dorsally, to Ophiura maculata, though the ventral view is, of course, quite different. Although this species is nearly related to urtica, it is so much more stoutly built and the disk scales are so much coarser that the two species are not likely to be confused. The adoral plates of craterodmeta and 
the presence of four arm spines on the basal joints of the arm are excellent diagnostic characters.

\section{AMPHIODIA MACRASPIS, new species. $a$}

Disk $11 \mathrm{~mm}$. in diameter; arms about $150 \mathrm{~mm}$. long, probably. Disk rather soft, inclined to be swollen and more or less deeply notched in interradii, covered with very numerous scales, which are much larger around the radial shields than they are at center of disk and in the interradii. Radial shields long and curved, rather more than three times as long as wide, separated throughout or in contact distally. Upper arm plates more or less triangular, with truncated angles, in contact with each other, at least at base of arm, rather wider than long. Interbrachial spaces below covered by a close, fine scaling. Oral shields pentagonal or more hexagonal, with somewhat rounded angles, much wider than long. Adoral plates large, about twice as long as broad, nearly or quite meeting within. Oral papillæ three on a side (in large specimens there is an additional small

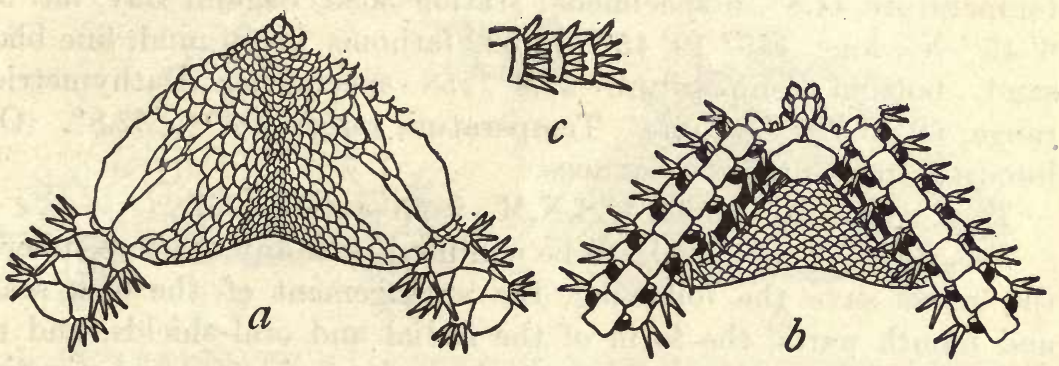

FTG. 66. $-\Lambda$ MPHIODIA MACRASPIS. $\times$ 5. $a$, FROM ABOVE; $b$, FROM BELOW; $c$, SIDE VIEW OF THREE ARM JOINTS NEAR DISK.

papilla at the distal end of the mouth slit), subequal, though the one at apex of jaw is rather thicker than the others; between first and second, the tentacle scale of the first oral pore appears and might be mistaken for another papilla. Genital slits, large. First under arm plate very small, wider than long; succeeding plates tetragonal, nearly square but sometimes longer than wide (as in type, fig. 66, $b$ ), and sometimes wider than long; broadly in contact throughout. Side arm plates small, not quite meeting above at base of arm, widely separated below; each plate carries five (at base of arm, sometimes, six) slender, sharp spines, of which the lowest is the longest, nearly equaling the joint, but the uppermost is not the shortest. Tentacle scale single, small; on some of the basal pores, a second scale is present. Color (dried from alcohol), disk, gray; arms, dirty whitish; in several specimens the radial shields, some of the larger disk scales, and the

a Makobs, signifying long, and doris signifying shield, in reference to the long, narrow radial shields. 
arms, especially the side arm plates, have a decidedly reddish tint, the red being of a brownish-orange shade.

Localities.-Albatross station 3696, off Honshu Island, Japan, 501 to 749 fathoms, green mud, volcanic ashes, sand, 23 specimens; station 3708, off Ose Zaki, Honshu Island, Japan, 60 to 70 fathoms, green mud, volcanic sand, ashes, 1 specimen; station 3709 , off Shimidzu Harbor, Honshu Island, Japan, 173 to 260 fathoms, stiff blue volcanic mud, rocks, 10 specimens; station 3789 , off Washington, lat. $48^{\circ} 21^{\prime} 45^{\prime \prime} \mathrm{N}$.; long. $124^{\circ} 52^{\prime} 30^{\prime \prime}$ W., 115 fathoms, coarse gray sand, gravel, 1 specimen; station 4862 , off Korea, lat. $36^{\circ} 20^{\prime} \mathrm{N}$.; long. $129^{\circ} 50^{\prime} \mathrm{E}$., 184 fathoms, green mud, bottom temperature $32.9^{\circ}$, 3 specimens; station 4997 , Gulf of Tartary, lat. $47^{\circ} 38^{\prime} 40^{\prime \prime} \mathrm{N}$.; long. $141^{\circ} 24^{\prime} 30^{\prime \prime}$ E., 318 fathoms, green mud, bottom temperature $32.8^{\circ}$, 11 specimens; station 5056, Suruga Gulf, lat. $34^{\circ} 57^{\prime} 35^{\prime \prime} \mathrm{N}$.; long. $138^{\circ} 43^{\prime} 35^{\prime \prime}$ E., 258 fathoms, green mud, broken shells, foraminifera, bottom temperature $46^{\circ}, 1$ specimen; station 5057, Suruga Gulf, lat. $34^{\circ} 58^{\prime} 40^{\prime \prime} \mathrm{N}$.; long. $138^{\circ} 34^{\prime}$ E., 270 fathoms, gray mud, bottom temperature $44.8^{\circ}, 6$ specimens; station 5085, Sagami Bay, lat. $35^{\circ}$ $6^{\prime} 45^{\prime \prime} \mathrm{N}$.; long. $139^{\circ} 19^{\prime} 45^{\prime \prime}$ E., 622 fathoms, green mud, fine black sand, bottom temperature $37.8^{\circ}, 58$ specimens. Bathymetrical range, 60 to 749 fathoms. Temperature range, $46^{\circ}$ to $32.8^{\circ}$. One hundred and fourteen specimens.

Type.-Cat. No. 25584, U.S.N.M., from station 5057.

This species is not likely to be confused with any other member of the genus save the following, the arrangement of the disk scales and mouth parts, the form of the radial and oral shields, and the number of arm spines and tentacle scales being very distinctive. The occurrence in large specimens of an extra oral papilla distally may naturally raise the question as to whether the species belongs in Amphiodia or Amphioplus. In view of all the characters, however, I do not think there can be any serious doubt that its relationships are actually with Amphiodia. The specimen from station 3789 is not peculiar, but the occurrence of this species at that point certainly calls for some comment.

\section{AMPHIODIA EURYASPIS, new species. $a$}

Disk $13 \mathrm{~mm}$. in diameter; arms about $150 \mathrm{~mm}$. long. Disk more or less decagonal, with each side of the decagon convex; the radial indentations of disk more marked than the interradial; disk covered with numerous irregular scales, of approximately equal size. Radial shields small, short, seldom twice as long as wide, in contact distally. Arm plates, interbrachial spaces below, oral shields, adoral plates, oral papillæ, tentacle scales and arm spines somewhat variable and

a Eúoús, signifying broad, and doris, signifying shield, in reference to the short, wide radial shields. 
not distinguishable by any constant characters from the same parts in the preceding species (macraspis). The distal oral papillæ are often distinctly pointed, the oral shields are sometimes as long as wide, and the number of arm spines is commonly four, though always five at base of arm, but never six, so far as I can see even in the largest specimen. Color (dried from alcohol), disk, gray or brownish; arms, very pale brownish, or yellowish or nearly white.

Localities.-Albatross station 3227, Bering Sea, lat. $54^{\circ} 36^{\prime} 30^{\prime \prime}$ N.; long. $166^{\circ} 54^{\prime} \mathrm{W}$., 225 fathoms, green mud, bottom temperature $38.6^{\circ}$, 72 specimens; station 3478 , off California, lat. $36^{\circ} 44^{\prime} 45^{\prime \prime}$ N.; long. $120^{\circ} 57^{\prime}$ W., 68 fathoms, gray sand, mud, 3 specimens and a mass of arms; station 4862 , off Korea, lat. $36^{\circ} 20^{\prime}$ N.; long. $129^{\circ} 50^{\prime}$ E., 184 fathoms, green mud, bottom temperature $32.9^{\circ}, 1$ specimen; station 4863 , off Korea, lat. $36^{\circ} 21^{\prime}$ N.; long. $129^{\circ} 53^{\prime}$ E., 250 fathoms, green mud, bottom temperature $32.7^{\circ}, 1$ specimen; station 4997 , Gulf of Tartary, lat. $47^{\circ} 38^{\prime} 40^{\prime \prime} \mathrm{N}$.; long. $141^{\circ} 24^{\prime} 30^{\prime \prime}$ E., 318 fathoms, green mud, bottom temperature $32.8^{\circ}, 2$ specimens; station 5066, Suruga

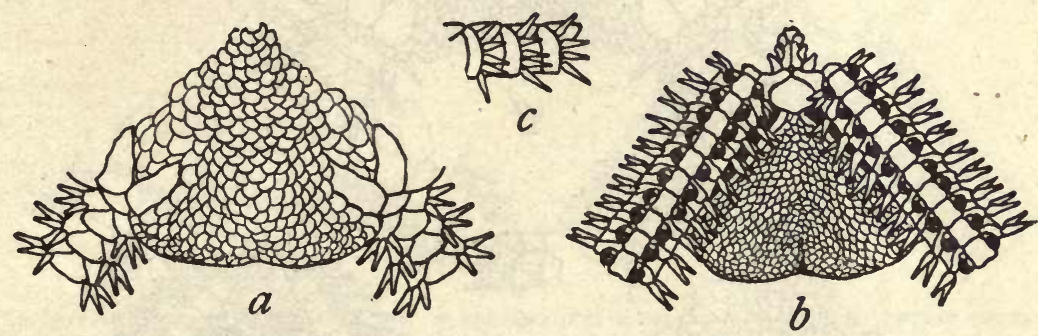

Fig. 67.-AMPHIODIA EURYASPIS. $\times$ 4. $a$, FROM ABOVE; $b$, FROM BELOW; $c$, SIDE VIEW OF THREE ARM JOINTS NEAR DISK.

Gulf, lat. $35^{\circ} 6^{\prime} 5^{\prime \prime} \mathrm{N}$.; long. $138^{\circ} 40^{\prime} 20^{\prime \prime}$ E., 211 to 293 fathoms, fine black sand, bottom temperature $50.8^{\circ}, 1$ specimen; Iliuliuk, Unalaska, 1 specimen; Bering Sea, 5 specimens. Bathymetrical range, 68 to 318 fathoms. Temperature range, $58^{\circ}$ to $32.7^{\circ}$. Eighty-six specimens.

Type.-Cat. No. 25652, U.S.N.M., from station 3478.

It is only after great hesitation that I have determined to keep this species separate from the preceding. The differences in the scaling of the disk and in the form of the radial shields are obvious and seem to be remarkably constant, so that there is no difficulty in deciding to which species a given specimen belongs. Yet it is difficult to find any other character, which is at all reliable, by which the two forms can be distinguished. As they were seldom both taken at the same station, thus indicating preference for somewhat different habitats, my impression of their distinctness is confirmed. The largest specimen of euryaspis measures $16 \mathrm{~mm}$. across the disk. One of the specimens from 3227 has six arms. 
AMPHIODIA PERIERCTA, new species. $a$

Disk $14 \mathrm{~mm}$. in diameter; arms about $150 \mathrm{~mm}$. long or more, probably. Disk distinctly pentagonal, with nearly straight sides, the margin formed by a row of quite distinct scales, which may stand more or less erect and be bluntly pointed. In the type, the interbrachial spaces are so swollen, presumably with the reproductive cells, that they project out far beyond this margin (see fig. $68 a$ ), while in a smaller specimen (fig. 68d) drying has caused enough shrinkage so that the disk margin is a little concave and the marginal scales are just below the edge, beyond which they project in, quite a conspicuous manner. Disk covered by numerous irregular scales, the largest of which are near the radial shields. Radial shields small, closely joined, at least
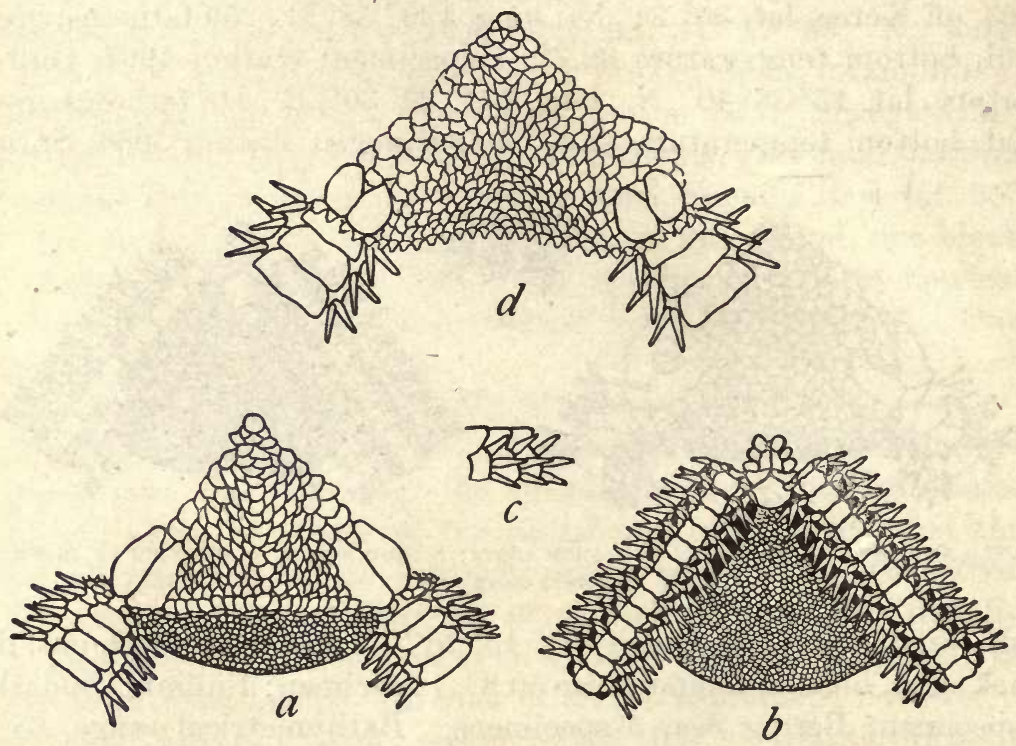

FIg. 68.-AMPHIODI PERIERCTA. $\times$ 3.5. $a$, FROM ABOVE; $b$, FROM BELOW; $c$, SIDE VIEW OF THREE ARM JOINTS NEAR DISK; $d$, A MUCH YOUNGER SPECIMEN, FROM ABOVE, $\times 9$.

distally; they are broadly oval in the young specimen, but are twice as long as wide in the type. Upper arm plates very wide, somewhat tetragonal with more or less rounded ends, two or three times as wide as long, broadly in contact throughout. Interbrachial spaces below, very closely covered with fine scales, in marked contrast to the disk. Oral shields small, somewhat pentagonal or triangular, with an inner angle, and outer side curved, wider than long. Adoral plates not conspicuous, wider without than within. Oral papillæ three on a side, thick, rounded and subequal. Genital slits large. First under arm plate, small, much wider than long; succeeding plates squarish,

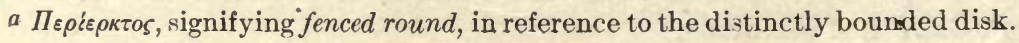


broadly in contact, with distal margin somewhat concave. Side arm plates small, not meeting either above or below; each plate carries three terete, sharp arm spines, of which the middle one is a trifle the longest and may exceed the joint. Tentacle scales two, rather large. Color (dried from alcohol), pale fawn-color, or yellowish-brown.

Localities.-Albatross station 2885 , off Oregon, lat. $45^{\circ} 56^{\prime} \mathrm{N}$.; long. $124^{\circ} 2^{\prime}$ W., 30 fathoms, fine gray sand, bottom temperature $49^{\circ}, 1$ specimen; Captains Harbor, Unalaska, 9 to 15 fathoms, stones and mud, Dall collection, 1 specimen.

Type.-Cat. No. 16391, U.S.N.M., from Captains Harbor, Unalaska.

The type-specimen is labeled "Amphiura occidentalis," and there is no doubt that periercta is closely related to that species. But a glance at the arm spines is sufficient to distinguish the two, for in occidentalis they are thick, flattened, and remarkably blunt, while in periercta they are terete and sharp.

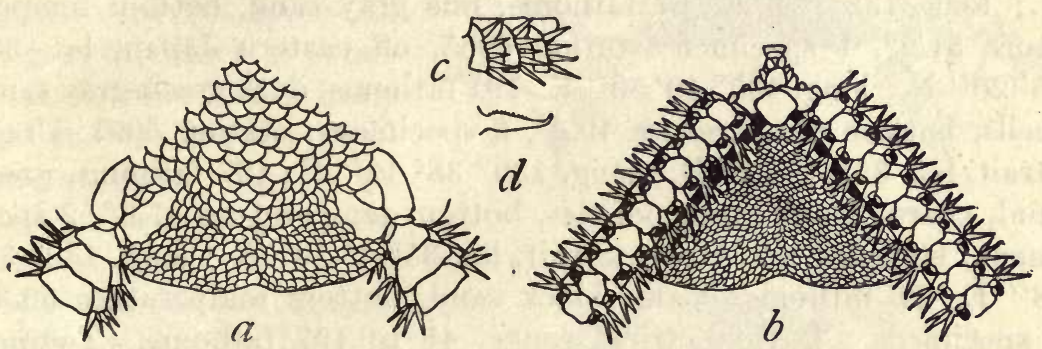

FIG. 69.-AMPHIODIA ANCISTROTA. $\times$ 5. $a$, FROM ABOVE; $b$, FROM BELOW; $c$, SIDE VIEW OF THREE ARM JOINTS NEAR DISK; $d$, NEXT TO THE LOWEST ARM SPINE, $X 10$.

AMPHIODIA ANCISTROTA, new species.a

Disk $10 \mathrm{~mm}$. in diameter; arms about $50 \mathrm{~mm}$. long. Disk covered by numerous small scales, which are somewhat smaller at the interradial margins than elsewhere; disk tends to be pentagonal with sides indented. Radial shields small, divergent, touching distally. Upper ends of genital scales, usually visible, just distal to radial shields, each often with a small, projecting spinelet. Upper arm plates, somewhat tetragonal, twice as wide as long, narrower proximally than distally, broadly in contact; lateral and proximal margins tend to merge into a continuous curve. Interbrachial spaces below covered with a coat of very fine scales. Oral shields, broadly oval, wider than long. Adoral plates nearly horizontal, very narrow at inner end, so broad at outer end that they look almost triangular. Oral papillæ, three on each side, subequal, rounded, and a fourth smaller at outer corner of mouth angle; the one at apex of jaw is the

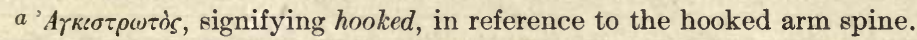

$34916^{\circ}-$ Bull. $75-11-11$ 
thickest of all. First under arm plate minute, but very distinct, longer than wide; succeeding plates squarish and broadly in contact, soon becoming pentagonal and narrowly in contact. Side arm plates small, not meeting above or below, at least at base of arm; each plate carries four, or rarely five, slender, very acute spines, of which the third or fourth is distinctly hooked at tip and microscopically serrate, and the fourth or fifth (lowest) is the longest, slightly exceeding the joint. Tentacle scales two, distinct if not large. Color (dried from alcohol), disk, grayish; arms, pale brownish or nearly white.

Localities.-Albatross station 3698, off Manazuru Zaki, Honshu Island, Japan, 153 fathoms, green mud, volcanic ashes, sand, 16 specimens; station 3713, off Ose Zaki, Honshu Island, Japan, 45 to 48 fathoms, volcanic sand, shells, rocks, 2 specimens; station 3739 , off Ose Zaki, Honshu Island, Japan, 55 to 65 fathoms, volcanic sand, shells, rocks, 21 specimens; station 4817 , Sea of Japan, lat. $38^{\circ} 12^{\prime}$ N.; long. $138^{\circ} 52^{\prime}$ E., 61 fathoms, fine gray sand, bottom temperature $51.9^{\circ}, 1$ specimen; station 4965 , off eastern. Japan, lat. $33^{\circ}$ $25^{\prime} 20^{\prime \prime} \mathrm{N}$.; long. $135^{\circ} 10^{\prime} 50^{\prime \prime}$ E., 191 fathoms, dark green-gray sand, shells, bottom temperature $49.4^{\circ}, 3$ specimens; station 5091, Uraga Strait, lat. $35^{\circ} 4^{\prime} 10^{\prime \prime}$ N.; long. $139^{\circ} 38^{\prime} 12^{\prime \prime}$ E., 197 fathoms, green mud, coarse black sand, pebbles, bottom temperature $47.6^{\circ}, 2$ specimens; station 5092, Uraga Strait, lat. $35^{\circ} 4^{\prime} 50^{\prime \prime} \mathrm{N}$.; long. $139^{\circ} 38^{\prime}$ $18^{\prime \prime}$ E., 70 fathoms, coarse black sand, bottom temperature $56.3^{\circ}$, 5 specimens. Bathymetrical range, 45 to 197 fathoms. Temperature range, $56.3^{\circ}$ to $47.6^{\circ}$. Fifty specimens.

Type.-Cat. No. 25601, U.S.N.M., from station 3698.

This is one of those perplexing species which link Amphiodia and Amphioplus so closely that the latter will have to be redefined if not abandoned. In the present species there are certainly four oral papillæ on a side, but the fourth (outermost) is so much smaller than the others that, in view of its other characters, I prefer to keep ancistrota in Amphiodia for the present. There may be more than one of the arm spines in each group hooked at the end, but as a rule there is only a single one and that only on the basal part of the arm. The upper arm plates and the tentacle scales taken in connection with the arm spines will serve to distinguish this species.

\section{AMPHIODIA DIGITULA, new species. $a$}

Disk $6 \mathrm{~mm}$. in diameter; arms about $35 \mathrm{~mm}$. long, probably. Disk covered by a close coat of numerous scales, of which those at the center are the largest and those at the interradial margins are very minute; the primary plates are scarcely distinguishable. Radial

a Digitulus (dim. of digitus), signifying a little finger, in reference to the finger-like processes on the spines borne by the genital scales. 
shields long and narrow, separated throughout or barely touching distally. Upper arm plates, broadly elliptical, though somewhat pointed laterally, twice as wide as long (or nearly so), nearly or quite in contact. Interbrachial spaces below covered by a very fine scaling, markedly in contrast to that of the disk. Oral shield ovoid, rather longer than wide, abruptly narrowed distally. Adoral plates long, narrow within, where they meet, but very broad at outer end. Oral papillæ three on a side, the one at apex of jaw thick and rounded, the second longer and pointed, the third smaller and rounded; between first and second, the scale of first oral tentacle pore may appear like another papilla. Genital slits large, each bounded by a long genital scale, the thickened outer end of which is visible from above, just distal to a radial shield; this thickened end carries a peculiar, slightly curved spine-like outgrowth, which is somewhat flattened and bears four or five digit-like processes at the tip (fig. 70, $d$ ). First under arm plate very small, squarish; succeeding plates rounded pentagonal, longer than wide, broadly in contact. Side.arm plates, rathersmall,scarcely meeting above, and not at all below; each plate carries four slender, acute spines, subequal (or the uppermost and lowest, longest), about equal to the joint. Tentacle pores large, each with
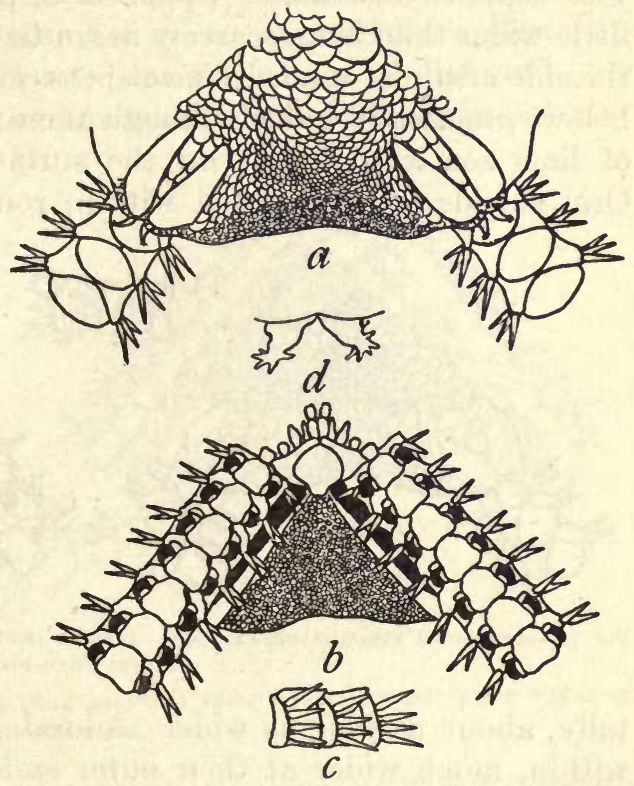

Fig. 70.-AMPHIODIA digitula. $\times$ 8. $a$, FROM ABOVE; $b$, FROM BELOW; $c$, SIDE VIEW OF THREE ARM JOINTS NEAR DISK; $d$, OUTGROWTHS ON UPPER END OF GENITAL SCALES, GREATLY ENLARGED. two good-sized scales. Color (dried from alcohol), very light grayish.

Localities.-Albatross station 3713, off Ose Zaki, Honshu Island, Japan, 45 to 48 fathoms, volcanic sand, shells, rocks, 1 specimen; station 4815 , Sea of Japan, lat. $38^{\circ} 16^{\prime}$ N.; long. $138^{\circ} 52^{\prime}$ E., 70 fathoms, dark green sand, bottom temperature $51^{\circ}, 1$ specimen.

Type. - Cat. No. 25530, U.S.N.M., from station 4815.

It is hard to determine how much weight may be properly placed on the peculiar digitate processes on the ends of the genital scales, as a specific character. They are remarkably well developed in the type but in the specimen from station 3713 they are much less 
noticeable. Moreover they are so fragile they might easily be broken off by rough handling, so that their absence would not prove that a given specimen did not belong to this species. The interbrachial scaling, arm plates and spines, oral shields and adoral plates are, however, reliable specific characters.

\section{AMPHIODIA STRONGYLOPLAX, new species.a}

Disk $5 \frac{1}{2} \mathrm{~mm}$. in diameter; arms about $50 \mathrm{~mm}$. long. Disk deeply notched in interradii, covered by a coat of numerous irregular plates, without definite arrangement. Radial shields somewhat curved, long and narrow, rather broadly in contact distally, but well separated within. Upper arm plates more or less rounded, little wider than long, scarcely in contact even at base of arm, though the side arm plates hardly meet between them. Interbrachial spaces below, practically naked, though there are numerous white granules of lime scattered about on the surface. Genital slits very large. Oral shields large, pointed within, rounded laterally, truncate dis-

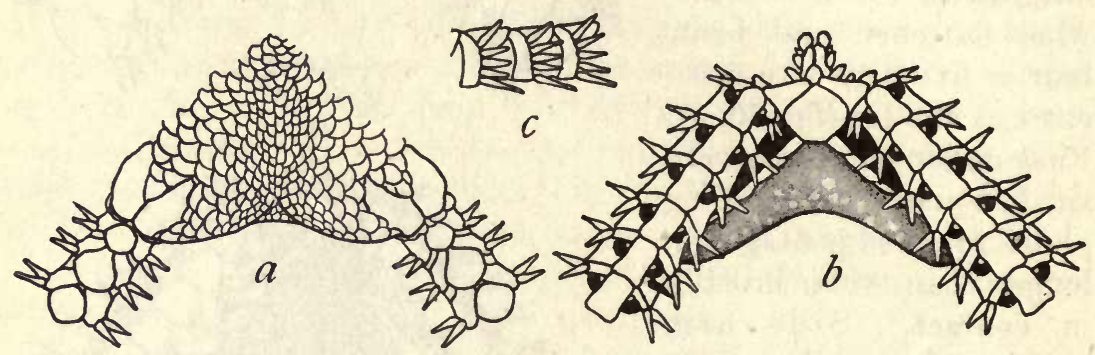

Fig. 71.-AMPHOdia STRONGYLOPLAX. $\times 9$. $a$, FROM ABOVE; $b$, FROM BELOW; $c$, SIDE VIEW OF THREE JOINTS NEAR DISK.

tally, about as long as wide. Adoral plates large, scarcely meeting within, much wider at their outer ends. Oral papillæ three, sometimes four, on a side. One at apex of jaw is thick and rounded; the second is small and pointed; the third is large and bluntly pointed; the fourth, if present, is very small. The scale of first oral tentacle pore is visible between the first and second papillæ. First under arm plate very small, narrower distally than within; succeeding plates tetragonal, with rounded corners, longer than wide, broadly in contact. Side arm plates moderate, each with five arm spines, of which the lowest is the longest and exceeds the joint. Tentacle pores large, each with a single, minute scale. Color (dried from alcohol), disk grayish, arms very light brownish; radial shields and arm plates with an orange-brown tint.

a $\Sigma \tau \rho o r r u\left\langle\lambda_{o s}\right.$, signifying round, and $\pi \lambda \dot{a} \xi$, signifying plate, in reference to the rounded upper arm plates. 
Locality.-Albatross station 2866, off Washington, lat. $48^{\circ} 9^{\prime} \mathrm{N}$.; long. $125^{\circ} 3^{\prime} \mathrm{W}$., 171 fathoms, gray sand, bottom temperature $43.2^{\circ}$, 8 specimens.

\section{Type.-Cat. No. 25615, U.S.N.M., from station 2866.}

This species bears a curious superficial resemblance to $A$. macraspis, but the bare interbrachial spaces, the upper arm plates, and the oral shields are quite unlike those of that species. As only one of the eight specimens possesses a disk, it is impossible to estimate the value of the bare interbrachial spaces; they may prove to be very variable.

\section{AMPHIODIA PSILOCHORA, new species.}

Disk $8 \mathrm{~mm}$. in diameter; arms about $65 \mathrm{~mm}$. long. Disk more or less deeply indented in interbrachial areas, covered by a close coat of scales, the largest of which are near the center of disk and close to the radial shields, while the smallest are at the interradial mar-

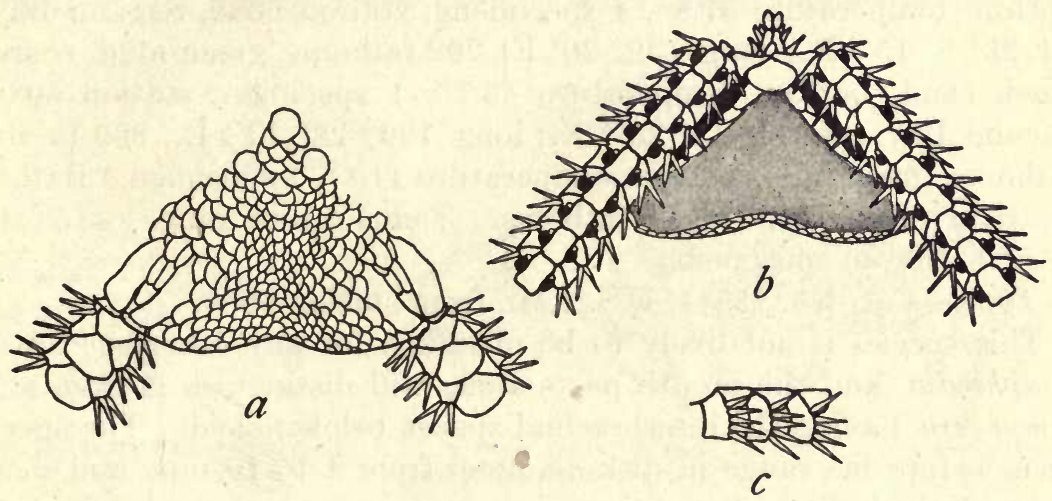

Fig. 72.-AMPHIOdI PSILOCHORA. $\times 6$. $a$, FROM ABOVE; $b$, FROM BELOW; $c$, STDE VIEW OF THREE ARM JOINTS NEAR DISK.

gins. Radial shields long and curved, separate or barely touching distally. Upper arm plates at first somewhat hexagonal, with the proximal side shortest, but soon the angles are rounded off and they become biconvex, much wider than long and scarcely or not at all in contact. Interbrachial spaces below bare. Oral shields somewhat variable, wider than long, with a broad proximal angle and a rounded (or sometimes truncate) outer margin. Adoral plates variable, nearly triangular, sometimes meeting within, but often well separated. Oral papillæ three on a side, the first one (at apex of jaw) thick and rounded; the second small, flat, and pointed; the third larger, often longer, and sometimes attenuate pointed. The tentacle scale of first oral pore is often visible between the first and

$a \Psi \iota \lambda b_{s}$, signifying bare, and $\chi \tilde{\omega} \rho o s$, signifying a space, in reference to the naked interbrachial spaces. 
second papillæ. Genital slits moderate. First under arm plate, minute; succeeding plates tetragonal, with rounded angles, longer than wide, broadly in contact. Side arm plates fairly large, barely meeting above, but scarcely below. Each plate carries five slender, sharp spines, of which the lowest is a little the longest and slightly exceeds the joint. Tentacle pores large, each with a single, small tentacle scale. Color (dried from alcohol), disk, gray; interbrachial spaces below light brown to nearly black; arms dull grayish to nearly white; radial shields sometimes (in large specimens) with a reddish tinge.

Localities.-Albatross station 3739, off Ose Zaki, Honshu Island, Japan, 55 to 65 fathoms, volcanic sand, shells, rocks, 4 specimens; station 4972 , off eastern Japan, lat. $33^{\circ} 25^{\prime} 45^{\prime \prime}$ N.; long. $135^{\circ} 33^{\prime}$ E., 440 fathoms, brown-green mud, foraminifera, bottom temperature $39.8^{\circ}, 1$ specimen; station 5085, Sagami Bay, lat. $35^{\circ} 6^{\prime} 45^{\prime \prime} \mathrm{N}$.; long. $139^{\circ} 19^{\prime} 45^{\prime \prime}$ E., 622 fathoms, green mud, fine black sand, bottom temperature $37.8^{\circ}, 4$ specimens; station 5086, Sagami Bay, lat. $35^{\circ} 8^{\prime} 15^{\prime \prime} \mathrm{N}$.; long. $139^{\circ} 20^{\prime}$ E., 292 fathoms, green mud, coarse black sand, bottom temperature $43.7^{\circ}, 1$ specimen; station 5088 , Sagami Bay, lat. $35^{\circ} 11^{\prime} 25^{\prime \prime}$ N.; long. $139^{\circ} 28^{\prime} 20^{\prime \prime}$ E., 369 to 405 fathoms, green mud, bottom temperature $41.8^{\circ}, 1$ specimen. Bathymetrical range, 55 to 622 fathoms. Temperature range, $43.7^{\circ}$ to $37.8^{\circ}$. Eleven specimens.

Type.-Cat. No. 25544, U.S.N.M., from station 5085.

This species is not likely to be mistaken for any other species of Amphiodia, and the mouth parts alone will distinguish it from any Amphiura having the interbrachial spaces below naked. The specimens before me range in disk diameter from 4 to $10 \mathrm{~mm}$. and show comparatively little diversity.

\section{AMPHIPHOLIS PUGETANA.}

Amphiura pugetana Lyman, Proc. Boston Soc. Nat. Hist., vol. 7, 1868, p. 193. Amphipholis pugetana Verrill, Trans. Conn. Acad., vol. 10, 1899, p. 312.

Localities.-Albatross station 2850 , off Alaska, lat. $54^{\circ} 52^{\prime} \mathrm{N}$.; long. $159^{\circ} 46^{\prime}$ W., 21 fathoms, broken shells, bottom temperature $48.2^{\circ}, 5$ specimens; station 2856 , off Alaska, lat. $58^{\circ} 7^{\prime}$ N.; long. $151^{\circ} 36^{\prime}$ W., 68 fathoms, gray sand, black specks, bottom temperature $44^{\circ}, 1$ specimen; station 2876 , off Washington, lat. $48^{\circ} 33^{\prime} \mathrm{N}$.; long. $124^{\circ} 53^{\prime}$ W., 59 fathoms, black sand, mud, bottom temperature $45.5^{\circ}, 3$ specimens; station 3052 , off Oregon, lat. $44^{\circ} \mathrm{N}$.; long. $124^{\circ} 57^{\prime}$ W., 48 fathoms, coral, broken shells, rocky, bottom temperature $49^{\circ}, 1$ specimen; station 3466 , off Washington, lat. $48^{\circ} 18^{\prime}$ $30^{\prime \prime} \mathrm{N}$.; long. $123^{\circ} 22^{\prime} \mathrm{W}$., 56 fathoms, gray sand, shells, rocky, bottom temperature $48.5^{\circ}, 1$ specimen; station 4230 , off Indian Point, Alaska, 108 to 240 fathoms, rocky, bottom temperature $42.4^{\circ}$, 
2 specimens; Puget Sound, 1 specimen; Monterey, California, 8 to 12 fathoms, 4 specimens. Bathymetrical range, 8 to 240 fathoms. Temperature range, $49^{\circ}$ to $44^{\circ}$. Eighteen specimens.

As no figures of this species have been published, it has been thought desirable to give the accompanying illustrations. The characteristic mouth parts easily distinguish this species from any - of the others taken by the Fisheries steamer Albatross. In fact, it is the only representative of its genus in the collection.

\section{AMPHIOPLUS RHADINOBRACHIUS, new species. $a$}

Disk $6 \mathrm{~mm}$. in diameter; arms about $100 \mathrm{~mm}$. long. Disk covered by a coat of several hundred scales, of nearly uniform size. Radial shields long and very slender, in contact distally but separated within. Upper arm plates much wider than long, strongly convex distally; at base of arm angular proximally, and slightly in contact, but farther out broadly convex proximally, and separated from each other. Interbrachial spaces below covered with much smaller scales than

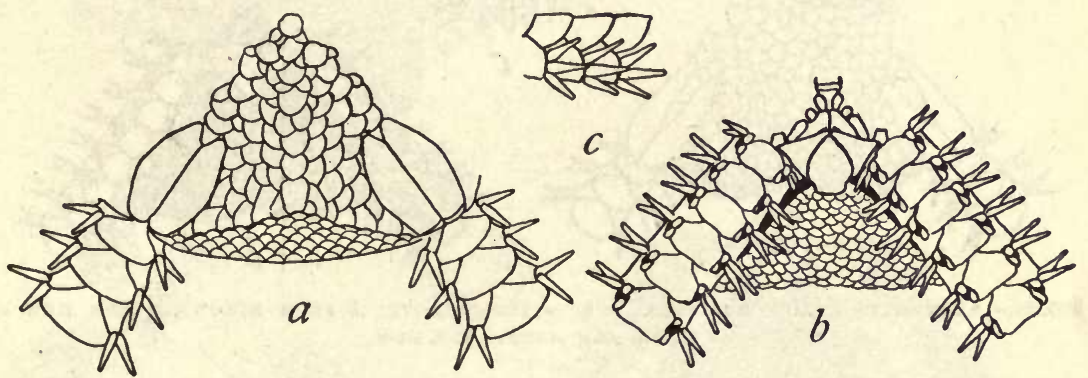

Fig. 73.-A MPHIPHOLIS PUGETANA. $\times 12$. $a$, FROM ABOVE; $b$, FROM BELOW; $c$, SIDE VIEW OF THREE ARM JOINTS NEAR DISK.

those of the disk. Genital slits large. Oral shields oval, longer than broad. Adoral plates large, narrow within where they nearly or quite meet, very much broader at outer ends. Oral papillæ four on a side, one thick and rounded at apex of jaw, the second and third nearly as large, but flat and rounded or pointed at tip, the fourth somewhat smaller; the tentacle scale of the first oral pore shows between the first and second papillæ and may be mistaken for another papilla. First under arm plate minute, pentagonal, about as long as broad; succeeding plates pentagonal or hexagonal, broader than long, becoming longer than broad, distinctly in contact, at least on base of arm. Side arm plates small, meeting above except at base of arm, not meeting below; each plate carries three sharp, slender spines, subequal, or the middle one longest. Tentacle scales, two. Color (dried from alcohol), light gray or whitish.

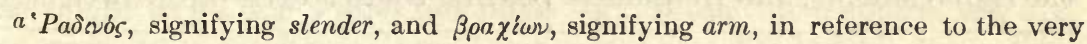
slender arms. 
Localities.-Albatross station 5053, Suruga Gulf, lat. $34^{\circ} 49^{\prime} 20^{\prime \prime}$ $\mathrm{N}$.; long. $138^{\circ} 40^{\prime} 15^{\prime \prime} \mathrm{E}$., 503 fathoms, green mud, bottom temperature $34.9^{\circ}, 1$ specimen; station 5054 , Suruga Gulf, lat. $34^{\circ} 52^{\prime} 45^{\prime \prime}$ N.; long. $138^{\circ} 42^{\prime} 20^{\prime \prime}$ E., 282 fathoms, green mud, broken shells, foraminifera, bottom temperature $45.3^{\circ}, 2$ specimens, without disks; station 5088, Sagami Bay, lat. $35^{\circ} 11^{\prime} 25^{\prime \prime}$ N.; long. $139^{\circ} 28^{\prime} 20^{\prime \prime}$ E., 369 to 405 fathoms, green mud, bottom temperature $41.8^{\circ}$, 1 specimen. Bathymetrical range, 282 to 503 fathoms. Temperature range, $45.3^{\circ}$ to $34.9^{\circ}$. Four specimens.

Type.-Cat. No. 25587, U.S.N.M., from station 5053.

The extremely slender arms and the characteristic mouth parts, taken in connection with the radial shields, three arm spines and two tentacle scales, make this an easy species to recognize. As the disks are wanting in the specimens from station 5054 , it is, of course, possible that their identification as rhadinobrachius is incorrect.

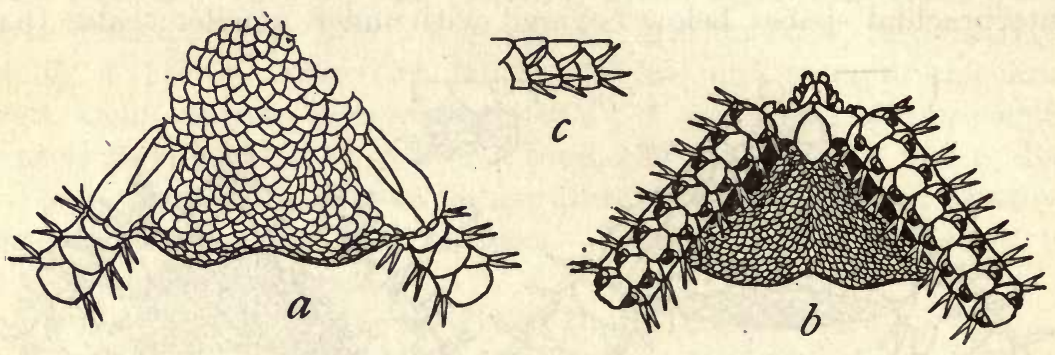

FIG. 74.-AMPHIOPLUS RHADINOBRACHUS. $\times$ 8. $a$, FROM ABOVE; $b$, FROM BELOW; $c$, SIDE VIEW OF THREE ARM JOINTS NEAR DISK.

AMPHIOPLUS ACANTHINUS, new species. $a$

Disk $14 \mathrm{~mm}$. in diameter; arms about $140 \mathrm{~mm}$. long. Disk somewhat decagonal (the decagon with somewhat convex sides), lightly notched radially, and deeply so interradially; covered with a close coat of very numerous scales, some of which bear slender acute spines one-half millimeter long; these spines are set into little pits, so that when they are rubbed off their former position is clearly indicated. Radial shields small, divergent, but in contact distally. Upper arm plates tetragonal or pentagonal with more or less rounded corners, twice as wide as long or more, broadly in contact basally but barely touching on terminal part of arm. Interbrachial spaces below covered by much finer scales than the disk, and without spines. Oral shields, oval or elliptical, much longer than wide. Adoral plates large and triangular, hardly meeting within. Oral papillæ four or five on a side, the one near apex of jaw largest. Genital slits very large; genital scales inconspicuous orally, but often noticeable from above just distal to the radial shields, and frequently bearing there a little outgrowth simi-

a Akóntผos, signifying thorny, in reference to the numerous disk spines. 
lar to that so characteristic of Amphiodia digitula. First under arm plate minute, squarish; succeeding plates somewhat hexagonal or pentagonal, about as wide as long, more or less in contact on basal part of arm; on many of them there is a minute tooth or sharp projection at the center of the distal margin. Side arm plates small, each with only three sharp, subequal spines, about as long as the joint - ar $-\mathrm{a}$ little longer. Tentacle scales, two. Color (dried from alcohol), nearly white, or light grayish-brown; upper and under arm plates sometimes rather heavily shaded with dull brownish-red.

Localities.-Albatross station 3695, off Tsuragi Saki Light, Honshu Island, Japan, 110 to 259 fathoms, green mud, fine sand, 30 speci-

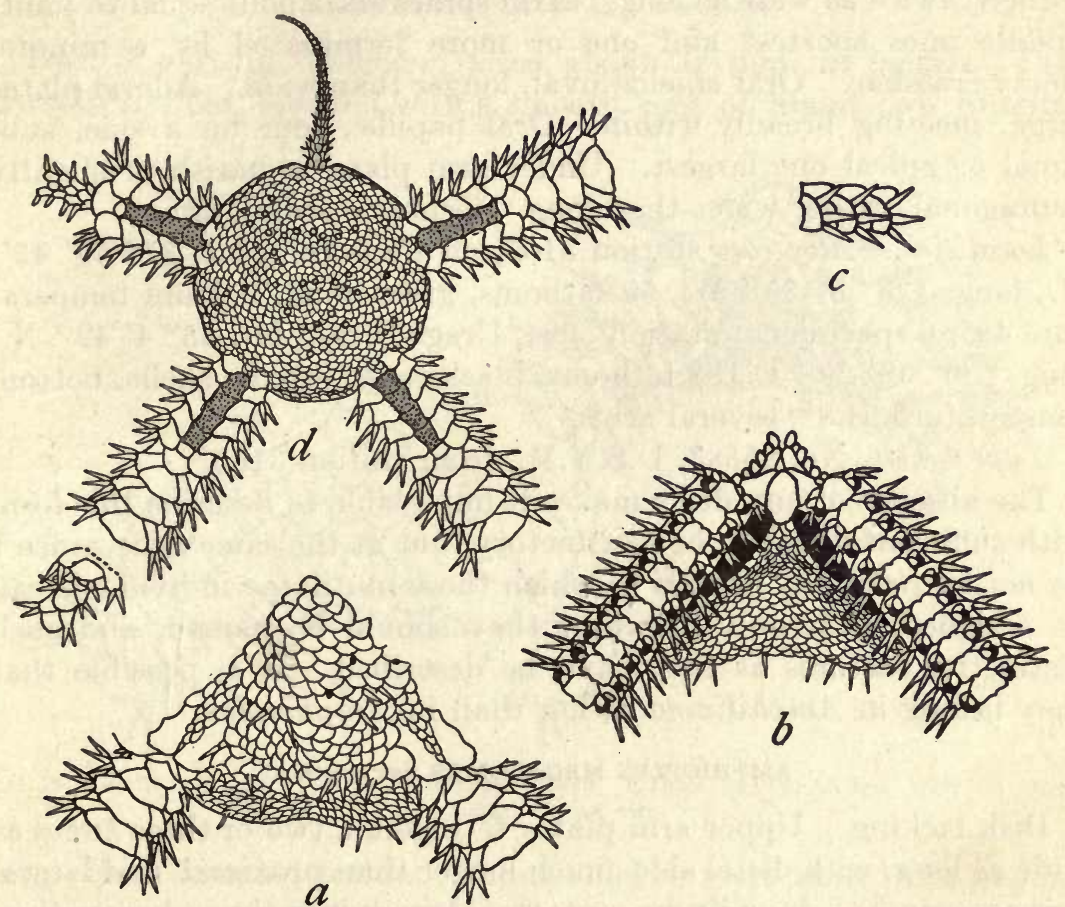

FIG. 75.- $A$ MPHIOPLUS ACANTHINUS. $\times$ 4. $a$, FROM ABOVE; $b$, FROM BELOW; $c$, SIDE VIEW OF THREE ARM JOINTS NEAR DISK; $d$, REGENERATED DISK AND THREE REGENERATED ARMS.

mens; station 5073, Suruga Gulf, lat. $34^{\circ} 46^{\prime} \mathrm{N}$.; long. $138^{\circ} 21^{\prime} 50^{\prime \prime}$ E., 148 fathoms, gray mud, bottom temperature $54.6^{\circ}, 2$ specimens.

Type.-Cat. No. 25595, U.S.N.M., from station 3695.

This is an unusually well-characterized species and yet its generic position is somewhat in doubt. As an Amphioplus it ought not to have spines on the disk, while, on the other hand, it will not go into Verrill's genus Amphilimna, where spiny-disked species of Amphioplus ought to go, for it does not have "six to ten" arm spines, nor are the tentacle scales "spiniform," nor are the radial shields "parallel, 
largely in contact." One of the specimens from station 3695 affords such a remarkably fine illustration of arm and disk regeneration after breaking and shedding, that it has seemed wise to show it (fig. $75 d$ ). The limits of the original disk are plainly shown on the bases of the four large arms, while the fifth arm is regenerating from a single basal joint The disk scales are surprisingly small, and the radial shields are very inconspicuous. The disk spines are represented by minute knobs. Two of the four large arms are regenerating from basal stumps.

\section{AMPHIOPLUS HEXACANTHUS, new species. $a$}

Disk lacking. Upper arm plates broadly hexagonal, with rounded corners, twice as wide as long. Arm spines six, about equal to joint; middle ones shortest and one or more terminated by a minute, glassy crossbar. Oral shields oval, longer than wide. Adoral plates large, meeting broadly within. Oral papillæ, four on a side, subequal or apical one largest. Under arm plates squarish or slightly pentagonal, rather wider than long. Tentacle scales, two.

Localities.-Albatross station 3165 , off California, lat. $37^{\circ} 59^{\prime} 45^{\prime \prime}$ N.; long. $123^{\circ} 8^{\prime} 35^{\prime \prime}$ W., 50 fathoms, green mud, bottom temperature $49^{\circ}, 6$ specimens; station 5094, Uraga Strait, lat. $35^{\circ} 4^{\prime} 42^{\prime \prime} \mathrm{N}$.; long. $139^{\circ} 38^{\prime} 20^{\prime \prime}$ E., 88 fathoms, black sand, broken shells, bottom temperature $54.8^{\circ}$, several arms.

Type.-Cat. No. 25583, U.S.N.M., from station 3165.

The absence of any disks makes it impossible to describe this form with sufficient detail to be satisfactory, but at the same time, since I do not know of any species to which these mutilated individuals can be assigned, it is only fair that they should be named, and such distinctive features as they have, be described. It is possible that they belong in Amphilimna rather than in Amphioplus.

\section{AMPHIOPLUS MEGAPOMUS, new species. ${ }^{\circ}$}

Disk lacking. Upper arm plates tetragonal, two or three times as wide as long, with distal side much longer than proximal and lateral corners rounded, broadly in contact. Arm spines three, longer than joint, middle one longer and thicker at base than the others. Oral shields diamond-shaped, with rounded corners and somewhat concave sides, much longer than wide. Adoral plates moderate, almost triangular. Oral papillæ four on a side, the apical ones small and widely separated from each other, the other three large, and nearly closing the mouth slit. Under arm plates broadly pentagonal, much

$a^{\prime \prime} E \xi$, signifying six, and $\ddot{a} \kappa \alpha \nu \theta a$, signifying spine, in reference to the number of arm spines.

$b$ M $\varepsilon_{r a s}$, signifying $b i g$, and $\pi \tilde{\omega} \mu a$, signifying lid, in reference to the large lid-like tentacle scales. 
wider than long, barely in contact. Tentacle scales two, unusually large and flat, nearly closing the large pores.

Locality.-Albatross station 4964 , off eastern Japan, lat. $34^{\circ} 5^{\prime} 30^{\prime \prime}$ N.; long. $134^{\circ} 56^{\prime} 40^{\prime \prime}$ E., 37 fathoms, fine gray sand, mud, bottom temperature $66.6^{\circ}, 2$ individuals without disks.

Type.-Cat. No. 25633, U.S.N.M., from station 4964.

It is too bad that this very well marked species should be represented in the collection only by two diskless specimens, for I know of no other species in which typical Amphioplus mouth parts are combined with such remarkable tentacle scales and arm plates. It would be most interesting to know the disk structure.

AMPHILEPIS PLATYTATA, new species. $a$

Disk $8 \mathrm{~mm}$. in diameter; arms about $32 \mathrm{~mm}$. in length. Disk excessively flat, covered with a smooth coat of about two hundred

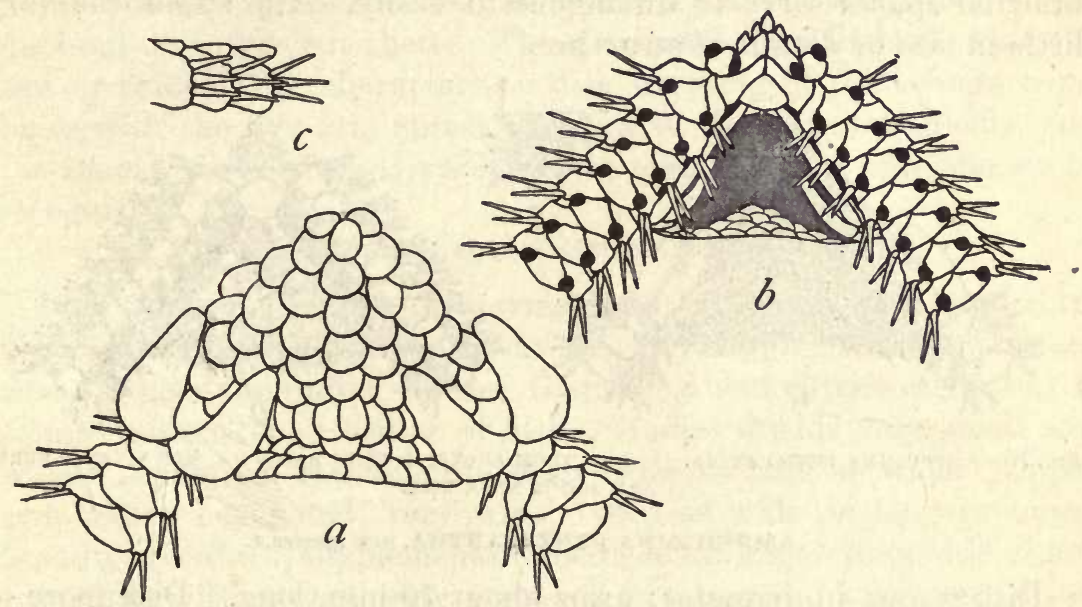

Fig. 76.-AMPHILEPIS PLATytata. $\times$ 6. $a$, FROM ABOVE; $b$, FROM BELOW; $c$, SIDE VIEW OF THREE ARM JOINTS NEAR DISK.

large, thin, rounded scales. Radial shields, more than twice as long as broad, well separated within, but just barely in contact distally. Upper arm plates broadly pentagonal, with somewhat rounded angles and a convex distal margin, twice as wide as long, not in contact except at very base of arm. Interbrachial spaces below, quite naked except for a few marginal scales. Oral shields triangular, with slightly convex sides, a little wider than long. Adoral plates large, wider without than within. Oral plates large, each carrying two low, wide, truncate papillæ. Teeth nearly triangular. Genital slits very inconspicuous. First under arm plate large, somewhat pentagonal, with inner lateral margins concave; succeeding plates also

a $\Pi \lambda a \tau \dot{\tau} \tau \alpha \tau o s$, signifying flattest, in reference to the exceedingly flat disk. 
pentagonal, but larger, and distinctly broader than long; they are barely in contact at first (first and second quite separate) but farther out become separated. Side arm plates rather large, meeting more or less completely above and below, except at very base of arm; each plate carries three slender, acute, subequal spines, longer than a joint. Tentacle scales, none, though pores are rather large. Color (dried from alcohol), disk light gray, arms nearly white.

Localities.-Albatross station 2859, off Alaska, lat. $55^{\circ} 20^{\prime} \mathrm{N}$.; long. $136^{\circ} 20^{\prime}$ W., 1,569 fathoms, gray ooze, bottom temperature $34.9^{\circ}, 12$ specimens; station 4761 , south of Shumagin Islands, lat. $53^{\circ} 57^{\prime} 30^{\prime \prime} \mathrm{N}$.; long. $159^{\circ} 31^{\prime} \mathrm{W}$., 1,973 fathoms, blue clay, bottom temperature $35^{\circ}, 1$ specimen.

Type.-Cat. No. 25734, U.S.N.M., from station 2859.

Although this species resembles $A$. papyracea Lyman quite closely in many particulars, the much coarser disk scales and the naked interbrachial spaces serve to distinguish it easily. The specimens vary little in size or details of structure.

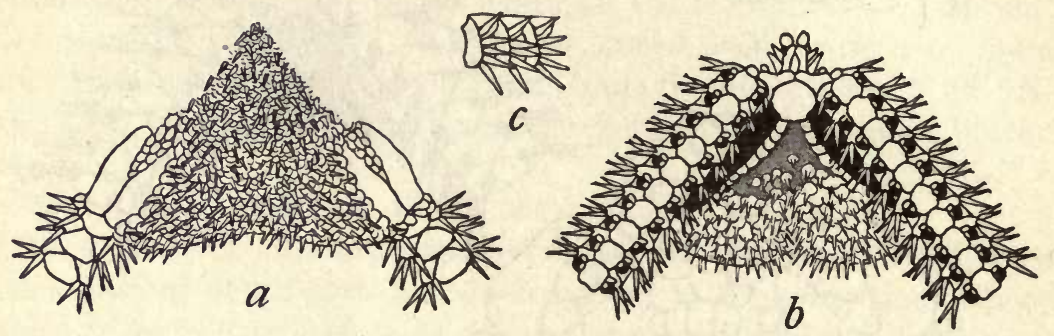

Fig. 77.- - M PHILIMNa PENTACANTHA. $\times 5$. $a$, FROM ABOVE; $b$, FROM BELOW; $c$, SIDE VIEW OF THREE ARM JOINTS NEAR DISK.

\section{AMPHILIMNA PENTACANTHA, new species. $a$}

Disk $9 \mathrm{~mm}$. in diameter; arms about $70 \mathrm{~mm}$. long. Disk more or less swollen, covered by a coat of hundreds of small scales, many of which carry minute sharp spines. Radial shields long, narrow, more or less joined, somewhat sunken. Upper arm plates at first somewhat tetragonal, with a long convex side distally, and angular proximally, soon becoming almost perfectly elliptical, much wider than long, and then gradually becoming proximally angular again; more or less lightly in contact, at least basally. Interbrachial spaces below somewhat sparsely scaled, especially near oral shield, but with numerous spinelets. Oral shields nearly circular or else a little longer than broad. Adoral plates nearly horizontal and triangular, meeting broadly within. Oral papillæ four on a side, the apical one thick and rounded, the next two elongate and pointed, the fourth very small

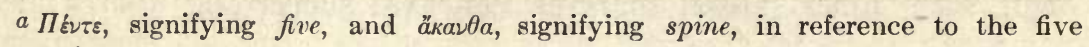
arm spines. 
and rounded; just back of the apical papilla is the small pointed scale of the first oral tentacle pore, which might very naturally be counted as a fifth oral papilla. Genital slits very large. First under arm plate very small, rounded; succeeding plates squarish or a little longer than wide, in contact at least on basal part of arm. Side arm plates moderate, meeting above and below very little or not at all; each one carries five slender, sharp spines, of which the lowest is longest and exceeds the joint. Tentacle scales two, not at all spiniform. Color (dried from alcohol), very light brownish, the disk more or less gray. Locality.-Albatross station 3131 , off California, lat. $36^{\circ} 41^{\prime} 30^{\prime \prime} \mathrm{N}$.; long. $121^{\circ} 54^{\prime} 10^{\prime \prime} \mathrm{W}$., 48 fathoms, brown mud, rocks, bottom temperature $50.8^{\circ}, 40$ specimens.

Type.-Cat. No. 25614, U.S.N.M., from station 3131.

This species appears, from its mouth parts, radial shields, and spiny disk to be entitled to a place in Amphilimna, but the small number of arm spines and the flat, rounded tentacle scales have made me hesitate to place it there. The specimens show little diversity in size or color. The characteristic disk covering of Ophiocnida combines with the five arm spines, the nearly circular oral shields, and the mouth parts of an Amphioplus to make this an easy species to recognize.

\section{OPHIONEREIS EURYBRACHIPLAX, new species. $a$}

Disk $24 \mathrm{~mm}$. in diameter; arms about $160 \mathrm{~mm}$. long, probably. Disk covered with a firm coat of minute, overlapping scales, which are coarsest near the radial shields; there are about fifteen scales to the 'square millimeter at center of disk. Radial shields very small and widely separated, rather more than twice as long as wide. Upper arm plates hexagonal, very wide, twice as wide as long or more, broadly in contact; supplementary pieces small, longer than wide, either triangular with outer side very convex or tetragonal with outer distal corner obliterated. Interbrachial spaces below covered with a coat of very fine scales. Oral shield triangular, longer than broad (in the Japanese specimen, fig. $78 b$, the breadth exceeds the length). Adoral plates small, at sides of oral shields, wide distally but pointed at inner end. Oral papillæ four or five on a side, truncate or blunt, the next to the outermost the widest. Genital slits small. First under arm plate squarish; succeeding plates tetragonal, with slightly curved sides and rounded angles, at first wider than long, but becoming sooner or later longer than wide, broadly in contact. Side arm plates small, not nearly meeting either above or below; each plate carries at first four, then three, stout blunt arm spines, rather exceeding the joint; basally the lowest is the longest but farther out the middle one

a Eủoús, signifying wide, and $\beta \rho \alpha \chi^{\imath} \omega \nu$, signifying arm, and $\pi \lambda \dot{a} \xi$, signifying plate, in reference to the characteristic upper arm plates. 
is longer and somewhat stouter than the others. Tentacle scale single, huge, circular or oval. Color (dried from alcohol), disk light brownish-gray, or dull purplish with a few small light spots; arms somewhat duller, irregularly and indistinctly banded with dull purple, especially on distal half; upper arm plates dull gray, often clouded with purplish, or else prettily mottled with dull purple and whitish; oral surface lighter.

Localities.-Albatross station 3159 , off California, lat. $37^{\circ} 47^{\prime} 20^{\prime \prime}$ $\mathrm{N}$.; long. $123^{\circ} 10^{\prime} \mathrm{W}$., 27 fathoms, rocky, 1 specimen; station 3168 , off California, lat. $38^{\circ} 1^{\prime} 25^{\prime \prime} \mathrm{N}$.; long. $123^{\circ} 26^{\prime} 55^{\prime \prime}$ W., 34 fathoms,
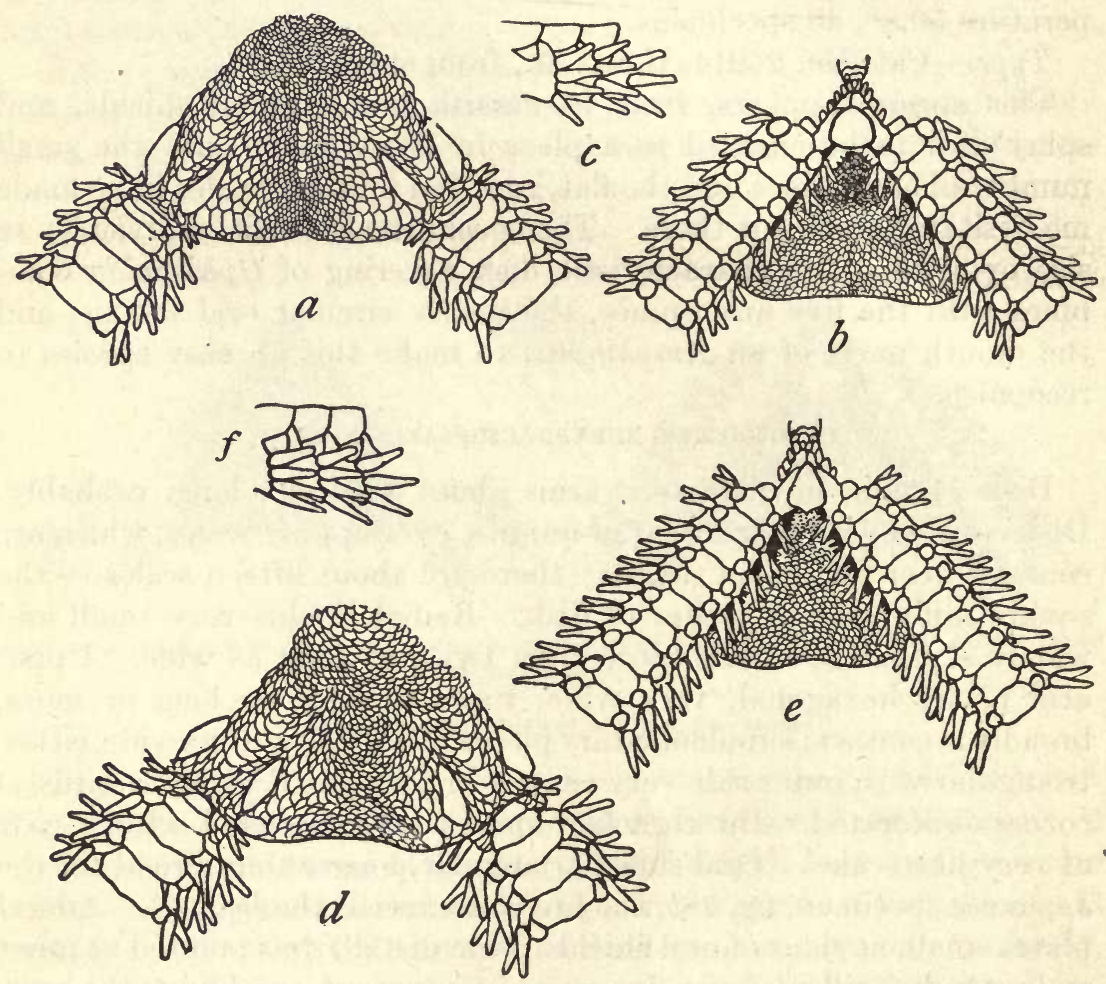

FIG. 78.-OPHIONEREIS EURYBRACHIPLAX. $a-c$, FROM JAPAN,$\times 3 . d-f$, FROM CALIFORNIA, $\times 2 . a$ AND $d$, FROM ABOVE; $b$ AND $e$, FROM BELOW; $c$ AND $f$, SIDE VIEW OF THREE ARM JOINTS NEAR DISK.

rocky, coral, 1 specimen; station 3702, off Honshu Island, Japan, 31 to 41 fathoms, volcanic mud, sand, rocks, 3 specimens; off California, station?, 1 specimen.

Type.-Cat. No. 25589, U.S.N.M., from off California.

This species may be distinguished at once from its Pacific relatives, annulata, porrecta, schayeri, and $n u d a$, by the very characteristic upper arm plates, which are quite unlike those of any of the four. It is a great pity that there should be any doubt about the locality of any of 
the specimeris, but I can not suppress the feeling that there is some mistake about the label " 3702 ." If that were read " 3102 ," a station in 27 fathoms, off central California, the distribution of the species would be quite natural. In view of the absence of Ophionereis, a tropical and subtropical, littoral genus, north of California, it is hard for me to believe that a Californian species occurs in Japan. I shall therefore assume that 3702 is a mistake for 3102 , at least until further specimens are taken in Japanese waters.

\section{OPHIOCRASIS, new genus. $a$}

Similar to Ophionereis, but with one or more secondary supplemental plates, just distal to the usual supplementary plates. Arms six in young, five in adults. Reproduction by fission apparently occurs.

Type-species - Ophiocrasis dictydisca.

The presence of secondary supplemental plates is somewhat exaggerated in the drawings given herewith (figs. $79 a, 79 d .79 g$ ), for it is almost impossible to represent them accurately, they are so small and delicate. In Ophionereis the upper arm plates and their supplementary plates, even in young and small specimens, are thick and when dry are clear cut, with well-defined smooth margins. In Ophiocrasis, however, when the arm is dried, it is seen that the upper arm plates are thin, with a fairly well-defined distal margin; the supplementary plates have the margin very poorly defined and close to them distally some additional minute plates are to be seen; of these the one adjoining the upper arm plate is the most sharply defined; the others are usually very hard to distinguish, and may be absent; these secondary plates can only be seen when the arm is dry and are best shown near the base of the arm. I have found nothing like them in Ophionereis, though I have examined old and young specimens of four species with great care. There seems little room for doubt that reproduction takes place early in life by fission, as this is clearly indicated by one specimen (see fig. $79 g$ ). At the same time I am forced to the conclusion that the six-rayed condition is juvenile and that the adult has only five rays. But it must be confessed that a larger series of specimens is needed to determine these facts beyond question.

\section{OPHIOCRASIS DICTYDISCA, new species. $b$}

Disk $7 \mathrm{~mm}$. in diameter; arms about $35 \mathrm{~mm}$. long. Disk covered by a delicate coat of very fine scales, coarser in the young and less embedded in the skin than in the adult. Radial shields small, elongate,

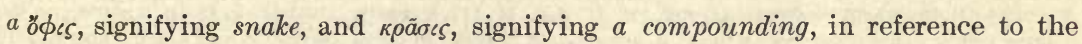
compounding of the supplementary arm plates, and to be symphonious with other ophiuran genera.

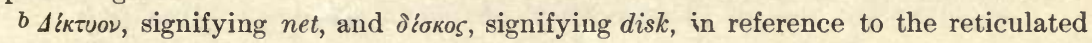
disk. 

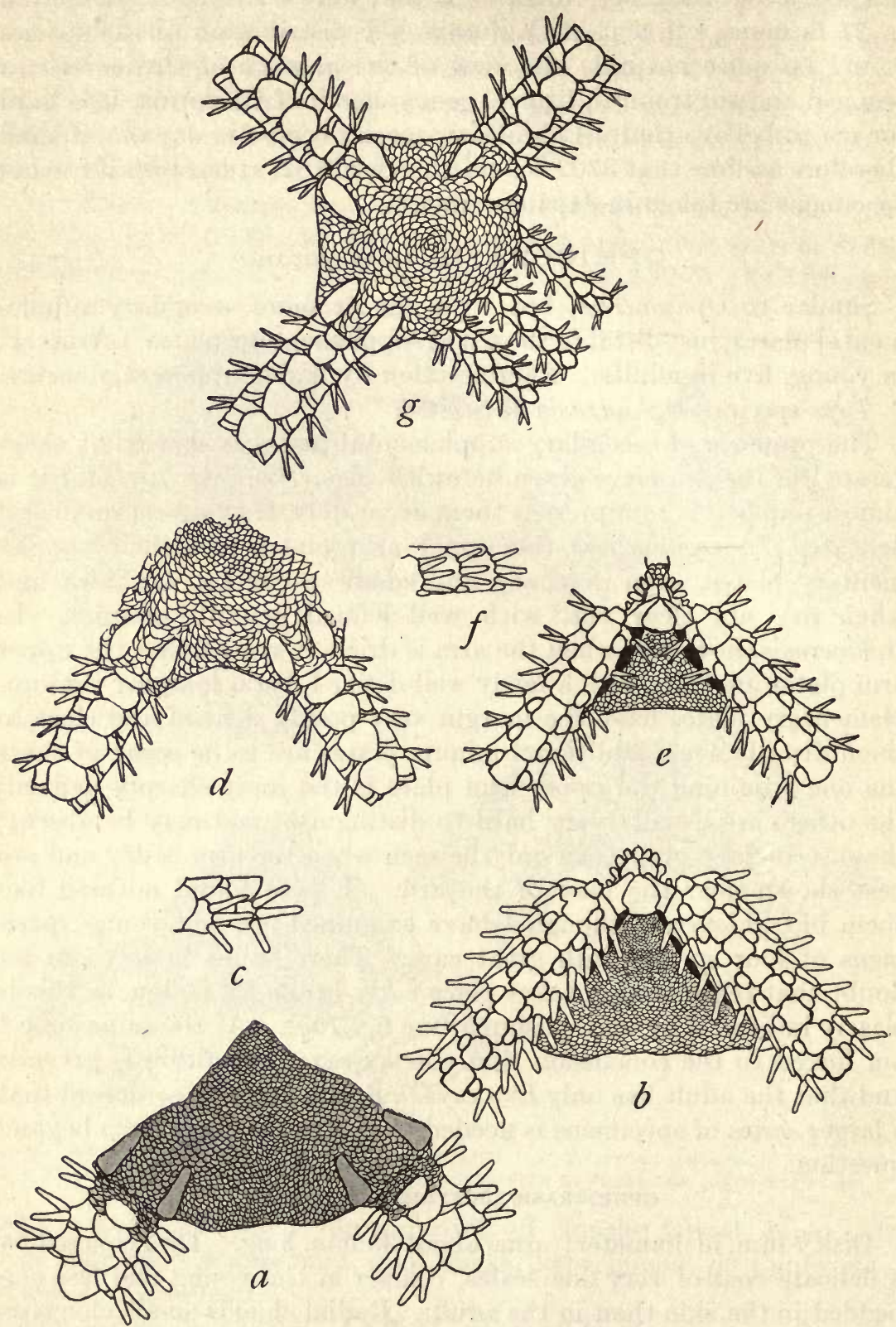

Fig. 79.-OPHIOCRASIS DICTYDISCA. $a-c, \times 7 ; d-g, \times 11$. $a$, FROM ABOVE; $b$, FROM BELOW; $c$, SIDE VIEW OF TWO ARM JOINTS NEAR DISK; $d$, A YOUNGER SPECIMEN, FROM ABOVE; $c$, THE SAME, FROM BELOW; $f$, SIDE VIEW OF THREE ARM JOINTS NEAR DISK; $g$, ANOTHER YOUNG SPECIMEN FROM ABOVE, SHOWING THE INEQUALITY OF THE TWO TRIOS OF ARMS. 
widely separated, nearly three times as long as wide. Upper arm plates as long as broad or nearly so, the distal margin very convex while the proximal half is three-sided with more or less, or almost completely, obliterated angles; supplementary plates rather large and, as described above, provided with minute secondary plates along their distal border. Interbrachial space below very closely covered with minute scales. Oral shields rounded triangular, or arrow-head shaped, somewhat longer than wide, particularly in the young (in fig. $79 e$ the shield is too wide). Adoral plates, long triangular, hardly meeting within. Jaws short, with four to six oral papillæ which are rather long, flat and rounded in the young, but become thick and truncate in the adult. First under arm plate somewhat pentagonal, of moderate size; succeding plates oblong or somewhat pentagonal, longer than wide, broadly in contact. Side arm plates small, each with three thick, blunt spines, of which either the middle or lowest is the longest, and about equals the joint. Tentacle scale single, very large, elliptical. Color (dried from alcohol), disk, yellowish with an irregular network of purplish-brown lines; arms grayish, banded with dull purple; the relative amount of yellow and purple on the disk is variable, as is also the number of bands on the arms and their distance from each other.

Localities.-Albatross station 3758, off Suno Saki, Honshu Island, Japan, 52 to 73 fathoms, blue clay, rocks, 1 specimen; station 4875 , Korea Strait, lat. $34^{\circ} 19^{\prime} \mathrm{N}$.; long. $130^{\circ} 9^{\prime}$ E., 59 fathoms, fine gray sand, broken shells, bottom temperature $62.1^{\circ}, 1$ specimen; station 4879 , Korea Strait, lat. $34^{\circ} 17^{\prime}$ N.; long. $130^{\circ} 15^{\prime}$ E., 59 fathoms, fine gray sand, broken shells, bottom temperature $62.1^{\circ}, 1$ specimen; off Japan, station?, 1 specimen.

Type.-Cat. No. 25715, U.S.N.M., from off Japan.

The specimens with six arms range from 2.5 to $4.5 \mathrm{~mm}$. in disk diameter. Specimens of Ophionereis porrecta of the same size have only five arms. It is of course possible that these six-armed specimens do not belong to the same species as the larger five-armed one which I have taken as the type of dictydisca, but their resemblances otherwise are so close I am satisfied of their identity.

\section{OPHIODORIS PERICALLES, new species. $a$}

Disk $11 \mathrm{~mm}$. in diameter; arms about $110 \mathrm{~mm}$. long. Disk covered by a close smooth coat of fine scales, distinctly larger along margin, in interbrachial areas. Radial shields small, widely separated, about twice as long as wide; distal to them, and extending downward on the genital scales, are a number of minute spinelets, the

a $\Pi_{\varepsilon \rho: \kappa} \alpha \lambda \lambda y_{\zeta}$, signifying very pretty, in reference to the form and markings.

$34916^{\circ}$-Bull. $75-11-12$ 
presence of which is one of the characteristic features of the genus. Interbrachial spaces below covered with a coat of very fine scales, which are coarsest near the margin. Oral shield longer than wide, pointed within, and rounded distally. Adoral plates very small, lying at the sides of the oral shield. Oral papillæ, four or five on a side, thick, bluntly pointed, the next to the outermost largest. . Genital slits inconspicuous. First under arm plate rounded; succeeding ones squarish, wider distally than proximally, scarcely as long as wide, in contact more or less fully throughout. Side arm plates small, each with three subequal, rather slender spines, about as long as a joint. Tentacle scales two or three, one large oval one on side arm plate and one or two very small ones attached to under arm plate. Color (dried from alcohol), variegated greenish-gray and white; the markings of the disk are often very symmetrical, but may be quite irregular; the arms are more or less distinctly banded with a darker

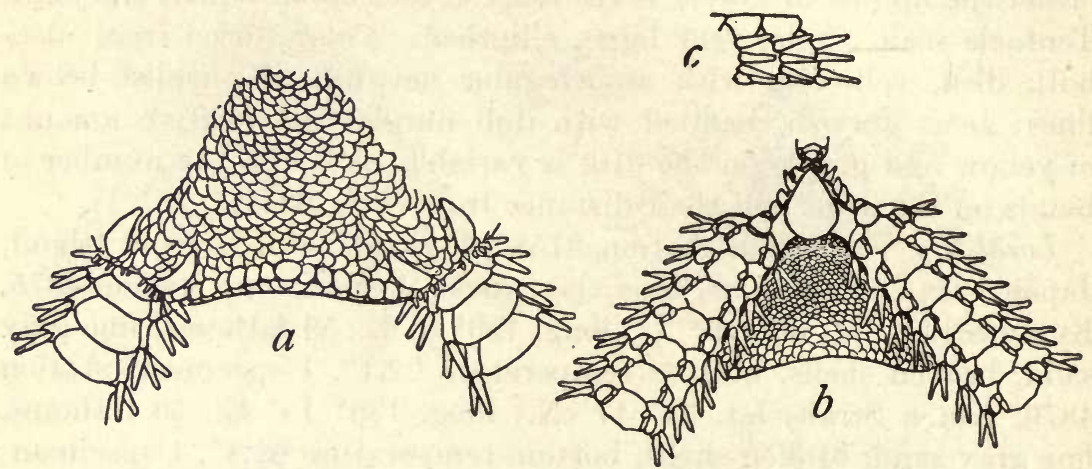

Fig. 80.-OPHIODORIS PERICAlles. $\times 4$. $a$, FROM ABOVE; $b$, FROM BELOW; $c$, SIDE VIEW OF THREE ARM JOINTS NEAR DISK.

shade of gray. As a rule the radial shields are white and from each one a curved line of white runs inward to the center of the disk.

Localities.-Albatross station 3740, off Ose Zaki, Honshu Island, Japan, 65 fathoms, volcanic sand, shells, pebbles, 1 specimen; station 4893 , Eastern Sea, lat. $32^{\circ} 32^{\prime}$ N.; long. $128^{\circ} 32^{\prime} 50^{\prime \prime}$ E., 95 to 106 fathoms, gray sand, broken shells, pebbles, bottom temperature $55.9^{\circ}, 2$ specimens; station 4894 , Eastern Sea, lat. $32^{\circ} 33^{\prime}$ N.; long. $128^{\circ} 32^{\prime} 10^{\prime \prime}$ E., 95 fathoms, gray sand, broken shells, pebbles, bottom temperature $55.9^{\circ}, 2$ specimens; station 4895 Eastern Sea, lat. $32^{\circ} 33^{\prime} 10^{\prime \prime} \mathrm{N}$.; long. $128^{\circ} 32^{\prime} 10^{\prime \prime} \mathrm{E}$., 95 fathoms, gray sand, broken shells, pebbles, bottom temperature $55.9^{\circ}, 4$ specimens; station 4936 , Eastern Sea, lat. $30^{\circ} 54^{\prime} 40^{\prime \prime}$ N.; long. $130^{\circ} 37^{\prime} 30^{\prime \prime}$ E., 103 fathoms, stones, bottom temperature $60.6^{\circ}, 1$ specimen. Bathymetrical range, 65 to 106 fathoms. Temperature range, $60.6^{\circ}$ to $55.9^{\circ}$. Ten specimens.

Type.-Cat. No. 25591 U.S.N.M., from station 4894. 
This very handsome ophiuran seems to be quite distinct from any of the three species upon which Kœhler based the genus, though it is obviously congeneric with them. Aside from its pretty coloration, it may be easily recognized by the very small adoral plates, the long, pointed oral shields, the wide upper arm plates and the small, widely separated radial shields. It seems to be nearest to $O$. malignus Kohler, but the differences in the shape of the disk, of the oral shields, of the radial shields, and of the upper arm plates are very marked.

\section{Family OPHIOHELID瓜 ${ }^{a}$}

\section{OPHIOMITRA CARDIOMORPHA, new species. $b$}

Disk $14 \mathrm{~mm}$. in diameter; arms' about $90 \mathrm{~mm}$. long. Disk divided into five wedge-shaped divisions by deep interradial sulci; each division is covered by a pair of large, naked, radial shields and a number of irregular plates; of these plates those at center of disk are the smallest, but many of them carry spines $2 \mathrm{~mm}$. or more in length, with rough tips; the marginal disk plates are entirely without spines but plates next to the radial shields of ten carry spines. Radial shields very large, roughly triangular, nearly twice as wide as long, separated for their entire length. Upper arm plates nearly twice as wide as long, the distal margin slightly convex or straight, the proximal strongly convex; basal ones slightly overlapping, though scarcely in contact, but on the greater part of the arm they are separated. Interbrachial areas below heart-shaped, covered with irregular smooth scales. Genital slits very conspicuous. Oral shield diamond-shaped, about as wide as long. Adoral plates large, wider without than within; oral plates small and indistinct. Oral papillæ five on a side, with an infradental one at apex of jaw; all but the last and penultimate, distinctly pointed. First under arm plate small, somewhat triangular; succeeding plates much wider than long, with the straight or angular distal margin longer than the proximal, and lateral margins more or less concave and diverging distally; except first and second, no two are in contact. Side arm plates large, meeting both above and below, though not broadly; each plate carries five long, slender arm spines, the uppermost longest (nearly equal to three joints), sharpest and smoothest; the lowest shortest, bluntest, and roughest. Tentacle scale single, large, thick, and sharp pointed. Color (dried from alcohol), very light gray, nearly white.

Localities.-Albatross station 4918, Eastern Sea, lat. $30^{\circ} 22^{\prime} \mathrm{N}$.; long. $129^{\circ} 8^{\prime} 30^{\prime \prime}$ E., 361 fathoms, gray sand, globigerina, broken shells, bottom temperature $42.7^{\circ}, 1$ specimen; station 4919 , Eastern Sea, lat. $30^{\circ} 34^{\prime}$ N.; long. $129^{\circ} 19^{\prime} 30^{\prime \prime}$ E., 440 fathoms, globigerina

$a$ For remarks on this family, see under Ophiacanthidæ (p. 195).

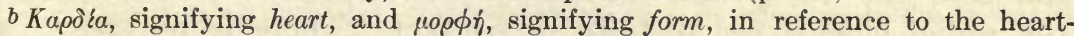
shaped interbrachial spaces, seen from below (see fig. $81 b$ ). 
ooze, bottom temperature $41.8^{\circ}, 4$ specimens; station 4956 , Bungo Channel, Japan, lat. $32^{\circ} 32^{\prime}$ N.; long. $132^{\circ} 25^{\prime}$ E., 720 fathoms, greenbrown mud, fine gray sand, foraminifera, bottom temperature $37.5^{\circ}$, 1 specimen; station 4969, off Shino Misaki, Japan, lat. $33^{\circ} 23^{\prime} 40^{\prime \prime} \mathrm{N}$.; long. $135^{\circ} 33^{\prime}$ E., 587 fathoms, brown mud, sand, stones, bottom temperature $38.9^{\circ}$, 1 specimen; station 5083, off Omai Saki, Japan, lat. $34^{\circ} 4^{\prime} 20^{\prime \prime} \mathrm{N}$.; long. $137^{\circ} 57^{\prime} 30^{\prime \prime}$ E., 624 fathoms, fine gray sand, globigerina, bottom temperature $38.1^{\circ}, 1$ specimen. Bathymetrical

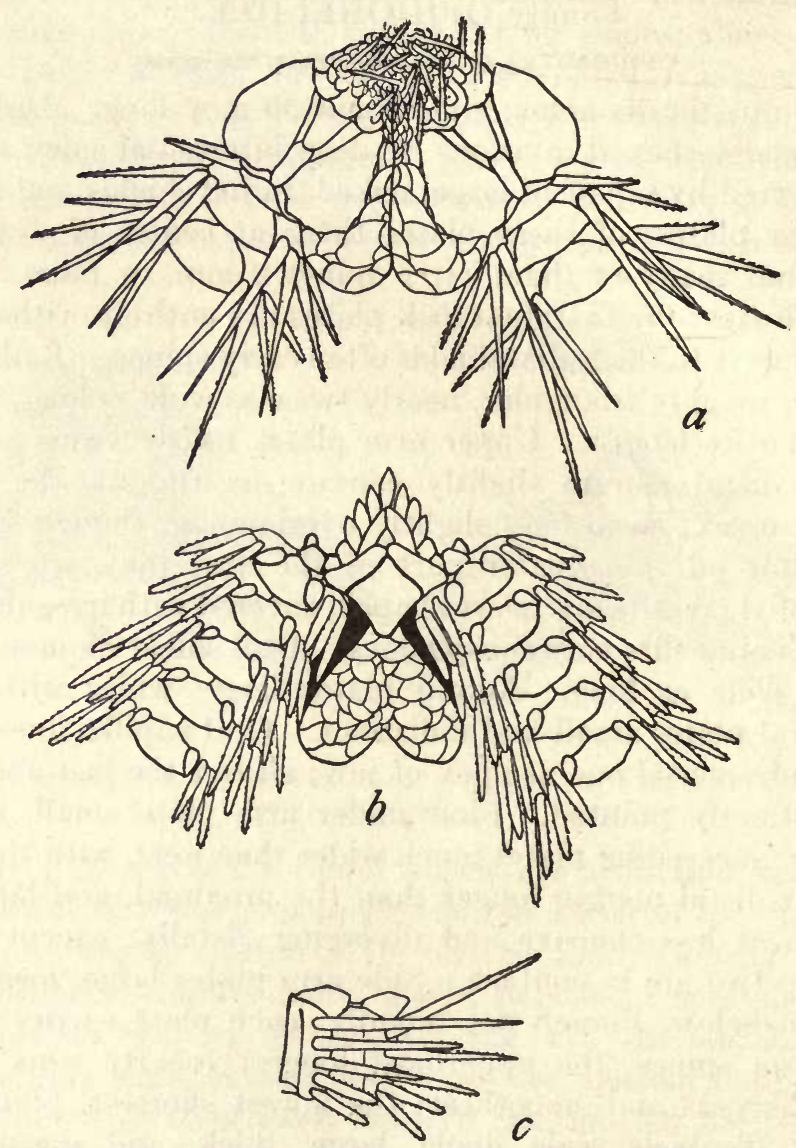

Fig. 81.-OPHIOMITRA CARDIOMORPHA. $\times$ 4. $a$, FROM ABOVE; $b$, FROM BELOW; $c$, SIDE VIEW OF TWO ARM JOINTS NEAR DISK.

range, 361 to 720 fathoms. Temperature range, $42.7^{\circ}$ to $37.5^{\circ}$. Eight specimens.

Type.-Cat. No. 25650, U.S.N.M., from station 4969.

The smallest of these specimens is rather less than $4 \mathrm{~mm}$. across the disk, but the specific characters are all well shown, except that the radial shields are distally in contact. There is no species of Ophiomitra now known with which this species is likely to be confused. 
OPHIOMITRA DISCYCLA, new species. $a$

Disk $5.5 \mathrm{~mm}$. in diameter; arms about $32 \mathrm{~mm}$. long. Disk circular, covered by numerous (125 to 175) plates of irregular size, one on each interradial margin being decidedly larger than the rest. Radial shields short and wide, closely joined except at their proximal end. Upper arm plates small, diamond-shaped or triangular with convex distal margin, about as wide as long, widely separated from each other. Interbrachial spaces below covered by very few, rather large plates. Genital slits short. Oral shields diamond-shaped, much

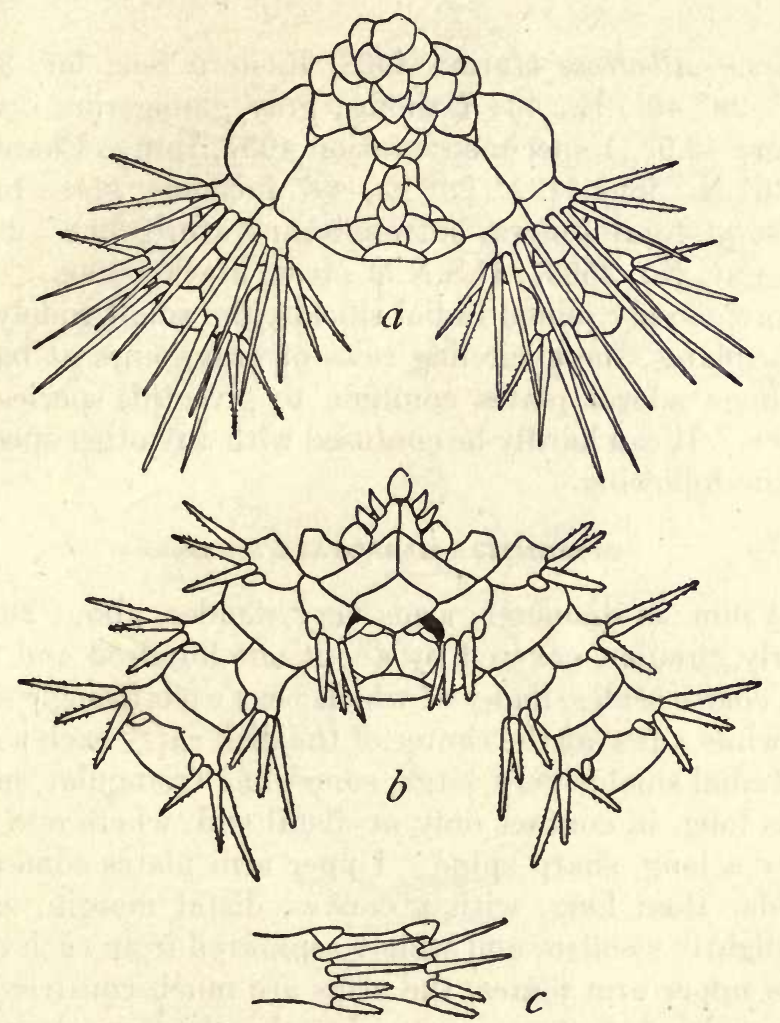

Fig. 82.-OPHoMitra DISCYCla. $\times 9$. $a$, FROM ABOVE; $b$, FROM BELOW; $c$, SIDE VIEW OF TWO ARM JOINTS NEAR DISK.

wider than long. Adoral plates very large, about as broad without as within where they meet; oral plates small and indistinct. Oral papillæ three on a side and one at apex of jaw; outermost, broad, flat and truncate, apical one, broad but sharp, others, narrow and pointed. First under arm plate large, somewhat hexagonal, wider within than distally; succeeding plates very much wider than long,

a Sis, signifying double, and кúkios, signifying ring, in reference to the two nearly complete rings, formed by the arm spines of the two basal joints. 
somewhat pentagonal, with a proximal angle and a straight distal margin. Side arm plates very large, meeting broadly both above and below; each plate carries four slender, pointed spines, but on the first joint beyond the disk, each side arm plate carries eight and on the second joint seven such spines; these sixteen and fourteen spines, respectively, nearly encircle the arm, except on the lower side; the uppermost spine is the longest and smoothest and may equal two joints; the lowest is shortest and roughest and is only about half as long as a joint, except on the first two or three. Tentacle scale single, oval, rather small. Color (dried from alcohol), very light gray, nearly white.

Localities.-Albatross station 4908 , Eastern Sea, lat. $31^{\circ} 40^{\prime} \mathrm{N}$.; long. $129^{\circ} 29^{\prime} 40^{\prime \prime}$ E., 434 fathoms, gray globigerina ooze, bottom temperature $42.9^{\circ}, 1$ specimen; station 4957, Bungo Channel, Japan, lat. $32^{\circ} 36^{\prime} \mathrm{N}$.; long. $132^{\circ} 23^{\prime}$ E., 437 fathoms, green-brown mud, fine gray sand, foraminifera, bottom temperature, $39.8^{\circ}, 2$ specimens.

Type.-Cat. No. 25637, U.S.N.M., from station 4908.

The short, closely joined radial shields, the small widely separated upper arm plates, the encircling rows of arm spines at base of arms and the huge adoral plates combine to give this species an unique appearance. It can hardly be confused with any other species, except possibly the following.

OPHIOMITRA HABROTATA, new species.a

Disk $3 \frac{1}{2} \mathrm{~mm}$. in diameter; arms very slender, about $28 \mathrm{~mm}$. long. Disk nearly circular, covered by about one hundred and fifty rather irregular, coarse scales, many of which bear each a single small, blunt spinelet, while a few at the center of the disk carry each a long, sharp spine. Radial shields very large, somewhat triangular, nearly twice as wide as long, in contact only at distal end, where one of the pair may carry a long, sharp spine. Upper arm plates somewhat triangular, wider than long, with a convex distal margin, smooth and shining, slightly swollen, and widely separated from each other. Between the upper arm plates, the arms are much constricted, so that they have a beaded appearance. Interbrachial spaces below, wide, covered by numerous rather coarse scales. Genital slits very small and inconspicuous. Oral shield very small, somewhat triangular, longer than broad. Adoral plates relatively huge, much wider without than within, where they meet; oral plates very small. Oral papillæ three or four on a side and one at apex of jaw; outermost very wide with a straight margin, the others narrow and pointed. First under arm plate hexagonal, longer than wide; succeeding plates about as long as wide or longer, pentagonal or squarish, widely separated from each

$a^{*} A \beta \rho \delta s$, signifying delicate, dainty, in reference to its light and delicate structure. 
other. Side arm plates very large, meeting broadly both above and below; each plate carries five straight, slender, sharp, smooth spines, the uppermost longest and considerably exceeding the joint; on the first two joints outside the disk there are eight or nine spines, which meet the corresponding series of the same joint on the upper side of the arm, and thus the arm is encircled at its base (as in discycla) by two nearly complete rings of eighteen and sixteen spines. Tentacle scale single, oval but acute. Color (dried from alcohol), disk very pale gray, arms very light yellowish.

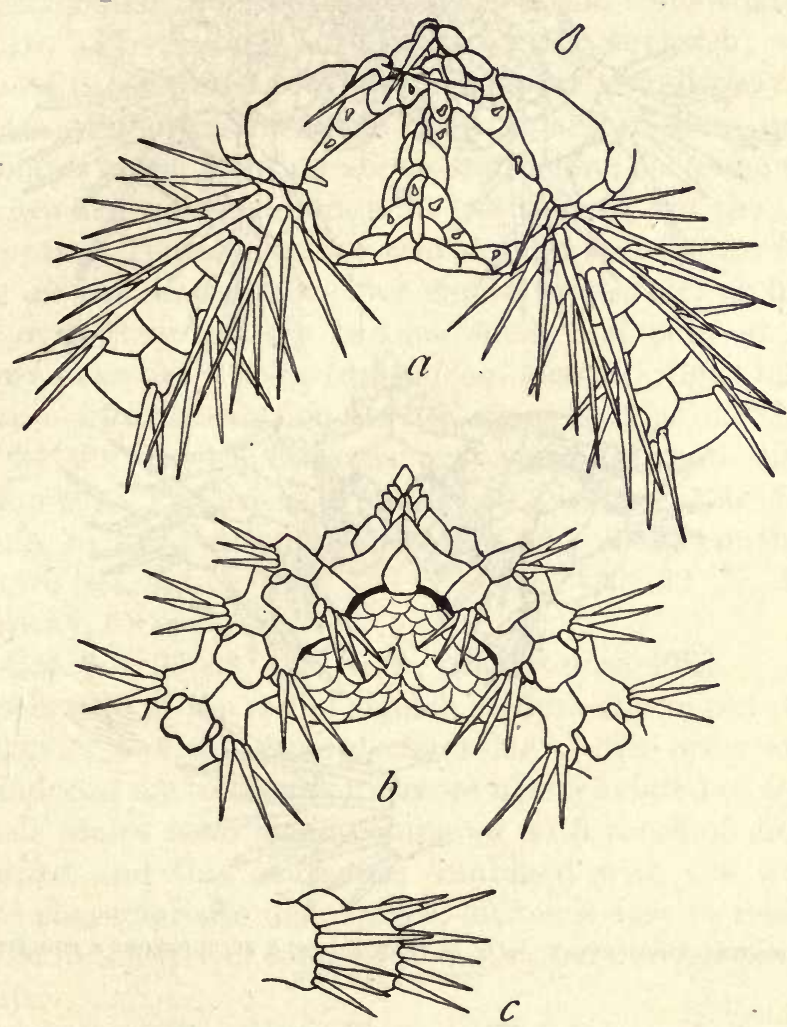

Fig. 83.-OPhiomitra habrotata. $\times$ 15. $a$, FROM ABOVE; $b$, FROM BELOW; $c$, SIDE VIEW OF TWO ARM JOINTS NEAR DISK.

Localities.-Albatross station 4893, Eastern Sea, lat. $32^{\circ} 32^{\prime} \mathrm{N}$.; long. $128^{\circ} 32^{\prime} 50^{\prime \prime}$ E., 95 to 106 fathoms, gray sand, broken shells, pebbles, bottom temperature $55.9^{\circ}, 1$ specimen; station 4900 , Eastern Sea, lat. $32^{\circ} 28^{\prime} 50^{\prime \prime} \mathrm{N}$.; long. $128^{\circ} 34^{\prime} 40^{\prime \prime}$ E., 139 fathoms, gray sand, broken shells, bottom temperature $52.9^{\circ}, 4$ specimens; station 4902 , Eastern Sea, lat. $32^{\circ} 30^{\prime} 50^{\prime \prime}$ N.; long. $128^{\circ} 34^{\prime} 40^{\prime \prime}$ E., 139 fathoms, gray sand, broken shells, bottom temperature $52.9^{\circ}, 2$ specimens.

Type.-Cat. No. 25609, U.S.N.M., from station 4900. 
Although this species is like discycla in many points, notably the arrangement of the arm spines, it is at once distinguished from that species by the spiny disk, separated radial shields, very small oral shields, and decidedly more "beaded" or "knotted" arms. The large spine at the distal end of the radial shields is a conspicuous feature when fully developed, but it is frequently small and sometimes

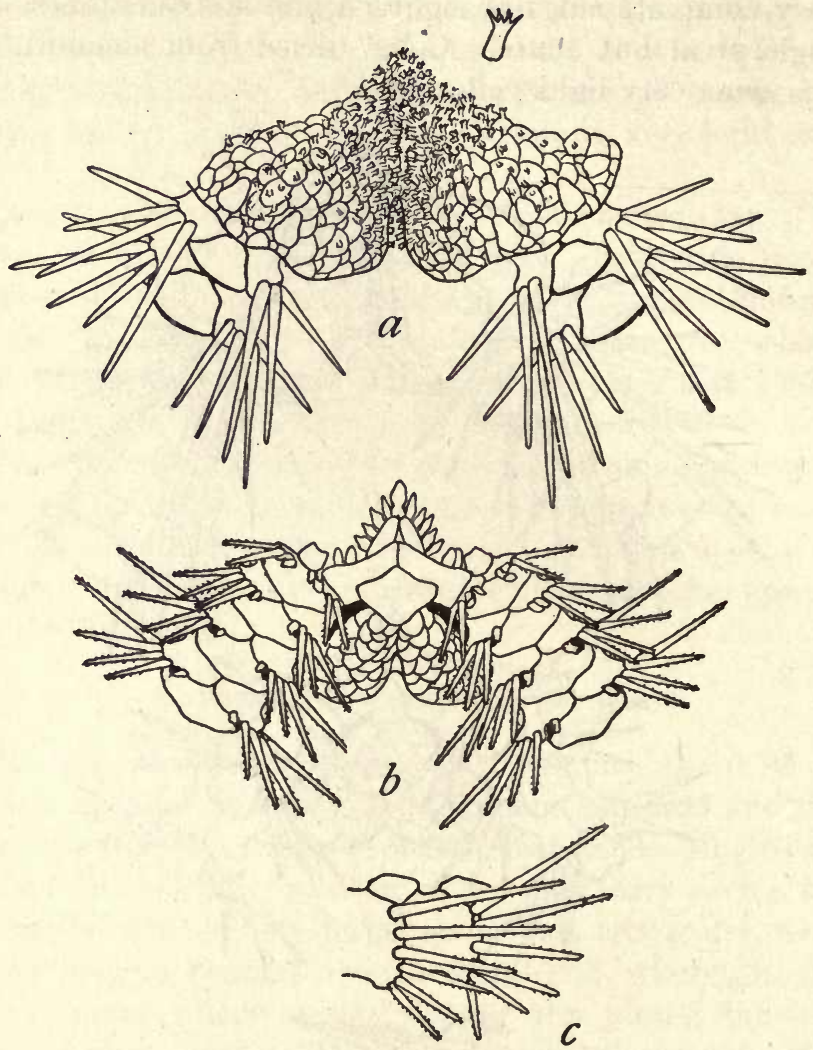

FIG. 84.-OPHIOMITRA MICROPHYLAX. $\times 6$. $a$, FROM ABOVE; $b$, From BELOW; $c$, SIDE VIEW OF TWO ARM JOINTS NEAR DISK.

appears to be wanting. The very broad, outermost mouth papilla reminds one immediately of the similar papilla in the genus Amphipholis.

\section{OPHIOMITRA MICROPHYLAX, new species. $a$}

Disk $9 \mathrm{~mm}$. in diameter; arms about $60 \mathrm{~mm}$. long. Disk with deep interradial notches, covered with numerous small scales, most of which bear minute thorny stumps; these are most numerous at the

$a_{\text {M }}$ єкós, signifying little, and $\phi \cup \lambda a \xi$, signifying guard, in reference to the small size of the tentacle scales. 
center of the disk and fewest near the radial shields. Radial shields very small, widely separated, only the distal ends visible, and these are hardly distinguishable from the larger disk scales. Upper arm plates pentagonal or bell-shaped, wider than long, well separated from each other or the basal ones barely in contact. Interbrachial spaces below covered with small scales. Genital slits rather small. Oral shields wider than long, somewhat rhombic but with distal half larger than proximal. Adoral plates large, much wider without than within where they meet; oral plates small. Oral papillæ six or seven on a side, subequal, pointed; an unpaired one somewhat larger at apex of jaw. First under arm plate small, squarish; succeeding plates two or three times as wide as long, convex distally and with more or less of a proximal angle, well separated from each other. Side arm plates large, meeting above and below; each one carries six slender, sharp arm spines, all more or less thorny, but the uppermost nearly smooth. Tentacle scales two on the first pore of the arm, sometimes on the second also, but single thereafter; at first rather large and oval, they quickly become small and pointed and often quite thorny near tip. Color (dried from alcohol), light brown.

Localities.-Albatross station 4901, Eastern Sea, lat. $32^{\circ} 30^{\prime} 10^{\prime \prime}$ N.; long. $128^{\circ} 34^{\prime} 40^{\prime \prime}$ E., 139 fathoms, gray sand, broken shells, 1 specimen; station 4933 , Eastern Sea, lat. $30^{\circ} 59^{\prime}$ N.; long. $130^{\circ} 29^{\prime} 50^{\prime \prime}$ E., 152 fathoms, rocky, bottom temperature $56^{\circ}, 22$ specimens; station 4934, Eastern Sea, lat. $30^{\circ} 58^{\prime} 30^{\prime \prime}$ N.; long. $130^{\circ} 32^{\prime}$ E., 103 to 152 fathoms, rocky, 18 specimens.

Type.-Cat. No. 25608, U.S.N.M., from station 4933.

The appearance of the radial shields inclines one to put this species in Ophiacantha, but the general character of the arms and mouth parts has induced me to consider it more nearly related to Ophiomitra. The tentacle scales seem small compared with those of most species of Ophiomitra, and this character, combined with the small radial shields and characteristic disk spines, makes it easy to recognize the species, even in the face of some little individual diversity in these and other points.

OPHIOMITRA BYTHIASPIS, new species. $a$

Disk $12 \mathrm{~mm}$. in diameter; arms about 60 to $70 \mathrm{~mm}$. long, probably. Disk divided by deep interradial sulci into five wedge-shaped parts, each of which is subdivided by the narrow, deeply sunken radial shields into three nearly equal portions; disk covering consists of numerous irregular plates, smallest at center and largest near margins; many of these plates carry each a low, smooth, blunt, cylindrical stump. Radial shields about four times as long as wide; slightly

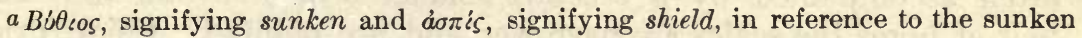
radial shields. 
curved, deeply sunken below the disk scales, widely separated throughout. Upper arm plates wider than long, with a convex or straight distal margin and a strongly convex, often angular, proximal margin; thus somewhat broadly pentagonal with only the two distal, lateral angles marked; they are much swollen and widely separated. Interbrachial spaces below rather broad, somewhat heart-shaped, covered by irregular plates which are large at the margin but become very small near the oral shield. Genital slits short but rather conspicuous. Oral shields rhombic or pentagonal, about as wide as long.
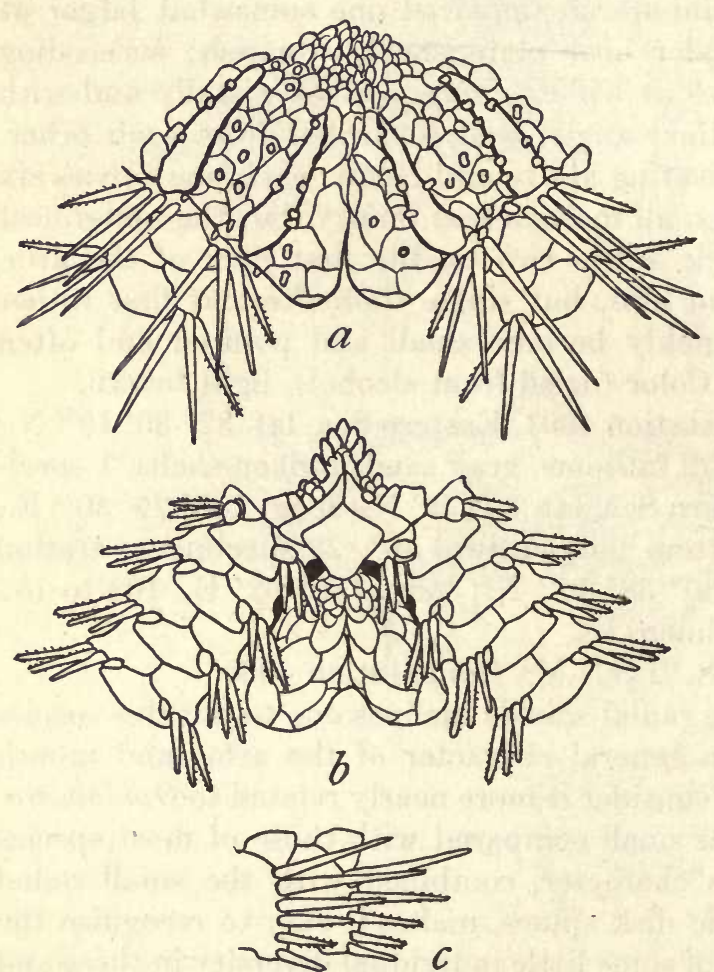

FIG. 85.-OPHIOMITRA BYTHIASPIS. $\times 5$. $a$, FROM ABOVE; $b$, FROM BELOW; $c$, SIDE VIEW OF TWO ARM JOINTS NEAR DISK. Adoral plates long and narrow, about as wide without as within, where they meet; oral plates very small. Oral papillæ about five on a side and one at apex of jaw, the outer ones are truncate, but the inner are more or less sharply pointed; between the penultimate and antepenultimate papillæ are several small granules, which apparently serve as tentacle scales to the oral tentacle pore. First under arm plate pentagonal, about as wide as long; second plate nearly triangular, but truncated at the angles, wider than long; succeeding plates nearly tetragonal, much wider than long, widely separated from each other. Side arm plates very large, meeting both above and below; each plate carries, on rather a conspicuous vertical ridge, six or five long slender arm spines, of which the uppermost, which may equal two joints, is the longest (sometimes the second is the longest), smoothest, and sharpest, while some of the lower, shorter spines are quite rough near the tip. Tentacle scale single; those on the basal pores are very large and broadly oval and are often accompanied by a second, smaller scale; beyond the third pair of pores the scales are narrower and are pointed. Coior (dried from alcohol), very light gray. 
Locality.-Albatross station 4979 , off eastern Japan, lat. $33^{\circ} 53^{\prime} \mathrm{N}$.; long. $137^{\circ} 42^{\prime}$ E., 943 fathoms, brown mud, fine sand, foraminifera, bottom temperature $36.4^{\circ}$, 1 specimen.

- Type.-Cat. No. 25636, U.S.N.M., from station 4979.

The groups of granular papillæ near the distal end of the mouth slits are very peculiar, giving a characteristic appearance to the oral region, and indicate a possible relationship to Ophiocamax lithosora. Whether the sunken appearance of the radial shields and the correspondingly remarkable division of the disk into fifteen wedge-shaped parts is characteristic of the species or only an accentuated individual peculiarity can not, of course, be determined without more material. But it is hard to doubt that the main features of the peculiar disk will be found to be characteristic of the species.

\section{OPHIOMITRA POLYA-}

CANTHA, new species. $a$

Disk $6 \mathrm{~mm}$. in diameter; arms about $30 \mathrm{~mm}$. long. Disk circular, covered with numerous small, rather regular scales, many of which
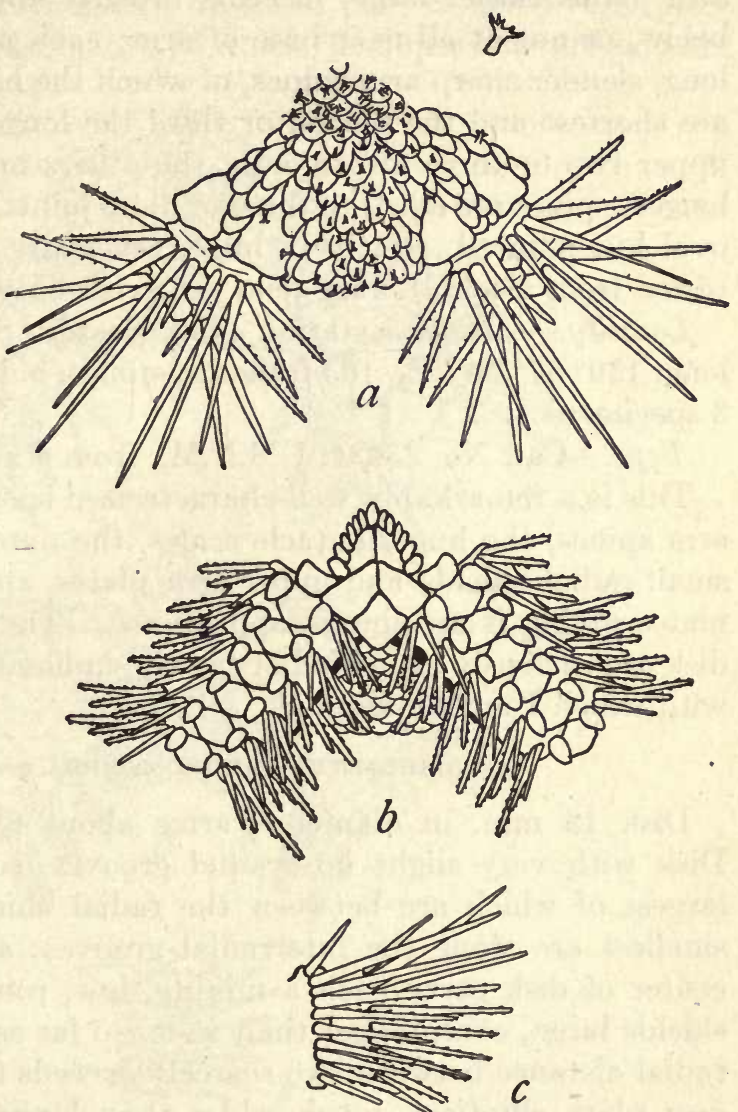

Fig. 86.-OPhiomitra POLyaCANTHA. $\times$ 8. $a$, FROM ABOVE; $b$, From BELOW; $c$, SIDE VIEW OF TWO ARM JOINTS NEAR DISK.

bear each a low, thorny stump. Radial shields small, triangular or squarish, about as wide as long, distinctly separated. Upper arm plates small, rhombic or triangular, with convex distal margin, widely separated from each other; between the upper arm plates the arm is somewhat constricted. Interbrachial spaces below, covered with

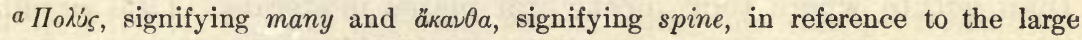
number of arm spines. 
scales like those of the disk. Genital slits long. Oral shields rhomabic, about as long as wide. Adoral plates very large, tetragonal, meeting broadly within; oral plates moderate. Oral papillæ about six on a side and one at apex of jaw ; they are long, flat, and somewhat spatulate, the outer ones the widest. First under arm plate, tetragonal, wider than long; succeeding plates somewhat hexagonal, about as long as wide; basal ones in contact or at least overlapping. Side arm plates rather large, meeting broadly above, but only narrowly below, or not at all near base of arm; each plate carries nine or ten long, slender sharp arm spines, of which the highest (first) and lowest are shortest and the second or third the longest; the lowest and the upper two or three are smooth, the others more or less prickly; the longest spines are equal to three or more joints. Tentacle scale single, oval but pointed, relatively huge, especially at base of arm. Color (dried from alcohol), very pale yellowish-brown.

Locality.-Albatross station 4936, Eastern Sea, lat. $30^{\circ} 54^{\prime} 40^{\prime \prime} \mathrm{N}$.; long. $130^{\circ} 37^{\prime} 30^{\prime \prime}$ E., 103 fathoms, stones, bottom temperature $60.6^{\circ}$, 3 specimens.

\section{Type.-Cat. No. 25631, U.S.N.M., from station 4936.}

This is a remarkably well-characterized species, the numerous long arm spines, the huge tentacle scales, the numerous oral papillæ, the small radial shields and upper arm plates, and the very large adoral plates giving it an unique appearance. The thorny stumps on the disk are curiously expanded at the tip, unlike those of any Ophiomitra with which I am acquainted.

\section{OPHIOMITRA CODONOMORPHA, new species. $a$}

Disk $13 \mathrm{~mm}$. in diameter; arms about $65 \mathrm{~mm}$. long, probably. Disk with very slight interradial grooves, covered with scales, the largest of which are between the radial shields (radially) and the smallest are along the interradial grooves; a few of the scales near center of disk carry each a minute, low, rough projection. Radial shields large, oval, longer than wide, so far separated that the interradial distance between two scarcely exceeds the radial. First upper arm plate elliptical, much wider than long; succeeding plates distinctly bell-shaped, about as wide as long, scarcely in contact; more or less noncalcified skin is visible among the basal plates of the arm. Interbrachial spaces below covered by rather numerous scales. Genital slits short and wide. Oral shields much wider than long, somewhat triangular, with a wide distal and two lateral angles, but the proximal base also tends to form a wide angle between the two adoral plates, which are nearly horizontal, and are a little narrower without than within where they meet; oral plates moderate. Oral papillæ

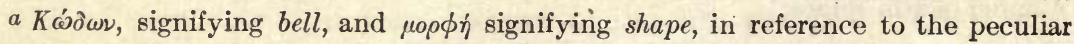
upper arm plates. 
large, about three on a side and one at apex of jaw; long, flat, and more or less pointed; outermost somewhat the largest. First under arm plate hexagonal, much wider than long; second plate somewhat triangular, barely in contact with the first, wider than long; succeeding plates separated, much wider than long, nearly tetragonal, but the sides are not straight; proximal margin with a slight median point and distal, with a shallow median notch. Side arm plates large, meeting below but hardly above on basal part of arm; each plate carries eight sharp, slender spines, of which the upper ones are smooth,

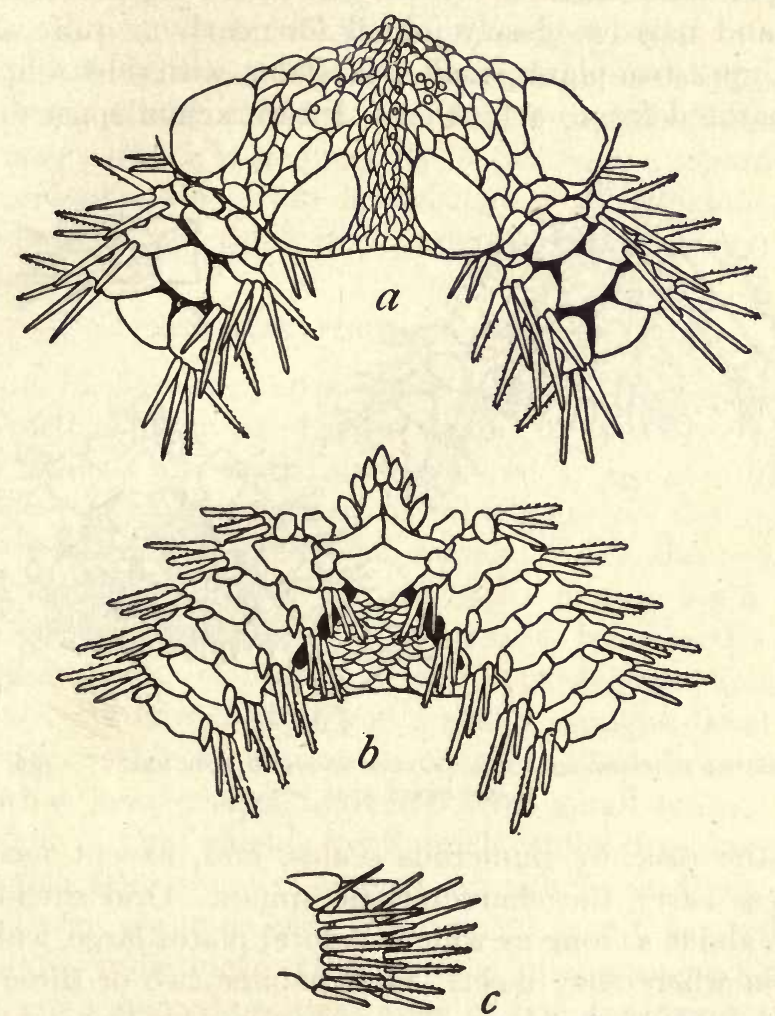

Fig. 87.-OphIomitra CODONOMORPHA. $\times$ 4. $a$, FROM ABOVE; $b$, FROM BELOW; $c$, SIDE VIEW OF tWo ARM JOINTS NEAR DISK.

the others (except the lowest) being rough or thorny; the next to the uppermost is longest, considerably exceeding the joint. Tentacle scale single; on first arm pore the scale is rounded oval and relatively enormous, but the succeeding scales are much smaller and are soon narrow and pointed. Color (dried from alcohol), light gray.

Locality.-Albatross station 4979 , off eastern Japan, lat. $33^{\circ} 53^{\prime} \mathrm{N}$.; long. $137^{\circ} 42^{\prime}$ E., 943 fathoms, brown mud, fine sand, foraminifera, bottom temperature $36.4^{\circ}, 1$ specimen.

Type.-Cat. No. 25603, U.S.N.M., from station 4979. 
This is still another well-characterized and easily recognized species, of which the collection contains but a single specimen. The position of the radial shields, the shape of the upper arm plates, and the large size of the first tentacle scales are noticeable features.

\section{OPIIIOMITRA ACONTOPHORA, new species. $a$}

Disk $3 \mathrm{~mm}$. in diameter; arms about $20 \mathrm{~mm}$. long. Disk covered by numerous small scales, which are more or less concealed by the many long, slender spear-like spines which they carry; these spines are sharp pointed and have a few teeth near the tip. Radial shields very long and narrow, closely joined for nearly or quite their entire length. Upper arm plates small, triangular, with sides a little curved, widely separated from each other. Interbrachial spaces below cov-

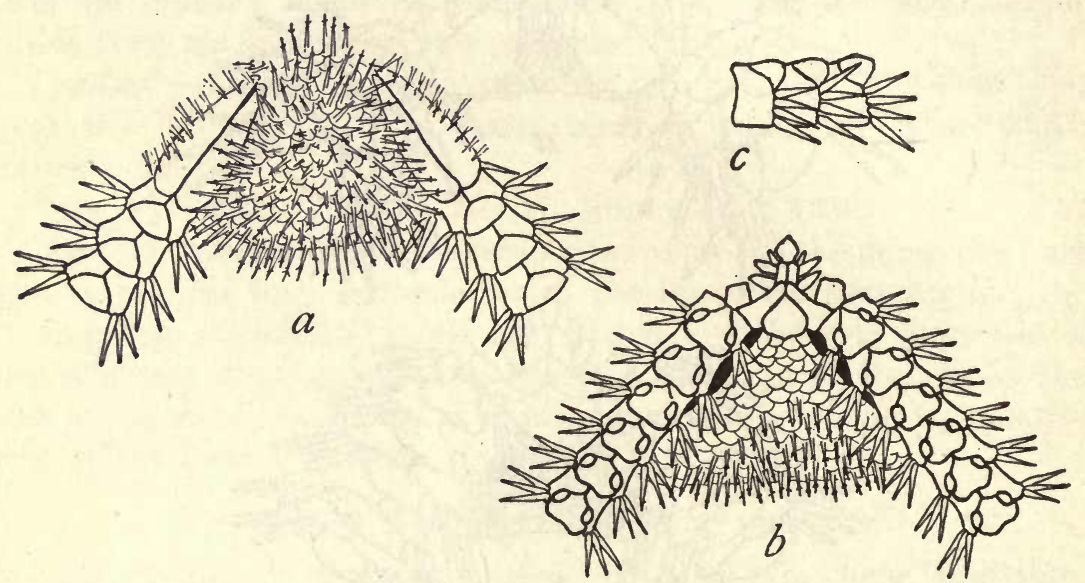

Fig. 88.-OPHIOMItRA ACONTOPHORA. $\times 16$. $a$, FROM ABOVE; $b$, FROM BELOW; $c$, SIDE VIEW OF THREE ARM JOINTS NEAR DISK.

ered, like the disk, by numerous scales, and, except near the oral shield, these carry the characteristic spines. Oral shields rounded triangular, about as long as wide. Adoral plates large, wider without than within where they meet. Oral papillæ two or three on a side, and one at apex of jaw, long, flat, and pointed. Genital slits rather large. First under arm plate pentagonal, about as wide as long; succeeding plates rather wider than long, pentagonal, with lateral margins concave, separated from each other, except the first two or three. Side arm plates large, meeting both above and below; each plate carries four sharp, straight spines, of which the lowest is a little the longest and slightly exceeds the joint. Tentacle scale single, of moderate size. Color (dried from alcohol), nearly white.

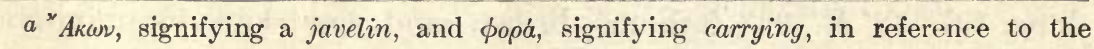
numerous javelin-like spines borne on the disk. 
Localities.-Albatross station 3338 , off Alaska, lat. $54^{\circ} 19^{\prime}$ N.; long. $159^{\circ} 40^{\prime}$ W., 625 fathoms, green mud, sand, bottom temperature $37.3^{\circ}, 13$ specimens; station 4765 , off Aleutian Islands, lat. $53^{\circ} 12^{\prime}$ N.; long. $171^{\circ} 37^{\prime}$ W., 1,217 fathoms, fine black sand, bottom temperature $35.2^{\circ}, 32$ specimens; station 4781 , Bering Sea, lat. $52^{\circ} 14^{\prime} 30^{\prime \prime}$ $\mathrm{N}$.; long. $174^{\circ} 13^{\prime} \mathrm{E}$., 482 fathoms, fine gray sand, pebbles, bottom temperature $38.6^{\circ}, 1$ specimen; station 4803 , off Kurile Islands, lat. $46^{\circ} 42^{\prime} \mathrm{N}$.; long. $151^{\circ} 45^{\prime} \mathrm{E}$., 229 fathoms, coarse pebbles, black sand, bottom temperature $37^{\circ}, 1$ specimen. Bathymetrical range, 229 to 1,217 fathoms. Temperature range, $38.6^{\circ}$ to $35.2^{\circ}$.

Type.-Cat. No. 25648, U.S.N.M., from station 4781.

This pretty little ophiuran differs so much from the other species of Ophiomitra in the shape of the radial shields and the spines of the disk that it may perhaps more properly be placed in a separate genus. But in the present state of our knowledge of the Ophiohelidæ and Ophiacanthidæ, I do not think it desirable to make new genera, if it can be avoided.

\section{OPHIOCAMAX LITHOSORA, new species. $a$}

Disk $17 \mathrm{~mm}$. in diameter; arms about $125 \mathrm{~mm}$. long. Disk rather high, with a vertical diameter of about $6 \mathrm{~mm}$., divided into five wedgeshaped areas by deep interradial sulci, covered by a coat of numerous, small, irregular scales, the largest of which are on the interradial sides of the distal ends of the radial shields; many disk scales carry each a low cylindrical stump with two to six minute teeth near the apex. Radial shields long, narrow, separated, more or less sunken among the disk scales. Upper arm plates pentagonal, much wider than long, with a proximal angle and a nearly straight distal margin; only two or three at base of arm in contact. Interbrachial spaces below somewhat heart-shaped; covered with small scales. Genital slits conspicuous. Oral shields very much wider than long, with a proximal angle, but broadly convex or nearly straight distally. Adoral plates large, about as wide at outer end as at inner, where they meet; oral plates indistinct. Oral papillæ numerous and irregular, ten or fifteen on a side; those near apex of jaw are longer and more pointed than the distal ones, which are rounded and crowded together, and look somewhat like little heaps of pebbles. First under arm plate squarish; succeeding plates tetragonal, very much wider than long; second plate has proximal margin much shorter than distal and is in contact with first; remaining plates, widely separated. Side arm plates rather large, meeting below and above; each plate carries six or seven long, slender spines, the upper ones smooth, the lower, more or less thorny; uppermost spine, or next one, longest,

$a \Lambda \theta_{0 s}$, signifying stone, and $\sigma \omega \rho o ́ s$, signifying heap, in reference to the appearance of the distal clusters of oral papillæ. 
about equal to three joints. Tentacle scales, three at first arm pore, two at second and one thereafter; long, rounded at tip or pointed, very conspicuous. Color (dried from alcohol), nearly white.

Localities.-Albatross station 4918 , Eastern Sea, lat. $30^{\circ} 22^{\prime} \mathrm{N}$.; long. $129^{\circ} 8^{\prime} 30^{\prime \prime}$ E., 361 fathoms, gray sand, globigerina, broken shells, bottom temperature $42.7^{\circ}, 1$ specimen; station 4967 , off eastern Japan, lat. $33^{\circ} 25^{\prime} 10^{\prime \prime} \mathrm{N}$.; long. $135^{\circ} 37^{\prime} 20^{\prime \prime}$ E., 244 to 253 fathoms, brown mud, sand, foraminifera, bottom temperature $45.9^{\circ} ; 1$ specimen.

Type.-Cat. No. 25622, U.S.N.M., from station 4918.

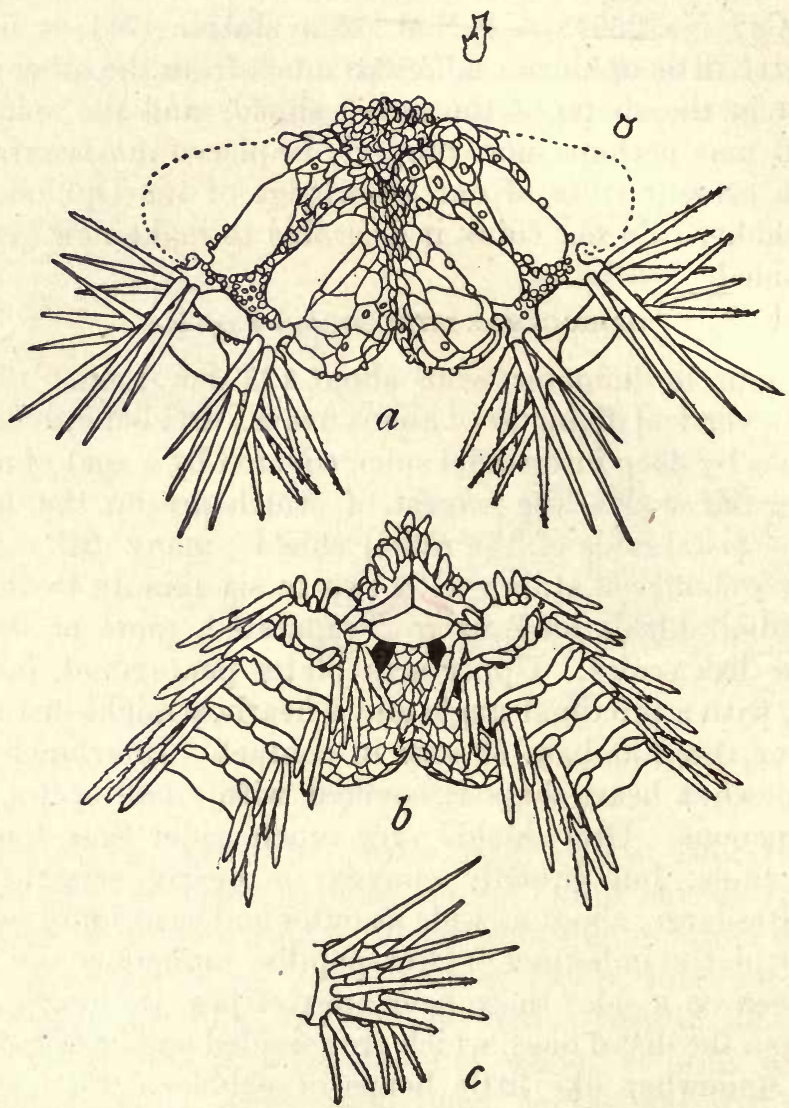

Fig. 89.-OPHIOcAMAX Lithosora. $\times 3$. $a$, FROM ABOVE; $b$, FROM BELOW; $c$, SIDE VIEW OF TWO ARM JOINTS NEAR DISK.

These specimens remind one at once of Ophiomitra bythiaspis, and I can not avoid the feeling that more abundant material will show that the two species are congeneric, if not identical. The differences in the radial shields, disk scales, disk spines, and oral shields are marked, as well as those in the oral papillæ, but in each of these points the three specimens vary among themselves, and the specimen of lithosora 
from station 4967 , is orally very much like bythiaspis, though on the upper side it is totally unlike that species. Indeed, I am not sure that this specimen from 4967 is really conspecific with the one from 4918 , but it seems best to so regard it for the present.

\section{OPHIOCAMAX POLYPLOCA, new species. $a$}

Disk $17 \mathrm{~mm}$. in diameter; arms about $125 \mathrm{~mm}$. long. Disk rather decagonal, with very slight interradial notches, covered largely by

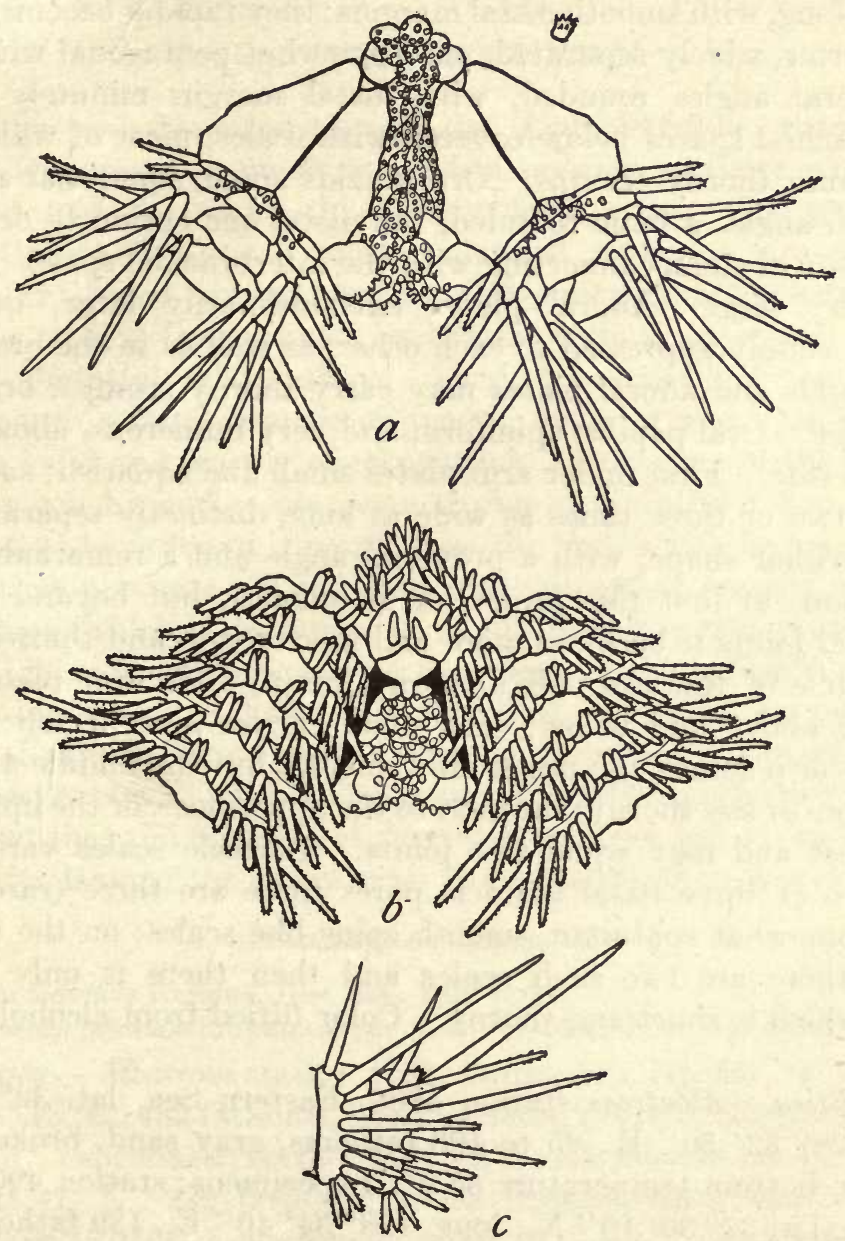

Fig. 90.-OPhIOCAMAX POLYPLOCA. $\times$ 3. $a$, FROM ABOVE; $b$, FROM BELOW; $c$, SIDE VIEW OF TWO ARM JOINTS NEAR DISK.

the radial shields except at center and on narrow interradial areas, where there are numerous overlapping scales; these scales bear

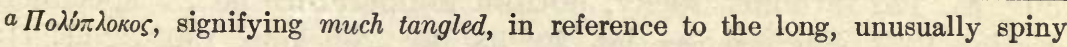
arms. 
more or less numerous, minute, thorny stumps. (In specimens smaller than the type, in addition to the thorny stumps, the scales at the center of the disk carry long, sharp, thorny spines; a specimen 8 $\mathrm{mm}$. across the disk has a cluster of fourteen such spines, 1.5 to $2 \mathrm{~mm}$. long.) Radial shields very large, twice as long as wide, smooth and bare, closely joined; in small specimens they are not so closely appressed, and there may even be several little stumps between them. Basal upper arm plates tetragonal and in contact, about twice as wide as long, with smooth distal margins; they rapidly become broader and shorter, widely separated, and somewhat pentagonal with proximal-lateral angles rounded, with distal margin minutely thorny. Interbrachial spaces below covered with scales, most of which carry the minute thorny stumps. Oral shields small, somewhat rhombic, but with angles a little rounded, the distal one curiously drawn out into a sort of stem, connecting with the interbrachial space. Genital slits very large. Adoral plates extraordinarily large, quadrantshaped, closely appressed to each other, as well as to the oral shield; oral shields and adoral plates may carry thorny stumps; oral plates indistinct. Oral papillæ spiniform and very numerous, about fifteen on each side. First under arm plates small and squarish; succeeding plates, two or three times as wide as long, distinctly separated, of a very peculiar shape, with a proximal angle and a remarkable distal projection; at first this projection is smooth, but beyond the first few basal joints it becomes more and more rough and thorny, and at the middle of the arm it is a thorny lump. Side arm plates large, meeting above and below; each plate carries nine or ten straight, rather sharp spines, the upper ones smooth, but the middle and lower ones more or less thorny; the next to the uppermost, or the uppermost, is longest and may equal five joints. Tentacle scales variable; on first two or three basal tentacle pores there are three (rarely four) long, somewhat spatulate, smooth spine-like scales; on the next few joints there are two such scales and then there is only a single scale, which is short and thorny. Color (dried from alcohol), nearly white.

Localities.-Albatross station 4893 , Eastern Sea, lat. $32^{\circ} 32^{\prime}$ N.; long. $128^{\circ} 32^{\prime} 50^{\prime \prime}$ E., 95 to 106 fathoms, gray sand, broken shells, pebbles, bottom temperature $55.9^{\circ}, 3$ specimens; station 4901 , Eastern Sea, lat. $32^{\circ} 30^{\prime} 10^{\prime \prime} \mathrm{N}$.; long. $128^{\circ} 34^{\prime} 40^{\prime \prime}$ E., 139 fathoms, gray sand, broken shells, bottom temperature $52.9^{\circ}, 1$ specimen; station 4903 , Eastern Sea, lat. $32^{\circ} 31^{\prime} 10^{\prime \prime}$ N.; long. $128^{\circ} 33^{\prime} 20^{\prime \prime}$ E., 107 to 139 fathoms, gray sand, broken shells, bottom temperature $52.9^{\circ}, 3$ specimens; station 4933 , Eastern Sea, lat. $30^{\circ} 59^{\prime}$ N.; long. $130^{\circ} 29^{\prime}$ $50^{\prime \prime}$ E., 152 fathoms, rocky, bottom temperature $56^{\circ}, 2$ specimens; station 4934 , Eastern Sea, lat. $30^{\circ} 58^{\prime} 30^{\prime \prime}$ N.; long. $130^{\circ} 32^{\prime}$ E., 103 to 152 fathoms, rocky, 18 specimens; station 4939, Kagoshima Gulf, 
lat. $31^{\circ} 18^{\prime} 30^{\prime \prime} \mathrm{N}$.; long. $130^{\circ} 42^{\prime}$ ' E., 85 fathoms, 1 specimen. 'Bathymetrical range, 85 to 152 fathoms. Temperature range, $56^{\circ}$ to $52.9^{\circ}$. Twenty-eight specimens.

Type.-Cat. No. 25588, U.S.N.M., from station 4933.

This very fine species is distinguished from the other members of the genus by the huge radial shields, which cover most of the disk, the very long, smooth, upper arm spines and the peculiar oral shields. It is probably nearest to O. rugosa Kœhler, from the Dutch East Indies.

\section{Family OPHIACANTHIDA.}

With the probable exception of the Ophiolepididæ, there is no group of Ophiurans so much in need of revision as those which are commonly included under this family designation. The preceding family (Ophiohelidæ) is a most unnatural group as proposed by Perrier (1891) ${ }^{a}$ and as used here, for Ophiomitra and Ophiocamax are very close to true Ophiacantha, and Ophiothotia is an almost unique genus of doubtful relationships. Verrill ${ }^{b}$ has divided the Ophiacanthidæ into a large number of genera, many of. which, to say the least, are valid and worthy of recognition. But-some of the characters, of which he makes use, seem to me of doubtful value, and in many cases I have found it hard to see the lines which he has drawn. Lack of time prevents my going into the subject at present with the thoroughness which it demands, and I am therefore reluctantly compelled to ignore Verrill's genera for the present and use Ophiacantha in a very wide sense. I have also stretched Ophiolebes to include a number of diverse forms, but in spite of using these two genera to their widest extent, it has been necessary to establish some new genera. It is hoped that the figures and descriptions given will atone in some measure for leaving the group even more chaotic than it was before.

\section{OPHIACANTHA BIDENTATA.}

Asterias bidentata Retzrus, Diss. Ast., 1805, p. 33.

Ophiacantha bidentata LJUngman, Öfy. Kon. Vet.-Akad. Förh., vol. 28, 1872, p. 652.

Localities.-Albatross station 4781, Bering Sea, lat. $52^{\circ} 14^{\prime} 30^{\prime \prime} \mathrm{N}$.; long. $174^{\circ} 13^{\prime}$ E., 482 fathoms, fine gray sand, pebbles, bottom temperature $38.6^{\circ}, 1$ specimen; station 4804 , off Kurile Islands, lat. $46^{\circ} 42^{\prime} \mathrm{N}$.; long. $151^{\circ} 47^{\prime}$ E., 229 fathoms, coarse pebbles, black sand, bottom temperature $35.9^{\circ}$ (?), 1 specimen; station 4812 , off Sado Island, lat. $38^{\circ}$ $33^{\prime}$ N.; long. $138^{\circ} 40^{\prime}$. E., 176 to 200 fathoms, fine brown mud, bottom temperature $34.9^{\circ}, 3$ specimens; station 4818 , off Sado Island, lat. $38^{\circ}$ $8^{\prime} 55^{\prime \prime} \mathrm{N}$.; long. $138^{\circ} 31^{\prime} 30^{\prime \prime}$ E., 225 to 245 fathoms, fine brown mud, bottom temperature $33.7^{\circ}$, 51 specimens; station 4819 , off Sado

$a$ Verrill used the same name in 1899 as though ignorant of Perrier's proposed family.

$b$ Trans. Conn. Acad., vol. 10, 1899, pp. 319-357. 
Island, lat. $38^{\circ} 9^{\prime} \mathrm{N}$.; long. $138^{\circ} 32^{\prime} 12^{\prime \prime}$ E., 245 fathoms, fine brown mud, bottom temperature $33.1^{\circ}, 28$ specimens; station 4820 , off Sado Island, lat. $37^{\circ} 37^{\prime} \mathrm{N}$.; long. $138^{\circ} 19^{\prime}$ E., 536 fathoms, green mud, bottom temperature $32.4^{\circ}, 3$ specimens; station 4822 , off Noto Peninsula, Japan, lat. $37^{\circ} 8^{\prime} 10^{\prime \prime}$ N.; long. $137^{\circ} 8^{\prime}$ E., 130 fathoms, green mud, bottom temperature $39.4^{\circ}, 11$ specimens; station 4828 , Sea of Japan, lat. $37^{\circ} 23^{\prime} \mathrm{N}$.; long. $137^{\circ} 36^{\prime}$ E., 163 fathoms, green mud, bottom temperature $34.9^{\circ}, 13$ specimens; station 4861 , off Korea, lat. $36^{\circ} 19^{\prime}$ N.; long. $129^{\circ} 47^{\prime}$ E., 163 fathoms, green mud, bottom temperature $33.4^{\circ}, 19$ specimens; station 4862, off Korea, lat. $36^{\circ} 20^{\prime} \mathrm{N}$.; long. $129^{\circ} 50^{\prime}$ E., 184 fathoms, green mud, bottom temperature $32.9^{\circ}, 2$ specimens; station 4982 , Sea of Japan, lat. $43^{\circ}$ $\mathrm{N}$.; long. $140^{\circ} 10^{\prime} 30^{\prime \prime} \mathrm{E}$., 390 to 428 fathoms, green mud, bottom temperature $32.7^{\circ}, 3$ specimens; station 4984 , Sea of Japan, lat. $43^{\circ}$ $4^{\prime} 20^{\prime \prime} \mathrm{N}$.; long. $140^{\circ} 12^{\prime} 10^{\prime \prime}$ E., 224 to 248 fathoms, green mud, bottom temperature $33^{\circ}, 6$ specimens; station 4986 , Sea of Japan, lat. $43^{\circ}$ $1^{\prime} 40^{\prime \prime}$ N.; long. $140^{\circ} 22^{\prime} 40^{\prime \prime}$ E., 172 fathoms, fine black sand, black mud, bottom temperature $33.9^{\circ}, 1$ specimen; station 4997 , Gulf of Tartary, lat. $47^{\circ} 38^{\prime} 40^{\prime \prime}$ N.; long. $141^{\circ} 24^{\prime} 30^{\prime \prime}$ E., 318 fathoms, green mud, bottom temperature $32.8^{\circ}, 8$ specimens. Bathymetrical range, 130 to 536 fathoms. Temperature range, $39.4^{\circ}$ to $32.4^{\circ}$. One hundred and fifty specimens.

This species is another example of an Ophiuran with an apparently circumpolar range, extending southward in both the Atlantic and Pacific oceans. It belongs thus in the same class with Ophiura sarsii, Ophiura nodosa, and Ophiophotis aculeata. ' It is noticeable, however, that the extension southward is only along the Asiatic side of the Pacific and not along the American coast. The Pacific specimens are apparently indistinguishable from individuals collected along the east coast of North America.

\section{OPHIACANTHA PENTAGONA.}

Ophiacantha pentagona Koehler, Ann. Sci. Nat. Zool. (8), vol. 4, 1897, p. 342.

Localities.-Albatross station 3698, off Manazuru Zaki, Honshu Island, Japan, 153 fathoms, green mud, volcanic ashes, sand, 1 specimen; station 3713, off Ose Zaki, Honshu Island, Japan, 45 to 48 fathoms, volcanic sand, shells, rocks, 1 specimen; station 3717 , off Ose Zaki, Honshu Island, Japan, 63 to 100 fathoms, volcanic sand, shells, rocks, 3 specimens; station 3737 , off Port Heda, Honshu Island, Japan, 161 to 167 fathoms, green mud, volcanic sand, 1 specimen; station 3758, off Suno Saki, Honshu Island, Japan, 52 to 73 fathoms, blue clay, rocks, 10 specimens; station 4879 , Korea Strait, lat. $37^{\circ}$ $17^{\prime} \mathrm{N}$; l long. $130^{\circ} 15^{\prime} \mathrm{E}$., 59 fathoms, fine gray sand, broken shells, bottom temperature $62.1^{\circ}, 2$ specimens; station 4891, Eastern Sea, lat. $32^{\circ} 27^{\prime} \mathrm{N}$.; long. $128^{\circ} 34^{\prime}$ E., 181 fathoms, gray sand, broken 
shells, rocks, bottom temperature $50.2^{\circ}, 1$ specimen; station 4893 , Eastern Sea, lat. $32^{\circ} 32^{\prime}$ N.; long. $128^{\circ} 32^{\prime} 50^{\prime \prime}$ E., 95 to 106 fathoms, gray sand, broken shells, pebbles, bottom temperature $55.9^{\circ}, 2$ specimens; station 4894 , Eastern Sea, lat. $32^{\circ} 33^{\prime}$ N.; long. $128^{\circ} 32^{\prime} 10^{\prime \prime}$ E., 95 fathoms, 'green sand, broken shells, pebbles, 1 specimen; station 4901 , Eastern Sea, lat. $32^{\circ} 30^{\prime} 10^{\prime \prime}$ N.; long. $128^{\circ} 34^{\prime} 40^{\prime \prime}$ E., 139 fathoms, gray sand, broken shells, bottom temperature $52.9^{\circ}, 1$ specimen; station 4902 , Eastern Sea, lat. $32^{\circ} 30^{\prime} 50^{\prime \prime}$ N.; long. $128^{\circ} 34^{\prime}$ $40^{\prime \prime}$ E., 139 fathoms, gray sand, broken shells, 1 specimen; station 4903 , Eastern Sea, lat. $32^{\circ} 31^{\prime} 10^{\prime \prime}$ N.; long. $128^{\circ} 33^{\prime} 20^{\prime \prime}$ E., 107 to 139 fathoms, gray sand, broken shells, 23 specimens; station 4904, Eastern Sea, lat. $32^{\circ} 31^{\prime} 20^{\prime \prime}$ N.; long. $128^{\circ} 32^{\prime} 40^{\prime \prime}$ E., 107 fathoms, fine gray sand, broken shells, 1 specimen; station 4905, Eastern Sea, lat. $31^{\circ} 39^{\prime} \mathrm{N}$.; long. $129^{\circ} 19^{\prime} \mathrm{E}$., 369 fathoms, bottom temperature $43.4^{\circ}, 1$ specimen; station 4916 , Eastern Sea, lat. $30^{\circ} 25^{\prime}$ N.; long. $129^{\circ} 6^{\prime} 40^{\prime \prime}$ E., 361 fathoms, gray sand, globigerina, broken shells, bottom temperature $42.7^{\circ}, 136$ specimens; station 4965 , off eastern Japan, lat. $33^{\circ} 35^{\prime} 20^{\prime \prime}$ N.; long. $135^{\circ} 10^{\prime} 50^{\prime \prime}$ E., 191 fathoms, dark green-gray sand, shells, bottom temperature $49.4^{\circ}, 3$ specimens; station 4967 , off eastern Japan, lat. $33^{\circ} 25^{\prime} 10^{\prime \prime} \mathrm{N}$.; long. $135^{\circ} 37^{\prime}$ $20^{\prime \prime}$ E., 244 to 253 fathoms, brown mud, sand, bottom temperature $45.9^{\circ}, 2$ specimens; station 4979 , off eastern Japan, lat. $33^{\circ} 53^{\prime} \mathrm{N}$.; long. $137^{\circ} 42^{\prime}$ E., 943 fathoms, brown mud, fine sand, foraminifera, bottom temperature $36.4^{\circ}, 9$ specimens; station 5055, Suruga Gulf, lat. $34^{\circ} 53^{\prime} \mathrm{N}$; l long. $138^{\circ} 44^{\prime} 50^{\prime \prime}$ E., 124 fathoms, green mud, gray sand, broken shells, pebbles, bottom temperature $56.6^{\circ}, 2$ specimens; station 5069, Suruga Gulf, lat. $35^{\circ} 3^{\prime} 10^{\prime \prime}$ N.; long. $138^{\circ} 47^{\prime}$ E., 108 to 131 fathoms, mud, sand, broken shells, bottom temperature $55.8^{\circ}$, 1 specimen; station 5070, Suruga Gulf, lat. $35^{\circ} 3^{\prime} 25^{\prime \prime}$ N.; long. $138^{\circ}$ $47^{\prime} 40^{\prime \prime}$ E., 108 fathoms, mud, sand, broken shells, bottom temperature $57.6^{\circ}, 1$ specimen; station 5084 , off Omai Saki Light, lat. $34^{\circ} \mathrm{N}$.; long. $137^{\circ} 49^{\prime} 40^{\prime \prime}$ E., 918 fathoms, green mud, fine sand, globigerina, bottom temperature $36.8^{\circ}, 4$ specimens. Bathymetrical range, 45 to 943 fathoms. Temperature range, $62.1^{\circ}$ to $36.4^{\circ}$. Two hundred and seven specimens.

These specimens show great diversity in color (dried from alcohol) and in the relative length of arm (compared to disk diameter). The color varies in different specimens from cream-white to deep grayishbrown. The length of arm varies from four to six times the diameter of the disk. There is so little divergence from Kohler's figures and description that I need mention only two points; the distal margin of the upper and under arm plates is very convex except on the first two or three joints and the plates are very much farther apart than in his figures; the basal rows of spines of opposite sides are almost completely approximated dorsally. The largest specimen is nearly $8 \mathrm{~mm}$. 
across the disk, but most of them are much less than that and some may be the young of other species. The extensive bathymetrical and temperature ranges would indicate the presence of more than one species in the lot, but such small specimens of Ophiacantha can seldom be positively identified.

\section{OPHIACANTHA LEVISPINA.}

Ophiacantha levispina Lyman, Bull. Mus. Comp. Zoöl., vol. 5, 1878, p. 147.

Localities.-Albatross station 4908, Eastern Sea, lat. $31^{\circ} 40^{\prime} \mathrm{N}$.; long. $129^{\circ} 29^{\prime} 40^{\prime \prime}$ E., 434 fathoms, gray globigerina ooze, bottom temperature $42.0^{\circ}, 7$ specimens; station 4912 , Eastern Sea, lat. $31^{\circ}$ $39^{\prime} 40^{\prime \prime} \mathrm{N}$.; long. $129^{\circ} 20^{\prime}$ E., 391 fathoms, gray globigerina ooze, bottom temperature $41.9^{\circ}, 1$ specimen; station 4915, Eạstern Sea, lat. $31^{\circ} 31^{\prime} \mathrm{N}$.; long. $129^{\circ} 25^{\prime} 30^{\prime \prime}$ E., 427 fathoms, gray globigerina ooze, broken shells, bottom temperature $41.9^{\circ}, 2$ specimens; station 4916 , Eastern Sea, lat. $30^{\circ} 25^{\prime}$ N.; long. $129^{\circ} 6^{\prime} 40^{\prime \prime}$ E., 361 fathoms, gray sand, globigerina, broken shells, bottom temperature $42.7^{\circ}, 11$ specimens; station 4917 , Eastern Sea, lat. $30^{\circ} 24^{\prime}$ N.; long. $129^{\circ} 6^{\prime}$ E., 361 fathoms, gray sand, globigerina, broken shells, bottom temperature $42.7^{\circ}, 8$ specimens; station 4918 , Eastern Sea, lat. $30^{\circ} 22^{\prime} \mathrm{N}$.; long. $129^{\circ} 8^{\prime} 30^{\prime \prime}$ E., 361 fathoms, gray sand, globigerina, broken shells, bottom temperature $42.7^{\circ}, 11$ specimens; station 4919 , Eastern Sea, lat. $30^{\circ} 34^{\prime}$ N.; long. $129^{\circ} 19^{\prime} 30^{\prime \prime}$ E., 440 fathoms, globigerina ooze, bottom temperature $41.8^{\circ}, 19$ specimens; station 4956 , off southern Japan, lat. $32^{\circ} 32^{\prime} \mathrm{N}$.; long. $132^{\circ} 25^{\prime} \mathrm{E}$., 720 fathoms, green-brown mud, fine gray sand, foraminifera, bottom temperature $37.5^{\circ}, 7$ specimens; station 4971 , off eastern Japan, lat. $33^{\circ} 23^{\prime} 30^{\prime \prime}$ N.; long. $135^{\circ} 34^{\prime}$ E., 649 fathoms, green-brown mud, foraminifera, bottom temperature, $38.1^{\circ}, 1$ specimen; station 4980 , off eastern Japan, lat. $34^{\circ} 9^{\prime} \mathrm{N}$.; long. $137^{\circ} 55^{\prime}$ E., 507 fathoms, brown mud, fine sand, foraminifera, bottom temperature $39^{\circ}, 4$ specimens; station 4984 , Sea of Japan, lat. $43^{\circ} 4^{\prime} 20^{\prime \prime}$ N.; long. $140^{\circ} 12^{\prime} 10^{\prime \prime}$ E., 224 to 248 fathoms, green mud, bottom temperature $33^{\circ}, 1$ specimen; station 5083, off Omai Saki Light, lat. $34^{\circ} 4^{\prime} 20^{\prime \prime}$ N.; long. $137^{\circ} 57^{\prime} 30^{\prime \prime}$ E., 624 fathoms, fine gray sand, globigerina, bottom temperature $38.1^{\circ}, 2$ specimens. Bathymetrical range, 224 to 720 fathoms. Temperature range, $42.9^{\circ}$ to $33^{\circ}$. Seventy-four specimens.

Lyman considered his single specimen, which measured $6 \mathrm{~mm}$. across the disk, as immature, but the largest specimen before me is only $9 \mathrm{~mm}$. in disk diameter and the great majority are under $7 \mathrm{~mm}$. The broad distal oral papilla is the most striking mark of this species and is fortunately very constant. It serves to distinguish levispina from pentagona at once, although in other characters the two species often approach each other very nearly. There is considerable diversity shown in the shape of the arm plates and oral shields; the latter 
are usually much wider than long, but they are sometimes longer than wide. None of the Albatross specimens have the under arm plates as narrow as in Lyman's figures, and the upper arm plates are relatively larger than he shows them, but I do not think these can be specific differences.

\section{OPHIACANTHA ADIAPHORA, new species. $a$}

Disk $7 \mathrm{~mm}$. in diameter; arms about $28 \mathrm{~mm}$. long. Disk pentagonal covered closely with little stumps, nearly one-third millimeter high, which are about cylindrical and terminate in several slender, more or less diverging teeth. Radial shields concealed. Upper arm plates small, nearly triangular, widely separated. Interbrachial spaces below, like disk, except that the scales are visible just distal to oral shield. Genital slits small. Oral shield rather small, wider than long, somewhat rhombic, with rounded angles and concave sides. Adoral plates moderate, wider without than within, where they do not always meet. Oral papillæ subequal, narrow,

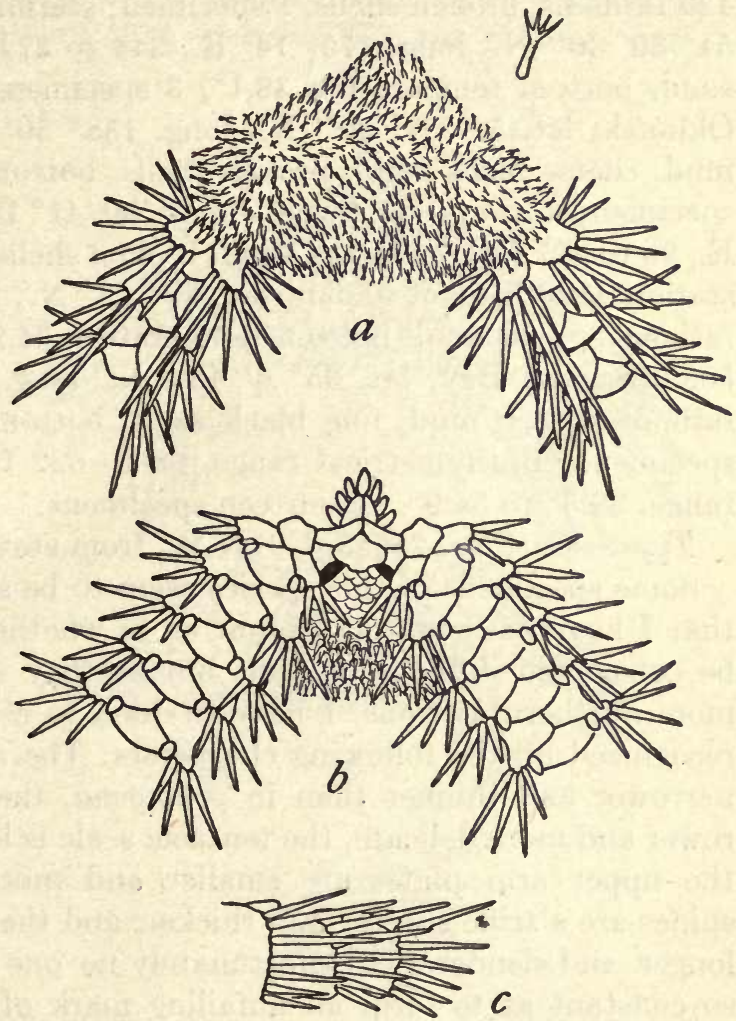

Fig. 91.-OPhiacantha Adiaphora. $\times 7$. $a$, FROM ABOVE; $b$, FROM BELOW; $c$, SIDE VIEW OF THREE ARM JOINTS NEAR DISK.

flat, bluntly pointed, three on a side and one at apex of jaw. First under arm plate rather large, pentagonal, nearly as long as wide; succeeding plates hexagonal, pentagonal, or tetragonal, much wider than long, well separated from each other. Side arm plates rather large, meeting broadly above and below, each with six or seven long, straight, pointed spines; these spines are not perfectly smooth, but seem so to the unaided eye; the uppermost (or one next to it) is the longest

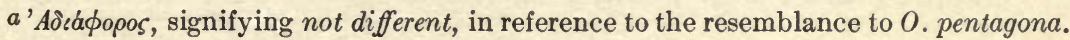


and equals two or three joints. Tentacle scale single (sometimes two on basal pores), moderate, rounded or bluntly pointed. Color (dried from alcohol), nearly white, or bright brownish-yellow, or brownishgray.

Localities.-Albatross station 3480 , Bering Sea, lat. $52^{\circ} 6^{\prime}$ N.; long. $171^{\circ} 45^{\prime}$ W., 283 fathoms, black sand, coral, rocky, 3 specimens; station 4769, Bering Sea, lat. $54^{\circ} 30^{\prime} 40^{\prime \prime}$ N.; long. $179^{\circ} 14^{\prime}$ E., 237 to 244 fathoms, gray sand, green mud, bottom temperature $38.5^{\circ}, 2$ specimens; station 4771 , Bering Sea, lat. $54^{\circ} 30^{\prime} \mathrm{N}$.; long. $179^{\circ} 17^{\prime} \mathrm{E}$., 426 fathoms, broken shells, 1 specimen; station 4772, Bering Sea, lat. $54^{\circ} 30^{\prime} 30^{\prime \prime} \mathrm{N}$.; long. $179^{\circ} 14^{\prime}$ E., 344 to 372 fathoms, green-brown sand, bottom temperature $38.1^{\circ}, 3$ specimens; station 4797 , Sea of Okhotsk, lat. $52^{\circ} 37^{\prime} 30^{\prime \prime} \mathrm{N}$.; long. $158^{\circ} 50^{\prime}$ E., 68 fathoms, green mud, coarse black sand, broken shells, bottom temperature $36.6^{\circ}, 1$ specimen; station 4809 , Sea of Japan, lat. $41^{\circ} 18^{\prime} \mathrm{N}$.; long. $140^{\circ} 8^{\prime} 40^{\prime \prime}$ E., 90 to 207 fathoms, gray sand, broken shells, pebbles, 2 specimens; station 4828 , Sea of Japan, lat. $37^{\circ} 23^{\prime}$ N.; long. $137^{\circ} 36^{\prime}$ E., 163 fathoms, green mud, bottom temperature $34.9^{\circ}, 1$ specimen; station 5085, Sagami Bay, lat. $35^{\circ} 6^{\prime} 45^{\prime \prime} \mathrm{N}$.; long. $139^{\circ} 19^{\prime} 45^{\prime \prime}$ E., 622 fathoms, green mud, fine black sand, bottom temperature $37.8^{\circ}, 1$ specimen. Bathymetrical range, 68 to 622 fathoms. Temperature range, $38.5^{\circ}$ to $34.9^{\circ}$. Fourteen specimens.

Type.-Cat. No. 25543, U.S.N.M., from station 4772.

Some specimens of this species seem to be so near to $O$. pentagona that I have been in great doubt as to whether the species ought. to be considered different or not, but as they are mostly from much more northern stations, I have decided to establish it. It may be recognized by the following characters: The adoral plates are much narrower and thinner than in pentagona, the oral papillæ are narrower and more delicate, the tentacle scale is larger and more obtuse, the upper arm plates are smaller and more triangular, the arm spines are a trifle shorter and thicker, and the disk stumps are much longer and slenderer. Unfortunately no one of these characters is so constant as to form an unfailing mark of distinction, yet when all are taken into account the two species are distinguishable. The tentacle scales and disk stumps furnish the best characters, particularly in adults. Comparison of the figures given here with the figures of pentagona given by Kœhler ${ }^{a}$ will serve to emphasize the resemblances, rather than the differences, between the two species. The largest specimen of adiaphora before me is $9 \mathrm{~mm}$. across the disk and is remarkable for having six arms and six jaws; it is not otherwise peculiar. 
OPHIACANTHA RHACHOPHORA, new species, $a$

This species is so close to the two preceding that a detailed description would be quite superfluous. Its only specific peculiarities lie in the very rough arm spines (except the uppermost), tentacle scales, and even oral papillæ. In extreme cases the tips of the distal oral papillæ bear several teeth or little thorns, and the tentacle scales are sharp pointed with a thorn or two on each side. Other specimens have these peculiarities less marked and approach very near to pentagona, and I do not feel sure that rhachophora is anything more than a slight variety of that species. For the present, however, I think it well to distinguish it by a separate name.

Localities.-Albatross station 3698, off Manazuru Zaki, Honshu Island, Japan, 153 fathoms, green mud, volcanic ashes, sand, 1 specimen; station 3717 , off Ose Zaki, Honshu Island, Japan, 63 to 100 fathoms, volcanic sand, shells, rocks, 2 specimens; station 3750, off Suno Saki, Honshu Island, Japan, 83 to 140 fathoms, gray sand, broken shells, pebbles, 1 specimen; station 4771, Bering Sea, lat. $54^{\circ} 30^{\prime} \mathrm{N}$.; long. $179^{\circ} 17^{\prime}$ E., 426 fathoms, broken shells, bottom temperature $38.1^{\circ}, 2$ specimens; station 4772 , Bering Sea,

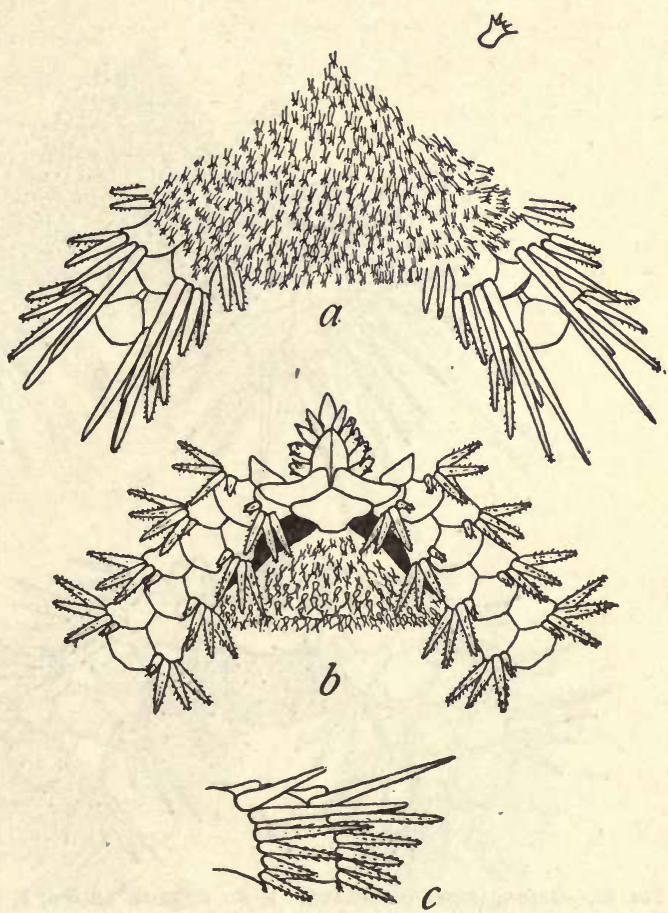

Fig. 92.-OPHIACANTHA RHACHOPHORA. $\times 8$. $a$, FROM ABOVE; $b$, FROM BELOW; $c$, SIDE VIEW OF TWO ARM JOINTS NEAR DISK. lat. $54^{\circ} 30^{\prime} 30^{\prime \prime} \mathrm{N}$.; long. $179^{\circ} 14^{\prime} \mathrm{E}$., 344 to 372 fathoms, greenbrown sand, 1 specimen; station 4775 , Bering Sea, lat. $54^{\circ} 33^{\prime} 30^{\prime \prime}$ $\mathrm{N}$.; long. $178^{\circ} 44^{\prime}$ E., 584 fathoms, green mud, black specks, foraminifera, bottom temperature $37.2^{\circ}, 16$ specimens; station 4809 , Sea of Japan, lat. $41^{\circ} 36^{\prime} 12^{\prime \prime}$ N.; long. $140^{\circ} 8^{\prime} 40^{\prime \prime}$. E., 90 to 207 fathoms, gray sand, pebbles, broken shells, 12 specimens; station 4893 , Eastern Sea, lat. $32^{\circ} 32^{\prime}$ N.; long. $128^{\circ} 32^{\prime} 50^{\prime \prime}$ E., 95 to 106 fathoms, gray sand, broken shells, pebbles, bottom tempera-

$a ' P a \chi b s$, signifying a briar, and $\phi o \rho d$, signifying a carrying, in reference to the very thorny arm spines and tentacle scales. 
ture $55.9^{\circ}, 2$ specimens; station 4902 , Eastern Sea, lat. $32^{\circ} 30^{\prime} 50^{\prime \prime}$ N.; long. $128^{\circ} 34^{\prime} 40^{\prime \prime}$ E., 139 fathoms, gray sand, broken shells, bottom temperature $52.9^{\circ}, 2$ specimens; station 4903 , Eastern Sea, lat. $32^{\circ} 31^{\prime} 10^{\prime \prime} \mathrm{N}$.; long. $128^{\circ} 33^{\prime} 20^{\prime \prime}$ E., 107 to 139 fathoms, gray sand, broken shells, bottom temperature $52.9^{\circ}, 1$ specimen; station 4965 , off eastern Japan, lat. $33^{\circ} 35^{\prime} 20^{\prime \prime}$ N.; long. $135^{\circ} 10^{\prime} 50^{\prime \prime}$ E., 191 fathoms, dark green-gray sand, shells, bottom temperature $49.4^{\circ}, 71$ specimens; station 4967 , off eastern Japan, lat. $33^{\circ} 25^{\prime} 10^{\prime \prime}$ N.; long. $135^{\circ} 37^{\prime} 20^{\prime \prime}$ E., 244 to 253 fathoms, brown mud, sand, foraminifera, bottom temperature $45.9^{\circ}, 2$ specimens; station 5079 , off Omai Saki Light, lat. $34^{\circ} 15^{\prime}$ N.; long. $138^{\circ}$ E., 475 to 505 fathoms,
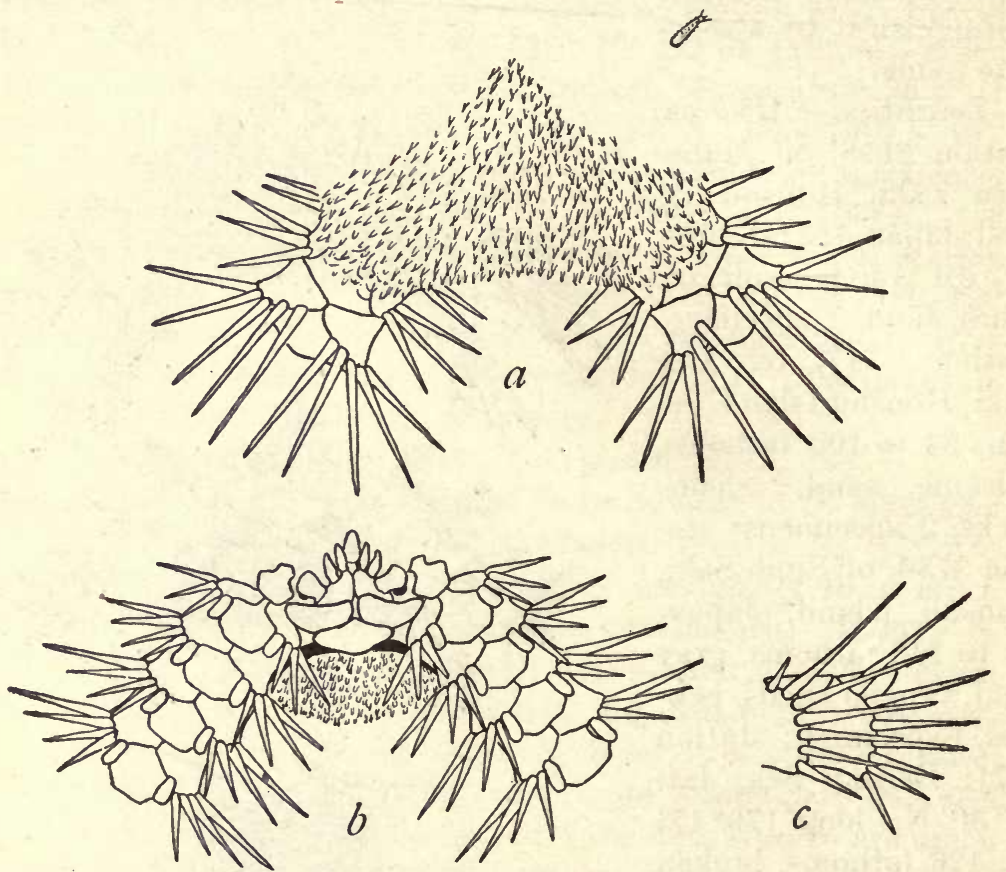

Fig. 93.-OPHIACANTHA OMOPLATA. $\times 8$. $a$, FROM ABOVE; $b$, From BELOW; $c$, SIDE VIEW OF TWO ARM JOINTS NEAR DISK.

pebbles, bottom temperature $39.1^{\circ}, 4$ specimens; station 5091 , Uraga Strait, lat. $35^{\circ} 4^{\prime} 10^{\prime \prime}$ N.; long. $139^{\circ} .38^{\prime} 12^{\prime \prime}$ E., 197 fathoms, green mud, coarse black sand, pebbles, bottom temperature $47.6^{\circ}$, 5 specimens. Bathymetrical range, 63 to 584 fathoms. Temperature range, $55.9^{\circ}$ to $37.2^{\circ}$. One hundred and twenty-two specimens.

Type.-Cat. No. 25630, U.S.N.M., from station 4902.

\section{OPHIACANTHA OMOPLATA, new species. $a$}

Similar to adiaphora in size and proportions and in many other respects. Upper arm plates a little larger and relatively wider

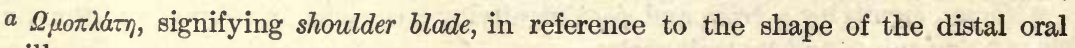
papilla. 
than in that species. Disk spines with shorter and more numerous thorns, so that they are really rough spines. Outermost oral papilla wide and rounded, shaped like the shoulder blade of many Carnivora. Oral shield very wide and short. Tentacle scale conspicuous, long, rounded at tip; often distinctly furrowed. Under arm plates more nearly square than in adiaphora.

Locality.-Albatross station 4861 , off Korea, lat. $36^{\circ} 19^{\prime}$ N.; long. $129^{\circ} 47^{\prime}$ E., 163 fathoms, green mud, bottom temperature $33.4^{\circ}, 2$ specimens.

Type--Cat. No. 25740, U.S.N:M., from station 4861.

Although this species is very near to the three preceding I do
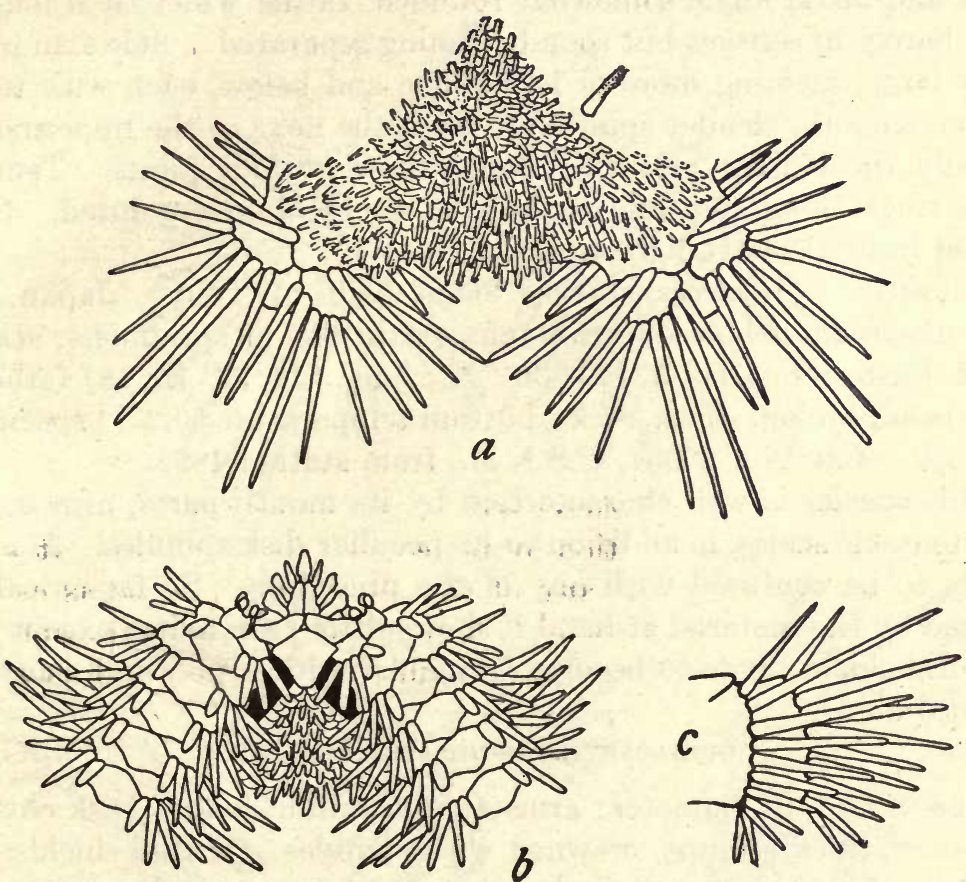

Fig. 94.-Ophiacantha acanthinotata. $\times 6$. $a$, From ABove; $b$, From Below; $c$, Side view of two ARM JOINTS NEAR DISK.

not think there can be much question of its validity. The distal mouth papilla and the disk spinules are very characteristic features, and the peculiar tentacle scales are quite noticeable.

OPHIACANTHA ACANTHINOTATA, new species. $b$

Disk $9 \mathrm{~mm}$. in diameter; arms about $45 \mathrm{~mm}$. long. Disk covered with numerous rough blunt spines, about half a millimeter long.

$b^{\prime} A \kappa a \nu \theta \iota \nu o ́ \tau a \tau o s$, signifying most spiny, in reference to the large number and length of both disk and arm spines. 
Radial shields completely concealed. Upper arm plates triangular, nearly as long as wide, the basal ones more or less in contact. Interbrachial spaces below, covered with scales which are partly obscured by spines, similar to those of the disk. Genital slits large. Oral shields somewhat pentagonal, longer than broad, with distal end narrower. Adoral plates moderate, not peculiar. Oral papillæ about three on a side, notably elongated, the distal one largest and somewhat widened at tip; there are two small scales protecting the second pair of oral pores, close to the first under arm plate; there is a long infradental papilla at apex of jaw. First under arm plate small, squarish; succeeding plates more or less hexagonal, with both proximal and distal angle somewhat rounded, rather wider than long, at first barely in contact but soon becoming separated. Side arm plates very large, meeting more or less above and below, each with ten or eleven smooth, slender spines, of which the next to the uppermost is usually the longest and may equal three or four joints. Tentacle scale single, long, flat, and rounded at tip or bluntly pointed. Color (dried from alcohol), light brown.

Localities.-Albatross station 3661, Gulf of Tokyo, Japan, 169 fathoms, mud, pebbles, bottom temperature $48^{\circ}, 9$ specimens; station 4892 , Eastern Sea, lat. $32^{\circ} 27^{\prime} 30^{\prime \prime}$ N.; long. $128^{\circ} 33^{\prime}$ E., 181 fathoms, gray sand, broken shells, rocks, bottom temperature $50.2^{\circ}, 1$ specimen.

Type.-Cat. No. 25634, U.S.N.M., from station 4892.

This species is well characterized by its mouth parts, arm spines, and tentacle scales, in addition to its peculiar disk spinules. It is not likely to be confused with any of the preceding. So far as can be judged by the material at hand it shows little variability, except that the oral shield tends to become triangular with a proximal base and a distal angle.

\section{OPHIACANTHA ANCHILABRA, new species. $a$}

Disk $8 \mathrm{~mm}$. in diameter; arms about $35 \mathrm{~mm}$. long. Disk covered by short, thick stumps, crowned with spinules. Radial shields concealed. Arms wide and little constricted between the upper arm plates; width of arm at base nearly equal to one-half radius of disk. Upper arm plates broadly triangular, widely separate. Interbrachial spaces below covered with scales which are little obscured by the stumps they carry. Oral shields much wider than long, with little or no proximal angle and a broadly curved distal edge. Adoral plates large, about as wide without as within, where they do not always meet. Oral papillæ, about three on a side and one at apex of jaw, long, thick, and bluntly pointed. Genital slits short. First under

$a^{N} A \gamma \chi \ell$, signifying near to, and $\lambda a ́ \beta \rho o s$, signifying voracious (Latin vorax), in reference to its obvious relationship to O. vorax Kœhler. 
arm plate wider than long, in contact with second, which is correspondingly heptagonal; succeeding plates hexagonal, separated, at first wider than long but rapidly becoming longer than wide; at middle of arm the under arm plates are so encroached on by the huge tentacle scales that their length may be nearly twice their least breadth. Side arm plates large, meeting both above and below; each plate carries about nine (seven to eleven in different specimens). long, smooth spines, of which the second or third (from above) is the longest, and may equal four joints. Tentacle scale single, very large, often as long as the under arm plate, or nearly so, more or less pointed. Color (dried from alcohol), very light brown.
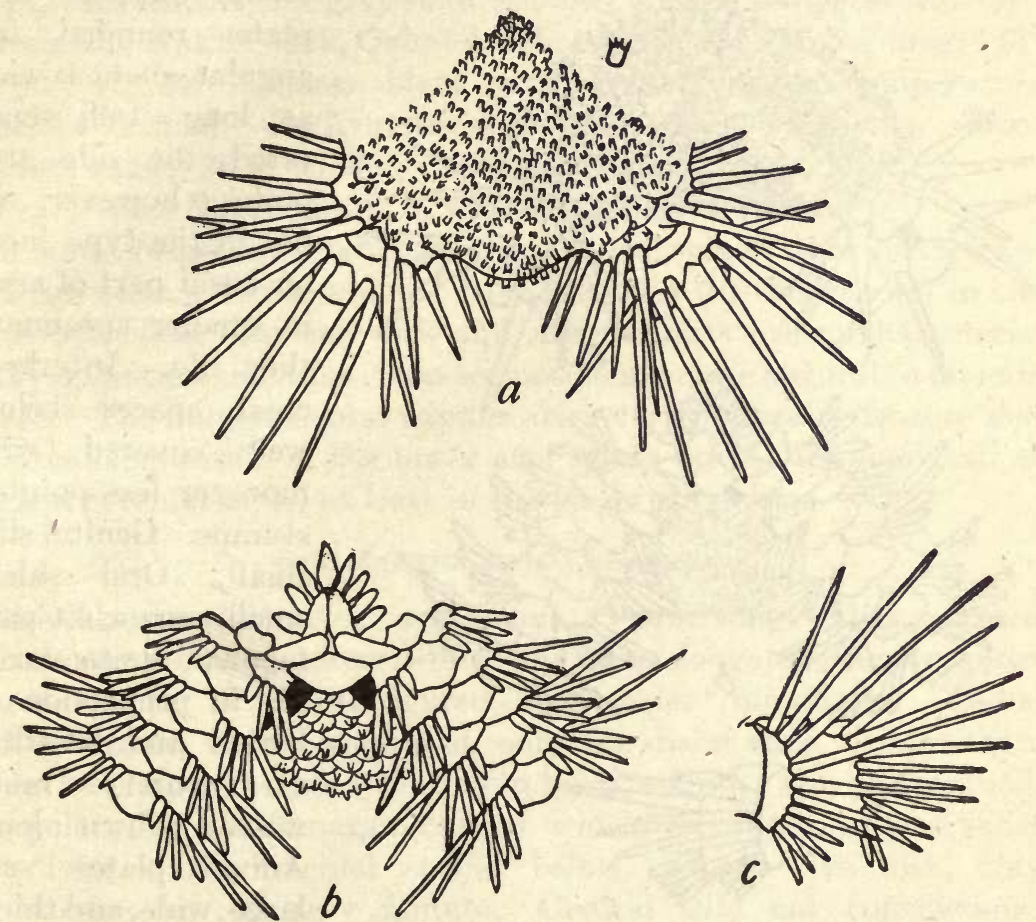

Fig. 95.-OPHICANtha ANCHILABRA. $\times 6$. $a$, FROM ABOVE; $b$, FRom BELOW; $c$, SIDE VIEW OF TWO ARM JOINTS NEAR DISK.

Localities.-Albatross station 4971 , off eastern Japan, lat. $33^{\circ} 23^{\prime} 30^{\prime \prime}$ N.; long. $135^{\circ} 34^{\prime}$ E., 649 fathoms, brown-green mud, foraminifera, bottom temperature $38.1^{\circ}$, 1 specimen; station 5084, off Omai Saki Light, lat. $34^{\circ} \mathrm{N}$.; long. $137^{\circ} 49^{\prime} 40^{\prime \prime}$ E., 918 fathoms, green mud, fine sand, globigerina, bottom temperature $36.8^{\circ}, 5$ specimens.

Type.-Cat. No. 25654, U.S.N.M., from station 5084.

Although this species is nearly related to pentagona and its allies, it is easily distinguished from that group by its much broader and stouter arms, and its longer and thicker oral papillæ; the long under 
arm plates near middle of arm are also a good character. On the whole the nearest ally of anchilabra is Kœhler's species vorax, from which it seems to differ only in the smooth arm spines and in the absence of bare scales and radial shields at the bases of the arms.

OPHIACANTHA TRACHYBACTRA, new species.a

Disk $12 \mathrm{~mm}$. in diameter; arms about $60 \mathrm{~mm}$. long. Disk covered by numerous, nearly cylindrical stumps, crowned with several minute spinules. Radial shields concealed, but in dry specimens their form and position is clearly indicated by long, narrow, well-separated
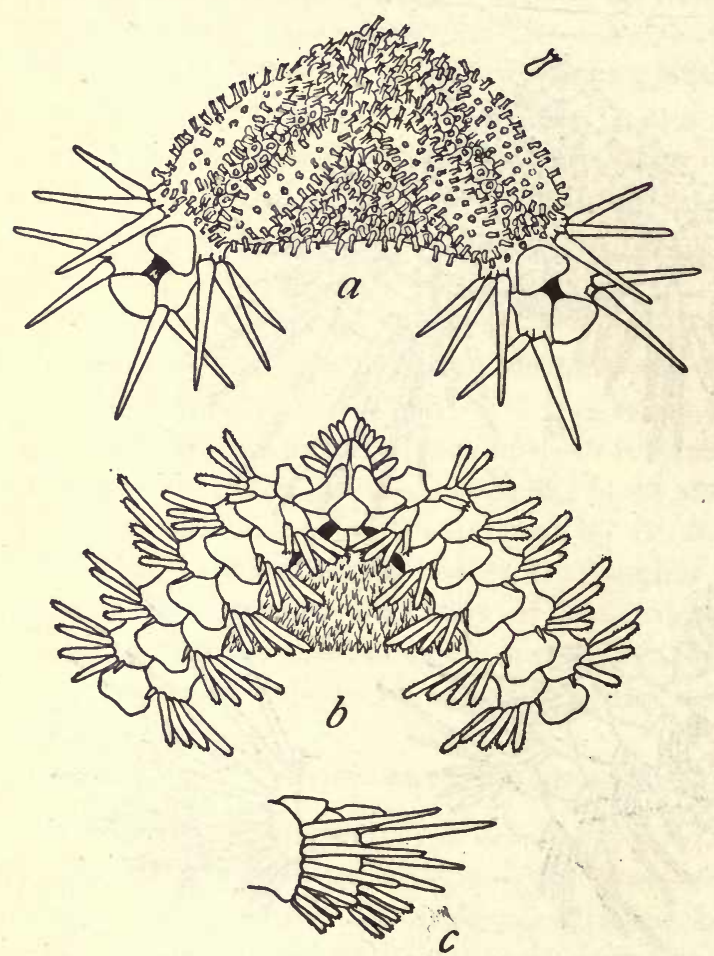

Fig. 96.-Ophicantha trachybactra. $\times$ 4. $a$, From above; $b$, FROM BELOW; $c$, SIDE VIEW OF TWO ARM JOINTS NEAR DISK. ridges. Arms rather stout; upper arm plates rounded triangular, about as wide as long, well separated; the side arm plates, however, do not in the type meet on basal part of arm; in smaller specimens they do. Interbrachial spaces below well covered with more or less pointed stumps. Genital slits small. Oral shield small, somewhat pentagonal, quite variable in proportion of length and breadth; commonly much wider than long. Adoral plates very large, wide, and thick, meeting broadly within. Oral papillæ numerous, five or six on a side, besides one at apex of jaw, subequal, long, thick, bluntly pointed. First under arm plate rather large, somewhat hexagonal, wider proximally than distally; succeeding plates ranging from nearly triangular to nearly square; wider than long, widely separated. Side arm plates large, separating the upper arm plates above (even if they do not quite meet each other) and meeting broadly below; each plate carries six or seven rather thick arm spines,

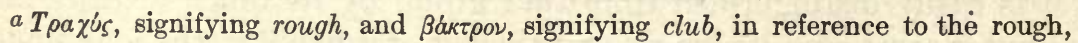
club-shaped, lower arm spines. 
of which the upper ones are smooth, tapering, and pointed, while the lower are club-shaped and have rough or thorny tips; uppermost longest, equal to two joints or nearly so; distally, the lower arm spines are crowded and turned inward to cover the lower surface of the arm. Tentacle scale single, very small and pointed; those on the first pair of arm pores are larger and blunter than the others, but the difference is not so great as is shown in fig. $96 b$. Color (dried from alcohol), very light brown.

Localities.-Albatross station 3338 , off Alaska, lat. $54^{\circ} 19^{\prime} \mathrm{N}$.; long. $159^{\circ} 40^{\prime} \mathrm{W}$., 625 fathoms, green mud, sand, bottom temperature $37.3^{\circ}$, 3 specimens; station 4781 , Bering Sea, lat. $52^{\circ} 14^{\prime} 30^{\prime \prime} \mathrm{N}$.; long. $174^{\circ}$ $13^{\prime}$ E., 482 fathoms, fine gray sand, pebbles, bottom temperature $38.6^{\circ}$, 1 specimen; station 5029 , Okhotsk Sea, lat. $48^{\circ} 22^{\prime} 30^{\prime \prime} \mathrm{N}$.; long. $145^{\circ}$ $43^{\prime} 30^{\prime \prime}$ E., 440 fathoms, black sand, gravel, bottom temperature $35.3^{\circ}, 1$ specimen. Bathymetrical range, 440 to 625 fathoms. Temperature range, $38.6^{\circ}$ to $35.3^{\circ}$. Five specimens.

Type.-Cat. No. 25649, U.S.N.M., from station 5029.

In some respects, notably the lower arm spines, this species approaches certain forms which I have included (in this report) in the genus Ophiolebes, but the disk and mouth parts are so characteristically ophiacanthine that it has seemed to me more natural to include it here. The numerous oral papillæ are a very noticeable feature and the peculiar position of the lower arm spines on the terminal half of the arm is remarkable, at least in the larger specimens.

\section{OPHIACANTHA DIPLOA, new species. $a$}

Disk $7 \mathrm{~mm}$. in diameter; arm about $45 \mathrm{~mm}$. long. Disk covered with thorny stumps, among which are some elongated thorny spines almost exactly like those figured by $\mathrm{K} œ \mathrm{ler}^{b}$ for $d u p l e x$. Radial shields narrow, widely separated, only the distal ends visible; there are no bare plates between or around them. Upper arm plates small, triangular with distal margin curved, widely separated, at first wider than long. Interbrachial spaces below covered like disk, only the stumps are all very minute. Genital slits not conspicuous. Oral shields much wider than long, rhombic with distal angle rounded. Adoral plates large, rather short and wide, meeting broadly within. Oral papillæ three or four on a side and one at apex of jaw, long, thick and sharp, subequal. First under arm plate about one-third as long as second, hexagonal, wider than long; succeeding plates also hexagonal and wider than long, but the distal angle is rounded, and there is a distinct median notch in the consequently convex distal margin; all the plates are separated or the basal ones are barely in contact.

\footnotetext{
a $\Delta \iota \pi \lambda o_{o s}$, signifying double, equivalent to Latin duplex in reference to the two kinds of spines on the disk and its close relationship to O.duplex Kœhler.

b Investigator, Deep Sea Oph., 1899, pl. 9, fig. 70.
} 
Side arm plates large, meeting broadly above and more or less below; each plate carries nine long, slender, nearly smooth arm spines, of which the uppermost (or next to it) is the longest, and may equal fully four joints; on the basal joints of the arm, the spine series of opposite sides meet immediately behind the upper arm plate; this union of the spine series is most marked on the first three joints distal to the disk, but at no point on the arm are the series of any one joint as far apart as the width of an upper arm plate. Tentacle scale single, of moderate size, flat, oval, and sharp. Color (dried from alcohol), nearly white, but with a yellowish tinge.

Locality.-Albatross station 4957, off southern Japan, lat. $32^{\circ} 36^{\prime}$ N.; long. $132^{\circ} 23^{\prime}$ E., 437 fathoms, green-brown mud, fine gray sand, foraminifera, bottom temperature $39.8^{\circ}, 2$ specimens.

Type.-Cat. No. 25741, U.S.N.M., from station 4957.

I was at first inclined to consider these specimens as representatives of $O$. duplex Kœhler, but further study has satisfied me they can not be that species. It does not seem necessary, however, to give figures, the relationship with duplex is so marked. The essential difference is in the number and arrangement of the arm spines; in duplex (10 $\mathrm{mm}$., disk diameter).there are eight, and, except the first basal series, they are not approximated dorsally, but are separated by the full width of the upper arm plates; in diploa $(7 \mathrm{~mm}$., disk diameter) there are nine, and the series are closely approximated dorsally immediately behind the upper arm plates. Moreover, while the spines in diploa are nearly smooth (rough under a magnification of eight diameters) and the longest are equal to fully four joints, Kœhler says of duplex, "piquants garnis de denticulations assez fortes; le premier ventral est plus long que l'article, le dernier dorsal est plus long que deux articles." The oral papillæ in diploa seem to be much more slender, and sharper than those of duplex, and the under arm plates are very different. The combination of these characters has persuaded me to distinguish diploa as a new species.

\section{OPHIACANTHA INUTILIS.}

Ophiacantha inutilis Køhler, Siboga Oph. Mer Prof., 1904, p. 111.

Localities.-Albatross station 4919, Eastern Sea, lat. $30^{\circ} 34^{\prime} \mathrm{N}$.; long. $129^{\circ} 19^{\prime} 30^{\prime \prime}$ E., 440 fathoms, globigerina ooze, bottom temperature $41.8^{\circ}, 1$ specimen; station 4965 , off eastern Japan, lat. $33^{\circ} 35^{\prime} 20^{\prime \prime} \mathrm{N}$.; long. $135^{\circ} 10^{\prime} 50^{\prime \prime}$ E., 191 fathoms, dark green-gray sand, shells, bottom temperature $49.4^{\circ}$, 1 specimen; station 5091, Uraga Strait, lat. $35^{\circ} 4^{\prime} 10^{\prime \prime} \mathrm{N}$.; long. $139^{\circ} 38^{\prime} 12^{\prime \prime}$ E., 197 fathoms, green mud, coarse black sand, pebbles, bottom temperature $47.6^{\circ}, 1$ specimen; station 5092, Uraga Strait, lat. $35^{\circ} 4^{\prime} 50^{\prime \prime}$ N.; long. $139^{\circ} 38^{\prime} 18^{\prime \prime}$ E., 70 fathoms, coarse black sand, bottom temperature $56.3^{\circ}, 1$ specimen. 
Bathymetrical range, 70 to 440 fathoms. Temperature range, $56.3^{\circ}$ to $41.8^{\circ}$. Four specimens.

These specimens range in size from 7 to $14 \mathrm{~mm}$. across the disk. The length of the disk spinules is very variable, as is the shape of the adoral plates, and the number and length of the sharp, slender spinules on the outer edge of the upper arm plates show great diversity; in the smallest specimens, the latter are wanting. The largest specimen has nine arm spines and the smallest has seven on the basal arm joints. Kœhler suggests that inutilis may be identical with gratiosa, one of the Investigator species he described in 1897, and these Japanese specimens incline me to think that this is probably so, but as I do not feel sure of it, I prefer to use the name inutilis for them.

OPHIACANTHA DIPLASIA, new species.a

Disk $23 \mathrm{~mm}$. in diameter; arms about $150 \mathrm{~mm}$. long. Disk covered with coarse, nearly spherical granules, which are slightly elongated at the interradial margins; distal to each of the radial shields, which are completely concealed, is a group of slender spines of various lengths (these spines were not seen in any of the other specimens examined, but all of them (16) were smaller than the type). Upper arm plates rhombic, more or less overlapping at base of arm and in contact far out toward the tip; at base of arm they are rather wider than long, but distally they become distinctly longer than wide; the distal angle of each plate is rounded or truncate and in large specimens, near the base of the arm, may carry one or more large granules like those of the disk; these are particularly numerous and noticeable in the type. Interbrachial spaces below more or less fully covered by somewhat elongated, pointed granules. Genital slits large. Oral shields variable, but wider than long and usually rhombic; often pentagonal, and not uncommonly with the distal part abruptly narrowed into a sort of bridge between the shield and the interbrachial space. Adoral plates remarkably variable; often short, moderately wide and wholly proximal to the oral shield; more commonly long and narrow, with more or less of an intrusive branch between the oral shield and first side arm plate; in the type, the adoral shields are distinctly L-shaped and completely inclose the oral shield, save for a short distal margin. Oral papillæ numerous, five to seven on a side and one or more at apex of jaw, besides (in the type) one or two extra ones on the surface of either the adoral or the oral plate; they are long, flattened, blunt, and subequal, or the outermost may be longer or wider than the others; it is sometimes very long. First under arm plate small, wider than long; succeeding plates squarish or by truncation of one or more angles, pentagonal, hexagonal, heptagonal, and

a $\Delta \iota \pi \lambda \lambda^{\prime} \sigma \iota s$, signifying twice as many, in reference to the pair of tentacle scales.

$34916^{\circ}-$ Bull. $75-11-14$ 
even octagonal; distal angles often rounded instead of truncate; all of the under arm plates are near together, but they may be slightly separated; they are often in contact. Side arm plates moderate, not meeting above and only slightly, if at all, below; each plate carries seven or eight smooth, stout but delicate arm spines, which are more or less distinctly flattened; the spines are not only hollow, but the central cavity is relatively very large; uppermost spine (or one next to it), longest, rather exceeding two joints; basal series of spines of opposite sides not noticeably approximate. Tentacle scales two on each pore, long, flat, and blunt; in large specimens the basal pores have three scales. Color (dried from alcohol), disk, brown of some shade,
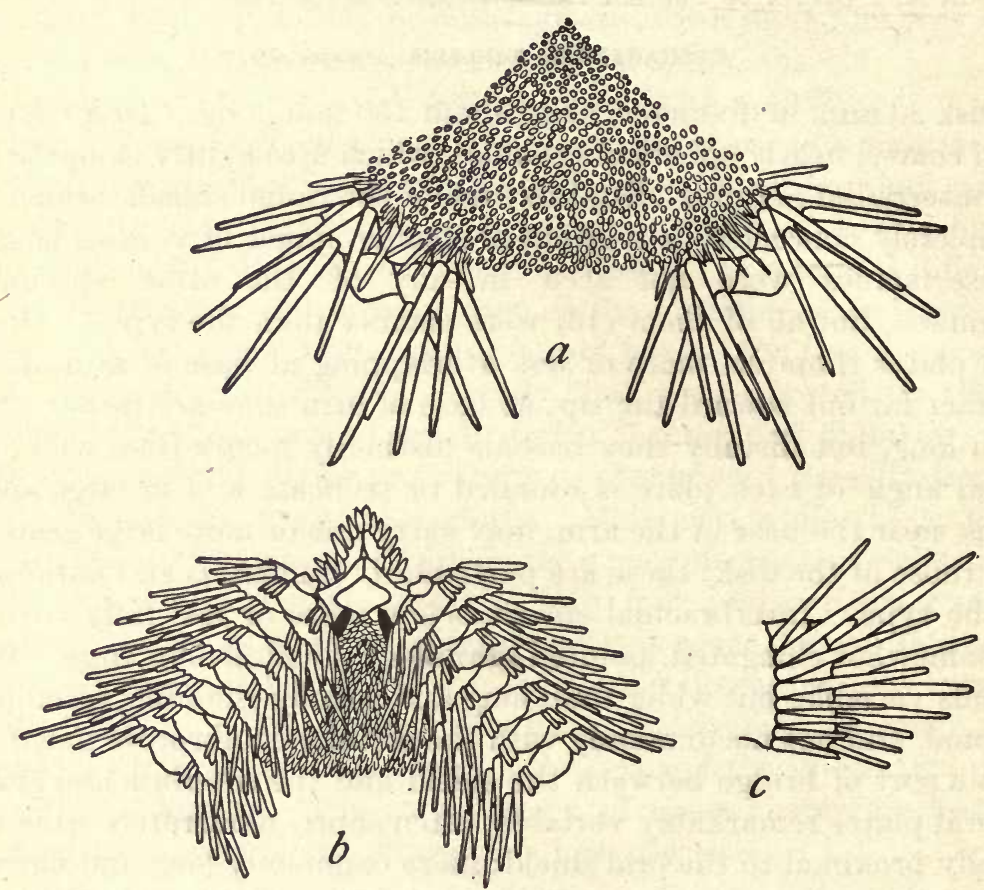

Fig. 97.-OPHicANtha diplasia. $\times 2.25$. $a$, FROM ABOVE; $b$, FROM BELOW; $c$, SIDE VIeW OF TWO ARM JOINTS NEAR DISK.

ranging from very light to very dark; arm spines usually much lighter than disk and often nearly white; occasionally the disk is dark brown, mottled with a lighter shade.

Localities.-Albatross station 3051, off Oregon, lat. $43^{\circ} 59^{\prime} 19^{\prime \prime} \mathrm{N}$.; long. $124^{\circ} 58^{\prime} 30^{\prime \prime}$ W., 59 fathoms, coral, broken shells, rocky, 23 specimens; station 3053 , off Oregon, lat. $44^{\circ} 4^{\prime} 30^{\prime \prime} \mathrm{N}$.; long. $124^{\circ} 50^{\prime}$ W., 64 fathoms, coral, broken shells, rocky, bottom temperature $47.3^{\circ}, 5$ specimens; station 3054 , off Oregon, lat. $44^{\circ} 13^{\prime} \mathrm{N}$.; long. $124^{\circ} 44^{\prime} 30^{\prime \prime}$ W., 53 fathoms, rocks, bottom temperature $48^{\circ}$, 3 specimens; station 3078 , off Oregon, lat. $43^{\circ} 59^{\prime} 15^{\prime \prime} \mathrm{N}$.; long. $124^{\circ} 46^{\prime} \mathrm{W}$., 
68 fathoms, green mud, bottom temperature $45.7^{\circ}, 6$ specimens; station 3079 , off Oregon, lat. $43^{\circ} 59^{\prime} 15^{\prime \prime} \mathrm{N}$.; long. $124^{\circ} 44^{\prime} 40^{\prime \prime} \mathrm{W}$., 55 fathoms, rocky, bottom temperature $46.7^{\circ}, 12$ specimens; station 3119 , off California, lat. $36^{\circ} 56^{\prime} 30^{\prime \prime}$ N.; long. $122^{\circ} 17^{\prime} 40^{\prime \prime}$ W., 54 fathoms, rocky, coral, bottom temperature $50.9^{\circ}, 20$ specimens; station 3160 , off California, lat. $37^{\circ} 48^{\prime} 35^{\prime \prime} \mathrm{N}$. ; long. $123^{\circ} 12^{\prime} 40^{\prime \prime} \mathrm{W}$., 39 fathoms, rocky, bottom temperature $51.8^{\circ}, 1$ specimen; station 3163 , off California, lat. $37^{\circ} 56^{\prime} 40^{\prime \prime} \mathrm{N}$.; long. $123^{\circ} 25^{\prime} 30^{\prime \prime}$ W., 69 fathoms, fine gray, sand, bottom temperature $48.5^{\circ}, 3$ specimens; station 3350 , off California, lat. $38^{\circ} 58^{\prime} 10^{\prime \prime} \mathrm{N}$.; long. $123^{\circ} 57^{\prime} 5^{\prime \prime} \mathrm{W}$., 75 fathoms, fine sand, mud, bottom temperature $48.4^{\circ}, 7$ specimens. Bathymetrical range, 39 to 75 fathoms. Temperature range, $51.8^{\circ}$ to $45.7^{\circ}$. Eighty specimens.

Type.-Cat. No. 25647, U.S.N.M., from station 3051.

This large species, though so variable in many characters, is well defined by its granular disk covering, numerous smooth flattened arm spines, rhombic upper arm plates and two (or even three) long and conspicuous tentacle scales. The specimens before me range in disk diameter from 12 to $23 \mathrm{~mm}$. The most interesting of the variable features is the remarkable diversity shown in the form of the adoral plates; in many cases the oral shield is in contact with the first side arm plate, while the adoral plates are wholly proximal to it; but it is equally common to find the oral shield more or less isolated by the inclosing arms of the adoral plate. Comparison of specimens shows that in the young the adoral plates are proximal to the oral shield, while in large specimens they have pushed down in between the shield and the arm. While this is largely a matter of age it is not wholly so, for great individual diversity is shown; moreover the different mouth angles of a single individual often differ from each other to a notable degree. In view of this condition in this species, I find myself in doubt as to the value of the form of the adoral shields as a generic character in the Ophiacanthidæ, and this is one of the chief reasons why I have not followed Verrill's classification.

\section{OPHIACANTHA ENNEACTIS, new species.a}

Disk $5 \mathrm{~mm}$. in diameter; arms nine, $15 \mathrm{~mm}$. long. Disk closely covered by spines and sharp granules; the spines cover the central area, but are few or wanting at the margins; they are long, straight, slender, sharp and nearly smooth; the granules are most abundant marginally, but are not crowded anywhere; they are sharply conical and end in a glassy tip which may have two or even three points. Radial shields completely concealed. Upper arm plates somewhat pentagonal with the disto-lateral angles rounded; the first one or two are wider than long but the others are as long as wide or longer; all are widely

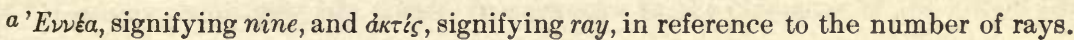




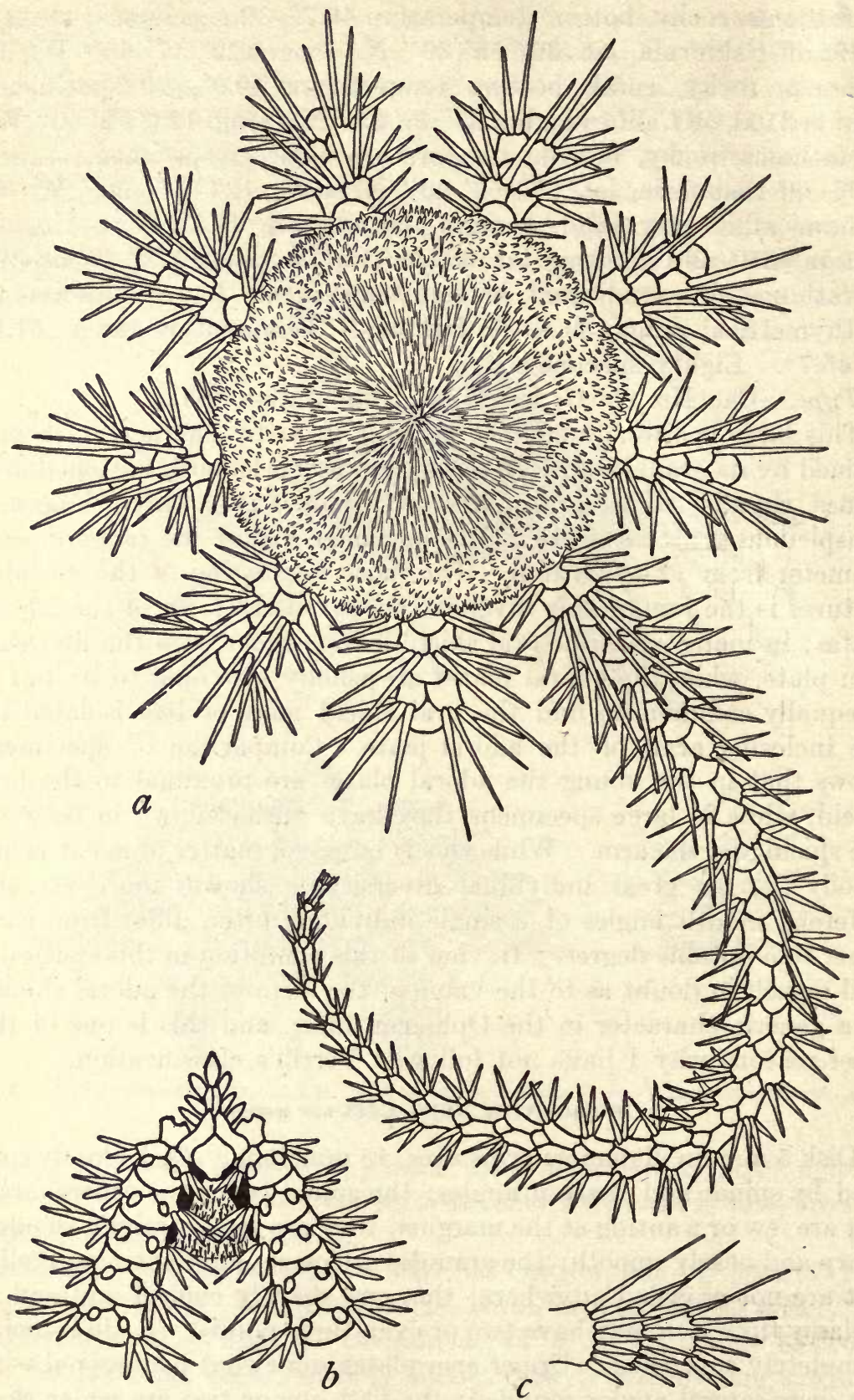

FIg. 98.-OPHIACANTHA ENNEACTIS. $\times$ 10. $a$, FROM ABOVE, SHOWING ONE ARM NEARLY COMPLETE: $b$, FROM BELOW; $c$, SIDE VIEW OF THREE ARM JOINTS NEAR DISK. 
separated. Interbrachial spaces below covered with elongated sharp granules, or spinelets. Genital slits large. Oral shields rounded, about as long as wide, pointed proximally but with a truncate, distal angle. Adoral plates somewhat variable, about three times as long as wide, meeting broadly within, either wholly proximal to the oral shield or else pushing down more or less between it and the first side arm plate. Jaws very narrow, and compressed, each with about seven long, flat, pointed oral papillæ, which are subequal or the apical one is largest. First under arm plate hexagonal, longer than wide, with proximal margin deeply notched; succeeding plates broadly triangular with lateral angles rounded and distal margin convex, much wider than long; all the under arm plates are widely separated from each other. Side arm plates large, meeting broadly above and below; each plate carries seven slender, smooth, pointed spines, of which the uppermost is longest and may exceed two joints. Tentacle scales single, large, oval and flat, more or less pointed at tip. Color (dried from alcohol), very pale brownish.

Locality.-Albatross station 4781, Bering Sea, lat. $52^{\circ} 14^{\prime} 30^{\prime \prime} \mathrm{N}$.; long. $174^{\circ} 13^{\prime}$ E., 482 fathoms, fine gray sand, pebbles, bottom temperature $38.6^{\circ}, 1$ specimen.

Type.-Cat. No. 25598, U.S.N.M., from station 4781.

This remarkable ophiuran reminds one at once of Ophiacantha vivipara, an Antarctic species in which the females have six to eight arms $^{a}$ although the males have only five. ${ }^{b}$ It is easily distinguished by the differences in disk covering, under arm plates and oral papillæ, but one naturally wonders whether both sexes in this north Pacific species have nine arms or whether there is here also a sexual dimorphism. Other related questions naturally arise, but in the presence of only a single specimen it is futile to discuss them. We can only hope that further collecting in Bering Sea will bring to light more abundant material of this most interesting Ophiacantha.

OPHIACANTHA PRIONOTA, new species.c

Disk $9 \mathrm{~mm}$. in diameter; arms about $42 \mathrm{~mm}$. long. Disk covered with a coarse scaling, which is only partially concealed by numerous rough, stout spines, nearly a millimeter long. Distal ends of radial shields visible, widely separated. Upper arm plates rhombic, with distal angle rounded, or triangular with distal margin strongly convex, about as wide as long, only the first two or three in contact. Interbrachial spaces below covered with scales, upon which only a few

$a$ Wyville Thomson (Jour. Linn. Soc. London, vol. 13, 1876, p. 77) says there are six to nine arms and that he never saw fewer than six.

$b$ See Kœhler, Zool. Anz., vol. 31, 1907, p. 229.

c II cov $\omega \tau$ tos, signifying like a saw, in reference to the character of the lowest arm spines. 
scattered spines are borne. Genital slits very large. Oral shield nearly triangular, rather wider than long. Adoral plates very large, wider without than within where they meet. Oral papillæ three on a side and one at apex of jaw; the apical papilla and those on each side are relatively huge, thick, rhombic, or triangular, and sharp; distal papillæ smaller, narrower, and blunter. First under arm plate rather large, squarish, wider than long; succeeding plates separated, somewhat pentagonal, with very wide distal margin, and narrow proximal angle; toward the tip of the arm, the proximal half of each under arm plate is very narrow. Side arm plates moderate,

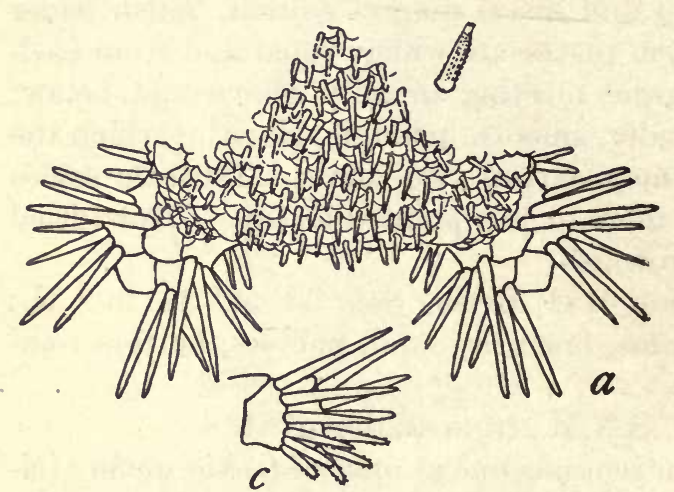
meeting slightly above and below; each plate carries six short arm spines, of which the uppermost is longest and may equal three joints; the upper ones are terete, smooth, and pointed; the lower are flat and more or less toothed or serrate on the margins, as well as rough on the surface; at the base of the arm the flattening is confined chiefly to the lowest spine of each series, but distally all of the lower spines show it to a greater or less degree; of course, the flatter the spine, the more marked are the serrations. Tentacle scale single

Fig. 99.-OPHIACANTHA PRIONOTA. $\times 5.5$. $a$, FROM ABOVE; $b$, FROM BELOW; $c$, SIDE VIEW OF TWO ARM JOINTS NEAR DISK.

(rarely two on first pore of arm), rather large, flat, oval, pointed. Color (dried from alcohol), light brown.

Locality. -Albatross station 4928 , off southern Japan, lat. $29^{\circ} 51^{\prime}$ N.; long. $131^{\circ} 2^{\prime} 30^{\prime \prime}$ E., 1,008 fathoms, gray sand, globigerina, bottom temperature $36.8^{\circ}, 1$ specimen.

Type.-Cat. No. 25729, U.S.N.M., from station 4928.

This species is so well characterized by the disk covering, the huge oral papillæ, the big adoral plates and the serrate lower arm spines, that it is not likely to be confused with any other. It would be interesting to know whether it is strictly an abyssal form or, like $O$. bidentata, has a great bathymetric range. It is futile to speculate on the basis of one specimen, but it is perhaps worth noting that the 
disk spines and the large adoral plates recall some of the deep-sea types collected by the Challenger.

\section{OPHIACANTHA GRANULOSA.}

Ophiacantha granulosa Lyman, Bull. Mus. Comp. Zoöl., vol. 5, 1878, p. 138.

Localities.-Albatross station 3755, off Suno Saki, Honshu Island, Japan, 52 to 77 fathoms, gray sand, coral, 4 specimens; station 4895, Eastern Sea, lat. $32^{\circ} 33^{\prime} 10^{\prime \prime}$ N.; long. $128^{\circ} 32^{\prime} 10^{\prime \prime}$ E., 95 fathoms, green sand, broken shells, pebbles, 1 specimen; station 4936, Eastern Sea, lat. $30^{\circ} 54^{\prime} 40^{\prime \prime}$ N.; long. $130^{\circ} 37^{\prime} 30^{\prime \prime}$ E., 103 fathoms, stones, bottom temperature $60.6^{\circ}, 5$ specimens.

None of the specimens are as large as Lyman's type, but they do not differ in any structural feature so far as I can see. They range in disk diameter from 3 to $6 \mathrm{~mm}$. The numerous, long, slender, smooth spines, the granular disk covering, and the bare radial shields are a very distinctive combination of characters.

\section{OPHIACANTHA NORMANI.}

Ophiacantha normani Lyman, Bull. Mus. Comp. Zoöl., vol. 6, 1879, p. 58.

Localities.-Albatross station 2853 , off Alaska, lat. $56^{\circ} \mathrm{N}$.; long. $154^{\circ}$ $20^{\prime}$ W., 159 fathoms, gray sand, bottom temperature $41^{\circ}, 81$ specimens; station 2858, off Alaska, lat. $58^{\circ} 17^{\prime} \mathrm{N}$.; long. $148^{\circ} 36^{\prime} \mathrm{W} ., 230$ fathoms, blue mud, gravel, bottom temperature $39.8^{\circ}, 37$ specimens; station 2860 , off Washington, lat. $51^{\circ} 23^{\prime} \mathrm{N}$.; long. $130^{\circ} 34^{\prime} \mathrm{W}$., 876 fathoms, green mud, bottom temperature $36.5^{\circ}, 14$ specimens; station 2871, off Washington, lat. $46^{\circ} 55^{\prime} \mathrm{N}$.; long. $125^{\circ} 11^{\prime}$ W., 559 fathoms, brown ooze, bottom temperature $38.4^{\circ}, 811$ specimens; station 2873 , off Washington, lat. $48^{\circ} 30^{\prime} \mathrm{N}$.; long. $124^{\circ} .57^{\prime} \mathrm{W} ., 40$ fathoms, rocks, bottom temperature $47.8^{\circ}, 1$ specimen; station 3069 , off Washington, lat. $47^{\circ} 25^{\prime} 30^{\prime \prime} \mathrm{N}$.; long. $125^{\circ} 42^{\prime} \mathrm{W}$., 760 fathoms, green mud, bottom temperature $37.6^{\circ}, 10$ specimens; station 3070 , off Washington, lat. $47^{\circ} 29^{\prime} 30^{\prime \prime} \mathrm{N}$.; long. $125^{\circ} 43^{\prime} \mathrm{W}$., 636 fathoms green mud, bottom temperature $37.9^{\circ}, 302$ specimens; station 3071 , off Washington, lat. $47^{\circ} 29^{\prime} \mathrm{N}$.; long. $125^{\circ} 33^{\prime} 30^{\prime \prime}$ W., 685 fathoms, green mud, bottom temperature $38^{\circ}, 102$ specimens; station 3073 , off Washington, lat. $47^{\circ} 28^{\prime} \mathrm{N}$.; long. $125^{\circ} 15^{\prime} \mathrm{W}$., 477 fathoms, green mud, bottom temperature $49.2^{\circ}, 20$ specimens; station 3074 , off Washington, lat. $47^{\circ} 22^{\prime} \mathrm{N}$.; long. $125^{\circ} 48^{\prime} 30^{\prime \prime}$ W., 877 fathoms, green mud, bottom temperature $36.6^{\circ}, 33$ specimens; station 3075 , off Washington, lat. $47^{\circ} 22^{\prime} \mathrm{N}$.; long. $125^{\circ} 41^{\prime} \mathrm{W}$., 859 fathoms, green mud, bottom temperature $36.6^{\circ}, 122$ specimens; station 3316 , Bering Sea, lat. $54^{\circ} 1^{\prime}$ N.; long. $166^{\circ} 48^{\prime} 45^{\prime \prime}$ W., 309 fathoms, black sand, gravel, bottom temperature $38.2^{\circ}, 150$ specimens; station 3317 , Bering Sea, lat. $53^{\circ} 57^{\prime} 40^{\prime \prime}$ N.; long. $166^{\circ} 57^{\prime}$ W., 165 fathoms, coarse sand, 
gravel, rocks, 3 specimens; station 3330 , Bering Sea, lat. $54^{\circ} 0^{\prime} 45^{\prime \prime}$ N.; long. $166^{\circ} 53^{\prime} 50^{\prime \prime}$ W., 351 fathoms, black sand, mud, bottom temperature $37.8^{\circ}, 154$ specimens; station 3331 , Bering Sea, lat. $54^{\circ}$ $1^{\prime} 40^{\prime \prime} \mathrm{N}$.; long. $166^{\circ} 48^{\prime} 50^{\prime \prime}$ W., 350 fathoms, mud, 1 specimen; station 3332 , Bering Sea, lat. $54^{\circ} 2^{\prime} 50^{\prime \prime}$ N.; long. $166^{\circ} 45^{\prime}$ W., 406 fathoms, rocky sand, 1 specimen; station 3337 , off Alaska, lat. $53^{\circ}$ $55^{\prime} 30^{\prime \prime} \mathrm{N}$.; long. $163^{\circ} 26^{\prime} \mathrm{W}$., 280 fathoms, green mud, rocks, bottom temperature $39.3^{\circ}, 50$ specimens; station 3338 , off Alaska, lat. $54^{\circ} 19^{\prime}$ N.; long. $159^{\circ} 40^{\prime}$ W., 625 fathoms, green mud, sand, 163 specimens; station 3340 , off Alaska, lat. $55^{\circ} 26^{\prime} \mathrm{N}$.; long. $155^{\circ} 26^{\prime}$ W., 695 fathoms, mud, 75 specimens; station 3343 , off Washington, lat. $47^{\circ} 40^{\prime}$ $40^{\prime \prime} \mathrm{N}$.; long. $125^{\circ} 20^{\prime} \mathrm{W}$., 516 fathoms, green mud, bottom temperature $38.2^{\circ}, 250$ specimens (+" 1 bushel rejected"); station 3346 , off Washington, lat. $45^{\circ} 30^{\prime}$ N.; long. $124^{\circ} 52^{\prime}$ W., 786 fathoms, green mud, bottom temperature $37.3^{\circ}, 18$ specimens; station 3347 , off Washington, lat. $45^{\circ} 9^{\prime} 35^{\prime \prime} \mathrm{N}$.; long. $124^{\circ} 45^{\prime} \mathrm{W}$., 345 fathoms, mud, bottom temperature $40.9^{\circ}, 69$ specimens; station 3480 , Bering Sea, lat. $52^{\circ} 6^{\prime} \mathrm{N}$.; long. $171^{\circ} 45^{\prime} \mathrm{W}$., 283 fathoms, black sand, coral, rocky, 2 specimens; station 3607 , Bering Sea, lat. $54^{\circ} 11^{\prime} 30^{\prime \prime}$ N.; long. $167^{\circ}$ $25^{\prime}$ W., 987 fathoms, green mud, black lava, sand, bottom temperature $35.9^{\circ}, 53$ specimens; station 3608 , Bering Sea, lat. $55^{\circ} 19^{\prime} \mathrm{N}$.; long. $168^{\circ} 11^{\prime} \mathrm{W}$., 276 f fathoms, gray sand, bottom temperature $37.8^{\circ}$, 845 specimens; station 3609 , Bering Sea, lat. $55^{\circ} 35^{\prime}$ N.; long. $168^{\circ}$ $20^{\prime}$ W., 74 fathoms, green mud, sand, bottom temperature $37.9^{\circ}, 6$ specimens; station 3696, off Manazuru Zaki, Honshu Island, Japan, 501 to 749 fathoms, green mud, volcanic ashes, sand, 73 specimens; station 4767 , Bering Sea, lat. $54^{\circ} 12^{\prime}$ N.; long. $179^{\circ} 7^{\prime} 30^{\prime \prime}$ E., 771 fathoms, green mud, bottom temperature $36.5^{\circ}, 6$ specimens; station 4768 , Bering Sea, lat. $54^{\circ} 20^{\prime} 30^{\prime \prime}$ N.; long. $179^{\circ} 9^{\prime} 30^{\prime \prime}$ E., 764 fathoms, green-brown mud, fine black sand, bottom temperature $37^{\circ}, 2$ specimens; station 4775 , Bering Sea, lat. $54^{\circ} 33^{\prime} 30^{\prime \prime} \mathrm{N}$.; long. $178^{\circ}$ $44^{\prime}$ E., 584 fathoms, green mud, black specks, foraminifera, bottom temperature $37.2^{\circ}, 387$ specimens; station 4893 , Eastern Sea, lat. $32^{\circ}$ $32^{\prime} \mathrm{N}$.; long. $128^{\circ} 32^{\prime} 50^{\prime \prime}$ E., 95 to 106 fathoms, gray sand, broken shells, pebbles, bottom temperature $55.9^{\circ}, 2$ specimens; station 4971 , off eastern Japan, lat. $33^{\circ} 23^{\prime} 30^{\prime \prime}$ N. ; long. $135^{\circ} 34^{\prime}$ E., 649 fathoms, brown-green mud, foraminifera, bottom temperature $38.1^{\circ}, 3$ specimens; station 4972 , off eastern Japan, lat. $33^{\circ} 25^{\prime} 45^{\prime \prime}$ N.; long. $135^{\circ}$ $33^{\prime}$ E., 440 fathoms, brown-green mud, foraminifera, bottom temperature $39.8^{\circ}, 2$ specimens; station 4977 , off eastern Japan, lat. $33^{\circ} 23^{\prime}$ N. ; long. $135^{\circ} 37^{\prime} 40^{\prime \prime}$ E., 544 fathoms, brown mud, fine sand, bottom temperature $38.9^{\circ}, 4$ specimens; station 4980 , off eastern Japan, lat. $34^{\circ} 9^{\prime} \mathrm{N}$.; long. $137^{\circ} 55^{\prime}$ E., 507 fathoms, brown mud, fine sand, foraminifera, bottom temperature $39^{\circ}, 5$ specimens; station 5015 , Okhotsk Sea, lat. $46^{\circ} 44^{\prime}$ N.; long. $144^{\circ} 2^{\prime}$ E., 510 fathoms, green 
mud, bottom temperature $35.9^{\circ}, 4$ specimens; station 5023, Okhotsk Sea, lat. $48^{\circ} 43^{\prime} 30^{\prime \prime}$ N.; long. $145^{\circ} 3^{\prime}$ E., 75 fathoms, sand, pebbles, bottom temperature $30.9^{\circ}, 1$ specimen; station 5033 , Yezo Strait, lat. $44^{\circ} 4^{\prime} 20^{\prime \prime} \mathrm{N}$.; long. $145^{\circ} 28^{\prime}$ E., 533 fathoms, green mud, fine black sand, bottom temperature $35.9^{\circ}, 1$ specimen; station 5036 , south of Hokkaido, lat. $41^{\circ} 58^{\prime} \mathrm{N}$.; long. $142^{\circ} 30^{\prime} 30^{\prime \prime}$ E., 464 fathoms, brown mud, bottom temperature $37.9^{\circ}, 2$ specimens; station 5082 , off Omai Saki, lat. $34^{\circ} 5^{\prime} \mathrm{N}$.; long. $137^{\circ} 59^{\prime}$ E., 662 fathoms, green mud, fine sand, globigerina, bottom temperature $37.7^{\circ}, 76$ specimens; station 5083, off Omai Saki, lat. $34^{\circ} 4^{\prime} 20^{\prime \prime}$ N.; long. $137^{\circ} 57^{\prime} 30^{\prime \prime}$ E., 624 fathoms, fine gray sand, globigerina, bottom temperature $38.1^{\circ}, 3$ specimens; station 5085, Sagami Bay, lat. $35^{\circ} 6^{\prime} 45^{\prime \prime}$ N.; long. $139^{\circ}$ $19^{\prime} 45^{\prime \prime}$ E., 622 fathoms, green mud, fine black sand, bottom temperature $37.8^{\circ}, 2$ specimens; station 5087, Sagami Bay, lat. $35^{\circ} 9^{\prime} 40^{\prime \prime}$ N.; long. $139^{\circ} 19^{\prime} 5^{\prime \prime}$ E., 614 fathoms, green mud, bottom temperature $37.5^{\circ}, 1$ specimen. No label, 12 specimens. Bathymetrical range, 40 to 987 fathoms. Temperature range, $55.9^{\circ}$ to $30.9^{\circ}$. Three thousand nine hundred and fifty-nine specimens.

The above list is sufficient evidence of the abundance of this species in the north Pacific, but in spite of this abundance and the great geographical and bathymetrical range, it shows remarkable constancy in its specific characters. Among all these thousands of specimens, ranging in disk diameter from $3 \frac{1}{2}$ to $22 \mathrm{~mm}$., there are no notable variations and the individual diversity shown is very slight. One specimen from station 3696 is, however, perfectly tetramerous. In specimens under $8 \mathrm{~mm}$. disk diameter there are only three arm spines, but even in the largest specimens the fourth spine is found only on the basal joints of the arm. The extent to which the disk scales are concealed by the granules, the size and pointedness of the granules, the number of granules on the upper arm plates, the form of the under arm plates and the shape of the teeth are the principal features in which a normal amount of diversity is shown. Lyman, in his final report on the Challenger ophiurans, transferred this species to Ophiomitra, but subsequent writers have, as a rule, considered it as more properly an Ophiacantha, and it certainly seems to belong in that genus, in a broad sense. According to Verrill's classification, it would be a very typical member of his proposed genus Ophialcxa.

\section{OPHIACANTHA CATALEIMMOIDA, new species.}

Disk $17 \mathrm{~mm}$. in diameter; arms about 75 to $80 \mathrm{~mm}$. long. Disk covered more or less sparsely with coarse, rounded granules, as in normani. Radial shields, as in that species, with distal half bare,

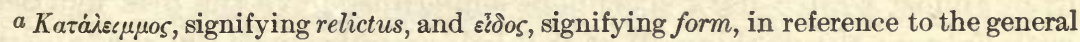
resemblance to $O$. relicta Kœhler.
} 
widely separated. Upper arm plates more or less rhombic, or triangular with distal margin convex or straight, wider than long, only a few of the basal ones in contact; distal margin of some basal ones carrying granules as in normani. Interbrachial spaces below with a sparse granulation. Genital slits very large. Oral shield tetragonal, very short and wide. Adoral plates rather large, proximal to oral shield, meeting broadly within, slightly curved. Oral papillæ rather large, three on a side and often one at apex of jaw, subequal or the distal one largest. First under arm plate small, wider than long; succeeding plates heptagonal, hexagonal, or pentagonal, according to the truncation or rounding of the proximal and distal
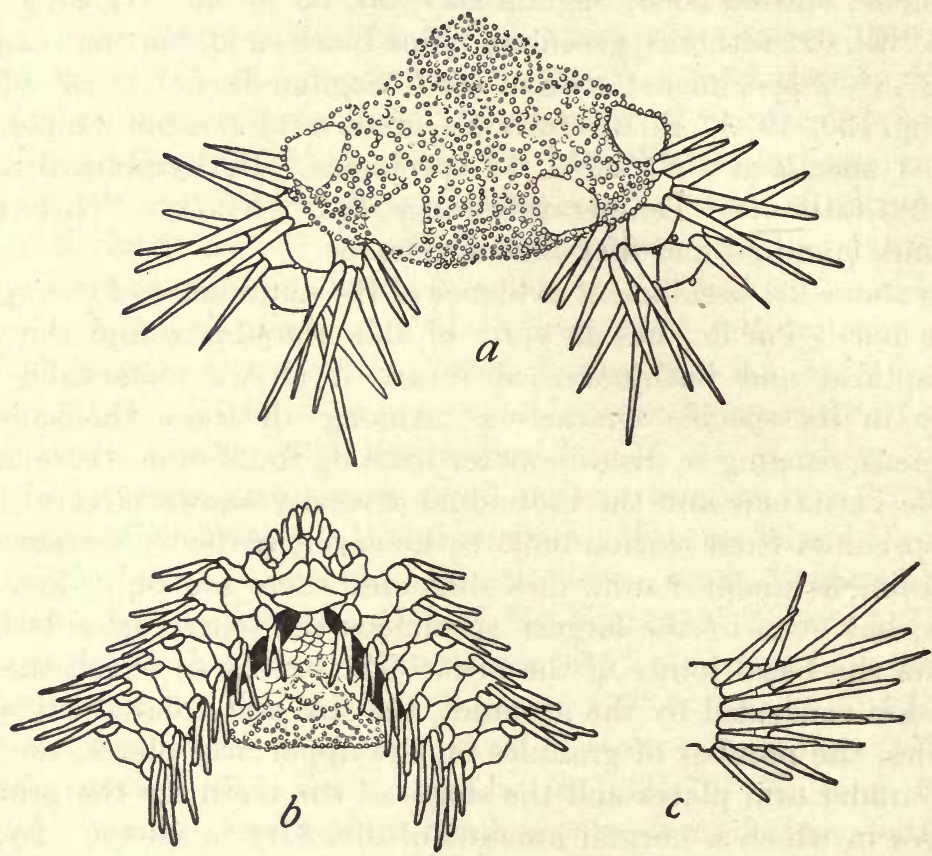

Fig. 100.-Ophiacantha Cataleimmoida. $\times 3$. $a$, From ABOVE; $b$, From Below; $c$, Side view of tWo ARM JOINTS NEAR DISK.

angles, wider than long, all but the first two distinctly separated. Side arm plates moderate, in contact both above and below; each plate carries six or seven straight, smooth spines, of which the next to the uppermost is longest and may exceed three joints; rows of spines not approximate dorsally. Tentacle scale single, very large, flat, rounded, and more or less distinctly curved outward around the base of the lowest arm spine. Color (dried from alcohol), quite variable, ranging from deep purplish-brown to light yellowish-brown or even almost white; dark specimens sometimes have the disk mottled with lighter; the rubbing off of the disk granules, with its consequent 
exposure of the close, even sealing of the disk, greatly affects the color, for the scales are gray of some shade, often quite dark; sometimes the radial scales are dark while the interradial are light. The arms are sometimes prettily banded with light and dark.

Localities.-Albatross station 2853 , off Alaska, lat. $56^{\circ} \mathrm{N}$.; long. $154^{\circ} 20^{\prime} \mathrm{W}$., 159 fathoms, gray sand, bottom temperature $41^{\circ}, 104$ specimens; station 3332 , off Alaska, lat. $54^{\circ} 2^{\prime} 50^{\prime \prime}$ N.; long. $166^{\circ}$ $45^{\prime}$ W., 406 fathoms, rocky, sand, 4 specimens; station 3338, off Alaska, lat. $54^{\circ} 19^{\prime} \mathrm{N}$.; long. $159^{\circ} 40^{\prime}$ W., 625 fathoms, green mud, sand, bottom temperature $37.3^{\circ}, 3$ specimens; station 3339 , off Alaska, lat. $54^{\circ} 46^{\prime} \mathrm{N}$.; long. $157^{\circ} 43^{\prime} 30^{\prime \prime}$ W., 138 fathoms, mud, gravel, bottom temperature $37.4^{\circ}, 106$ specimens ("half a peck rejected"); station 3340 , off Alaska, lat. $55^{\circ} 26^{\prime} \mathrm{N}$.; long. $155^{\circ} 26^{\prime}$ W., 695 fathoms, mud, bottom temperature $36.8^{\circ}, 2$ specimens; station 4781 , Bering Sea, lat. $52^{\circ} 14^{\prime} 30^{\prime \prime}$ N.; long. $174^{\circ} 13^{\prime}$ E., 482 fathoms, fine gray sand, pebbles, bottom temperature $38.6^{\circ}, 3$ specimens; station 4804 , off Kurile Islands, lat. $46^{\circ} 42^{\prime} \mathrm{N}$.; long. $151^{\circ} 47^{\prime}$ E., 229 fathoms, coarse pebbles, black sand, bottom temperature $35.9^{\circ}$, 1 specimen; station 4980 , off eastern Japan, lat. $34^{\circ} 9^{\prime} \mathrm{N}$.; long. $137^{\circ} 55^{\prime}$ E., 507 fathoms, brown mud, fine sand, foraminifera, bottom temperature $39^{\circ}, 39$ specimens; station 5079, off Omai Saki Light, lat. $34^{\circ} 15^{\prime} \mathrm{N}$.; long. $138^{\circ} \mathrm{E}$., 475 to 505 fathoms, pebbles, bottom temperature $39.1^{\circ}, 10$ specimens; station 5080, off Omai Saki Light, lat. $34^{\circ} 10^{\prime} 30^{\prime \prime} \mathrm{N}$.; long. $138^{\circ} 40^{\prime} \mathrm{E} ., 505$ fathoms, fine gray sand, globigerina, bottom temperature $38.7^{\circ}, 1$ specimen; station 5083 , off Omai Saki Light, lat. $34^{\circ} 4^{\prime} 20^{\prime \prime}$ N.; long. $137^{\circ} 57^{\prime} 30^{\prime \prime}$ E., 624 fathoms, fine gray.sand, globigerina, bottom temperature $38.1^{\circ}, 38$ specimens; station 5093, Uraga Strait, lat. $35^{\circ} 3^{\prime} 15^{\prime \prime} \mathrm{N}$.; long. $139^{\circ}$ $37^{\prime} 42^{\prime \prime}$ E., 302 fathoms, coarse black sand, bottom temperature $43.9^{\circ}$, 2 specimens. Loc.?, 12 specimens. Bathymetrical range, 138 to 695 fathoms. Temperature rarge, $43.9^{\circ}$ to $35.9^{\circ}$. Three hundred and twenty-five specimens.

Type.-Cat. No. 25625, U.S.N.M., from station 3339.

Although at first sight this species is very near both relicta Kœhler and normani Lyman, it is quite distinct from either. The arm spines are as numerous as in relicta, but they are perfectly smooth, while the remarkable tentacle scales are very characteristic.

OPHIACANTHA CEIDISCA, new species.a

Disk $10 \mathrm{~mm}$. in diameter; arms about $50 \mathrm{~mm}$. long. Disk decidedly tumid, or swollen, its vertical diameter being about $4 \mathrm{~mm}$.; it is very closely covered by minute granules, which are not, however, in

a' $0 \_\delta \varepsilon \omega$, signifying to swell, and $\delta\llcorner\sigma \kappa o s$, signifying disk, in reference to the very elevated disk. 
actual contact with each other. Radial shields, or at least distal ends of them, bare, roundish, well separated. Upper arm plates triangular, those on basal half of arm more or less in contact and consequently with proximal angle, more or less truncate, wider than long; distal margin with a series of granules like those of the disk, and others are often scattered on the surface of the plates. Interbrachial spaces below less thickly granulated than disk. Genital slits very large. Oral shield somewhat rhombic with lateral and distal angles rounded, much wider than long. Adoral plates long, narrow, straight. Oral papillæ three or four on a side, and one at apex of jaw, long, flat, pointed, subequal or apical one largest. First under arm plate small, wider than long, narrower distally; second plate more or less triangular, wider than long; succeeding plates squarish, their outlines, par-

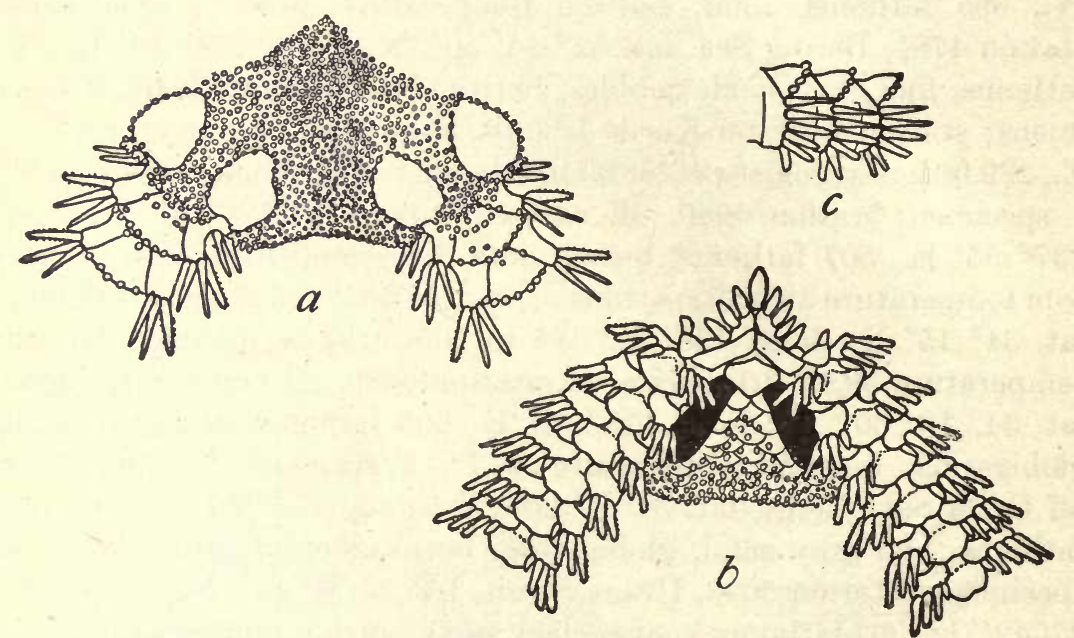

Fig. 101.-Ophiacantha EDIDISCA. $\times 5$. $a$, FROM ABOVE; $b$, FROM BELOW; $c$, SIDE VIEW OR THREE ARM JOINTS NEAR DISK.

ticularly proximally, quite indistinct; they are well separated and between each two there is more or less of a depression; it is difficult to determine whether the side arm plates meet in the depression or not. Side arm plates not very large, not meeting above and apparently not below; each plate carries six short, stout, arm spines, of which the upper two are longest, though hardly exceeding the joint, and smoothest; lowest spines quite rough, at least near tip. Tentacle scale single, not very large, pointed. Color (dried from alcohol), yellowish or grayish.

Localities.-Albatross station 4957, off southern Japan, lat. $32^{\circ} 36^{\prime}$ N.; long. $132^{\circ} 23^{\prime}$ E., 437 fathoms, green-brown mud, fine gray sand, foraminifera, bottom temperature $39.8^{\circ}, 1$ specimen; station 4959 , 
off southern Japan, lat. $32^{\circ} 36^{\prime} 30^{\prime \prime} \mathrm{N}$.; long. $132^{\circ} 23^{\prime} 20^{\prime \prime}$ E., 405 to 578 fathoms, green-brown mud, fine gray sand, foraminifera, bottom temperature $40.1^{\circ}, 3$ specimens; station 4960 , off southern Japan, lat. $32^{\circ} 34^{\prime} \mathrm{N}$.; long. $132^{\circ} 21^{\prime} 45^{\prime \prime}$ E., 578 fathoms, green-brown mud, fine gray sand, foraminifera, bottom temperature, $38.7^{\circ}, 1$ specimen; station 4976 , off eastern Japan, lat. $33^{\circ} 22^{\prime} 50^{\prime \prime} \mathrm{N}$.; long. $135^{\circ} 38^{\prime} 30^{\prime \prime}$ E., 544 to 545 fathoms, brown mud, small stones, bottom temperature $38.7^{\circ}, 1$ specimen; station 5080 , off Omai Saki Light, lat. $34^{\circ} 10^{\prime}$ $30^{\prime \prime} \mathrm{N}$.; long. $138^{\circ} 40^{\prime} \mathrm{E}$., 505 fathoms, fine gray sand, globigerina, bottom temperature $38.7^{\circ}, 1$ specimen. Bathymetrical range, 405 to 578 fathoms. Temperature range, $40.1^{\circ}$ to $38.7^{\circ}$. Seven specimens.

Type.-Cat. No. 25731, U.S.N.M., from station 4959.

This is an interesting species for while the figures and description reveal a close relationship to normani and relicta, the general appearance is quite different owing to the tumid disk and the slender arms with short spines. Indeed the arms, and particularly the arm spines, are much like those of some species of Ophiolebes. The under arm plates, with the depressions between, also give an impression quite different from that of any of the related species of Ophiacantha.

\section{OPHIACANTHA LEUCORHABDOTA, new species. $a$}

Disk $16 \mathrm{~mm}$. in diameter; arms about $65 \mathrm{~mm}$. long. Disk covered with a sparse coating of very coarse granules, only three to five to the square millimeter; most of the granules are spherical or nearly so but some have minute spinelets on the free end. Radial shields large, bare, near together but not in contact, longer than broad. Upper arm plates rhombic with proximal angle more or less truncate, distal angle rounded and distal sides curved (concave); first one. wider than long, second longer than wide, remainder as wide as long or wider; all more or less in contact. Interbrachial spaces below well covered with granules. Genital slits long but not conspicuous. Oral shield pentagonal with all angles, except proximal, rounded, wider than long. Adoral plates rather large, about as wide without as within where they meet; oral plates moderately large. Oral papillæ numerous, five or six on each side and one or more at apex of jaw, long, flat, blunt, the distal one distinctly the largest. First under arm plate longer than wide, narrower distally; succeeding plates much wider than long, narrower proximally, nearly, if not quite, in contact; they are pentagonal with proximo-lateral sides concave and distal angle rounded, or if this angle is truncated they are of course hexagonal. Side arm plates rather large, not meeting above and

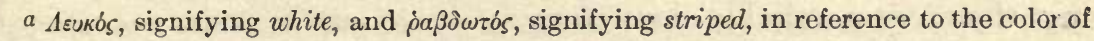
the arms. 
scarcely so below; each plate carries eight or nine smooth, stout spines, of which the two uppermost are longest and about equal to two joints. Tentacle scales two on first pair of arm pores but single thereafter, large, flat, rounded, with a decided tendency to curve around the base of lowest arm spine. Color (dried from alcohol), brown; inner ends of radial shields and a broad longitudinal stripe on each arm, white; arm spines, disk granules, and oral surface very light.

Locality.-Albatross station 4934, Eastern Sea, lat. $30^{\circ} 58^{\prime} 30^{\prime \prime}$ N.; long. $130^{\circ} 32^{\prime}$ E., 103 to 152 fathoms, rocky, bottom temperature $60.6^{\circ}$ to $56^{\circ}, 1$ specimen.
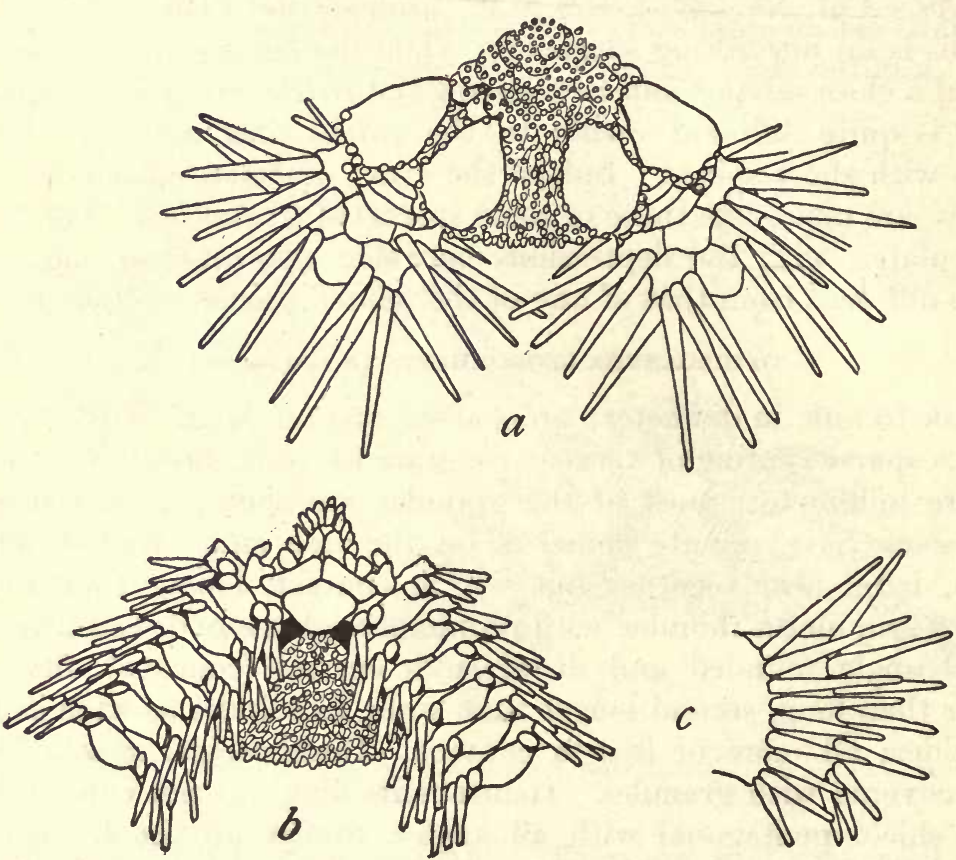

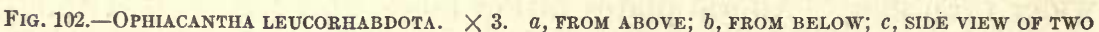
ARM JOINTS NEAR DISK.

Type.-Cat. No. 25655, U.S.N.M., from station 4934.

This species is easily the handsomest Ophiacantha in the collection. The combination of large, bare radial shields, rhombic upper arm plates in contact, numerous oral papillæ, numerous stout, smooth arm spines and characteristic tentacle scales, with the striking coloration, will prevent confusion with any other species. Of course, it must be borne in mind that the coloration may prove to be a very inconstant and therefore unreliable character. 


\section{OPHIACANTHA EURYPOMA, new species. $a$}

Disk $15 \mathrm{~mm}$. in diameter; arms about $85 \mathrm{~mm}$. long. Disk covered with very minute thorny stumps, which are more or less rubbed off, leaving the underlying scaling bare. Radial shields roundish, bare, near together, and sometimes almost touching distally. Upper arm plates triangular, about as wide as long, well separated, except two at base of arm, which are tetragonal and broadly in contact. Interbrachial space below, like disk. Genital slits small. Oral shield rhombic, with rounded angles, wider than long. Adoral plates large, only about twice as long as wide, meeting broadly within. Oral papillæ three on a side and one at apex of jaw ; all are long and con-
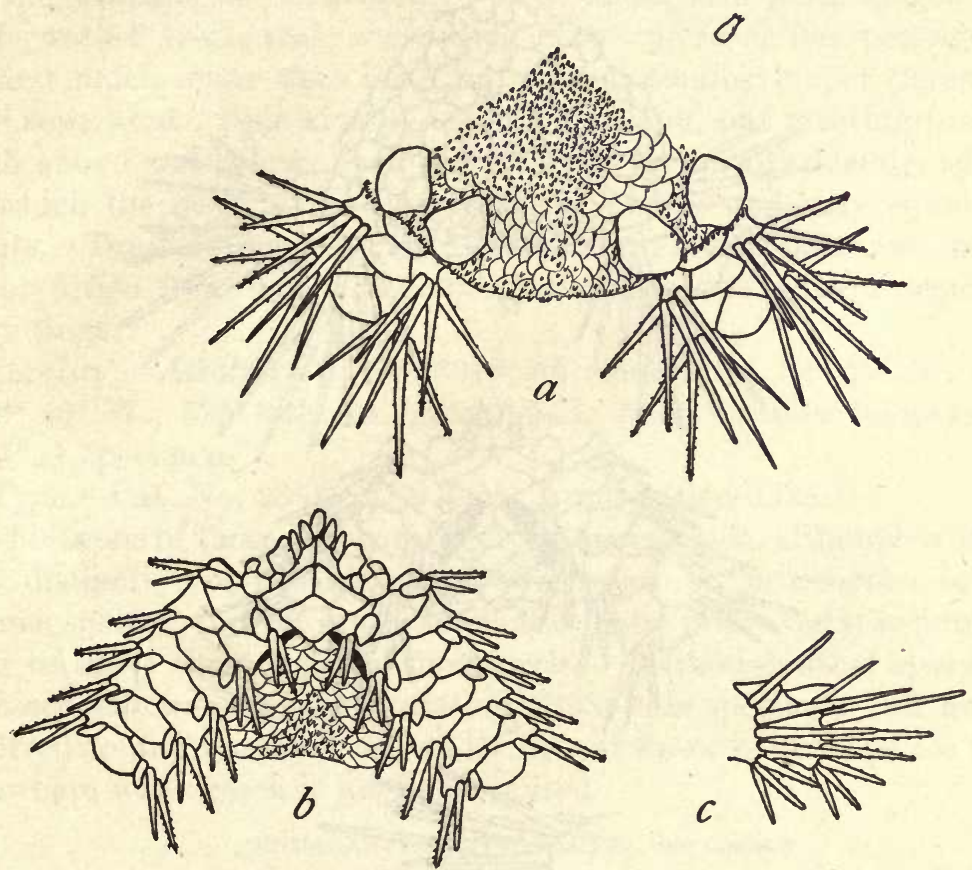

Fig. 103.-OPhIACANTha EURYPoma. $\times$ 3.5. $a$, FROM ABOVE; $b$, FROM BELOW; $c$, SIDE VIEW OF TWO ARM JOINTS NEAR DISK.

spicuous, and all but the outermost are narrow and sharp; outermost very wide, squarish. First under arm plate hexagonal, wider than long; second plate, in contact with first, broadly bell-shaped, much wider than long; succeeding plates heptagonal, hexagonal or tetragonal, at first wider than long, but becoming longer than wide, separated from each other. Side arm plates moderate, meeting slightly above and below; each plate carries seven or eight slender spines, the upper ones smooth, the lower ones very slightly thorny, the lowest

a Eủoús, signifying broad, and $\pi \tilde{\omega} \mu a$, signifying $l i d$, in reference to the broad, distal oral papilla. 
smooth; next to uppermost longest, equal to rather more than two joints. Tentacle scale single, very large, especially on first pair of pores, flat and blunt or somewhat pointed. Color (dried from alcohol), very light yellowish.

Locality.-Albatross station 2859, off Alaska, lat. $55^{\circ} 20^{\prime}$ N.; long. $136^{\circ} 20^{\prime}$ W., 1,569 fathoms, gray ooze, bottom temperature $34.9^{\circ}, 3$ specimens.

Type.-Cat. No. 25626, U.S.N.M., from station 2859.

Although this species is obviously related to normani, cataleimmoida, and oedidisca, it may be readily distinguished from any of those species by the thorny stumps, rather than granules, on the disk; the proximity

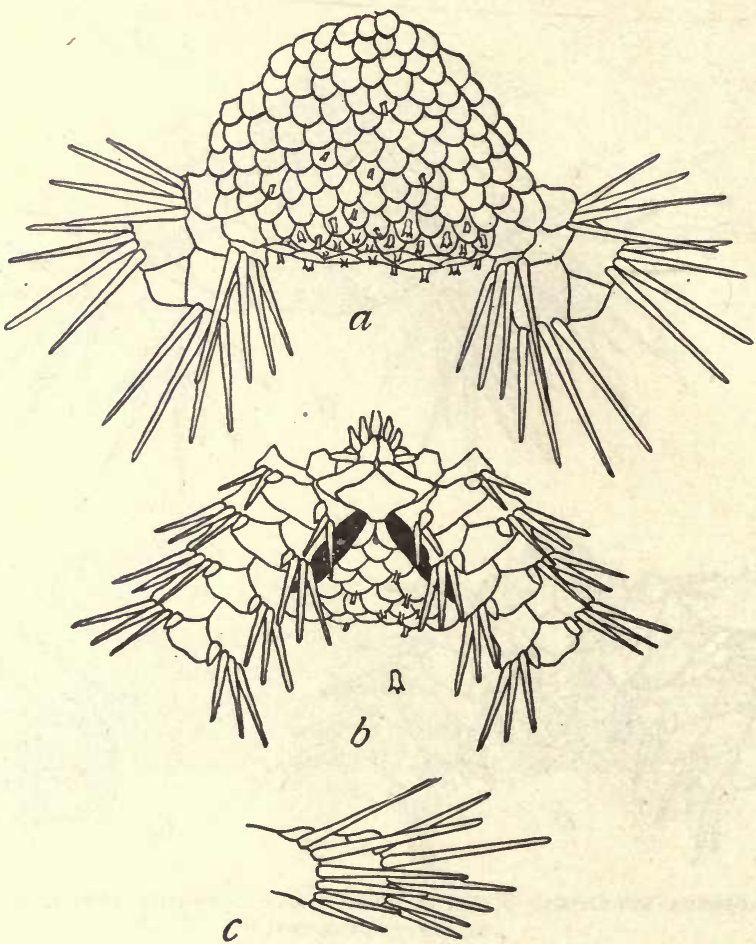

Fig. 104.-OPHIACANTHA LEPIDOTA. $\times 10 . \quad a$, FROM ABOVE; $b$; FROM BELoW; $c$, SIDE VIEW OF TWO ARM JOINTS NEAR DISK.

of the radial shields, the huge outer oral papilla, and the numerous very slender arm spines. The general appearance is lighter and more fragile than that of any of the related species.

\section{OPHIACANTHA LEPIDOTA, new species. $a$}

Disk $5 \mathrm{~mm}$. in diameter; arms about $20 \mathrm{~mm}$. long, probably. Disk covered by large overlapping scales, upon which are borne low, thorny

a $\Lambda \varepsilon \pi \varepsilon \delta \omega \tau \delta$, signifying covered with scales, in reference to the coarse scaling of the disk (fig. 104a); very likely not particularly applicable to an uninjured specimen. 
stumps; how numerous the stumps normally are the present condition of the specimen does not permit us to determine. Radial shields exposed only at the extreme distal ends where they are not quite in contact. Upper arm plates triangular, as long as wide or longer, widely separated; arms decidedly constricted between each pair. Interbrachial space below like disk above. Genital slits large. Oral shield broadly pentagonal, much wider than. long; distal side very short. Adoral plates moderate, three times as long as broad, meeting very narrowly within. Oral papillæ three on a side and one at apex of jaw, long, thick, bluntly pointed; distal papilla much the widest. (In fig. $104 b$ the distal papilla is drawn in an oblique position, so that its full width is not indicated.) First under arm plate longer than wide, rather hexagonal; succeeding plates more or less pentagonal, at first much wider than long, but soon becoming longer than wide, well separated. Side arm plates low and long, but meeting broadly both above and below; each plate carries six smooth, slender spines, of which the next to the uppermost is longest and may equal two joints. Tentacle scale single, quite large, oval, flat, and blunt. Color (dried from alcohol), dirty whitish, the disk with a decidedly gray tinge.

Locality.-Albatross station 3338 , off Alaska, lat. $54^{\circ} 19^{\prime}$ N.; long. $159^{\circ} 40^{\prime}$ W., 625 fathoms, green mud, sand, bottom temperature $37.3^{\circ}, 1$ specimen.

Type.-Cat. No. 25529, U.S.N.M., from station 3338.

This is one of those exasperating specimens which, although without any distinctive or notable characters, refuse to be assigned to any known species, and yet are so small and badly preserved it is humiliating to make them types of new species. Although other species of Ophiacantha were taken at station 3338 , this specimen can not be referred to any one of them, and I do not know of any species from elsewhere with which it might be united.

\section{OPHIACANTHA EUPHYLACTEA, new species. $a$}

Disk $7 \mathrm{~mm}$. in diameter; arms about $35 \mathrm{~mm}$. long. Disk covered by a fine scaling (coarse near radial shields), which was probably concealed in life by the minute, thorny stumps, of which there are now only a few scattered ones left. Distal ends of radial shields exposed and nearly in contact. Upper arm plates rounded pentagonal or hexagonal, at first wider than long, but soon becoming as long as wide. Although not actually in contact, they separate the side arm plates widely. Interbrachial space below like disk. Genital slits very large. Oral shield tetragonal, with wide proximal

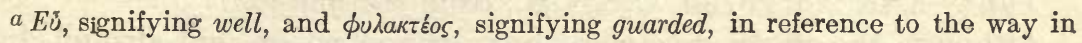
which the lower arm spines protect the tentacles.

$34916^{\circ}-$ Bull. $75-11-15$ 
angle, much broader than long. Adoral plates -short and wide, hardly meeting within. Oral papillæ very long, stout, pointed, three or four on a side, subequal, and a larger one at apex of jaw. First under arm plate very large, squarish, about as long as wide; succeeding plates squarish or hexagonal, wider than long, broadly separated from each other. Side arm plates moderate, well separated above, but meeting broadly below. Each plate carries six to eight short, thick, bluntly pointed arm spines; upper ones smooth, second and third longest, not quite equal to two joints; lowest three or four smaller (much smaller at middle of arm), more or less flat-
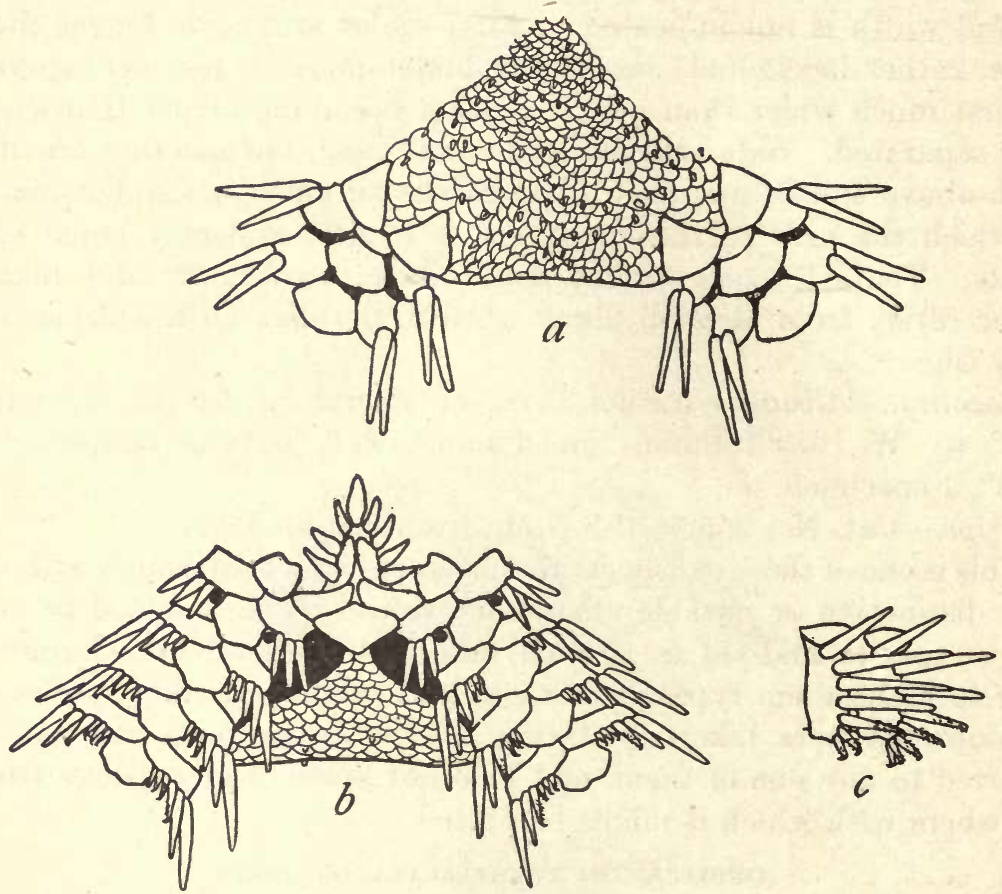

Fig. 105.-OPHIACANTHA EUPHYLACTEA. $\times 7$. $a$, FROM ABOVE; $b$, FROM BELOW; $c$, SIDE VIEW OF TWO ARM JOINTS NEAR DISK.

tened, rough, and hooked at tip. Tentacle scales none, but the three or four lowest arm spines form a very efficient protection for the tentacles, which are, however, except the first two or three pairs, very small. Color (dried from alcohol), whitish.

Locality.-Albatross station 3697, off Manazuru Zaki, Honshu Island, Japan, 120 to 265 fathoms, gray mud, volcanic sand, 1 specimen.

Type.-Cat. No. 25730, U.S.N.M., from station 3697.

Although the single specimen shows the effect of acid alcohol, by a certain amount of decalcification, which is most marked on the 
upper arm plates, the arm spines, and the oral papillæ, its characters are so unique $I$ have no hesitation in making it the type of a new species. I would call particular attention to the huge, spiniform oral papillæ; the very large first under arm plate widely separated from second; the absence of tentacle scales, and the very characteristic lower arm spines.

\section{OPHIACANTHA HYLACANTHA, new species. $a$}

Disk $11 \mathrm{~mm}$. in diameter; arms about $60 \mathrm{~mm}$. long. Disk covered by numerous stout, pointed, rough spines, nearly or quite a milli-
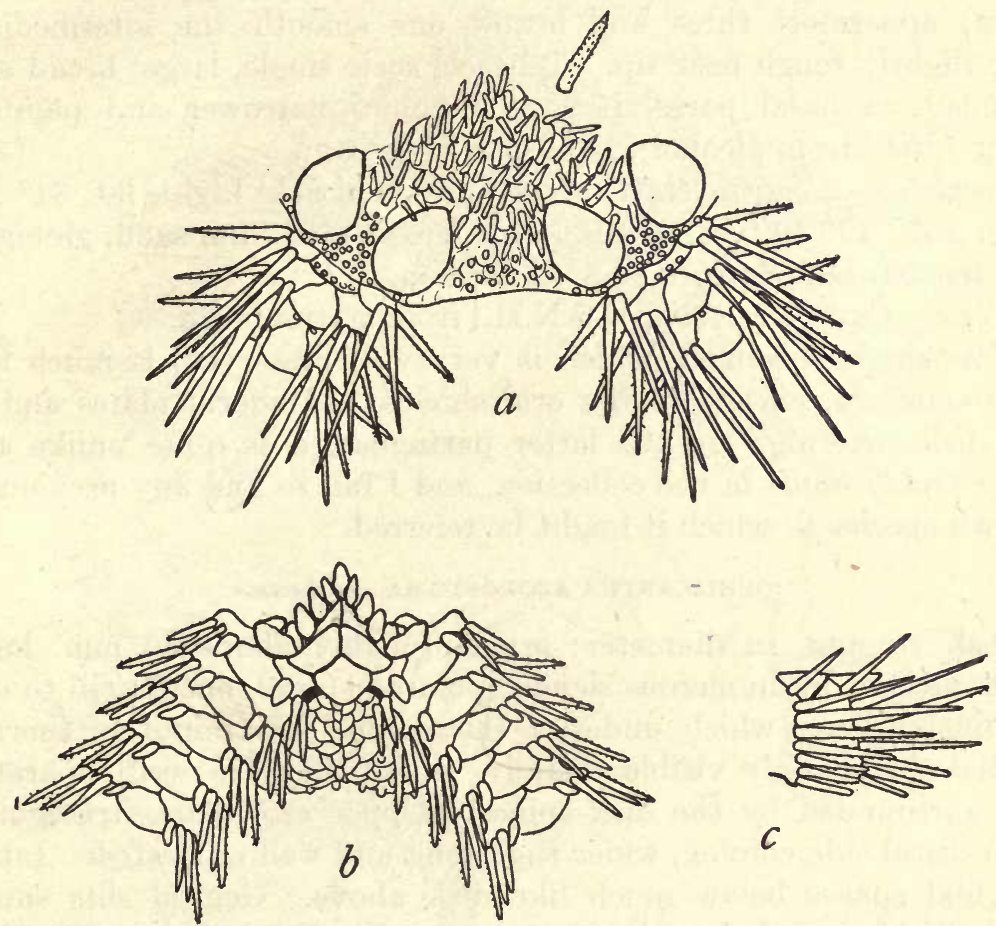

Fig. 106.-OPHIACANTHA HYLACANTHA. $\times$ 4.5. $a$, FROM ABOVE; $b$, FROM BELOW; $c$, SIDE VIEW QF TWO ARM JOINTS NEAR DISK.

meter long. Among the spines are scattered coarse granules, but whereas the spines are chiefly near the center of the disk, the granules are chiefly marginal, particularly distal to the radial shields. Radial shields large, well separated, rather longer than wide, bare and smooth. Upper arm plates more or less triangular, as long as wide or longer; basal ones in contact, but farther out they are separated; some basal ones bear marginal granules, as in normani.

$a^{\prime \prime} r \lambda \eta$, signifying forest, and $a ̈ \kappa a \nu \theta a$, signifying spine, in reference to the forest of spines on the disk. 
Interbrachial spaces below covered with scales, carrying a few elongated granules. Genital slits small. Oral shields rhombic, with rounded angles, about as long as wide. Adoral plates very large, about half as wide as long, meeting broadly within. Oral papillæ large, three on a side and one at apex of jaw, bluntly pointed, subequal, or distal one largest. Under arm plates wider than long, the first about half as large as second; first and second distinctly in contact, second and third hardly so, the remainder separated. Side arm plates rather large, meeting above and below, except at very base of arm. Each plate carries eight stout spines, of which the second or third (from above) is the longest, equaling two joints or more; uppermost three and lowest one smooth, the intermediate four slightly rough near tip. Tentacle scale single, large; broad and rounded on basal pores, it soon becomes narrower and pointed. Color (dried from alcohol), light grayish-brown.

Locality.-Albatross station 5084, off Omai Saki Light, lat. $34^{\circ} \mathrm{N}$; long. $137^{\circ} 49^{\prime} 40^{\prime \prime}$ E., 918 fathoms, green mud, fine sand, globigerina, bottom temperature $36.8^{\circ}, 1$ specimen.

Type.-Cat. No. 25593, U.S.N.M., from station 5084.

This single specimen, which is very well preserved, is much like cataleimmoida, except in the oral shields and adoral plates and in the disk covering. In the latter particular, it is quite unlike any other Ophiacantha in the collection, and I fail to find any previously known species to which it might be referred.

\section{OPHIACANTHA ATOPOSTOMA, new species. $a$}

Disk $10 \mathrm{~mm}$. in diameter; arms probably about $50 \mathrm{~mm}$. long. Disk covered by numerous slender pointed spines, one-fourth to one millimeter long, which under a microscope are minutely thorny. Radial shields only visible distally, where they are well separated and surrounded by the disk spines. Upper arm plates triangular, with distal side convex, wider than long and well separated. Interbrachial spaces below much like disk above. Genital slits small. Oral shields rounded, wider than long, with distal side more or less projecting. Adoral plates large, twice as long as wide, meeting broadly within. Oral papillæ five or six on a side (sometimes a single one at apex of jaw), the proximal ones narrow and pointed, the distal one (outermost) broad, flat and rounded at tip; distal to this broad papilla and borne on the proximal edge of the adoral plate, is a sharp, slender, spinelike papilla (sometimes there are two). First under arm plate small and squarish, a trifle wider than long; second plate in contact with first, heptagonal, wider than long; third barely touch-

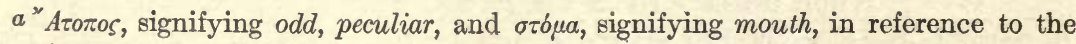
peculiar mouth parts. 
ing second, hexagonal, about as long as wide; succeeding plates separated, more or less pentagonal, with rounded distal margin, longer than wide. Side arm plates large, meeting above and below, each with seven stout, smooth, not very sharp spines, of which the uppermost is longest and exceeds two joints. Tentacle scales two on first pair (or first two pairs) of arm pores; after that single, but very large, flat and oval. Color (dried from alcohol), light grayish-brown or dirty whitish.
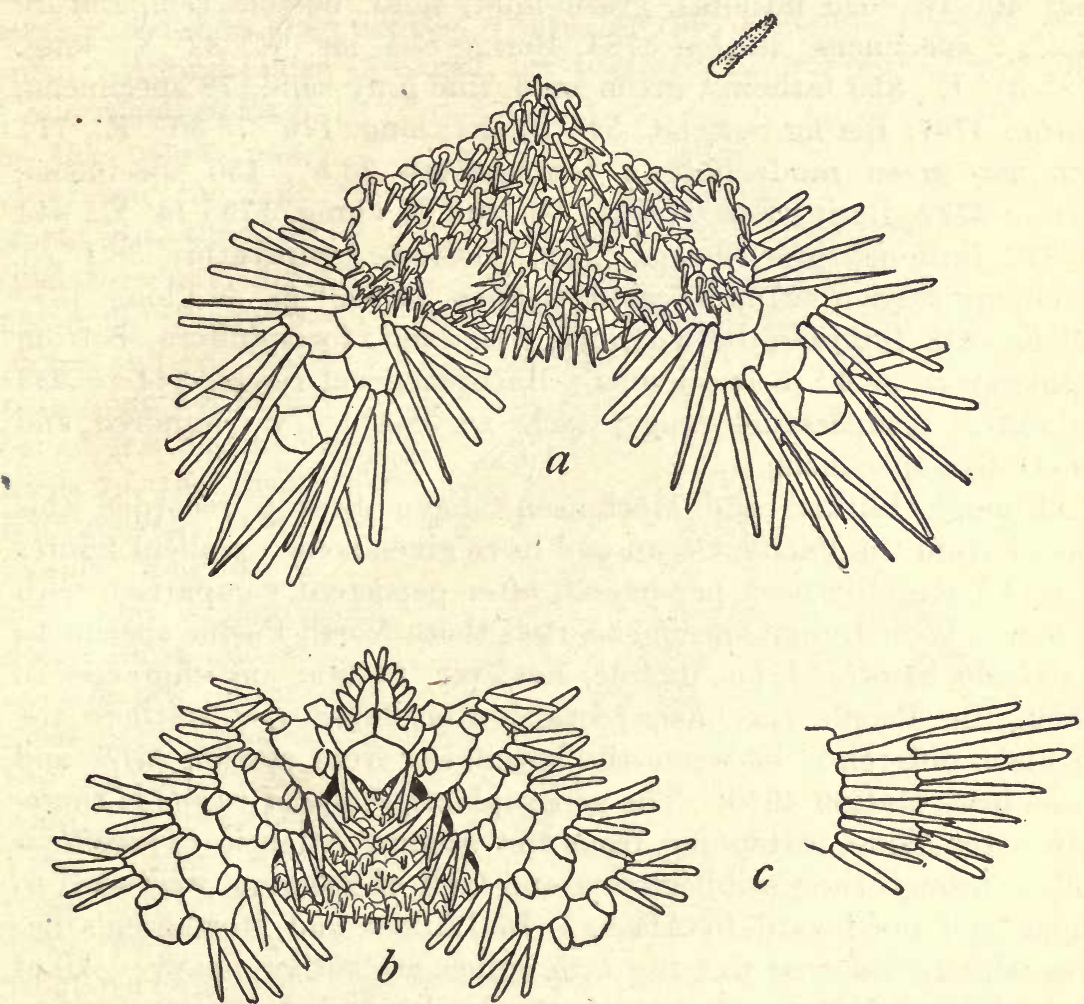

Fig. 107.-Ophlacantha atopostoma. $\times 5$. $a$, From ABove; $b$, From Below; $c$, Side view of two ARM JOINTS NEAR DISK.

Locality.-Albatross station 4772 , Bering Sea, lat. $54^{\circ} 30^{\prime} 30^{\prime \prime} \mathrm{N}$.; long. $179^{\circ} 14^{\prime}$ E., 344 to 372 fathoms, green-brown sand, bottom temperature $38.1^{\circ}, 1$ specimen.

Type.-Cat. No. 25599, U.S.N.M., from station 4772.

Although this specimen is in very poor condition, the mouth parts are so peculiar and characteristic that, taken in connection with the disk covering, they warrant the description of a new species. I do not know of any other with which it is likely to be confused, although it resembles $O$. stimulea Lyman in many characters; the exposed radial 
shields and characteristic adoral plates, with their spines, readily distinguish it from that southern species.

\section{OPHIACANTHA BAIRDI.}

Ophiacantha bairdi Lyman, Bull. Mus. Comp. Zoöl., vol. 10, 1883, p. 256.

Localities.-Albatross station 3070 , off Washington, lat. $47^{\circ} 29^{\prime} 30^{\prime \prime}$ N.; long. $125^{\circ} 43^{\prime}$ W., 636 fathoms, green mud, bottom temperature $37.9^{\circ}, 59$ specimens; station 3338 , off Alaska, lat. $54^{\circ} 19^{\prime} \mathrm{N}$.; long. $159^{\circ} 40^{\prime}$ W., 625 fathoms, green mud, sand, bottom temperature $37.3^{\circ}, 2$ specimens; station 3784 , Bering Sea, lat. $54^{\circ} 32^{\prime}$ N.; long. $178^{\circ} 31^{\prime}$ E., 850 fathoms, green mud, fine gray sand, 78 specimens; station 4767 , Bering Sea, lat. $54^{\circ} 12^{\prime}$ N.; long. $179^{\circ} 7^{\prime} 30^{\prime \prime}$ E., 771 fathoms, green mud, bottom temperature $36.5^{\circ}$, 150 specimens; station 4772 , Bering Sea, lat. $54^{\circ} 30^{\prime} 30^{\prime \prime}$ N.; long. $179^{\circ} 14^{\prime}$ E., 344 to 372 fathoms, green-brown sand, bottom temperature $38.1^{\circ}, 1$ specimen; station 4979 , off eastern Japan, lat. $33^{\circ} 53^{\prime} \mathrm{N}$.; long. $137^{\circ}$ $42^{\prime}$ E., 943 fathoms, brown mud, fine sand, foraminifera, bottom temperature $36.4^{\circ}, 5$ specimens. Bathymetrical range, 344 to 943 fathoms. Temperature range, $38.1^{\circ}$ to $36.4^{\circ}$. Two hundred and ninety-five specimens.

Although Lütken and Mortensen ${ }^{a}$ have already recorded this species from the Pacific Ocean and have given some excellent figures of it, I have only been persuaded, after persistent comparison with Lyman's West Indian specimens, that these North Pacific specimens are really bairdi. I am unable, however, to find any character in which the Pacific specimens consistently differ, nor is there the slightest difference between the specimens from station 4767 and those from station 4979. The geographical range of bairdi is therefore astonishing, extending from the eastern Atlantic (Travailleur coll.), through the Caribbean Sea and Gulf of Panama, westward to Japan and northward to Alaska. In Lütken and Mortensen's figures, already referred to ${ }^{a}$ the arm spines are rather heavy. All of the specimens before me have very slender and sharp arm spines. Kœhler $^{b}$ speaks of bairdi as having twō tentacle scales, whereas Lyman definitely says, and Lütken and Mortensen clearly figure, one; none of the specimens before me have more than one, even on the first arm pores. This species is very near Ophioconis, and it is virtually impossible to find any character which would warrant their being placed in separate families, yet our present system of classification severs them widely. There is not a little individual diversity in the relative abundance of spines and granules on the disk of bairdi. In some specimens there are no granules sufficiently elongated to be 
called spines, while in other cases nearly all of the granules are elongated and most of them are really spiniform.

\section{OPHIACANTHA LAMBDA, new species. $a$}

Disk $10 \mathrm{~mm}$. in diameter; arms about $60 \mathrm{~mm}$. long. Disk covered by a dense coat of small, elongated granules. Radial shields bare distally, widely separated. Upper arm plates rhombic or triangular, with distal side convex, widely separated. Interbrachial spaces below, less closely covered than disk, with elongated granules. Oral shield very large, wider than long, pointed within, laterally rounded. Genital slits small. Adoral plates L-shaped, meeting within, the short arm of the $L$ about half as long as the other, and separating the oral shield from the first side arm plate. Inner ends of adoral plates and the oral plates carry a number of granules like those of the disk, but shorter. Oral papillæ four on a side, and a large, flat, pointed one at apex of jaw; outermost papilla much the largest, very wide, truncate. First under arm plate large, wider than long, somewhat hexagonal; succeeding plates

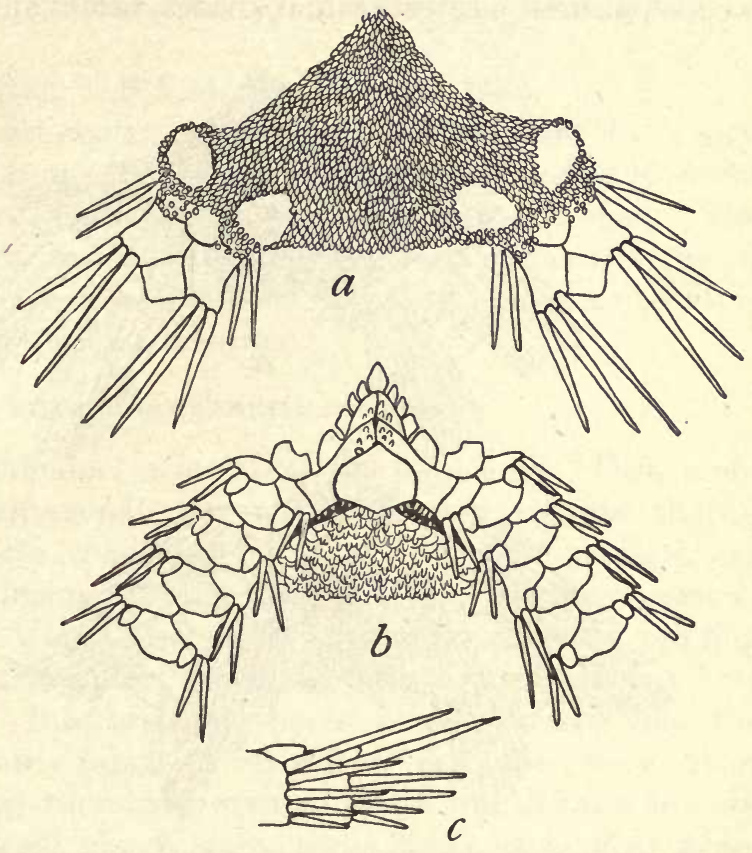

Fig. 108.-OPhIACANTHA LAMBda. $\times 5$. $a$, FROM ABOVE; $b$, FROM BELOW; $c$, SIDE VIEW OF TWO ARM JOINTS NEAR DISK.

also wider than long, pentagonal with distal side convex; all are widely separated from each other. Side arm plates large, meeting above and below, each with five smooth pointed arm spines, of which the uppermost is much the longest, nearly equaling three joints. Tentacle scale single, very large, oval, flat, not at all pointed. Color (dried from alcohol), nearly white.

Locality.-Albatross station 4957 , off southern Japan, lat. $32^{\circ} 36^{\prime}$ N.; long. $132^{\circ} 23^{\prime}$ E., 437 fathoms, green-brown mud, fine gray sand, foraminifera, bottom temperature $39.8^{\circ}, 2$ specimens. 


\section{Type.-Cat. No. 25722, U.S.N.M., from station 4957.}

Although this species is obviously near to bairdi, and therefore very near Ophioconis, it is easily distinguished from these allies by the exposed radial shields, the characteristic mouth parts and the few arm spines; the rounded tentacle scales are also different from those of bairdi.

OPHIACANTHA LOPHOBRACHIA, new species. $a$

Disk about $4 \frac{1}{2} \mathrm{~mm}$. in diameter; arms about $15 \mathrm{~mm}$. long. Disk completely covered with a dense coat of short spines, which are thick and of nearly uniform height. Radial shields completely concealed. Upper arm plates small, nearly triangular, somewhat wider than long, well separated. Interbrachial spaces below apparently covered like

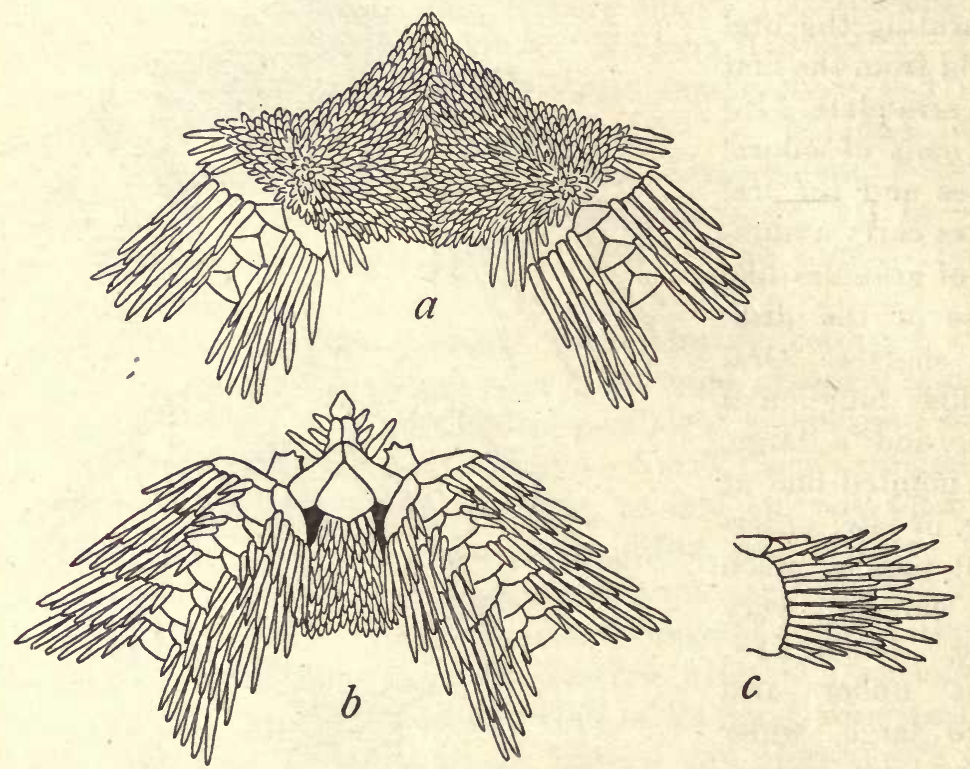

Fig. 109.-OPHICANTHA LOPHOBRAChia. $\times 12$. $a$, FROM ABOVE; $b$, FROM BELOW; $c$, SIDE VIEW JF THREE ARM JOINTS NEAR DISK.

disk. Genital slits short but wide. Oral shield nearly triangular (madreporite, rhombic) longer than wide. Adoral plates very large, wider without where they separate oral shield from arm plate than within where they meet. Jaw terminated by a large, nearly triangular tooth, the lowest of the vertical series. On each side are three oral papillæ, narrow and spine-like. The outermost is much the longest and is virtually a tentacle scale for the first oral tentacle, which is very large. First under arm plate hexagonal, longer than broad, widely separated from second, which is somewhat larger, pen-

$a \Lambda b \phi o s$ signifying ridge, and $\beta \rho \alpha \chi^{i} \omega \nu$, signifying $a r m$, in reference to the unusually notable ridges on the side arm plates. 
tagonal, and wider than long; succeeding plates pentagonal, wider than long, well separated from each other. Side arm plates short but high, meeting broadly above and below; median area of each plate elevated into a narrow, conspicuous ridge, as high as half the diameter of the arm between the ridges. Each ridge carries eight or nine straight, smooth, pointed spines, of which the middle ones are longest and a little exceed two joints. Tentacle scales three on the first two pairs of arm pores, and after that single; sharp and spinelike, nearly as long as a joint. Color (dried from alcohol), yellowbrown.

Locality.-Albatross station 4933 , Eastern Sea, lat. $30^{\circ} 59^{\prime}$ N.; long. $130^{\circ} 29^{\prime} 50^{\prime \prime}$ E., 152 fathoms, rocky; bottom temperature $56^{\circ}, 1$ specimen.

Type.-Cat. No. 25536, U.S.N.M., from station 4933.

This single small specimen is in such poor condition that it is a pity to designate it as the type of a new species, but nevertheless it shows clearly such distinctive characters that no other course is open. The mouth parts (including the oral shields), the very marked ridges on which the arm spines are borne, and the very long, spine-like tentacle scales are worthy of particular mention.

\section{OPHIACANTHA BATHYBIA, new species. $a$}

Disk $12 \mathrm{~mm}$. in diameter; arms about $70 \mathrm{~mm}$. long. Disk more or less distinctly pentagonal, covered with very minute thorny stumps. Radial shields concealed but their form and position are indicated in dry specimens, through the skin; they are long, narrow, and well separated. Upper arm plates rounded triangular, tending to rhombic, somewhat swollen, about as wide as long, all but first two well separated. Interbrachial spaces below covered like the disk. Genital slits fairly large. Oral shield very much wider than long, with a somewhat rounded proximal angle and distal side only slightly convex. Adoral plates large, three times as long as wide, meeting broadly within; usually they partly inclose the oral shield, sending a branch down between it and the side arm plate; sometimes, however, they are wholly proximal to the oral shield which is then in contact with the side arm plate. Oral papillæ three or four on a side, with sometimes an odd one at apex of jaw; outermost flat, wide, and truncate; others narrower, thicker, and more pointed. First under arm plate oblong, nearly twice as wide as long, barely in contact with second which is broadly pentagonal or triangular, very wide distally, with a somewhat curved margin; succeeding plates similar but smaller, and relatively longer, well separated. Side arm

\footnotetext{
a Batús, signifying deep, and Blos, signifying life, in reference to the great depth at which it lives.
} 
plates moderate, meeting both above and below; each plate carries half a dozen slender, sharp spines, the uppermost longest and exceeding three joints; the two upper spines are smooth but the lower ones are rough near the tip. Tentacle scales single, small, spiniform, and sharp. Color (dried from alcohol), whitish, yellowish, or grayish.

Localities.-Albatross station 2859, off Alaska, lat. $55^{\circ} 20^{\prime} \mathrm{N}$.; long. $136^{\circ} 20^{\prime}$ W., 1,569 fathoms, gray ooze, bottom temperature $34.9^{\circ}, 183$ specimens; station 2860, off British Columbia, lat. $51^{\circ} 23^{\prime}$ N.; long. $130^{\circ} 34^{\prime}$ W., 876 fathoms, green mud, bottom temperature $36.5^{\circ}$, 11 specimens; station 3603 , Bering Sea, lat. $55^{\circ} 23^{\prime}$ N.; long. $170^{\circ}$ $31^{\prime}$ W., 1,771 fathoms, brown ooze, bottom temperature $35.1^{\circ}, 3$

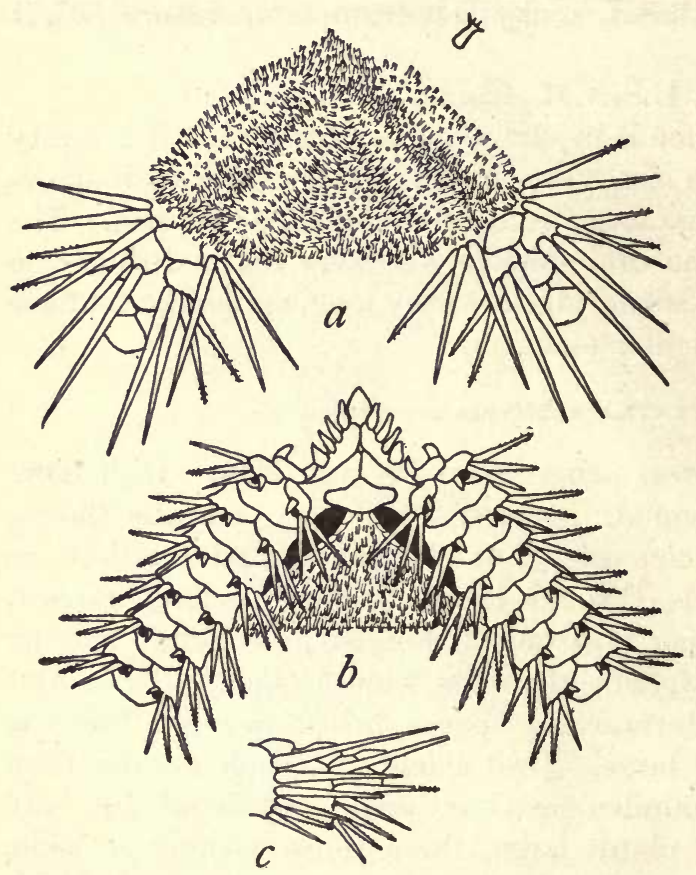

Fig. 110.-Ophicantha Bathybia. $\times$ 4. $a$, From ABove; $b$, FROM BELOW; $c$, SIDE VIEW OF TWO ARM JOINTS NEAR DISK. specimens; station 4761 , off Shumagin Islands, lat. $53^{\circ} 57^{\prime} 30^{\prime \prime}$ N.; long. $159^{\circ} 31^{\prime} \mathrm{W}$., 1,973 fathoms, blue clay, bottom tempera ture $35^{\circ}, 14$ specimens; station 4766, Bering Sea, lat. $52^{\circ} 38^{\prime} \mathrm{N}$.; long. $174^{\circ} 49^{\prime}$ W., 1,766 fathoms, character of bottom and bottom temperature not observed, 117 specimens. Bathymetrical range, 876 to 1,973 fathoms. Temperature range, $36.5^{\circ}$ to $34.9^{\circ}$. Three hundred and twentyeight specimens.

Type-Cat. No. 25541, U.S.N.M., from station 2859.

Although this species has no very distinctive marks, it appears to be different from any other known member of Ophiacantha. The form and position of the adoral plates are unfortunately not absolutely reliable characters, but taken in connection with others may be useful. The disk covering, the upper arm plates, the arm spines, and the tentacle scales are the most important characters in that connection. The species seems to be a typically abyssal ophiuran and it is rather remarkable that it is so little differentiated from more shallow-water species. 


\section{OPHIACANTHA LEUCOSTICTA, new species. $a$}

Disk $17 \mathrm{~mm}$. in diameter; arms about $70 \mathrm{~mm}$. long. Disk covered with a thin, uncalcified skin, which appears to be speckled with both black and white; examination with a lens shows that the black spots are due to organic tissue on the inner surface of the skin, while the white spots are due to minute, elongated calcareous granules; these granules are borne by plates which for the most part have a diameter scarcely exceeding that of the granules, but around the radial shields they are developed into ordinary overlapping scales. Radial shields rather large, distinctly separated, the distal half exposed but bearing on the outer margin one or more elongated granules. Upper arm plates rounded, hexagonal, or elliptical, much wider than long, more

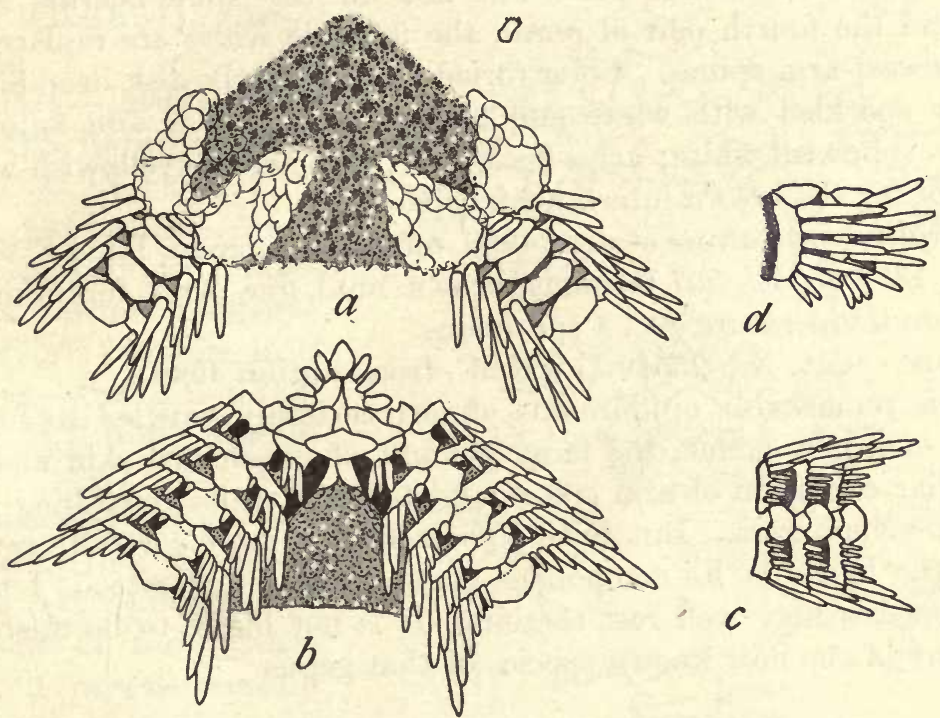

Fig. 111.-Ophlacantha leucosticta. $\times 3$. $a$, From ABOVE; $b$, From Below; $c$, three ARM JOINTS NEAR MIDDLE OF ARM, SEEN FROM BELOW; $d$, SIDE VIEW OF TWO ARM JOINTS NEAR DISK.

or less in contact with each other, at least on basal part of arm. Interbrachial space below like disk above. Genital slits large. Oral shields somewhat rhombic, twice as wide as long. Adoral plates moderate, short and wide, hardly meeting within. Oral papillæ three on a side, broad, flat, rounded. Teeth very large and conspicuous. First under arm plate hexagonal, about as long as wide; succeeding plates more or less octagonal and longer than broad, but rapidly becoming hexagonal, tetragonal, or rounded and much wider than long; the first two or three are in contact, but the succeeding plates appear to be separated by a depression; whether the side arm plates meet in this depression, or whether it is a proximal pro-

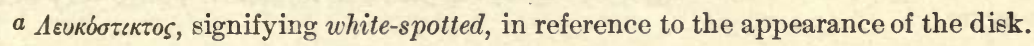


longation of the under arm plates, or whether its floor is formed simply of connective tissue, is not clear from an external examination of the dry specimen. Side arm plates very short and separated from each other by an area of bare, uncalcified skin, as wide as themselves; each plate carries a conspicuous vertical ridge on which are borne seven or eight arm spines; of these the four or five uppermost are stout, smooth, and blunt, the two middle ones longest and nearly equaling two joints; the three or four lowest spines are very much smaller than the upper ones, are rough or hooked at the tip, and practically serve as tentacle-scales (see fig. 111c). Tentacle pores very large; first one usually with no tentäcle scale, but sometimes with a small one; next three pairs of pores with a single well-marked scale on the side arm plate but not on the spine-bearing ridge; beyond the fourth pair of pores, the tentacle scales are replaced by the lowest arm spines. Color (dried from alcohol), disk deep brown, finely speckled with white and black; radial shields and adjoining scales yellowish-white; arms light drab; oral surface yellowish-white, except for the brown interbrachial spaces.

Locality.-Albatross station 4980 , off eastern Japan, lat. $34^{\circ} 9^{\prime} \mathrm{N}$.; long. $137^{\circ} 55^{\prime}$ E., 507 fathoms, brown mud, fine sand, foraminifera, bottom temperature $39^{\circ}, 4$ specimens.

Type.-Cat. No. 25549 U.S.N.M., from station 4980.

This remarkable ophiuran is almost certainly entitled to be the type of a new genus, the large amount of uncalcified skin and the peculiar condition of arm spines and tentacle scales furnishing good generic characters. But until Ophiacantha is more carefully revised and the limits of its component genera better understood, I think this species may well rest therein. It is not likely to be mistaken for any of the now known species of that genus.

OPHIACANTHA MACRARTHRA, new species. $a$

Disk $2 \mathrm{~mm}$. in diameter; arms about $7 \mathrm{~mm}$. long. Disk covered with few coarse scales, upon which are borne some minute stumps, more or less elongated, conical, and with several terminal teeth. Radial shields hardly distinguishable from the other disk scales, closely joined. Upper arm plates minute, triangular or rhombic, widely separated. Interbrachial spaces below like disk above. Genital slits very large. Oral shield large, wider than long, distally rounded but with a proximal angle. Adoral plates large, L-shaped, meeting within and separating the oral shield from the side arm plate; oral plates rather large. Oral papillæ three on a side and one at apex of jaw; latter much the largest, broad, flat, pointed; outer-

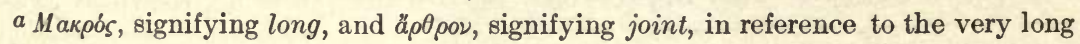
arm joints. 
most papilla (perhaps more properly the tentacle scale of the outer oral tentacle) very long, slender, spiniform, and acute; the other two are similar but shorter. First under arm plate very large, hexagonal, a little broader than long; second plate larger, pentagonal, much broader than long; third plate smaller than second but similar; succeeding plates similar but much smaller and tending to become squarish; all the plates are widely separated. Side arm plates very large, all but first two or three pairs much longer than high, meeting broadly both above and below; each plate carries three arm spines, of which the uppermost is smooth, acute, and equals the joint, while the lower two are shorter and rough at the tip. Tentacle pores large; tentacle scale single,small, spiniform. Color (dried from alcohol), dirtywhitish.

\section{Locality.-Albatross sta-} tion 4775 , Bering Sea, lat. $54^{\circ} 33^{\prime} 30^{\prime \prime} \mathrm{N}$.; long. $178^{\circ}$ $44^{\prime}$ E., 584 fathoms, green mud, black specks, foraminifera, bottom temperature $37.2^{\circ}, 1$ specimen.

Type.-Cat. No. 25739, U.S.N.M., from station 4775 .

Although there is every indication that this specimen is very young (except the size of the genital slits), it reveals certain characters that are so distinctive it seems best to give it a name. The mouth parts and the un-

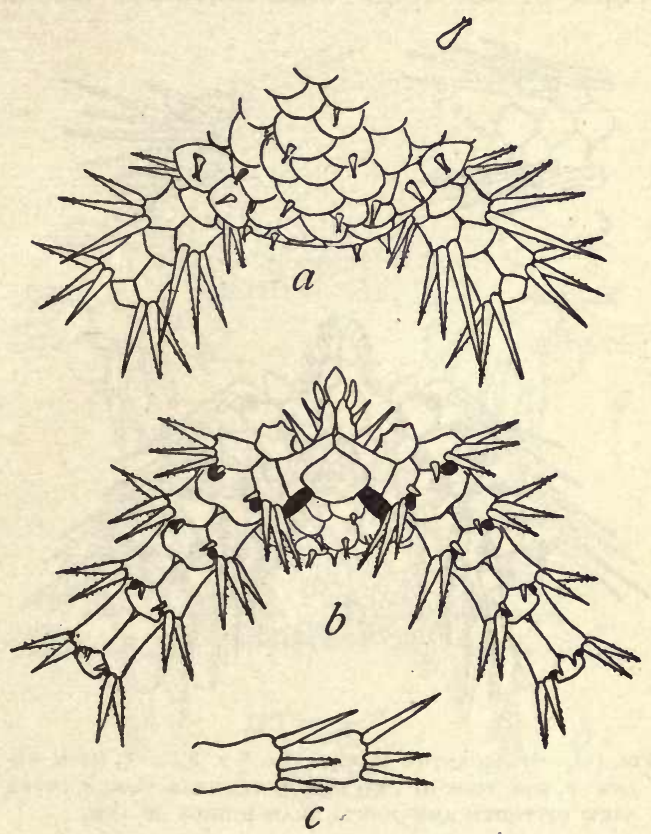

Fig. 112.-OPHIACANTHA MACRARTHRA. $\times 25 . a$, From ABOVE; $b$, FROM BELOW; $c$, SIDE VIEW OF TWO ARM JOINTS NEAR DISK. usually long (for this family) side arm plates are quite remarkable and will make the species easy to recognize.

\section{OPHIACANTHA MEGATRETA, new species. $a$}

Disk wanting, but judging from the scars on bases of arms, it was about $25 \mathrm{~mm}$. in diameter; arms about $115 \mathrm{~mm}$. long, beyond disk scars. Upper arm plates more or less rhombic, with rounded angles,

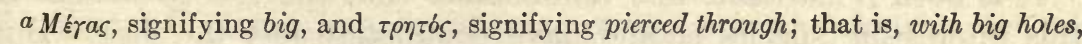
in reference to the conspicuous tentacle pores. 
as long as wide (except at base of arm) or longer, overlapping or in contact on basal half of arm, but becoming separated distally. Interbrachial space below with scales, at least near oral shield. Genital slits large. Oral shield as long as wide or longer, rounded heptagonal (in smaller specimen, oral shield rhombic with rounded angles, distinctly wider than long). Adoral plates large, L-shaped, meeting within, completely separating the oral shield from side arm plate (in smaller specimen, proximal or long arm of the $L$ more or less aborted and consequently not meeting within). Oral papillæ five or six on a side, thick, blunt, crowded; distal to them, and attached to adoral plate, are several small spine-like papillæ, which are the tentacle scales of the huge oral tentacles (second pair). First under arm
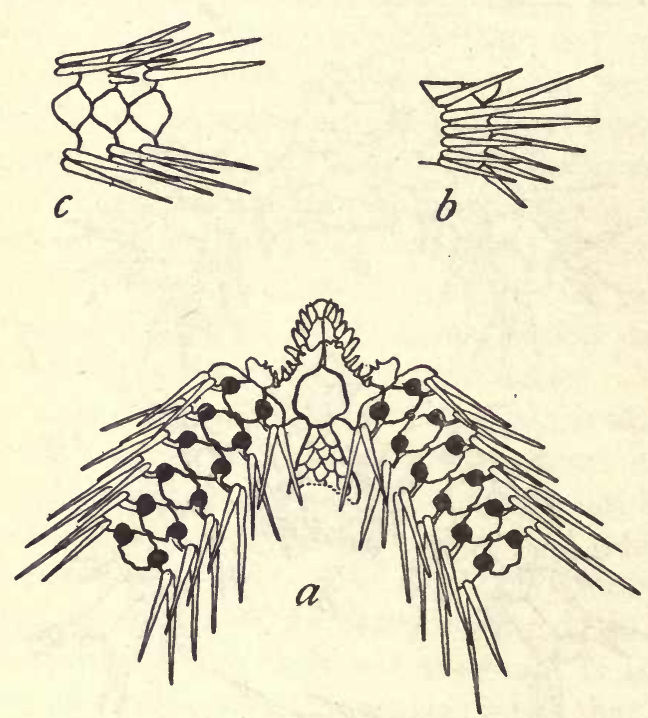

Fig. 113.-OPHiacantha megatreta. $\times 2.25$. $a$, From BELOW; $b$, SIDE VIEW OF TWO ARM JOINTS NEAR DISK; $c$, UPPER VIEW OF THREE ARM JOINTS NEAR MIDDLE OF ARM.

or six long, slender, (or next one) is longest, equaling about two joints. Tentacle pores very large; tentacle scales none. Color (dried from alcohol), whitish.

Localities.-Albatross station 4969 , off eastern Japan, lat. $33^{\circ} 23^{\prime}$ $40^{\prime \prime} \mathrm{N}$.; long. $135^{\circ} 33^{\prime}$ E., 587 fathoms, brown mud, sand, stones, bottom temperature $38.9^{\circ}, 1$ specimen; station 4979 , off eastern Japan, lat. $33^{\circ} 53^{\prime}$ N.; long. $137^{\circ} 42^{\prime}$ E., 943 fathoms, brown mud, fine sand, foraminifera, bottom temperature $36.4^{\circ}, 1$ specimen.

Type.-Cat. No. 25596, U.S.N.M., from station 4969.

It is both remarkable and unfortunate that the two specimens of this interesting species should have completely lost the disk. But 
there is no question of their close relationship to $O$. bartletti Lyman, and they therefore belong in Verrill's genus Ophiopora, which I believe is probably a very natural group. The only important differences between bartletti and megatreta, which these damaged specimens show, is in the shape of the upper arm plates and in the number of arm spines. Possibly perfect specimens will show differences in the disk.

\section{OPHIOLEBES ASAPHES, new species.a}

Disk $9 \mathrm{~mm}$. in diameter; arms about $20 \mathrm{~mm}$. long. Disk more or less completely covered with rough unequal granules or low stumps. Radial shields long, narrow, well separated, partly bare (along the middle) or wholly concealed, their position more or less clearly indicated. Upper arm plates rounded, the first two or three wider than long, the others roughly circular; they are well separated from each other, but the side arm plates do not meet between them; in many places, though not necessarily on all arms, supplementary plates appear between the upper arm plates; when these are not present the space is occupied by uncalcified tissue. Interbrachial spaces below covered with scales, upon

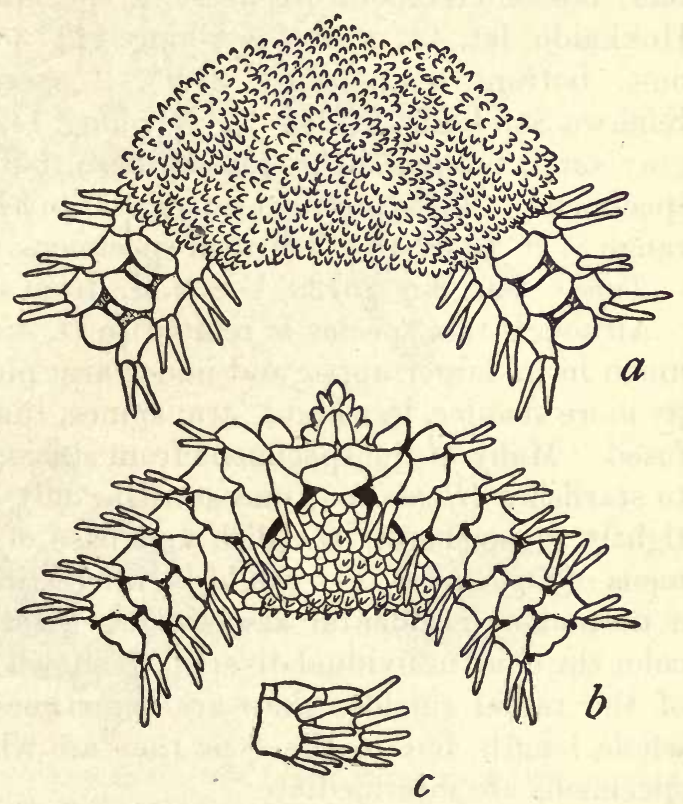

Fig. 114.-OPHIOLEBES ASAPHes. $\times 6 . a$, FROM ABOVE; $b$, FROM BELOW; $c$, SIDE VIEW OF TWO ARM JOINTS NEAR DISK. which a few of the rough granules are borne. Genital slits short and narrow. Oral shield rounded rhombic, very much wider than long. Adoral plates large but poorly defined, wider without than within, where they do not quite meet. Oral papillæ three on a side, short, blunt. All the mouth parts are more or less covered by a thick skin, which obscures their outlines even when dry. First under arm plate large, wider than long and wider within than distally; second and third plates somewhat pentagonal, with distal side notched, wider than long; succeeding plates somewhat kidney-shaped,

$a$ 'A $a \phi \eta$ 's, signifying indistinct, in reference to the indistinctness of many of the plates. 
wider than long; all the under arm plates are well separated from each other, and the side arm plates nearly or quite meet between them. The lower surface of the arm is, like the mouth parts, covered by a skin which obscures the outlines of the plates and makes it very hard to see the sutures. Side arm plates low but rather long, meeting below but not above; each plate carries five short, thick, smooth, blunt spines, of which the uppermost is longest, and slightly exceeds a joint. Tentacle pores minute; tentacle scales, none; the pores are protected by the lower end of the arm spine ridge and the spines which it bears. Color (dried from alcohol), reddish, yellowish, or grayish-brown.

Localities.-Albatross station 5018, off Saghalin, lat. $46^{\circ} 41^{\prime} 30^{\prime \prime} \mathrm{N}$.; long. $143^{\circ} 57^{\prime} 40^{\prime \prime}$ E., 100 fathoms, brown mud, black stones, pebbles, bottom temperature $30.4^{\circ}, 2$ specimens; station 5037 , off the Hokkaido, lat. $42^{\circ} 2^{\prime} 40^{\prime \prime} \mathrm{N}$.; long. $142^{\circ} 33^{\prime} 20^{\prime \prime}$ E., 175 to 349 fathoms, bottom temperature $37.9^{\circ}, 2$ specimens; station 5049 , off Kinkwa San Light, lat. $38^{\circ} 12^{\prime}$ N.; long. $142^{\circ} 2^{\prime}$ E., 182 fathoms, dark gray sand, broken shells, foraminifera, bottom temperature $37.8^{\circ}, 9$ specimens. Bathymetrical range, 100 to 349 fathoms. Temperature range $37.9^{\circ}$ to $30.4^{\circ}$. Thirteen specimens.

Type-Cat. No. 25738, U.S.N.M., from station 5018.

Although this species is related to $O$. scorteus Lyman it differs so much in its larger upper and under arm plates, its shorter arms, and its more slender, less blunt, arm spines, that the two can not be confused. Many of the specimens from station 5049 are clinging tightly to starfishes (Henricia); one starfish, only $42 \mathrm{~mm}$. from tip to tip, is tightly grasped over the disk and base of the arms by three specimens of Ophiolebes. It would be interesting to know whether this is a normal or accidental association. Aside from the differences in color the chief individual diversity is shown in the amount of exposure of the radial shields; they are sometimes visible for nearly their whole length, but in the type they are wholly concealed and other specimens are intermediate.

\section{OPHIOLEBES BRACHYGNATHA, new species. $a$}

Disk $10 \mathrm{~mm}$. in diameter; arms about $40 \mathrm{~mm}$. long. Disk covered by numerous rough, low, pointed stumps. Radial shields more or less exposed, long, very narrow, parallel, and widely separated. Upper arm plates tetragonal, with distal side somewhat curved, and much longer than proximal; they are well separated and between them appear squarish supplementary plates of much smaller size. Interbrachial spaces below much like disk above, but scaling shows more distinctly. Genital slits short but wide. Oral shields small, rhombic, wider than long. Adoral plates rather large, curved, hardly meeting

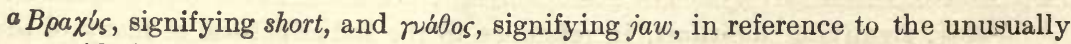
short, wide jaws. 
within. Oral plates small and so nearly parallel with adorals that the jaw is somewhat rounded and projects very little. Oral papillæ four on a side and usually an infradental one at apex of jaw; the papillæ are thick and blunt, and the outermost is clearly the largest. First under arm plate very large, somewhat rounded, hexagonal, wider than long; second plate somewhat larger, pentagonal, widest distally; succeeding plates more rounded, soon becoming elliptical and then onger than broad, and ultimately long pentagonal with distal end rounded; all the under arm plates are more or less separated from
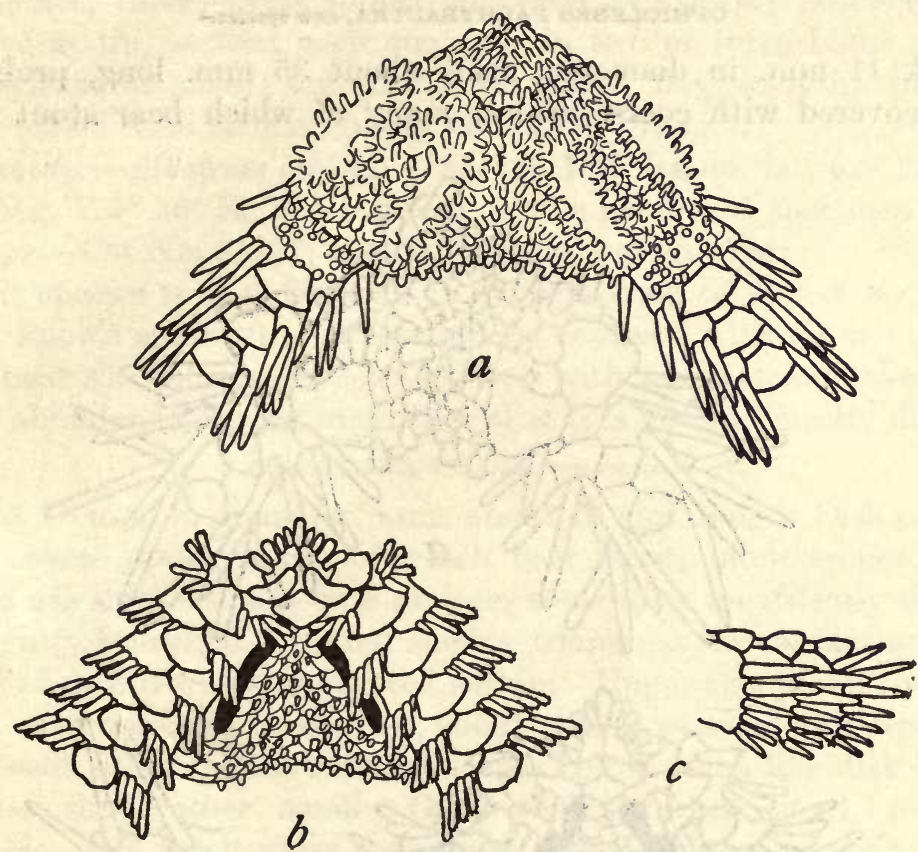

Fig. 115.-OPHIOLEBES BRACHYGNATHA. $\times 5$. $a$, FROM ABOVE; $b$, FROM BELOW; $c$, SIDE VIEW OF THREE ARM JOINTS NEAR DISK.

each other except the first two. Side arm plates moderate, not meeting above and only slightly so below; each plate carries seven or eight stout, blunt arm spines; upper two longest, exceeding joint, smooth; next two similar, but distinctly smaller; lowest three or four very much smaller, somewhat flattened, and with rough tips; they lie more or less appressed to lower surface of arm, pointing distally and inward. Tentacle pores small, first pair with a more or less prominent spiniform tentacle scale; a few other pores may have minute tentacle scales, but as a rule the scales are completely replaced functionally by the lowest arm spines. Color (dried from alcohol), light yellowish. $34916^{\circ}-$ Bull. $75-11-16$ 
Localities.-Albatross station 4803 , off Simushir Island, lat. $46^{\circ} 42^{\prime}$ N.; long. $151^{\circ} 45^{\prime}$ E., 229 fathoms, coarse pebbles, black sand, bottom temperature $35.9^{\circ}, 1$ specimen; station 4804 , off Simushir Island, lat. $46^{\circ} 42^{\prime} \mathrm{N}$.; long. $151^{\circ} 47^{\prime}$ E., 229 fathoms, coarse pebbles, black sand, bottom temperature $35.9^{\circ}, 3$ specimens.

Type.-Cat. No. 25592, U.S.N.M., from station 4804.

This species is in its proportions much like vestitus, but it is not very near that species. The disk spinules, the arm spines, and the jaws furnish its most distinctive features.

OPHIOLEBES PACHYBACTRA, new species.a

Disk $11 \mathrm{~mm}$. in diameter; arms about $35 \mathrm{~mm}$. long, probably. Disk covered with coarse scales, many of which bear stout club-
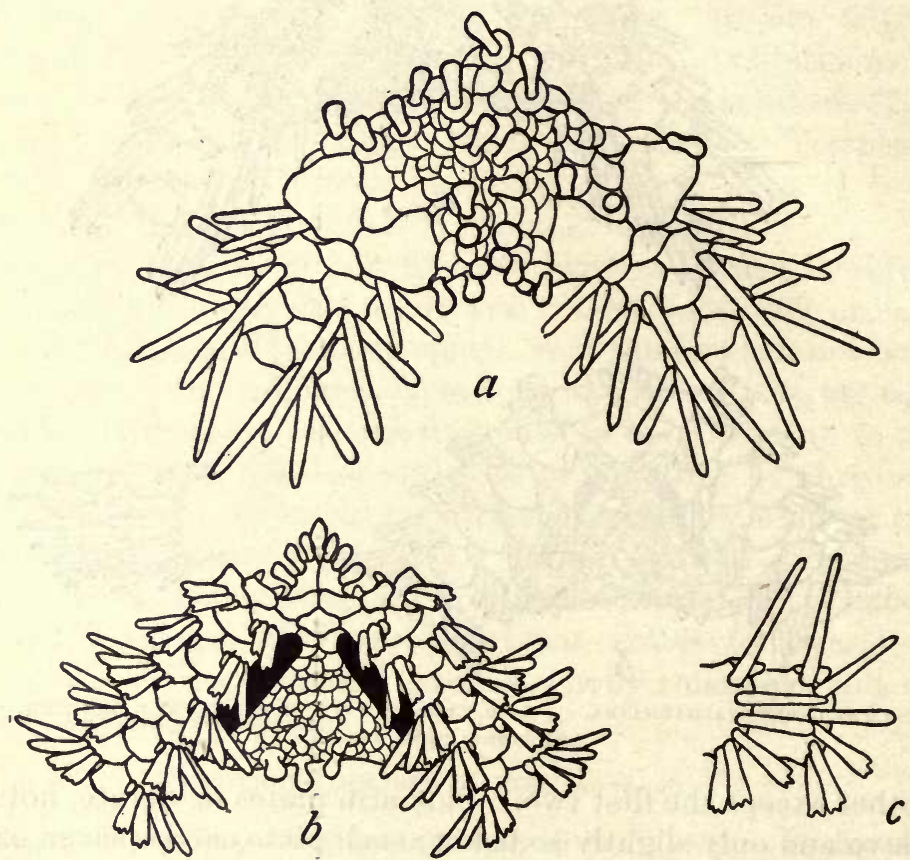

Fig. 116.-OPHIOLEBES PACHYBACTRA. $\times$ 4.5. $a$, FROM ABOVE; $b$, FROM BELOW; $c$, SIDE VIEW OF TWO ARM JOINTS NEAR DISK.

shaped spines, which are much thicker at the tip than at the base. Radial shields moderate, roughly triangular, in contact distally but widely separated within. Upper arm plates triangular or rhombic, much wider than long, well separated from each other. Interbrachial spaces below covered by scales somewhat smaller than those of disk. Genital slits very large. Oral shields small, rounded rhombic,

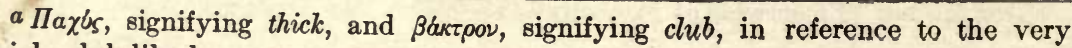
thick, club-like lower arm spines. 
wider than long. Adoral plates each about as large as oral shield, roughly pentagonal, twice as long as wide; oral plates rather large. Oral papillæ, three on a side and one at apex of jaw, rather thick and club-shaped. First under arm plate small, wider than long; second plate somewhat triangular, nearly as long as wide; succeeding plates more pentagonal or hexagonal, as long as wide or longer; all the plates, except the first two, are well separated from each other. Side arm plates large, meeting above and below; each plate carries six stout arm spines, of which the uppermost is longest and exceeds two joints; three lowest spines thickened and deeply notched (vertically) at tip, so that each one ends in two or three blunt points. Tentacle pores small; tentacle scales single, flat, smooth, rounded. Color (dried from alcohol), dirty yellowish-white.

Locality.-Albatross station 4784, off Attu Island, lat. $52^{\circ} 55^{\prime} 40^{\prime \prime}$ N.; long. $173^{\circ} 26^{\prime}$ E., 135 fathoms, coarse pebbles, 1 specimen.

Type.-Cat No. 25737, U.S.N.M., from station 4784 .

This species is so unlike any of the preceding or any of the previously known species that it can not be confused with them, but it is very near the following species (tylota), with which it was taken, and more abundant material may show that it is not specifically distinct.

\section{OPHIOLEBES TYLOTA, new species.a}

Disk $10 \mathrm{~mm}$. in diameter; arms about $40 \mathrm{~mm}$. long. Disk covered with coarse scales, many of which bear stout, blunt spines; these spines are thickest near base and are sometimes imperfectly divided or slightly branched. Radial shields triangular, in contact at inner distal angle but widely separated within. Upper arm plates rhombic, basal ones more or less rounded, about as long as wide, well separated from each other. Interbrachial spaces below much like disk above. Genital slits rather small. Oral shields rather small, rounded rhombic, very much wider than long. Adoral plates nearly as large, about twice as long as wide; oral plates well developed. Oral papillæ, three on a side and one at apex of jaw, long, thick, and blunt. First under arm plate squarish; second plate much larger, somewhat pentagonal, longer than wide; succeeding plates rapidly becoming wider than long, with distal margin curved and notched at the middle; all plates except first two separated from each other, though not always distinctly. Side arm plates large, meeting above, but not below, at base of arm; each plate carries six stout arm spines, of which the uppermost is longest and nearly equal to three joints; lower ones rough at tip and sometimes thickened and slightly notched. Tentacle pores moderate; tentacle scale single, flat, somewhat elongated, smooth, rounded at tip. Color (dried from alcohol), whitish, yellow, dirty brownish, or bright brown.

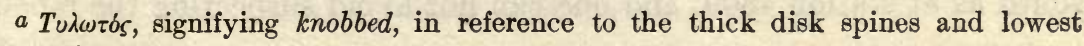
arm spines. 
Localities.-Albatross station 3599 , Bering Sea, lat. $52^{\circ} 5^{\prime} \mathrm{N}$.; long. $177^{\circ} 40^{\prime}$ E., 55 fathoms, rocky, fine sand, shells, 56 specimens; station 378.5, Bering Sea, north of Rat Islands, 270 fathoms, gray sand, broken shells, 1 specimen; station 4771 , Bering Sea, lat. $54^{\circ}$ $30^{\prime} \mathrm{N}$.; long. $179^{\circ} 17^{\prime}$ E., 426 fathoms, broken shells, 2 specimens; station 4781, off Agattu Island, lat. $52^{\circ} 14^{\prime} 30^{\prime \prime} \mathrm{N}$.; long. $174^{\circ} 13^{\prime} \mathrm{E}$., 482 fathoms, fine gray sand, pebbles, bottom temperature $38.6^{\circ}$, 22 specimens; station 4782 , off Attu Island, lat. $52^{\circ} 55^{\prime} \mathrm{N}$.; long. $173^{\circ} 27^{\prime}$ E., 57 to 59 fathoms, rocks, gravel, 2 specimens; station 4784 , off Attu Island, lat. $52^{\circ} 55^{\prime} 40^{\prime \prime}$ N.; long. $173^{\circ} 26^{\prime}$ E., 135 fathoms, coarse pebbles, 14 specimens; station 4809 , Sea of Japan, lat. $41^{\circ}$ $18^{\prime} \mathrm{N}$.; long. $140^{\circ} 8^{\prime} 40^{\prime \prime}$ E., 90 to 207 fathoms, gray sand, pebbles, broken shells, 4 specimens. Bathymetrical range, 55 to 482 fathoms.

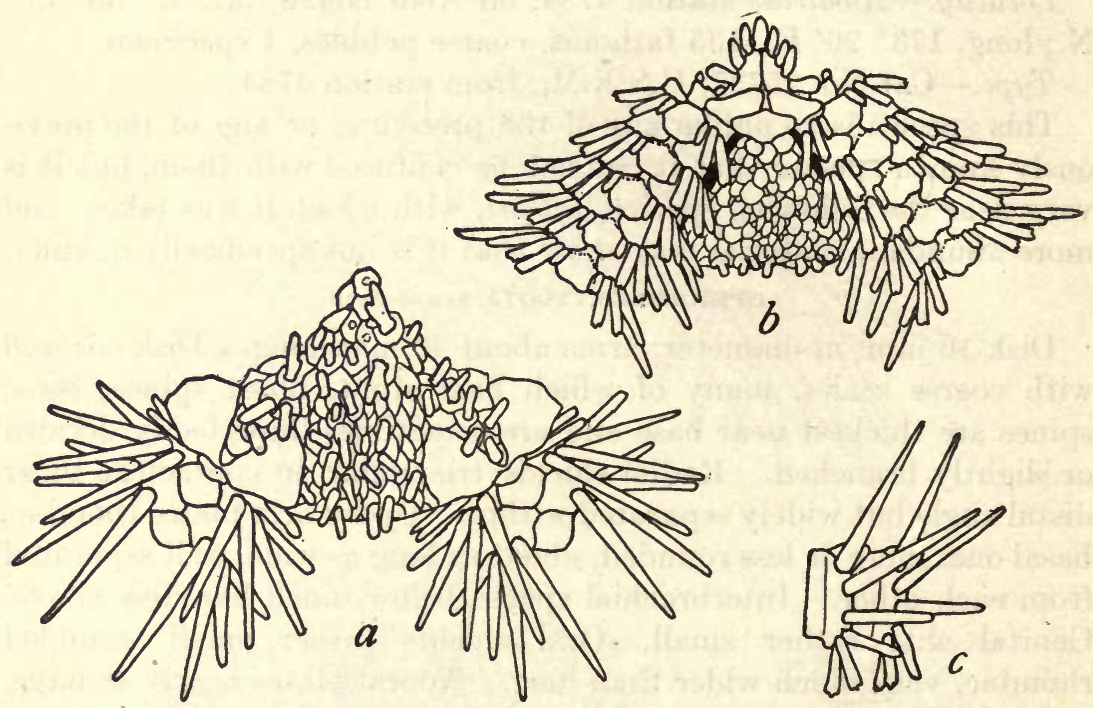

Fig. 117.-OPHIOLEBES TYLOTA. $\times$ 5. $a$, FROM ABOVE; $b$, FROM BELOW; $c$, SIDE VIEW OF TWO ARM JOINTS NEAR DISK.

Temperature range, ? to $38.6^{\circ}$. One hundred and one specimens.

Type.-Cat. No. 25726, U.S.N.M., from station 3599.

The characteristic disk-covering and arm spines are quite sufficient to distinguish this from any of the other species, but it must be confessed that the preceding species (pachybactra) is very closely related. The differences shown by the arm spines are of degree rather than of kind, but I find it hard to believe that the same is true of the disk spines. Possibly pachybactra is a "mutant" from tylota. The specimens from station 4809 are almost exactly like those from station 3785 , but have the disk spines much shorter than in the type. It is remarkable that this species should have been taken so far south as at station 4809 , and one can not avoid suspecting the label. 
Disk $11 \mathrm{~mm}$. in diameter; arms about $35 \mathrm{~mm}$. long. Disk covered by thick, rounded plates of variable size, upon and among which are scattered numerous coarse, rounded granules, which are largest around the radial shields. Radial shields large, oval, widely separated from each other. Upper arm plates rhombic, about as tong as wide. Interbrachial spaces below covered by rounded plates and granules like those of disk. Genital slits inconspicuous. Oral shields very small, rounded pentagonal, about as long as wide. Adoral plates twice as long as wide; oral plates moderate; all of these plates about the mouth are indistinct, due to the skin which covers them. Oral papillæ four on a side and one at apex of jaw; thick and rounded, or pointed at tip; outermost papilla much the largest. First under arm plate small, thick, squarish, or rounded; succeeding plates thick and swollen and poorly defined, on account of the skin covering. They seem to be wider than long, but their exact shape is hard to determine; all but the first two seem to be separated from each other. Side arm plates moderate, meeting slightly above but not below, somewhat thick and swollen. Each plate carries five to seven short, thick, blunt spines, of which the up-
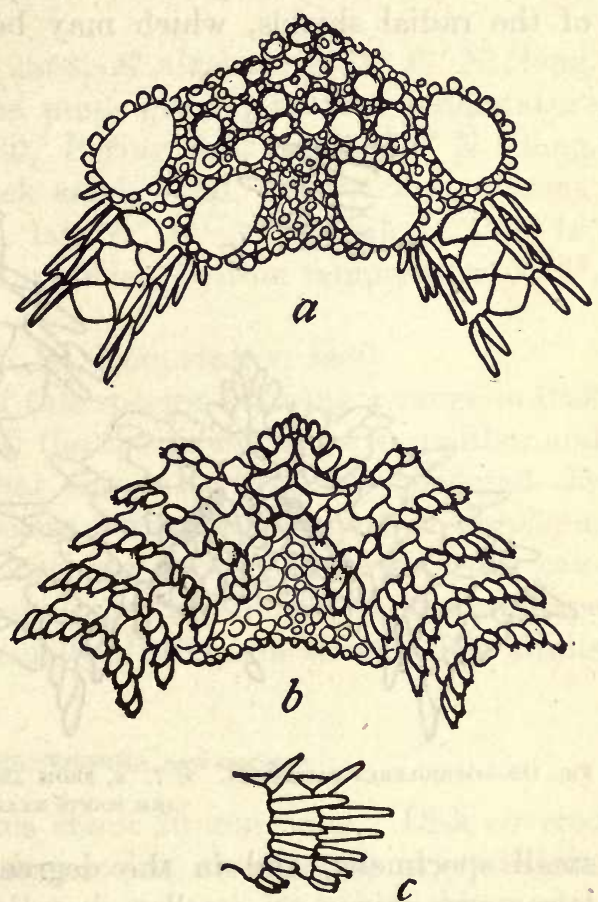

FIG. 118.-OPHOLEBES DIAPHORA. $\times$ 4.5. $a$, FROM ABOVE; $b$, FROM BELOW; $c$, SIDE VIEW OF TWO ARM JOINTS NEAR DISK.

permost or next lower is longest and equals a joint and a half; lower spines short and very stout, with rough, prickly tips; lowest spine may be almost spherical. Tentacle pores small; tentacle scale single, large, rounded, but rough at tip. Color (dried from alcohol), yellowish or yellowish-brown.

Localities.-Albatross station 3599, Bering Sea, lat. $52^{\circ} 5^{\prime}$ N.; long. $177^{\circ} 40^{\prime}$ E., 55 fathoms, rocky, fine sand, shells, 4 specimens; station 4779 , Bering Sea, lat. $52^{\circ} 11^{\prime}$ N.; long. $179^{\circ} 57^{\prime}$ W., 54 to 56 fathoms, 
broken shells, pebbles, sand, 2 specimens; station 4781, off Agattu Island, lat. $52^{\circ} 14^{\prime} 30^{\prime \prime} \mathrm{N}$.; long. $174^{\circ} 13^{\prime}$ E., 482 fathoms, fine gray sand, pebbles, bottom temperature $38.6^{\circ}, 8$ specimens; station 4784, off Attu Island, lat. $52^{\circ} 55^{\prime} 40^{\prime \prime}$ N.; long. $173^{\circ} 26^{\prime}$ E., 135 fathoms, coarse pebbles, 7 specimens. Bathymetrical range, 54 to 482 fathoms. Temperature range, ? to $38.6^{\circ}$. Twenty-one specimens.

Type.-Cat. No. 25721, U.S.N.M., from station 3599.

Although the type of this species comes from the same station where that of tylota was taken, the two species are so unlike they can not be confused. Specimens of diaphora show great diversity in the number of disk granules and arm spines, in the size and form of the radial shields, which may be quite small and indistinct in

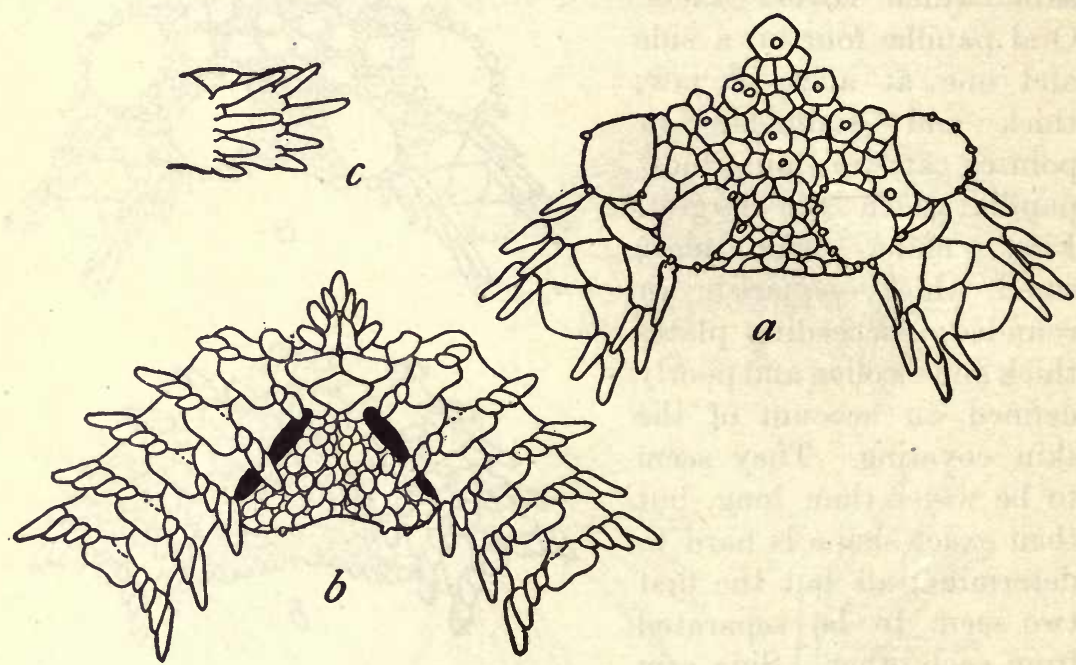

Fig. 119.-OPHIOLEBES PAUCISPINA. $\times$ 7. $a$, FROM ABOVE; $b$, FROM BELOW; $c$, SIDE VIEW OF TWO ARM JOINTS NEAR DISK.

small specimens, and in the degree to which the plates and the lower arm spines are swollen, but their identification is rarely difficult. Young specimens might, however, be confused with the next species, owing to their having only four or five arm spines and few disk granules.

OPHIOLEBES PAUCISPINA, new species. $a$

Disk $7 \mathrm{~mm}$. in diameter; arms about $22 \mathrm{~mm}$. long. Disk covered with coarse, thick scales, some of which bear rounded granules. Radial shields moderate, rounded, well separated from each other. Upper arm plates thick and more or less swollen, rounded, triangular or rhombic; except first two, separated from each other. Inter-

a Pauci, signifying few, and spinus, signifying a spine, in reference to the small number of arm spines. 
brachial spaces below covered by coarse scales. Genital slits large. Oral shields rhombic, wider than long. Adoral plates thick, about twice as long as wide; oral plates small. Oral papillæ, three on a side and one at apex, thick and blunt, outermost largest. Under arm plates tetragonal, much wider than long, the distal margin with more or less of a median notch; well separated from each other. Side arm plates large and somewhat swollen, meeting above and below. Each plate carries four short, thick, smooth arm spines, of which the uppermost or next lower is the longest, and hardly exceeds a joint. Tentacle pores minute or wanting; tentacle scale single, large, thick, rounded or bluntly pointed. Color (dried from alcohol), yellowish-brown.

Localities.-Albatross station 2858, off Alaska, lat. $58^{\circ} 17^{\prime} \mathrm{N}$.; long. $148^{\circ} 36^{\prime}$ W., 230 fathoms, blue mud, gravel, bottom temperature $39.8^{\circ}, 2$ specimens; station 3480 , Bering Sea, lat. $52^{\circ} 6^{\prime}$ N.; long. $171^{\circ} 45^{\prime}$ W., 283 fathoms, black sand, coral, rocky, 26 specimens; station 4781, off Agattu Island, lat. $52^{\circ} 14^{\prime} 30^{\prime \prime} \mathrm{N}$.; long. $174^{\circ} 13^{\prime}$ E., 482 fathoms, fine gray sand, pebbles, bottom temperature $38.6^{\circ}$, 2 specimens.

Type.-Cat. No. 25620, U.S.N.M., from station 3480.

There is an excellent series of this species, showing a range in disk diameter from 4 to $10 \mathrm{~mm}$. All the specimens agree in number and character of arm spines, so that this may well be considered the distinguishing mark of the species. Small specimens of diaphora, with only four or five arm spines, are hard to separate from paucispina, though the thicker granulation of the disk and the shape of the under arm plates will usually distinguish them. The adults can not be confused.

\section{OPHIOLEBES BREVISPINA, new species. $a$}

Disk $8 \mathrm{~mm}$. in diameter; arms about $20 \mathrm{~mm}$. long. Disk covered with thick, irregular, overlapping scales, showing no very definite arrangement and without granules or spines. Radial shields moderate, rounded, widely separated. Upper arm plates rounded, swollen, much wider than long, nearly or quite in contact on basal half of arm. Interbrachial spaces below, covered by thick scales. Genital slits short. Oral shields rhombic or pentagonal, about as long as wide. Adoral plates short and very wide, with inner ends rounded; oral plates large. Oral papillæ three on a side and one at apex of jaw, rounded or pointed at tip, outermost largest. Under arm plates tetragonal or pentagonal, wider than long, all but first two widely separated from each other. Side arm plates large, more or less swollen, meeting below and nearly or quite meeting above; each plate

a Brevis, signifying short, and spinus, signifying a spine, in reference to the very short arm spines. 
carries three or four small, very stout, blunt spines, of which the next to the lowest is longest, but scarcely equals half a joint. Tentacle pores apparently wanting, but tentacle scales well developed, single, thick and blunt or pointed. Color (dried from alcohol), yellowishbrown.

Locality.-Albatross station 3480 , Bering Sea, lat. $52^{\circ} 6^{\prime}$ N.; long. $171^{\circ} 45^{\prime}$ W., 283 fathoms, black sand, coral, rocky, 22 specimens.
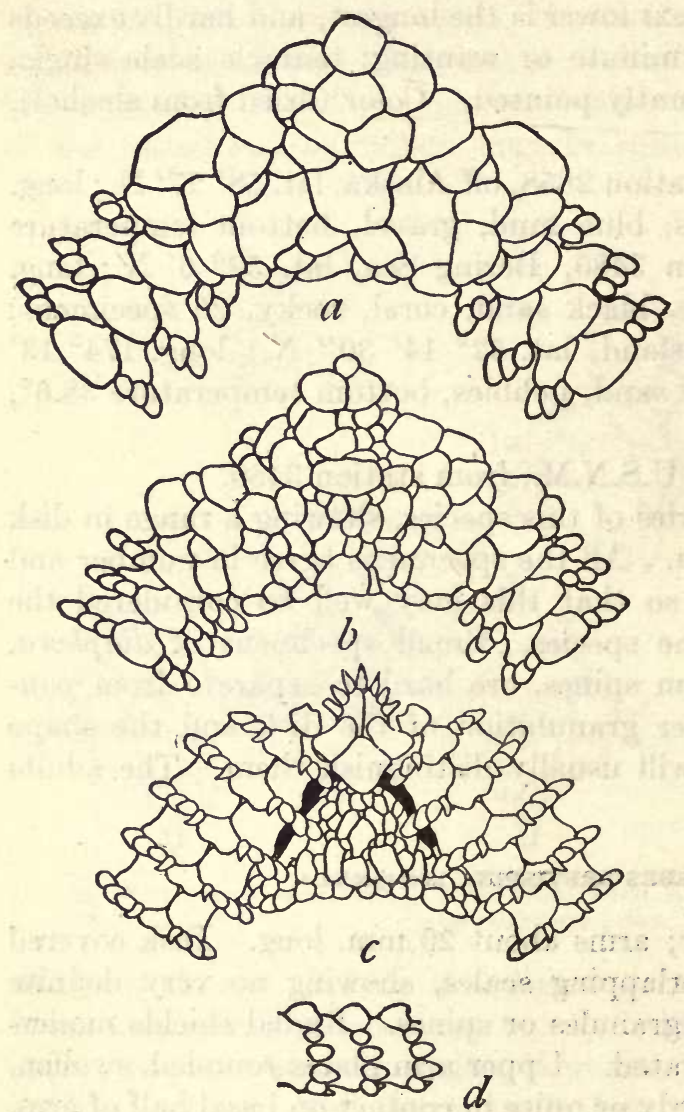

Fig. 120.-OPHOLEBES BREVISPINA. $a$, yOUNG SPECIMEN, FROM $\triangle B O V E, \times 8$. $b, \triangle D U L T$, FROM ABOVE, $\times 6$. $c$, FROM BELOW, $\times 6$. $d$, SIDE VIEW OF THREE ARM JOINTS OF ADULT NEAR DISK, $\times 6$,

Type.-Cat.No.25736, U.S.N.M., from station 3480 .

It is a curious coincidence that we should have here another case of a new species of Ophiolebes from the same station as its nearest relative, the type of $O$. paucispina having come from station 3480 . There does not seem to be any room for doubt, however, that the two species are really distinct, for the differences in disk covering and in arm spines are very marked and appear to be perfectly constant.

The foregoing seven species deserve a word of comment, as they form quite a homogeneous group, apparently characteristic of the Aleutian Island region and northern Japan. The two Japanese species are easily distinguished from the others by thelong and narrow radial shields. It is somewhat remarkable that none of the Aleutian species extends southward on the American coast. All of the species have the plates more or less covered by skin, but the extent to which they are obscured varies with the individual. As the drawings and descriptions have been made from dried specimens, little attention has been paid to this character. 


\section{OPHIOPHRURA, new genus. $a$}

Disk covered with a smooth coat of fine scales, entirely concealing the radial shields; oral tentacle scales very long and conspicuous; tentacle scales of arm numerous, three or four guarding each pore; otherwise as in Ophiacantha.

Type-species.-Ophiophrura liodisca.

Although obviously related to Ophiacantha, the following species is so well characterized it seems to me best to make it the type of a new genus. The smooth, finely scaled disk, without an external hint of radial shields, looks very different from any Ophiacantha I have seen, while the very long spine-like scales at the distal ends of the mouth slits and the numerous tentacle scales give the oral surface an equally characteristic appearance.

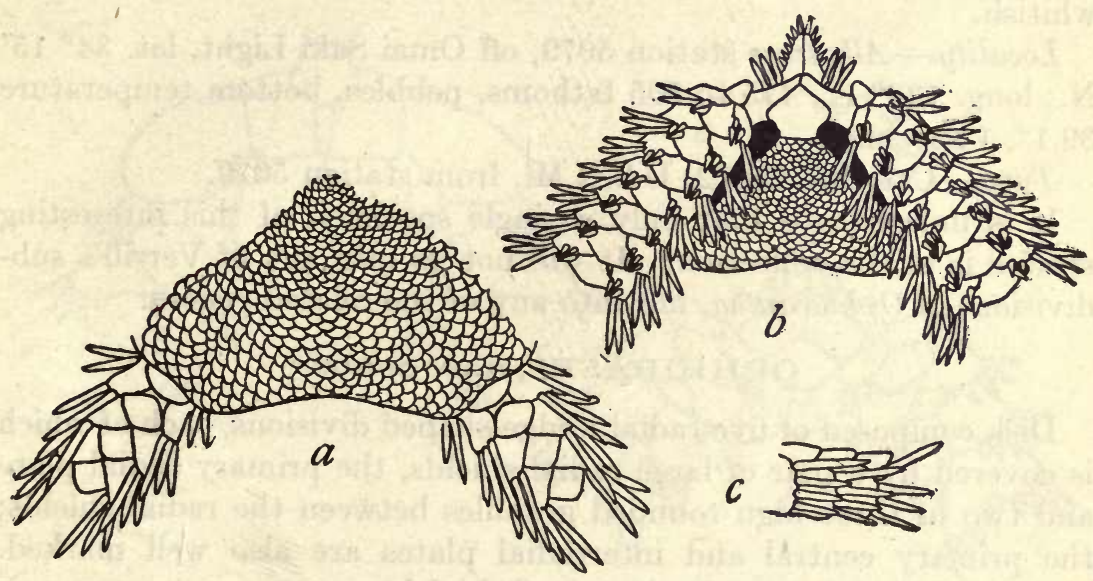

FiG. 121.-OPHIOPHRURA LIODISCA. $\times 6$. $a$, FROM ABOVE; $b$, FROM BELOW; $c$, SIDE VIEW OF THREE ARM JOINTS NEAR DISK.

\section{OPHIOPHRURA LIODISCA, new species. $b$}

Disk $8 \mathrm{~mm}$. in diameter; arms about 20 to $25 \mathrm{~mm}$. long, probably. Disk covered with a smooth coat of very fine scales which entirely conceal the radial shields. Upper arm plates rhomboidal with distal angle rounded, about as long as wide; basal ones nearly or quite in contact, but middle and distal ones well separated. Interbrachial spaces below covered like disk by fine scales. Genital slits large. Oral shields pentagonal, nearly as long as wide, disto-lateral sides concave. Adoral plates narrow and meeting within, broad without and separating oral shield from first side arm plate; oral plates long and narrow. Oral papillæ numerous, nine or ten on a side, of which

$a^{\prime} 0 \phi \iota 0$ and $\phi \rho o u \rho d$, signifying a guard, in reference to the numerous tentacle scales.

$b$ A'os, signifying smooth, and o'cokos, signifying disk, in reference to the absence of all spines and granules from the disk. 
the three distalmost are long, flat, pointed spines, serving as oral tentacle scales; remaining six or seven, small, narrow, and sharp. (The contrast between the inner and outer oral papillæ is not quite so abrupt as appears in fig. 121b.) First under arm plate small, thimbleshaped, longer than wide; succeeding plates hexagonal or heptagonal, longer than wide, more or less in contact. (The change in form in the under arm plates in fig. $121 b$, by which they become wider than long, is a mistake.) Side arm plates moderate, meeting narrowly or not at all above, and not at all below; each plate carries four flattened, hollow, fragile, bluntly pointed arm spines, of which the uppermost is longest and nearly equals two joints. Tentacle pores large, each one protected by three or four sharp, spiniform scales, of which one is on the under, the others on the side, arm plate. Color (dried from alcohol), disk grayish, arms and oral surface dirty whitish.

Locality.-Albatross station 5079, off Omai Saki Light, lat. $34^{\circ} 15^{\prime}$ N.; long. $138^{\circ}$ E., 475 to 505 fathoms, pebbles, bottom temperature $39.1^{\circ}, 1$ specimen.

Type.-Cat. No. 25672, U.S.N.M., from station 5079.

It is unfortunate that only a single specimen of this interesting species is in the collection. It will not go into any of Verrill's subdivisions of Ophiacantha, nor into any of the related genera.

\section{OPHIURASES, new genus. $a$}

Disk composed of five radial wedge-shaped divisions, each of which is covered by a pair of large radial shields, the primary radial plate and two or three high rounded granules between the radial shields; the primary central and interradial plates are also well marked. Mouth parts and arms much as in Ophiolebes.

\section{Type-species.-Ophioceramis (?) obstricta Lyman.}

That Lyman was in doubt as to the true relationships of this species is evident from the question mark with which he wrote the generic name. It seems to me that its relationships are with Ophiolebes, rather than with the Ophiolepididæ, for it agrees with that genus in its habits and arm structure very closely. But the difference in the disk is so marked, a new genus seems to be necessary. Kohler's Ophiogyptis is, I think, nearly related, but the under surface of the arms in that genus is quite different.

\section{OPHIURASES OBSTRICTUS.}

Ophioceramis (?) obstricta Lyman, Bull. Mus. Comp. Zoöl., vol. 5, 1878, p. 124.

Localities.-Albatross station 4890, Eastern Sea, lat. $32^{\circ} 26^{\prime} 30^{\prime \prime}$ N.; long. $128^{\circ} 36^{\prime} 30^{\prime \prime}$ E., 135 fathoms, rocky, bottom temperature

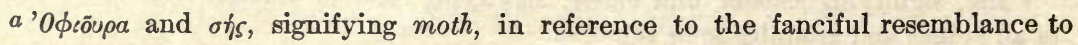
a thick-bodied moth at rest, of the radial wedges which compose the disk (fig. 122a). 
$52.3^{\circ}, 1$ specimen; station 4893 , Eastern Sea, lat. $32^{\circ} 32^{\prime}$ N.; long. $128^{\circ} 32^{\prime} 50^{\prime \prime}$ E., 95 to 106 fathoms, gray sand, broken shells, pebbles, bottom temperature $55.9^{\circ}, 1$ specimen; station 4895 , Eastern Sea, lat. $32^{\circ} 33^{\prime} 10^{\prime \prime} \mathrm{N}$.; long. $128^{\circ} 32^{\prime} 10^{\prime \prime}$ E., 95 fathoms, green sand, broken shells, pebbles, 2 specimens; station 4936, Eastern Sea, lat. $30^{\circ} 54^{\prime} 40^{\prime \prime} \mathrm{N}$.; long. $130^{\circ} 37^{\prime} 30^{\prime \prime}$ E., 103 fathoms, stones, bottom temperature $60.6^{\circ}, 2$ specimens. Bathymetrical range, 95 to 135 fathoms. Temperature range, $60.6^{\circ}$ to $52.3^{\circ}$. Six specimens.

Comparison of these individuals with a cotype of Lyman's in the Museum of Comparative Zoölogy collection leaves no room for doubt that they are identical. The Albatross specimens were taken clinging to sponges, hydroids, and corals, so that their habits seem to resemble those of Ophiolebes and some allied genera. As the figures given in the Challenger Ophiuroidea ${ }^{a}$ do not agree either with

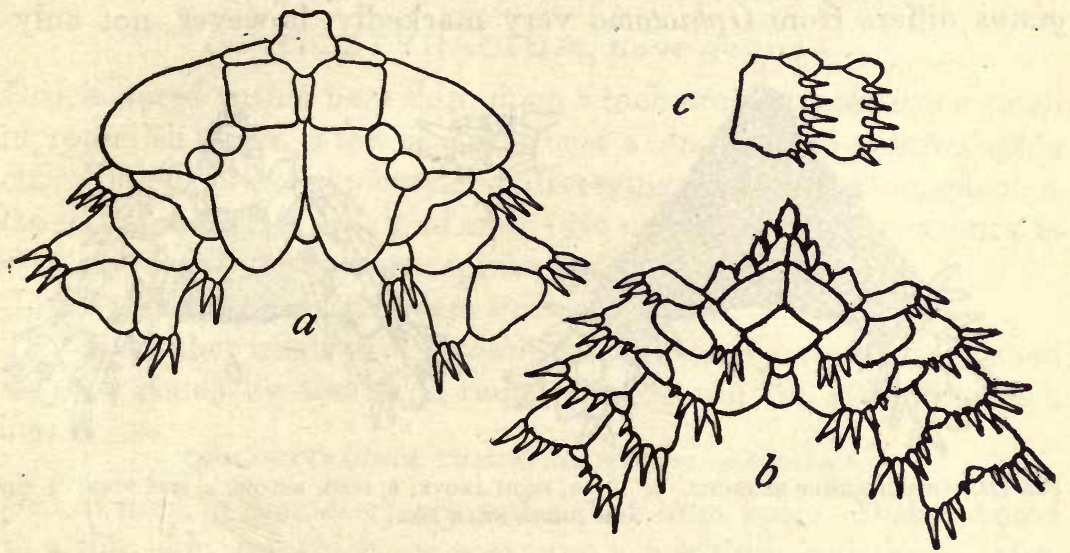

Fig. 122.-OPHIURASES OBSTRICTUS. $\times$ 10. $a$, FROM ABOVE; $b$, FROM BELOW; $c$, SIDE VIEW OF TWO ARM JOINTS NEAR DISK.

Lyman's description or with any of the specimens before me, it seems best to give new figures of this interesting little species. If I did not have a Challenger cotype for comparison, I should not criticise Lyman's figures, but should suppose I had a different species. As it is, I think Lyman's fig. 2 is erroneous in having the radial shields separated interradially, as well as radially by squarish plates, and his fig. 1 has the under arm plates very different from any specimen I have seen. In the figures given herewith the real appearance of both surfaces may be seen. It might be suggested that Lyman's figures were drawn from a larger and more mature specimen than those here given, but he gives the disk diameter as $4 \mathrm{~mm}$. and does not speak of any larger specimens. He refers to the first under arm plate as "rounded and conspicuous;" it is not so in any of the spec- 
imens before me. He calls the arm spines "blunt," while they seem to me to be unusually sharp. He says the "color in alcohol" is "pale brown;" all the specimens before me have the radial shields and bands on the arms grayish, the rest of the animal whitish; the degree of contrast varies much in different specimens, but is usually very slight.

\section{OPHIOLOGIMUS, new genus. ${ }^{a}$}

Disk covered by a fine coat of scales, more or less concealed by thin skin; both skin and scales extend out on base of arms. No visible radial shields. Upper and under arm plates well developed. Tentacle scales present. Oral papillæ numerous, but arm spines few.

Type-species. Ophiologimus hexactis.

This genus may be defined as Ophioscotex with well-developed upper arm plates, a definition used by Lyman for Ophiotoma. Ophiologimus differs frcm Ophiotoma very markedly, however, not only in

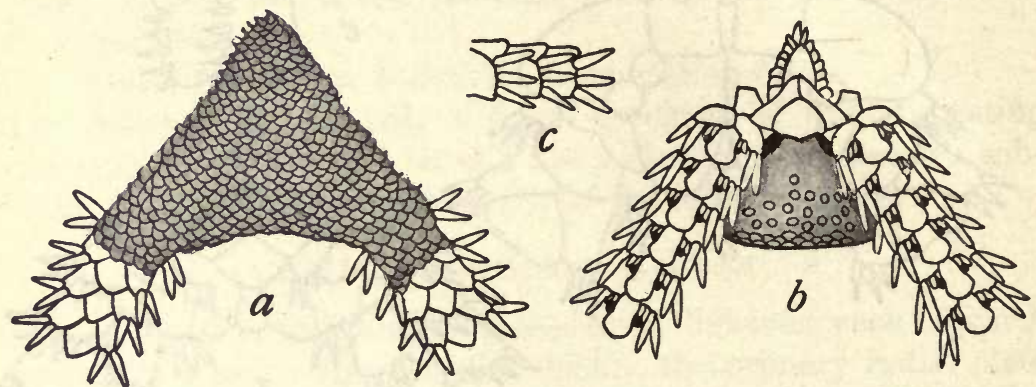

Fig. 123.-OPHIOLOGIMUS HeXACTIS. $\times$ 10. $a$, FROM ABOVE; $b$, FROM BELOW; $c$, SIDE VIEW OF THREE ARM JOINTS NEAR DISK.

disk covering but especially in the presence of well-developed tentacle scales.

OPHIOLOGIMUS HEXACTIS, new species. $b$

Disk $5 \mathrm{~mm}$. in diameter; arms, six, about $20 \mathrm{~mm}$. long. Disk covered by a close coat of fine scales, more or less concealed by skin. No visible radial shields. Bases of arms covered like disk. Upper arm plates thin but well developed, rhombic with distal angle rounded, longer than wide, more or less overlapping. Interbrachial spaces below covered by skin, which contains, peripherally, scattered scales. Genital slits rather small. Oral shields rounded triangular, wider than long. Adoral plates large, three times as long as wide, meeting broadly within and separating oral shield from first under arm plate without; oral plates indistinct. Oral papillæ numerous, very small, thin and truncate; outer ones largest. First under arm plate pen-

$a^{\prime} 0 \phi e o$ and $\lambda b \gamma c \mu o s$, signifying worthy of mention, remarkable.

$b^{\prime \prime} E \xi$, signifying six, and aktis, signifying ray, in reference to the number of arms. 
tagonal; succeeding plates pentagonal, quickly becoming tetragonal, with distal side convex; all are longer than wide and more or less fully in contact. Side arm plates small, not meeting either above or below; each plate carries three hollow, flat, smooth, bluntly pointed, subequal arm spines, about as long as a joint. Tentacle pores large, each one guarded by two flat, thin, rounded, subequal scales. Color (dried from alcohol), pale brown or dirty whitish.

Locality.-Albatross station 3749, off Suno Saki, Honshu Island, Japan, 83 to 158 fathoms, black sand, shells, 1 specimen.

Type.-Cat. No. 25724, U.S.N.M., from station 3749.

It is a great pity that the Fisheries steamer Albatross, in her later, more extensive collecting around Japan, failed to meet with this species again. It resembles an Ophioscolex, but the upper arm plates are so well marked and the two tentacle scales so distinct and regular, it will not be confused with any known species of that genus.

\section{OPHIOSTYRACIUM, new genus. ${ }^{a}$}

Disk covered with a bare skin, upon which are scattered some small thin, roundish plates, a few of which bear a single sharp-pointed spine each. Radial shields evident, long, diverging, each with a conspicuous spike-like spine on its proximal end. No upper arm plates or tentacle scales. Oral papillæ and arm spines few.

Type species.-Ophiostyracium trachyacanthum.

This is another relative of Ophioscolex, but is at once distinguished from that genus by the large radial shields and the spike-like disk spines.

\section{OPHIOSTYRACIUM TRACHYACANTHUM, new species. $b$}

Disk $6 \mathrm{~mm}$. in diameter; arms about $25 \mathrm{~mm}$. long. Disk covered with a thin skin, on which are scattered a few thin, indistinct scales, the more conspicuous of which carry long, sharp spines. Radial shields large, thick, three times as long as wide, rounded at the ends, nearly or quite touching distally but diverging widely within. Each shield carries near its proximal end a very large, sharp, spike-like spine. Upper arm plates wanting. Interbrachial space below bare. Genital slits very large. Oral shield rounded pentagonal, wider than long, with disto-lateral sides concave. Adoral plates very large, meeting broadly within, and separating oral shield from side arm plates without; oral plates and oral tentacle pores conspicuous. Oral papillæ spiniform, three on a side and one at apex of jaw; distalmost smallest, short, rounded, looking as though it arose from first under arm plate, below oral tentacle pore. First under arm plate roundish; succeeding plates tetragonal, with rounded corners, and

$a$ " $0 \phi \iota 0$ and $\sigma \tau$ odkıov, signifying a small spike, in reference to the spike-like spines on the disk.

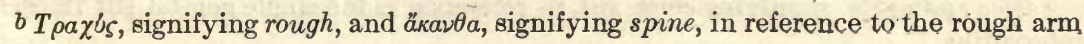
spines. 
after the third well separated and with very indistinct outlines. Side arm plates rather large, not quite meeting either above or below; each plate carries three solid, flattened, serrate or rough, bluntly pointed arm spines, of which the middle one is longest and slightly exceeds a joint; base of spine white and opaque, like side arm plate, but remainder glassy. Tentacle pores very large, but no tentacle scales. Color (dried from alcohol), disk dark greenish, radial shields pure white, arms and oral surface, whitish.

Locality.-Albatross station 4919, Eastern Sea, lat. $30^{\circ} 34^{\prime} \mathrm{N}$.;

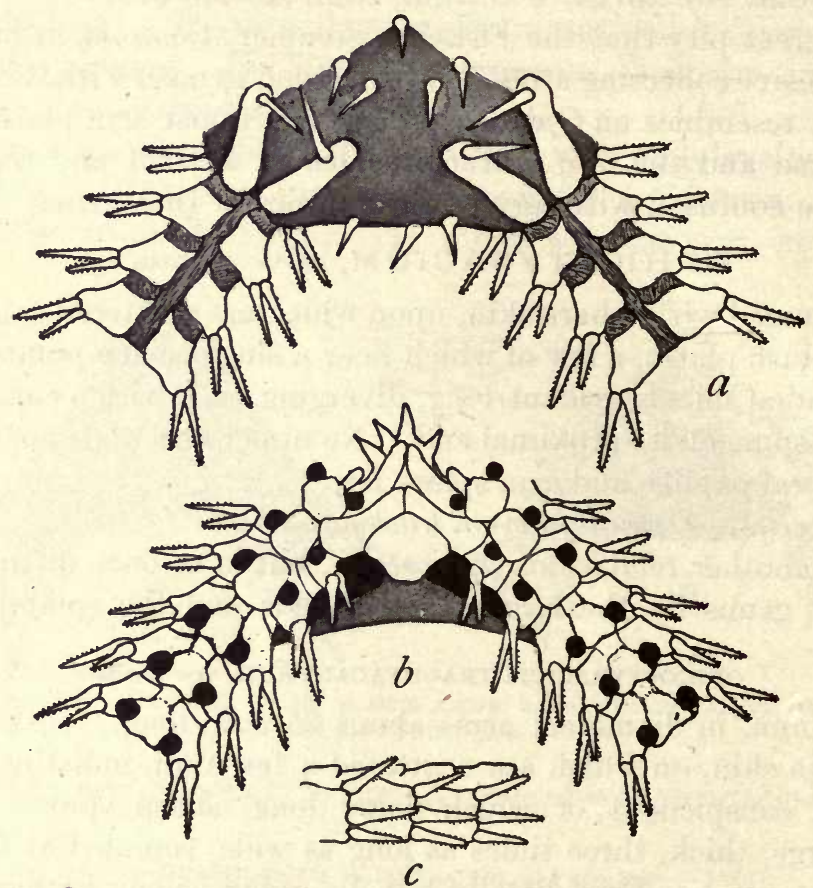

Fig. 124.-OPhostyracium trachyacanthum. $\times$ 9. $a$, From ABOVE; $b$, From BELOW; $c$, SIDE VIEW OF THREE ARM JOINTS NEAR DISK.

long. $129^{\circ} 19^{\prime} 30^{\prime \prime}$ E., 440 fathoms, globigerina ooze, oottom temperature $41.8^{\circ}, 1$ specimen.

Type.-Cat. No. 25733, U.S.N.M., from station 4919.

This individual is well preserved and its remarkable features stand out distinctly, so that one wishes more than usually that a good series were available.

OPHIOSCHIZA, new genus. $a$

Disk covered with irregular plates and large radial shields. Upper arm plates wanting, except one or two rudimentary ones at base of

$a^{\prime \prime} 0 \phi_{\ell}$ and $\sigma \chi \zeta \zeta a$, signifying crack, slit, in reference to the single genital slit in each interradius. 
arm. Oral shields wanting, except in one interradius. Under arm plates numerous, forming an irregular pavement. No tentacle scales. Arm spines reduced in number and size, with hooked tip. Genital slit single in each interradius, just distal to adoral plates.

Type-species.-Ophioschiza monacantha.

This is one of the most remarkable ophiurans in the collection, the combination of a well-scaled disk, with the absence of upper arm plates and oral shields and the presence of hooked arm spines being most unusual, while the occurrence of a single genital slit in each interbrachial space is certainly unique. The relationships of such a strange form are most obscure but it is almost certain that it does not belong here. The tips of the arms are spirally coiled as in Asteronyx and its allies and $I$ am inclined to think that Ophioschiza is probably one of the Cladophiuræ.

OPHIOSCHIZA MONACAN rHA, new

Disk $6 \mathrm{~mm}$. in diameter; arms about $20 \mathrm{~mm}$. long. Disk flat, covered with a coat of coarse scales, of which two in each interradius are larger than the others. Radial shields very large, twice as long as broad, separated from each other by a narrow strip of small scales. Upper arm plates wanting save for one or two rudimentary ones at very base of arm. Inter-

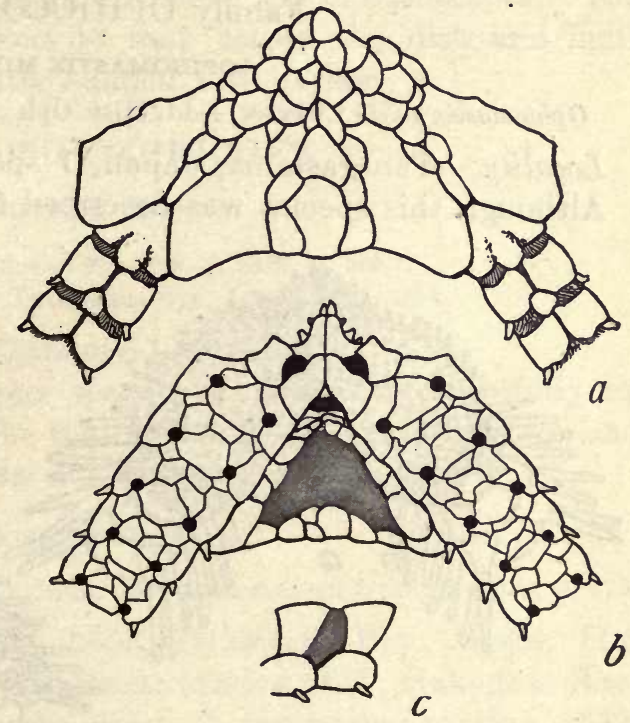

Fig. 125.-OPHIOSCHIZA MONACANTHA. $X$ 9. $a$, FROM ABOVE; $b$, FROM BELOW; $c$, SIDE VIEW OF TWO ARM JOINTS NEAR DISK.

brachial spaces below covered with bare skin but entirely surrounded by coarse scales. Genital slit, short, oblong, placed transversely in proximal angle of interbrachial space. Oral shields wanting except in one interradius, where a rudimentary one much wider than long lies proximal to genital slit. Adoral plates large and distinct, hardly twice as long as wide, meeting broadly within; oral plates moderate but oral tentacle pores very large. Oral papillæ rudimentary, three or four on a side. First under arm plate large, pentagonal, longer than wide; succeeding plates broken up into an irregular pavement, the component parts of which are

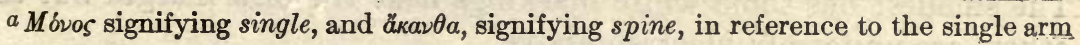
spine. 
more or less indistinct. Side arm plates very low, rounded, each with a single, short blunt spine, not one-third as long as joint; under the microscope this spine is seen to have the hook-shape so characteristic of Cladophiuræ. Tentacle pores distinct, but tentacle scales entirely wanting. Color (dried from alcohol), pale yellowish.

Locality.-Albatross station 3480 , Bering Sea, lat. $52^{\circ} 6^{\prime} \mathrm{N}$.; long. $171^{\circ} 45^{\prime}$ W., 283 fathoms, black sand, coral, rocky, 1 specimen.

Type.-Cat. No. 25735, U.S.N.M., from station 3480.

Further material of this interesting ophiuran will be necessary before its real relationships can be positively determined. There is a possibility that the type-specimen is immature. The single oral shield present may very likely be the madreporite.

\section{Family OPHIOCOMID无.}

\section{OPHIOMASTIX MIXTA.}

Ophiomastix mixta Lürken, Add. Hist. Oph., pt. 3, 1869, p. 44.

Locality.-Tanegashima, Japan, 1 specimen.

Although this species was described forty years ago, it has never

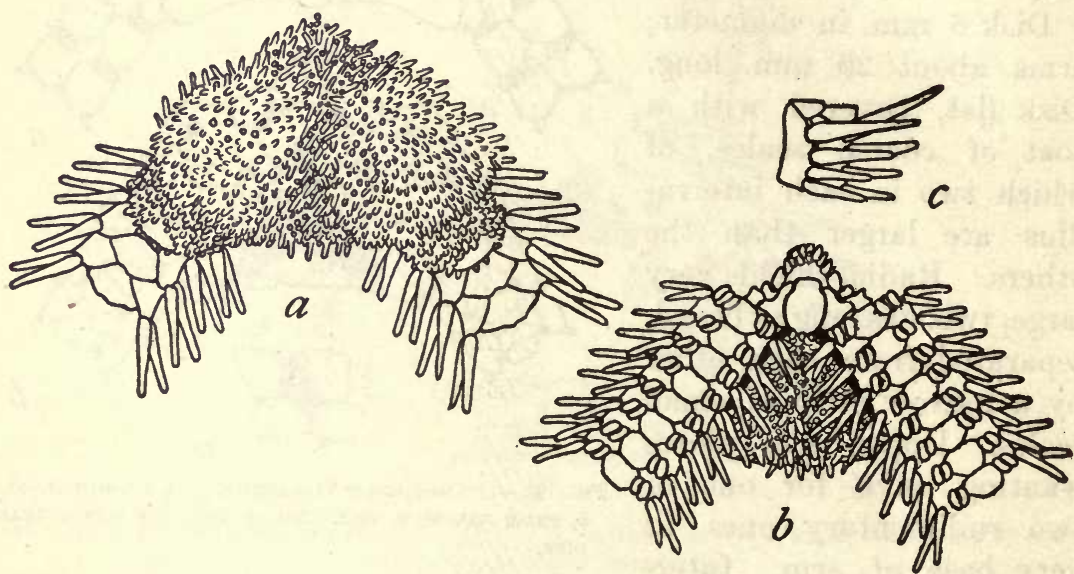

Fig. 126.-OPHOMASTIX MiXTA. $\times 3 . a$, FROM ABOVE; $b$, FROM BELOW; $c$, SIDE VIEW OF TWO ARM JOINTS NEAR DISK.

been figured, so it seems worth while to illustrate its principal features here. The specimen before me has three tentacle scales on each of the basal arm pores, but this is not characteristic of the species.

\section{OPHIOCOMA BREVIPES.}

Ophiocoma brevipes Peters, Arch. f. Naturg., vol. 18 (1), 1852, p. 85.

Locality.-Tanegashima, Japan, 1906, 6 specimens.

The disk diameter of these individuals ranges from 8 to $27 \mathrm{~mm}$. The smallest has some white markings near the disk margin but the others are uniformly blackish above. 


\section{OPHIOCOMA ERINACEA.}

Ophiocoma erinaceus Müller and Troschel, Sys. Ast., 1842, p. 98.

Locality.-Kagoshima Bay, Japan, 1 specimen.

The disk diameter of this specimen is $23 \mathrm{~mm}$. and the upper arm spines are remarkably long, 8 to $10 \mathrm{~mm}$. The specific name has always been written erinaceus, but there seems to be no good reasen why it should not conform in gender to the generic name.

\section{OPHIOPTERIS PAPILLOSA.}

Ophiocoma papillosa Lyman, Ill. Cat. Mus. Comp. Zoöl., vol. 8, pt. 2, 1875. p. 11.

Locality.-Monterey, California, 8 to 12 fathoms, 3 specimens.

There seems to be no question that this species is congeneric with $O$. antipodum, although it has hitherto been left in Ophiocoma. The specimens before me are about $13 \mathrm{~mm}$. across the disk and light brown in color, the arms faintly banded with darker.

\section{Family OPHIOTHRICIDE.}

OPHIOTHRIX CILIARIS.

Ophiura ciliaris Lamarck, Anim. s. Vert., vol. 2, 1816, p. 545.

Ophiothrix ciliaris Müller and Troschel, Sys. Ast., 1842, p. 114.

Locality.-Kobe, Japan, 8 fathoms, 1 specimen.

This is one of the Challenger specimens, identified doubtfully by Lyman as ciliaris. It is unlike that species in certain characters, and I suspect it is probably a form of koreana.

\section{OPHIOTHRIX KOREANA.}

Ophiothrix koreana Duncan, Jour. Linn. Soc. London (Zool.), vol. 14, 1879, p. 473.

Localities.-Albatross station 3656, Hakodate Bay, Japan, 11.5 fathoms, green mud, sand, 1 specimen; station 3657, Hakodate Bay, Japan, 13.5 fathoms, fine gray sand, 2 specimens; station 3659 , Hakodate Bay, Japan, 15.5 fathoms, fine gray sand, 1 specimen; station 3661, Gulf of Tokyo, Japan, 169 fathoms, mud, pebbles, 2 specimens; station 3698, off Manazuru Zaki, Japan, 153 fathoms, green mud, volcanic ashes, sand, 9 specimens; station 3702 , off Seno Umi, Japan, 31 to 41 fathoms, volcanic mud, sand, rocks, 1 specimen; station 3704, off Seno Umi, Japan, 94 to 150 fathoms, fine volcanic sand, 2 specimens; station 3707, off Ose Zaki, Japan, 63 to 75 fathoms, volcanic sand, ashes, gravel, 20 specimens; station 3713, off Ose Zaki, Japan, 45 to 48 fathoms, volcanic sand, shells, rocks, 1 specimen; station 3716, off Ose Zaki, Japan, 65 to 125 fathoms, volcanic sand, shells, rocks, 4 specimens; station 3717 , off Ose Zaki, Japan, 63 to 100 fathoms, volcanic sand, shells, rocks, 10 specimens; station 3720 , off Ose Zaki, Japan, 63 fathoms, volcanic sand, shells, 2 specimens; 
station 3725, off Noma Saki, Japan, 13 fathoms, sand, shells, gravel, 2 specimens; station 3730 , off Omai Zaki, Japan, 34 to 37 fathoms, mud, gravel, rocks, 6 specimens; station 3741, off Ose Zaki, Japan, 63 to 68 fathoms, volcanic sand, shells, pebbles, 5 specimens; station 3752 , off Suno Saki, Japan, 54 to 100 fathoms, gray sand, gravel, 12 specimens; station 3755 , off Suno Saki, Japan, 52 to 77 fathoms, gray sand, coral, 3 specimens; station 3756, off Suno Saki, Japan, 50 to 77 fathoms, rotten coral, 4 specimens; station 3757 , off Suno Saki, Japan, 41 to 50 fathoms, coarse coral sand, gravel, 1 specimen; station 3758, off Suno Saki, Japan, 52 to 73 fathoms, blue clay, rocks, 2 specimens; station 3764 , off Suno Saki, Japan, 44 to 50 fathoms, fine gravel, broken shells, 7 specimens; station 4807, Sea of Japan, lat. $41^{\circ} 36^{\prime} 12^{\prime \prime} \mathrm{N}$.; long. $140^{\circ} 36^{\prime} \mathrm{E}$., 44 to 47 fathoms, shells, coarse gravel, 1 specimen; station 4808 , Sea of Japan, lat. $41^{\circ} 35^{\prime} 50^{\prime \prime} \mathrm{N}$.; long. $140^{\circ} 36^{\prime} 45^{\prime \prime}$ E., 47 fathoms, sand, shells, coarse gravel, 3 specimens; station ' 4816 , Sea of Japan, lat. $38^{\circ} 14^{\prime}$ N.; long. $138^{\circ} 54^{\prime}$ E., 64 fathoms, fine gray sand, bottom temperature $51.7^{\circ}, 2$ specimens; station 4826 , Sea of Japan, lat. $37^{\circ} 25^{\prime}$ N.; long. $137^{\circ} 32^{\prime}$ E., 114 fathoms, fine gray sand, black specks, bottom temperature $42.5^{\circ}$, 3 specimens; station 4832 , Sea of Japan, lat. $36^{\circ} 14^{\prime} 30^{\prime \prime}$ N.; long. $135^{\circ} 56^{\prime} 30^{\prime \prime}$ E., 76 to 79 fathoms, dark gray sand, bottom temperature $53.2^{\circ}, 5$ specimens; station 4833 , Sea of Japan, lat. $36^{\circ} 13^{\prime}$ $40^{\prime \prime} \mathrm{N}$.; long. $135^{\circ} 56^{\prime} 30^{\prime \prime}$ E., 79 fathoms, dark gray sand, rocks, bottom temperature $53.2^{\circ}, 66$ specimens; station 4842 , coast of Korea, lat. $36^{\circ} 13^{\prime} \mathrm{N}$.; long. $133^{\circ} 27^{\prime}$ E., 82 fathoms, fine gray sand, shells, bottom temperature $54.6^{\circ}, 6$ specimens; station 4875 , Korea Strait, lat. $34^{\circ} 19^{\prime} \mathrm{N}$.; long. $130^{\circ} 9^{\prime}$ E., 59 fathoms, fine gray sand, broken shells, 6 specimens; station 4876 , Korea Strait, lat. $34^{\circ} 20^{\prime} \mathrm{N}$; long. $130^{\circ} 10^{\prime}$ E., 59 fathoms, fine gray sand, broken shells, bottom temperature $62.1^{\circ}, 27$ specimens; station 4877 , Korea Strait, lat. $34^{\circ} 20^{\prime} 30^{\prime \prime} \mathrm{N}$.; long. $130^{\circ} 11^{\prime}$ E., 59 fathoms, fine gray sand, broken shells, 11 specimens; station 4878 , Korea Strait, lat. $34^{\circ} 18^{\prime} 30^{\prime \prime} \mathrm{N}$.; long. $130^{\circ} 14^{\prime} 30^{\prime \prime}$ E., 59 fathoms, fine gray sand, broken shells, 5 specimens; station 4885 , Eastern Sea, lat. $32^{\circ} 31^{\prime} 30^{\prime \prime}$ N.; long. $129^{\circ}$ $30^{\prime} 15^{\prime \prime}$ E., 53 fathoms, dark gray sand, broken shells, 3 specimens; station 4888 , Eastern Sea, lat. $32^{\circ} 26^{\prime}$ N.; long. $129^{\circ} 27^{\prime} 30^{\prime \prime}$ E., 71 fathoms, dark gray sand, broken shells, 1 specimen; station 4891, Eastern Sea, lat. $32^{\circ} 27^{\prime}$ N.; long. $128^{\circ} 34^{\prime}$ E., 181 fathoms, gray sand, broken shells, rocks, bottom temperature $50.2^{\circ}, 2$ specimens; station 4893, Eastern Sea, lat. $32^{\circ} 32^{\prime}$ N.; long. $128^{\circ} 32^{\prime} 50^{\prime \prime}$ E., 106 fathoms, gray sand, broken shells, pebbles, bottom temperature $55.9^{\circ}, 33$ specimens; station 4894 , Eastern Sea, lat. $32^{\circ} 33^{\prime}$ N.; long. $128^{\circ}$ $32^{\prime} 10^{\prime \prime}$ E., 95 fathoms, green sand, broken shells, pebbles, 3 specimens; station 4895 , Eastern Sea, lat. $32^{\circ} 33^{\prime} 10^{\prime \prime}$ N.; long. $128^{\circ}$ $32^{\prime} 10^{\prime \prime}$ E., 95 fathoms, green sand, broken shells, pebbles, 1 specimen; 
station 4900 , Eastern Sea, lat. $32^{\circ} 28^{\prime} 50^{\prime \prime}$ N.; long. $128^{\circ} 34^{\prime} 40^{\prime \prime}$ E., 139 fathoms, gray sand, broken shells, bottom temperature $52.9^{\circ}$, 14 specimens; station 4901 , Eastern Sea, lat. $32^{\circ} 30^{\prime} 10^{\prime \prime} \mathrm{N}$.; long. $128^{\circ} 34^{\prime} 40^{\prime \prime}$ E., 139 fathoms, gray sand, broken shells, 5 specimens; station 4902 , Eastern Sea, lat. $32^{\circ} 30^{\prime} 50^{\prime \prime}$ N.; long. $128^{\circ} 34^{\prime} 40^{\prime \prime}$ E. 139 fathoms, gray sand, broken shells, 3 specimens; station 4903 , Eastern Sea, lat. $32^{\circ} 31^{\prime} 10^{\prime \prime}$ N.; long. $128^{\circ} 33^{\prime} 20^{\prime \prime}$ E., 107 to 139 fathoms, gray sand, broken shells, 26 specimens; station 4933, Eastern Sea, lat. $30^{\circ} 59^{\prime}$ N.; long. $130^{\circ} 29^{\prime} 50^{\prime \prime}$ E., 152 fathoms, rocky, bottom temperature $56^{\circ}, 1$ specimen; station 4934 , Eastern Sea, lat. $30^{\circ} 58^{\prime} 30^{\prime \prime}$ N.; long. $130^{\circ} 32^{\prime}$ E., 103 to 152 fathoms, rocky, 2 specimens; station 4937 , Kagoshima Gulf, lat. $31^{\circ} 13^{\prime} \mathrm{N}$.; long. $130^{\circ} 43^{\prime} 10^{\prime \prime}$ E., 58 fathoms, mud, lava, pebbles, bottom temperature $64.8^{\circ}, 32$ specimens; station 4946 , off southern Japan, lat. $31^{\circ} 29^{\prime} 10^{\prime \prime} \mathrm{N}$.; long. $130^{\circ} 34^{\prime} 30^{\prime \prime}$ E., 39 fathoms, brown sand, broken shells, pebbles, bottom temperature $68.7^{\circ}, 1$ specimen; station 4947 , off southern Japan, lat. $31^{\circ} 28^{\prime} 20^{\prime \prime}$ N.; long. $130^{\circ} 35^{\prime} 30^{\prime \prime}$ E., 51 fathoms, 1 specimen; station 5055, Suruga Gulf, lat. $34^{\circ} 53^{\prime} \mathrm{N}$.; long. $138^{\circ} 44^{\prime} 15^{\prime \prime}$ E., 124 fathoms, green mud, gray sand, broken shells, pebbles, bottom temperature $56.6^{\circ}, 2$ specimens; station 5068 , Suruga Gulf, lat. $35^{\circ} 2^{\prime} 25^{\prime \prime}$ N.; long. $138^{\circ} 46^{\prime} 55^{\prime \prime}$ E., 77 to 131 fathoms, black sand, broken shells, bottom temperature $63^{\circ}, 1$ specimen; station 5069, Suruga Gulf, lat. $35^{\circ} 3^{\prime} 10^{\prime \prime} \mathrm{N}$.; long. $138^{\circ} 47^{\prime}$ E., 108 to 131 fathoms, mud, sand, broken shells, bottom temperature $55.8^{\circ}, 11$ specimens; station 5070 , Suruga Gulf, lat. $35^{\circ} 3^{\prime} 25^{\prime \prime}$ N.; long. $138^{\circ} 47^{\prime} 40^{\prime \prime}$ E., 108 fathoms, mud, sand, broken shells, bottom temperature $57.6^{\circ} ; 8$ specimens; station 5091, Uraga Strait, lat. $35^{\circ} 4^{\prime} 10^{\prime \prime} \mathrm{N}$.; long. $139^{\circ} 38^{\prime} 12^{\prime \prime}$ E., 197 fathoms, green mud, coarse black sand, pebbles, bottom temperature $47.6^{\circ}, 6$ specimens; station 5092, Uraga Strait, lat. $35^{\circ} 4^{\prime} 50^{\prime \prime}$ N.; long. $139^{\circ} 38^{\prime} 18^{\prime \prime}$ E., 70 fathoms, coarse black sand, bottom temperature $56.3^{\circ}, 3$ specimens; station 5093, Uraga Strait, lat. $35^{\circ} 3^{\prime} 15^{\prime \prime} \mathrm{N}$.; long. $139^{\circ}$ $37^{\prime} 42^{\prime \prime}$ E., 302 fathoms, coarse black sand, bottom temperature $43.9^{\circ}, 1$ specimen; station 5094, Uraga Strait, lat. $35^{\circ} 4^{\prime} 42^{\prime \prime} \mathrm{N}$.; long. $139^{\circ} 38^{\prime} 20^{\prime \prime}$ E., 88 fathoms, black sand, broken shells, bottom temperature $54.8^{\circ}, 5$ specimens; station 5095 , Uraga Strait, lat. $35^{\circ}$ $5^{\prime} 34^{\prime \prime}$ N.; long. $139^{\circ} 38^{\prime} 36^{\prime \prime}$ E., 58 fathoms, fine black sand, broken shells, bottom temperature $57.8^{\circ}, 14$ specimens. Bathymetrical range, $11 \frac{1}{2}$ to 302 fathoms. Temperature range, $68.7^{\circ}$ to $42.5^{\circ}$. Four hundred and eleven specimens.

There is no doubt that this is a most variable species and these specimens ranging in disk diameter from 3 to $17 \mathrm{~mm}$., reveal it to a remarkable degree. They vary in color, in abundance and size of disk stumps and spines, in slenderness of arm spines and in degree to which radial shields are bare, and extremes in any one of these 
points may agree well in others. Few of the specimens answer to Duncan's description of the color, but the majority have the longitudinal white stripe on upper side of arm more or less distinct. Greenish, whitish, gray, and brown tints are more common than red in dried specimens. The arms are often banded with light and dark shades. The radial shields are usually bare, but are often partly, and sometimes wholly covered with the more or less trifid stumps. In some specimens there are no spines on the disk, only the trifid stumps; in others the disk spines are more numerous than the stumps, and the latter are occasionally very few. The relative length of the thorns and the base, of the stumps, and the degree to
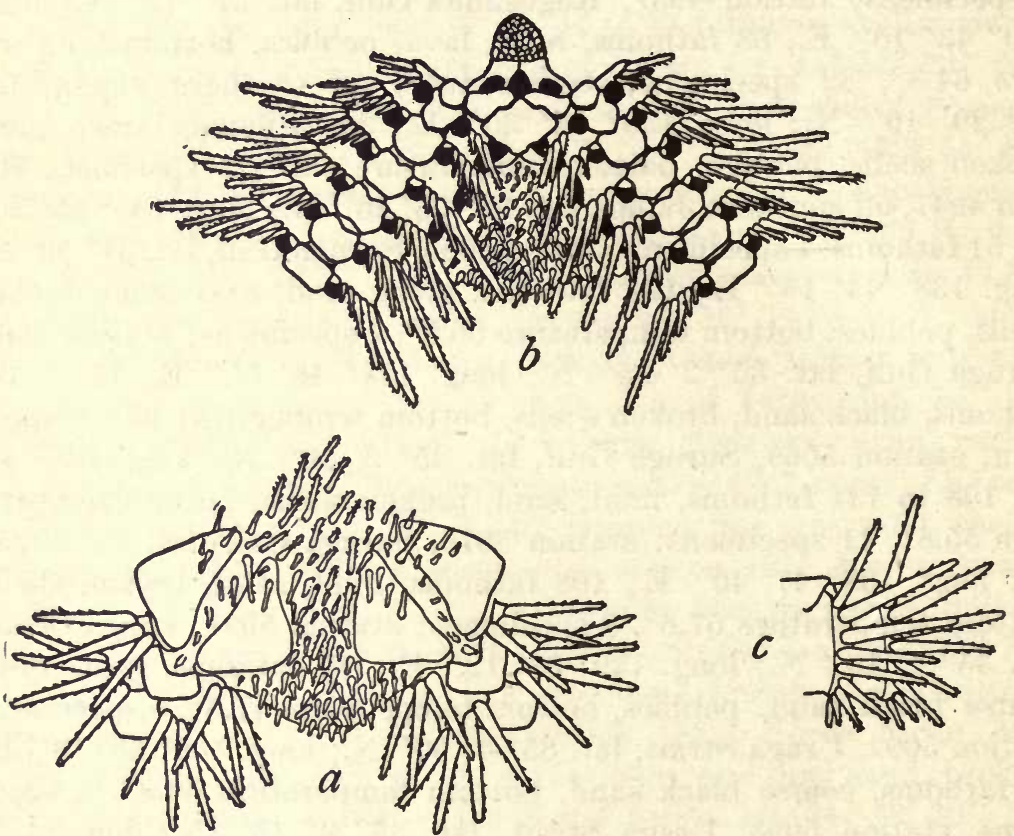

FIG. 127.-OPHIOTHRIX KOREANA. $\times$ 3. $a$, FROM ABOVE; $b$, FROM BELOW; $c$, SIDE VIEW OF TWO ARM JOINTS NEAR DISK.

which the thorns are united to each other by membrane vary greatly. In some specimens the stumps are practically wanting and the disk spines very long and crowded; these specimens are so different from typical koreana that I attempted to separate them as a distinct species but connecting links are too numerous to permit one to follow that course. The arm spines are usually slender and somewhat tapering, not rarely almost acicular though rough, but they are sometimes stouter and very blunt; occasionally they are flattened; the lowest forms a hook, as described by Duncan, but this very inconspicuous feature is not at all diagnostic, for the same structure occurs to a greater or less degree in many species of Ophiothrix. 
The largest specimen (fig. 127) has almost no trifid stumps, but numerous rough disk spines of very variable length. In fig. 128a is shown one of the most interesting varieties, a specimen from station 5055; in this individual the disk stumps have very long thorns, usually only two, and these are united to each other by a membrane; there are no disk spines; the arm spines are unusually slender and the upper arm plates are unusually long, somewhat

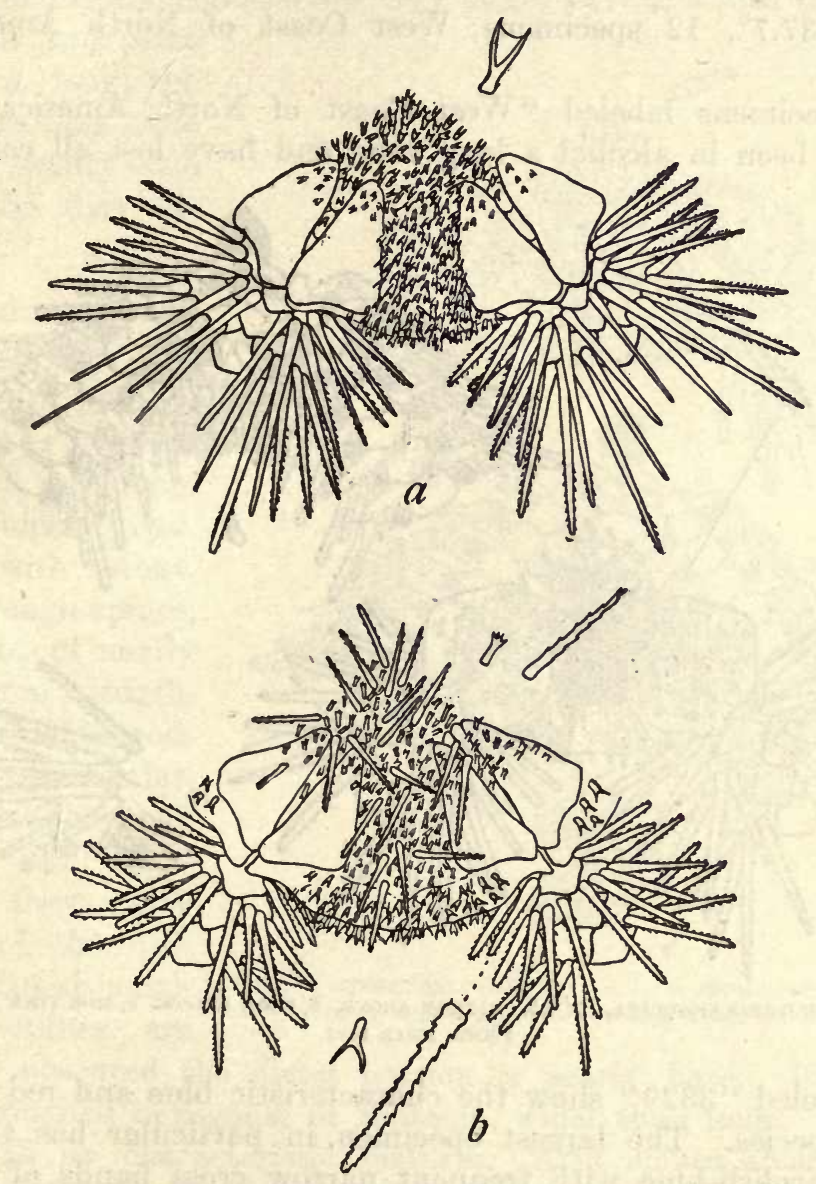

Fig. 128.-OPHITHRIX KOREANA. $a$, PART OF SPECIMEN FROM STATION 5055, FROM ABOVE, $\times 6$; $b$, PART OF SPECIMEN FROM STATION 4878, FROM ABOVE, $\times 8$.

pentagonal with distal angle rounded and proximo-lateral sides longest and concave, rather than straight; the disk is nearly white, the arms very pale brown, with a broad longitudinal white stripe bordered on each side with reddish, faintly indicated on upper side of arm. Another interesting specimen, taken at station 4878 , is shown in fig. $128 b$; this individual has extraordinarily long and prominent disk spines and the color of the disk is unique, uniform 
deep purple, the disk spines, and distal ends of radial shields (with adjoining disk margin) nearly white in marked contrast.

\section{OPHIOTHRIX SPICULATA.}

Ophiothrix spiculata LeConte, Proc. Acad. Nat. Sci. Philadelphia, vol. 5, 1851, p. 318.

Localities.-Albatross station 3329, Bering Sea, lat. $53^{\circ} 56^{\prime} 50^{\prime \prime}$ N.; long. $167^{\circ} 8^{\prime} 15^{\prime \prime}$ W., 399 fathoms, fine black sand, bottom temperature $37.7^{\circ}, 12$ specimens; West Coast of North America, 3 specimens.

The specimens labeled "West Coast of North America" have evidently been in alcohol a long time and have lost all color, but

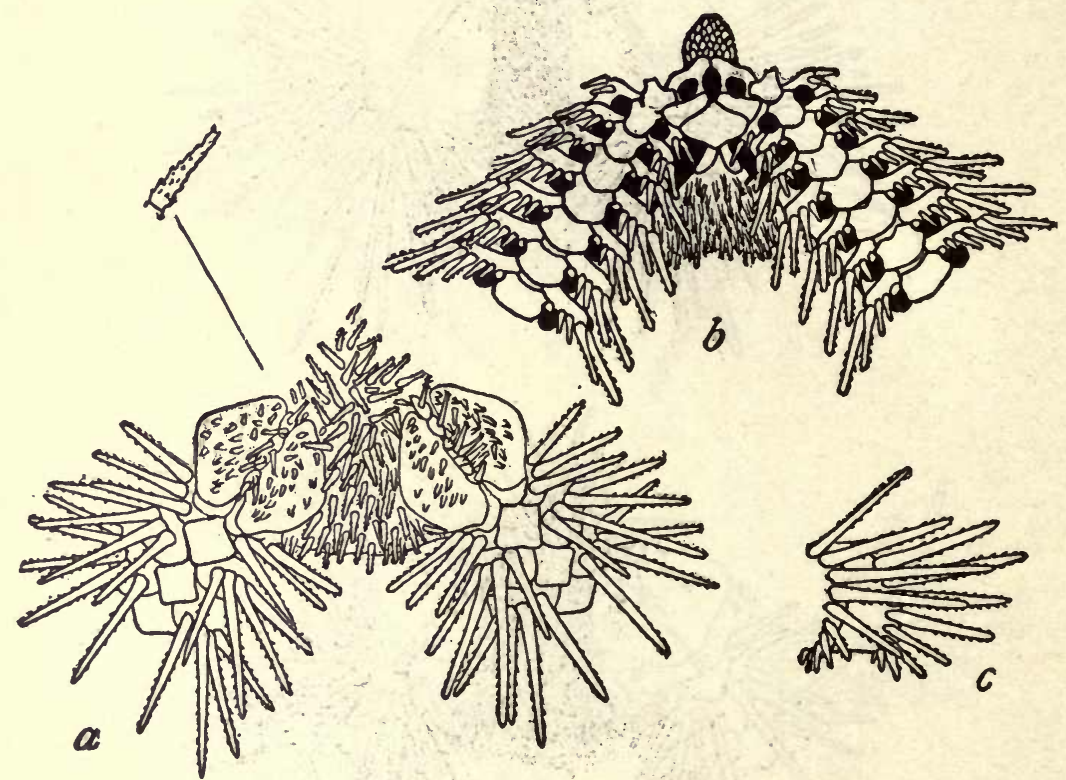

FIG. 129.-OPHIOTHRIX SPICULATA. $\times$ 4.5. a, FROM ABOVE; 3 , FROM BELOW; $c$, SIDE VIEW OF TWO ARM JOINTS NEAR DISK.

those labeled " 3329 " show the characteristic blue and red coloring of the species. The largest specimen. in particular has the arms bright purplish-blue with frequent narrow cross bands of reddish. All the specimens agree in having the disk fully, and the radial shields sparsely, covered with rough spinelets, which can scarcely be divided into "stumps" and "spines," but differ from each other only in length and thickness. This is the only difference between these specimens, and typical examples from Pearl Islands, Panama. It is hard to believe that there is not some mistake about the label, "3329," for it is most extraordinary that such a bright-colored, littoral, Panamic form as spiculata should occur in deep water in Bering Sea. The 
record may well be regarded as very doubtful, at least until the species is reported from Alaska.

\section{OPHIOTHRIX LONGIPEDA.}

Ophiura longipeda LAMarck, Anim. s. Vert., vol. 2, 1816, p. 544.

Ophiothrix longipeda Müller and Troschel, Sys. Ast., 1842, p. 113.

Locality.-Ousima, Japan, 3 specimens.

Two of these specimens are very large, having a disk diameter of $30 \mathrm{~mm}$. and arms $645 \mathrm{~mm}$. long; the arms are thus more than twenty-one times the disk diameter.

\section{OPHIOTHRIX HYLODES,} new species. $a$

Disk $10 \mathrm{~mm}$. in diameter; arms about $45 \mathrm{~mm}$. long. Disk thickly cov. ered with stout blunt, rough spines, which are of nearly $\mathrm{u}$ i f orm length. Radial shields moderate, triangular, much longer than wide, well separated; they carry many of the disk spines, but although their outlines are

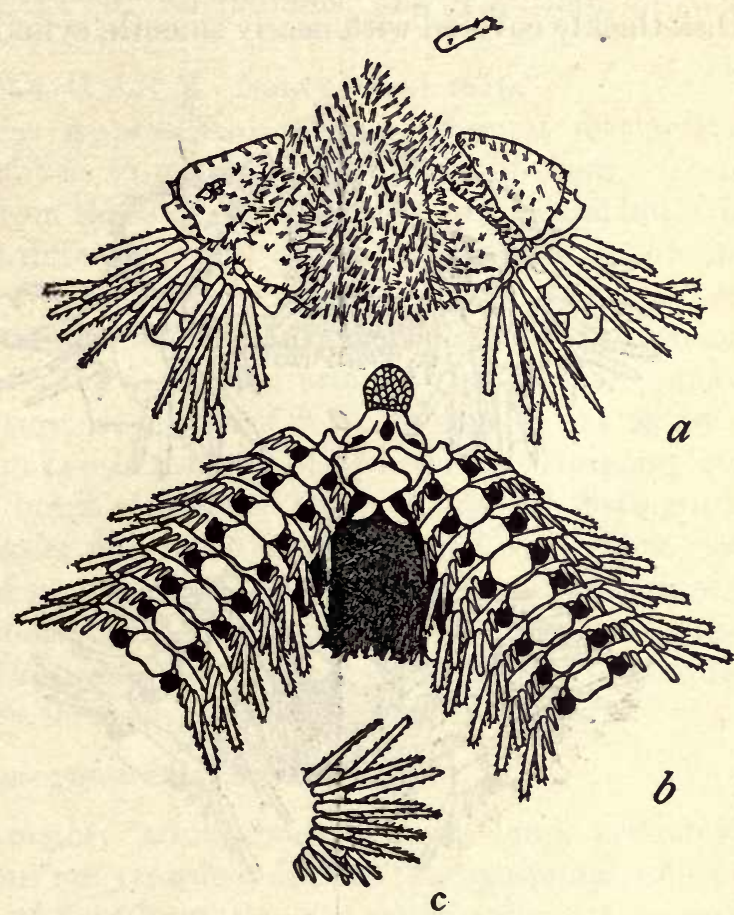

Fig. 130.-OPHOTHRIX HYLODES. $\times 5$. $a$, FROM ABOVE; $b$, FROM BELOW; $c$, SIDE VIEW OF TWO ARM JOINTS NEAR DISK. thereby obscured the distal portion is nearly bare. Upper arm plates rounded hexagonal or rhombic, wider than long. Oral surface with no characteristic features. Arm spines about eight in number, of moderate length, rough, blunt, and somewhat flattened. Color (dried from alcohol), variable; in type, disk and oral surface brown; arms dull purplish with a longitudinal light stripe more or less clearly indicated; in other specimens, disk pale brown or greenish, arms greenish, with longitudinal light stripe very faintly indicated.

Localities.-Misaki, Japan, 2 specimens; Ayukawa, Japan, 1 specimen. "Northwestern Pacific, probably Japan," 1 specimen.

Type.-Cut. No. 25723, U.S.N.M., from Misaki. 
Although the general appearance of these specimens is quite distinctive, and trifid stumps appear to be wholly wanting, the indications of a longitudinal white stripe on the upper side of the arms make me suspicious that this is only an extreme variety of koreana. Observations on an extended series of living specimens at Misaki would very easily settle the matter.

\section{OPHIOTHRIX PANCHYENDYTA, new species. $a$}

Disk $11 \mathrm{~mm}$. in diameter; arms about 35 to $40 \mathrm{~mm}$. long, probably. Disk thickly covered with nearly smooth, cylindrical spines, blunt and
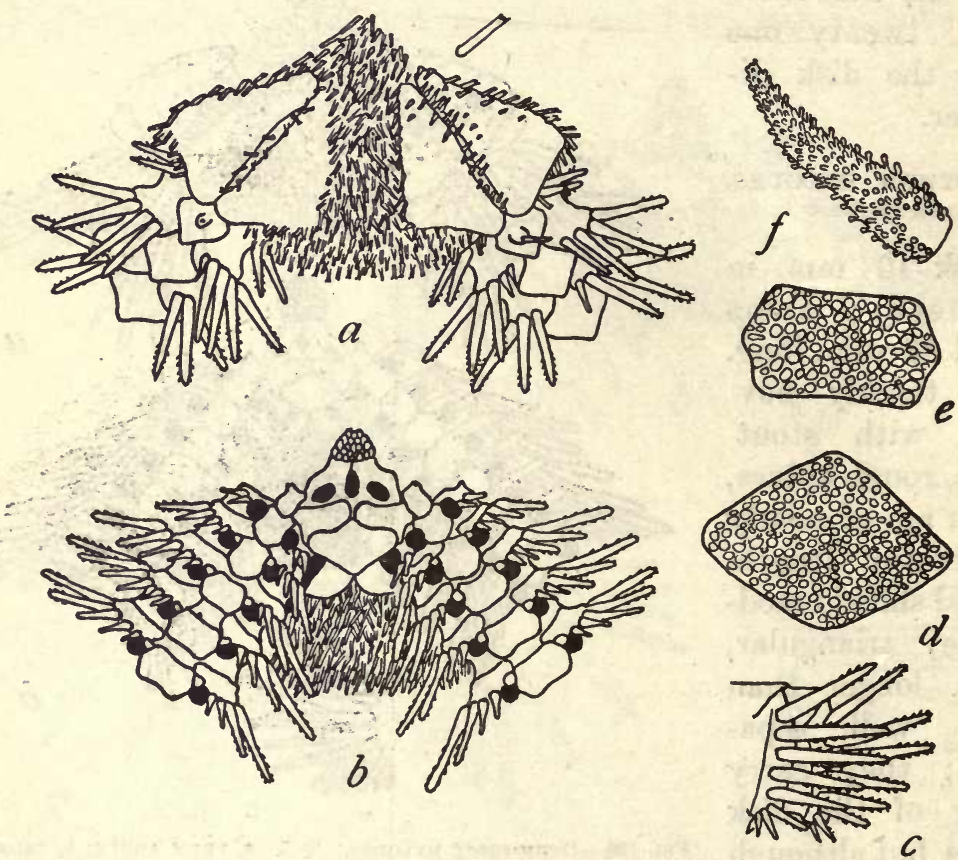

FIG. 131.-OPHIOTHRIX PANCHYENDYTA. $a$, FROM ABOVE, $\times 5 ; b$, FROM BELOW, $\times 5 ; c$, SIDE VIEW OF TWO ARM JOINTS NEAR DISK, $\times 5 ; d$, AN UPPER ARM PLATE, $\times 15 ; e$, AN UNDER ARM PLATE, $\times 15$; $f$, A tentacle, $\times 15$.

rough at tip. Radial shields very large, smooth, nearly free from spines, in contact at inner, distal corner, but elsewhere separated by a narrow series of scales bearing numerous small spines. Upper arm plates (fig. 131d) rhombic, coarsely granular, a little swollen, wider than long, in contact throughout; the first one carries a tubercle on which is borne a conspicuous spine. Interbrachial spaces below fully covered with scales and spinelets like those of disk. Oral shields, adoral plates, and under arm plates rather indistinct (as

$a$ Már $\chi$ u, signifying wholly, and źvoutós, signifying clothed, in reference to the interbrachial spaces below being entirely covered with scales and spinelets. 
though skin-covered) and slightly swollen, coarsely granular. Under arm plates (fig. 131e) widely separated, very much wider than long. Arm spines about eight, rather short, slightly flattened at blunt, rough tip. Tentacles large and very papillose (fig. 131f), therefore tentacle pores very large. Color (dried from alcohol), very pale fawn color.

Locality.-Albatross station 4876 , Korea Strait, lat. $34^{\circ} 20^{\prime} \mathrm{N}$.; long. $130^{\circ} 10^{\prime}$ E., 59 fathoms, fine gray sand, broken shells, bottom temperature $62.1^{\circ}, 3$ specimens; station 4877 , Korea Strait, lat. $34^{\circ}$ $20^{\prime} 30^{\prime \prime} \mathrm{N}$.; long. $130^{\circ} 11^{\prime} \mathrm{E}$., 59 fathoms, fine gray sand, broken shells, 1 specimen.

Type.-Cat. No. 25644, U.S.N.M., from station 4876.

Although this species is possessed of a number of distinctive characters, I am in doubt as to the reliability of any of them. Thus the disk spines differ from those of either koreana or hylodes, but it is not really an essential difference, and the coarse granulation of the upper arm plates, very different from what is shown by the other species, is probably not a distinctive peculiarity. So the conspicuous spine-bearing tubercle on the first upper arm plate of each arm, may not be a constant feature, and even if it is, similar, if not as conspicuous, tubercles occur in other species of Ophiothrix. The complete covering of the interbrachial spaces below helps to distinguish panchyendyta from hylodes and most specimens of koreana, but not from all! The arms of panchyendyta seem to be unusually short, but as all are broken, it is not possible to reach a positive decision on the point. As the general appearance of these specimens is quite unique, they may well stand by themselves for the present.

\section{OPHIOTHRIX EUSTEIRA, new species. $a$}

Disk $9 \mathrm{~mm}$. in diameter; arms about $60 \mathrm{~mm}$. long, probably. Disk with numerous, but not crowded, minute thorny stumps and at center with a number of very long, slender, rough spines; there are smaller, smoother spines between the radial shields and rarely in the interradial spaces. Radial shields very large, covering most of disk, free from stumps and spines; interradial distance between two about twice radial; lateral margins straight, distal margin concave. Upper arm plates beyond first, rhombic, longer than wide, in contact and strongly carinate. Interbrachial spaces below well covered with minute stumps. Genital slits large. Oral shields very much wider than long, rounded laterally. Adoral plates large, broader without than within, where they meet. Tooth papillæ about thirty, rather pointed, forming a high narrow oval group. First four or five under arm plates, longer than wide, next five or six squarish, succeeding plates

a Ev, signifying well, and orcipa, signifying keel, in reference to the form of the upper arm plates. 
longer than wide again. Side arm plates moderate, not meeting either above or below; each plate carries six or seven long, slender, acute, thorny spines, of which the lowest is very small, while the uppermost or next is longest and at base of arm may equal fully four joints. Tentacle pores very large, each with a single small tentacle scale which may be lacking on the first one or two joints. Color (dried from alcohol), light wood-brown, disk spines, arm spines, and keel on upper arm plates white in marked contrast.
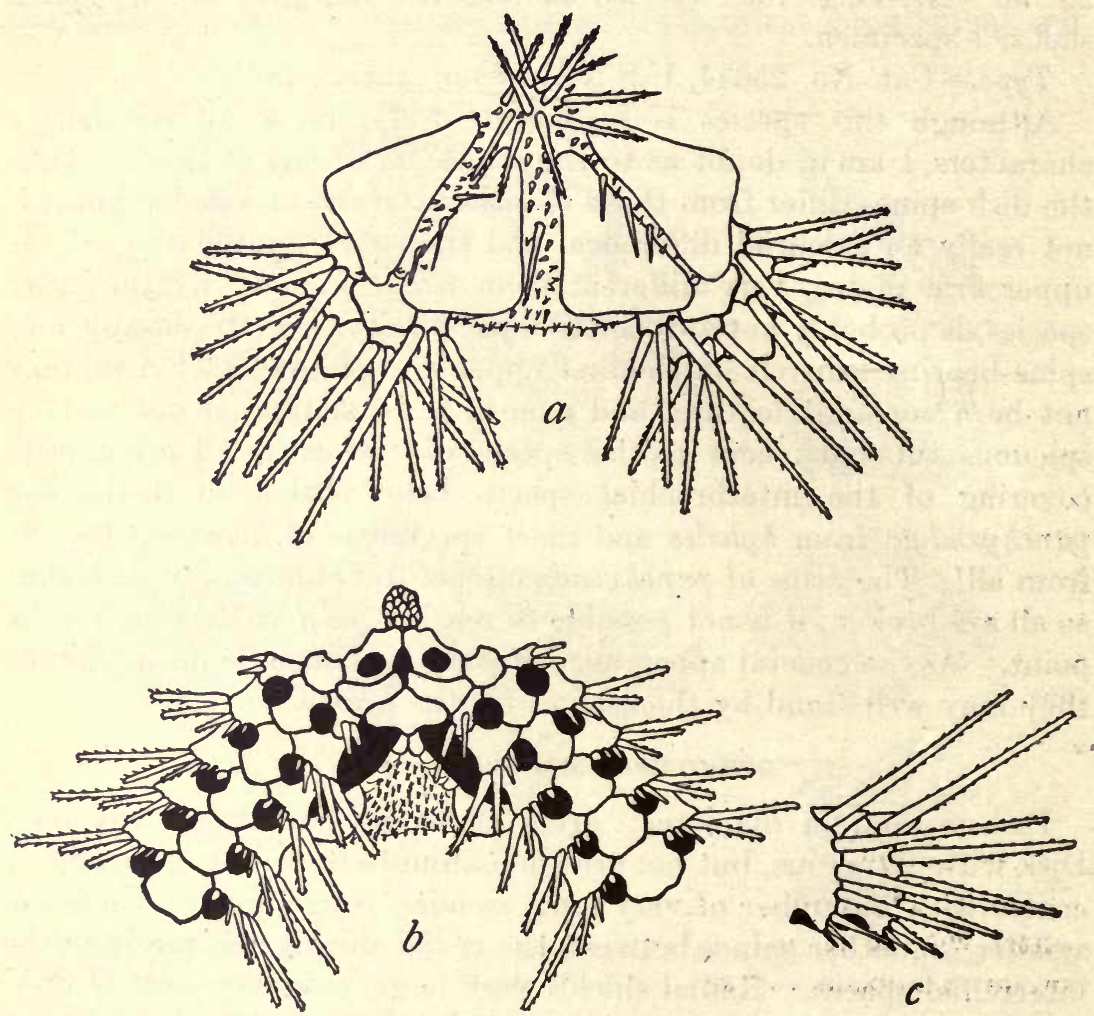

Fig. 132.-OPHIOTHRIX EUSTEIRA. $\times 8$. $a$, FROM ABOVE; $b$, FROM BELOW; $c$, SIDE VIEW OF TWO ARM JOINTS NEAR DISK.

Locality.-Ousima, Japan, William Stimpson, collector, 2 specimens. Type.-Cat. No. 3319, U.S.N.M., from Ousima.

There can be no question about the distinctness of this beautiful species which has lain unnamed for half a century, in the collections of the National Museum. The few, long, white arm spines, the long under arm plates, and the long, strongly keeled upper arm plates are striking features apart from the characters of the disk. It seems strange that such a handsome and noticeable species should have so long awaited description, and it is also rather remarkable that no 
specimens of it were taken by the Fisheries steamer Albatross on either of her Japanese cruises.

\section{OPHIOTHRIX MACROBRACHIA, new species. a}

Disk $11 \mathrm{~mm}$. in diameter; arms apparently about $165 \mathrm{~mm}$. long. Disk covered with a thick skin containing scales which bear slender, minutely thorny spines of variable length and acuteness. Radial shields very large, but completely hidden by the skin, except at inner distal corner, where they are barely in contact. Upper arm plates pentagonal, becoming squarish far out on arm; first four or five small and separated from each other by skin; succeeding twenty or so in contact; remainder more or lessseparated. Interbrachial spaces below

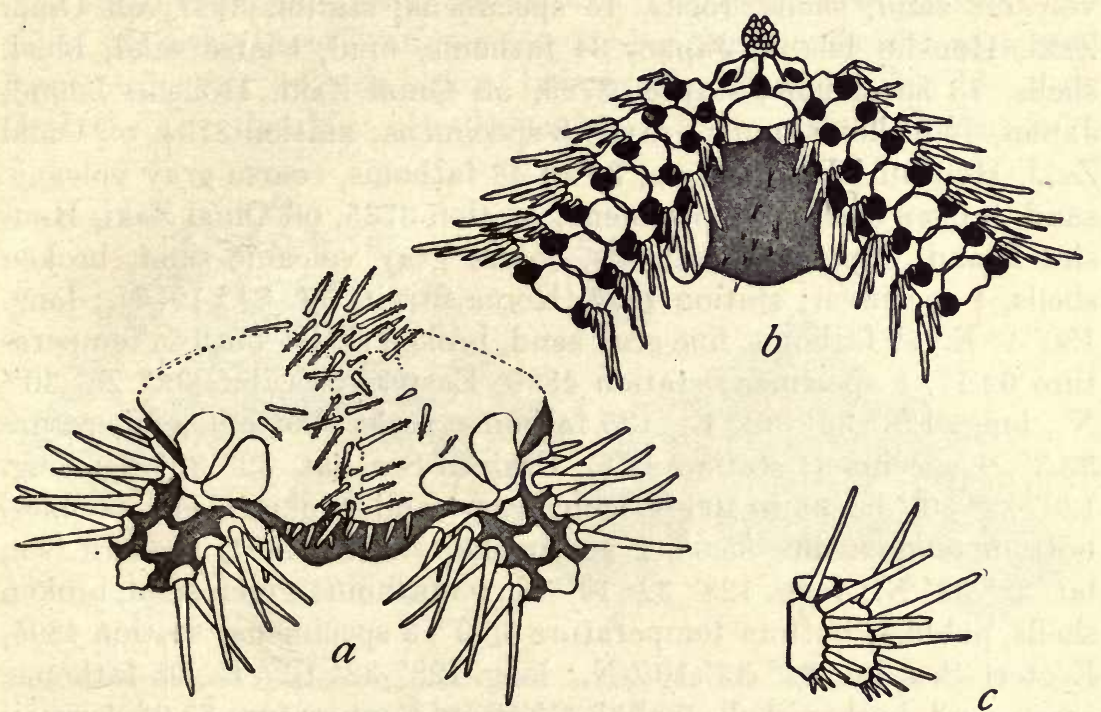

FIG. 133.-OPHIOTHRIX MACROBRACHIA. $\times$ 4.5. $a$, FROM ABOVE; $b$, FROM BELOW; $c$, SIDE VIEW OF TWO ARM JOINTS NEAR DISK.

quite naked, the thin skin with only a few scattered minute spinelets. Oral shields wide, sometimes twice as wide as long, more or less oval or elliptical. Adoral plates very small, not meeting within; jaw frames with a large median perforation. Teeth about four and teeth papillæ about twenty on each jaw. Under arm plates with rather indistinct outlines, but hardly in contact with each other, and usually well separated; first two or three longer than wide, following squarish or wider than long until toward tip of arm, they become longer than wide again; each plate has a more or less distinct median, minute notch in distal and proximal margins, connected by a longitudinal line on its surface, the cause of which is hard to determine, for it is not

a Makpós, signifying long, and $\beta \rho a \chi^{i} \omega \nu$, signifying arm, in reference to the very long arms. 
due to a ridge, a furrow, or color; possibly the plate is thinner along that line. Side arm plates not very large, each with about eight blunt, nearly smooth arm spines, of which the lowest are very small, while the two or three uppermost are equal to two or three joints: Tentacle pores large but tentacle scales wanting. Color (dried from alcohol), disk pure white, arms and spines very pale cream or fawn color, interbranchial spaces below dark brown or blackish; a few specimens have a reddish tinge, and in one very small specimen the bare part of the radial shields is deep pink.

Localities.-Albatross station 3707, off Ose Zaki, Honshu Island, Japan, 63 to 75 fathoms, volcanic sand, ashes, gravel, 5 specimens; station 3715, off Ose Zaki, Honshu Island, Japan, 65 to 68 fathoms, volcanic sand, shells, rocks, 15 specimens; station 3727, off Omai Zaki, Honshu Island, Japan, 34 fathoms, mud, coarse sand, black shells, 13 specimens; station 3729, off Omai Zaki, Honshu Island, Japan, 34 fathoms, mud, gravel, 8 specimens; station 3734, off Omai Zaki, Honshu Island, Japan, 36 to 48 fathoms, coarse gray volcanic sand, broken shells, 10 specimens; station 3735, off Omai Zaki, Honshu Island, Japan, 36 fathoms, coarse gray volcanic sand, broken shells, 1 specimen; station 4875 , Korea Strait, lat. $34^{\circ} 19^{\prime}$ N.; long. $130^{\circ} 9^{\prime}$ E., 59 fathoms, fine gray sand, broken shells, bottom temperature $62.1^{\circ}, 1$ specimen; station 4890 , Eastern Sea, lat. $32^{\circ} 26^{\prime} 30^{\prime \prime}$ N.; long. $128^{\circ} 36^{\prime} 30^{\prime \prime}$ E., 135 fathoms, rocky, bottom temperature $52.3^{\circ}, 1$ specimen; station 4893 , Eastern Sea, lat. $32^{\circ} 32^{\prime}$ N.; long. $128^{\circ} 32^{\prime} 50^{\prime \prime}$ E., 95 to 106 fathoms, gray sand, broken shells, pebbles, bottom temperature $55.9^{\circ}, 2$ specimens; station 4894 , Eastern Sea, lat. $32^{\circ} 33^{\prime} \mathrm{N}$.; long. $128^{\circ} 32^{\prime} 10^{\prime \prime}$ E., 95 fathoms, green sand, broken shells, pebbles, bottom temperature $55.9^{\circ}, 3$ specimens; station 4895 , Eastern Sea, lat. $32^{\circ} 33^{\prime} 10^{\prime \prime}$ N.; long. $128^{\circ} 32^{\prime} 10^{\prime \prime}$ E., 95 fathoms, green sand, broken shells, pebbles, bottom temperature $55.9^{\circ}, 5$ specimens; station 4936, Eastern Sea, lat $30^{\circ} 54^{\prime} 40^{\prime \prime} \mathrm{N}$.; long. $130^{\circ} 37^{\prime}$ $30^{\prime \prime}$ E., 103 fathoms, stones, bottom temperature $60.6^{\circ}, 10$ specimens; station 4948, Bungo Channel, lat. $31^{\circ} 19^{\prime}$ N.; long. $131^{\circ} 23^{\prime}$ E., 65 fathoms, dark gray volcanic sand, broken shells, pebbles, bottom temperature $62.6^{\circ}, 5$ specimens; station 5069, Suruga Gulf, lat. $35^{\circ}$ $3^{\prime} 10^{\prime \prime} \mathrm{N}$.; long. $138^{\circ} 47^{\prime}$ E., 108 to 131 fathoms, mud, sand, broken shells, bottom temperature $55.8^{\circ}, 1$ specimen; station 5070, Suruga Gulf, lat. $35^{\circ} 3^{\prime} 25^{\prime \prime}$ N.; long. $138^{\circ} 47^{\prime} 40^{\prime \prime}$ E., 108 fathoms, mud, sand, broken shells, bottom temperature $57.6^{\circ}, 2$ specimens. Bathymetrical range, 34 to 135 fathoms. Temperature range, $62.6^{\circ}$ to $52.3^{\circ}$. Eighty-two specimens.

Type.-Cat. No. 25712, U.S.N.M., from station 4875.

This unusually handsome and well-characterized species reminds one strongly of Ophiogymna, but the disk spines and upper arm plates are those of an Ophiothrix and it seems better to place it in that genus. 
The contrast between the disk and the interbrachial spaces below, both in texture of skin and in color, is most striking, and the very long arms with nearly smooth arm spines are additional features of interest. The specimens before me range in disk diameter from 4.5 to $11 \mathrm{~mm}$.

\section{FAMILY OPHIOMYXIDE.}

OPHIOBYRSA ACANTHINOBRACHIA, new species. $a$

Disk $20 \mathrm{~mm}$. in diameter; arms about $280 \mathrm{~mm}$. long. Disk covered. by a soft skin, which carries numerous scattered plates, each of which bears a single, small spinelet. Radial shields faintly indicated and part of distal end more or less visible. Upper arm plates broken up into small fragments, each one of which carries a little spinelet like those of disk; these transverse spine-bearing bands are separated from each other by bare skin. Interbrachial spaces below like disk. Genital slits rather big. Mouth parts and lower surface of arms more

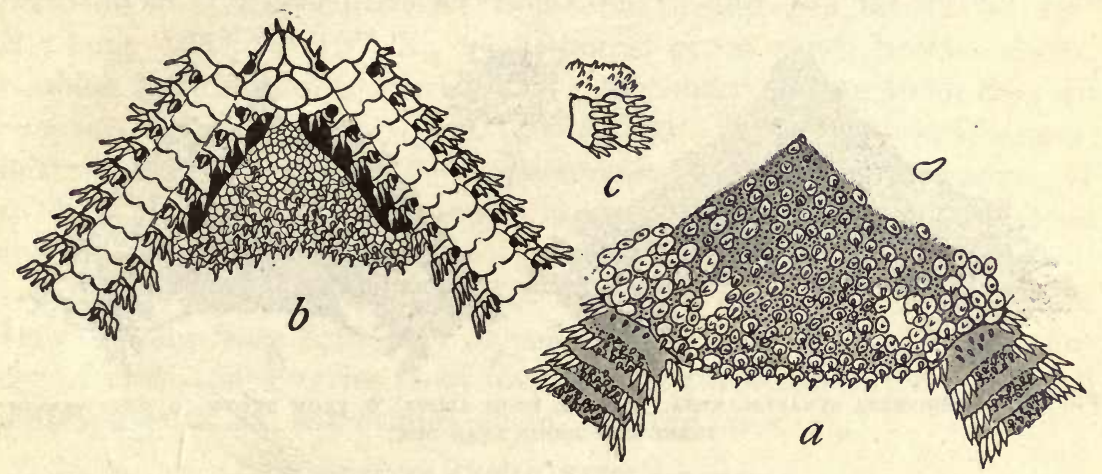

Fig. 134.-OPHIOBYRSA ACANTHINOBRACHIA. X 2.5. $a$, FROM ABOVE; $b$, FROM BELOW; $c$, SIDE VIEW OF TWO ARM JOINTS NEAR DISK.

or less concealed by skin. Oral shields rounded triangular about as long as wide. Adoral plates large, short, and wide, hardly meeting within; oral plates about as large. Oral papillæ few, minute, irregular. Teeth (or tooth papillæ) spiniform, rough at tip, in two more or less irregular vertical series. Under arm plates obscure, squarish, with rounded corners, wider than long, distal margin with a deep notch. Side arm plates small, each one bearing six or seven small, acute, subequal skin-covered arm spines, about half as long as joint; lowest arm spine hooked. No tentacle scales. Color (dried from alcohol), dull yellowish or reddish brown; young specimens, yellow.

Localities.-Albatross station 4894, Eastern Sea, lat. $32^{\circ} 33^{\prime}$ N.; long. $128^{\circ} 32^{\prime} 10^{\prime \prime}$ E., 95 fathoms, green sand, broken shells, pebbles,

$a^{\prime}$ 'Aкá $\theta \iota \nu 0 \varsigma$, signifying thorny, and $\beta \rho a \chi i \omega \nu$, signifying arm, in reference to the numerous small spines on the upper arm plates. 
bottom temperature $55.9^{\circ}, 2$ specimens; station 4895 , Eastern Sea, lat. $32^{\circ} 33^{\prime} 10^{\prime \prime} \mathrm{N}$.; long. $128^{\circ} 32^{\prime} 10^{\prime \prime}$ E., 95 fathoms, green sand, broken shells, pebbles, bottom temperature $55.9^{\circ}, 2$ specimens; station 5070, Suruga Gulf, lat. $35^{\circ} 3^{\prime} 25^{\prime \prime}$ N.; long. $138^{\circ} 47^{\prime} 40^{\prime \prime}$ E., 108 fathoms, mud, sand, broken shells, bottom temperature $57.6^{\circ}, 2$ specimens.

Type.-Cat. No. 25585, U.S.N.M., from station 4895.

The transverse spiny bands on the upper side of the arms will readily distinguish this species from all of its allies. The specimens before me have a disk diameter ranging from 5 to $20 \mathrm{~mm}$.

\section{OPHIOBYRSA SYNAPTACANTHA, new species. $a$}

Disk $12 \mathrm{~mm}$. in diameter; arms about $220 \mathrm{~mm}$. long. Disk covered by skin containing numerous rounded scales, only a few of which carry minute sharp spinelets. Radial shields small, well separated, plainly indicated and made conspicuous by the linear group of spinelets which they carry, at least on the proximal end. Upper arm

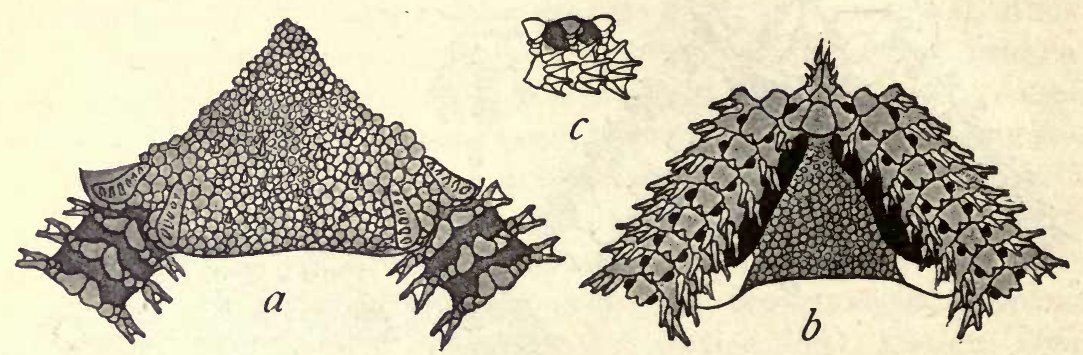

FIG. 135.-OPHIOBYRSA SYNAPTACANTHA. $\times$ 4. $a$, FROM ABOVE; $b$, FROM BELOW; $c$, SIDE VIEW OF THREE ARM JOINTS NEAR DISK.

plates separated by naked skin, broken into several pieces, of which two median are largest; none of them carry spines or spinelets. Interbrachial spaces below like disk. Genital slits large. Plates of whole oral surface more or less obscured by skin. Oral shields small, apparently squarish-oval, longer than wide. Adoral plates at sides of shield very small, much longer than wide. Oral papillæ and teeth (tooth papillæ?) as in acanthinobrachia. Under arm plates indistinct, apparently longer than wide, with a deep median notch in distal margin. Side arm plates small, each with four cylindrical, blunt, spines, about as long as joint, more or less united to each other by a fold of skin, which includes two-thirds or more of each spine. No tentacle scales. Color (dried from alcohol), dark brown.

Locality.-Albatross station 4933 , Eastern Sea, lat. $30^{\circ} 59^{\prime} \mathrm{N}$; long. $130^{\circ} 29^{\prime} 50^{\prime \prime}$ E., 152 fathoms, rocky, bottom temperature $56^{\circ}$, 1 specimen.

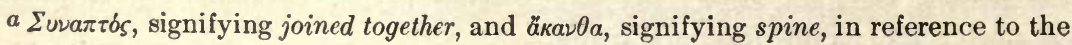
webbed arm spines. 
Type.-Cat. No. 25714, U.S.N.M., from station 4933.

There may be some question whether the webbed arm spines are not sufficient to remove this species from Ophiobyrsa, but the upper arm plates, disk covering, mouth parts, and lack of tentacle scales seem to me sufficient reasons for placing it in that genus. The smooth upper surface of the arms, plus the webbed arm spines, will serve to distinguish synaptacantha from the other members of the group.

\section{OPHIOMYXA AUSTRALIS.}

Ophiomyxa australis LüTkEN, Add. Hist. Oph., pt. 3, 1869, p. 45.

Localities.-Albatross station 3757, off Suno Saki, Honshu Island, Japan, 41 to 50 fathoms, coarse coral sand, gravel, 8 specimens; station 4880 , Korea Strait, lat. $34^{\circ} 16^{\prime}$ N.; long. $130^{\circ} 16^{\prime}$ E., 59 fathoms, fine gray sand, broken shells, bottom temperature $62.1^{\circ}$, 1 specimen; station 4894 , Eastern Sea, lat. $32^{\circ} 33^{\prime}$ N.; long. $128^{\circ} 32^{\prime}$ $10^{\prime \prime}$ E., 95 fathoms, green sand, broken shells, pebbles, bottom temperature $55.9^{\circ}, 2$ specimens ; station 4895 , Eastern Sea, lat. $32^{\circ} 33^{\prime} 10^{\prime \prime}$ N.; long. $128^{\circ} 32^{\prime} 10^{\prime \prime}$ E., 95 fathoms, green sand, broken shells, pebbles, bottom temperature $55.9^{\circ}, 1$ specimen; station 4936 , Eastern Sea, lat. $30^{\circ} 54^{\prime} 40^{\prime \prime} \mathrm{N}$.; long. $130^{\circ} 37^{\prime} 30^{\prime \prime}$ E., 103 fathoms, stones, bottom temperature $60.6^{\circ}, 2$ specimens. Bathymetrical range, 41 to 103 fathoms. Temperature range, $62.1^{\circ}$ to $55.9^{\circ}$. Fourteen specimens.

These specimens range in disk diameter from 6 to $20 \mathrm{~mm}$. and vary in color from light gray or yellowish to deep brown. The number of arm spines varies from four (rarely three, often five) in small individuals to six, sometimes seven, in large ones.

\section{OPHIOMYXA ANISACANTHA, new species. $a$}

Disk $20 \mathrm{~mm}$. in diameter; arms about $120 \mathrm{~mm}$. long. Similar to australis, except that the disk skin is thinner and the marginal scales are wanting; the oral papillæ are smaller, especially the outermost, which are smallest, and are well spaced; and the arm spines are longer and fewer, three (rarely two, often four) in small individuals and four (very rarely five) in large ones; uppermost spine largest and stoutest next lower shorter and somewhat more slender; third very slender, about equal to second; lowest as long as or longer than uppermost, but very much more slender. Color (dried from alcohol), ranging from nearly white to dull reddish-brown.

Localities.-Albatross station 3749, off Suno Saki, Honshu Island, Japan, 83 to 158 fathoms, black sand, shells, 11 specimens; station 4892 , Eastern Sea, lat. $32^{\circ} 27^{\prime} 30^{\prime \prime}$ N.; long. $128^{\circ} 33^{\prime}$ E., 181 fathoms, gray sand, broken shells, rocks, bottom temperature $50.2^{\circ}, 1$ speci-

$a^{*} A \nu \iota \sigma o s$, signifying $u n e q u a l$, and $\not \varkappa \kappa a \nu \theta a$, signifying spine, in reference to the inequality of the arm spines. 
men; station 4893 , Eastern Sea, lat. $32^{\circ} 32^{\prime}$ N.; long. $128^{\circ} 32^{\prime} 50^{\prime \prime}$ E., 95 to 106 fathoms, gray sand, broken shells, pebbles, bottom temperature $55.9^{\circ}, 4$ specimens ; station 4912 , Eastern Sea, lat. $31^{\circ} 39^{\prime} 40^{\prime \prime}$ N.; long. $129^{\circ} 20^{\prime}$ E., 391 fathoms, gray globigerina ooze, bottom temperature $41.9^{\circ}, 1$ specimen; station 5069, Suruga Gulf, lat. $35^{\circ} 3^{\prime}$ $10^{\prime \prime} \mathrm{N}$.; long. $138^{\circ} 47^{\prime}$ E., 108 to 131 fathoms, mud, sand, broken shells, bottom temperature $55.8^{\circ}, 3$ specimens; station 5070, Suruga Gulf, lat. $35^{\circ} 3^{\prime} 25^{\prime \prime}$ N.; long. $138^{\circ} 47^{\prime} 40^{\prime \prime}$ E., 108 fathoms, mud, sand, broken shells, bottom temperature $57.6^{\circ}, 5$ specimens; station 5091, Uraga Strait, lat. $35^{\circ} 4^{\prime} 10^{\prime \prime}$ N.; long. $139^{\circ} 38^{\prime} 12^{\prime \prime}$ E., 197 fathoms, green mud, coarse black sand, pebbles, bottom temperature $47.6^{\circ}, 1$ specimen. Bathymetrical range, 83 to 391 fathoms. Temperature range, $57.6^{\circ}$ to $41.9^{\circ}$. Twenty-six specimens.

Type.-Cat. No. 25605, U.S.N.M., from station 4892.

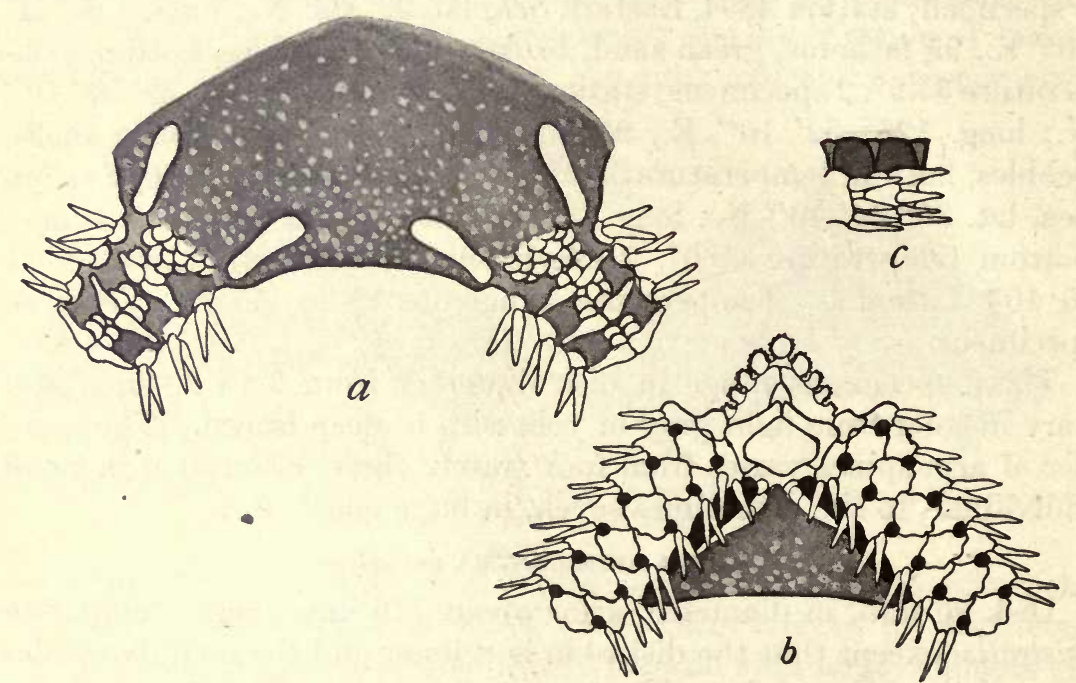

Fig. 136.-OPHIOMyXA ANISACANTHA. $\times 2.5$. $a$, FROM ABOVE; $b$, FROM BELOW; $c$, SIDE VIEW OF TWO ARM JOINTS NEAR DISK.

The differences in number, length, and proportions of arm spines between this species and australis seem to be very constant, and consequently adult specimens of the two species are easy to distinguish. Naturally very small specimens can not be separated so easily, but on comparison even they can be distinguished. In the series of anisacantha before me the disk diameter ranges from 5 to $21 \mathrm{~mm}$.

\section{OPHIOPHRIXUS, new genus. ${ }^{a}$}

Disk nearly naked, carrying only a few scattered scales. Radial shields narrow and compressed, bearing a linear series of erect, acute

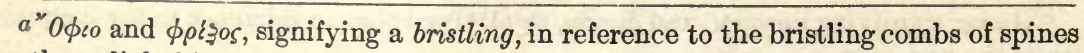
on the radial shields. 
spines. Upper arm plates wanting. Teeth spiniform in a double series, followed by a few tooth papillæ; oral papillæ reduced to a few tubercles. Under arm plates present. Arm spines rough and skincovered. Tentacle scales wanting.

Type-species.-Ophiophrixus acanthinus.

Although this genus has the form and general appearance of Ophiomyxa, it is evident from the mouth parts that it is not really very nearly related to that group. The notable radial shields and the absence of upper arm plates are further obvious, but not so essential, differences.

\section{OPHIOPHRIXUS ACANTHINUS, new species. $a$}

Disk $12 \mathrm{~mm}$. in diameter; arms about 80 to $85 \mathrm{~mm}$. long. Disk covered with a thin skin carrying, near center, a few scattered scales,

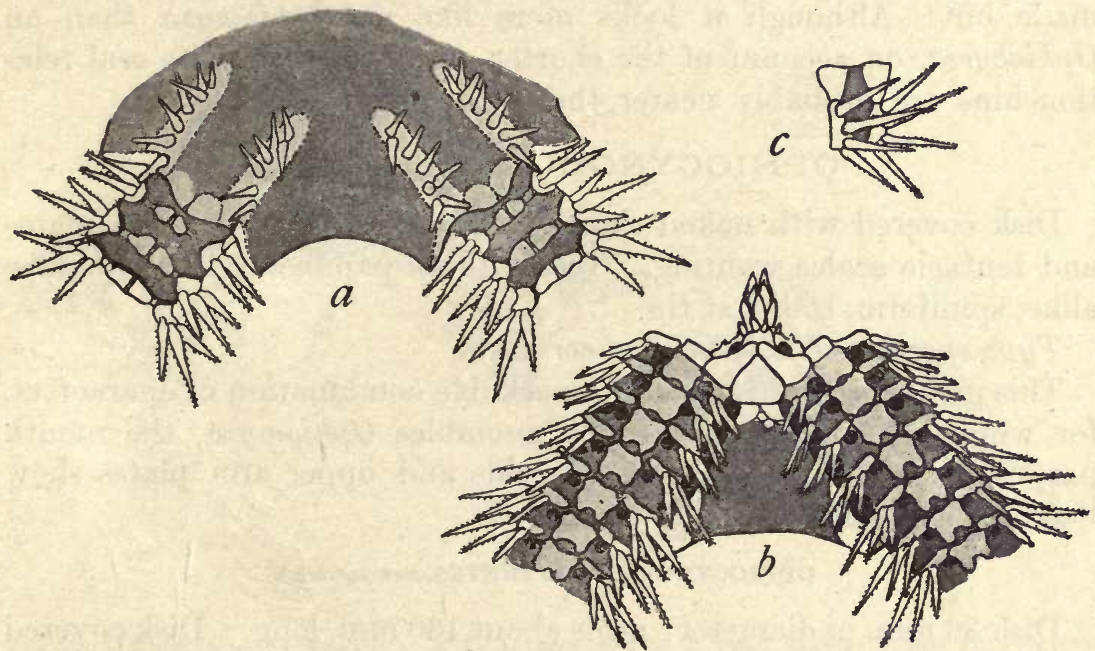

Fig. 137.-OPHIOPHRIXUS ACANTHINUS. $\times$ 4. $a$, FROM ABOVE; $b$, FROM BELOW; $c$, SIDE VIEW OF TWO ARM JOINTS NEAR DISK.

each of which bears a minute spine. Radial shields narrow, and compressed into a distinct ridge, well separated, parallel; each one carries six or seven erect, acute spines. Between distal ends of radial shields of each pair are two large calcareous plates in contact with each other. Upper arm plates wanting, but arm bones show through thin skin of arm. Interbrachial spaces below naked. Genital slits large. Oral shields rather large, triangular, with curved lateral margins, about as long as wide. Adoral plates large, much broader without than within where they meet. Jaws very short, each with a double series of rough spiniform teeth, below which, at apex of jaw, are four or five small, blunt tooth papillæ, irregularly arranged;

$a^{\prime}$ 'A $\alpha \dot{\alpha} \theta \in \nu \circ s$, signifying thorny, in reference to the appearance of the arms.

$34916^{\circ}-$ Bull. $75-11-18$ 
on each side of jaw, there are often to be found one or two small blunt tubercles, which may be regarded as rudimentary oral papillæ. First under arm plate wider than long; second and third about square; succeeding plates more or less indistinct, each with a deep median notch in distal margin. Side arm plates small and narrow; each plate carries four slender, acute, thorny, skin-covered spines; next to uppermost longest and equal to two joints. Tentacle pores large but tentacle scales none. Color (dried from alcohol), yellow brown:

Locality.-Albatross station 3704, off Seno Umi, Honshu Island, Japan, 94 to 150 fathoms, fine volcanic sand, 1 specimen.

Type.-Cat. No. 25713, U.S.N.M., from station 3704.

This unique specimen, one of the most interesting in the whole collection, is unusually well preserved, so that its characters are easily made out. Although it looks more like an Ophiomyxa than an Ophiobyrsa, on account of the shorter and wider arms, its real relationships are probably nearer the latter genus.

\section{OPHIOCYNODUS, new genus. ${ }^{a}$}

Disk covered with naked skin. Radial shields, upper arm plates and tentacle scales wanting. Teeth; tooth papillæ and oral papillæ alike, spiniform, rough at tip.

Type-species.-Ophiocynodus corynetes.

This genus presents a really remarkable combination of characters, for while its general appearance resembles Ophiomyxa, the mouth parts and the absence of radial shields and upper arm plates show it is no near relative of that group.

\section{OPHIOCYNODUS CORYNETES, new species. $b$}

Disk $30 \mathrm{~mm}$. in diameter; arms about $160 \mathrm{~mm}$. long. Disk covered with a naked skin on which are scattered some calcareous grains. Radial shields wanting, but expanded upper ends of genital plates show through the skin at base of arm. No upper arm plates. Interbrachial spaces below, naked. Oral shields small, longer than wide, wider within than without. Adoral plates large, three times as long as wide; oral plates large. Teeth, tooth papillæ, and oral papillæ all alike, rather numerous, spiniform and rough at tip; upper teeth largest; distal oral papillæ smallest. Under arm plates large, distinct, except first two longer than wide. Side arm plates small, each with three subequal spines, nearly equal to two joints; uppermost spine pointed, lowest club-shaped with a marked swelling at tip; middle spine intermediate; all spines are rough at tip, and more

$a$ " $0 \phi \Leftarrow o$ and kuvóous, signifying canine tooth, in reference to the spiniform teeth and oral papillæ.

b Kopuritns, signifying a club-bearer in reference to the form of the lower arm spines. 
or less skin-covered. Tentacle pores very large but tentacle scales none. Color (dried from alcohol), disk, deep brown, arms yellowish or dirty whitish.

Localities.-Albatross station 3071 , off Washington, lat. $47^{\circ} 29^{\prime}$ N.; long. $125^{\circ} 33^{\prime} 30^{\prime \prime}$ W., 685 fathoms, green mud, bottom temperature $38^{\circ}, 1$ specimen; station 3347 , off Washington, lat. $45^{\circ} 9^{\prime} 35^{\prime \prime} \mathrm{N}$.; long. $124^{\circ} 45^{\prime}$ W., 345 fathoms, mud, bottom temperature $40.9^{\circ}$, 1 specimen.

Type.-Cat. No. 25607, U.S.N.M., from station 3347.

It is unfortunate that both of the specimens are badly damaged, the disk being entirely gone in the smaller specimen and more than three-fifths gone in the larger. In spite of this defect, however, the larger specimen shows its unique characters very clearly, so that I have not hesitated to base the new species and genus upon it. Most

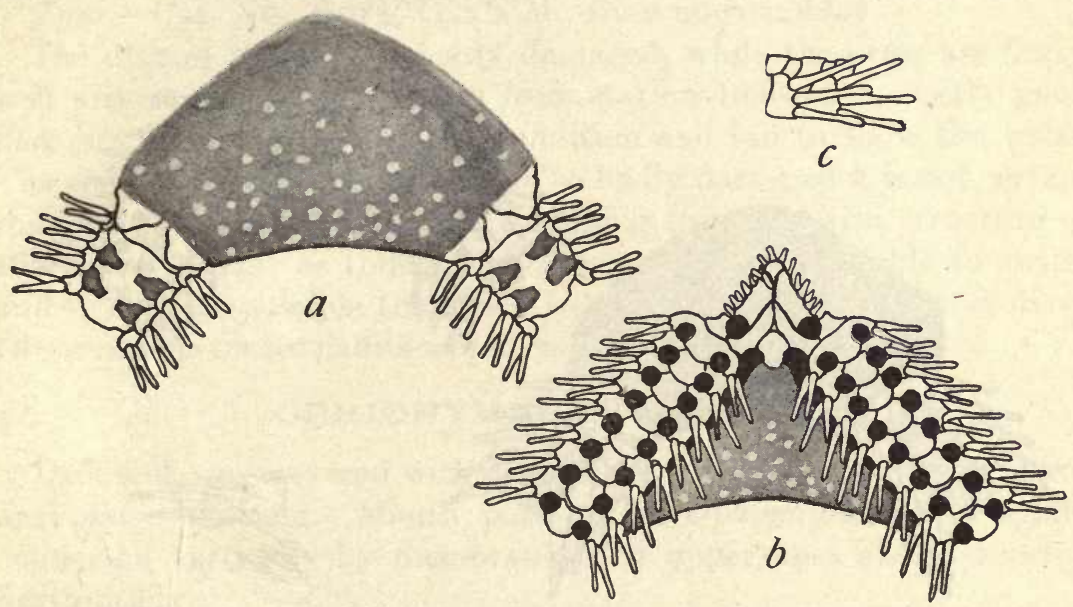

Fig. 138.-OPHIOCYNODUS CORYNETES. $\times 2$. $a$, FROM ABOVE; $b$, FROM BELOW; $c$, SIDE VIEW OF TWO ARM JOINTS NEAR DISK.

of the lower arm spines are much more conspicuously clubbed and thorny at the tip than is shown in the figures. Better specimens may reveal scales present in the skin of the disk.

\section{OPHIOSYZYGUS, new genus. $a$.}

Disk covered with skin in which are embedded, at least near margin, numerous minute delicate scales, on which are borne larger calcareous granules. Radial shields, upper arm plates, and tentacle scales wanting. Arm spines few, with upper ones successively united to each other by a broad, thin, horizontal membrane. Teeth reduced to cluster of few, minute, rough spinelets at apex of jaw. Oral papillæ small and few, but distinct, not like teeth.

$a^{. \prime} 0 \phi \iota 0$ and oúvuros, signifying joined together, in reference to the uniting of the arm spines by membrane. 
Type-species.-Ophiosyzygus disacanthus.

Although this genus is doubtless rather nearly related to Ophiocynodus, the disk structure being essentially the same in the two, the difference in mouth parts is too marked to allow them to be united, even if the remarkable web on the arm spines of Ophiosyzygus be ignored.

\section{OPHIOSYZYGUS DISACANTHUS, new species. $a$}

Disk $16 \mathrm{~mm}$. in diameter; arms about $60 \mathrm{~mm}$. long probably. Disk covered with an apparently naked skin, which under a microscope is seen to contain numerous thin scales, and bears scattered calcareous granules. Radial shields wanting, but expanded ends of genital plates are conspicuous through skin at base of each arm. Upper arm plates wanting. Interbrachial spaces below naked. Genital slits small. Oral shields small, about as long as wide. Adoral

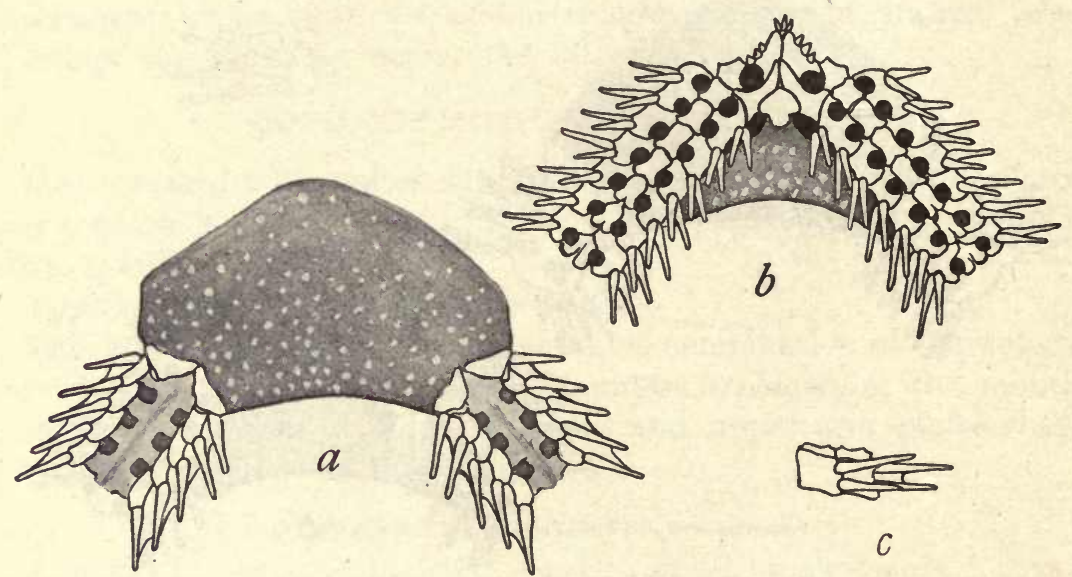

FIg. 139.-OPHIOSYZYgUS DISACANTHUS. $\times 3$. $a$, FROM A BOVE; $b$, FROM BELOW; $c$, SIDE VIEW OF TWO ARM JOINTS NEAR DISK.

plates large, much wider without than within where they meet. Oral papillæ, about three on a side, at distal end of mouth slit, small, almost conical, acute. Teeth (tooth papillæ?) few, irregular in number, size, and position, spiniform with rough tips, clustered at apex of jaw. Under arm plates longer than wide, somewhat tetragonal, distinct at base of arm, but quickly becoming very thin and indistinct, especially proximally. Side arm plates low but becoming very long distally, each bearing on its swollen, distal end, two spines, of which upper equals (at base of arm) two joints and lower is distinctly shorter; spines, slender, acute. Upper spine on each joint connected with adjoining upper spines by a thin, broad, horizontal membrane,

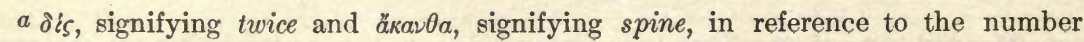
of arm spines. 
which extends out well beyond middle of spine, thus forming a sort of "fin" on each side of arm; each lower spine is connected with upper spine of same joint by a narrow membrane; these little vertical "fins" are much less conspicuous, however, than the horizontal one above them. Tentacle pores very large but tentacle scales none. Color (dried from alcohol), disk brown, spotted with white calcareous granules; arms nearly white.

Localities.-Albatross station 4934, off Kagoshima Gulf, lat. $30^{\circ}$ $58^{\prime} 30^{\prime \prime} \mathrm{N}$.; long. $130^{\circ} 32^{\prime}$ E., 103 to 152 fathoms, rocky, bottom temperature $60.6^{\circ}$ to $56^{\circ}, 1$ specimen; station 4936 , off Kagoshima Gulf, lat. $30^{\circ} 54^{\prime} 40^{\prime \prime}$ N.; long. $130^{\circ} 37^{\prime} 30^{\prime \prime}$ E., 103 fathoms, stones, bottom temperature $60.6^{\circ}, 1$ specimen; station 5094, Uraga Strait, lat. $35^{\circ} 4^{\prime} 42^{\prime \prime}$ N.; long. $139^{\circ} 38^{\prime} \cdot 20^{\prime \prime}$ E., 88 fathoms, black sand, broken shells, bottom temperature $54.8^{\circ}, 1$ specimen.

Type.-Cat. No. 25671, U.S.N.M., from station 4934.

The disk of the type is badly damaged, while the arms are fairly well preserved. The specimen from station 4936 has a pretty good disk but the arms are in poor condition and fail to show the webs. The specimen from station 5094 is so badly damaged it is not certain that it belongs to this species. Judging from the arm structure of the type, it seems as though this species ought to be able to swim, and it is quite possible that such is its regular mode of locomotion. Observations on its habits would be most interesting.

OPHIOHYMEN, new genus. $a$

Disk and arms covered with naked skin. Radial shields and upper arm plates wanting. Mouth parts as in Ophiomyxa. Arm spines connected vertically by membranes and upper ones also connected horizontally.

Type-species.-Ophiohymen gymnodiscus.

This genus is a curious connecting link between Ophiosyzygus, which it resembles in disk and arm structure, and Ophiomyxa. which it is like in its mouth parts.

\section{OPHIOHYMEN GYMNODISCUS, new species. $b$}

Disk $8 \mathrm{~mm}$. in diameter; arms about $35 \mathrm{~mm}$. long. Disk and arms covered with a thick skin, extending also over interbrachialspaces below, lower surface of arms and jaws and even to tips of oral papillæ. No radial shields, upper arm plates or tentacle scales. Upper ends of genital plates scarcely visible at base of arms, from above, but genital scales extending into interbrachial spaces, plainly visible from below

$a^{\prime \prime} 0 \phi\left\llcorner o\right.$ and $\dot{y} \mu i_{j}$, signifying membrane in reference to membrane connecting arm spines.

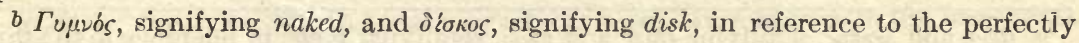
bare disk. 
(fig. 140b). Outlines of under arm plates indistinct; apparently they are wider than long. Oral shields large, about as long as wide. Adoral plates long and narrow, almost L-shaped; oral plates well developed. Genital slits long. Oral papillæ about five on a side, most proximal largest, rounded and finely serrate at tip. Teeth large, flat, with rounded and serrate tips. Arm spines three, lowest slightly longest equalling joint, and middle one usually shortest; each vertical series of three are joined to each other by a membrane, reaching nearly to their tips; in addition, all uppermost spines are joined to each other by a narrow horizontal membrane, which reaches to or beyond middle of spines. Color (dried from alcohol), dull purplishred, arms indistinctly banded with yellowish.

Locality.-Albatross station 4903 , Eastern Sea, lat. $32^{\circ} 31^{\prime} 10^{\prime \prime}$ N.; long. $128^{\circ} 33^{\prime} 20^{\prime \prime}$ E., 107 to 139 fathoms, gray sand, broken shells, bottom temperature $52.9^{\circ}$ (?), 1 specimen.

Type.-Cat. No. 25537, U.S.N.M., from station 4903.

This specimen is badly damaged, most of the disk being gone, but

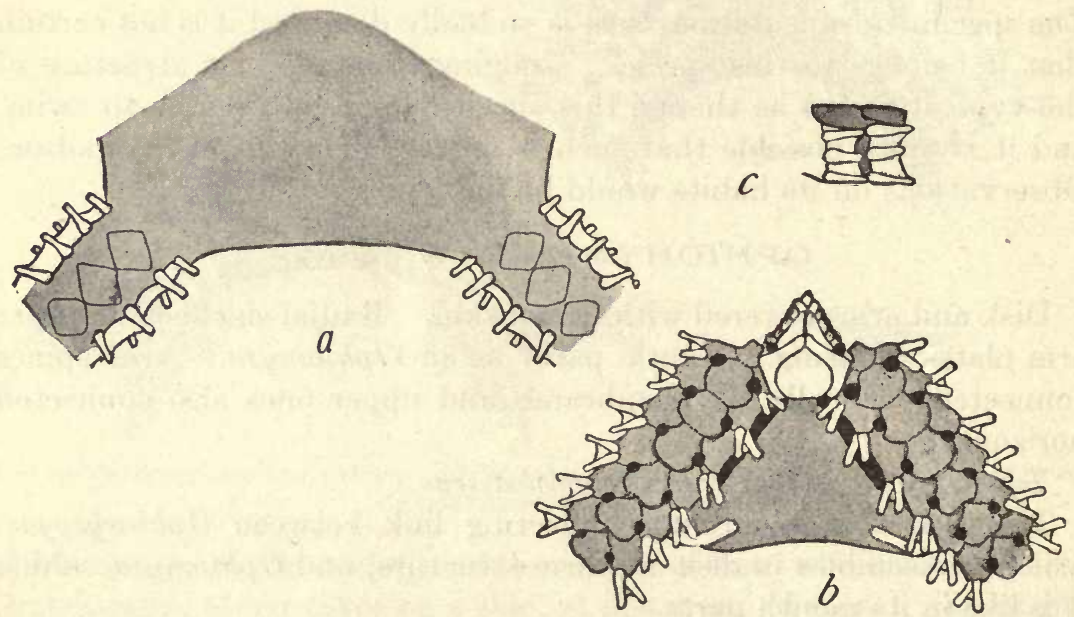

Fig. 140.-OPHiohymen GYMNodiscus. $\times 6$. $a$, FROM ABOVE; $b$, FRoM BELOW; $c$, SIDE VIEW OF TWo ARM JOINTS NEAR DISK.

its characters seem to be well shown nevertheless. Further material is necessary to determine some points of structure, and observations on living material can alone show what the functions of the arm membranes are. It is easy to suppose they are natatorial.

\section{OPHIOLEPTOPLAX, new genus. $a$}

Disk and arms covered by naked skin. Radial shields wanting. Upper arm plates apparently present in form of very thin, transpar-

$a^{\prime \prime} 0 \phi \iota 0$ and $\lambda \varepsilon \pi \tau \dot{s}$, , signifying thin, and $\pi \lambda \dot{\alpha} \xi$, signifying plate, in reference to the thin transparent upper arm plates. 
ent scales. Oral papillæ very few and small. Teeth reduced to a small cluster at apex of jaw. No tentacle scales.

Type-species.-Ophioleptoplax megapora.

The specimen upon which this genus rests is probably immature, but I can not refer it to any known species or genus. In its mouth parts it is very near Ophiosyzygus, but its arm structure is quite different. Yet I am not satisfied that the supposed upper arm plates are really homologous with the upper arm plates of other genera. They are certainly not calcareous and they may be nothing but skin thickenings on each joint. Their appearance in this specimen may be an individual peculiarity.

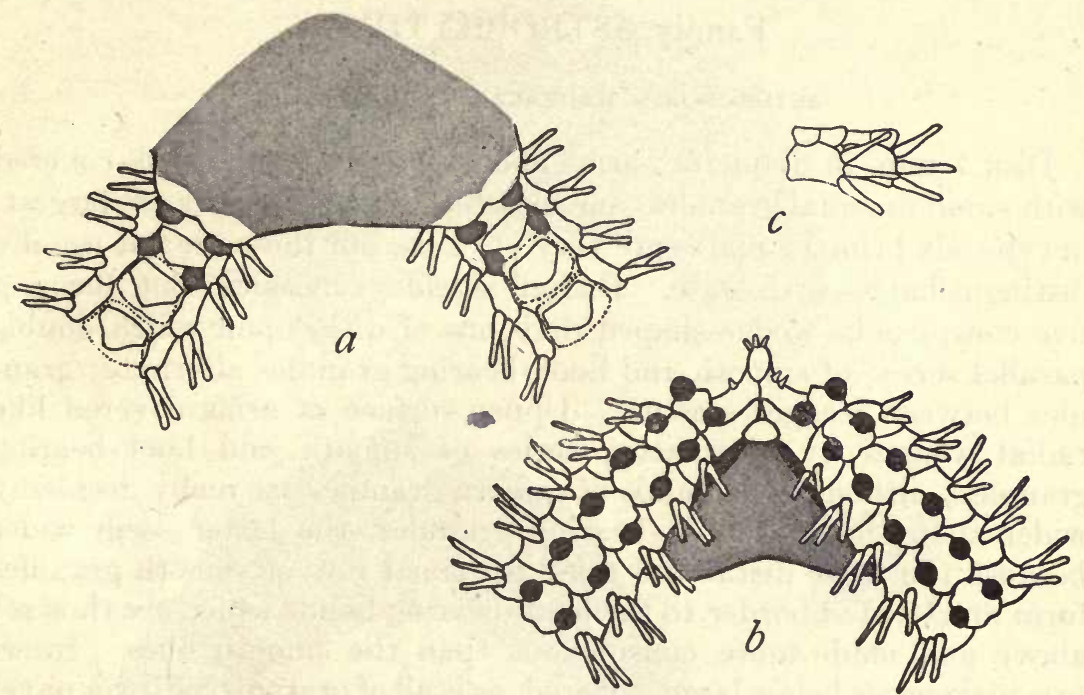

Fig. 141.-Opholeptoplax MEgapora. $\times$ 8. $a$, From ABOVe; $b$, From Below; $c$, Side view of tWo ARM JOINTS NEAR DISK.

OPHIOLEPTOPLAX MEGAPORA, new species.a

Disk $6 \mathrm{~mm}$. in diameter; arms about $25 \mathrm{~mm}$. long. Disk covered with a thick, naked skin. Radial shields wanting, but upper ends of genital plates are visible at base of each arm. Upper arm plates represented by what appear to be very thin transparent noncalcareous scales, squarish in outline and rather wider than long; arm bones plainly visible through them. Interbrachial spaces below naked. Genital slits small. Oral shields very small, wider than long. Adoral plates very large, much wider without than within. Oral papillæ, one to three on each side, minute, sharp conical spinelets. Teeth (tooth papillæ?) reduced to a small cluster at apex of jaw, of very small, rough-pointed spinelets. Under arm plates longer than

a MEras, signifying big, and $\pi \dot{o} \rho{ }^{\prime}$, signifying $a$ pore, in reference to the large tentacle pores. 
wide, with deeply concave sides, on account of the huge tentacle pores, which have no tentacle scales. Side arm plates low, each with three subequal, cylindrical, blunt spines, a trifle longer than joint. Color (dried from alcohol), disk brown; arms whitish.

Locality.-Albatross station 4888, Eastern Sea, lat. $32^{\circ} 26^{\prime}$ N.; long. $129^{\circ} 27^{\prime} 30^{\prime \prime}$ E., 71 fathoms, dark gray sand, broken shells, bottom temperature $59.7^{\circ}, 1$ specimen.

Type.-Cat. No. 25619, U.S.N.M., from station 4888.

This specimen is well preserved but I think it is immature and the validity not only of the genus, but of the species as well, must remain doubtful until further material is obtained.

\section{Family ASTROPHYTID瓜.}

\section{ASTEROPORPA HADRACANTHA, new species. $a$}

Disk $7 \mathrm{~mm}$. in diameter; arms about $35 \mathrm{~mm}$. long. Disk covered with small unequal granules, among which some at center are largest; in type, six primary plates are very obvious, but these are not usually distinguishable with ease. Radial shields concealed but forming five conspicuous wedge-shaped divisions of disk, upon which double parallel series, of smooth and hook-bearing granules alternate; granules between wedges smooth. Upper surface of arms covered like radial wedges by alternating series of smooth and hook-bearing granules; although the bands of smooth granules are really decidedly wider than those of hook-bearing granules, the latter seem wider because the most distal and most proximal row of smooth granules form an elevated border to the hook-bearing bands which are thus set above and made more conspicuous than the smooth ones. Interbrachial spaces below large, covered, as is all of oral surface, by a pavement of granules. Genital slits small, oblique but approaching vertical. Teeth and tooth papillæ longer and more slender than oral papillæ, which are few, short, and pointed. Under surface of arms paved with granules. First pair of tentacle pores of arm, small, unprotected; - succeeding pores protected by a ridge carrying tentacle scales or arm spines. Second pore has two or three such scales, third three or four, and succeeding pores five or six such spinelets; they are short and thick, lowest particularly so and about as thick as long, thorny with glassy points at tip. Color (dried from alcohol), very light brown or nearly white.

Localities.-Albatross station 3727, off Omai Zaki, Honshu Island, Japan, 34 fathoms, mud, coarse sand, broken shells, 2 specimens;

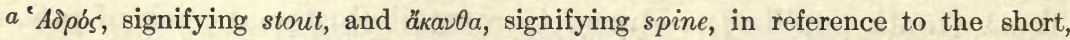
thick arm spines. As Örstedt and Lütken's original spelling, "Asteroporpa," is philologically correct, it ought to be used rather than the contracted form, "Astroporpa." 
station 3730, off Omai Zaki, Honshu Island, Japan, 34 to 37 fathoms, mud, gravel, rocks, 1 specimen; station 3764, off Suno Saki, Honshu Island, Japan, 44 to 50 fathoms, fine gravel, broken shells, 1 specimen; station 4936 , Eastern Sea, lat. $30^{\circ} 54^{\prime} 40^{\prime \prime}$ N.; long. $130^{\circ} 37^{\prime} 30^{\prime \prime}$ E. 103 fathoms, stones, bottom temperature $60.6^{\circ}, 1$ specimen. Bathymetrical range, 34 to 103 fathoms. Five specimens.

Type.-Cat. No. 25727, U.S.N.M., from station 3764.

It is a matter of no little interest to find this genus occurring off the coast of Japan, for it was previously known only from the West Indies and Australia. The present species differs from those pre-
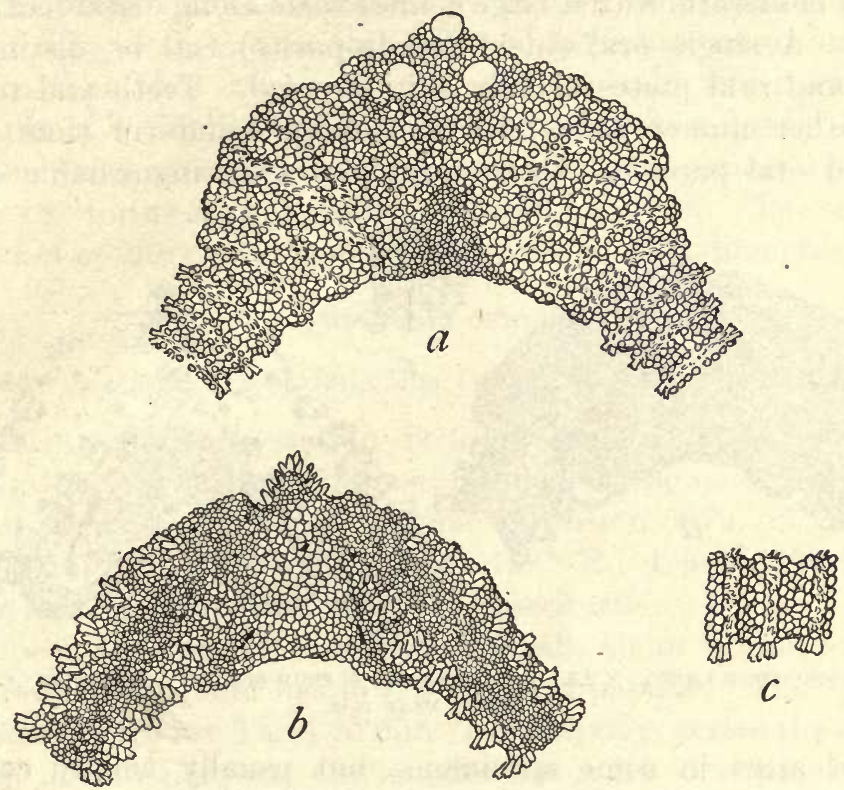

c

Fig. 142.-Asteroporpa hadracantha. $\times$ 7. $a$, From ABove; $b$, From Below; $c$, Side VIEW of three JOINTS NEAR DISK.

viously known in its very short and thick arm spines, the lowest one on the basal part of the arm being particularly characteristic. It is interesting to find that in the relative width of the alternate bands of granules on the arm the Japanese species does not resemble the Australian form. Comparison of fig. 142 with that of A. australianus $^{a}$ shows how distinct the two species are.

\section{ASTROCHELE LAEVIS, new species.b}

Disk $20 \mathrm{~mm}$. in diameter; arms about $100 \mathrm{~mm}$. long, probably. Disk high, convex, covered with a thick, uniform coat of flattened,

$a$ Mem. Aust. Mus., vol. 4, pl. 54, fig. 2.

$b$ Lævis, signifying smooth, in reference to the relatively low and flat disk granules. 
slightly convex granules. Radial shields completely covered, but their presence indicated by five pairs of conspicuous ridges, extending from arm bases to center of disk. Margin of disk formed by a calcareous thickening which bears large granules like those on radia shields. None of the granules are conical or spine-bearing. Upper surface of arm covered by alternating, but not clearly defined, bands of smooth and hook-bearing granules; smooth granules not crowded, scattered; hook-bearing granules more regularly arranged in two rather crowded series. Whole oral surface covered by granulebearing skin, with granules thickest on interbrachial spaces. Genital slits moderate, with a large genital scale along distal half of inner margin. A single oral shield (madreporite) can be distinguished. Adoral and oral plates usually skin covered. Teeth and tooth papillæ rather numerous, longer and more spiniform than the few scattered oral papillæ. Under arm plates distinguishable on basal

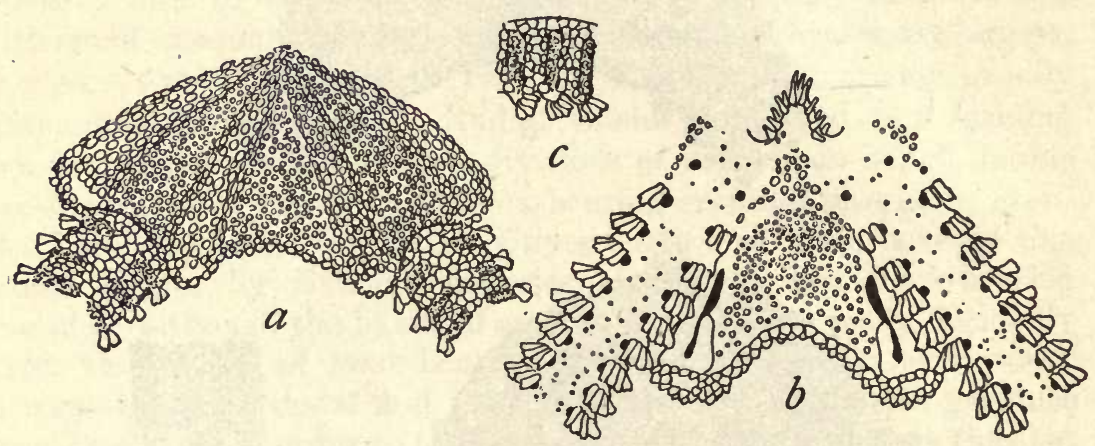

Fig. 143.-ASTROCHELE LeVIS. $\times 2.5$. $a$, FROM $\triangle$ BOVE; $b$, FROM BELOW; $c$, SIDE VIEW OF THREE ARM JOINTS NEAR DISK.

joints of arms in some specimens, but usually wholly concealed. Basal tentacle pores of arm minute and unprotected; second pair with two or three short, thick, flattened arm spines (tentacle scales ?) which carry little glassy points at tip; succeeding pores with three or four (sometimes five) such spinelets, of which innermost is largest, borne on a low, thick ridge just proximal to pore. Color (dried from alcohol), cream-white to deep yellow.

Localities.-Albatross station 3317, Bering Sea, lat. $53^{\circ} 57^{\prime} 40^{\prime \prime} \mathrm{N}$.; long. $166^{\circ} 59^{\prime} \mathrm{W}$., 165 fathoms, coarse sand, gravel, rocks, bottom temperature $39.5^{\circ}, 1$ specimen; station 3319 , Bering Sea, lat. $53^{\circ} 40^{\prime}$ $30^{\prime \prime} \mathrm{N}$.; long. $167^{\circ} 30^{\prime} \mathrm{W}, 59$ fathoms, black sand, bottom temperature $40.8^{\circ}, 8$ specimens; station 3480 , Bering Sea, lat. $52^{\circ} 6^{\prime} \mathrm{N}$.; long. $171^{\circ} 45^{\prime} \mathrm{W}$., 283 fathoms, black sand, coral, rocky, 5 specimens; station 4771 , Bering Sea, lat. $54^{\circ} 30^{\prime}$ N.; long. $179^{\circ} 17^{\prime}$ E., 426 fathoms, broken shells, 4 specimens; station 4781 , Bering Sea, lat. 
$52^{\circ} 14^{\prime} 30^{\prime \prime} \mathrm{N}$.; long. $174^{\circ} 13^{\prime} \mathrm{E} ., 482$ fathoms, fine gray sand, pebbles, bottom temperature $38.6^{\circ}, 4$ specimens. Bathymetrical range, 59 to 482 fathoms. Temperature range, $40.8^{\circ}$ to $38.6^{\circ}$. Twenty-two specimens.

Type.-Cat. No. 25716, U.S.N.M., from station 3319.

It is most interesting to find this genus, hitherto known only from the western Atlantic, in the Pacific Ocean off Alaska. The Alaskan species is very nearly allied to lymani from the Atlantic, but judging from the material available to me it differs distinctly in the flat, convex disk grains; in lymani many of the disk grains are conical and some are almost spine-like, especially on the radial shields and disk margin. The teeth and tooth papillæ of lævis are more slender and spiniform than they are in lymani, and the skin which covers the whole animal is thicker and more full of granules in lævis. None of these differences is very radical and more abundant material may show that the two forms are not really specifically distinct. The specimens of lxvis before me range from 8 to $20 \mathrm{~mm}$. in disk diameter.

\section{OPHIOCREAS CEDIPUS.}

Ophiocreas æedipus Lyman, Bull. Mus. Comp. Zoöl., vol. 6, 1879, p. 65.

Localities.-Albatross station 4979, off eastern Japan, lat. $33^{\circ} 53^{\prime}$ N.; long. $137^{\circ} 42^{\prime}$ E., 943 fathoms, brown mud, fine sand, foraminifera, bottom temperature $36.4^{\circ}, 1$ specimen; station 5079, off Omai Saki light, Japan, lat. $34^{\circ} 15^{\prime} \mathrm{N}$; long. $138^{\circ}$ E., 475 to 505 fathoms, pebbles, bottom temperature $39.1^{\circ}, 2$ specimens.

The specimen from station 4979 is small, about $9 \mathrm{~mm}$. across the disk, dirty whitish, and has low, blunt oral papillæ. The specimens from station 5079 are 5 and $20 \mathrm{~mm}$., respectively, across the disk, and are deep purplish brown; the smaller has a few oral papillæ in the mouth angles, but the larger has none. None of the specimens has any unusual swelling at base of arms, but aside from that fact the large one answers very well to Lyman's description and figures. As the swelling of the arm bases is probably associated with the full development of the reproductive organs, it does not seem to me that its presence or absence can be considered a specific character. It is probably best, therefore, to consider the large specimen before me an example of redipus. In spite of its oral papillæ the little specimen from the same station seems to be undoubtedly identical, and therefore I can not regard the specimen from station 4979, in which oral papillæ are well developed, as a different species, even though its color also is quite different. But it is possible, nevertheless, that more abundant material would show this latter specimen to be specifically distinct. 
ASTROCERAS PERGAMENA.

Astroceras pergamena Lyman, Bull. Mus. Comp. Zoöl., vol. 6, 1879, p. 62.

Localities.-Albatross station 3716, off Ose Zaki, Honshu Island, Japan, 65 to 125 fathoms, volcanic sand, shells, rocks, 17 specimens; station 3729, off Omai Zaki, Honshu Island, Japan, 34 fathoms, mud, gravel, 1 specimen; station 3730, off Omai Zaki, Honshu Island, Japan, 34 to 37 fathoms, mud, gravel, rocks, 5 specimens; station 3735, off Omai Zaki, Honshu Island, Japan, 36 fathoms, coarse gray volcanic sand, broken shells, 33 specimens; station 3755 , off Suno Saki, Honshu Island, Japan, 52 to 77 fathoms, gray sand, coral, 4 specimens; station 4893 , Eastern Sea, lat. $32^{\circ} 32^{\prime}$ N.; long. $128^{\circ} 32^{\prime}$ $50^{\prime \prime}$ E., 95 to 106 fathoms, gray sand, broken shells, pebbles, bottom temperature $55.9^{\circ}, 3$ specimens; station 4894 , Eastern Sea, lat. $32^{\circ}$ $33^{\prime}$ N.; long. $128^{\circ} 32^{\prime} 10^{\prime \prime}$ E., 95 fathoms, gray sand, broken shells, pebbles, 2 specimens; station 4895 , Eastern Sea, lat. $32^{\circ} 33^{\prime} 10^{\prime \prime} \mathrm{N}$.; long. $128^{\circ} 32^{\prime} 10^{\prime \prime}$ E., 95 fathoms, gray sand, broken shells, pebbles, 1 specimen; station 4936 , Eastern Sea, lat. $30^{\circ} 54^{\prime} 40^{\prime \prime} \mathrm{N}$.; long. $130^{\circ}$ $37^{\prime} 30^{\prime \prime}$ E., 103 fathoms, stones, bottom temperature $60.6^{\circ}, 1$ specimen; station 5070, Suruga Gulf, lat. $35^{\circ} 3^{\prime} 25^{\prime \prime}$ N.; long. $138^{\circ} 47^{\prime} 40^{\prime \prime}$ E., 108 fathoms, mud, sand, broken shells, bottom temperature $57.6^{\circ}$, 2 specimens. Bathymetrical range, 34 to 125 fathoms. Temperature range, $60.6^{\circ}$ to $55.9^{\circ}$. Sixty-nine specimens.

This is a remarkably interesting series of specimens ranging in disk diameter from 1 to $8 \mathrm{~mm}$. The smallest specimens have no tubercles on either radial shields or arms, but these appear most irregularly with increasing size, those on the radial shields appearing first, but some of those on the basal joints of the arm may appear before all the radial shields have them; thus in a specimen $5 \mathrm{~mm}$. across the disk there are tubercles on the basal joints of all the arms but only on four of the radial shields. Another specimen $5 \mathrm{~mm}$. across has each of the radial shields provided with a tubercle, as in Lyman's type, and similar ones are present on the two basal joints of each arm. In the specimens $8 \mathrm{~mm}$. across the disk, the tubercles are present but not equally developed, on the basal six or seven joints of each arm. On the disk and arms of the smallest specimens are minute, round, calcareous granules, and on the arms these are arranged in very regular transverse rows, corresponding to the upper arm plates. As growth goes on and the large tubercles appear these granules disappear, first from the disk and then from the base of the arm, but even in the largest specimen they are abundant beyond the basal part of the arm. Lyman does not refer to their presence in the type-specimen, which was $19 \mathrm{~mm}$. across the disk, so that it is probable they ultimately all disappear.

Another most interesting fact revealed by the series before me is that the young Astroceras has; like many specimens of Amphiuridæ, 
six arms. The specimens under $5 \mathrm{~mm}$. across the disk all have six arms, except two which have seven, while those above that size have only five. Furthermore, the six arms are not of equal size, but three are large and three are small, often very small, indicating that reproduction by fission has taken place. None of the specimens reveals how the six-armed young becomes the symmetrical five-armed adult, but in two specimens the middle arm of the smaller trio is distinctly smaller than its two neighbors, and it may be that this middle arm is ultimately resorbed or lost by autotomy. The study of the actual development of Astroceras, taking into account the plane of symmetry of both larva and adult, would prove most interesting and important.

\section{ASTERONYX LOVENI.}

Asteronyx a loveni Müller and Troschel, Sys. Ast., 1842, p. 119.

Localities.-Albatross station 2860 , off Washington, lat. $51^{\circ} 23^{\prime} \mathrm{N}$.; long. $130^{\circ} 34^{\prime} \mathrm{W}$., 876 fathoms, green mud, bottom temperature $36.5^{\circ}$, 65 specimens; station 2861 , off Washington, lat. $51^{\circ} 14^{\prime} \mathrm{N}$.; long. $129^{\circ} 50^{\prime} \mathrm{W}$., 204 fathoms, bottom temperature $42.6^{\circ}, 3$ specimens; station 3069 , off Washington, lat. $47^{\circ} 25^{\prime} 30^{\prime \prime}$ N.; long. $125^{\circ} 42^{\prime} \mathrm{W}$., 760 fathoms, green mud, bottom temperature $37.6^{\circ}, 3$ specimens; station 3075 , off Washington, lat. $47^{\circ} 22^{\prime} \mathrm{N}$.; long. $125^{\circ} 41^{\prime}$ W., 859 fathoms, green mud, bottom temperature $36.6^{\circ}, 13$ specimens; station 3112 , off California, lat. $37^{\circ} 8^{\prime} \mathrm{N}$.; long. $122^{\circ} 47^{\prime} \mathrm{W}$., 296 fathoms, fine gray sand, bottom temperature $41.8^{\circ}, 40$ specimens; station 3126 , off California, lat. $36^{\circ} 49^{\prime} 20^{\prime \prime} \mathrm{N}$.; long. $122^{\circ} 12^{\prime} 30^{\prime \prime}$ W., 456 fathoms, green mud, bottom temperature $42.8^{\circ}, 3$ specimens; station 3128 , off California, lat. $36^{\circ} 41^{\prime} 50^{\prime \prime} \mathrm{N}$.; long. $122^{\circ} 7^{\prime} 30^{\prime \prime}$ W., 627 fathoms, blue mud, bottom temperature $38.9^{\circ}, 4$ specimens; station 3338 , off Alaska, lat. $54^{\circ} 19^{\prime} \mathrm{N}$.; long. $159^{\circ} 40^{\prime}$ W., 625 fathoms, green mud, sand, bottom temperature, $37.3^{\circ}, 277$ specimens; station 3489 , Bering Sea, lat. $57^{\circ} \mathrm{N}$.; long. $173^{\circ} 14^{\prime} \mathrm{W}$., 184 fathoms, green mud, gray sand, bottom temperature $38.5^{\circ}, 4$ specimens; station 3670 , off Monterey, Cal., lat. $36^{\circ} 43^{\prime} \mathrm{N}$.; long. $122^{\circ} 12^{\prime} \mathrm{W}$., 581 fathoms, green mud, sand, bottom temperature $37.8^{\circ}, 1$ specimen; station 3749 , off Suno Saki, Honshu Island, Japan, 83 to 158 fathoms, black sand, shells, 16 specimens; station 3784 , Bering Sea, lat. $54^{\circ} 32^{\prime} \mathrm{N}$.; long. $178^{\circ} 31^{\prime}$ E., 850 fathoms, green mud, fine gray sand, 1 specimen; station 4781 , Bering Sea, lat. $52^{\circ} 14^{\prime} 30^{\prime \prime}$ N.; long. $174^{\circ} 13^{\prime}$ E., 482 fathoms, fine gray sand, pebbles, bottom temperature $38.6^{\circ}, 1$ specimen; station 4957 , off southern Japan, lat. $32^{\circ} 36^{\prime} \mathrm{N}$. ; long. $132^{\circ} 23^{\prime} \mathrm{E}$., 437 fathoms, green-brown mud, fine gray sand, foraminifera, bottom temperature $39.8^{\circ}, 2$ specimens; station 4959 , off southern Japan, lat.

$a$ The name has very commonly been contracted to "Astronyx," but as Müller and Troschel's spelling is philologically correct it ought to be retained. 
$32^{\circ} 36^{\prime} 30^{\prime \prime} \mathrm{N}$.; long. $132^{\circ} 23^{\prime} 20^{\prime \prime}$ E., 405 to 578 fathoms, greenbrown mud, fine gray sand, foraminifera, bottom temperature $40.1^{\circ}$ to $38.7^{\circ}, 1$ specimen; station 4960 , off southern Japan, lat. $32^{\circ} 34^{\prime} \mathrm{N}$.; long. $132^{\circ} 21^{\prime} 45^{\prime \prime}$ E., 578 fathoms, green-brown mud, fine gray sand, foraminifera, bottom temperature $38.7^{\circ}, 2$ specimens; station 4969 , off eastern Japan, lat. $33^{\circ} 23^{\prime} 40^{\prime \prime} \mathrm{N}$.; long. $135^{\circ} 33^{\prime}$ E., 587 fathoms, brown mud, sand, stones, bottom temperature $38.9^{\circ}$, 13 specimens; station 4970 , off eastern Japan, lat. $33^{\circ} 23^{\prime} 30^{\prime \prime} \mathrm{N}$.; long. $135^{\circ} 36^{\prime} 30^{\prime \prime}$ E., 500 to 649 fathoms, brown mud, black sand, shells, bottom temperature $39.1^{\circ}, 1$ specimen; station 4971 , off eastern Japan, lat. $33^{\circ} 23^{\prime} 30^{\prime \prime} \mathrm{N}$.; long. $135^{\circ} 34^{\prime}$ E., 649 fathoms, brown-green mud, foraminifera, bottom temperature $38.1^{\circ}, 10$ specimens; station 4972 , off eastern Japan, lat. $33^{\circ} 25^{\prime} 45^{\prime \prime}$ N. ; long. $135^{\circ} 33^{\prime}$ E., 440 fathoms, brown-green mud, foraminifera, bottom temperature $39.8^{\circ}, 3$ specimens; station 4976 , off eastern Japan, lat. $33^{\circ} 22^{\prime} 50^{\prime \prime}$ N.; long. $135^{\circ}$ $38^{\prime} 30^{\prime \prime}$ E., 545 fathoms, brown mud, small stones, bottom temperature $38.7^{\circ}, 2$ specimens; station 4977 , off eastern Japan, lat. $33^{\circ} 23^{\prime}$ N.; long. $135^{\circ} 37^{\prime} 40^{\prime \prime}$ E., 544 fathoms, brown mud, fine sand, bottom temperature $38.9^{\circ}, 4$ specimens; station 4980 , off eastern Japan, lat. $34^{\circ} 9^{\prime} \mathrm{N}$.; long. $137^{\circ} 55^{\prime}$ E., 507 fathoms, brown mud, fine sand, foraminifera, bottom temperature $39^{\circ}, 4$ specimens; station 5015, Okhotsk Sea, lat. $46^{\circ} 44^{\prime}$ N. ; long. $144^{\circ} 2^{\prime}$ E., 510 fathoms, green mud, bottom temperature $35.9^{\circ}, 2$ specimens; station 5018 , Okhotsk Sea, lat. $46^{\circ} 41^{\prime} 30^{\prime \prime} \mathrm{N}$.; long. $143^{\circ} 57^{\prime} 40^{\prime \prime}$ E., 100 fathoms, brown mud, black sand, pebbles, bottom temperature $30.4^{\circ}, 1$ specimen; station 5029, Okhotsk Sea, lat. $48^{\circ} 22^{\prime} 30^{\prime \prime}$ N.; long. $145^{\circ} 43^{\prime} 30^{\prime \prime}$ E., 440 fathoms, black sand, gravel, bottom temperature $35.3^{\circ}, 10$ specimens; station 5048, off Kinka San Light, Japan, lat. $38^{\circ} 9^{\prime} 24^{\prime \prime}$ N.; long. $141^{\circ} .52^{\prime} 30^{\prime \prime}$ E., 129 fathoms, dark gray sand, broken shells, bottom temperature $40.7^{\circ}, 1$ specimen; station 5079, off Omai Saki, Japan, lat. $34^{\circ} 15^{\prime}$ N.: long. $138^{\circ}$ E., 475 to 505 fathoms, pebbles, bottom temperature $39.1^{\circ}, 1$ specimen; station 5080, off Omai Saki, Japan, lat. $34^{\circ} 10^{\prime} 30^{\prime \prime} \mathrm{N}$.; long. $138^{\circ} 40^{\prime} \mathrm{E}$., 505 fathoms, fine gray sand, globigerina, bottom temperature $38.7^{\circ}, 5$ specimens; station 5082 , off Omai Saki, Japan, lat. $34^{\circ} 5^{\prime}$ N. ; long. $137^{\circ} 59^{\prime}$ E., 662 fathoms, green mud, fine sand, globigerina, bottom temperature $37.7^{\circ}, 2$ specimens; station 5083, off Omai Saki, Japan, lat. $34^{\circ} 4^{\prime} 20^{\prime \prime}$ N.; long. $137^{\circ} 57^{\prime}$ $30^{\prime \prime}$ E., 624 fathoms, fine gray sand, globigerina, bottom temperature $38.1^{\circ}$, 1 specimen; station 5084, off Omai Saki, Japan, lat. $34^{\circ} \mathrm{N}$.; long. $137^{\circ} 49^{\prime} 40^{\prime \prime}$ E., 918 fathoms, green mud, fine sand, globigerina, bottom temperature $36.8^{\circ}, 2$ specimens. Bathymetrical range, 83 to 918 fathoms. Temperature range, $42.8^{\circ}$ to $30.4^{\circ}$. Four hundred and ninety-eight specimens.

This fine series of specimens, ranging in size from young ones only $5 \mathrm{~mm}$. across the disk up to huge adults $45 \mathrm{~mm}$. in disk diameter, has 
been compared with European and West Indian specimens, and no differences, other than those of age and individual diversity, have been found. I have also examined specimens of Lütken's and Mortensen's three Panamic species (dispar, plana, and excavata) and believe they are quite distinct. The north Pacific specimens of loveni show great diversity in the relative size of the different arms, but, as a rule, full-grown specimens have one or two of the arms much broader than the others. Thus, a specimen $40 \mathrm{~mm}$. across the disk has the greatest width of each of the five arms, successively, as follows, $9,6,7 \frac{1}{2}, 6 \frac{1}{2}$, and $5 \mathrm{~mm}$. Lütken and Mortensen give this peculiarity as the striking feature of dispar, but I think it is probably a characteristic of sexually mature adults of any species in the genus. Its degree of development varies greatly. Two extremes may be given as follows:

Disk, $22 \mathrm{~mm}$. across; arms successively 8, 3, 3, 5, and $3 \mathrm{~mm}$. broad.

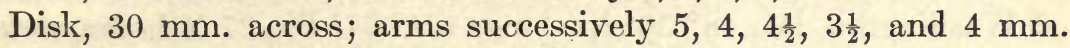
broad.

The geographical range of loveni is noteworthy, for, although it does not appear to be an Arctic or subarctic form, it occurs in the north Atlantic from the coast of Norway southwestward along the east coast of the United States to St. Vincent in the Lesser Antilles; in the north Pacific from Bering Sea, $57^{\circ} \mathrm{N}$., to Timor on the south; and in the Indian Ocean to the Laccadive Islands on the west. Yet it is apparently wanting in the Panamic region and in the eastern Atlantic, where it is replaced by allied species.

\section{TRICHASTER PALMIFERUS.}

Euryale palmiferum LAMaRcK, Anim. s. Vert., vol. 2, 1816, p. 539.

Tricaster palmifer AgAssiz, Mém. Soc. Sci. Nat. Neuchatel, vol. 1, 1835, p. 193.

Trichaster palmiferus Müller and Troschel, Sys. Ast., 1842, p. XIV and 120.

Localities.-Albatross station 4929, Colnett Strait, lat. $30^{\circ} 12^{\prime} 30^{\prime \prime}$ N.; long. $130^{\circ} 43^{\prime}$ E., 84 fathoms, broken shells, coral, pebbles, bottom temperature $74.8^{\circ}, 2$ specimens; station 4931 , Colnett Strait, lat. $30^{\circ} 12^{\prime} \mathrm{N}$.; long. $130^{\circ} 43^{\prime} 40^{\prime \prime}$ E., 83 fathoms, broken shells, pebbles, coral, bottom temperature $75.4^{\circ}, 1$ specimen.

In the specimen from station 4931 each radial shield carries a small conical tubercle at its distal end. Such tubercles are wanting in the other specimens.

\section{GORGONOCEPHALUS CARYI.}

Astrophyton caryi Lyman, Proc. Boston Soc. Nat. Hist., vol. 7, 1860, p. 424.

Gorgonocephalus caryi LyMAN, Challenger Oph., 1881, p. 264.

Astrophyton stimpsonii Verrill, Proc. Boston Soc. Nat. Hist., vol. 12, 1869, p. 388 .

Gorgonocephalus japonicus DöDERLEIN, Zool. Anz., vol. 25, 1902, p. 321.

Localities.-Albatross station 2844 , off Alaska, lat. $53^{\circ} 56^{\prime} \mathrm{N}$.; long. $165^{\circ} 40^{\prime}$ W., 54 fathoms, gray sand, bottom temperature $42^{\circ}, 15$ 
specimens; station 2847 , off Alaska, lat. $55^{\circ} 1^{\prime} \mathrm{N}$.; long. $160^{\circ} 12^{\prime} \mathrm{W}$., 48 fathoms, fine gray sand, bottom temperature $42^{\circ}, 3$ specimens; station 2850 , off Alaska, lat. $54^{\circ} 52^{\prime} \mathrm{N}$.; long. $159^{\circ} 46^{\prime} \mathrm{W}$., 21 fathoms, broken shells, bottom temperature $48.2^{\circ}, 1$ specimen; station 2852 , off Alaska, lat. $55^{\circ} 15^{\prime} \mathrm{N}$.; long. $159^{\circ} 37^{\prime} \mathrm{W}$., 58 fathoms, black sand, bottom temperature $41.8^{\circ}, 29$ specimens; station 2853, off Alaska, lat. $56^{\circ} \mathrm{N}$.; long. $154^{\circ} 20^{\prime} \mathrm{W}$., 159 fathoms, gray sand, bottom temperature $41^{\circ}, 2$ specimens; station 2854 , off Alaska, lat. $56^{\circ} 55^{\prime} \mathrm{N}$.; long. $153^{\circ} 4^{\prime}$ W., 60 fathoms, black sand, bottom temperature $42.8^{\circ}$, 2 specimens; station 2858 , off Alaska, lat. $58^{\circ} 17^{\prime} \mathrm{N}$.; long. $148^{\circ} 36^{\prime}$ W., 230 fathoms, blue mud, gravel, bottom temperature $39.8^{\circ}$, 1 specimen; station 2870 , off Washington, lat. $46^{\circ} 44^{\prime} \mathrm{N}$.; long. $124^{\circ}$ $32^{\prime}$ W., 58 fathoms, rocky, bottom temperature $46.5^{\circ}, 13$ specimens; station 2873 , off Washington, lat. $48^{\circ} 30^{\prime} \mathrm{N}$.; long. $124^{\circ} 57^{\prime}$ W., 40 fathoms, rocks, bottom temperature $47.8^{\circ}, 3$ specimens; station 2874 , off Washington, lat. $48^{\circ} 30^{\prime} \mathrm{N}$.; long. $124^{\circ} 57^{\prime} \mathrm{W}$., 27 fathoms, rocks, shells, bottom temperature $50.3^{\circ}, 2$ specimens; station 2887 , off Oregon, lat. $43^{\circ} 58^{\prime} \mathrm{N}$.; long. $124^{\circ} 57^{\prime} \mathrm{W} ., 42$ fathoms, clay and pebbles, bottom temperature $47.1^{\circ}, 2$ specimens; station 3047 , off Oregon, lat. $46^{\circ} 47^{\prime} \mathrm{N}$.; long. $124^{\circ} 30^{\prime} 15^{\prime \prime} \mathrm{W}$., 50 fathoms, fine gray sand, bottom temperature $45.9^{\circ}, 4$ specimens; station 3051 , off Oregon, lat. $43^{\circ} 59^{\prime} 15^{\prime \prime} \mathrm{N}$.; long. $124^{\circ} 58^{\prime} 30^{\prime \prime} \mathrm{W}$., 59 fathoms, coral, broken shells, rocky, 1 specimen; station 3081 , off Oregon, lat. $43^{\circ}$ $59^{\prime} \mathrm{N}$.; long. $124^{\circ} 20^{\prime} \mathrm{W}$., 61 fathoms, green mud, sand, bottom temperature $45.8^{\circ}, 1$ specimen; station 3106 , off California, lat. $37^{\circ} 21^{\prime}$ N.; long. $122^{\circ} 51^{\prime} \mathrm{W}$., 77 fathoms, fine gray sand, 2 specimens; station 3174 , off California, lat. $38^{\circ} 15^{\prime} 30^{\prime \prime} \mathrm{N}$.; long. $123^{\circ} 14^{\prime} 15^{\prime \prime} \mathrm{W} ., 65$ fathoms, green mud, bottom temperature $49.5^{\circ}, 1$ specimen; station 3213 , off Alaska, lat. $54^{\circ} 10^{\prime} \mathrm{N}$.; long. $162^{\circ} 57^{\prime} 30^{\prime \prime} \mathrm{W}$., 41 fathoms, black sand, 3 specimens; station 3214 , off Alaska, lat. $54^{\circ} 13^{\prime} \mathrm{N}$.; long. $163^{\circ} 6^{\prime} \mathrm{W}$., 38 fathoms, gray sand, gravel, 1 specimen; station 3240 , Bering Sea, lat. $58^{\circ} 30^{\prime}$ N.; long. $159^{\circ} 35^{\prime} 30^{\prime \prime}$ W., $14 \frac{1}{2}$ fathoms, fine black sand, 9 specimens; station 3241 , Bering Sea, lat. $58^{\circ} 38^{\prime} 30^{\prime \prime} \mathrm{N}$.; long. $159^{\circ} 33^{\prime} 30^{\prime \prime} \mathrm{W}$., 14 fathoms, black mud, bottom temperature $38^{\circ}$, 2 specimens; station 3250 , Bering Sea, lat. $58^{\circ} 11^{\prime} 30^{\prime \prime}$ N.; long. $163^{\circ} 2^{\prime} .45^{\prime \prime}$ W., $17 \frac{1}{2}$ fathoms, gray sand, bottom temperature $46.2^{\circ}$, 4 specimens; station 3251 , Bering Sea, lat. $57^{\circ} 35^{\prime} 50^{\prime \prime}$ N.; long. $164^{\circ}$ $5^{\prime}$ W., 25.5 fathoms, fine gray sand, bottom temperature $37.5^{\circ}, 12$ specimens; station 3252 , Bering Sea, lat. $57^{\circ} 22^{\prime} 20^{\prime \prime} \mathrm{N}$.; long. $164^{\circ}$ $24^{\prime} 40^{\prime \prime}$ W., 29.5 fathoms, black mud, bottom temperature $44.8^{\circ}$, 1 specimen; station 3254 , Bering Sea, lat. $56^{\circ} 50^{\prime} \mathrm{N}$.; long. $164^{\circ} 27^{\prime}$ $50^{\prime \prime}$ W., 46 fathoms, green mud, sand, bottom temperature $36.2^{\circ}$, 1 specimen; station 3272 , Bering Sea, lat. $55^{\circ} 31^{\prime} 40^{\prime \prime}$ N.; long. $163^{\circ}$ $7^{\prime}$ W., 31 fathoms, black and red sand, bottom temperature $42^{\circ}$, 2 specimens; station 3274 , Bering Sea, lat. $55^{\circ} 34^{\prime} 30^{\prime \prime} \mathrm{N}$.; long. $162^{\circ}$ 
$31^{\prime} 45^{\prime \prime}$ W., 19 fathoms, black sand, shells, 5 specimens; station 3276 , Bering Sea, lat. $55^{\circ} 51^{\prime} 15^{\prime \prime}$ N.; long. $162^{\circ} 3^{\prime}$ W., 18 fathoms, gravel, sand, rocks, bottom temperature $42^{\circ}, 2$ specimens; station 3278 , Bering Sea, lat. $56^{\circ} 12^{\prime} 30^{\prime \prime} \mathrm{N}$.; long. $162^{\circ} 13^{\prime} \mathrm{W} ., 47$ fathoms, fine gray sand, bottom temperature $38.8^{\circ}, 1$ specimen; station 3280 , Bering Sea, lat. $56^{\circ} 27^{\prime}$ N.; long. $162^{\circ} 8^{\prime}$ W., 36 fathoms, fine gray sand, bottom temperature $41^{\circ}, 21$ specimens; station 3281, Bering Sea, lat. $56^{\circ} 14^{\prime} \mathrm{N}$.; long. $161^{\circ} 41^{\prime} 15^{\prime \prime}$ W., 36 fathoms, gray sand, black specks, 7 specimens; station 3282 , Bering sea, lat. $56^{\circ} 30^{\prime} 45^{\prime \prime}$ - N.; long. $161^{\circ} 50^{\prime} 15^{\prime \prime} \mathrm{W}$., 53 fathoms, fine sand, green mud, bottom temperature $38.2^{\circ}, 2$ specimens; station 3284 , Bering Sea, lat. $56^{\circ}$ $16^{\prime} 50^{\prime \prime} \mathrm{N}$.; long. $160^{\circ} 53^{\prime} \mathrm{W}$., 25 fathoms, fine gravel, bottom temperature $43^{\circ}, 2$ specimens; station 3285 , Bering Sea, lat. $56^{\circ} 45^{\prime} 45^{\prime \prime}$ N.; long. $160^{\circ} 42^{\prime} 45^{\prime \prime}$ W., 35 fathoms, gray sand, black specks, bottom temperature $41^{\circ}, 3$ specimens; station 3286, Bering Sea, lat. $56^{\circ} 39^{\prime} 30^{\prime \prime}$ N.; long. $160^{\circ} 29^{\prime}$ W., 37 fathoms, fine gray sand, shells, gravel, bottom temperature $41.5^{\circ}, 1$ specimen; station 3287 , Bering Sea, lat. $56^{\circ} 44^{\prime} 30^{\prime \prime} \mathrm{N}$.; long. $159^{\circ} 16^{\prime} \mathrm{W}$., 16 fathoms, black sand, 1 specimen; station 3294 , Bering Sea, lat. $57^{\circ} 16^{\prime} 45^{\prime \prime}$ N.; long. $159^{\circ}$ $3^{\prime} 30^{\prime \prime}$ W., 30 fathoms, black gravel, bottom temperature $41^{\circ}, 1$ specimen; station 3297 , Bering Sea, lat. $57^{\circ} 38^{\prime} \mathrm{N}$.; long. $159^{\circ} 7^{\prime} 30^{\prime \prime} \mathrm{W}$., 26 fathoms, gray sand, bottom temperature $41.5^{\circ}, 1$ specimen station 3301 , Bering Sea, lat. $58^{\circ} 12^{\prime} 45^{\prime \prime} \mathrm{N}$.; long. $160^{\circ} 37^{\prime} 30^{\prime \prime} \mathrm{W}$. 17 fathoms, fine gray sand, 1 specimen; station 3304 , Bering Sea, lat. $58^{\circ} 2^{\prime} 30^{\prime \prime} \mathrm{N}$.; long. $161^{\circ} 13^{\prime} 45^{\prime \prime} \mathrm{W}$., 28 fathoms, fine gray sand, 1 specimen; station 3306 , Bering Sea, lat. $57^{\circ} 24^{\prime} 30^{\prime \prime}$ N.; long. $161^{\circ}$ $17^{\prime}$ W., 33 fathoms, fine gray sand, bottom temperature $38.9^{\circ}$, 1 specimen; station 3321 , Bering Sea, lat. $53^{\circ} 33^{\prime} 30^{\prime \prime} \mathrm{N}$.; long. $167^{\circ}$ $15^{\prime} 40^{\prime \prime}$ W., 54 fathoms, dark mud, bottom temperature $41.5^{\circ}$, 1 specimen; station 3322 , Bering Sea, lat. $53^{\circ} 28^{\prime} 45^{\prime \prime}$ N.; long. $167^{\circ}$ $23^{\prime} 50^{\prime \prime}$ W., 35 fathoms, black sand, bottom temperature $42.4^{\circ}$, 1 specimen; station 3323 , Bering Sea, lat. $53^{\circ} 26^{\prime}$ N.; long. $167^{\circ} 31^{\prime}$ $10^{\prime \prime}$ W., 51 fathoms, fine black sand, bottom temperature $42^{\circ}, 1$ specimen; station 3326 , Bering Sea, lat. $53^{\circ} 40^{\prime} 25^{\prime \prime} \mathrm{N}$.; long. $167^{\circ} 41^{\prime} 40^{\prime \prime}$ W., 576 fathoms, mud, bottom temperature $37.5^{\circ}, 1$ specimen; station 3331 , Bering Sea, lat. $54^{\circ} 1^{\prime} 40^{\prime \prime}$ N.; long. $166^{\circ} 48^{\prime} 50^{\prime \prime}$ W., 350 fathoms, mud, 2 specimens; station 3443 , off Washington, lat. $48^{\circ} 13^{\prime}$ $30^{\prime \prime} \mathrm{N}$.; long. $123^{\circ} 11^{\prime} 20^{\prime \prime}$ W., 97 fathoms, green mud, pebbles, bottom temperature $46^{\circ}, 1$ specimen; station 3449 , off Washington, lat. $48^{\circ} 29^{\prime} 40^{\prime \prime} \mathrm{N}$.; long. $124^{\circ} 40^{\prime} 10^{\prime \prime} \mathrm{W}$., 135 fathoms, gray sand, gravel, 4 specimens; station 3452 , off Washington, lat. $48^{\circ} 24^{\prime} 40^{\prime \prime}$ N.; long. $124^{\circ} 29^{\prime} 10^{\prime \prime}$ W., 125 fathoms, rocky, black gravel, bottom temperature $44.5^{\circ}, 1$ specimen; station 3454 , off Washington, lat. $34916^{\circ}-$ Bull. $75-11-19$ 
$48^{\circ} 27^{\prime} 50^{\prime \prime} \mathrm{N}$.; long. $124^{\circ} 42^{\prime} 40^{\prime \prime}$ W., 152 fathoms, gray sand, rocky, bottom temperature $44.2^{\circ}, 3$ specimens; station 3465 , off Washington, lat. $48^{\circ} 21^{\prime} \mathrm{N}$.; long. $123^{\circ} 14^{\prime}$ W., 48 fathoms, rocky, bottom temperature $49.9^{\circ}, 4$ specimens; station 3480 , Bering Sea, lat. $52^{\circ} 6^{\prime} \mathrm{N}$.; long. $171^{\circ} 45^{\prime} \mathrm{W}$., 283 fathoms, black sand, coral, rocky, 2 specimens; station 3483 , Bering sea, lat. $57^{\circ} 18^{\prime} \mathrm{N}$.; long. $171^{\circ} 18^{\prime} \mathrm{W}$., 56 fathoms, green mud, bottom temperature $36.8^{\circ}$, 2 specimens; station 3484 , Bering Sea, lat. $57^{\circ} 18^{\prime}$ N.; long. $171^{\circ}$ $54^{\prime} \mathrm{W}$., 60 fathoms, blue mud, bottom temperature $37.4^{\circ}, 1$ specimen; station 3504 , Bering Sea, lat. $56^{\circ} 57^{\prime}$ N.; long. $169^{\circ} 27^{\prime}$ W., 34 fathoms, fine gray sand, black specks, bottom temperature $37.8^{\circ}, 1$ specimen; station 3505 , Bering Sea, lat. $57^{\circ} 9^{\prime}$ N.; long. $168^{\circ} 17^{\prime}$., W., 44 fathoms, fine gray sand, bottom temperature $38.1^{\circ}, 1$ specimen; station 3507 , Bering Sea, lat. $57^{\circ} 43^{\prime}$ N.; long. $164^{\circ} 42^{\prime}$ W., 31 fathoms, fine gray sand, bottom temperature $37.5^{\circ}, 1$ specimen; station 3511 , Bering Sea, lat. $57^{\circ} 32^{\prime}$ N.; long. $169^{\circ} 38^{\prime}$ W., 39 fathoms, fine sand, dark mud, bottom temperature $37.2^{\circ}, 2$ specimens; station 3512 , Bering Sea, lat. $57^{\circ} 49^{\prime} 30^{\prime \prime}$ N.; long. $169^{\circ} 27^{\prime}$ W., 38 fathoms, fine sand, green mud, bottom temperature $36.6^{\circ}, 1$ specimen; station 3513 , Bering Sea, lat. $58^{\circ} 27^{\prime}$ N.; long. $169^{\circ} 1^{\prime}$ W., 35 fathoms, fine sand, green mud, 1 specimen; station 3514 , Bering Sea, lat. $59^{\circ} 22^{\prime}$ N.; long. $168^{\circ} 21^{\prime}$ W., 21 fathoms, fine gray sand, bottom temperature $40.8^{\circ}$, 1 specimen; station 3522 , Bering Sea, lat. $57^{\circ} 58^{\prime} \mathrm{N}$.; long. $170^{\circ} 9^{\prime}$ W., 41 fathoms, coarse gray sand, gravel, bottom temperature $35.7^{\circ}, 1$ specimen; station 3523 , Bering Sea, lat. $57^{\circ} 39^{\prime} \mathrm{N}$.; long. $170^{\circ} 2^{\prime} \mathrm{W}$., 39 fathoms, green mud, fine sand, bottom temperature $38^{\circ}, 1$ specimen; station 3524 , Bering Sea, lat. $57^{\circ} 24^{\prime}$ N.; long. $169^{\circ} 56^{\prime}$ W., 36 fathoms, gray sand, pebbles, bottom temperature $40.3^{\circ}$, 1 specimen; station 3527 , Bering Sea, lat. $57^{\circ} 48^{\prime} \mathrm{N}$.; long. $171^{\circ} 21^{\prime}$ W., 52 fathoms, green mud, bottom temperature $38^{\circ}, 1$ specimen; station 3528 , Bering Sea, lat. $58^{\circ} 19^{\prime} 30^{\prime \prime} \mathrm{N}$.; long. $172^{\circ} 2^{\prime} \mathrm{W}$., 55 fathoms, dark green mud, fine sand, bottom temperature $35.9^{\circ}$, 1 specimen; station 3536 , Bering Sea, lat. $57^{\circ} 5^{\prime} \mathrm{N}$.; long. $170^{\circ} 35^{\prime}$ W., 40 fathoms, green mud, fine sand, bottom temperature $42.4^{\circ}$, 1 specimen; station 3540 , Bering Sea, lat. $56^{\circ} 27^{\prime} \mathrm{N}$.; long. $166^{\circ} 8^{\prime} \mathrm{W}$., 51 fathoms, green mud, fine sand, bottom temperature $36^{\circ}, 1$ specimen; station 3541 , Bering Sea, lat. $56^{\circ} 14^{\prime}$ N.; long. $164^{\circ} 8^{\prime}$, W., 49 fathoms, black mud, fine sand, bottom temperature $36.1^{\circ}, 1$ specimen; station 3542 , Bering Sea, lat. $56^{\circ} 10^{\prime} \mathrm{N}$.; long. $163^{\circ} 26^{\prime} \mathrm{W}$., 49 fathoms, dark mud, fine sand, bottom temperature $39.2^{\circ}, 1$ specimen; station 3547 , Bering Sea, lat. $54^{\circ} 16^{\prime}$ N.; long. $165^{\circ} 45^{\prime}$ W., 51 fathoms, fine black sand, bottom temperature $45^{\circ}, 1$ specimen; station 3559 , Bering Sea, lat. $56^{\circ} 56^{\prime} \mathrm{N}$.; long. $169^{\circ} 52^{\prime} \mathrm{W}$., 39 fathoms, gray sand, broken shells, bottom temperature $42.5^{\circ}, 1$ specimen; station 3676 (no records of this are preserved), 3 specimens; station 3707, off Ose 
Zaki, Honshu Island, Japan, 63 to 75 fathoms, volcanic sand, ashes, gravel, 6 specimens; station 4777 , Bering Sea, lat. $52^{\circ} 11^{\prime} \mathrm{N}$.; long. $179^{\circ} 49^{\prime}$ E., 43 to 52 fathoms, fine gravel, 3 specimens; station 4779 , Bering Sea, lat. $52^{\circ} 11^{\prime}$ N.; long. $179^{\circ} 57^{\prime}$ E., 54 to 56 fathoms, broken shells, pebbles, sand, 4 specimens; station 4782 , Bering Sea, lat. $52^{\circ} 55^{\prime} \mathrm{N}$.; long. $173^{\circ} 27^{\prime}$ E., 57 to 59 fathoms, rock, gravel, 3 specimens; station 4784 , off Attu Island, lat. $52^{\circ} 55^{\prime} 40^{\prime \prime} \mathrm{N}$.; long. $173^{\circ} 26^{\prime} \mathrm{E}$., 135 fathoms, coarse pebbles, 3 specimens; station 4787 , off Copper Island, lat. $54^{\circ} 50^{\prime} 50^{\prime \prime} \mathrm{N}$.; long. $167^{\circ} 13^{\prime} 30^{\prime \prime}$ E., 54 to 57 fathoms, green sand, 1 specimen; station 4788, off Copper Island, lat. $54^{\circ} 50^{\prime} 24^{\prime \prime} \mathrm{N}$.; long. $167^{\circ} 13^{\prime} \mathrm{E}$., 56 to 57 fathoms, green sand, 1 specimen; station 4812 , Sea of Japan, lat. $38^{\circ} 33^{\prime}$ N.; long. $138^{\circ}$ $40^{\prime}$ E., 176 to 200 fathoms, fine brown mud, bottom temperature $34.9^{\circ}, 1$ specimen; station 4874 , Korea Strait, lat. $34^{\circ} 38^{\prime}$ N.; long. $130^{\circ} 3^{\prime}$ E., 66 fathoms, green sand, broken shells, bottom temperature $59.7^{\circ}, 1$ specimen; station 4892 , Eastern Sea, lat. $32^{\circ} 27^{\prime} 30^{\prime \prime} \mathrm{N}$.; long. $128^{\circ} 33^{\prime} \mathrm{E}$., 181 fathoms, gray sand, broken shells, rocks, bottom temperature $00.2^{\circ}, 1$ specimen; station 4912 , Eastern Sea, lat. $31^{\circ}$ $39^{\prime} 40^{\prime \prime} \mathrm{N}$.; long. $129^{\circ} 20^{\prime}$ E., 391 fathoms, gray globigerina ooze, bottom temperature $41.9^{\circ}, 1$ specimen; station 4935 , Eastern Sea, lat. $30^{\circ} 57^{\prime} 20^{\prime \prime} \mathrm{N}$.; long. $130^{\circ} 35^{\prime} 10^{\prime \prime}$ E., 103 fathoms, stones, bottom temperature $60.6^{\circ}, 1$ specimen, station 4983 , Sea of Japan, lat. $43^{\circ} 1^{\prime} 35^{\prime \prime}$ N.; long. $140^{\circ} 10^{\prime} 40^{\prime \prime}$ E., 428 fathoms, green mud, bottom temperature $32.7^{\circ}, 3$ specimens; station 4985 , Sea of Japan, lat. $43^{\circ}$ $5^{\prime} 20^{\prime \prime} \mathrm{N}$.; long. $140^{\circ} 15^{\prime} 15^{\prime \prime}$ E., 224 fathoms, green mud, bottom temperature $33.1^{\circ}, 3$ specimens; station 4986 , Sea of Japan, lat. $43^{\circ}$ $1^{\prime} 40^{\prime \prime} \mathrm{N}$.; long. $140^{\circ} 22,40^{\prime \prime}$ E., 172 fathoms, fine black sand, black mud, bottom temperature $33.9^{\circ}, 2$ specimens; station 4987 , Sea of Japan, lat. $43^{\circ} 19^{\prime} 20^{\prime \prime} \mathrm{N}$.; long. $140^{\circ} 17^{\prime}$ E., 59 fathoms, rocky, bottom temperature $44.8^{\circ}, 1$ specimen; station 5005, off Saghalin, lat. $46^{\circ} 4^{\prime} 40^{\prime \prime} \mathrm{N}$.; long. $142^{\circ} 27^{\prime} 30^{\prime \prime}$ E., 42 to 43 fathoms, green mud, fine gray sand, bottom temperature $30.7^{\circ}$ ?, 2 specimens; station 5006 , off Saghalin, lat. $46^{\circ} 4^{\prime}$ N.; long. $142^{\circ} 29^{\prime}$ E., 42 to 43 fathoms, green mud, fine gray sand, bottom temperature $36.1^{\circ}, 1$ specimen; station 5007 , off Saghalin, lat. $46^{\circ} 3^{\prime}$ N.; long. $142^{\circ} 31^{\prime}$ E., 42 fathoms, green mud, fine gray sand, bottom temperature $34.8^{\circ}, 2$ specimens; station 5008 , off Saghalin, lat. $46^{\circ} 7^{\prime} 50^{\prime \prime}$ N.; long. $142^{\circ} 37^{\prime} 20^{\prime \prime}$ E., 40 fathoms, green mud, fine gray sand, bottom temperature $33.9^{\circ}, 1$ specimen; station 5020, Okhotsk Sea, lat. $48^{\circ} 32^{\prime} 45^{\prime \prime} \mathrm{N}$.; long. $145^{\circ} 7^{\prime}$ $30^{\prime \prime}$ E., 73 fathoms, green mud, sand, pebbles, bottom temperature $30.9^{\circ}, 1$ specimen; station 5021 , Okhotsk Sea, lat. $48^{\circ} 32^{\prime} 30^{\prime \prime} \mathrm{N}$.; long. $145^{\circ} 8^{\prime} 45^{\prime \prime}$ E., 73 fathoms, green mud, sand, pebbles, bottom temperature $30.9^{\circ}, 3$ specimens. Wrangel, Alaska, 1 specimen; Unalaska, 30 fathoms, 1 specimen; Ikatan Bay, Alaska, 1 specimen; 
Killisnoo, Alaska, 1 specimen; Straits of Fuca, 1 specimen; Alaska, 7 specimens; Constantine Harbor, 8 to 10 fathoms, 1 specimen; lat. $66^{\circ} 12^{\prime}$ N.; long. $168^{\circ} 54^{\prime}$ W., 1 fragment; Mechigme Bay, Siberia, 5 specimens; Arctic Ocean, 3 specimens; locality ?, 8 specimens. Bathymetrical range, 8 to 576 fathoms. Temperature range, $60.6^{\circ}$ to $30.7^{\circ}$. Three hundred and four specimens.

This unusually fine series of "basket-fish," ranging in disk diameter from 9 to $115 \mathrm{~mm}$. (this being, I believe, the largest ophiuran on record), has enabled me to determine the status of some of the many species of Gorgonocephalus. There is, I think, no room for doubt that G. stimpsonii and G. japonicus are both synonyms of G. caryi, the last name having priority. There is much individual diversity in the abundance and coarseness of the granules on the disk, as well as in the number and length of the arm divisions. Thus a specimen from off California has few long arm divisions and small granules confined to the radial shields, while the Saghalin and many Alaskan specimens have many short arm divisions and coarse, irregular granules all over the disk. Specimens similar to the one from California are in the collection, however, from Alaska and also from Japan, and intergradations between the extremes are common. The specimen from station 4935 (disk diameter $21 \mathrm{~mm}$.) is notable for long, narrow genital slits and the presence of only 2 arm spines on most of the joints, and those two unusually long, though they do not equal the joint. There is more than a possibility that caryi is not specifically distinct from eucnemis, but I have not had sufficient material of the latter species to enable me to settle the point. My suspicions go even further and lead me to think that agassizii, eucnemis, and caryi may prove to be three names for a single species. Material from the west coast of Greenland and the regions north of America would be very desirable in settling the question. The geographical range of caryi from California northward and northwestward to nearly $60^{\circ}$ N. in Bering Sea, and thence southward and southwestward to below $31^{\circ} \mathrm{N}$. in the Eastern Sea is remarkably extensive.

GORGONOCEPHALUS SAGAMINUS.

Gorgonocephalus sagaminus DöDerlerN, Zool. Anz., vol. 25, 1902, p. 321.

Localities.-Albatross station 3707, off Ose Zaki, Honshu Island, Japan, 63 to 75 fathoms, volcanic sand, ashes, gravel, 11 specimens; station 3715, off Ose Zaki, Honshu Island, Japan, 65 to 68 fathoms, volcanic sand, shells, rocks, 1 specimen; station 3720 , off Ose Zaki, Honshu Island, Japan, 63 fathoms, volcanic sand, shells, 1 specimen; station 3740, off Ose Zaki, Honshu Island, Japan, 65 fathoms, volcanic sand, shells, pebbles, 3 specimens; station 4894, Eastern Sea, lat. $32^{\circ} 33^{\prime} \mathrm{N}$.; long. $128^{\circ} 32^{\prime} 10^{\prime \prime} \mathrm{E}$., 95 fathoms, green sand, broken shells, pebbles, 1 specimen; station 4986 , Sea of Japan, lat. $43^{\circ} 1^{\prime} 40^{\prime \prime}$ 
N.; long. $140^{\circ} 22^{\prime} 40^{\prime \prime}$ E., 172 fathoms, fine black sand, black mud, bottom temperature $33.9^{\circ}, 1$ specimen; station 4987 , Sea of Japan, lat. $43^{\circ} 19^{\prime} 20^{\prime \prime} \mathrm{N}$.; long. $140^{\circ} 17^{\prime} \mathrm{E}$., 59 fathoms, rocky, bottom temperature $44.8^{\circ}, 1$ specimen. Bathymetrical range, 59 to 172 fathoms. Temperature range, $44.8^{\circ}$ to $33.9^{\circ}$. Nineteen specimens.

This is a beautiful and well-characterized species, easily recognized by the very fine granulation and minute arm spines. The specimens before me range in disk diameter from 9 to $50 \mathrm{~mm}$. and vary in color from very pale gray to yellowish-gray and fawn-color.

\section{ASTROPHYTON CORNUTUM.}

Gorgonocephalus cornutus KæHLer, Ann. Sci. Nat., Zool. (8), vol. 4, 1898, p. 368. Astrophyton coniferum DöDERlern, Zool. Anz., vol. 25, 1902, p. 325.

Astrophyton cornutum KaHLER, Siboga Oph. Litt., 1905, p. 127.

Localities.-Albatross station 4929, Colnett Strait, lat. $30^{\circ} 12^{\prime} 30^{\prime \prime}$ N.; long. $130^{\circ} 43^{\prime}$ E., 84 fathoms, broken shells, coral, pebbles, bottom temperature $74.8^{\circ}, 2$ specimens; 4931 , Colnett Strait, lat. $30^{\circ} 12^{\prime} \mathrm{N}$.; long. $130^{\circ} 43^{\prime} 40^{\prime \prime}$ E., 83 fathoms, broken shells, pebbles, coral, bottom temperature $75.4^{\circ}, 8$ specimens.

These specimens vary in color from nearly white to light reddishbrown. Although they are small (disk diameter, 9 to $13 \mathrm{~mm}$.), there seems to be no question as to their identity with Döderlein's species, coniferum. As I can not find any tangible character by which they can be distinguished from cornutum of Kœhler I am obliged to consider the names as synonyms.

\section{ASTROPHYTON PARDALIS.}

Astrophyton pardalis DöDerlein, Zool. Anz., vol. 25, 1902, p. 323.

Astrophyton globiferum DöDerLeIN, Zool. Anz., vol. 25, 1902, p. 324.

Localities.-Albatross station 3729, off Omai Zaki, Honshü Island, Japan, 34 fathoms, mud, gravel, 2 specimens; station 3735, off Omai Zaki, Honshu Island, Japan, 36 fathoms, coarse gray volcanic sand, broken shells, 2 specimens; station 4781, near Agattu Island, lat. $52^{\circ} 14^{\prime} 30^{\prime \prime} \mathrm{N}$.; long. $174^{\circ} 13^{\prime}$ E., 482 fathoms, fine gray sand, pebbles, bottom temperature, $38.6^{\circ}$, 1 specimen; station 4875 , Korea Strait, lat. $34^{\circ} 19^{\prime} \mathrm{N}$.; long $130^{\circ} 9^{\prime} \mathrm{E}$., 59 fathoms, fine gray sand, broken shells, bottom temperature $62.1^{\circ}, 1$ specimen; station 4877 , Korea Strait, lat. $34^{\circ} 20^{\prime} 30^{\prime \prime}$ N.; long. $130^{\circ} 11^{\prime}$ E., 59 fathoms, fine gray sand, broken shells, bottom temperature $62.1^{\circ}, 1$ specimen; station 4934 , Eastern Sea, lat. $30^{\circ} 58^{\prime} 30^{\prime \prime}$ N. ; long. $130^{\circ} 32^{\prime}$ E., 103 to 152 fathoms, rocky, bottom temperature $60.6^{\circ}$ to $56^{\circ}, 1$ specimen; station 5070, Suruga Gulf, lat. $35^{\circ} 3^{\prime} 25^{\prime \prime} \mathrm{N}$.; long. $138^{\circ} 47^{\prime} 40^{\prime \prime}$ E., 108 fathoms, mud, sand, broken shells, bottom temperature $57.6^{\circ}, 1$ specimen; Fusan, Korea, 1 specimen. Bathymetrical range, 34 to 482 fathoms. Temperature range, $62.1^{\circ}$ to $38.6^{\circ}$. Ten specimens. 
Although these specimens vary in color from uniform very dark brown, through yellow spotted with blackish, to uniform light gray with the larger tubercles white, and in size from a disk diameter of $6 \mathrm{~mm}$. to one of 65 , I am utterly unable to differentiate them into more than a single species. The specimen from station 4781 is only $6 \mathrm{~mm}$. across the disk and is very dark purplish-brown; it is very possibly not this species, but I know of no other to which it can be referred. The specimen from station $3735,11 \mathrm{~mm}$. across the disk, is undoubtedly pardalis as it answers to Döderlein's description in every particular; the name is peculiarly appropriate to such a specimen. The specimen from station 4934 is similar but is much larger (40 mm. disk diameter) and the colors are dimmer, so that the spotting is much less noticeable. Moreover many, if not most, of the granules have lost their acicular points and scattered all over the upper surface of the arms are rounded, whitish tubercles; a few are present also on the disk. The specimen from station 4875 (disk diameter, $21 \mathrm{~mm}$.) differs only in that the ground color is gray, not at all yellowish, with the spots dull purplish, and the granules are nearly all rounded, very rarely with a point. The specimen from station 4877 (disk diameter, $53 \mathrm{~mm}$.) is like the last mentioned, but there are no spots or markings of any kind; the color is yellowish-gray, with tubercles and large granules whitish. The specimen from Fusan $(65 \mathrm{~mm}$.) is similar but the color is very pale brown. Finally; the specimen from station 5070 ( $53 \mathrm{~mm}$.) is like the one from station 4877 , but is a little lighter gray and the granules are even more flat and pavement-like; the white tubercles are still evident, however, particularly well out on the arms. The situation, therefore, is this: The specimen from station 3735 is pardalis; the specimen from station 4934 is undoubtedly the adult of the same; but the specimen from station 4877 can not be separated specifically from it; yet the specimen from station 5070, which appears to be A. globiferum, is undoubtedly conspecific with the one from station 4877 . Therefore globiferum appears to be a synonym of pardalis.

\section{EURYALE ANOPLA, new species. $a$}

Disk $34 \mathrm{~mm}$. in diameter; arms about $170 \mathrm{~mm}$. long, each with eight or nine forks. Disk covered with a smooth skin. . Radial shields conspicuous, moderately broad and arched, meeting at center of disk or nearly so; each shield carries two to five low, blunt, inconspicuous tubercles. Upper surface of arms, which are rather higher than broad, covered with smooth, naked skin. Interbrachial spaces below heavily granulated, except distally. Genital slits conspicuous. Sur-

$a^{*}$ Avorios, signifying not heavy-armed, in reference to the absence of large conical tubercles and spines on the disk. 
face of oral frame and lower surface of arms covered with a smooth, naked skin. Apex and sides of jaws more or less finely but irregularly tuberculous. Teeth broad, truncate or bluntly pointed, about five or six in each series. First pair of tentacles nearer mouth than they are to margin of oral frame, without scales or spinules of any kind; succeeding pairs protected by two subequal, finely thorny, very blunt, club-shaped spines, not quite as long as a joint and half as thick as long; on outer branches of arm, these spines become slender, and hook-

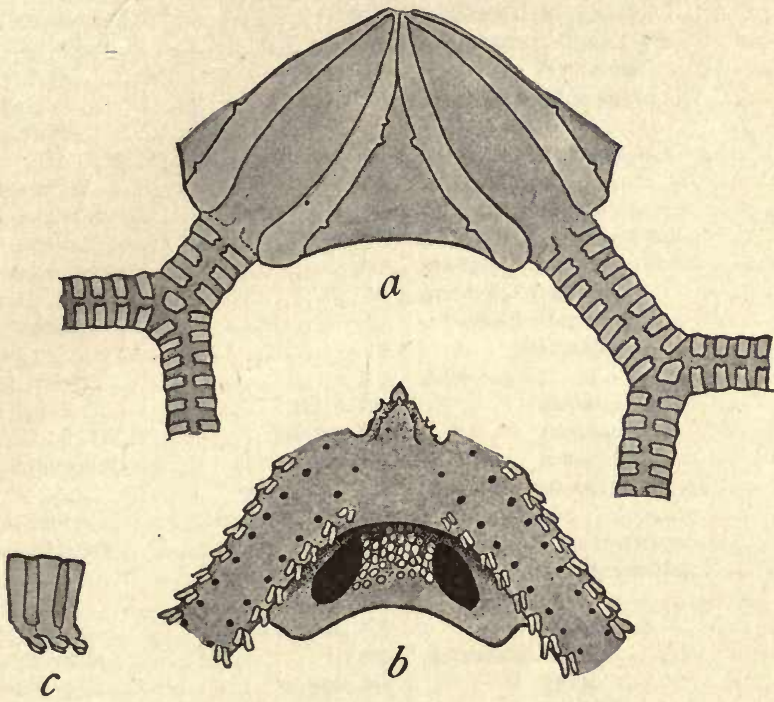

Fig. 144.-EURYALE ANOPLA. $\times 1.5$. $a$, FROM ABOVE; $b$, FROM BELOW; $c$, SIDE VIEW OF THREE ARM JOINTS NEAR DISK.

bearing at tip. Color (dried from alcohol), dark brown, lighter at tips of arms; oral frame and under side of arms dull yellow.

Locality.-Albatross station 4934, Eastern Sea, lat. $30^{\circ} 58^{\prime} 30^{\prime \prime}$ N.; long. $130^{\circ} 32^{\prime} \mathrm{E}$., 103 to 152 fathoms, bottom temperature $60.6^{\circ}$ to $56^{\circ}, 1$ specimen.

Type.-Cat. No. 25590, U.S.N.M., from station 4934 .

This species is so well characterized by the nearly naked disk and the perfectly smooth arms that it can not be mistaken for either of the other species of the genus. 


\section{i}

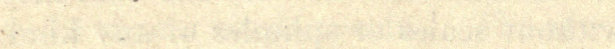

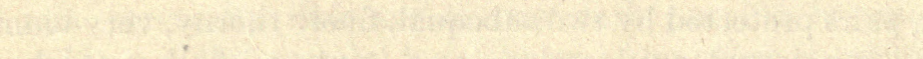

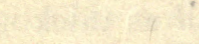




\section{INDEX.}

[The important reference to each genus and species is in heavy-faced type.]

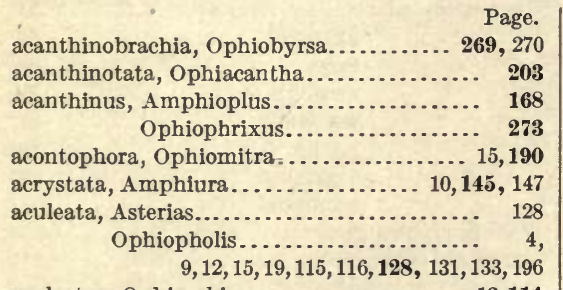
aculeatus, Ophiambix................. 13,114 adiaphora, Ophiacantha....... 8, 18, 199, 200, 202 adspersus, Ophiernus............ 10,12,15,95, 96 agassizii, Gorgonocephalus................ 292 alba, Ophiozona...................... 36 albata, Ophioglypha..................... 68 Amphilepis........................... 15 papyracea.................. 172 platytata.................. 13, 16, 171 Amphilimna..................... 169, 170,173 pentacantha.............. 10,172 Amphiodia..................... 20,158, 162,166 ancistrota.............. 20,161, 162 craterodmeta............ 8, 155, 156 digitula................ 20, 162, 169 euryaspis...........9, 17, 20,158, 159 macraspis........... 10,20,157, 165 occidentalis................ 11,155 periercta............... 11, 160, 161 psilochora.................. 165 strongyloplax.............. 10,164 "urtica..................... 11,154 Amphioplus............ 158, 162, 169, 170, 171, 173 acanthinus................ 168 hexacanthus.............. 10,170 megapomus................ 170 rhadinobrachius........... $\mathbf{1 6 7}, 168$

Amphipholis........................ 184 pugetana.................. 11, 166

Amphiura.................... 20,147, 152,166 acrystata............... 10,145, 147 bellis...................... 20,140 carchara.............. 9, 15, 17, 142 diomedeæ ......... 10,15, 17, 18, 20, 140 ecnomiotata.................. 148 enopla..................... 144 gymnopora.................. 154 leptodoma.................... 143 micraspis.................... 150 occidentalis.................. 155, 161 psilopora................... 153, 154 pugetana..................... 166 pycnostoma................... 151 sundevalli .................. 12,141 trachydisca................... 149 urtlea. 154,156
Amphiuridæ

anchilabra, Ophiacantha............ 14, 204, 206 anchista, Pectinura................... 23, 25 ancistrota, Amphiodia............. 20, 161, 162 anisacantha, Ophiomyxa.......... 5, 20,271, 272 annectens, Ophiernus.................. 95, 96 annulata, Ophionereis................... 174 anopla, Euryale....................... 18, 294 antarctica, Ophioconis................... 28, 30 Anthophiura......................... 15,92 axiologa.............. 13, 16, 92,93 antipodum, Ophiopteris ................ 257 armigerum, Ophiomusium............. 112 asaphes, Ophiolebes................... 8, 239 Asterias aculeata....................... 128 bidentata...................... 195

Asteronyx .......................... 255 dispar....................... 287 excavata.................. 287 loveni............ 5, 9, 12,16,285, 287 plana...................... 287

Asteroporpa........................ $\quad 280$ australianus ...... 281 hadracantha............... 18, 280 Astroceras............................. 284, 285
pergamena................. $5,18,284$ Astrochele........................... 18, 281 lævis ................... 281, 283 lymani..................... 283

Astronyx.............................. 285

Astroporpa.......................... 280

Astrophytidæ....................... $\quad \mathbf{2 8 0}$

Astrophyton caryi....................... 287

coniferum.................. 293

cornutum................ 293 globiferum............... 293, 294 pardalis............... 18, 293, 294 stimpsonii.................. 287

atacta, Ophiura...................... 14,85 atopostoma, Ophiacantha.............. 18,228 australianus, Asteroporpa............... 281 australis, Ophiomyxa............. 18, 20, 271, 272 axiologa, Anthophiura.............. 13, 16,92,93

bairdi, Ophiacantha............ 9, 12, 18, 230,232 bakeri, Ophiopholis....... 10,115, 116, 121, 123, 128 bartletti, Ophiacantha.................. 239 bathybia, Ophiacantha............. 8, 14, 15, 233 Ophiura ................. 13, 16, 58, 60 bellis, Amphiura...................... 20,140 bidentata, Asterias....................... 195

Ophlacantha ........... 8, 12,195, 214 bispinosa, Ophiozona................... 33,34 brachyactis, Ophiopholis.......... 18, 115, 116, 117 Ophiura. $8,16,87$ 
Page.

138,140

brachyaspis, Ophiactis

135

brachygenys, Ophiactis................. 135

brevipes, Ophiocoma..................... 256

brevispina, Ophiolebes................. 20,247

brevispinum, Ophiocten................. 98,99

bullata, Ophiura........................ 75

bythiaspis, Ophiomitra ........... 14, 185, 192, 193

calyptolepis, Ophiura ............ 67, 68, 69, 70 cancellatum, Ophiomusium........ 15, 20,106, 112 carchara, Amphiura.............. 9,15,17,142 cardiomorpha, Ophiomitra............... 179

caryi, Astrophyton...................... 287

Gorgonocephalus ... 5, 9, 17, 18, 20,21,287, 292 Ophiopholis................. 115, 132,133 cataleimmoida, Ophiacantha..... 8, 20, 217, 224, 228 charischema, Ophiocten............ 5, 18,97,99 clliaris, Ophiothrix.................... 257 Ophiura ...................... 257 clasta, Ophiura........................ 14,64 clemens, Ophioglypha.................... 68 codonomorpha, Ophiomitra............. 14, 188 confragosa, Ophioglypha................. 65 coniferum, Astrophyton.................. 293 convexa, Ophiura...................... $\quad 75$ cornutum, Astrophyton.................. 293 cornutus, Gorgonocephalus................ 293 corynetes, Ophiocynodus............... 10,274 craterodmeta, Amphiodia............. 8, 155, 156 cryptolepis, Ophiura .................. 9,69,70 cylindrica, Pectinura.................... $\quad 25$

depressum, Ophiocten.

diaphora, Ophiolebes............. 20,245,246,247

diastata, Ophioconis.

27,28

dictydisca, Ophiocrasis

175,177

digitula, Amphiodia.

$20,162,169$

diomedeæ, Amphiura.......... 10,15,17, 18, 20,140

diplasia, Ophiacantha................... 10,209

diploa, Ophiacantha ................. 207,208

disacantha, Ophiopenia.................. 8, 102

disacanthus, Ophiosyzygus............... 18,276

discycia, Ophiomitra.............. 181, 183, 184

dispar, Asteronyx...................... 287

divisa, Ophioglypha.................... 65

duplex, Ophiacantha................. 207,208

dyscrita, Ophiactis..................... 18,137

eburneum, Ophiomusium............... 112

echinata, Ophiocoma.................... 22

ecnomiotata, Amphiura.................. 148

elevata, Ophiozona................ 5, $\mathbf{3 1 , 3 3 , 3 4}$

enneactis, Ophlacantha.................. 211

erinacea, Ophiocoma.................... $\quad 257$

erinaceus, Ophiocoma.................... 257

esmarki, Ophioplocus.................... $\quad 31$

eucnemis, Gorgonocephalus ............... 292

etropla, Amphiura....................... 144

euphylactea, Ophiacantha................. 225

Euryale anopla....................... 18, 294

palmiferum..................... 287

euryaspis, Amphiodia........... 9,17, 20,158,159

eurybrachiplax, Ophionereis.............. 10,173

eurypoma, Ophiacantha............... 13, 16, 223

eusteira, Ophiothrix................... 265

excavata, Asteronyx ................... 287
Page.

fistigatus, Ophiochiton

flagellata, Ophioglypha ................. 60

Ophiura.......... $8,9,10,16,18,19,60$

glabrum, Ophiomusium................. 114

globiferum, Astrophyton............... 293, 294

glyptodisca, Ophiura.................. 91,92

gorgonia, Ophiarachna..................

Ophlarachnella.................

Gorgonocephalus....................... 292

agassizii............... 292

caryi.... 5, 9, 17, 18,20,21, 287,292 cormutus................ 293 eucnemis ............... 292 japonicus............. 287,292 sagaminus...........20,21, 292 stimpsonii.............. 292

grandis, Ophioglypha.................. 62,63

granulosa, Ophlacantha................ 18,215

gratiosa, Ophiacantha.................. 209

grisea, Ophioplinthus................... 21

gymnochora, Ophiactis.................. 139

gymnopora, Amphiura.................. 154

gymnodiscus, Ophiohymen............. 278

habrotata, Ophiomitra................. 5, 182

hadra, Ophiura................... 11, 14,80

hadracantha, Asteroporpa.............. 18, 280

Hemieuryale........................ 21 pustulata.................... 21

tuberculosa.................. 21

Hemipholis.......................... 137 hexacanthus, Amphioplus.............. 10,170 hexactis, Ophiologimus................. 252 hylacantha, Ophiacantha.............. 14,227 hylodes, Ophiothrix................. 263, 265

imbecillis, Ophioglypha................. 62

Ophiura...................... 69.

imbricata, Ophiolepis................... 30

imbricatus, Ophioplocus............... 30,31

infernalis, Ophiarachnella................ 27

Inutilis, Ophiacantha................. 208, 209

involuta, Ophioglypha................62,63

irrorata, Ophioglypha................... 62 Ophiura........... 8,9,10,14, 15,62, 63

japonica, Ophiopholis................ 123,127 Ophiopholis aculeata var........ 15, $17,115,116,121,123,128$

japonicus, Gorgonocephalus............ 287, 292 Ophioplocus.................. $\mathbf{3 0 , 3 1}$

jejuna, Ophiogypha.................... 67

jolliensis, Ophiomusium.............. 9, 20,111

kennerlyi, Ophiopholis.............. 115,132 133 Ophlopholis aculeata var....... 11

$115,116,128,132$

kinbergi, Ophioglypha.................. 37 Ophiura.........37, $44,45,46,47,48,55$ koreana, Ophiothrix. .. 5, 12,17, 18, 257, 260, 264, 265

lævis, Astrochele.................... 281,283

lambda, Ophiacantha.................. 281 laqueatum, Ophiomusium............... 18, 106 lepldota, Ophiacantha................ 14,224 leptoctenia, Ophiura.. 4, $9,15,18,19,51,55,58,59,60$ leptodoma, Amphiura.................. 143 leucorhabdota, Ophiacantha.......... 18, 221 
Page.

leucosticta, Ophiacantha

14,235

levispina, Ophiacantha.

20,198

liodisca, Ophlophrura.

249

lithosora, Ophiocamax............ 187,191, 192

ljungmani, Ophloglypha.

Ophiura..................... 55,60

longipeda, Ophiothrix ................. 263 Ophiura..................... 263

longispina, Ophlopholis................ 10, $115,116,119,121,122,123,128$

Ophiozona.................. 33, 36

longispinus, Ophiotrochus.............. 14,94 lophobrachia, Ophiacantha............. 18, 232 loveni, Asteronyx........... 5, 9, 12,16, 285, 287 lunare, Ophiomusium............... 18, 20,107 lütkenl, Ophioglypha................... 45 Ophiomusium ............... 18, 20,107 Ophiura........ 5, 11, 19,44,45, 46, 47,55 ymani. Astrochele ...................... 283 Ophiomusium.... 9, 12,15,17,18,20,63,107

macrarthra, Ophiacantha........... 14, 18,236 macraspis, Amphiodia........... 10,20,157, 165 macrobrachia, Ophiothrix............ 5, 18,267 maculata, Ophioglypha.................. 49 Ophiura...............8, $8,48,156$ malignus, Ophiodoris................... 179 marmorata, Pectinura.................... 25 medusa, Ophioplinthus.................. 21 megalaspis, Ophiarachnella............. 5, 25, 27 megapoma, Ophiura................... $\quad 79$ megapomus, Amphioplus............... 170 megapora, Ophioleptoplax............... 279 megatreta, Ophiacantha............ 14,237, 239 micracantha, Ophiura................. 18, 19,47 micraspis, Amphiura................... 150 microphylax, Ophiomitra.............. 18,184 milliaria, Ophioconis.................... 28, 30 mirabilis, Ophiolepis................... 117 Ophiopholis...... 8, 19, 115, 116, 117, 119 mixta, Ophiomastix..................... $\mathbf{2 5 6}$ monacantha, Ophioschiza................ 255 monostœeha, Ophiura...............65, 67,86 multispinum, Ophiomusium...... 10,14,113, 114 murrhina, Sigsbeia.

21

nodosa, Ophiura.............. 4, 12, 70, 131, 196 normanl, Ophiacantha..................

$5,9,15,17,18,20,215,219,221,224$

nuda, Ophionereis.................... 174

obstricta, Ophioceramis................ 250

obstrictus, Ophiurases................. 5, 18,250

occidentalis, Amphiodia............... 11, 15i

Amphiura.................155, 161

œdidisca, Ophiacantha................. 219, 224

œdiplax, Ophiura................ 12, 16, 74, 75

œdipus, Ophiocreas...................... 283

omoplata, Ophiacantha..............., 16, 202

oöplax, Ophiocten.................... 99

Ophiacantha... 2, $3,15,18,19,20,21,28,185,195,213$, $217,221,222,225,228,231,236,249,250$ acanthinotata............... 203 adiaphora........8, $8,18,199,200,202$ anchilabra............. 14,204, 206 atopostoma............... 18,228
Ophiacantha bairdi ........... 9,12, 18,230, 232

bartletti.................. 239

bathybia............. 8, 14, 15,233

bidentata............ 8,12,195, 214

cataleimmoida...... 8, 20,217, 224, 228

diplasia.................. 10,209

diploa................... 207, 208

duplex................... 207,208

enneactis................... 211

euphylactea................. 225 eurypoma............... 13, 16,223

granulosa................... 18,215

gratiosa................... 209

hylacantha............... 14,227

inutilis................... 208, 209

lambda ................... 231

lepidota .................... 14,224

leucorhabdota ............. 18,221

leucosticta ................ 14,235

levispina .................. 20,198

lophobrachia............... 18,232

macrarthra ............. 14, 18,236

megatreta ............ 14,237, 239

normani .................. 4, $5,9,15,17,18,20,215,219,221,224$

œdidisca ................ 219, 224

omoplata................. 16,202

pentagona.................... 5,

$16,17,18,20,196,198,200,201,205$

prionota................. 13, 213

relicta................ 20,219,221

rhachophora .........5,8,9,18,20,201 stimulea.................... 229

trachybactra................ 206

vivipara................... 213

vorax...................... 206

Ophiacanthidae.................. 179, 191,195

Ophiactis...................... 3,138,139,140

brachyaspis............... 138, 140

brachygenys................. 135

dyscrita..................... 18,137

gymnochora................... 139

pteropoma................... 134

Ophialcæa............................ 217

Ophlambix............................. 15, 114

aculeatus ................... 13,114

Ophiarachna gorgonia................... 25

Ophiarachnella gorgonia................. 25

infernalis................. 27

megalaspis............. 5, 25, 27

Ophiernus adspersus............ 10,12,15,95, 96 annectens................... 95,96

Ophiobyrsa........................ 271,274

acanthinobrachia.......... 269, 270

synaptacantha........... 18,270, 271

Ophiocamıax.......................... 195

lithosora............ 187,191, 192

polyploca................ 5, 18,198

rugosa.................... 195

Ophioceramis obstricta................. 250

Ophlochiton fastigatus.................... 13

Ophlocnida........................... 173

Ophiocoma......................... 16,22,257

brevipes.................. 256

echinata..................... 22

erinacea................... 257 
Ophlocoma papillosa..................... 257 rilsei........................ 22 Ophiocomidae........................ 6,256 Ophioconis.................... 2,28,230,232 antarctica................. 28, 30 diastata................... 27, 28 miliaria.................... 28, 30 papillata................... 28, 30

Ophiocrasis............................. 175 dictydisca.............. 175, 177 Ophiocreas œdipus...................... 283

Ophiocten brevispinum ................. 98, 99 charischema............ 5, 18,97, 99 depressum................... 98 oöplax.................... 99 pacificum................... 9,14,96 Ophiocynodus....................... 274,276 corynetes............... 10,274 Ophiodermatidæ..................... 6,23 Ophiodoris malignus.................... 179 pericalles................ 5, 18, 173 Ophioglypha........................ $\quad 36$ albata....................... 68 clemens..................... 67 confragosa.................. 65 divisa...................... 65 flagellata.................... 60 grandis................... 62,63 imbecillis.................. 62 involuta.................. 62,63 irrorata................... 62 jejuna..................... 67 kinbergi................... 37 ljungmani................. 55 lütkeni.................... 45 maculata.................. 49 orbiculata................. 62,63 ponderosa.................. 77 robusta.................... 51 sculpta.................. 73 sculptilis................. 77 sinensis................... 37 solida..................... 91 sterea...................... 75 tumulosa.................. 62,63 undata................... 91 variabilis................. 77

Ophiogymna.......................... 268 Ophiogyptis......................... 250 Ophiohelidæ.................... 179, 191, 195 Ophiohymen........................ 277 gymnodiscus.............. 277

Ophiolebes............ 18, 20, 195, 207, 221, 240, 248 asaphes..................... 8, 239 brachygnatha............. 8, 16, 240 brevispina..................20, 247 diaphora............. 20,245,246,247 pachybactra................ 242,244 paucispina...........20, 246, 247,248 scorteus.................... 240 tylota.............. 8, 20, 243,244, 246 vestitus...................... 242 Ophiolepididæ........................ 3, 30,195 Ophiolepis imbricata. mirabilis ..................... sundevalli................... 141
Page.

Ophioleptoplax..................... $\quad \mathbf{2 7 8}$ megapora.............. $\mathbf{2 7 9}$

Ophlologimus....................... 252 hexactis................. 252

Ophiomastix mixta................... $\quad 256$

Ophiomastus.......................... 92

Ophiomitra......... 2, 15, 19, 185, 188, 191, 195, 217 acontophora............... 15, 190 bythiaspis........... 14,185, 192, 193 cardiomorpha............... 179 codonomorpha.............. 14, 188 discycla............. 181, 183, 184 habrotata................. 5, 182 microphylax.............. 18, 184 polyacantha................. 18,187

Ophiomusium.................. 18, 19, 20, 92 armigerum............... 112 cancellatum........ 15, 20,106, 112 eburneum............... 112 glabrum................ 114 jolliensis............... 9, 20,111 laqueatum............... 18, 106 lunare.............. 18, 20,107 lütkeni.............. 18, 20,107 lymani.... 9, 12, 15, 17, 18, 20, 63, 107 multispinum....... 10,14,113, 114 sanctum................ 109 simplex......... 5, 18, 20,109, 111 trychnum..........20,109, 111

Ophiomyxa.................. 18, 273, 274, 277 anisacantha........... 5, 20, 271, 272 australis........... 18, 20, 271, 272

Ophiomyxidæ ...................... 6, 269

Ophionephthys........................ 147

Ophionereis.......................... 175 annulata..................... 174 eurybrachiplax.............. 10,173 nuda..................... 174 porrecta................. 174, 177 schayeri................... 174

Ophiopenia........................ 19,102 disacantha.................. 8,102 tetracantha............... 104, 105 Ophiopholis................. 18, 19, 114,115, 116 aculeata............ 4, $9,12,15$,

$19,115,116,128,131,133,196$ var. japonica.......... 15,

$17,115,116,121,123,128$ var. kennerly1............11, $115,116,128,132,133$ var. typica........... 116 bakeri....... 10,115, 116, 121, 123, 128 brachyactis ......... 18, 115, 116, 117 caryi................. 115, 132, 133 japonica.................. 123, 127 kennerlyi............. 115, 132, 133 longispina.................. 10,

$115,116,119,121,122,123,128$ mirabilis..... 8, 19,115, 116, 117, 119

Ophiophrixus.................... 272 acanthinus................. 273

Ophiophrura.......................... 249 liodisca................... $\mathbf{2 4 9}$

Ophioplinthus........................ 21 grisea................... 21 medusa.................. 21 
Page.

Ophioplocus........................... 16 esmarki..................... 31 imbricatus................. 30,31 japonicus.................... 30, 31

Ophiopora........................... 239 Ophiopteris antipodum.................. 257 papillosa..................... 10,257

Ophiopyrgus......................... 254, 255

Ophioschiza.............................. 25. Ophioscolex..................... 114,252,253

Ophiostyracium........................ 258 trachyacanthum.......... 253

Ophiosyzygus................ 275, 276,277,279 disacanthus.............. 18,276

Ophiotholia.......................... 195

Ophiothricidæ....................... 6, 257

Ophiothrix........ 16,18,19,21,36,121, 260, 265, 268 ciliaris..................... 257

eusteira ...................... 265

hylodes................... 263, 265 koreana.... 5, 12, 17, 18, 257, 260, 264, 265 longipeda................... 263 macrobrachia............. 5, 18,267 panchyendyta............. 264, 265 spiculata.................... 10, 262

252

Ophiotrochus .......................... 14,15 longispinus................. 14,94 panniculus.................. 95

Ophiozona .......................... 18, 102 alba............................ 36 bispinosa...................... 33,34 elevata.................. 5, 31, 33, 34 longispina...................... 33, 36 platydisca.................... 34 polyplax....................... projecta...................... 5,36 Ophiura................... 3, 15, 18, 19, 21, 36, 93 atacta........................ 14,85 bathybia.................. 13,16,58, 60 brachyactis................... 8, 16,87 bullata....................... 75 calyptolepis.............. 67, 68, 69, 70 ciliaris......................... 257 clasta.......................... 14,64

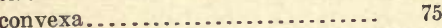
cryptolepis.................. 9,69,70 flagellata............ 8, $9,10,16,18,19,60$ glyptodisca................... 91, 92 hadra........................ 11, 14,80 imbecillis...................... 62 irrorata ............. 8,9,10,14, 15, 62,63 kinbergi............ 37, 44, 45, 46, 47, 48, 55 leptoctenia... 4, $9,15,18,19, \mathbf{5 1}, 55,58,59,60$ ljungmani..................... 55,60 longipeda...................... 263 lütkenl.......... 5, 11, 19, 44,45, 46, 47, 55 maculata.................. 8, $18, \mathbf{4 9}, 156$ megapoma..................... 79 micracantha................. 18, 19,47 monostœcha................ 65, 67,86 nodosa.............. 4, 12, 70, 131, 196 œdiplax.................. 12, 16, 74, 75 penichra...................... 8, 12,84 pomphophora............... 89, 90,91 ponderosa............... $9,77,80,81,85$
Page.

Ophiura quadrispina ........... 8, 18, 19, 55, 58,60 sarsii.............. 4, 9,12,13,17,18,19, $37,44,45,46,47,48,55,131,196$ sculpta......................... 5,73
sculptilis.................... 12, 13,77 sterea............ $7,75,76,78,84,85,88$ stiphra................ 12, 18,82, 84, 85 stuwitzii...................... 12, 73 Ophiurases ............ 250 obstrictus.................. 5, 18, 250 orbiculata, Ophioglypha................62,63

pachybactra, Ophiolebes............... 242, 244 pacificum, Ophiocten................... 9,14,96 palmifer, Tricaster...................... 287 palmiferum, Euryale.................... 287 palmiferus, Trichaster.................. 287 panchyendyta, Ophiothrix............ 264, 265 panniculus, Ophiotrochus................ 95 papillata, Ophioconis.................. 28, 30 paplllosa, Ophlocoma................... 257 Ophiopteris.................. 10,257 papyracea, Amphilepis................... 172 pardalis, Astrophyton............... 18,293, 294 paucispina, Ophiolebes........... 20,246, 247,248 Pectinura ............................ 28 anchista..................... 23, 25 cylindrica....................... 25 marmorata...................... 25 stearnsii....................... 25 penichra, Ophiura..................... 8, 12,84 pentacantha, Amphilimna.............. 10,172 pentagona, Ophiacantha................. 5, $16,17,18,20,196,198,200,201,205$ pergamena, Astroceras................ 5, 18,284 pericalles, Ophiodoris................ 5,18,177 periercta, Amphiodia................ 11,160, 161 plana, Asteronyx....................... 287 platydisca, Ophiozona................... 34 platytata, Amphilepis................ 13, 16,171 polyacantha, Ophiomitra.............. 18,187 polyplax, Ophiozona.................... 35 polyploca, Ophiocamax............... 5, 18,193 pomphophora, Ophlura............... 89, 90, 91 ponderosa, Ophioglypha.................. 77 Ophiura............... 9, 77.80,81,85 porrecta, Ophionereis................. 174, 177 prionota, Ophiacantha.................. 13,213 projecta, Ophiozona..................... $5, \mathbf{3 6}$ psilochora, Amphiodia................... 165 psilopora, Amphiura................. 153, 154 pteropoma, Ophiactis.................... 134 pugetana, Amphipholis.................. 11,166 Amphiura.................... 166

pustulata, Hemieuryale.................. 21 pycnostoma, Amphiura................. 151 quadrispina, Ophiura. $8,18,19,55,58,60$ relicta, Ophiacantha................ 20,219,221 rhachophora, Ophiacantha....... 5, 8, 9, 18, 20,201 rhadinobrachius, Amphioplus.......... 167, 168 riisei, Ophiocoma....................... robusta, Ophioglypha................... 5 rugosa, Ophiocamax..................... 195 sagaminus, Gorgonocephalus.......... 20,21,292 sanctum, Ophiomusium................ 109 
Page.

sarsii, Ophiura.................... 4,9,12,

$13,17,18,19,37,44,45,46,47,48,55,131,196$ schayeri, Ophionereis

scorteus, Ophiolebes..................... 240

sculpta, Ophioglypha................... $\quad 73$

Ophiura..................... 5,73

sculptilis, Ophioglypha................. 77

Ophiura.................... 12, 13, 77

Sigsbeia murrhina.................... 21

simplex, Ophiomusium......... 5, 18, 20,109, 111

sinensis, Ophioglypha.................. $\quad 37$

solida, Ophioglypha.................... 91

spiculata, Ophiothrix.................. 10,262

stearnsii, Pectinura........................ 25

sterea, Ophioglypha.................... $\quad 75$

Ophiura............... $7,75,76,78,84,85,88$

stimpsonii, Astrophyton ................. 287

Gorgonocephalus............. 292

stimulea, Ophiacantha.................. 229

stiphra, Ophiura................ 12, 18,82,84,85

strongyloplax, Amphiodia.............. 10,164

stuwitzii, Ophiura..................... 12, 73

sundevalli, Amphiura................. 12,141
Page.

sundevalli, Ophiolepis ................... 141

synaptacantha, Ophiobyrsa........... 18,270, 271

tetracantha, Ophiopenia................. 104, 105

trachyacanthum, Ophiostyracium......... 253

trachybactra, Ophiacantha............... $\quad 206$

trachydisca, Amphiura.................. $\quad 149$

Tricaster palmifer....................... 287

Trichaster palmiferus.................... 287

trychnum, Ophiomusium............ 20,109, 111

tuberculosa, Hemieuryale................. 21

tumulosa, Ophioglypha................. 62,63

tylota, Ophiolebes............. $8,20, \mathbf{2 4 3}, 244,246$

typica, Ophiopholis aculeata var........... 116

undata, Ophioglypha..................... 91

urtica, Amphiodia.................... 11,154

Amphiura...................... 154,156

variabilis, Ophioglypha................... 77

vestitus, Ophiolebes...................... $\quad 242$

vivipara, Ophiacantha ................... 213

vorax, Ophiacantha.................... 208 


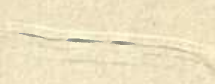




1 





\section{DAY USE RETURN TO DESK FROM WHICH BORROWED}

EARTH SCIENCES LIBRARY This book is due on the last date stamped below, or on the date to which renewed.

Renewed books are subject to immediate recall.

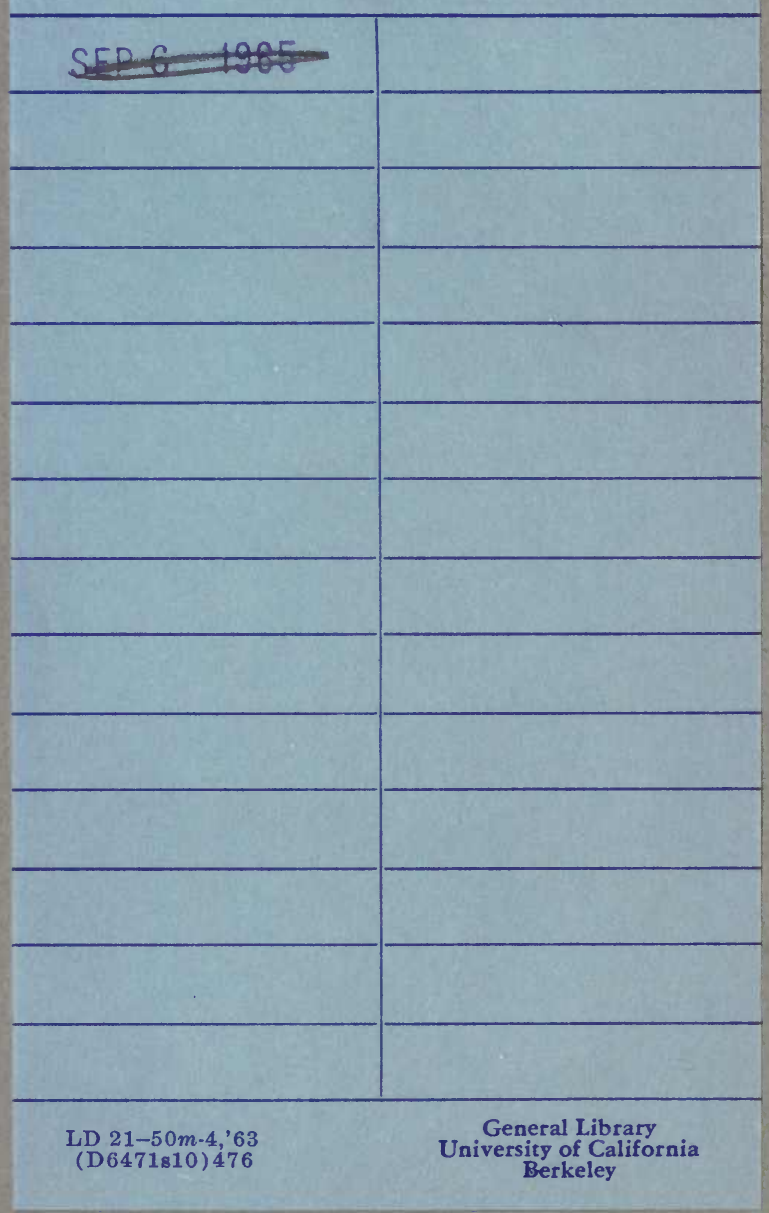


$-524$ 
